UNIVERSIDADE DE SÃO PAULO

ESCOLA DE ENGENHARIA DE SÃO CARLOS

DEPARTAMENTO DE HIDRÁULICA E SANEAMENTO

Serviço de Pós-Graduação EESC/USP

EXEMPLAR REVISADO

Data de entrada no Serviço... 0 . ..../...................

Ass.:

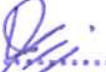

\title{
Tratamento biológico termofílico de efluente sintético de polpa celulósica através do processo combinado anaeróbio - aeróbio
}

\author{
Dirlane de Fátima do Carmo
}

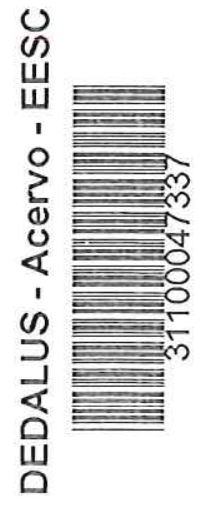

Tese apresentada à Escola de Engenharia de São Carlos, Universidade de São Paulo, como parte dos requisitos para obtenção do título de Doutora em Engenharia Civil, área de Hidráulica e Saneamento

Orientador: Prof. Dr. Eduardo Cleto Pires

São Carlos, SP

Abril/2004 


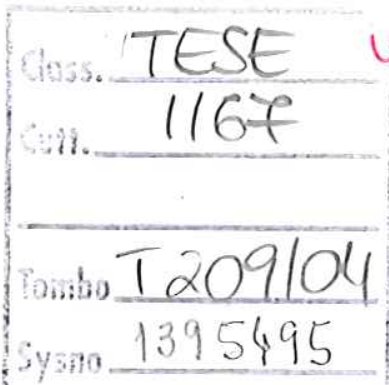

Ficha catalográfica preparada pela Seção de Tratamento da Informação do Serviço de Biblioteca - EESC/USP

Carmo, Dirlane de Fátima do

Tratamento biológico termofílico de efluente sintético de polpa celulósica através do processo combinado anaeróbio - aeróbio / Dirlane de Fátima do Carmo. -- São Carlos, 2004.

Tese (Doutorado -- Escola de Engenharia de São Carlos-Universidade de São Paulo, 2004.

Área: Hidráulica e Saneamento.

Orientador: Prof. Dr. Eduardo Cleto Pires.

1. Termofílico. 2. UASB. 3. Lodos ativados.

4. Efluente. 5. Pasta de celulose náo branqueada.

I. Título. 
Candidata: Engenheira DIRLANE DE FÁTIMA DO CARMO

Tese defendida e julgada em 25-06-2004 perante a Comissão Julgadora:
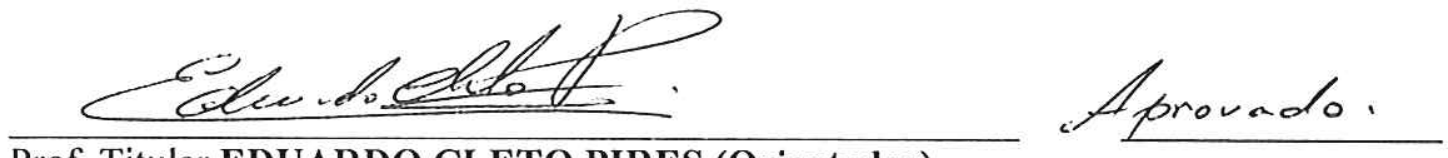

Prof. Titular EDUARDO CLETO PIRES (Orientador)

(Escola de Engenharia de São Carlos/USP)

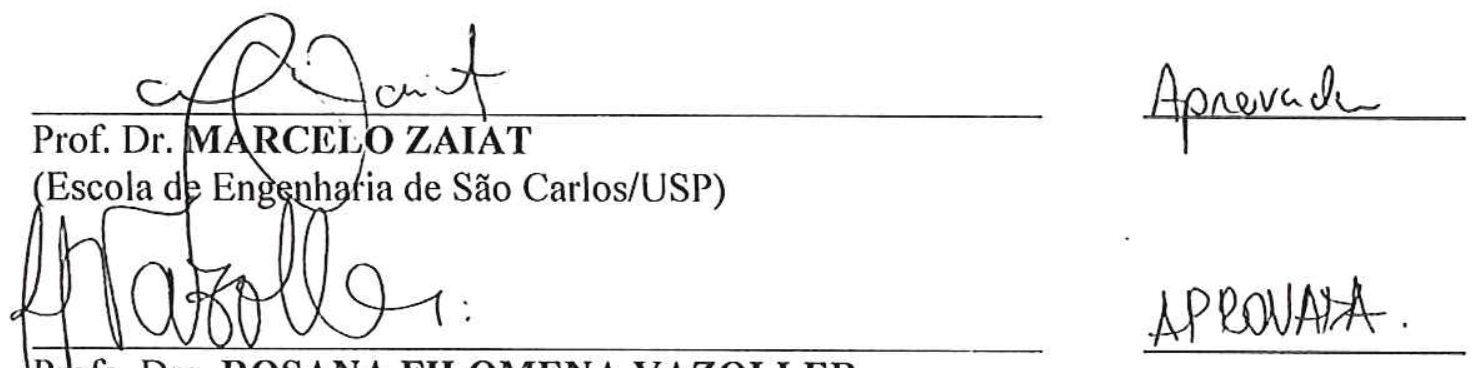

Profa. Dra. ROSANA FILOMENA VAZOLLER

(Instituto de Ciências Biomédicas/USP)

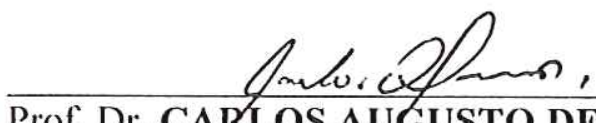

Prof. Dr. CARLOS AUGUSTO DE LEMOS CHERNICHARO

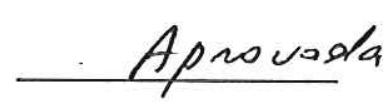

(Universidade Federal de Minas Gerais/UFMG)

Prof. Dr. CLÁUDIO MUDADO SILVA

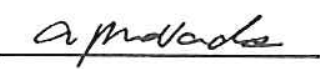

(Universidade Federal de Viçosa/UFV)

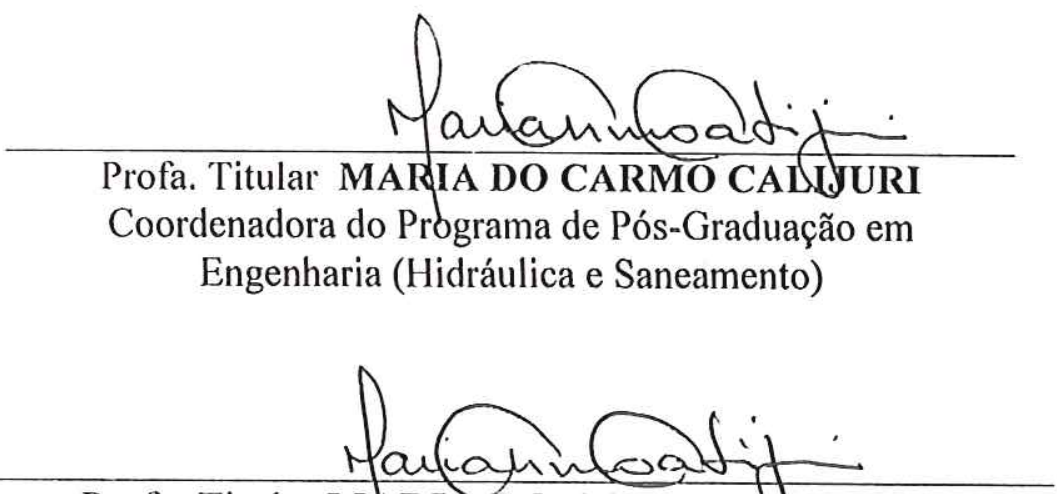

Profa. Titular MARIA DO CARMO QALIJURI

Membro com categoria mais elevada da CPG, em exercício 
Este trabalfo é dedicado à minfia família, meus exemplos de vida,

Que tanto me ensinaram e ensinam

Estando sempre ao meu lado, apesar da distância

E que me estimulam a ter sede do saber, sempre.

Meus pais, Baltazar e Margarida;

Meus irmãos e cunfados, Denilson, Denise, Dircilene, Vânia e Jurandir; e meus sobrinfios, Douglas, Rafaele Ana Caroline

E ao Luciano 


\section{AGRADECIMENTOS}

A Deus, por ter me dado força, saúde e perseverança para a realização e conclusão deste trabalho.

Ao Prof. Eduardo Cleto Pires pela orientação, atenção, confiança e sobretudo pela amizade.

Ao $\mathrm{CNPq}$, pela bolsa concedida.

À Indústria de Papel e Celulose VCP, unidade de Luis Antônio, por ceder o licor negro e inóculo aeróbio utilizados neste trabalho.

À banca de qualificação (Prof. Marco Reali e Luiz Daniel) e à banca de defesa (Prof. Marcelo Zaiat, Carlos A. Chernicharo, Rosana F. Vazoller e Cláudio Mudado), pelas correções e sugestões.

À Prof. Elizabeth Moraes pelas correções, colaboração, carinho e amizade.

À Maria Angela Tallarico Adorno pela amizade e por estar sempre "na torcida".

À Ana Paula Paim pelo cuidado, atenção, interesse e amizade.

À Prof. Bernadete, por estar sempre pronta a sanar minhas dúvidas diversas e pela amizade,

À Andréa Buzzini, pelos conselhos, orientações e dicas, sobretudo pela amizade.

À Marilu, pela paciência e pelos "ensinamentos" no início da parte experimental.

À Eloísa Pozzi, pelo auxílio na microscopia, pelas diversas sugestões, atenção e carinho dispensado.

À toda turma do SHS, especialmente ao pessoal do Laboratório de Processos Biológicos e do Laboratório de Tratamento e Reuso: Ana Paula Miqueleto, Betão, Edson, Neyson, Tininha, Bruna, Hélio, Sidney, André Oliveira, André Coelho, André Campos, Dalva, Renata, Jeanete, Carlos Magno, Luci, Ari, Arnaldo, Fábio, Sandra, Estela, Flávia Talarico, Valquíria, Tiago, Tiago Momenti, Karina, João, Eduardo, Estela, Sandra, Márcia, Flávio, Rogers, Samantha, Chico Vela, Sávia, Giovana, Cristiano, Julia, Fernandão, Kelly, Cláudia, Cáscia, Marcelinho, Rogério, Douglas, Katt, Luís Hamilton, Luís Ricardo e Lara.

Ao estudante de iniciação científica Renato Obladen, pelos dados cedidos no teste de transferência de oxigênio.

Aos meus amigos da Universidade Federal de Viçosa pela amizade que perdura nestes anos, mesmo com a distância, principalmente a Adriano Alves e Ailton. 
Ao meu amigo Lucas Naoe, pelo carinho e pela amizade constante.

À Helen, por todo carinho e amizade sincera.

Aos meus amados amigos Marisi e Doriguetto, pela amizade incondicional, pelo apoio de sempre, pelos conselhos, pela torcida, pela adorável convivência e também pelo "auxílio casa".

Aos funcionários do SHS: Sá, Flávia, D. Terezinha, Wagner, André, Paulo, Júlio, Cidinha, Chico, Pavi, especialmente ao Roberto Bérgamo e Rose, por todo auxílio prestado e pela boa vontade em fazê-lo.

Aos amigos de todos os departamentos, especialmente a Fernandinho e Amauri.

A todos os amigos, especialmente a Cristina Iamamoto, Monique, Clésia, Suzanne e Donato, João Paulo, Luiz Baras e Ivana Nardi.

Às companheiras de república Mercia, Luana e Isabel, pela convivência de anos a fio.

Às amigas distantes, mas não menos importantes: Sissy, Conceição, Sílvia Barguil, Camilinha, Andréa, Ciclene e Luciana Mendonça, por estarem sempre tão presentes.

À minha nova família, Sirlene \& Cia, pela acolhida.

Ao meu estado, Minas Gerais, por ser meu porto seguro e pelas boas lembranças de locais e de pessoas, que me fizeram sentir tantas saudades nesses sete anos de distância.

Ao Luciano, pelo carinho, paciência, amor e por todo o "esforço" para estarmos juntos, especialmente pela dedicação na parte final e estressante do trabalho.

À minha família, tão fantástica, tão bonita, tão amada, melhor presente que alguém poderia ter.

E a todos, que colaboraram de alguma forma para que esse trabalho fosse realizado. 


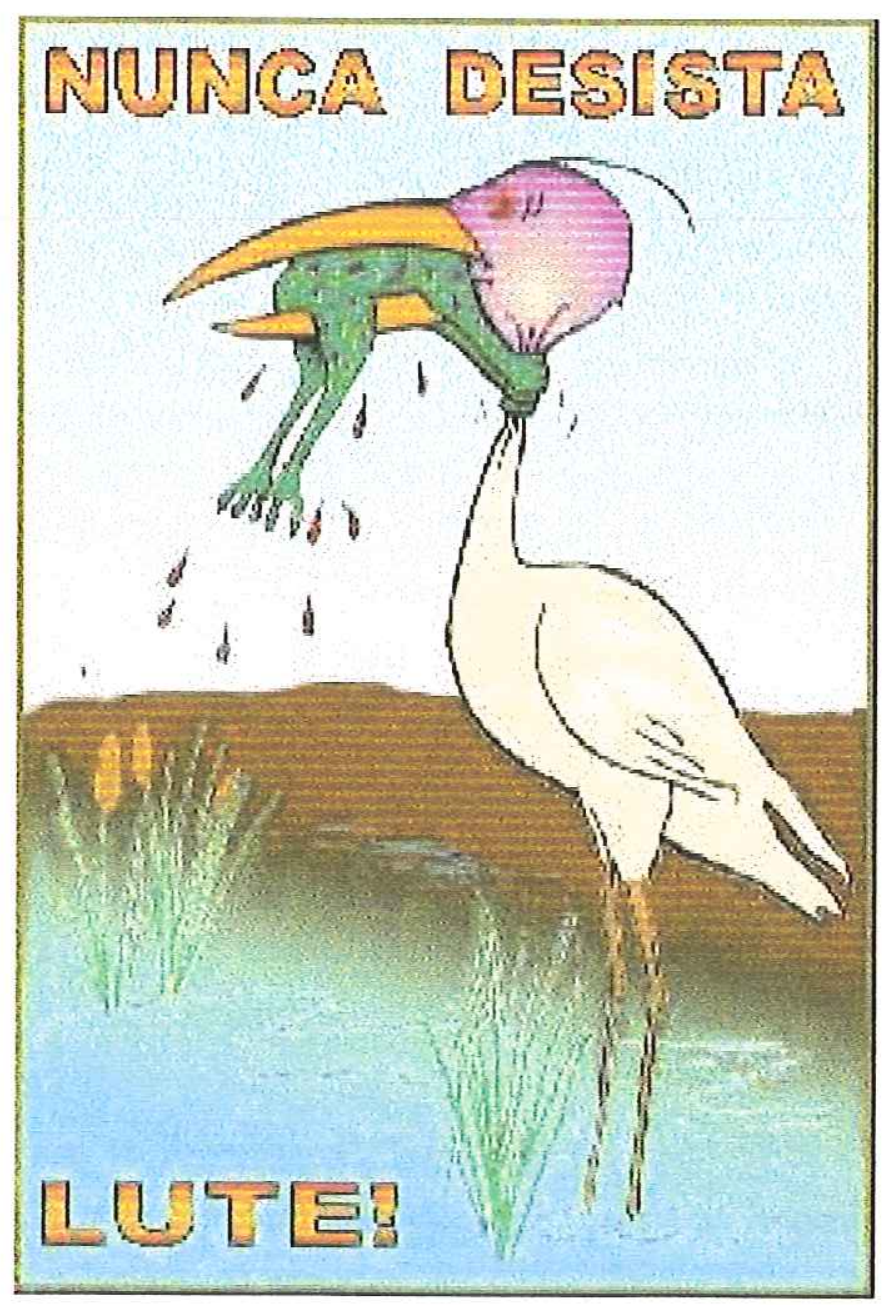

"Duas crianças estavam patinando num lago congelado da Alemanfia. Era uma tarde nublada e fria, $e$ as crianças brincavain despreocupadas. De repente, o gelo se quebrou e uma delas caiu, ficando presa na fenda que se formou. A outra, vendo seu amiguinfio preso e se congelando, tirou um dos patins e começou a golpear o gelo com todas as suas forças, conseguindo por fim quebrá-fo e libertar o amigo.

Quando os bombeiros chiegaram e viram o que fiavia acontecido, perguntaram ao menino:

- Como você conseguiu fazer isso? É impossível que tenfia conseguido quebrar o gelo, sendo tão pequeno e com mãos tão frágeis!

Nesse instante, alguém que passava pelo local, comentou:

- Eu sei como ele conseguiu.

Todos perguntaram:

- Pode nos dizer como?

- É simples. - respondeu - NNão fiavia ninguém ao seu redor, para lhe dizer que não seria capaz."

"Deus nos fez perfeitos e não escollie os capacitados, capacita os escolfidos. Fazer ou não fazer algo só depende de nossa vontade e perseverança."

Albert Einstein 


\section{SUMÁRIO}

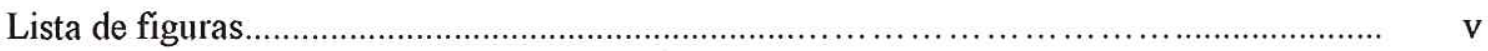

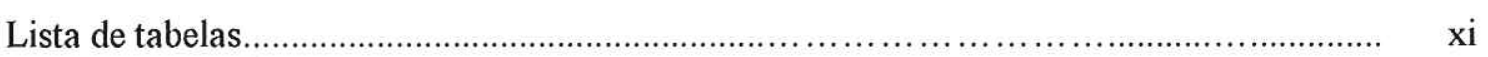

Lista de abreviaturas, siglas e símbolos....................................................................... $\mathrm{xv}$

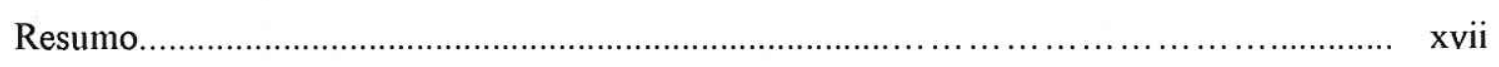

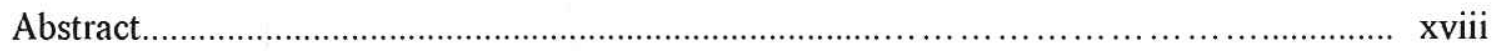

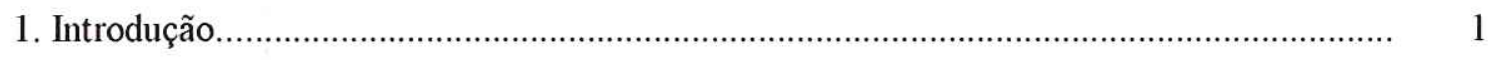

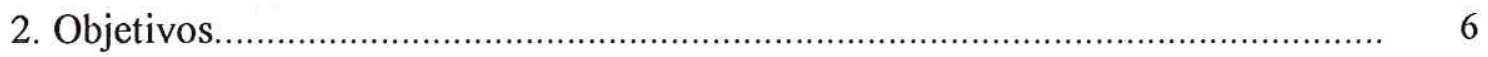

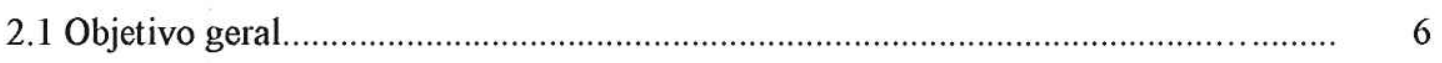

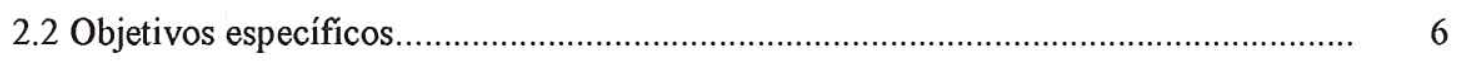

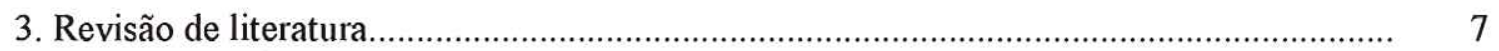

3.1. A questão da água e sua relação com o tratamento de efluentes na indústria de papel celulose

3.2. Efluentes gerados pelas indústrias de papel e celulose no processo de fabricação....... 9

3.3. Sistemas de tratamento de efluente usualmente utilizado em indústria de papel e 13 celulose.

3.4. Tratamento biológico da água residuária das indústrias de papel e celulose.............. 14

3.5. Microrganismos termofílicos: definição e características............................................ 18

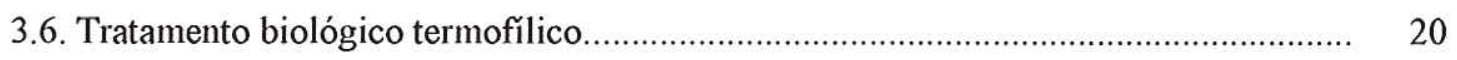

3.6.1. Tratamento anaeróbio termofílico.................................................................. 21

3.6.1.1. Diferenças entre grânulos mesofílico e termofílico...................................... 23

3.6.1.2. Experimentos utilizando tratamento termofílico anaeróbio...................... 26

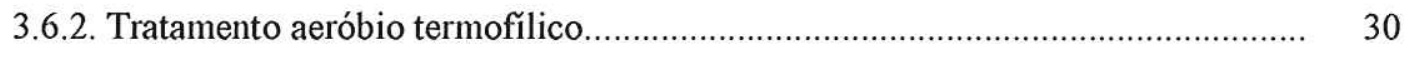

3.6.2.1. Diferenças entre flocos mesofilico e termofílico...................................... 33

3.6.2.2. Experimentos utilizando tratamento termofílico aeróbio......................... 37

3.6.3. Sistema biológico combinado termofílico......................................................... 40 
3.7. Fatores que afetam o crescimento microbiano em sistemas de tratamento biológico.. 42

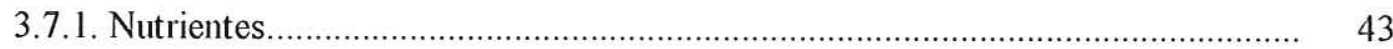

3.7.2. Temperatura de operação.................................................................................... 44

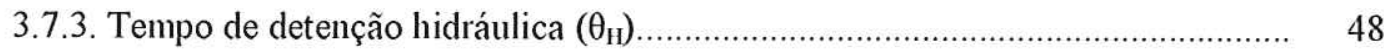

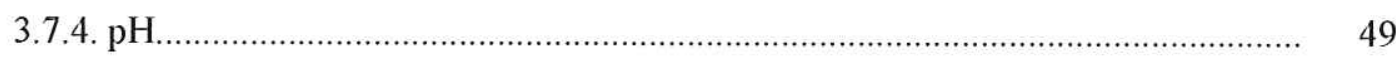

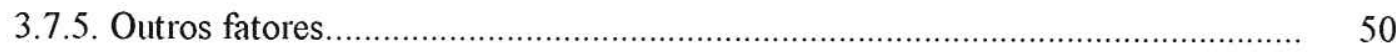

3.8. Taxa de transferência de oxigênio............................................................................. 50

3.9. Experiências no Departamento de Hidráulica e Saneamento no tratamento biológico mesofílico para água residuária das indústrias de papel $\mathrm{e}$ celulose.

3.10. Considerações gerais sobre o presente trabalho.......................................................... 54

4. Material e métodos.......................................................................................................... 56

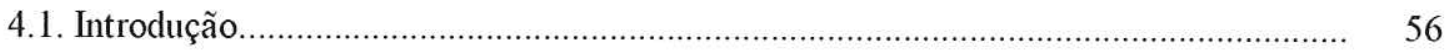

4.2. Aparato experimental......................................................................................... 57

4.2.1. Sistema combinado de tratamento...................................................................... 57

4.2.1.1. Sistema anaeróbio............................................................................. 57

4.2.1.2. Sistema aeróbio...................................................................................... 59

4.3. Água residuária sintética........................................................................................... 60

4.4. Inoculação e operação dos reatores............................................................................. 62

4.4.1. Inoculação dos reatores........................................................................................ 63

4.4.2. Operação dos reatores......................................................................................... 65

4.4.3. Operação para manutenção do sistema ................................................................. 65

4.5. Monitoramento dos reatores........................................................................................ 66

4.5.1. Análises físico-químicas......................................................................................... 66

4.5.2. Análises cromatográficas ............................................................................ 67

4.5.2.1. Análise do biogás........................................................................................ 67

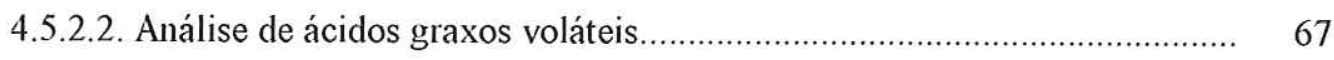

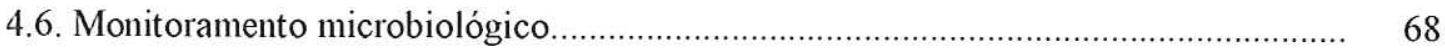

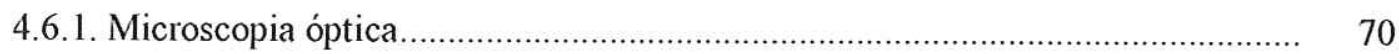

4.6.2. Microscopia de varredura ........................................................................... $\quad 70$

4.6.3. Número Mais Provável (NMP) ……….............................................................. $\quad 70$ 
4.6.4. Caracterização e quantificação de microrganismos filamentosos........................ 72

4.6.4.1. Coloração de Gram, modificado do método de Hucker............................ 72

4.6.4.2. Coloração de Neisser....................................................................................... 73

4.6.4.3. Coloração de Polibetahidroxibutirato (PHB) ............................................. 74

4.6.4.4. Coloração de bainha.................................................................................... 74

4.6.4.5. Teste de oxidação de enxofre................................................................ 75

4.7. Teste de transferência de oxigênio........................................................................... 77

4.8. Teste do aumento súbito de temperatura...................................................................... 80

5. Resultados e discussão................................................................................................ 81

5.1. Teste de transferência de oxigênio........................................................................ 82

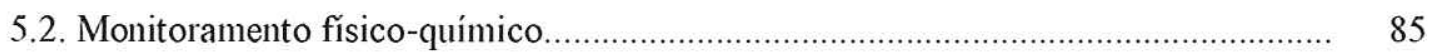

5.2.1. Primeira fase: mesofilica ............................................................................ 85

5.2.1.1. Primeira etapa mesofilica........................................................................ 86

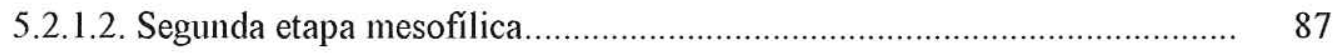

5.2.1.3. Terceira etapa mesofilica .................................................................. 88

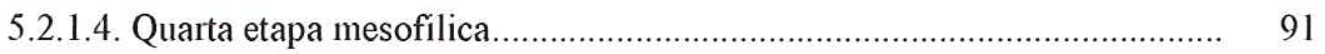

5.2.1.5. Quinta etapa mesofilica........................................................................ 93

5.2.1.6. Sexta etapa mesofilica ............................................................................... 94

5.2.1.7. Sétima etapa mesofilica....................................................................... 95

5.2.1.8. Oitava etapa mesofilica........................................................................ 98

5.2.1.9. Avaliação do desempenho dos reatores na fase mesofilica...................... 99

5.2.2. Segunda fase: termofílica....................................................................... 104

5.2.2.1. Primeira etapa termofílica.............................................................. 105

5.2.2.2. Segunda etapa termofílica ...................................................................... 106

5.2.2.3. Terceira etapa termofílica............................................................... 107

5.2.2.4. Quarta etapa termofilica............................................................. 110

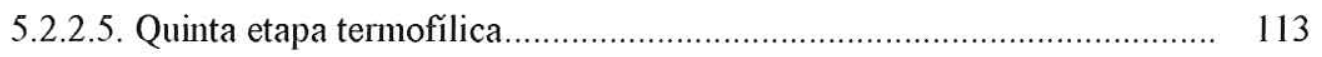

5.2.2.6. Avaliação do desempenho dos reatores na fase termofílica.................... 118

5.3. Efeito da temperatura na comunidade microbiana dos reatores................................ 122

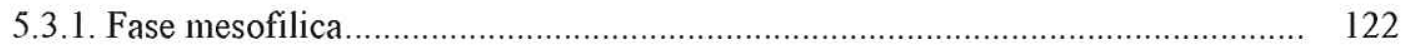


5.3.1.1. Faixa de temperatura entre $25,0^{\circ} \mathrm{C}$ e $32,5^{\circ} \mathrm{C}$ (etapas 1 a 6 )

5.3.1.2. Faixa de temperatura entre $32,5^{\circ} \mathrm{C}$ e $42,5^{\circ} \mathrm{C}$ (etapas 6 a 8)

5.3.2. Fase termofilica.

5.3.2.1. Faixa de temperatura de $45^{\circ} \mathrm{C}$ a $57^{\circ} \mathrm{C}$ (etapas 1 a 5 ).

5.3.3. Comparação entre as microscopias realizadas nas fases mesofilica e termofílica.

5.3.4. Organismos metanogênicos

5.3.5. Microscopia eletrônica de varredura (MEV)

5.4. Efeito da temperatura sobre os parâmetros monitorados.

5.4.1. Efeito da temperatura na remoção de DQO 150

5.4.2. Efeito da temperatura no $\mathrm{pH}$ e na alcalinidade 152

5.4.3. Efeito da temperatura nas concentrações de sólidos suspensos 154

5.4.4. Efeito da temperatura nas concentrações de ácidos graxos voláteis. 158

5.4.5. Efeito da temperatura na composição do biogás 163

5.5. Teste do aumento súbito da temperatura 165

5.6. Comparação entre os reatores operando nas fases mesofilica e termofilica 169

6. Conclusões. 174

7. Recomendações 177

8. Referências Bibliográficas 179

9. Anexos 


\section{LISTA DE FIGURAS}

Figura 1.1- Destino das exportações brasileiras no ano de 1995.

Figura 3.1 - Principais pontos de lançamento de efluentes de indústrias de papel e celulose. Fonte: Modificada de Sierra-Alvarez (1990).....

Figura 4.1 - Fluxograma do sistema de tratamento empregado neste trabalho.

Figura.4.2 - Esquema do reator UASB empregado e pontos de amostragem.....

Figura.4.3 - Esquema do reator de lodos ativados empregado (dimensões em cm)......

Figura $4.4-$ Sistema completo utilizado neste trabalho.

Figura 4.5 - Chave dicotômica simplificada para identificação de microrganismos filamentosos. Adaptada de Jenkins et al. (1984) e Eikelboom (1975). Fonte: Bitton (1994)

Figura 5.1 - Valores da concentração de saturação e do coeficiente de transferência do oxigênio na água, em relação ao aumento de temperatura, considerando as taxas de aeração de $45 \mathrm{~L} \cdot \mathrm{h}^{-1}, 30 \mathrm{~L} \cdot \mathrm{h}^{-1}$ e $15 \mathrm{~L} \cdot \mathrm{h}^{-1}$.

Figura 5.2 - Valores da concentração de saturação e do coeficiente de transferência do oxigênio na água residuária sintética, em relação ao aumento de temperatura, considerando as taxas de aeração de $45 \mathrm{~L} \cdot \mathrm{h}^{-1}, 30 \mathrm{~L} \cdot \mathrm{h}^{-1} \mathrm{e}$ $15 \mathrm{~L} \cdot \mathrm{h}^{-1}$.

Figura 5.3 - Valores da concentração de saturação e do coeficiente de transferência do oxigênio na água e na água residuária sintética em relação ao aumento de temperatura, considerando a taxa de aeração de $30 \mathrm{~L} \cdot \mathrm{h}^{-1}$

Figura 5.4 - Fase mesofílica ( $1^{\mathrm{a}}$ fase): temperatura considerada $\left({ }^{0} \mathrm{C}\right)$, DQO $\left(\mathrm{mg} . \mathrm{L}^{-1}\right)$ e tempo de detenção hidráulica (h) em cada etapa.

Figura 5.5 - Médias da DQO total e filtrada da água residuária sintética (ARS), do efluente do reator UASB (e-UASB) e do efluente do reator de lodos ativados (e-LA) nas 8 etapas da fase mesofilica, considerando as diferentes temperaturas de operação.

Figura 5.6 - Médias da eficiência de remoção de DQO total e filtrada da água residuária sintética (ARS), do efluente do reator UASB (e-UASB) e do efluente do reator de lodos ativados (e-LA) nas 8 etapas da fase mesofilica, considerando as diferentes temperaturas de operação.

Figura 5.7 - Médias das concentrações de nitrogênio $\left(\mathrm{N}_{2}\right)$, Metano $\left(\mathrm{CH}_{4}\right)$ e Gás carbônico $\left(\mathrm{CO}_{2}\right)$ na composição do biogás do reator UASB nas 8 etapas da fase mesofilica, considerando as diferentes temperaturas de operação $(\mathrm{T}) \ldots .$. 
Figura 5.8 - Valores de $\mathrm{pH}$ e médias das concentrações de ácidos graxos voláteis (AGV) e alcalinidade total (AT) na água residuária sintética (ARS) e efluentes do reator UASB (e-UASB) e do reator de lodos ativados (e-LA) nas 8 etapas da fase mesofilica, considerando as diferentes temperaturas de operação $(T)$.

Figura 5.9 - Valores médios e desvios das concentrações de sólidos suspensos totais (SST) e sólidos suspensos voláteis (SSV): na água residuária sintética (ARS) e efluentes do reator UASB (e-UASB) e do reator de lodos ativados (e-LA), nas 8 etapas da fase mesofilica, considerando as diferentes temperaturas de operação $(\mathrm{T})$.

Figura 5.10 - Valores médios e desvios das concentrações de sólidos suspensos totais (SST) e sólidos suspensos voláteis (SSV) no licor misto (LM) e decantador do reator aeróbio, nas 8 etapas da fase mesofilica, considerando as diferentes temperaturas de operação $(\mathrm{T})$

Figura 5.11 - Fase termofilica ( $2^{\mathrm{a}}$ fase): etapas, temperatura considerada $\left({ }^{0} \mathrm{C}\right)$, DQO (mg. $\left.L^{-1}\right)$ e tempo de detenção hidráulica.

Figura 5.12 - Médias da DQO total e filtrada da água residuária sintética (ARS), do efluente do reator UASB (e-UASB) e do efluente do reator de lodos ativados (e-LA) nas 5 etapas da fase termofilica, considerando as diferentes temperaturas de operação

Figura 5.13 - Médias da efíciência de remoção de DQO total e filtrada da água residuária sintética (ARS), do efluente do reator UASB (e-UASB) e do efluente do reator de lodos ativados (e-LA) nas 5 etapas da fase termofilica, considerando as diferentes temperaturas de operação

Figura 5.14 - Médias das concentrações de nitrogênio $\left(\mathrm{N}_{2}\right)$, Metano $\left(\mathrm{CH}_{4}\right)$ e Gás carbônico $\left(\mathrm{CO}_{2}\right)$ na composição do biogás do reator UASB nas 5 etapas da fase termofilica, considerando as diferentes temperaturas de operação $(\mathrm{T}) \ldots$

Figura 5.15 - Valores de pH e médias das concentrações de ácidos graxos voláteis (AGV) e alcalinidade total (AT) na água residuária sintética (ARS) e efluentes do reator UASB (e-UASB) e do reator de lodos ativados (e-LA) nas 5 etapas da fase termofilica, considerando as diferentes temperaturas de operação $(\mathrm{T})$

Figura 5.16 - Valores médios e desvios das concentrações de sólidos suspensos totais (SST) e sólidos suspensos voláteis (SSV) na água residuária sintética (ARS) e efluentes do reator UASB (e-UASB) e do reator de lodos ativados (e-LA), nas 5 etapas da fase termofilica, considerando as diferentes temperaturas de operação $(\mathrm{T})$

Figura 5.17 - Valores médios e desvios das concentrações de sólidos suspensos totais (SST) e sólidos suspensos voláteis (SSV) no licor misto (LM) e decantador do reator aeróbio, nas 5 etapas da fase termofilica, considerando as diferentes temperaturas de operação

Figura 5.18 - Inóculo do reator UASB: predomínio de Methanosaeta sp (a) e Methanosarcina sp (b) 
Figura 5.19- Microrganismos visualizados na $2^{\mathrm{a}}$ etapa mesofilica $\left(25^{\circ} \mathrm{C}\right)$ : bacilos e sarcinas com fluoresência tênue no reator UASB (a) e protozoários semelhantes a Vorticella sp, um os organismos predominantes no inóculo do reator aeróbio.

Figura 5.20 - Microrganismos visualizados na $4^{\mathrm{a}}$ etapa mesofilica $\left(25^{\circ} \mathrm{C}\right)$ : semelhantes a Methanosaeta sp (a) e bacilos fluorescentes (b) presentes no reator UASB; rotífero presente no reator de lodos ativados (c) e ciliados fixos semelhantes a Opercularia sp no inóculo aeróbio da Faber Castell (c)

Figura 5.21 - Microrganismos visualizados no reator UASB $7^{\text {a }}$ etapa $\left(35^{\circ} \mathrm{C}\right)$ : semelhantes ao gênero Methanosarcina sp. (a) bacilos delgados fluorescentes (b)

Figura 5.22 - Microrganismos visualizados no reator de lodos ativados na $7^{\mathrm{a}}$ etapa $\left(35^{\circ} \mathrm{C}\right)$ : aspecto geral do floco (a) rotíferos (1) e ciliado livre semelhante a Aspidisca sp (2), (b)

Figura 5.23 - Microrganismos visualizados no reator UASB na $7^{\mathrm{a}}$ etapa $\left(37,5^{\circ} \mathrm{C}\right)$ : bacilos curvos (a), Methanosaetas sp (b).

Figura 5.24 - Microrganismos visualizados no reator de lodos ativados na $7^{\text {a }}$ etapa $\left(37,5^{\circ} \mathrm{C}\right)$ : ciliado pedunculado semelhante a Acineta sp (a), protozoário semelhante a Podophrya sp e Periacineta sp (b).

Figura 5.25 - Microrganismos visualizados no reator UASB na $8^{\mathrm{a}}$ etapa $\left(42,5^{\circ} \mathrm{C}\right)$ : semelhantes aos gêneros Methanosaeta sp (a) Methanosarcina sp. (b).........

Figura 5.26 - Microrganismos visualizados no reator de lodos ativados na $8^{\text {a }}$ etapa $\left(42,5^{\circ} \mathrm{C}\right)$ : aspecto geral do floco (a), estreptococos e filamentos semelhantes a Thiothrix sp (b).

Figura 5.27 - Microrganismos visualizados no reator UASB na $1^{\text {a }}$ etapa termofílica $\left(45^{\circ} \mathrm{C}\right)$ : semelhantes ao gênero Methanosaetas sp (a), Methanosarcina sp (b).

Figura 5.28 - Microrganismos visualizados no reator de lodos ativados na $1^{\text {a }}$ etapa termofilica $\left(45^{\circ} \mathrm{C}\right)$ : ameba semelhante a Amoeba sp (a), estreptococos (b)....

Figura 5.29 - Microrganismos visualizados no reator UASB na $4^{\mathrm{a}}$ etapa termofílica $\left(52^{\circ} \mathrm{C}\right)$ : semelhantes ao gênero Methanosaetas sp (a), e bacilos diversos (b)

Figura 5.30 - Microrganismos visualizados no reator de lodos ativados na $4^{\mathrm{a}}$ etapa termofilica $\left(52^{\circ} \mathrm{C}\right)$ : aspecto geral do floco (a), filamentosas e ciliado (b)......

Figura 5.31 - Microrganismos visualizados no reator de lodos ativados na $4^{\mathrm{a}}$ etapa termofilica $\left(52^{\circ} \mathrm{C}\right)$ : duas morfologias predominantes após o "bulking", semelhantes a Thiothrix I e $N$. limicola II (a), aspecto geral do floco após o aumento da taxa de aeração (b).

Figura 5.32 - Coloração dos organismos filamentosos visualizados no reator de lodos ativados na $4^{\mathrm{a}}$ etapa termofílica $\left(52^{\circ} \mathrm{C}\right)$ : presença de bainha (a), bacilos Gram negativos (b).

Figura 5.33 - Coloração dos organismos filamentosos visualizados no reator de lodos ativados na $4^{\mathrm{a}}$ etapa termofilica $\left(52^{\circ} \mathrm{C}\right)$ : filamentos Gram negativos (a), filamentos Neisser positivo e negativo.... 
Figura 5.34 - Coloração dos organismos filamentosos visualizados no reator de lodos ativados na $4^{\mathrm{a}}$ etapa termofilica $\left(52^{\circ} \mathrm{C}\right)$ : filamento $\mathrm{PHB}$ positivo (a), filamento PHB negativo (b)

Figura 5.35 - Microrganismos visualizados no reator de lodos ativados na $5^{\text {a }}$ etapa termofilicam $\left(57^{\circ} \mathrm{C}\right)$ : aspecto geral do floco (a), morfologias variadas de bacilos (b)

Figura 5.36 - Coloração de Gram dos organismos filamentosos presentes no reator de lodos ativados na $5^{\text {a }}$ etapa termofilica $\left(57^{\circ} \mathrm{C}\right)$ : presença abundante de filamento semelhante a Nocardia sp, Gram positiva e de $N$. Limicolla II, Gram negativa (a), $N$. limicolla $I$ e $N$. limicola II, ambas Gram negativas (b).

Figura 5.37 - Coloração de Neisser dos organismos filamentosos presentes no reator de lodos ativados na $5^{\text {a }}$ etapa termofilica $\left(57^{\circ} \mathrm{C}\right)$ semelhantes a: Thiothrix $\mathrm{I}$ em feixe, Neisser positiva e N. Limicola II, Neisser negativa (a), Nocardia sp, Neisser positiva de grânulo (b)

Figura 5.38 - Coloração de PHB dos organismos filamentosos presentes no reator de lodos ativados na $5^{\mathrm{a}}$ etapa termofílica $\left(57^{\circ} \mathrm{C}\right)$ semelhantes a: bacilos, PHB negativo (a), Nocardia sp ao fundo, PHB negativa e Thiothrix sp, PHB positiva (b)

Figura 5.39 - Coloração de bainha dos organismos filamentosos presentes no reator de lodos ativados na $5^{\mathrm{a}}$ etapa termofílica $\left(57^{\circ} \mathrm{C}\right)$ semelhantes a: Nocardia, ausência de bainha (a), N. Limicola II, ausência de bainha (b).

Figura 5.40 - Coloração de enxofre dos organismos filamentosos presentes no reator de lodos ativados na $5^{\text {a }}$ etapa termofilica $\left(57^{\circ} \mathrm{C}\right)$ semelhantes a: $N$. Limicola II e Nocardia sp (a), Thiothrix sp (b).

Figura 5.41 - Microrganismos visualizados no reator de lodos ativados na $5^{\text {a }}$ etapa termofilica $\left(57^{0} \mathrm{C}\right)$ : aspecto geral do floco (a), predominância de bacilos (b)

Figura 5.42 - Microrganismos visualizados no reator UASB na $5^{\text {a }}$ etapa termofílica $\left(57^{\circ} \mathrm{C}\right)$ : Methanosarcinas sp e respectiva fluorescência (a e b).

Figura 5.43 - Microrganismos visualizados no reator UASB na $5^{\text {a }}$ etapa termofílica $\left(57^{\circ} \mathrm{C}\right)$ : feixe de Methanosaeta sp (a) e filamentos e Methanosaeta sp (b)....

Figura 5.44 - Microrganismos visualizados no reator UASB após choque térmico na $5^{\mathrm{a}}$ etapa termofilica $\left(57^{\circ} \mathrm{C}\right)$ : Methanosaetas sp (a) e bacilos (b)

Figura 5.45 - Microrganismos visualizados no reator de lodos ativados após choque térmico na $5^{\mathrm{a}}$ etapa termofílica $\left(57^{\circ} \mathrm{C}\right)$ : aspecto geral do floco (a) presença de filamento semelhante a N. Limicola II (b) presença de Nocardia sp e bacilos (c), feixes de Thiothrix (d)

Figura 5.46 - Microrganismos visualizados na amostra de NMP com inóculo de lodo do reator UASB termofílico: frasco 2 (diluição $10^{-1}$ ); microrganismos semelhantes a sarcinas (a); frasco 7 (diluição $10^{-2}$ ): microrganismos semelhantes a cocos (b) 
Figura 5.47 - Microrganismos visualizados na amostra de NMP com inóculo de lodo do reator UASB termofílico: frasco 11 (diluição $10^{-3}$ ); microrganismos semelhantes a saethas e bacilos, alguns com inclusões (a); frasco 17 (diluição $10^{-4}$ ): microrganismos semelhantes a bacilos (agrupados e em cadeia), alguns com inclusões (b)

Figura 5.48 - Microrganismos visualizados na amostra de NMP com inóculo de lodo do reator de lodos ativados termofílico: frasco 34 (diluição $10^{-1}$ ): predominância de microrganismos semelhantes a bacilos, presença de filamentos e sarcinas que não fluorescem (a); frasco 34 (diluição $10^{-1}$ ): microrganismos semelhantes a bacilos e filamentos delgados (b).

Figura 5.49 - Aspecto geral do grânulo anaeróbio termófilo de reator tratando efluente simulado da indústria de celulose não branqueada. Aumento de 43X (a); aumento de $200 \mathrm{X}$ (b)

Figura 5.50 - MEV - aumento de 5000X: células em formato de bacilos arredondados (a); células em formato de bacilos e cocos, presença de filamentos (b) e (c), células em formato de $\operatorname{cocos}(\mathrm{d})$.

Figura 5.51 - MEV - aumento de 5000X: células em formato de bacilos arredondados (a); células em formato de bacilos e cocos, presença de filamentos (b) e (c), células em formato de $\operatorname{cocos}(\mathrm{d})$

Figura 5.52 - Eficiências de remoção de DQO em relação ao tempo de operação, considerando as oito etapas mesofilicas e as cinco etapas termofilicas (SC sistema combinado, ou seja, eficiência global; La - eficiência do reator de lodos ativados e UASB - eficiência do reator UASB).

Figura 5.53 - Variação do $\mathrm{pH}$ na água residuária sintética e nos efluentes dos reatores anaeróbio e aeróbio em relação ao tempo de operação, considerando as oito etapas mesofilicas e as cinco etapas termofilicas.

Figura 5.54 - Variação das concentrações de alcalinidade total na água residuária sintética e nos efluentes dos reatores UASB e de lodos ativados em relação ao tempo de operação, considerando as oito etapas mesofílicas e as cinco etapas termofilicas.

Figura 5.55 - Variação de sólidos suspensos voláteis na água residuária sintética e no efluente dos reatores anaeróbio e aeróbio em relação ao tempo de operação, considerando as oito etapas mesofilicas e as cinco termofilicas.

Figura 5.56 - Variação de sólidos suspensos voláteis no licor misto do reator de lodos ativados em relação ao tempo de operação, considerando as oito etapas mesofilicas e as cinco termofílicas.

Figura 5.57 - Variação de AGV na água residuária sintética e no efluente dos reatores anaeróbio e aeróbio em relação ao tempo de operação, considerando as oito etapas mesofilicas e as cinco termofílicas.

Figura 5.58 - Concentrações de ácidos determinados por cromatografia gasosa em amostras do efluente do reator UASB na oitava etapa mesofilica (etapa 0) e nas 5 etapas termofilicas.

Figura 5.59 - Concentrações de ácidos determinados por cromatografía gasosa em amostras da água residuária sintética (a) e do efluente do reator de lodos ativados (b) na oitava etapa mesofilica (etapa 0 ) e nas 5 etapas termofílicas. 
Figura 5.60 - Variação das porcentagens de $\mathrm{N}_{2}, \mathrm{CH}_{4}$ e $\mathrm{CO}_{2}$ no biogás do reator biológico anaeróbio durante o tempo de operação, considerando as oito etapas mesofilicas e as cinco termofilicas.

Figura 5.61 - Resultados do monitoramento dos reatores UASB e de lodos ativados no teste do aumento súbito da temperatura. 


\section{LISTA DE TABELAS}

Tabela 3.1 - Maior grupo de procariotos termofílicos e hipertermofilicos (BROCK \& MADIGAN, 1988)

Tabela 3.2 - Comparação de constantes biocinéticas em temperaturas mesofílicas e termofilicas (LAPARA \& ALLEMAN, 1999).....

Tabela 4.1 - Composição do licor negro usado no preparo da água residuária sintética..

Tabela 4.2 - Fase mesofilica (1) e termofílica (2) e etapas correspondentes, tipo e volume de licor negro utilizado, temperatura, tempo de detenção hidráulica, taxa de carregamento hidráulico e orgânico e tempo de duração da etapa no reator UASB.

Tabela 4.3 - Fase mesofílica (1) e termofílica (2) e etapas correspondentes, tipo e volume de licor negro utilizado, temperatura, tempo de detenção hidráulica, taxa de carregamento hidráulico e orgânico e tempo de duração da etapa para o reator de lodos ativados.

Tabela $4.4-$ Análises para monitorar o sistema global

Tabela $4.5-$

Coleta de amostras para monitoramento microbiológico.

Tabela $4.6-$

Esquema da planilha do programa Excel utilizada no teste de transferência de oxigênio.

Tabela 4.6 - Esquema da planilha do programa Excel utilizada no teste de transferência de oxigênio (continuação)...

Tabela 4.7 - Etapas do teste do aumento súbito da temperatura, tipo e volume de licor utilizado, DQO da água residuária sintética, tempo de detenção hidráulica dos reatores e o tempo de operação em cada etapa.

Tabela 5.1- Concentrações de saturação e coefícientes de transferência de oxigênio obtidos em teste na água utilizando várias temperaturas e vazões de aeração.

Tabela 5.2 - Concentrações de saturação e coeficientes de transferência de oxigênio obtidos em teste com a água residuária sintética utilizando várias temperaturas e vazões de aeração.

Tabela 5.3 - Valores dos parâmetros monitorados na segunda $\left(26^{\circ}\right.$ ao $63^{\circ}$ dia $)$ e terceira etapa $\left(64^{0}\right.$ ao $104^{0}$ dia $)$.

Tabela 5.4 - Faixa de variação dos parâmetros monitorados na quarta etapa $\left(118^{0}\right.$ ao $146^{\circ}$ dia) na água residuária sintética e nos efluentes dos reatores anaeróio e aeróbio respectivamente. 
Tabela 5.5 - Faixa de variação dos parâmetros monitorados na quinta etapa ( $147^{\circ}$ ao $158^{0}$ dia).

Tabela 5.6 - Faixa de variação dos parâmetros monitorados na sexta etapa $\left(159^{0}\right.$ ao $168^{0}$ dia)

Tabela 5.7 - Faixa de variação dos parâmetros monitorados na sétima etapa ( $169^{0}$ ao $210^{\circ}$ dia) nos reatores anaeróbio e aeróbio.

Tabela 5.8 - Parâmetros monitorados na oitava etapa $\left(211^{\circ}\right.$ ao $245^{\circ}$ dia) nos reatores anaeróbio e aeróbio respectivamente.

Tabela 5.9 - Caracterização da água residuária sintética e dos efluentes dos reatores na fase de transição do sistema de mesofílico para termofilico.

Tabela 5.10 - Faixas de variação dos parâmetros monitorados na primeira etapa termofílica $\left(246^{\circ}\right.$ ao $257^{\circ}$ dia) nos reatores anaeróbio e aeróbio respectivamente.

Tabela 5.11 - Faixas de variação dos parâmetros monitorados na segunda etapa da Fase termofílica $\left(258^{\circ}\right.$ ao $291^{\circ}$ dia) nos reatores anaeróbio e aeróbio respectivamente.

Tabela 5.12 - Faixas de variação dos parâmetros monitorados na terceira etapa da Fase termofílica $\left(292^{0}\right.$ ao $298^{\circ}$ dia) nos reatores anaeróbio e aeróbio respectivamente.

Tabela 5.13 - Parâmetros monitorados na quarta etapa da Fase termofílica $\left(299^{\circ}\right.$ ao $354^{\circ}$ dia) nos reatores anaeróbio e aeróbio.

Tabela 5.14 - Faixa de variação dos parâmetros monitorados na quinta etapa da Fase termofílica $\left(355^{\circ}\right.$ ao $390^{\circ}$ dia) nos reatores anaeróbio e aeróbio respectivamente.

Tabela 5.15 - Organismos predominantes no reator UASB nas três faixas de trabalho selecionadas.

Tabela 5.16 - Organismos predominantes no reator de lodos ativados nas três faixas de trabalho selecionadas.

Tabela 5.17 - NMP: frascos positivos e negativos em relação à produção de metano com inóculos anaeróbio termófilo (reator UASB) e aeróbio termófilo (reator de lodos ativados).

Tabela 5.18 - Microrganismos predominantes no reator UASB nas três faixas de trabalho selecionadas.

Tabela 5.19 - Microrganismos predominantes no reator de lodos ativados nas três faixas de trabalho selecionadas.

Tabela 5.20 - Faixa de variação das eficiências de remoção de DQO obtidas nos reatores biológicos nos diferentes intervalos de temperatura de trabalho....

Tabela 5.21 - Faixa de variação do $\mathrm{pH}$ nos efluentes dos reatores biológicos nos diferentes intervalos de temperatura de trabalho.

Tabela 5.22 - Variação das concentrações de alcalinidade total nos efluentes dos reatores biológicos nos diferentes intervalos de temperatura de trabalho.... 
Tabela 5.23 - Perda de biomassa pelos reatores (mgSSVefluente. $\left.\mathrm{d}^{-1}\right)$......

Tabela 5.24 - Variação das concentrações de sólidos suspensos voláteis e sólidos suspensos total nas diferentes faixas de temperatura operadas.

Tabela 5.25 - Variação das concentrações de AGV nos efluentes dos reatores biológicos nas diferentes faixas de temperatura operadas.

Tabela 5.26 - Variação das concentrações no biogás nas diferentes faixas de temperatura operadas

Tabela 5.27 - Resumo dos dados monitorados na fase mesofilica $\left(37,5^{\circ} \mathrm{C}\right.$ a $\left.42,5^{\circ} \mathrm{C}\right) \ldots \ldots$

Tabela 5.28 - Resumo dos dados monitorados na fase termofilica $\left(52,0^{\circ} \mathrm{C}\right.$ a $\left.57,0^{\circ} \mathrm{C}\right) \ldots \ldots$

Tabela 5.29 - Comparação entre trabalhos com reatores aeróbios e anaeróbios operando em faixa de temperatura mesofilica e termofílica.

Tabela 5.29 - Comparação entre trabalhos com reatores aeróbios e anaeróbios operando em faixa de temperatura mesofilica e termofílica (continuação)

Tabela A1 - Concentrações de DQO nos reatores na fase mesofílica $1^{\mathrm{a}}$ a $2^{\mathrm{a}}$ etapa....... 190

Tabela A2 - Concentrações de DQO nos reatores na fase mesofílica $3^{\mathrm{a}}$ a $4^{\mathrm{a}}$ etapa.......

Tabela A3 - Concentrações de DQO nos reatores na fase mesofílica $5^{\mathrm{a}}$ a $8^{\mathrm{a}}$ etapa

Tabela A4 - Concentrações de DQO nos reatores na fase termofílica $1^{\mathrm{a}}$ a $5^{\mathrm{a}}$ etapa.

Tabela A5 - Valores de efíciência de remoção de DQO monitorados nos reatores na fase mesofilica $1^{\mathrm{a}}$ a $2^{\mathrm{a}}$ etapa.

Tabela A6. - Valores de efíciência de remoção de DQO monitorados nos reatores na fase mesofílica $3^{\mathrm{a}}$ a $4^{\mathrm{a}}$ etapa.

Tabela A7 - Valores de efíciência de remoção de DQO monitorados nos reatores na fase mesofilica $5^{\mathrm{a}}$ a $8^{\mathrm{a}}$ etapa.

Tabela A8 - Valores de eficiência de remoção de DQO monitorados nos reatores na fase termofilica $1^{\mathrm{a}}$ a $5^{\mathrm{a}}$ etapa.

Tabela A9 - Valores de $\mathrm{pH}$ monitorados nos efluentes dos reatores na fase mesofilica: $1^{\mathrm{a}}$ a $6^{\mathrm{a}}$ etapa

Tabela A10 - Valores de $\mathrm{pH}$ monitorados nos efluentes dos reatores na fase mesofílica: $7^{\mathrm{a}}$ a $8^{\mathrm{a}}$ etapa.

Tabela A11 - Valores de $\mathrm{pH}$ monitorados nos efluentes dos reatores na fase termofílica: $1^{\text {a }}$ a $5^{\mathrm{a}}$ etapa.

Tabela A12 - Concentrações de ácidos graxos voláteis nos efluentes dos reatores na fase mesofílica: $2^{\mathrm{a}}$ a $6^{\mathrm{a}}$ etapa.

Tabela Al3 - Concentrações de ácidos graxos voláteis nos efluentes dos reatores na fase mesofílica ( $7^{\mathrm{a}}$ a $8^{\mathrm{a}}$ etapa) e fase termofilica ( $1^{\mathrm{a}}$ a $3^{\mathrm{a}}$ etapa)

Tabela A14 - Concentrações de ácidos graxos voláteis nos efluentes dos reatores na fase termofilica: $4^{\mathrm{a}}$ a $5^{\mathrm{a}}$ etapa. 
Tabela A15 - Concentrações de alcalinidade parcial e total nos efluentes dos reatores na fase mesofilica: $2^{\mathrm{a}}$ a $3^{\mathrm{a}}$ etapa.

Tabela A16 - Concentrações de alcalinidade parcial e total nos efluentes dos reatores na fase mesofílica: $4^{\mathrm{a}}$ a $8^{\mathrm{a}}$ etapa.

Tabela A17 - Concentrações de alcalinidade parcial e total nos efluentes dos reatores na fase mesofilica: $4^{\mathrm{a}}$ a $8^{\mathrm{a}}$ etapa.

Tabela A18 - Concentrações de alcalinidade parcial e total nos efluentes dos reatores na fase termofílica: $1^{\mathrm{a}}$ a $5^{\mathrm{a}}$ etapa.

Tabela A19 - Composição do biogás do reator UASB monitorada na fase mesofílica: $1^{\text {a }}$ a $3^{\text {a }}$ etapa.

Tabela A20 - Composição do biogás do reator UASB monitorada na fase mesofílica: $4^{\mathrm{a}}$ a 8 etapa.

Tabela A21 - Composição do biogás do reator UASB monitorada na fase termofílica: $1^{\mathrm{a}}$ a $5^{\mathrm{a}}$ etapa.

Tabela A22 - Sólidos totais, sólidos totais voláteis e sólidos totais fixos na água residuária sintética e efluente dos reatores anaeróbio e aeróbio: fase mesofilica ( $4^{\mathrm{a}}$ etapa a $8^{\mathrm{a}}$ etapa) e fase termofílica ( $1^{\mathrm{a}}$ etapa).

Tabela A23 - Sólidos totais, sólidos totais voláteis e sólidos totais fixos na água residuária sintética e efluente dos reatores anaeróbio e aeróbio: fase termofilica ( $2^{\mathrm{a}}$ etapa a $5^{\mathrm{a}}$ etapa)

Tabela A24 - Diferença entre o afluente e efluente dos reatores anaeróbio e aeróbio em relação a sólidos totais, sólidos totais voláteis e sólitos totais fixos: fase mesofilica ( $4^{\mathrm{a}}$ etapa a $8^{\mathrm{a}}$ etapa) e fase termofilica ( $1^{\mathrm{a}}$ etapa).

Tabela A25 - Diferença entre o afluente e efluente dos reatores anaeróbio e aeróbio em relação a sólidos totais, sólidos totais voláteis e sólitos totais fixos: fase termofilica ( $2^{\mathrm{a}}$ a $5^{\mathrm{a}}$ etapa)

Tabela A26 - Sólidos suspensos totais e voláteis na água residuária sintética e efluente dos reatores anaeróbio e aeróbio: fase mesofilica ( $4^{\mathrm{a}}$ etapa a $8^{\mathrm{a}}$ etapa) e fase termofilica ( $1^{\mathrm{a}}$ etapa).

Tabela A27 - Sólidos suspensos totais e voláteis na água residuária sintética e efluente dos reatores anaeróbio e aeróbio: fase termofílica ( $2^{\mathrm{a}}$ a $5^{\mathrm{a}}$ etapa)

Tabela A28 - Sólidos suspensos totais e voláteis no licor misto e decantador do reator aeróbio: fase mesofilica ( $4^{\mathrm{a}}$ etapa a $8^{\mathrm{a}}$ etapa) e fase termofilica ( $1^{\mathrm{a}}$ etapa)..

Tabela A29 - Sólidos suspensos totais e voláteis no licor misto e decantador do reator aeróbio: fase termofilica ( $2^{\mathrm{a}}$ a $5^{\mathrm{a}}$ etapa).

Tabela A30 - Diferença entre o afluente e efluente dos reatores anaeróbio e aeróbio em relação a sólidos suspensos totais, sólidos totais voláteis e sólitos totais fixos: fase mesofilica ( $4^{\mathrm{a}}$ a $8^{\mathrm{a}}$ etapa) e fase termofilica ( $2^{\mathrm{a}}$ a $5^{\mathrm{a}}$ etapa). 


\section{LISTA DE ABREVIATURAS, SIGLAS E SÍMBOLOS}
ARS - água residuária sintética
AGV - ácidos graxos voláteis
AOX - halogênios orgânicos adsorvíveis
BRS - bactérias redutoras de sulfato
CS - concentração de saturação
DBO - demanda bioquímica de oxigênio
DLVO - Derjaguin-Landau-Verwey-Overbeek
DP $\quad$ - desvio padrão
DQO - demanda química de oxigênio
ECP - substâncias poliméricas extracelulares (extracellular polymeric substances)
e-UASB - efluente do reator anaeróbio UASB
e-LA - efluente do reator aeróbio de lodos ativados
HMDS - hexametildisilano
kla - coeficiente de transferência de oxigênio
LA - lodos ativados
LNC - licor negro concentrado
LNI - licor negro intermediário
MEV - microscopia eletrônica de varredura
n.d. - não determinado
NMP - número mais provável
OD - oxigênio dissolvido 
SMEWW - Standard Methods for the Examination of Water And Wastewater

SSV - sólidos suspenso voláteis

SSVLM - sólidos suspensos voláteis no licor misto

ST $\quad-$ sólidos totais

STF $\quad-$ sólidos totais fixos

STV - sólidos totais voláteis

SV - sólidos voláteis

$\mathrm{T} \quad-$ temperatura

$\mathrm{TCH} \quad-\quad$ taxa de carregamento hidráulico

TCO - taxa de carregamento orgânico

TRS - tempo de retenção de sólidos

ARS - Água residuária sintética

A/M - Relação entre concentração de matéria orgânica e concentração de microrganismo

UASB - "Upflow Anaerobic Sludge Blanket" (reator anaeróbio de manta de lodo e fluxo ascendente)

$\theta_{\mathrm{H}} \quad$ - tempo de detenção hidráulica 


\section{RESUMO}

CARMO, D. F. (2004). Tratamento biológico termofilico de efluente sintético de polpa celulósica através do processo combinado anaeróbio - cieróbio. São Carlos. 242p. Tese (Doutorado) - Escola de Engenharia de São Carlos, Universidade de São Paulo.

A viabilidade técnica de um sistema termofilico combinado de reatores anaeróbioaeróbio foi avaliada para tratamento de efluente sintético da indústria de pasta de celulose não branqueada. Estas indústrias apresentam efluente com temperatura superior a $40^{\circ} \mathrm{C}$ e o tratamento termofílico pode eliminar a necessidade do resfriamento, necessário para a faixa mesofilica de tratamento, reduzindo custos. Os reatores foram inoculados com lodo mesofílico com gradual adaptação para a condição termofílica. Na faixa mesofilica $\left(37,5^{\circ} \mathrm{C}\right.$ a $\left.42,5^{\circ} \mathrm{C}\right)$ a eficiência do sistema foi de $(69 \pm 3) \%$, com maior eficiência do reator anaeróbio $(56 \pm 7) \%$. Depois que os reatores apresentaram equilíbrio dinâmico aparente, a temperatura foi gradualmente aumentada de $45,0^{\circ} \mathrm{C}$ para $52^{\circ} \mathrm{C}$. As eficiências de remoção de DQO do sistema variaram de $57 \%$ a $88 \%$. A porcentagem de metano no biogás foi decrescendo com o aumento de temperatura, de $77 \%$ para valores abaixo do limite de deteção do método cromatográfico utilizado. A eficiência do reator anaeróbio foi baixa e houve acúmulo de ácidos, principalmente acético. O reator aeróbio apresentou maior eficiência de remoção de DQO porém a concentração no licor misto foi baixa. Após a alteração no tempo de detenção hidráulica dos reatores UASB e de lodos ativados para 24 horas e 8 horas, respectivamente, os reatores operaram em faixa de temperatura de $52^{\circ} \mathrm{C}$ a $57^{\circ} \mathrm{C}$ por 85 dias. As eficiências de remoção de DQO do sistema variaram de $54 \%$ a $70 \%$. A eficiência do reator UASB continuou baixa enquanto o reator aeróbio apresentou bom desempenho, com eficiências variando de $3 \%$ a $35 \%$ e de $43 \%$ a $75 \%$, respectivamente. As concentrações de SSV no licor misto aumentaram, variando de $122 \mathrm{mg} . \mathrm{L}^{-1}$ a $2940 \mathrm{mg} . \mathrm{L}^{-1}$. Em faixa de temperatura termofilica houve predomínio de Methanosctetas sp e bacilos no reator anaeróbio, não havendo diferenciação significativa de morfologias comparando com a fase mesofílica. No reator aeróbio houve diferenciação a partir da temperatura de $42,5^{\circ} \mathrm{C}$ e predominaram bacilos, cocos e filamentos em temperatura termofilica. Os resultados demonstram a viabilidade do tratamento termofilico, mas outros experimentos são necessários antes da aplicação industrial do processo.

Palavras-chave: termofilico, UASB, lodos ativados, efluente, pasta de celulose não branqueada 


\begin{abstract}
CARMO, D. F. (2004). Thermophilic treatment biologic of synthetic effluent from unbleached cellulose pulp through combined system anaerobic-aerobic. São Carlos. 242p. Thesis (Doctorate) - Escola de Engenharia de São Carlos, Universidade de São Paulo.
\end{abstract}

The technical feasibility of a combined thermophilic anaerobic-aerobic biological reactors configuration was evaluated in this work using a synthetic unbleached pulp mill effluent. These industries introduce effluent with temperature greater $40^{\circ} \mathrm{C}$ and the treatment would eliminate the need of cooling that is required for the mesophilic range, reducing the costs. The reactors were inoculated with mesophilic sludge with gradual adaptation to the termophilic condition. In the mesophilic range $\left(37.5^{\circ} \mathrm{C}\right.$ to $\left.42.5^{\circ} \mathrm{C}\right)$ the efficiency of the combined system was $(69 \pm 3) \%$, with the higher efficiency in the anaerobic reactor $(56 \pm 7) \%$. After the reactors reached apparent steady state regime the temperature was gradually increased from $42.5^{\circ} \mathrm{C}$ to $52^{\circ} \mathrm{C}$. The system efficiency ranged from $57 \%$ to $88 \%$. The percentage of methane in the biogas decreased with the increase in temperature, from $77 \%$ to values below the detection limit of the chromatographic measurement used in this work. The anaerobic efficiency was low and the reactor accumulated fatty acid, mostly acetic. The aerobic reactor presented higher efficiency removal of COD but the mixed liquor concentration was lower. After adjustment in the hydraulic retention time of both reactors, with the UASB operating with 24 hours HRT and the aerobic with 8 hours HRT, the reactors operated in the temperature range of $52^{\circ} \mathrm{C}$ to $57^{\circ} \mathrm{C}$ during 85 days. The overall removal efficiency ranged from $54 \%$ to $70 \%$. The efficiency of the UASB reactor remained lower while the aerobic reactor presented good performance, with COD removal efficiency in the range of $3 \%$ to $35 \%$, respectively. The mixed liquor VSS concentration increased with the increase in temperature from $122 \mathrm{mg} . \mathrm{L}^{-1}$ to $2940 \mathrm{mg} . \mathrm{L}^{-1}$. In thermophilic temperature there was predominance of Methanosaetas sp and baccilus in the anaerobic reactor, without significant differentiation of morphology in comparison with the mesophilic temperature. In the aerobic reactor there was differentiation in temperature of $42.5^{\circ} \mathrm{C}$ and baccilus, cocus and filamentous predominated in the thermophilic temperature. These results indicated the feasibility of the thermophilic treatment but other experiments are needed before industrial application of this process.

Keywords: thermophilic, UASB, activated sludge, industrial wastewater, unbleached pulp wastewater 



\section{INTRODUÇÃO}

"Aquilo que se começa está metade feito". (Jorácio, poeta latino-65-8 a.c)

O papel para escrever surgiu no Egito, entre os séculos XXV e XX a.C, confeccionado a partir de tiras de juncos compridos (papiros), que cresciam ao longo do Nilo, sendo as tiras coladas com goma. No século II d.C., os chineses inventaram um processo de fabricação de papel a partir de bambu e algodão (celulose quase pura), processo que só foi introduzido na Europa no século XIII (MAIA, 2001).

Segundo Maia (2001) com a invenção da imprensa, a procura por papel aumentou e trapos (algodão e linho) forneciam a fibra celulósica. A partir do século XIX a máquina foi introduzida no processo de fabricação do papel e os trapos foram substituídos por madeira. O cilindro e as máquinas de "Fourdrinier" transformaram a fabricação do papel numa indústria de processo contínuo. A partir daí foram desenvolvidos vários processos mecânicos e químicos para produção da pasta celulósica. Atualmente, o processo com sulfato (Kraft) é o predominante, com incidência superior a 75\%; seguido pelos processos mecânicos e termomecânicos (cerca de $10 \%$ ), os processos com sulfito $(8 \%)$, sendo a porcentagem restante de processos mistos.

Os maiores produtores e também consumidores de papel são os países desenvolvidos. Os EUA, Japão e Canadá respondem por cerca de $47 \%$ da produção mundial, sendo que os EUA, Japão e Alemanha consomem $50 \%$ de todo o papel produzido. O Brasil ocupa o $11^{\circ}$ lugar entre os países produtores e o $12^{\circ}$ entre os consumidores de papel (BNDES, 2003).

Considerando a exportação, o Brasil já se situa como um dos três maiores fornecedores mundiais de papel para imprimir e escrever não revestido, à base de 
celulose. Em 1995, o Brasil exportou 720 mil toneladas, o que significou 40\% da produção nacional desse tipo de papel. Quanto à exportação de celulose sulfato branqueada, o Brasil ocupa a quarta posição. Considerando a fibra curta, o Brasil é o $2^{\circ}$ maior exportador e o primeiro no caso do eucalipto, detendo $45 \%$ das vendas dessa fibra (BNDES, 2003).

Para exemplificar, na Figura 1.1 são apresentados os destinos e as porcentagens das exportações de papel do Brasil no ano de 1995.

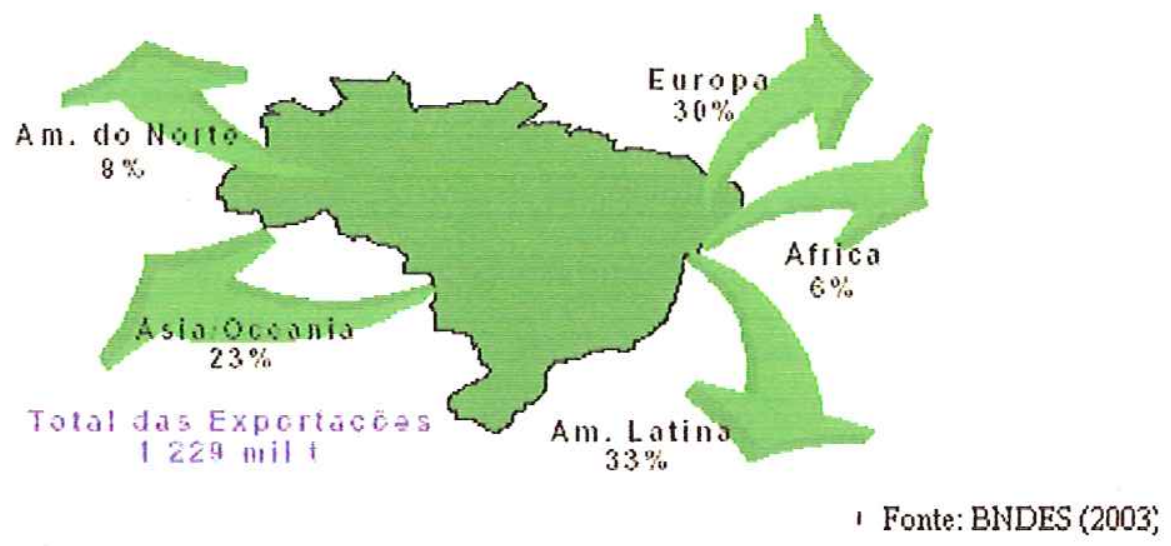

FIGURA 1.1. Destino das exportações brasileiras no ano de 1995.

Nesse mercado das indústrias de papel e celulose a competição é feita pelo preço e qualidade, sendo que a diferenciação do produto torna-se cada vez mais relevante. Nos últimos anos, esse processo de diferenciação foi acelerado e também houve criação de novos produtos, além de algumas inovações na tecnologia do processo e uso intensivo de sistemas computadorizados para controle de toda a produção.

Outro aspecto que vem se tornando cada vez mais relevante, é a qualidade ambiental resultante do processo de fabricação, com a pressão exercida em três vetores: exigência de produtos que não agridam o meio ambiente, deslocamento de matériaprima de origem florestal por reciclável e uso de tecnologias limpas (BNDES, 2003).

Essa pressão para controle ambiental é justificada, visto que, historicamente, as indústrias de polpa e papel têm sido consideradas como as maiores consumidoras de recursos naturais (madeira e água) e de energia (combustíveis fósseis, eletricidade), além de contribuírem significativamente para as descargas de poluentes no ambiente (THOMPSON et al., 2001). 
Em relação ao consumo de água, o volume utilizado varia de acordo com o tipo de papel produzido, podendo atingir valores elevados até com as mais modernas e eficientes técnicas operacionais, as quais incluem reciclagem de alguma parte da água.

Em alguns processos de fabricação, podem ser utilizados até 60 metros cúbicos de água por tonelada de papel produzido (AHN \& FORSTER, 2002).

Assim, o tratamento da água residuária com a possibilidade de seu reúso parcial ou até mesmo total, com o menor custo, é de grande interesse, tanto em relação à economia na produção quanto em relação à proteção do meio ambiente, visto que implica em menores impactos tanto pela poluição, quanto pelo consumo.

De acordo com Maia (2001), os efluentes dessas indústrias, principalmente de pasta, contêm substâncias orgânicas dissolvidas e sólidos suspensos (fibras, cascas, etc.) que, lançados nos cursos de água, levam a geração de lodo e podem desoxigenar o ambiente. Estima-se que o efluente de uma fábrica de pasta de celulose, sem tratamento, equivale ao esgoto de uma cidade de um milhão de habitantes.

Nos últimos anos, as indústrias vêm buscando "melhorar a qualidade" de seu efluente: tem-se generalizado o tratamento de efluentes líquidos ao nível secundário, as reciclagens internas vêm se intensificando, as filtrações têm se tornado mais eficazes, o branqueamento tem deixado de ser feito à base de cloro, a fím de evitar a produção de organoclorados e a produção de dioxinas também passou a ser objeto de preocupação.

Além disso, a publicação de índices de emissão de sólidos suspensos, demanda bioquímica de oxigênio (DBO) e halogênios orgânicos adsorvíveis (AOX) tornou-se comum por parte das empresas.

Considerando-se o tratamento secundário das águas residuárias industriais, a digestão anaeróbia é um processo freqüentemente empregado, mas não tão utilizado quanto o processo de lodos ativados nas indústrias de polpa e papel (AHN \& FORSTER, 2002 b).

Entretanto, An et al. (1996), baseando-se em resultados de experimentos, concluíram que o sistema anaeróbio-aeróbio mesofilico apresenta resultados melhores que os tratamentos realizados apenas por um dos processos. De acordo com os autores, o processo anaeróbio apresenta um papel essencial nas remoções de cor e demanda química de oxigênio (DQO), melhorando também a capacidade de biodegradação em termos da relação $\mathrm{DBO}_{5} / \mathrm{DQO}$, gerando assim um efluente com melhores características para ser tratado sob condições aeróbias. 
Dados típicos de remoção de DQO dos efluentes da indústria de papel utilizando tratamento anaeróbio mostram eficiência de remoção de DQO relativamente constante, cerca de $80 \%$, sendo que o efluente gerado apresenta DQO em torno de $800 \mathrm{mg} . \mathrm{L}^{-1}$. Essa DQO remanescente significa que alguma forma adicional de tratamento é requerida (THOMPSON et al., 2001). Assim, a utilização de um sistema combinado anaeróbio-aeróbio é, em princípio, indicada.

Contudo, para implementação do tratamento biológico das águas residuárias dessas indústrias, há necessidade de resfriamento, visto que são normalmente lançadas em temperatura superior a $40^{\circ} \mathrm{C}$.

A possibilidade de reduzir ou eliminar o resfriamento necessário, bem como a possibilidade de velocidades de reação mais rápidas (menores equipamentos), têm levado a grandes esforços para determinar a viabilidade de operação de biorreatores de lodos ativados em altas temperaturas (BARR et al., 1996), visto que processos anaeróbios termofilicos têm demonstrado potencial, ao menos em escala de laboratório, para tratamento de águas residuárias.

De acordo com Rintala \& Lepisto (1997), alguns resultados de tratamento anaeróbio termofilico em escala piloto para o tratamento de águas residuárias industriais têm sugerido a viabilidade do processo, podendo ser citados os seguintes exemplos: vinhaça (SOUZA et al., 1992); cervejaria (OHTSUKI et al., 1994), indústrias processadoras de vegetais (RINTALA \& LEPISTO, 1997).

A priori, o tratamento aeróbio termofilico apresenta vantagens que incluem altas velocidades de biodegradação, baixa produção de lodo e excelente estabilidade do processo, além do tratamento sem resfriamento da água residuária e sem perda do desempenho do reator. As velocidades de utilização do substrato reportadas na literatura técnica são três a dez vezes maiores que as observadas em processos mesofílicos análogos e as velocidades de produção do lodo são, geralmente, similares aos processos de tratamento anaeróbio (LAPARA \& ALLEMAN, 1999).

Além disso, recentes estudos têm revelado que as velocidades de biodegradação têm se mantido constantes em uma ampla faixa de temperatura, de $25^{\circ} \mathrm{C}$ a $65^{\circ} \mathrm{C}$ (LAPARA \& ALLEMAN, 1999).

Analisando o efluente das indústrias de papel e celulose, Vogelaar et al. (2002) consideraram o tratamento aeróbio termofílico viável para aplicação nessas indústrias, sendo a alta turbidez efluente, maior desvantagem citada na literatura, provavelmente compensada pelo ganho de energia no processo sob condições termofílicas. 
De acordo com Kortekaas et al. (1995), durante a última década, a tecnologia de tratamento anaeróbio também tem sido aplicada com sucesso para vários tipos de efluentes da indústria de polpa e papel.

Logo, considerando-se as várias vantagens citadas para sistemas combinados, bem como para processos termofílicos, um estudo da viabilidade da associação desses processos de tratamento seria de grande interesse para a indústria de papel e celulose, sob diversos aspectos.

Assim, a realização deste trabalho visou verificar a viabilidade do sistema combinado de reatores, anaeróbio seguido pelo aeróbio, em escala de laboratório e faixa de temperatura termofilica, para tratar um efluente que simulava a água residuária da indústria de pasta de celulose não branqueada. 


\section{OBJETIVOS}

"Nunca fazemos bem alguma coisa enquanto näo paramos para
pensar na maneira de fazê-la."
(Wilfian Hazlitt, escritor inglês - 1778-1830)

\subsection{Objetivo Geral}

$\checkmark$ Esse trabalho teve como objetivo principal verificar a viabilidade do tratamento de efluente da indústria de pasta de celulose não branqueada, utilizando-se um sistema combinado de reatores (anaeróbio/aeróbio) operando em faixa de temperatura termofilica.

\subsection{Objetivos Especificos}

$\checkmark$ Adaptar inóculos mesofílicos anaeróbio e aeróbio para operarem em condições de temperatura termofilica;

$\checkmark$ Avaliar a possível variação dos parâmetros físico-químicos e microbiológicos durante a adaptação à temperatura, comparando-se os desempenhos nas faixas mesofilica e termofilica;

$\checkmark$ Comparar o desempenho dos reatores inoculados com lodo mesofilico operando com aumentos gradual e repentino da temperatura;

Verificar o desempenho das configurações de reatores escolhidas neste trabalho para operação sob condições termofillicas. 


\section{REVISÃO DE LITERATURA}

"Senfuma cultura pode sobreviver quando se pretende exclusiva"

Mafiatma Gandfii (1869-1948)

\subsection{A questão da água e sua relação com o tratamento de efluentes na indústria de papel e celulose}

Os processos industriais e tecnológicos que passaram a utilizar os recursos naturais em escalas cada vez maiores, bem como o elevado crescimento da população humana, têm provocado, ao longo do tempo, graves danos aos sistemas naturais (FIGUEROA, 1996).

A água é um exemplo de recurso natural que vem sofrendo degradação contínua. Por muitos séculos foi considerada inesgotável e explorada sem limites pelo homem, sendo que o seu consumo é, muitas vezes, proporcional aos crescimentos industrial, agrícola e populacional (FALKENMARK, 1997; CORSON, 1996).

A escassez futura de água tenderá a limitar o crescimento na agricultura e indústria, e poderá por em risco a nutrição, a saúde e desenvolvimento econômico. Essa escassez pode resultar de uma série de fatores, incluindo fontes limitadas, grandes demandas e uso irracional (CORSON, 1996).

Para prevenir a falta de água, as nações devem gerenciá-la com mais eficiência, introduzir a reciclagem, prevenir a poluição e promover a conservação desse recurso, renovável, porém com reservas limitadas (FALKENMARK, 1997; CORSON, 1996).

Springer (1993), em contrapartida, acredita que há água disponível para o consumo humano em quantidade suficiente para suprimento no futuro. Entretanto, o autor reconhece que o problema será o de manter sua qualidade boa o suficiente para satisfazer as necessidades humanas para agricultura, abastecimento, recreação e para processos industriais. 
Assim sendo, converge-se para o mesmo fím: a água deve ter seu uso racionalizado, conciliando-se a conservação do ambiente com o progresso tecnológico.

Logo, o sistema econômico também deve se adaptar às limitações do meio ambiente, incorporando os custos ambientais decorrentes de sua exploração (FIGUEROA, 1996).

Segundo Souza (1997), para que seja atingida ou mantida a qualidade desejada do recurso, é preciso existir um sistema de gestão com suporte legal, onde estejam definidas as atuações dos envolvidos com a questão.

No caso da água, uma das estratégias de gerenciamento é a cobrança pelo seu uso e disposição, mesmo por usuários que possuam seu próprio sistema de captação, tratamento e disposição de água servida. Para o setor industrial, essa estratégia pode levar a um aumento do custo do produto final, visto que a água pode ser utilizada de diferentes formas no processo de produção (SOUZA, 1997):

- na fabricação de produtos como bebidas e alimentos;

- durante o processo de produção, para por exemplo, resfriar caldeiras ou como água para refrigeração;

- complementarmente ao processo de fabricação em diversos fins, como higiene dos operários, limpeza de equipamentos, prevenção e controle de incêndios.

Nos EUA, programas e políticas efetivas de limpeza dos corpos hídricos fornecem incentivos à reciclagem da água usada nas indústrias, o que, além de economizá-la, também reduz a poluição (CORSON, 1996).

A reutilização da água poderia melhorar em muito a eficiência em seu uso, sendo que a reciclagem industrial pode causar uma diferença radical no uso de água de uma região (CORSON,1996). De acordo com Wri \& $\operatorname{Iied}^{1}$ (1987) apud Corson (1996), esse fato já foi comprovado por algumas indústrias que conseguiram inclusive, economizar capital. Estes autores, citam como exemplo, as indústrias de papel na Suécia, que, utilizando a recirculação, cortaram o consumo de água pela metade, dobrando, ao mesmo tempo, a produção.

De acordo com Springer (1993), as indústrias de papel e celulose ocupam a terceira posição em termos de retirada de água e a quinta posição em relação à contribuição para o problema de poluição da água.

Deve-se considerar que essas indústrias estão em franco processo de crescimento, podendo contribuir cada vez mais para o processo de degradação da água. 
Segundo o BNDES (2003), a produção e o consumo mundial de papel vêm crescendo há mais de quinze anos. A taxa média verificada na década de 80 , para o crescimento da demanda mundial, foi de $3,6 \%$ a.a. e de 3,3\% a.a. para o período 1990/95. A perspectiva para o horizonte 1995/2005 é que essa taxa seja mantida.

Assim, tecnologias que visam a racionalização do uso de água, bem como a minimização do lançamento de efluentes pelas indústrias de papel e celulose, apresentam elevada importância.

Para o tratamento efetivo desses efluentes exige-se o conhecimento de sua composição e a escolha da melhor forma de tratamento a ser aplicada.

\subsection{Efluentes gerados pelas indústrias de papel e celulose no processo de fabricação}

O estudo e o controle dos efluentes dessa indústria, têm sido objeto de consideráveis esforços, em pesquisas realizadas em todo o mundo, durante as últimas décadas (IONESCU \& MORO, 1989).

Segundo Rezende et al. (2000), a natureza e a composição do efluente das indústrias de papel e celulose encontram-se bem documentadas em termos de parâmetros de controle da poluição, mas as quantidades e as concentrações dos efluentes de cada indústria variam de acordo com os tipos de processos utilizados e práticas operacionais, bem como o grau de reuso da água.

Logo, a composição dos efluentes dos processos de polpação e branqueamento é complexa porque depende de vários fatores, como: a fonte de madeira, a química do processo de branqueamento, o grau de fechamento de circuito, o controle de derrames, o sistema de coleta e manejo dos condensados, as substâncias adicionadas no processo, a carga orgânica que entra na planta de branqueamento (grau de deslignificação), o tipo de tratamento do efluente e a eficiência obtida, bem como das instabilidades no processo (REZENDE et al., 2000).

Assim, as indústrias de papel e celulose diferem em tamanho, tipo de matéria prima processada, processos industriais e produtos finais.

Os vários setores da indústria geram efluentes que são misturados antes do tratamento, produzindo o efluente geral ou efluente combinado. Essa mistura normalmente é composta pelo licor da polpação, a água de lavagem da polpa, o efluente da planta de branqueamento e, no caso de indústrias integradas ${ }^{2}$, o efluente da máquina de papel (REZENDE et al., 2000).

\footnotetext{
${ }^{2}$ Indústrias integradas são aquelas que no mesmo local produzem a polpa e o papel.
} 
As características gerais do efluente da indústria de polpa e papel podem ser listadas como: alto conteúdo de lignina; elevada concentração de halogênios orgânicos adsorvíveis (AOX) devido ao uso de cloro e compostos de cloro no processo de branqueamento; cor; baixa biodegradabilidade (é indicada pela alta relação entre as demandas química e bioquímicade oxigênio - DQO/DBO), freqüentemente na média de quatro a seis; além de potenciais problemas de toxicidade (TEZEL at al., 2001).

No trabalho de Sierra-Alvarez (1990) é apresentado um fluxograma com as principais etapas na produção da polpa celulósica e do papel e as fontes pontuais de água residuária (Figura 3.1). Deve-se considerar que a madeira, um dos materiais brutos mais utilizados na indústria de polpa, é composta por fibras de celulose, carboidratos como o amido e açúcares, bem como lignina que atua como uma substância adesiva para as fibras de celulose.

A indústria de polpa separa a celulose das substâncias não celulósicas. $\mathrm{O}$ material então é dissolvido quimicamente para formar a polpa celulósica (THOMPSON et al., 2001).

De acordo com Maia (2001), a pasta formada não é apenas matéria-prima da indústria do papel, sendo também utilizada por outras indústrias: fabricação de seda artificial; ésteres e éteres de celulose; nitrato de celulose (indústrias de plásticos e explosivos).

No processo Kraft, o licor negro ou lixívia negra é formado juntamente com a pasta crua de celulose, durante o processo de digestão da madeira, em temperatura de aproximadamente $180^{\circ} \mathrm{C}$, na presença de hidróxido de sódio e sulfeto de sódio em solução aquosa (licor branco). O licor negro formado possui um teor de sólidos de $14 \%$ a $17 \%$, sendo chamado de licor negro fraco - LNF. É composto por materiais dissolvidos resultantes da solubilização da madeira e pelos resíduos dos produtos utilizados no tratamento, após seu cozimento em um digestor (UC, 2003).

O licor negro apresenta altas demandas bioquímica e química de oxigênio e também alta concentração de sólidos totais, juntamente com compostos lignínicos de baixa degradabilidade, os quais são significativamente tóxicos para o ambiente (GROVER et al., 1999). Estes autores caracterizaram amostras de licor negro de indústria de celulose. As amostras apresentaram altas concentrações de sólidos (totais, suspensos e dissolvidos totais) e de lignina, alto $\mathrm{pH}$ e baixa concentração de ácidos voláteis. 


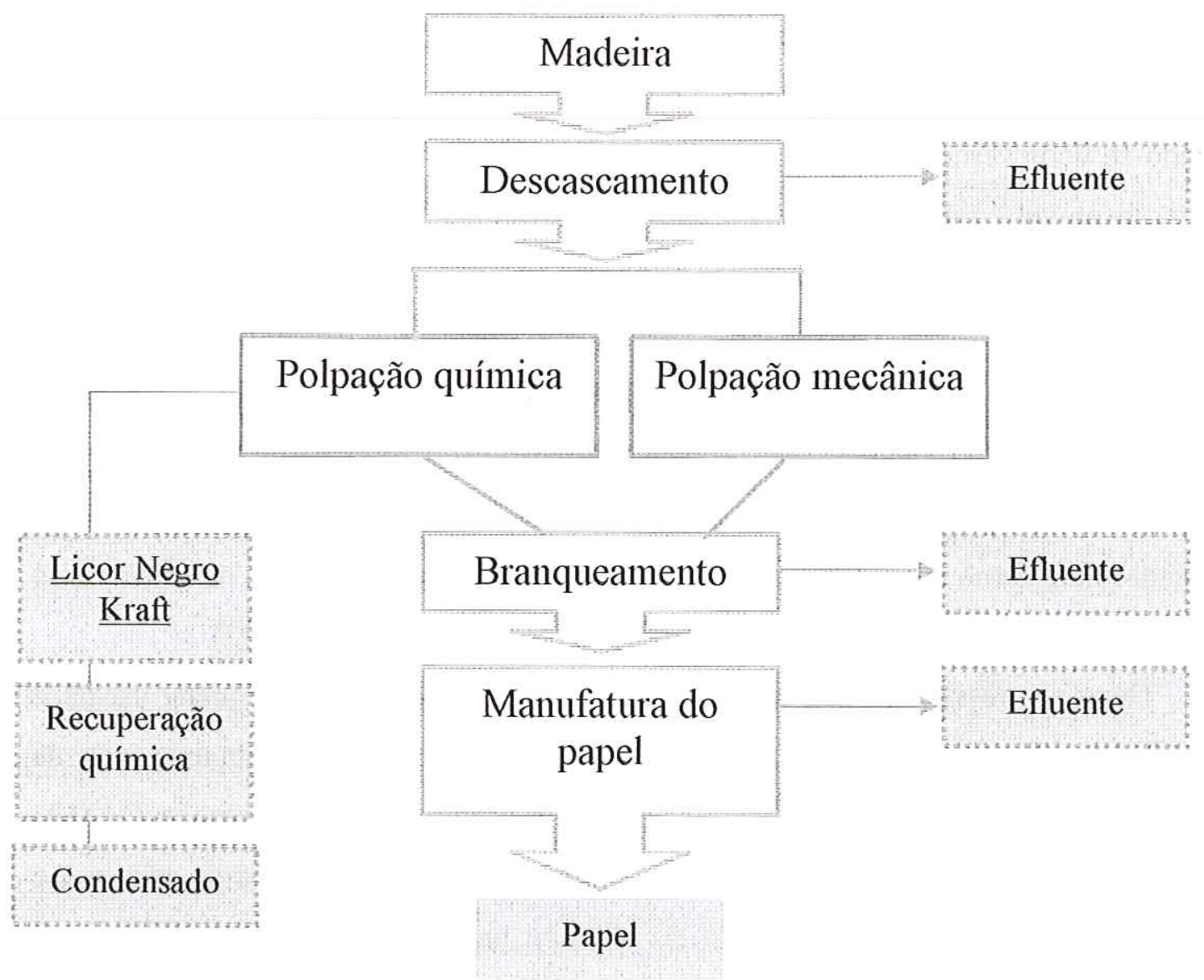

FIGURA 3.1. Principais pontos de lançamento de efluentes de indústrias de papel e celulose. Fonte: Modificada de Sierra-Alvarez (1990).

O licor negro constitui somente $10 \%$ a $15 \%$ das águas residuárias totais das indústrias de celulose, sendo sua maior parte recuperada quimicamente, porém contribuindo mesmo assim, com aproximadamente $95 \%$ da poluição global do efluente (RANGAN ${ }^{3}, 1987$ apud GROVER et al., 1999).

A recuperação química de algumas substâncias utilizadas na primeira etapa da formação da polpa de celulose, pode ser feita após a separação do licor negro fraco da pasta formada, sua concentração por evaporação, formando-se o licor negro forte e concentrado (LNC). Este licor apresenta um teor de sólidos de aproximadamente $65 \%$ e é queimado na caldeira de recuperação. Nesse ponto do processo, os materiais combustíveis do licor negro são utilizados para produzir vapor e gerar energia necessária à produção de pasta (UC, 2003). 
Os sais de sódio presentes no licor negro, por ação do calor gerado na combustão, dão origem à massa fundente (o smelt), formada essencialmente por carbonato e sulfeto de sódio. O smelt é dissolvido em licor branco fraco ou em água, obtendo-se licor verde, cuja coloração é devida à presença de impurezas de ferro. A matéria insolúvel é removida e o licor clarificado resultante é submetido ao tratamento com cal viva (óxido de cálcio) em reator (apagador), onde se forma hidróxido de cálcio.

No apagador, além da reação de apagamento, inicia-se a reação de caustificação que se completa nos caustificadores, obtendo-se hidróxido de sódio solúvel e carbonato de cálcio precipitado (lamas de cal). Após a separação da mistura, resulta o licor branco clarificado (solução de $\mathrm{NaOH}$ ) que é enviado para o digestor. As lamas resultantes são calcinadas num forno após desidratação e espessamento formando óxido de cálcio. Está assim fechado o ciclo de recuperação dos componentes do licor (UC, 2003).

Deve ser ressaltado que a recuperação desses produtos em pequena escala é inviável, pelo alto custo operacional. Dessa forma, o licor negro representa uma fonte de poluição muito importante em países onde pequenas indústrias são comuns (MAIA, 2001; GROVER et al., 1999). Assim, para pequenas indústrias de polpa de celulose, é necessário um processo de tratamento do efluente menos onerosa (DANGCONG \& QITING, 1993).

Recentemente, no Brasil, houve o vazamento de licor negro de um reservatório da Indístria Cataguases de Papel e Celulose, na Zona da Mata Mineira. Esse derrame atingiu o corpo hídrico de trinta e nove municípios no estado de Minas Gerais e oito municípios no norte do estado do Rio de Janeiro, em uma extensão de $50 \mathrm{Km}$. A priori, foi considerado o maior desastre ecológico registrado em água doce no Brasil (GEOTRACK, 2003).

Em linhas gerais, considerando-se o efluente bruto de uma indústria de celulose Kraft branqueada, as concentrações de $\mathrm{DBO}_{5}$ variam de $250 \mathrm{mg} \cdot \mathrm{L}^{-1}$ a $400 \mathrm{mg} . \mathrm{L}^{-1}$, as concentrações de DQO de $400 \mathrm{mg} . \mathrm{L}^{-1}$ a $1350 \mathrm{mg} \cdot \mathrm{L}^{-1}$ e os sólidos em suspensão geralmente tendem a variar de $20 \mathrm{mg} . \mathrm{L}^{-1}$ a $400 \mathrm{mg} . \mathrm{L}^{-1}$, podendo atingir até $1000 \mathrm{mg} . \mathrm{L}^{-1}$, dependendo da operação da fábrica. Se, no branqueamento, o composto utilizado for à base de cloro (cloro molecular ou dióxido de cloro), nos efluentes destas indústrias podem estar presentes grandes variedades de compostos organoclorados, altamente tóxicos (REZENDE et al., 2000). 
Também deve ser lembrado que, além da carga orgânica elevada e de poluentes presentes, os efluentes das indústrias de papel e celulose apresentam-se normalmente acima da temperatura ambiente.

Assim, o lançamento direto desses resíduos em rios, além dos problemas de contaminação e possível eutrofização do manancial, pode causar aumento da taxa metabólica dos organismos do rio, aumentando a demanda por oxigênio e a menor solubilidade do oxigênio em alta temperatura pode agravar o problema e provocar mudança na população presente nesses rios. Além disso, se não houver turbulência suficiente para efetuar uma mistura completa e uniforme da temperatura no corpo hídrico, pode ocorrer também choque térmico nos organismos que passarem pela área de descarte do efluente.

Logo, as indústrias de celulose, pelo grau de impacto que podem representar para o meio ambiente, estão sob foco e pressão ambientalista. Para se adequarem à legislação ambiental cada vez mais rígida, e também visando diminuir o custo energético de produção, muito esforço tem sido gasto nos últimos anos para reduzir o consumo de água por unidade de polpa, bem como recircular a água nos processos de fabricação, buscando zerar o efluente lançado, fechando os sistemas de água dessas indústrias (VOGELAAR et al., 2002; PATRICK et al., $1994^{4}$ apud TRIPATHI \& ALLEN, 1999; SPRINGER, 1993).

\subsection{Sistemas de tratamento de efluente usualmente utilizados em indústria de papel e celulose}

Em relação ao tratamento de efluentes muito se evoluiu e muitos investimentos têm sido realizados, sendo que nos últimos anos têm se generalizado o tratamento no nível secundário. As novas tecnologias implantadas, muitas vezes resultam em menor descarte de efluente, que pode ser tratado por diferentes processos físicos e químicos, utilizando-se, por exemplo, sedimentadores ou flotadores, bem como tratamento biológico.

Os processos de tratamento convencionais para os efluentes da indústria de polpa e papel são: precipitação química, lagoas de estabilização, tratamento anaeróbio e lodos ativados ou várias modificações desse processo. O principal sistema de tratamento utilizado nessas indústrias, consiste na clarificação primária sucedida por tratamento secundário, geralmente de natureza biológica. Dos numerosos processos de tratamento 
biológico disponíveis, o de lodos ativados é o mais utilizado pelas indústrias de papel e celulose. Quando os problemas econômicos e a taxa de tratamento são considerados, o tratamento anaeróbio pode oferecer uma opção viável para essas águas residuárias (THOMPSON et al., 2001; TEZEL et al., 2001; SPRINGER, 1993).

Deve ser considerado porém, que para utilização de ambos os processos, tanto anaeróbio, quanto aeróbio, há necessidade do resfriamento dessas águas residuárias, normalmente lançadas em temperatura superior a $40^{\circ} \mathrm{C}$.

Processos terciários para tratamento adicional ou remoção da cor são raros, mas podem tornar-se mais comuns no futuro, quando a legislação tornar-se mais rigorosa (THOMPSON et al., 2001).

\subsection{Tratamento biológico da água residuária das indústrias de papel e celulose}

Toda água residuária gerada pelas indústrias de papel e celulose é suscetível ao tratamento biológico (SPRINGER, 1993). Entretanto, em relação à água residuária algumas características devem ser consideradas.

Os efluentes dessas indústrias são tradicionalmente deficientes em nitrogênio e em fósforo. Assim, para o tratamento biológico desse efluente há necessidade de suplementação desses nutrientes (SPRINGER, 1993).

Segundo Saunamäki (1997), um custo mais eficaz de um sistema de tratamento da água residuária das indústrias de papel e celulose parece ser a combinação de tratamento biológico anaeróbio e aeróbio.

De maneira geral, se determinada água residuária é passível de ser tratada por processo aeróbio, ela o será pelo processo anaeróbio também (FORESTI, 1987).

Entretanto, ao longo dos anos, sistemas anaeróbios e aeróbios têm sido concorrentes para o tratamento direto de águas residuárias das mais variadas características.

Recentemente, vem se difundindo a idéia de que ambos os processos possuem vantagens e desvantagens e que, ao invés de se contraporem, ambos poderão ser utilizados combinados, aproveitando-se melhor as vantagens que cada um oferece (CAMPOS, 1999).

O uso combinado de reatores anaeróbios e aeróbios apresenta-se com grande potencial prático para o polimento ou pós-tratamento de águas residuárias, incluindo não somente o tratamento complementar da matéria orgânica, como também, a remoção 
de outros poluentes, quando necessário. No reator anaeróbio ocorre a remoção da maior parte da matéria orgânica, ficando o remanescente para o reator aeróbio (CAMPOS, 1999).

Segundo Campos (1999), algumas vantagens específicas desse sistema combinado, quando comparado com sistema apenas aeróbio são: redução do volume total dos tanques; eliminação do digestor do lodo porque a digestão ocorre no próprio reator UASB; geração de menor volume total de lodo estabilizado, facilitando o manuseio para a disposição final, diminuindo a demanda de oxigênio e energia para o tanque aeróbio e eliminando a necessidade de dimensionar os aeradores pela demanda máxima de oxigênio, devido ao papel de equalização do UASB. Assim, diminuiriam significativamente as desvantagens atribuídas ao reator aeróbio, porque seriam reduzidos os custos de energia, o volume do tanque e a produção de lodo excedente.

Logo, o sistema anaeróbio-aeróbio é utilizado quando se deseja obter um efluente com alta qualidade, sendo que a maior parte da remoção caberia ao reator anaeróbio, ficando o remanescente para o aeróbio.

Considerando que o tratamento de efluentes da indústria de pasta de celulose freqüentemente emprega o reator de lodos ativados, deve ser ressaltado que, de acordo com Von Sperling et al. (2001), recentemente, a opção da utilização destes reatores como pós tratamento de efluentes de reatores anaeróbios passou a ser pesquisada e utilizada em função de inúmeras vantagens, principalmente associadas ao menor consumo de energia elétrica e à menor produção de lodo.

O uso dos reatores UASB e de lodos ativados combinados é uma alternativa promissora e está começando a ser implantada em escala real (VON SPERLING et al., 2001).

Tradicionalmente, as indústrias de papel e celulose empregam o tratamento biológico com bons resultados, tanto pela utilização de reatores anaeróbios quanto de aeróbios. Em escala real, normalmente, o sistema combinado não é utilizado.

Nos países nórdicos, o lodo ativado é o sistema mais freqüentemente aplicado para essas indústrias (SAUNAMÄKI, 1997).

De acordo com Thompson et al. (2001), dois aspectos operacionais são críticos para as estações de lodos ativados: a manutenção de uma concentração de oxigênio dissolvido aceitável nos tanques de aeração e a manutenção de boas características de sedimentação do lodo. 
A baixa sedimentação do lodo ("bulking") tem causado problemas operacionais desde a década de 1920 (MORGAN \& BECK, $1928^{5}$ apud THOMPSON et al., 2001) e estações de tratamento por lodos ativados tratando efluente das indústrias de papel e celulose parecem ser particularmente propensas a apresentar este problema (THOMPSON et al., 2001).

$\mathrm{O}$ aumento do reuso das águas de processo, a disponibilidade limitada e/ou os altos custos de manutenção de equipamentos de resfriamento, os abastecimentos limitados de água doce e a redução da acessibilidade do resfriamento através da diluição direta do efluente têm despertado o interesse na operação dos reatores de lodos ativados em faixa de temperatura termofilica (BARR et al., 1996).

Embora um sistema de lodos ativados possa operar eficientemente em alta temperatura, é igualmente importante a habilidade do sistema permanecer estável e viável durante períodos curtos de fechamento e/ou perturbações quando a temperatura poderá oscilar, caindo substancialmente e retornando aos níveis anteriores rapidamente. Isto porque reatores de lodos ativados tratando efluentes industriais, podem ser submetidos a rápido resfriamento e reaquecimento em circunstâncias não usuais. A tolerância a mudanças radicais na temperatura e rápida retomada da eficiência de tratamento aceitável é um pré-requisito para o sucesso da implementação do tratamento termofilico aeróbio na indústria (BARR et al., 1996).

Considerando-se a aplicação do tratamento anaeróbio para efluentes da indústria de polpação química, a dificuldade é atribuída à toxicidade dessas águas residuárias às arqueas metanogênicas (KORTEKAAS et al., 1995).

A concentração que causa $50 \%$ de inibição da atividade metanogênica está na média de 2 gDQO.L $\mathrm{L}^{-1}$ a 8 gDQO. $\mathrm{L}^{-1}$ para licor negro de soda e efluente da polpação quimiotermomecânica (SIERRA-ALVAREZ, 1994). Vários fragmentos de baixas massas moleculares da lignina também podem estar envolvidos nas características inibitórias destas águas residuárias (SIERRA-ALVAREZ \& LETTINGA, 1991).

A toxicidade metanogênica da fração de resina é atribuída à característica lipofilica dos extrativos. Compostos lipofílicos tendem a acumular nas membranas das células microbianas, afetando, conseqüentemente, as proteínas presentes na membrana, bem como sua função de barreira (SIKKEMA et al., 1994), mudanças que resultam na redução da atividade metabólica (KORTEKAAS et al., 1995). 
Além disso, de acordo com os resultados obtidos com a variação na taxa de carregamento orgânico, Grover et al. (1999) concluíram que o licor negro em altas concentrações é tóxico ao tratamento anaeróbio e que para ser tratado na indústria, necessita ser diluído com efluentes gerados em outros estágios do processo de fabricação, antes de ser submetido ao tratamento.

Porém, Kortekaas et al. (1995), baseados em outros autores, alegam que esses extrativos vegetais, não degradados sob condições anaeróbias, são degradados em tratamentos aeróbios, havendo assim a possibilidade de desintoxicação durante o póstratamento aeróbio.

O ąlto conteúdo de enxofre nos efluentes das indústrias de polpa e papel também parece sugerir que o tratamento anaeróbio não deveria ser uma opção apropriada devido a potencial produção de gás sulfídrico (LETTINGA et al., 1991).

Contrapondo-se a algumas das observações acima, na última década, a tecnologia de tratamento anaeróbio tem sido aplicada, com sucesso, para vários tipos de efluentes da indústria de polpa e papel (KORTEKAAS et al., 1995).

Além disso, o uso de processos anaeróbios nas águas residuárias das indústrias de papel e celulose é desejável, visto que, organoclorados, se presentes, podem ser tratados devido a potencialidade desses processos em tratar muitas águas residuárias contendo tais substâncias orgânicas e compostos fenólicos, refratários sob condições aeróbias (GUAGLIANONI et al., 1998; VOCHTEN et al.;1988 apud An et al.; 1996; BUZZINI, 2000).

Outro ponto importante a ser considerado é que normalmente o tratamento biológico é feito na faixa de temperatura mesofilica, de $30^{\circ} \mathrm{C}$ a $40^{\circ} \mathrm{C}$, apresentando boa performance operacional. Entretanto, a água residuária dessas indústrias, com temperatura normalmente superior a $40^{\circ} \mathrm{C}$, necessita passar por torre de resfriamento, antes do tratamento biológico.

De acordo com Vogelaar et al. (2002), dependendo da qualidade do efluente do tratamento biológico a $35^{\circ} \mathrm{C}$, há possibilidade de seu retorno ao processo de fabricação. Para isto, é necessário o reaquecimento para $55^{\circ} \mathrm{C}$.

Processos de tratamento mesofilicos têm sido empregados satisfatoriamente há vários anos. Entretanto, se a purificação da água de processo fosse feita a $55^{\circ} \mathrm{C}$, as perdas de energia devidas ao resfriamento e reaquecimento seriam evitadas. 
Deve-se ressaltar também que o fechamento do circuito de água em indústrias de papel e celulose já vem sendo aplicado com vantagens, devido ao menor consumo específico de água e redução da descarga de efluentes. Contudo, a recirculação resulta em um acúmulo de compostos orgânicos e inorgânicos nocivos, que podem afetar o produto final e os equipamentos industriais (VOGELAAR et al., 2002; PATRICK et al., $1994^{4}$ apud TRIPATHI \& ALLEN, 1999).

Considerando o aumento de sistemas fechados em indústrias de papel e celulose, a alta carga orgânica desses efluentes e as temperaturas elevadas da água de processo, a aplicabilidade dos sistemas de tratamento biológico em temperaturas termofilicas tem se tornado cada vez mais interessante (VOGELAAR et cl., 2002). Assim, a seguir são feitas algumas considerações a respeito dos organismos termófilos, suas características básicas e desempenhos em processos de tratamento, bem como a comparação desses com sistemas mesofilicos.

\subsection{Microrganismos termofílicos: definição e características}

De acordo com Brock (1986) termófilo é um organismo capaz de viver em alta temperatura ou próximo à máxima temperatura do grupo taxonômico do qual faz parte.

Do ponto de vista do tratamento biológico de água residuária, terminologia comum para tratamento utilizando microrganismos termofílicos, geralmente inclui processos operando em temperatura igual ou superior a $45^{\circ} \mathrm{C}$ (LAPARA \& ALLEMAN, 1999).

Muitos fatores capacitam os termófilos a crescerem em temperatura elevada: os ribossomos, as membranas e as várias enzimas dos microrganismos termofílicos. A perda de função da membrana citoplasmática em baixas temperaturas pode ser o que determina a temperatura de crescimento mínimo dos termófilos (PELCZAR JR, 1996).

Estudos sobre as enzimas termofílicas têm mostrado, freqüentemente, pouca diferença da seqüência de aminoácidos que catalisam a mesma reação em sistema mesofílico. As enzimas e proteínas na célula, o mecanismo de síntese de proteínas (envolvem os ribossomos e outros constituintes) e estruturas como a membrana citoplasmática de termófilos e hipertermófilos, são igualmente estáveis ao aquecimento (BROCK \& MADIGAN, 1988). 
Os termofílicos têm membrana lipídica rica em ácidos graxos saturados, que formam ligação hidrofóbica muito mais forte que ácidos graxos insaturados, aumentando a estabilidade da membrana (BROCK \& MADIGAN, 1988).

Segundo Jahren et al. (2002), baseado em vários autores, as altas necessidades energéticas para manutenção celular e os altos coeficientes de decaimento microbiano para termofilicos, indicam que a quantidade de lodo excedente, pode ser bem menor para processo de tratamento termofílico do que para mesofilico.

De acordo com Madigan et al. (1998), organismos termofílicos em tratamentos de águas residuárias são representados por dois reinos: Archae e Bacteria, sendo o segundo dominante em processos aeróbios termofilicos, em temperatura moderada, variando de $45^{\circ} \mathrm{C}$ a $60^{\circ} \mathrm{C}$. Os hipertermófilos atuam em temperaturas superiores a $75^{\circ} \mathrm{C}$ (Tabela 3.1).

O efeito da temperatura elevada, aparentemente, depende do grupo metanogênico dominante. As temperatura máximas reportadas para o crescimento de Methanosarcina sp. termofilica estão em torno de $62^{\circ} \mathrm{C}$; para Methanothrix (Methanosaeta) sp. cerca de $70^{\circ} \mathrm{C}$; para Methanobacterium sp. cerca de $75^{\circ} \mathrm{C}$ e o ótimo para coculturas que oxidam acetato variam entre $60^{\circ} \mathrm{C}$ e $65^{\circ} \mathrm{C}$ (ZINDER, 1990).

TABELA 3.1. Maior grupo de procariotos termofílicos e hipertermofílicos (BROCK \& MADIGAN, 1988).

\begin{tabular}{lclc}
\hline \multicolumn{1}{c}{ Gênero } & $\begin{array}{c}\text { Temperatura } \\
\text { média }\left({ }^{\circ} \mathbf{C}\right)\end{array}$ & \multicolumn{1}{c}{ Gênero } & $\begin{array}{c}\text { Temperatura } \\
\text { média }\left({ }^{\circ} \mathbf{C}\right)\end{array}$ \\
\hline Cianobactérias & $55-70$ & Desulfotomaculum sp. & $37-55$ \\
Bactérias Verdes & $45-60$ & Aeróbias Gram negativas & $50-75$ \\
Bactérias Gram positivas & $40-73$ & Anaeróbias Gram negativas & $50-75$ \\
Bacillus sp. & $50-70$ & Thermotoga/Aquifex & $55-95$ \\
Clostridium sp. & $50-75$ & Thermus & $60-80$ \\
Bactérias do ácido lático & $50-65$ & Metanogênicas & $45-110$ \\
Actinomicetos & $55-75$ & Hipertermófilas dependente de & $60-113$ \\
Thiobacillus sp. & $50-60$ & Thermoplasma & $37-60$ \\
Spirochaetae & 54 & & \\
\hline
\end{tabular}




\subsection{Tratamento biológico termofílico}

Segundo Quarmby \& Forster (1995), águas residuárias industriais recalcitrantes, com alta carga orgânica e liberadas em altas temperaturas têm potencial para tratamento termofílico. Além das indústrias de papel e celulose, podem ser citados como exemplo, os efluentes das indústrias de café instantâneo e de óleo de palmeira, dentre outras.

É possível encontrar, na literatura, diversos trabalhos experimentais sobre tratamentos termofilicos aplicados para diferentes efluentes. Contudo, os resultados e as conclusões acerca desse tratamento podem variar muito, dependendo da configuração do reator, das características da água residuária tratada ou das condições operacionais utilizadas. Sendo assim, as opiniões sobre a utilização do tratamento termofílico, contrapondo-se ao tradicional tratamento mesofílico são divergentes.

O que pode ser observado, tanto na literatura, quanto em encontros científicos, é que alguns pesquisadores consideram os processos anaeróbios termofilicos instáveis e ineficazes (KUGELMAN \& GUIDA, 1989; CHERNICHARO, 1997; VAN LIER et al., 1996; GUERRERO et al., 1999).

O tratamento aeróbio termofílico, por sua vez, é ainda mais questionado pela dúvida de sua aplicabilidade pelas baixas concentrações de saturação de oxigênio em alta temperatura. Os valores da saturação de oxigênio em água decrescem quando a temperatura aumenta $\left(6,9 \mathrm{mg} \cdot \mathrm{L}^{-1}\right.$ a $35^{0} \mathrm{C}$ e $4,5 \mathrm{mg} \cdot \mathrm{L}^{-1}$ a $\left.55^{0} \mathrm{C}\right)$. O coeficiente de difusão para o oxigênio entretanto, é significativamente maior em temperaturas elevadas $\left(2,8.10^{-5} \mathrm{~cm}^{2} \mathrm{~s}^{-1}\right.$ a $35^{0} \mathrm{C}$ e $4,3 \cdot 10^{-5} \mathrm{~cm}^{2} \mathrm{~s}^{-1}$ a $55^{0} \mathrm{C}$, calculado pela equação de WilkeChang $^{7}$, de acordo com Jahren et al.; 2002). A taxa de transferência do oxigênio em altas temperaturas pode, portanto, ser tão boa ou até mesmo melhor do que sob condições mesofílicas.

Nos trabalhos sobre processos termofilicos encontrados na literatura atual, os objetivos, em geral, são o aprimoramento das configurações dos reatores, bem como das condições operacionais, a fim de explorar o potencial desses sistemas de tratamento e suas viabilidades econômicas. A maioria desses trabalhos foi realizado em escala de laboratório, empregando-se reatores anaeróbios ou aeróbios e, a combinação de ambos.

$D={ }^{7} D, 4 \times 10^{-8}\left(\begin{array}{c}0 \\ \delta v m w \\ v\end{array}\right)^{0.6} T ;$

onde D é o coeficiente de difusividade o oxigênio; $\mathrm{T}(\mathrm{K})$ é a temperatura absoluta, $\delta{ }^{0} v$ é um termo de associação para o solvente (2,6 para água), $m w=18 \mathrm{~g} \cdot \mathrm{mol}^{-1}$ (peso molecular da água); $\mu v^{\prime}=8,9 \times 10^{-1} \mathrm{cp}$ (viscosidade da água); $\mathrm{V}_{\mathrm{c}}$ $\left(\mathrm{cm}^{3} \cdot \mathrm{mol}^{-1}\right)$ é o volume molar do oxigênio. 
A seguir, é apresentada uma síntese das conclusões de alguns autores sobre tratamentos termofilicos anaeróbios e aeróbios, sendo citados alguns experimentos. Deve-se ressaltar que são também apresentados trabalhos nos quais são aplicados tratamentos mesofilicos com a finalidade de comparações.

\subsubsection{Tratamento anaeróbio termofílico}

De acordo com Kim et al. (2002b), processos operando em temperatura mesofilica $\left(30^{\circ} \mathrm{C}\right.$ a $\left.40^{\circ} \mathrm{C}\right)$ têm sido adotados para digestão anaeróbia, mostrando bom desempenho operacional. Entretanto, processos termofilicos $\left(50^{\circ} \mathrm{C}\right.$ a $\left.60^{\circ} \mathrm{C}\right)$ também apresentam várias vantagens, como aumento da taxa de metabolização de sólidos orgânicos, aumento da separação líquido-sólido e maior eliminação de organismos patogênicos.

Tem sido demonstrado, por estudos prévios, que maiores taxas de utilização de substrato e de decaimento caracterizam os microrganismos termofilicos anaeróbios quando comparados aos mesofilicos (KIM et al., 2002b).

Segundo Dinsdale et al. (1997a) esta alta taxa de utilização de substrato oferece a vantagem potencial da utilização de maiores taxas de carregamento e portanto estações de tratamento menores do que sistemas mesofilicos equivalentes.

Jahren et al. (1999), baseados em outros autores, também citaram a vantagem da maior taxa de degradação em tratamento anaeróbio termofílico e ainda acrescentaram que esse sistema produz mais metano que os mesofílicos.

Como as taxas de reação aumentam com a temperatura, maiores cargas potenciais de carregamento e/ou consideráveis menores tempos de retenção são esperados se o tratamento anaeróbio for aplicado sob condições termofílicas (ZINDER, 1986).

Além disso, os resultados obtidos por Jahren et al. (1999) sugerem que o tratamento anaeróbio termofílico pode ser viável como uma parte do sistema de tratamento interno para fechar o circuito de água no processo de polpação termomecânica.

Rintala \& Lepisto (1997) sugerem a combinação do processo de tratamento anaeróbio termofílico, por exemplo, com membranas, quando se deseja o reuso da água de processo. 
Outra vantagem, citada por Lau \& Fang (1997), é que sob condições termofílicas, os poluentes podem ser degradados em taxas mais elevadas e patógenos podem ser mais eficientemente eliminados.

De acordo com o modelo cinético Stover-Kincannon ${ }^{8}$, aplicado em reator de biofiltro operado a $35^{\circ} \mathrm{C}$ e a $55^{\circ} \mathrm{C}$, foi verificado por $\mathrm{Ahn} \&$ Forster (2000) que a máxima taxa de utilização de DQO ocorreu no fíltro termofílico, sendo cerca de 15 vezes maior que a obtida no filtro mesofílico.

Entretanto, de acordo com van Lier et al. (1996), alguns resultados divergentes e decepcionantes obtidos por vários pesquisadores utilizando tratamento anaeróbio termofilico de água residuária são, provavelmente, a razão desses processos serem raramente aplicados. Algumas desvantagens citadas por Kugelman \& Guida (1989) e também por Chernicharo (1997) são a baixa qualidade do sobrenadante e a instabilidade do processo relacionada à alta concentração crônica de ácidos graxos, especialmente propionato.

Outro ponto a ser considerado é que, sob condições de alta temperatura, a baixa viscosidade do lodo e a ocasional ocorrência de agregados termofílicos menos estáveis podem dificultar a separação do lodo (VAN LIER et al., 1997). De acordo com van Lier et al. (1996) agregados termofílicos são menos estáveis devido à alta taxa de mineralização do lodo.

Contudo, de acordo com Lettinga \& Hulshoff Pol (1991), processos de reatores anaeróbios de manta de lodo e fluxo ascendente, mesofilicos, usados amplamente para tratamento de águas residuárias industriais, atingiram até aquela data, mais de 200 instalações em todo o mundo.

Segundo Chernicharo (1997), a experiência da operação de digestores na faixa termofilica não tem sido totalmente satisfatória e não está claro se os benefícios advindos superam as desvantagens. Segundo esse autor, o processo anaeróbio termofílico é considerado muito sensível a mudanças bruscas de temperatura, podendo provocar um desbalanceamento entre as duas maiores populações microbianas e, conseqüentemente, falha do processo.

Guerrero et al. (1999), baseados em literatura, compararam o tratamento anaeróbio termofilico com o mesofilico e também concluíram que a operação sob condições termofílicas é freqüentemente considerada como menos estável quando 
comparada ao tratamento mesofílico, devido à alta susceptibilidade a variações na temperatura, interrupções na alimentação e cargas de choque.

Além disso, segundo os autores, um importante aspecto que deve ser considerado é o efeito da temperatura no equilíbrio de dissociação da amônia, visto que altas temperaturas favorecem maiores frações da amônia livre, podendo causar efeitos tóxicos na população de microrganismos metanogênicos.

Contudo, Lau \& Fang (1997), comparando os resultados do seu experimento com outros na literatura, concluíram que microrganismos termofílicos parecem ser mais resistentes ao aumento de temperatura do que mesofilicos. Porém, foi verificado que aumentos de temperatura têm efeitos mais severos para grânulos termofílicos que decréscimos. Esses autores usaram reatores UASB e, de acordo com Van Lier et al. (1996), baseados em investigações, o reator UASB é apresentado como sendo menos susceptível a essas mudanças sob condições termofílicas.

Porém, Van Lier et al. (1996) questionaram o uso de reatores de manta de lodo em estágio simples, pois as altas condições de carregamento podem resultar em maior perda do lodo disperso e granular. Além disso, de acordo com esses autores, sob condições termofílicas, a grande turbulência causada pela alta produção de biogás pode levar a um excessivo carreamento de lodo metanogênico.

Apesar das desvantagens atribuídas ao processo anaeróbio termofilico, as vantagens tornam o processo atraente. Muitos pesquisadores comparam esse tratamento com o mesofílico e buscam melhores configurações ou mudanças no controle operacional, avaliando a viabilidade da aplicação do processo termofílico. A seguir, são apresentados alguns trabalhos e comparações feitas entre processos mesofilicos e termofílicos utilizando diferentes configurações de reatores, condições operacionais e substratos.

\subsubsection{Diferenças entre grânulos mesofílico e termofílico}

Os grânulos são compostos por microrganismos e uma matriz de biopolímeros. (QUARMBY \& FORSTER, 1995). Essa agregação peculiar dos microrganismos anaeróbios em biofilmes e grânulos otimiza a cooperação porque reduz distâncias de transferências dos metabólitos e aumenta significativamente a sedimentabilidade da biomassa, permitindo efetiva retenção do lodo granular no reator (SPEECE, 1996). 
O conhecimento sobre a formação e estrutura dos grânulos é ainda limitado (QUARMBY \& FORSTER, 1995). A estrutura do lodo granulado mesofílico tem sido descrita como consistindo de três camadas distintas. A camada mais externa é composta principalmente por uma população heterogênea, com predomínio de bactérias acidogênicas produtoras de hidrogênio e também microrganismos utilizadores de hidrogênio, semelhantes a Methanosarcina sp., Methanococus sp. e Methanospirillum sp. A camada do meio é composta por organismos semelhantes a cocos e filamentos de bactérias, e a camada central acetoclástica é composta por muitas cavidades de gás e quase que exclusivamente por organismos semelhantes a Methanothrix sp. (GUIOT, 1992).

A presença de organismos metanogênicos, utilizadores de hidrogênio, na camada exterior sugere que o hidrogênio livre é impedido de entrar na segunda camada. Os organismos utilizadores de hidrogênio presentes na segunda camada seriam capazes de remover o hidrogênio produzido pelo alto nível de atividade metabólica das acetogênicas. Assim, um agregado de três camadas seria um arranjo metabólico completo e muito estável que criaria as condições ambientais ótimas para todos os seus componentes (GUIOT, 1992).

De acordo com Quarmby \& Forster (1995), a partir de dados não publicados de Quarmby, um estudo do lodo granulado mesofílico mostrou que, embora a população heterogênea de microrganismos localizada na superfície pareça ser comum por todo o lodo granular, há diferenças nítidas na arquitetura interna que parecem ser dependentes não somente da natureza do substrato, mas também de fatores operacionais, os quais podem incluir $\mathrm{pH}$ e tempo de detenção hidráulica. Também é possível que a temperatura possa afetar a composição do lodo.

A estrutura em três camadas também tem sido descrita para lodo granular termofilico. A camada mais externa consiste de um pseudoparênquima de células cocóides, possivelmente espécies de Methanosarcina sp. Foram observadas na camada do meio, células ovais frouxamente organizadas, sendo o centro formado por bactérias em forma de filamentos, muitas cavidades de gás e algumas formas de filamento não metanogênicos (Bochem et al. ${ }^{9}, 1982$ apud Quarmby \& Forster, 1995).

De acordo com Lens et al. (1993) e van Lier et al (1996), a imobilização dos microrganismos termofilicos em biofilmes e/ou grânulos, pode aumentar a 
termoestabilidade do processo pois a taxa máxima de conversão, provavelmente, deve ser determinada pela limitação da difusão no substrato.

Em um teste feito por van Lier et al. (1996), foi verificado que a destruição da estrutura do grânulo pode aumentar a taxa global de transferência de massa pela menor distância necessária para a difusão, conseqüentemente, resulta em maior sensibilidade a temperatura. Aparentemente a destruição da estrutura do grânulo apresenta dois efeitos: por um lado, diminui a atividade de degradação devido a ruptura das associações sintróficas, por outro, pode levar a uma maior atividade do lodo devido a um aumento da taxa de transferência de massa.

De acordo com van Lier et al. (1996), geralmente, lodos granulados termofílicos adaptados são caracterizados por alta atividade específica e diâmetro de $1 \mathrm{~mm}$ a $3 \mathrm{~mm}$. Aparentemente, a baixa atividade específica em menores temperaturas é compensada pela maior afinidade pelo substrato.

Segundo Forster (1991), outros fatores que podem determinar a estabilidade do grânulo são a ecologia microbiana e os polímeros extracelulares (ECP).

Uma certa quantidade de ECP no grânulo pode causar a estabilização do floco (PAVONI et al. ${ }^{10}, 1972$ apud QUARMBY \& FORSTER, 1995). Quando a quantidade de ECP aumenta, o grânulo pode tornar-se mais estável e resistente ao rompimento. Entretanto, excesso de ECP pode causar uma degradação na estrutura como um resultado da repulsão pelas cargas negativas do polímero (MORGAN et al., 1990).

De acordo com MORGAN et al., (1991) e Quarmby \& Forster (1995), baseados em outros autores, no lodo granulado, aproximadamente $1 \%$ a $4 \%$ dos sólidos totais consistem de ECP, compostos principalmente por aminoácidos: asparagina, glutamina e alanina.

A quantidade de ECP produzida é dependente do tipo de microrganismo presente no grânulo (QUARMBY \& FORSTER, 1995).

As bactérias acidogênicas são conhecidas por produzir mais ECP que as arqueas metanogênicas, portanto, o número de tipos diferentes de organismos presentes no grânulo pode afetar a quantidade de ECP produzido (MORGAN, 1991 ${ }^{11}$ apud QUARMBY \& FORSTER, 1995).

\footnotetext{
${ }^{10}$ PAVONI, J. L.; TENNEY, M. W.; ECHELBERGER, W. F. (1972). Bacterial exocellular polymers and biological flocculation. J. Wat. Pollut. Control Fed. 44, 414-431.

${ }^{11}$ MORGAN, J. W. (1991). Microbial Aspects of Anaerobic granular sludge formation. PhD thesis, University of Birmingham.
} 
Para comparar a estabilidade do grânulo mesofílico em relação ao termofílico, Quarmby \& Forster (1995) utilizaram o efeito de ultra-som e analisaram a turbidez do sobrenadante das amostras, correlacionando, indiretamente, a turbidez à estabilidade do grânulo. Foi verificado que as amostras termofilicas mostraram-se menos estáveis que as amostras mesofilicas equivalentes. Comparando-se a resistência com a microbiota presente, verificaram que o gênero Methanothrix sp. pode produzir mais ECP que o Methanosarcina sp., fato que pode aumentar a estabilidade do grânulo. Deve-se considerar que as amostras mesofilicas tinham o centro rico em Methanothrix sp. e os grânulos termofilicos continham quantidades significativas de Methanosarcina sp.

A formação de lodo granular espesso, bem como baixas concentrações de substrato efluente são dois fatores esperados para a maior limitação de transferência de massa, e conseqüentemente, baixa atividade específica do lodo. Esses fatores particularmente são demonstrados em reatores de alta taxa, com alto tempo de retenção de sólidos (VAN LIER et al., 1996).

\subsubsection{Experimentos utilizando tratamento termofílico anaeróbio}

SOUZA et al. (1992) demonstraram a viabilidade de um reator UASB termofílico $\left(55\right.$ a $\left.57^{\circ} \mathrm{C}\right)$ para tratamento de vinhaça. Este reator foi operado em planta piloto de escala industrial, na usina de São Martinho (Pradópolis, São Paulo). Foram obtidas altas taxas de carregamento orgânico (25 a30 kg DQO $/ \mathrm{m}^{3}$ de reator.dia), cerca do dobro daquelas normalmente usadas para tratamentos mesofílicos similares de vinhaça nesse tipo de reator. Em 280 dias de operação, a eficiência de remoção de DQO no reator foi em torno de $72 \%$, sendo que a taxa de produção de biogás foi de $10 \mathrm{~m}^{3} / \mathrm{m}^{3} \mathrm{de}$ reator.dia.

Lau \& Fang (1997) testaram o efeito de variações na temperatura em reatores UASB termofilicos, operados a $55^{\circ} \mathrm{C}$. Os reatores que operavam com eficiência de remoção de DQO na faixa de $85 \%$ a $90 \%$ foram submetidos a aumento e a decréscimo da temperatura de operação.

De acordo com os autores, a temperatura de choque reduziu significativamente o desempenho dos reatores. No reator submetido a um aumento da temperatura para $65^{\circ} \mathrm{C}$ por oito dias, a eficiência de remoção foi reduzida para valores abaixo de $60 \%$. Foi verificado aumento na concentração de butirato e acetato, de $5 \mathrm{mg} \cdot \mathrm{L}^{-1}$ para $20 \mathrm{mg} \cdot \mathrm{L}^{-1} \mathrm{e}$ de $50 \mathrm{mg} . \mathrm{L}^{-1}$ para $300 \mathrm{mg} . \mathrm{L}^{-1}$, respectivamente. No reator submetido a uma temperatura 
de $37^{\circ} \mathrm{C}$ por 16 dias, a eficiência de remoção foi de apenas $40 \%$. Foram verificados aumentos na concentração de ácidos graxos voláteis (AGV) e ligeira queda no pH.

Segundo Lau \& Fang (1997), houve aumento na concentração de propionato de $400 \mathrm{mg} . \mathrm{L}^{-1}$ para $2500 \mathrm{mg} . \mathrm{L}^{-1} \mathrm{e}$, conseqüentemente, necessidade de controlar a queda de $\mathrm{pH}$, pela adição de bicarbonato de sódio. Ambos reatores foram capazes de recuperar a eficiência de remoção de DQO, dezoito dias após a adição de bicarbonato e reajuste da temperatura para $55^{\circ} \mathrm{C}$.

Utilizando teste de atividade metanogênica específica, Lau \& Fang (1997) observaram que as metanogênicas acetotróficas não foram tão atingidas pelas variações de temperatura quanto os outros microrganismos e que a atividade dos grânulos foi mais afetada pelo aumento da temperatura.

No trabalho de Lepisto \& Rintala (1999), com três reatores UASB operados em diferentes temperaturas $\left(35^{\circ} \mathrm{C}, 55^{\circ} \mathrm{C}\right.$ e $\left.70^{\circ} \mathrm{C}\right)$ não houve diferença aparente no desempenho dos reatores UASB a $35^{\circ} \mathrm{C}$ e a $55^{\circ} \mathrm{C}$. Estes reatores operaram com tempo de detenção hidráulica de 1,1 h e taxas de carregamento orgânico de 34 gDQO.L. $L^{-1} \cdot d^{-1}$ a $35 \mathrm{gDQO} \cdot \mathrm{L}^{-1} \cdot \mathrm{d}^{-1}$. Ambos reatores apresentaram remoção de ácidos graxos voláteis de $98 \%$ a $99 \%$. O reator a $70^{\circ} \mathrm{C}$ foi operado com tempo de detenção hidráulica de 2 a 3 horas e taxa de carregamento orgânico de 12 gDQO. $\mathrm{L}^{-1} \cdot \mathrm{d}^{-1}$ a 20 gDQO.L $\mathrm{L}^{-1} \cdot \mathrm{d}^{-1}$ e atingiu efíciência de remoção de AGV de $66 \%$ a $74 \%$. De acordo com os autores, as qualidades dos efluentes dos reatores operados a $35^{\circ} \mathrm{C}$ e a $55^{\circ} \mathrm{C}$ foram superiores à do reator operado a $70^{\circ} \mathrm{C}$, diferenciadas principalmente por altas concentrações de propionato no reator de maior temperatura.

Kim et al. (2002) compararam a estabilidade e a eficiência da digestão anaeróbia sob condições termofilica $\left(55^{\circ} \mathrm{C}\right)$ e mesofilica $\left(35^{\circ} \mathrm{C}\right)$, utilizando quatro configurações diferentes de reatores: mistura completa com um único estágio alimentado em batelada; mistura completa com um único estágio alimentado continuamente; mistura completa em dois estágios alimentado em batelada e tanque de reação com um único estágio, sem mistura.

Os autores observaram que, durante a partida, os reatores de um único estágio foram menos estáveis em ambas as temperaturas, enquanto no tanque de reação com um único estágio, sem mistura, a aclimatação foi conseguida em menor tempo, com pH relativamente estável e baixa produção de AGV. Sob condições termofílicas, houve 
necessidade de suplementação de micronutrientes ( $\mathrm{Ca}, \mathrm{Fe}, \mathrm{Ni}$ e $\mathrm{Co})$ quando os $\mathrm{AGV}$ aumentaram, afim de remover o propionato (KIM et al., 2002).

De acordo com os autores, o tratamento no reator sem mistura, termofílico, mostrou melhor desempenho, com baixa produção de AGV, alta produção de gases e alta remoção de sólidos, implicando que a proximidade do consórcio microbiano pode minimizar o problema de baixa qualidade do efluente sob condições termofílicas. Quando a carga orgânica foi aumentada nos reatores sob condição termofilica até a falha do sistema, foi verificado o aumento da concentração de propionato em todos os reatores, com exceção do sem mistura (KIM et al., 2002).

Nos reatores mesofilicos, com o aumento da carga orgânica foi verificado um leve aumento na concentração de propionato, exceto para o reator de dois estágios (KIM et al., 2002).

Considerando os reatores sob as mesmas condições de aumento da taxa de carregamento orgânico, foi verificado que os reatores de alimentação contínua apresentaram menor produção de gases, enquanto os reatores sem mistura, apresentaram em ambas as temperaturas aumento dessa produção. Kim et al. (2002) concluíram que a proximidade do consórcio microbiano e a adição de nutrientes apresentou papel de grande importância no desempenho dos reatores.

Dinsdale et al. (1997a) compararam reatores UASB operando em faixas de temperatura mesofilica $\left(35^{\circ} \mathrm{C}\right)$ e termofílica $\left(55^{\circ} \mathrm{C}\right)$, com um estágio de acidificação, tratando efluente da indústria de café instantâneo. Os reatores estabilizaram com taxa de carregamento orgânico superior a $10 \mathrm{~kg}$.DQO. $\mathrm{m}^{3} \cdot \mathrm{d}^{-1}$ e tempo de detenção hidráulica de 24 horas. Nesse trabalho também foi observada a perda de sólidos. A melhor qualidade do efluente foi obtida no reator mesofilico, com uma média de remoção de DQO de $78 \%$ e AGV de 25 mg. $L^{-1}$ comparada à remoção de DQO de 70\% e AGV de 100 mg.L ${ }^{-1}$ no reator UASB termofílico, sob as mesmas condições. Entretanto, o reator termofílico suportou maior taxa de carregamento orgânico $\left(11,4 \mathrm{kgDQOm}^{-3} \cdot \mathrm{d}^{-1}\right)$ que o mesofílico $\left(10 \mathrm{kgDQOm}^{-3} \cdot \mathrm{d}^{-1}\right)$.

O tratamento anaeróbio termofílico utilizando reator UASB $\left(0,65 \mathrm{~m}^{3}\right)$ também foi estudado por Rintala \& Lepisto (1997). O objetivo desse trabalho foi avaliar a aplicabilidade do processo termofílico para o tratamento de água residuária de indústria de processamento de vegetais em escala piloto, sob condições reais de produção e, conseqüentemente, confirmar os resultados obtidos em escala de laboratório. Assim, o 
período experimental foi limitado a setenta dias, coincidente ao período de produção sazonal. O reator foi inoculado com lodo mesofilico e, segundo os autores, a acidificação ocorrida no início do processo, bem como o inadequado controle do $\mathrm{pH}$, atrasaram o crescimento das termófilas. A tendência de acidificação do processo foi devida ao não balanceamento do consórcio anaeróbio.

Segundo Ohtsuki et al. ${ }^{12}$ (1994) apud Rintala \& Lepisto (1997), a partida também pode ser atrasada pelo excesso de carga orgânica provocada pela lise dos microrganismos mesofilicos. Após nova inoculação e adição de hidróxido de sódio, o pH permaneceu acima de 6,9 até o fím do trabalho. A eficiência de remoção de DQO no experimento foi superior a $60 \%$ após trinta e cinco dias da primeira inoculação. Após setenta dias, obteve-se mais que $80 \%$ de remoção de DQO com taxa de carregamento de $4 \mathrm{kgDQO} \cdot \mathrm{m}^{-3} \cdot \mathrm{d}^{-1}$ (RINTALA \& LEPISTO, 1997).

Os autores citados anteriormente também analisaram a relação entre o crescimento do lodo e o aumento de temperatura. A máxima taxa de produção de metano foi obtida entre $55^{\circ} \mathrm{C}$ e $58^{\circ} \mathrm{C}$, sendo levemente menor a $50^{\circ} \mathrm{C}$. Em temperatura de $35^{\circ} \mathrm{C}$, a produção de metano foi insignificante.

Jahren et al. (1999), por sua vez, testaram a utilização, em escala de laboratório, de três diferentes configurações de reatores anaeróbios termofílicos $\left(55^{\circ} \mathrm{C}\right)$ para tratar licor branco de polpação termomecânica: reator híbrido, de múltiplos estágios e de biofilme e leito móvel. Em todos os reatores foi obtida remoção de DQO superior a $70 \%$, entretanto, para tal, houve a necessidade de adição de nutrientes $\left(\mathrm{NH}_{4} \mathrm{Cl}\right.$, $\mathrm{CaCl}_{2} 2 \mathrm{H}_{2} \mathrm{O}, \mathrm{MgSO}_{4} 7 \mathrm{H}_{2} \mathrm{O}$ e $\left.\mathrm{KH}_{2} \mathrm{PO}_{4}\right)$ e elementos traço $\left(\mathrm{FeCl}_{2} 4 \mathrm{H}_{2} \mathrm{O}, \mathrm{H}_{3} \mathrm{BO}_{3}, \mathrm{ZnCl}_{2}\right.$, $\mathrm{CuCl}_{2} 2 \mathrm{H}_{2} \mathrm{O}, \mathrm{MnCl}_{2} 4 \mathrm{H}_{2} \mathrm{O},\left(\mathrm{NH}_{4}\right) \mathrm{Mo}_{7} \mathrm{O}_{27} 4 \mathrm{H}_{2} \mathrm{O}, \mathrm{AlCl}_{3} 6 \mathrm{H}_{2} \mathrm{O}, \mathrm{CoCl}_{2} 6 \mathrm{H}_{2} \mathrm{O}, \mathrm{NiCl}_{2} 6 \mathrm{H}_{2} \mathrm{O}$, $\mathrm{Na}_{2} \mathrm{SeO}_{5} \mathrm{H}_{2} \mathrm{O}$, EDTA e resazurina.

Nesse trabalho de Jahren et al. (1999), o reator anaeróbio híbrido, composto por um reator UASB e um filtro, com taxa de carregamento de $15 \mathrm{kgDQO} . \mathrm{m}^{-3} \mathrm{~d}^{-1}$ e tempo de detenção hidráulica de 3,1 horas atingiu taxa de degradação acima de $10 \mathrm{kgDQO} \cdot \mathrm{m}^{-3} \mathrm{~d}^{-1}$. Com este reator foi possível utilizar altas taxas de carregamento orgânico e tempos de detenção hidráulica reduzidos com eficiência de remoção de DQO variando de $60 \%$ a $70 \%$.

\footnotetext{
${ }^{12}$ OHTSUKI, T.; TOMINAGA, S.; MORITA, T.; YODA, M. (1994). Thermophilic UASB system start-up and management - change in sludge characteristics in the start-up procedure using mesophilic granular sludge. In: Paper Pre-prints of the Seventh Int. Symposium on Anaerobic Digestion, Cape Town, January, 23-27. 1994. South-Africa, p. 348-357.
} 
O reator anaeróbio de estágios múltiplos consistia de três compartimentos, preenchidos com lodo granulado e material suporte, com taxas de carregamento entre $15 \mathrm{~kg}$.DQO. $\mathrm{m}^{3} \cdot \mathrm{d}^{-1}$ e $16 \mathrm{~kg}$.DQO. $\mathrm{m}^{3} \cdot \mathrm{d}^{-1}$ e tempo de detenção abaixo de 2,6 horas atingiu taxa de degradação acima de $9 \mathrm{~kg}$.DQO. $\mathrm{m}^{-3}$. Os resultados obtidos no reator de estágios múltiplos foram comparáveis aos processos anaeróbios termofílicos, entretanto o arranjo desse reator resultou em retenção da biomassa e de fibras que causaram o entupimento $\mathrm{e}$, conseqüentemente, caminhos preferenciais de passagem do afluente.

O reator anaeróbio com biofilme e leito móvel teve desempenho similar aos outros reatores, entretanto, com taxa de carregamento abaixo de $1,4 \mathrm{kgDQO} . \mathrm{m}^{-3} \cdot \mathrm{d}^{-1}$. Nesse reator, as taxas de carregamento orgânico tiveram que ser menores e a remoção alcançou 50 a $55 \%$ de eficiência, utilizando tempo de detenção hidráulica de 30 a 50 horas (JAHREN et al. ,1999).

\subsubsection{Tratamento aeróbio termofilico}

Os sistemas de tratamento aeróbio termofilico representam um processo único e relativamente novo para o tratamento de águas residuárias de alta carga e/ou em elevadas temperaturas.

Embora as pesquisas exploratórias dessa tecnologia datem da década de 1950, relativamente poucos sistemas têm sido implementados em grande escala e somente recentemente surgiu significativo interesse pelo tratamento aeróbio termofilico de águas residuárias (LAPARA \& ALLEMAN, 1999). De acordo com esses autores, muitas das instalações termofílicas foram desenvolvidas acidentalmente, quando águas residuárias de alta taxa foram liberadas para biodegradação e aumentaram significativamente as temperaturas dos reatores.

Dentre as vantagens do tratamento aeróbio termofílico estão as rápidas taxas de degradação e a rápida inativação de microrganismos patógenos (LAPARA \& ALLEMAN, 1999). As elevadas taxas de degradação reduzem o tempo de detenção necessário para o tratamento e, conseqüentemente, a vantagem potencial do tratamento biológico aeróbio de efluente em alta temperatura é o custo mínimo tanto energético quanto operacional (LAPARA \& ALLEMAN, 1999; TRIPATHI \& ALLEN, 1999). 
Além disso, as altas taxas de biodegradação podem melhorar a estabilidade do processo, pela rápida recuperação às condições de perturbação do sistema (LAPARA \& ALLEMAN, 1999).

Outra vantagem, é a menor quantidade de lodo em excesso em processos de tratamento termofilico quando comparado a mesofilicos, garantida pelos altos requerimentos energéticos para manutenção e os altos coeficientes de decaimento microbiano para termófilos (JAHREN et al., 2002; LAPARA \& ALLEMAN, 1999).

Segundo Lapara \& Alleman (1999), os tratamentos aeróbios termofilicos podem ser utilizados em indústrias cujas águas residuárias possuem altas temperaturas e também para efluentes com altas cargas, os quais contêm a energia necessária para facilitar a operação endotérmica, sem necessidade de aquecimento. Os resultados obtidos por vários pesquisadores com tratamentos termofilicos aeróbio de águas residuárias de indústrias de polpa e papel foram variáveis, sendo que a limitação comum dos desempenhos foi a falta de capacidade para separar as bactérias termofílicas do efluente tratado.

A turbidez do efluente, freqüentemente citada como desvantagem do processo, não é considerada crítica por Vogelaar et al. (2002). Segundo os autores, um efluente termofílico claro pode ser obtido no caso de substratos com menor quantidade de material coloidal. Considerando a aplicação em linha, do tratamento aeróbio termofílico para água residuária das indústrias de polpa e papel, segundo Vogelaar et al. (2002), a alta turbidez efluente é provavelmente compensada pelo ganho de energia no processo sob condições termofílicas, tornando o processo viável. Deve-se considerar, entretanto, que o trabalho de Vogelaar et al. (2002) foi realizado com águas residuárias de indústria de papel reciclado, com baixos teores de lignina e outros derivados do processo de polpação da madeira.

Comparado a outras tecnologias de tratamento, relativamente pouco é conhecido com relação ao processo de tratamento biológico aeróbio termofílico de águas residuárias contendo substratos solúveis e biodegradáveis (LAPARA \& ALLEMAN, 1999). Para as indústrias de papel e celulose, por exemplo, Tripathi \& Allen (1999) consideram que desde que o tratamento aeróbio termofilico do efluente foi inicialmente estudado, pouca informação está disponível sobre a aplicabilidade desse sistema.

Além disso, a temperatura de operação de sistemas de lodos ativados pode afetar a atividade microbiana, as taxas de transferência de oxigênio e as características de 
sedimentação do lodo, podendo influenciar na eficiência global do processo de tratamento (BARR et al., 1996).

De acordo com Barr et al. (1996), na maioria dos experimentos com alguma tentativa para estudar o efeito da temperatura no desempenho dos reatores, a comparação de resultados não foi possível pelas a diferenças das fontes de inóculo, dos períodos admitidos para aclimatar a operação a altas temperaturas de operação e das taxas nas quais a mudança de temperatura foi introduzida. Além disso, diferenças nas variáveis inerentes ao projeto experimental, como batelada versus alimentação contínua, escala de laboratório versis escala piloto, fonte do efluente (licor negro, Kraft, sulfito, sintético, municipal), bem como tempo de retenção dos sólidos e tempo de retenção hidráulica tornam comparações diretas difíceis (BARR et al., 1996).

Segundo Vogelaar et al. (2002), resultados acerca da aplicação de lodos ativados operando em temperaturas acima de $40^{\circ} \mathrm{C}$ têm se mostrado negativos e algumas vezes contraditórios.

Uns dos maiores problemas encontrados no tratamento biológico aeróbio em alta temperatura são as características insuficientes de floculação bacteriana (LAPARA \& ALLEMAN, 1999; CARTER \& BARRY, $1975^{13}$ apud TRIPATHI \& ALLEN, 1999).

A sedimentabilidade é dependente da estrutura e tipo de floco do lodo, que depende das condições ambientais e parâmetros de operação do processo. Portanto, para melhorar o desempenho desse sistema, o efeito da temperatura na sedimentação do lodo e um melhor entendimento sobre o floco microbiano são ferramentas importantes (TRIPATHI \& ALLEN, 1999)

Segundo Suvilampi (2003), baseado em outros autores, processos aeróbios termofílicos removem menos DQO solúvel que os aeróbios mesofilicos, tratando águas residuárias mais complexas, como efluentes pré-tratados das indústrias de polpa e papel ou das indústrias farmacêuticas. As possíveis razões para os altos valores de DQO coloidal e turbidez em processos de tratamento termofílico são, por exemplo, a composição da água residuária que alimenta os reatores, a alta densidade de bactérias livres e a fraca formação de floco e, com alta concentração de substâncias complexas.

Tripathi \& Allen (1999) também atribuem esta diferença de eficiência de remoção entre reatores aeróbios operados em faixa mesofilica e termofílica a diferenças na composição da água residuária e acrescentam que pode também ser devida a

\footnotetext{
${ }^{13}$ CARTER J. L. AND BARRY W. F. (1975) Effects of shocks temperature in biological systems. J. Environ. Eng. Div. Am.Soc. Civ. Eng. 101, 229-243.
} 
desigualdades na estrutura da comunidade microbiana do lodo gerado sob as condições mesofilicas e termofílicas.

De acordo com Jahren et al. (2002) também pode haver frações orgânicas na água residuária que são menos biodegradáveis em altas temperaturas.

Outra desvantagem citada por Lapara \& Alleman (1999) é que o custo de aeração de reatores aeróbios termofilicos representa claramente uma desvantagem se comparado a tecnologias anaeróbias. Além disso, as características de baixo crescimento do lodo em processos aeróbios termofilicos requerem mais oxigênio que processos análogos de lodos ativados mesofilicos. Por exemplo, mais substrato é convertido a dióxido de carbono e água ao invés de massa celular. Baseado em Sürücü et al (1976) ${ }^{14}$ citado por Lapara \& Alleman (1999) esses requerimentos de oxigênio são $14 \%$ maiores que os de processos convencionais aeróbios.

Entretanto, segundo Jahren et al. (2002), baseado em outros autores, os tratamentos aeróbios termofílicos de águas residuárias de indústrias de polpa e papel em temperaturas de $50^{\circ} \mathrm{C}$ a $55^{\circ} \mathrm{C}$ têm apresentado valores comparáveis aos tratamentos mesofílicos em termos de remoção de DBO e DQO, em experimentos em escala de laboratório, com taxas de carregamento orgânico acima de $8,4 \mathrm{~kg} . \mathrm{DQO} \cdot \mathrm{m}^{-3} \cdot \mathrm{d}^{-1}$. Além disso, o lodo dos processos de tratamento operados de $50^{\circ} \mathrm{C}$ a $53^{\circ} \mathrm{C}$ mostrou melhores características de sedimentação quando comparado aos de tratamento em temperaturas abaixo destes valores.

\subsubsection{Diferenças entre flocos mesofilico e termofilico}

A maioria dos pesquisadores tem reportado que as bactérias termofilicas aeróbias falham na agregação, sendo a separação da biomassa, do efluente tratado, um critério chave para o projeto (LAPARA \& ALLEMAN, 1999). Entretanto, de acordo com Lapara \& Alleman (1999), as opiniões entre os pesquisadores em relação à formação do floco termofilico têm sido divergentes: alguns pesquisadores têm reportado a formação do floco termofílico como mediana (STOVER \& SAMUEL, 1997 ${ }^{15}$ ) enquanto outros consideram-na excelente (GEHM, $1956^{16}$ apud BARR, 1996; BARR et al., 1996).

\footnotetext{
${ }^{14}$ SÜRÜCÜ, G. A.; CHIAN, E. S. K.; ENGELBRECHT, R. S. (1976) Aerobic thermophilic treatment of high strength wastewaters. J. Wat. Pollut. Control Fed. 48, p.669-679.

${ }^{15}$ STOVER E. L.; SAMUEL G. J. (1997) High rate thermo-philic pretreatment of high strength industrial waste-waters. In Proceedings of the 52nd Industrial Waste Conference, Purdue University, ed. J. E. Alleman, Ann Arbor Press, Ann Arbor, MI, U.S.A.

${ }^{16}$ GEHM H. W. (1956) Activated sludge at high temperatures and pH values. In Biological Treatment of Sewage and Industrial Wastes, Volume I: Aerobic Oxidation. eds. J. McCabe and W. W. Eckenfelder Jr., Reinhold Publishing Corporation, New York, NY, U.S.A.
} 
Tripathi \& Allen (1999) comparando reatores de lodos ativados operados a 35, 45,55 e a $60^{\circ} \mathrm{C}$ verificaram uma redução nas propriedades de sedimentação do lodo com o aumento da temperatura.

Logo, os fatores que contribuíram para esses resultados diferenciados entre experimentos de vários autores em relação à sedimentação em processos biológicos mesofílicos e termofilicos não estão bem claros.

De acordo com Bitton (1995), a sedimentação do lodo depende da relação entre alimento, microrganismos e idade do lodo. Boa sedimentação ocorre quando os microrganismos no lodo estão na fase endógena, isto é, quando as fontes de carbono e energia são limitadas e quando a taxa de crescimento específico é baixa. Boa sedimentação do lodo, com subseqüente eficiência de remoção de $\mathrm{DBO}$, ocorrem em baixas relações alimento/microrganismos (por exemplo, altas concentrações de sólidos suspensos no licor misto). Sedimentação pobre pode ser causada por mudanças repentinas nos parâmetros físicos (temperatura, $\mathrm{pH}$ ), ausência de nutrientes (nitrogênio, fósforo, micronutrientes) e presença de substâncias tóxicas (por exemplo, metais pesados), as quais podem causar defloculação parcial nos lodos ativados (CHUDOBA, $1989^{17}$ apud BITTON, 1995).

Segundo Jenkins et al. (1993), a alta aeração e mudanças na temperatura podem ocasionar crescimento disperso do lodo, usual em sistemas de lodos ativados de águas residuárias industriais que operam em temperatura de aproximadamente $35^{\circ} \mathrm{C}$ a $40^{\circ} \mathrm{C}$. Uma observação comum é a ocorrência de crescimento de lodo disperso e alta turbidez efluente, como resultado de aumento de aeração ou de mudanças na temperatura de valores abaixo de $35^{\circ} \mathrm{C}$ para valores acima desse. O crescimento disperso do lodo e a alta turbidez efluente usualmente diminuem depois de alguns dias, quando um novo grupo termotolerante se desenvolve.

Barr et al. (1996) não concordam com essa ligação da redução da sedimentabilidade do lodo com a operação em altas temperaturas $\left(45^{\circ} \mathrm{C}\right.$ a $\left.47^{\circ} \mathrm{C}\right)$. De acordo com os autores, as características de baixa sedimentação do lodo e turbidez efluente não podem ter sido resultantes do aumento da temperatura operacional, mas até certo ponto, resultaram de tempos reduzidos de retenção de sólidos e de detenção hidráulica utilizados ( 3 a 5 dias e 4 a 8 horas, respectivamente).

\footnotetext{
${ }^{17}$ CHUDOBA, J. (1989). Activated sludge bulking control. In: Encyclopedia of Env. Control Technology. V. 3. Wastewater treatment technology. P.N. Ed. Gulf. Houston. p. 171-202.
} 
Segundo Barr et al. (1996), condições operacionais semelhantes têm resultado em alta relação entre alimento e microrganismo (A/M), que promovem crescimento em escala logarítmica. O crescimento logarítmico das culturas microbianas no licor misto dos lodos ativados é bem conhecida por produzir lodo com características baixas de sedimentação, alta concentração de sólidos no efluente (turbidez efluente) e baixa eficiência de remoção de DQO (SUNDSTROM \& KLEI, $1979^{18}$ apud BARR et al., 1996).

Vogelaar et al. (2002), baseados em vários autores, propõem algumas hipóteses para explicar a reduzida capacidade do lodo termofílico em reduzir DQO coloidal:

1) Sob condições termofílicas, os protozoários e metazoários estão ausentes (baseado em observações dos próprios autores e resultados do trabalho de Lapara \& Alleman, 1999). Os protozoários são consumidores de bactérias livres e pequenas partículas coloidais e estão presentes em grande número nos sistemas mesofílicos. Complementando essa hipótese de Vogelaar et al. (2002), de acordo com Bitton (1995) o papel dos rotíferos em um sistema de lodos ativados pode ser duplicado: podem auxiliar na remoção de bactérias suspensas livres e contribuem para a formação do floco pela produção de "pellets" fecais rodeado por muco.

2) A coesão dos flocos em reatores de lodos ativados e a habilidade para atrair partículas coloidais são governadas por vários tipos de interações: tipo DLVO (teoria de Derjaguin-Landau-Verwey-Overbeek); transporte de cargas negativas EPS (extracellular polymeric substances), e/ou cátions polivalentes como $\mathrm{Ca}^{2+}$, $\mathrm{Fe}^{3+} \mathrm{e}$ interações hidrofóbicas. A interação hidrofóbica ou mais precisamente, efeito hidrofóbico, é principalmente um fenômeno entrópico, causado mais pela dificuldade em romper as fortes interações entre as moléculas de água do que pela atração de grupos apolares. O sistema resultante é um floco hidrofóbico e/ou moléculas hidrofóbicas organizadas para minimizar a perda de entropia das moléculas de água. Em altas temperaturas, devido ao aumento do efeito randômico da água, a formação de uma estrutura ao redor da molécula não polar tem um papel menos importante, resultando em baixa interação hidrofóbica. As interações eletrostáticas (DLVO e pontes de polímeros) são apenas fracamente dependentes da temperatura na faixa de $30^{\circ}$ a $55^{\circ} \mathrm{C}$. 
Liao et al. (2001) apresentaram recente estudo, combinando as propriedades da superfície do lodo com sua floculação, capacidade de sedimentação e sólidos suspensos no efluente. Os autores encontraram que a concentração de sólidos suspensos no efluente apresentava uma correlação profunda e inversa com a hidrofobicidade do lodo.

Zita \& Hermansson (1997) também mostraram que o aumento da superficie hidrofóbica em células de bactérias levou a uma forte adsorção ao floco no lodo ativado. Essa constatação, combinada com a dependência da temperatura da interação hidrofóbica, pode ser um forte indício em direção a uma explicação viável para a turbidez observada no efluente termofilico.

De acordo com Vogelaar et al. (2002), vários autores mencionaram que há redução do crescimento bacteriano com o aumento de temperatura, relacionada aos altos requerimentos para manutenção; entretanto, os resultados encontrados em seu experimento não mostraram diferença significativa na produção de lodo. Os autores atribuíram este fato à grande parte do lodo ser constituído de sólidos com ligações inertes ou levemente hidrossolúveis, enquanto uma pequena fração consistia de biomassa ativa.

Considerando ainda a biomassa de sistemas termofílicos, experimentos cinéticos em batelada realizados por Suchochleb \& Tripathi (1997) ${ }^{19}$ apud Tripathi \& Allen (1999), mostraram que a DQO recalcitrante aumenta em temperaturas maiores, e que a DQO não recalcitrante é removida dentro do tempo de tratamento em reatores seqüenciais em batelada, indicando que os níveis de biomassa não estavam limitando a degradação global.

Como demonstrado na tabela 3.2 (LAPARA \& ALLEMAN, 1999), a taxa máxima de utilização específica de substrato $\left(\mathrm{q}_{\mathrm{m}}\right)$, citada na literatura para tratamento termofílico aeróbio, tem sido, tipicamente, três a dez vezes maior que para sistemas mesofílicos análogos e a constante de manutenção $\left(k_{d}\right)$ é tipicamente dez vezes maior.

Como resultado dessa característica biocinética, a taxa na qual o lodo é produzido, é extraordinariamente menor nesses sistemas, tão baixa quanto às dos processos de tratamento anaeróbio (LAPARA \& ALLEMAN, 1999).

${ }^{19}$ SUCHOCHLEB, A.; TRIPATHI C. S. (1997) Kinetics of thermophilic biological treatment of bleached Kraft pulp mill effluent. Poster presentation in 90th Air and Waste Management Association Annual Meeting and Exhibition in Toronto. 
TABELA 3.2. Comparação de constantes biocinéticas em temperaturas mesofílicas e termofílicas (LAPARA \& ALLEMAN, 1999).

\begin{tabular}{|c|c|c|c|c|c|c|}
\hline Resíduo & $\begin{array}{c}\mathrm{T} \\
\left({ }^{0} \mathrm{C}\right)\end{array}$ & $\begin{array}{c}\mu_{\mathrm{m}} \\
\left(\mathrm{dia}^{-1}\right)\end{array}$ & $\frac{\mathrm{q}_{\mathrm{m}}}{\left(\mathrm{dia}^{-1}\right)}$ & $\begin{array}{c}\gamma_{\mathrm{T}} \\
\text { (mg.SST/mgDQO) }\end{array}$ & $\begin{array}{c}\mathrm{Kd} \\
\left(\mathrm{dia}^{-1}\right)\end{array}$ & Referências* \\
\hline Municipal & - & 3,75 & 5,6 & $0,67^{\mathrm{a}}$ & 0,07 & Lawrence \& Mcarty (1970) \\
\hline Municipal & 20 & 3 & 5 & 0,6 & 0,06 & $\begin{array}{l}\text { Tchobanglous } \\
\text { burton (1991) }\end{array}$ \\
\hline Industrial & 25 & 0,6 & 1,95 & $0,31^{b}$ & 0,03 & Kim et al. (1997) \\
\hline Industrial & 33 & 0,6 & 2,0 & 0,3 & 0,08 & $\begin{array}{l}\text { Campbell } \\
\text { Rocheleau (1976) }\end{array}$ \\
\hline Industrial & 45 & 5,8 & 16,5 & 0,35 & 0,52 & $\begin{array}{l}\text { Couillard \& } \\
\text { (1993) }\end{array}$ \\
\hline Industrial & 52 & 6,0 & 19,8 & 0,30 & 0,32 & Couillard et al. (1989) \\
\hline Industrial & 53 & 3,4 & 5,6 & $0,6^{\mathrm{c}}$ & 0,52 & Jackson (1983) \\
\hline Industrial & 58 & 10,1 & 21,1 & 0,32 & 0,78 & Couillard et al. (1989) \\
\hline Glicose & 58 & 5,2 & 15,4 & 0,34 & 0,48 & Sürücü et al. (1976) \\
\hline
\end{tabular}

Unidades alternativas: ${ }^{\mathrm{a}} \mathrm{mgSSV} / \mathrm{mgDBO}_{5},{ }^{\mathrm{b}} \mathrm{mgSSV} / \mathrm{mgDQO},{ }^{c} \mathrm{mgSST}_{\mathrm{mgDBO}}{ }_{5} .{ }^{*}$ referências citadas no traballho de Lapara \& Alleman (1999).

\subsubsection{Experimentos utilizando tratamento termofílico aeróbio}

A influência de diferentes valores de temperatura no tratamento biológico aeróbio foi estudada por Tripathi \& Allen (1999), utilizando quatro reatores seqüenciais em batelada (SBR), operados em paralelo, sob condições mesofilica e termofílicas $\left(35^{\circ} \mathrm{C}, 45^{\circ} \mathrm{C}, 55^{\circ} \mathrm{C}\right.$ e $\left.60^{\circ} \mathrm{C}\right)$.

Todos os reatores foram inoculados com lodo mesofilico, obtido de reator de lodos ativados operando em escala real, em duas indústrias de papel e celulose. A temperatura foi aumentada gradualmente, por um período de oito semanas, para aclimatar o lodo. A porcentagem de remoção de DQO variou de $40 \%$ a $76 \%$ com médias de $(75 \pm 9,7) \%,(73 \pm 10) \%,(62 \pm 9) \%$ e $(63 \pm 10) \%$ para os reatores operando a $35^{\circ} \mathrm{C}, 45^{\circ} \mathrm{C}, 55^{\circ} \mathrm{C}$ e $60^{\circ} \mathrm{C}$, respectivamente. As taxas de remoção de DQO foram significativamente maiores a $35^{\circ} \mathrm{C}$ e $45^{\circ} \mathrm{C}$ comparadas com as temperaturas de $55^{\circ} \mathrm{C}$ e $60^{\circ} \mathrm{C}$, sendo que, segundo os autores, não houve diferença considerável em relação à remoção de DQO para os reatores que operaram a $35^{\circ} \mathrm{C}$ e $45^{\circ} \mathrm{C}$ (TRIPATHI \& ALLEN, 1999).

De acordo com os autores, havia uma clara redução nas concentrações de sólidos suspensos no licor misto dos reatores operados em altas temperaturas. Foi verificado um aumento da concentração de sólidos suspensos no efluente tratado, de $20 \mathrm{mg} \cdot \mathrm{L}^{-1}$ para $80 \mathrm{mg} \cdot \mathrm{L}^{-1}$ e um correspondente decréscimo na concentração de SSVLM, de $2500 \mathrm{mg} . \mathrm{L}^{-1}$ para $1500 \mathrm{mg} . \mathrm{L}^{-1}$, da menor para a maior temperatura de operação. 
Também foram verificadas mudanças na população microbiana durante a aclimatação. Tripathi \& Allen (1999) verificaram que durante a aclimatação de reatores SBR à temperatura termofilica, o desempenho dos reatores foi baixo $(45 \%$ a $60 \%$ de remoção de DQO) comparado ao estado de equilíbrio (60\% a $76 \%$ de remoção de DQO). Além disso, coincidiu com a baixa remoção, a deterioração nas características de sedimentação durante a aclimatação ou mudança transitória na temperatura. Outra observação feita pelos autores foi a tendência de aumento de $\mathrm{pH}$ efluente quando operaram em altas temperaturas, sendo que o inverso aconteceu em relação aos sólidos suspensos no licor misto.

Jahren et al. (2002) testaram a utilização, em escala de bancada, de um reator aeróbio com biofilme e leito móvel, a $55^{\circ} \mathrm{C}$, para o tratamento de licor branco da polpação termomecânica. O reator com volume de $8,55 \mathrm{~L}$ teve $11 \%$ do seu volume útil ocupado pelo material suporte. A inoculação foi feita com lodo mesofilico de estação de lodos ativados tratando água residuária de indústria de papel. Durante o trabalho, o tempo de detenção hidráulica foi gradualmente reduzido de 30 horas para cerca de 14 horas $\mathrm{e}$ as taxas de carregamento foram aumentadas de $1,5 \mathrm{~kg}$.DQO. $\mathrm{m}^{-3} \cdot \mathrm{d}^{-1}$ a $2 \mathrm{~kg}$. DQO $\cdot \mathrm{m}^{-3} \cdot \mathrm{d}^{-1}$, atingindo valor máximo de $3,8 \mathrm{~kg} \cdot$ DQO $\cdot \mathrm{m}^{-3} \cdot \mathrm{d}^{-1}$. Essas mudanças foram feitas depois de 70 dias de operação.

De acordo com JAHREN et al. (2002), baseados em outros autores, processos aeróbios mesofilicos removem usualmente $55 \%$ a $80 \%$ da DQO de licor branco de polpação termomecânica. Nesse experimento, foi encontrada remoção de DQO de $60 \%$ a $65 \%$. A remoção de DQO inicial foi similar à obtida depois que o lodo adaptou-se à temperatura. Isto sugere que os microrganismos termofílicos aeróbios ou termotolerantes estão presentes em grandes quantidades em processos mesofílicos.

Comparando-se os resultados desse experimento com outro feito pelos mesmos autores, para tratar água residuária similar, porém utilizando um reator anaeróbio termofilico (JAHREN et al.; 1999), a remoção de DQO foi considerada semelhante, indicando que a DQO biodegradável total que poderia ser removida sob condições termofilicas, foi removida tanto no tratamento aeróbio, quanto no anaeróbio. Deve-se considerar que as taxas de carregamento orgânico aplicadas no reator aeróbio (acima de $3,8 \mathrm{~kg}$.DQO. $\mathrm{m}^{-3} \cdot \mathrm{d}^{-1}$ ) foram significativamente menores que as aplicadas no reator anaeróbio (15 kg.DQO $\left.\mathrm{m}^{-3} \cdot \mathrm{d}^{-1}\right)$. Entretanto, a taxa máxima de remoção do sistema aeróbio não foi alcançada com as taxas de carregamento utilizadas neste estudo. 
Comparando a produção de lodo no reator aeróbio termofílico $\left(0,3\right.$ gSS.gDQO $\left.{ }_{\text {removida }}\right)$ os valores encontrados foram similares aos de Rintala \& Vuoriranta (1988) ${ }^{20}$ apud Jahren et al. (2002) tratando água residuária semelhante, em um sistema mesofilico. De acordo com Jahren et al. (2002) a baixa concentração de biomassa nesse experimento (1400 a $1700 \mathrm{mg} . \mathrm{SSV} . \mathrm{L}^{-1}$ ) ocorreu, possivelmente, pelas baixas taxas de carregamento aplicadas ou limitação de nutrientes, resultando em uma baixa formação de biomassa.

No trabalho de Vogelaar et al. (2002) foi utilizada uma configuração de reator do tipo lodo ativado "plug flow", afim de obter um gradiente de substrato dentro do sistema, favorecendo a sedimentabilidade do lodo. Assim, dois reatores em escala de bancada foram operados em paralelo por 6 meses, sendo um termofílico $\left(55^{\circ} \mathrm{C}\right)$ e outro de referência, mesofilico $\left(30^{\circ} \mathrm{C}\right)$.

Os reatores foram alimentados com o efluente de um reator UASB operado a $35^{\circ} \mathrm{C}$, admitindo que poderia representar, razoavelmente bem, o efluente de um reator anaeróbio termofílico. O período de aclimatação do lodo foi de dois meses para ambas as temperaturas de operação $\left(35^{\circ} \mathrm{C}\right.$ e $\left.50^{\circ} \mathrm{C}\right)$, sendo os reatores operados com vinte, quinze e dez dias de tempo de retenção de sólidos. A porcentagem de remoção de DQO durante todo o período experimental foi de $(58 \pm 5) \%$ a $30^{\circ} \mathrm{C}$ e $(48 \pm 10) \%$ a $55^{\circ} \mathrm{C}$. As diferenças entre os sistemas quanto à remoção total de DQO foram devidas à menor remoção da fração solúvel e de colóides a $55^{\circ} \mathrm{C}$ quando comparado ao sistema de referência. A $30^{\circ} \mathrm{C}$, as porcentagens de remoção da fração solúvel de DQO foram de $(65 \pm 25) \%$, (75 \pm 17$) \%$ e $(86 \pm 22) \%$ para vinte, quinze e dez dias de tempo de retenção de sólidos, respectivamente. A $55^{\circ} \mathrm{C}$, essas porcentagens foram de $(48 \pm 34) \%$, $(40 \pm 28) \%$ e (70 \pm 25$) \%$, respectivamente (VOGELAAR et al., 2002).

Vogelaar et al. (2002) consideraram desprezível o efeito do tempo de retenção de sólidos na eficiência de remoção de DQO. De acordo com os autores, a fração coloidal da DQO efluente esteve relacionada com a concentração de material coloidal afluente, em ambos os sistemas, sendo que, o lodo termofilico não foi capaz de reter o material coloidal afluente tão bem quanto o mesofílico, apresentando, o efluente termofilico, alta turbidez. Visualmente, o efluente do reator mesofilico não era sempre completamente claro, mas significativamente menos turvo que o termofilico. Ambos os reatores apresentaram excelentes propriedades de sedimentação. Vogelaar et al. (2002)

\footnotetext{
${ }^{20}$ RINTALA, J. A.; VUORIRANTA, P. (1988). Anaerobic-aerobic treatment of thermomechanical pulping effluents.
} Tappi J. 71(9):201-7. 
consideram o tratamento aeróbio termofílico viável para aplicação em indústria, pelo ganho de energia, compensando a turbidez efluente. De acordo com os autores, um efluente claro termofilico pode ser obtido caso o afluente contenha apenas uma pequena quantidade de material coloidal.

Barr et al. (1996) compararam os efeitos do tempo de detenção hidráulica, do tempo de residência dos sólidos e de altas temperaturas em reatores aeróbios de lodo ativado, alimentados com efluente da indústria de polpa Kraft. Os reatores foram aclimatados em um período de dois meses, sendo operados a $35^{\circ} \mathrm{C}$, com tempo de detenção hidráulica variando de 10 a 12 horas, e tempo de retenção de sólidos variando de 12 a 15 dias. Durante esse período, os reatores removeram $(87,9 \pm 4,3) \%$ de DBO e $(32,4 \pm 9,0) \%$ de DQO, apresentando concentração de SSV no licor misto de (1675 \pm 97$) \mathrm{mg} . \mathrm{L}^{-1}$, e no efluente, de $(45,5 \pm 11,2) \mathrm{mg} . \mathrm{L}^{-1}$.

Variando o tempo de detenção hidráulica e o tempo de retenção de sólidos, Barr et al. (1996) observaram que o primeiro teve maior influência no desempenho dos reatores que o segundo. Maiores tempos de detenção hidráulica implicaram em melhora na remoção de $\mathrm{DBO}, \mathrm{DQO}$, toxicidade e $\mathrm{AOX}$, enquanto maiores tempos de retenção de sólidos tiveram efeito desprezível. As eficiências de remoção de DBO no reator de lodos ativados, em temperaturas de $41^{\circ} \mathrm{C}$ a $50^{\circ} \mathrm{C}$, bem como os SSVLM e a presença de SSV no efluente foram comparáveis às obtidas em faixa mesofilica. As efíciências de remoção de DQO nessa faixa de temperatura foram melhores, possivelmente, devidas à maior dissolução de compostos orgânicos em altas temperaturas. Essa explicação é digna de crédito dados os limites de solubilidade em água de muitos dos componentes dos efluentes da polpação.

Barr et al. (1996) consideraram que, de forma geral, o desempenho do reator em escala de bancada, na faixa de temperatura mesofilica, é tão bom quanto em temperatura termofilica, entretanto, devem ser estudadas possibilidades de melhorar a estabilidade do reator termofilico quando sujeito a variações na temperatura.

\subsubsection{Sistema biológico combinado termofílico}

A aplicabilidade do sistema combinado anaeróbio-aeróbio, como tratamento termofílico para águas residuárias de indústrias de papel e celulose, foi estudada em escala laboratorial e piloto por Jahren et al. (1999). No reator anaeróbio, a mistura era feita pela circulação do gás, enquanto, no reator aeróbio a aeração era também 
responsável pela mistura. O reator anaeróbio foi inoculado com lodo mesofílico e o aeróbio não foi inoculado, sendo ambos operados com vinhaça por um ano e meio antes do início do experimento. Posteriormente, foi coletado licor branco de polpação termomecânica $^{21}$ de uma indústria de polpa, duas vezes durante o experimento (substrato 1 e substrato 2).

Quando foi dada a partida utilizando licor branco como substrato, o reator anaeróbio apresentava uma concentração de biomassa (suspensa e fixa) de 3,3 g.SSV.L ${ }^{-1}$ e o reator aeróbio de 1,6 g.SSV.L ${ }^{-1}$. Depois de sete meses de trabalho com o substrato 1, a biomassa no reator anaeróbio alcançou uma concentração de 5,5 g.SSV.L ${ }^{-1}$ e no reator aeróbio de 6,5 g.SSV.L ${ }^{-1}$. A eficiência no reator anaeróbio foi cerca de $30 \%$ em taxas de carregamento orgânico de $7 \mathrm{~kg} \cdot \mathrm{DQO}_{\mathrm{sol}} \cdot \mathrm{m}^{-3} \cdot \mathrm{d}^{-1}$; globalmente, foi alcançada uma eficiência de $60 \%$. Entretanto, quando passou a ser utilizado o substrato 2, a efíciência de remoção de DQO solúvel passou a variar de $10 \%$ a $25 \%$ no reator anaeróbio e de $5 \%$ a $15 \%$ no reator aeróbio. Os reatores foram operados com tempo de detenção hidráulica na média de 24 a 8 horas para cada um (JAHREN et al., 1999).

Segundo os autores, pode haver diferentes razões para as taxas de remoção abaixo da expectativa, que entretanto, não foram bem estabelecidas. $\mathrm{O}$ processo pode ter sido inibido por componentes da água residuária, limitação de nutrientes, ou as frações biodegradáveis dos dois substratos eram diferentes.

Jahren et al. (1999) analisaram a taxa de DQO solúvel removida como função da taxa de carregamento biodegradável para o substrato 1 , e verificaram que a capacidade máxima do processo anaeróbio não foi alcançada durante o estudo. De acordo com os autores, a relação $\mathrm{DQO}_{\text {solúvel }} / \mathrm{DBO}_{5}$ para o substrato foi cerca de sete, indicando a presença de algum composto apenas levemente ou não completamente biodegradável.

Baseado em Rintala \& Puhakka (1994), a relação típica de DQO/DBO para efluente de indústria de polpapem termomecânica é de 2 a 2,3.

As concentrações de $\mathrm{AGV}$ no efluente do reator anaeróbio foram altas e não degradadas no reator aeróbio, clara indicação que o processo aeróbio sofreu inibição considerando que a hidrólise é normalmente uma etapa limitante da degradação aeróbia

\footnotetext{
${ }^{21}$ Deve-se salientar que na polpação termomecânica não são adicionados produtos químicos para auxiliar a polpação. Os compostos químicos encontrados nos efluentes são apenas as essências da própria madeira.
} 
(HENZE et al.; $1995^{22}$ apud JAHREN et al.;1999). Os sólidos no efluente aeróbio podem também ser originados da hidrólise de sólidos suspensos no efluente anaeróbio.De acordo com Jahren et al. (1999), o licor branco utilizado nesse trabalho apresentou altas concentrações de material pouco ou não biodegradável, não sendo representativo dos efluentes das indústrias de polpa termomecânica em geral. Assim, de acordo com os autores, os resultados demonstraram que o reator anaeróbio termofílico, seguido por aeróbio, pode ser viável para o tratamento termomecânico termofílico de água branca.

Não foram encontrados na literatura outros trabalhos, além do citado, utilizando sistema combinado termofilico.

\subsection{Fatores que afetam o crescimento microbiano em sistemas de tratamento biológico}

Como citado anteriormente, o tratamento biológico termofílico é utilizado normalmente quando o efluente a ser tratado apresenta-se em alta temperatura, caso de muitas indústrias. Porém, a maioria delas, quando utiliza o tratamento biológico, resfria o efluente para que ele seja tratado. Portanto, até mesmo em escala de laboratório, é difícil de obter-se lodo termofílico para inoculação. Assim, na maioria dos experimentos, os reatores são inoculados com lodo mesofilico e a temperatura é aumentada gradativamente. Há casos porém em que o aumento da temperatura é feito subitamente, em um só passo.

Logo, fatores que controlam o crescimento dos microrganismos devem ser cuidadosamente analisados para monitorar o sistema, verificando a adaptação à condição termofilica. Dentre esses fatores, merecem destaque: os nutrientes, a temperatura de operação, o tempo de detenção hidráulica e o pH, incluindo a acidez e alcalinidade. Outros parâmetros são importantes: a concentração do substrato afluente, a taxa de carregamento orgânico, oxigênio disponível e a toxicidade (GUERRERO et al., 1999; SPRINGER, 1993).

Considerando o controle microbiano, de acordo com Brock \& Madigan (1988) quatro fatores apresentam papel claro neste controle: temperatura, $\mathrm{pH}$, disponibilidade de água e oxigênio.

\footnotetext{
${ }^{22}$ HENZE, M.; HARREMÖES, P.; LACOUR IANSEN, J.; ARVIN, E. (1995). Wastewater treatment: biological and chemical process. Springer, Berlin.
} 
De acordo com Lapara \& Alleman (1999), para o tratamento aeróbio termofílico alguns níveis ótimos de parâmetros fundamentais como: temperatura, concentração de oxigênio dissolvido e $\mathrm{pH}$ não foram bem estabelecidos. Alguns trabalhos revelam o efeito da temperatura em processos de tratamento biológico termofílico, entretanto, os efeitos do oxigênio dissolvido e pH não foram reportados na literatura técnica.

\subsubsection{Nutrientes}

Entre os nutrientes necessários para o crescimento bacteriano está incluída grande quantidade de carbono, sendo que na água residuária a ser tratada, a matéria orgânica a ser removida serve como essa fonte.

Nitrogênio e fósforo também são nutrientes importantes e, se necessário, devem ser adicionados de forma a suprir as quantidades recomendadas para o processo anaeróbio (relação DQO:N:P de 500:5:1) ou aeróbio (relação DBO:N:P de 100:5:1).

Deve ser ressaltado que as taxas de metabolização do substrato são dependentes da disponibilidade de nutrientes e a taxa específica de utilização pode ser multiplicada quando os nutrientes encontram-se em excesso. Os efeitos tóxicos também são agravados por limitações nutricionais.

Em geral, o crescimento da biomassa termofilica em sistemas anaeróbios é similar àquele apresentado pelos microrganismos mesofílicos. Os maiores requerimentos para manutenção e alta taxa de morte em sistemas termofílicos podem resultar em menor crescimento da biomassa (SUNDARAM, 1986).

As arqueas metanogênicas necessitam de suplementos que são fatores de crescimento, como nitrogênio e elementos traço (OREMLAND, $1988^{23}$ apud JAHREN et al., 1999).

De acordo com Kim et al. (2002b), estudos realizados têm demonstrado que o crescimento dos microrganismos termofilicos anaeróbios, por unidade de substrato, é baixo. A taxa de decaimento, duas vezes maior que a das bactérias mesofilicas, pela tendência de lise das células sob condições termofilicas (SPEECE, $1996^{24}$ apud KIM, 2002) e o alto requerimento de energia para manutenção das propriedades moleculares específicas de reações enzimáticas em temperaturas termofílicas, são responsáveis pelo baixo crescimento (ZEIKUS, $1979^{25}$ apud KIM, 2002).

\footnotetext{
${ }^{23}$ OREMLAND, R. S. (1988). Biogeochemistry of methanogenic bacteria. In: ZEHNDER, A. J. B. Biology of Anaerobic Bacteria. Wiley, New York, p. 641-705.

${ }^{24}$ SPEECE, R.E. (1996). Anaerobic biotechnology for industrial wastewaters. Nashville, TN: Archae Press, 1996.

${ }^{25}$ ZEIKUS, J.G. (1979). Thermophilic bacteria: ecology, physiology, and technology. Enzyme Microb Technol $1979 ; 1: 243-51$.
} 
Segundo Lapara \& Alleman (1999), as bactérias mais prováveis de proliferação em reatores aeróbios termofílicos apresentam, comumente, exigências nutricionais únicas e especificas. Esta teoria é confirmada por Tripathi \& Allen (1999) que, em experimentos utilizando reatores aeróbios operando em temperaturas mesofilica e termofilica, concluíram que as comunidades microbianas dos reatores com temperaturas mais elevadas eram mais seletivas e usavam uma limitada faixa dos nutrientes disponíveis, expressos como DQO.

\subsubsection{Temperatura de operação}

A temperatura é um dos mais importantes fatores ambientais que influenciam no crescimento e na sobrevivência dos microrganismos. Com o aumento da temperatura, as reações químicas e bioquímicas podem ocorrer em maiores taxas, acelerando o crescimento. Entretanto, temperatura além da máxima pode danificar, irreversivelmente, proteínas, ácidos nucléicos e outros componentes celulares. Para todos os organismos existem temperaturas mínimas, abaixo das quais o crescimento não ocorre; temperaturas ótimas nas quais o crescimento é mais rápido e temperaturas máximas, acima das quais o crescimento não é possível (BROCK \& MADIGAN, 1988).

Vários experimentos com culturas puras ou biomassa complexa documentaram que termofílicas anaeróbias, não metanogênicas e populações metanogênicas têm diferentes requerimentos de temperatura com relação ao crescimento ótimo (AHRING et al., 2001).

Segundo Zeikus \& Winfrey $(1976)^{26}$ apud Vazoller (1995), a faixa de temperatura das arqueas metanogênicas é ampla, sendo observada produção de metano em temperaturas de $40^{\circ} \mathrm{C}$ a $55^{\circ} \mathrm{C}$, com rendimento ótimo entre $35^{\circ} \mathrm{C}$ e $42^{\circ} \mathrm{C}$. Porém Wiegel (1992) ${ }^{27}$ apud Ahring et al. (2001), considerou a faixa de atividade dos grupos microbianos metanogênicos distinta e estreita, quando comparada à das bactérias termofilicas, hidrolíticas e fermentativas, que apresentam crescimento ótimo em ampla faixa de temperatura, entre $55^{\circ} \mathrm{C}$ e $70^{\circ} \mathrm{C}$.

A temperatura afeta o equilíbrio de ionização, a solubilidade do substrato e até mesmo a biodisponibilidade de ferro (SPEECE, 1996), afetando também diretamente a velocidade específica de utilização do substrato. Porém, a velocidade global de remoção

\footnotetext{
${ }^{26}$ VAZOLLER, R. F. (1995). Avaliação do ecossistema microbiano de um biodigestor anaeróbio de fluxo ascendendente e manta de lodo, operado com vinhaça sob condições termofilicas. Tese (doutorado). Universidade de São Paulo - Escola de Engenharia de São Carlos. São Carlos. 259p.

${ }^{27}$ WIEGEL J. (1992) The obligately anaerobic thermophilic bacteria. In Thermophilic Bacteria, ed J. K. Kristjansson, pp. 105-184. CRC Press, Boca Raton, FL.
} 
de substrato é proporcional ao produto da velocidade específica pela concentração de microrganismos ativos no reator. Assim, o desempenho do reator dependerá da sua capacidade de reter a biomassa em seu interior, em diferentes temperaturas (CAMPOS et al., 1999).

A susceptibilidade para flutuações na temperatura diminui consideravelmente se a biomassa for imobilizada em grânulos. Esse fenômeno pode ser atribuído à limitação do substrato por resistência de difusão. Se a taxa de conversão do substrato nas camadas externas do grânulo for maior que a taxa de transporte de massa para camadas mais internas, somente parte do grânulo poderá contribuir para o processo de conversão. A profundidade de penetração nos grânulos, na verdade, depende da temperatura que determina a atividade máxima da biomassa e de vários fatores, como: concentração de substrato na fase líquida, tipo e tamanho dos grânulos; densidade e distribuição da biomassa ativa nos grânulos (VAN LIER et al., 1996).

Não é claro o efeito da temperatura na afinidade intrínseca pelo substrato em metanogênicas termofilicas dispersas, mas sabe-se que tem forte efeito na taxa máxima de conversão de AGV em lodo metanogênico termofilico. (VAN LIER et al., 1996).

Ahring et al. (2001) avaliaram o efeito do aumento da temperatura de $55^{\circ} \mathrm{C}$ para $65^{\circ} \mathrm{C}$ no desempenho e na dinâmica de uma população microbiana anaeróbia. Esse trabalho foi feito em escala de laboratório, utilizando reatores com volume útil de três litros, agitados continuamente e alimentados com estrume de gado, com taxa de carregamento de três gramas de sólidos voláteis por litro do volume de reator por dia. $\mathrm{O}$ tempo de detenção hidráulica foi de quinze dias. A estabilidade do reator foi obtida em um período de quarenta e cinco dias, para ambas as temperaturas.

Segundo os autores, o aumento da temperatura apresentou efeitos negativos no desempenho do digestor e na atividade microbiana. Houve um imediato distúrbio no balanço entre fermentativas, microrganismos produtores de ácidos e consumidores de ácidos envolvidos na metanogênese.

De acordo com Ahring et al. (2001), baseados em outros autores, na digestão anaeróbia, os caminhos metabólicos encontrados parecem ser idênticos para as condições mesofílicas e termofilicas. Entretanto, a degradação de carboidratos sob condições termofílicas tem apresentado menor produção de metabólitos fermentados.

Os autores concluíram que os altos níveis de ácidos voláteis, o acúmulo inicial e persistente e a queda simultânea na produção de metano, indicam que a degradação de 
ácidos voláteis e o consórcio metanogênico foram severamente afetados pelo aumento na temperatura e que essas populações são incapazes de balancear a atividade da população fermentativa. Por outro lado, a alta temperatura operacional não reduziu significantemente a eficiência da hidrólise microbiana e fermentativa. A acidificação, levemente menor a $65^{\circ} \mathrm{C}$, e valores muito similares encontrados para a produção de metano, indicam que a menor produção de metano a $65^{\circ} \mathrm{C}$ é resultado da incapacidade do consórcio metanogênico de, eficientemente, converter ácidos em alta temperatura.

O fato da capacidade de acidificação das populações fermentativas e hidrolíticas não terem sido significativamente afetadas pode, provavelmente, ser explicado por uma maior taxa metabólica de populações termófilas e extremófilas de bactérias hidrolíticas e fermentativas com aumento de temperatura (AHRING et al., 2001).

Do ponto de vista termodinâmico, um aumento da temperatura faz com que a reação de oxidação dos ácidos orgânicos seja mais favorável e reduz a produção de energia da reação de redução do hidrogênio (AHRING et al., 2001).

Como já citado, alguns autores (CHERNICHARO, 1997; KUGELMAN \& GUIDA, $1989^{28}$ apud KIM et al., 2002; GUERRERO et al., 1999; DINSDALE et al., 1997a) reportaram os sistemas termofílicos como mais sensíveis a mudanças na temperatura, que sistemas mesofilicos.

Entretanto, de acordo com os resultados obtidos por Lau \& Fang (1997), microrganismos termofílicos expostos a um aumento de temperatura foram capazes de recuperar a atividade metanogênica em torno de uma semana, após ser restabelecida a temperatura para a faixa ideal termofilica.

Lau \& Fang (1997) estudaram o efeito de um choque de temperatura na atividade de biogrânulos termofilicos de dois reatores UASB que tratavam água residuária contendo $9450 \mathrm{mg} . \mathrm{L}^{-1}$ de sacarose.

Os reatores operavam com tempo de detenção hidráulica de 24 horas, em temperatura de $55^{\circ} \mathrm{C}$, e eficiência de remoção de DQO variando de $85 \%$ a $90 \%$. Um dos reatores foi submetido a aumento de $10^{\circ} \mathrm{C}$ na temperatura por oito dias, enquanto o outro reator, a redução da temperatura para $37^{\circ} \mathrm{C}$ por 16 dias (LAU \& FANG, 1997).

Os resultados obtidos por Lau \& Fang (1997) indicaram que os microrganismos termofilicos no primeiro reator perderam a atividade metanogênica após serem expostos ao aumento de temperatura. Entretanto, foram capazes de recuperar completamente essa 
atividade oito dias depois da temperatura ser retornada para $55^{\circ} \mathrm{C}$. A eficiência de remoção de DQO caiu de $85 \%$ para valores abaixo de $60 \%$ após os oito dias, permanecendo nesses valores por cinco dias, quando voltou a aumentar. A efíciência atingiu $87 \%$ oito dias depois de ter voltado ao valor inicial, mas se manteve instável nas duas semanas seguintes.

Comparando-se os resultados desse trabalho com outros da literatura, os autores concluíram que os microrganismos termofílicos parecem ser mais resistentes ao aumento de temperatura do que os mesofílicos. No reator onde houve o decréscimo da temperatura de $55^{\circ} \mathrm{C}$ para $37^{\circ} \mathrm{C}$, após cinco dias de operação a eficiência caiu de $90 \%$ para $40 \%$. Depois disso, a temperatura foi mantida em $37^{\circ} \mathrm{C}$ e a eficiência de remoção foi gradualmente aumentando, atingindo eficiência de $70 \%$ quinze dias após o decréscimo da temperatura. Os grânulos do reator UASB, depois de alguns dias de aclimatação à temperatura de choque, adaptaram-se à baixa temperatura.

Assim, os autores Lau \& Fang (1997) concluíram que a mudança súbita da temperatura resultou em remoção deficiente de DQO e perda da biomassa, além de queda no $\mathrm{pH}$ e acúmulo de ácidos, particularmente propiônico. Porém, os reatores foram capazes de recuperar a eficiência com a alcalinização do meio e o retorno da temperatura para $55^{\circ} \mathrm{C}$. Os testes de atividade metanogênica específica mostraram que o aumento da temperatura desfavoreceu mais os grânulos que o decréscimo.

Segundo Lau \& Fang (1997), baseados em outros autores, o efeito da temperatura de choque dependerá da temperatura induzida, do tempo de exposição e da composição bacteriana do lodo.

Em reatores biológicos aeróbios, operando em temperatura de $50^{\circ} \mathrm{C}$, foi verificado por Barr et al. (1996) os efeitos de mudanças bruscas na temperatura. A rápida redução da temperatura resultou em perturbação temporária da eficiência de tratamento, proporcional à magnitude da redução de temperatura. Depois de reduções repentinas na temperatura de operação $\left(7^{0} \mathrm{C} ; 16,5^{\circ} \mathrm{C} ; 32^{0} \mathrm{C}\right.$ e $\left.40,5^{\circ} \mathrm{C}\right)$, verificou-se que pequenos choques na temperatura não apresentaram efeitos prejudiciais ao desempenho do reator, mas os maiores sim. Para as reduções menores $\left(7^{0} \mathrm{C}\right.$ e $\left.16,5^{\circ} \mathrm{C}\right)$ a recuperação ocorreu em período de 12 a 24 horas. Aproximadamente 72 horas foram necessárias para a recuperação do sistema às duas maiores reduções $\left(32^{\circ} \mathrm{C}\right.$ e $\left.40,5^{\circ} \mathrm{C}\right)$.

Tripathi \& Allen (1999) avaliaram em seu trabalho o efeito da temperatura na comunidade microbiana aeróbia (trabalho citado no item 3.6.2.2). Para isso, utilizaram 
técnicas de biologia molecular (método proposto por Victorio et al., 1996) e concluíram que a comunidade microbiana formadora da estrutura do lodo aeróbio do reator SBR a $35^{\circ} \mathrm{C}$ era distinta da submetida a $60^{\circ} \mathrm{C}$. Também concluíram que os reatores que operavam a $55^{\circ} \mathrm{C}$ e $60^{\circ} \mathrm{C}$ possuíam comunidades semelhantes. Para os autores, a comunidade microbiana aeróbia desenvolvida em altas temperaturas são mais seletivas.

\subsubsection{Tempo de detenção hidráulica $\left(\theta_{H}\right)$}

O tempo de detenção hidráulica define o tempo que a microbiota terá para metabolizar o substrato. De acordo com Speece (1996), para que ocorra o tratamento microbiológico, deve-se proporcionar tempo de contato compatível com a natureza do substrato, a qual reflete o grau de dificuldade dos microrganismos em degradá-lo. Ácidos graxos voláteis simples, de baixa massa molecular; açúcares e álcoois podem ser metabolizados em minutos, enquanto, substâncias complexas ou moléculas cloradas podem necessitar de horas ou dias. Além disso, de acordo com o autor citado, outros fatores interferem na determinação do melhor tempo de detenção hidráulica, como a fonte do inóculo e as condições ambientais.

O efeito do tempo de detenção hidráulica no desempenho de um reator aeróbio termofilico foi analisado por Barr et al. (1996). Os autores alteraram o tempo de detenção hidráulica e o tempo de retenção de sólidos nos reatores para determinar as condições ótimas de operação.

Em geral, foi observado por Barr et al. (1996) que a eficiência de remoção de DQO era mais fortemente influenciada pelo tempo de detenção hidráulica $\left(\theta_{\mathrm{H}}\right)$ do que pelo tempo de retenção de sólidos (TRS). Para cada TRS, a eficiência do tratamento em termos de remoção de DQO diminuía com a redução do tempo de detenção hidráulica, como era esperado, dado o aumento da relação alimento/microrganismo.

Considerando os dados de eficiência de remoção de DBO, parece que o impacto negativo do menor tempo de detenção hidráulica é mais pronunciado em menores tempos de retenção de sólidos (BARR et al.,1996).

O tempo de detenção hidráulica também pode ser alterado de forma a otimizar a biodegradação em reatores biológicos mesofilicos e termofílicos.

Guerrero et al. (1999) utilizaram o tempo de detenção hidráulica e a temperatura para otimizar a hidrólise e acidogênese de efluente de indústria de alimentos com altos 
conteúdos de sólidos e de proteínas. Assim, um reator mesofílico $\left(37^{0} \mathrm{C}\right)$ e um reator termofílico $\left(55^{\circ} \mathrm{C}\right)$ sofreram alterações no tempo de detenção hidráulica de 6 horas para 48 horas, visando encontrar o valor ótimo para otimização da hidrólise-acidogênese.

Os resultados obtidos por Guerrero et al. (1999) indicaram que as efíciências máximas de remoção de SSV foram obtidas em ambos os reatores operando com tempo de detenção hidráulica de 24 horas $(58 \%$ e $46 \%$ para o reator termofilico e mesofílico, respectivamente).

A eficiência de remoção de sólidos suspensos voláteis foi o fator chave para a seleção do tempo de detenção hidráulico ótimo, no caso, 24 horas de acordo com os resultados (GUERRERO et al., 1999).

\subsection{4. $p H$}

A faixa de $\mathrm{pH}$ em que a população bacteriana normalmente consegue sobreviver em estações de tratamento de águas residuárias varia de 5 a 9, com uma faixa ótima de operação próxima a valores neutros, cerca de 6,5 a 7,5.

As bactérias produtoras de ácido são menos sensíveis ao $\mathrm{pH}$ que as metanogênicas, podendo se mostrar bastante ativas mesmo em valores de $\mathrm{pH}$ em torno de 4,5 , tendo crescimento ótimo na faixa de $\mathrm{pH}$ entre 5,0 a 6,0. A operação de reator anaeróbio com $\mathrm{pH}$ constantemente abaixo de 6,5 ou acima de 8,0 pode ocasionar diminuição significativa da taxa de produção de metano.

$\mathrm{Na}$ digestão anaeróbia ocorre interação comensal entre os microrganismos metanogênicos e as acidogênicos, sendo que as primeiras dependem do substrato fornecido pelas últimas (CHERNICHARO, 1997).

Os ácidos orgânicos e hidrogênio produzidos pelas bactérias acidogênicas são transformados pelas metanogênicas em produtos finais gasosos, metano e gás carbônico. Assim, número suficiente de metanogênicas ou condições ambientais não favoráveis, impedirão a utilização dos ácidos na mesma taxa em que são produzidos, acumulandoos no sistema, consumindo rapidamente a alcalinidade, e provocando queda do $\mathrm{pH}$ (CHERNICHARO, 1997).

Segundo Chernicharo (1997), a identificação de cada ácido presente no reator poderá indicar qual tipo de arquea metanogênica está sendo afetada no tratamento.

$\mathrm{O} \mathrm{pH}$ pode variar durante a acidogênese, porque o sistema tende a tamponar em valores de $\mathrm{pH}$ na média de 5 a 7 , se nenhum controle for efetuado. $\mathrm{O} \mathrm{pH}$ final dependerá 
das condições ambientais existentes no reator, mas, principalmente, da natureza da água residuária (ALEXIOU et al., 1994).

Segundo Guerrero et al. (1999), a acidificação em reatores anaeróbios também é fortemente afetada pela temperatura, de acordo com a "lei de Arrhenius", mas há divergências acerca da melhor temperatura para otimização desse passo, tanto na faixa mesofilica $\left(30^{\circ} \mathrm{C}\right.$ a $\left.37^{\circ} \mathrm{C}\right)$ quanto na termofílica $\left(50^{\circ} \mathrm{C}\right.$ a $\left.60^{\circ} \mathrm{C}\right)$.

Considerando-se reatores aeróbios termofílicos, segundo Lapara \& Alleman (1999), não há trabalhos sobre o efeito do $\mathrm{pH}$ nesses sistemas, como citado anteriormente.

\subsubsection{Outros fatores}

A presença de compostos tóxicos em reatores biológicos pode destruir a população bacteriana, bem como inibir seu crescimento, dependendo da concentração. Entretanto, na maioria dos casos, a população microbiana pode se adaptar à presença do tóxico e tolerar altas concentrações, sem inibição.

A presença de sulfato no reator anaeróbio pode causar problemas pela produção de sulfeto e pela competição pelos mesmos substratos (acetato e gás hidrogênio), que se estabelece entre as bactérias redutoras de sulfato e as metanogênicas. Porém, sulfato pode também favorecer, em contrapartida, o controle da pressão parcial de hidrogênio. As bactérias redutoras de sulfato, por apresentarem coeficiente de meia saturação de ácido acético menor que o das metanogênicas, levam vantagem nessa competição (FORESTI, 1987).

Para o tratamento aeróbio termofílico, é necessário identificar as condições ótimas de operação e o melhor método para fornecer oxigênio (LAPARA \& ALLEMAN, 1999).

\subsection{Taxa de transferência de oxigênio}

Freqüentemente, apesar dos trabalhos já citados na literatura sobre utilização de sistemas biológicos termofilicos de tratamento, questiona-se se são realmente aeróbios, pela baixa concentração de saturação do oxigênio em altas temperaturas.

Os valores de saturação de oxigênio em água, como a maioria dos gases, diminuem com o aumento da temperatura, entretanto, os coeficientes de difusão do 
oxigênio $\left(2,8 \cdot 10^{-5} \mathrm{~cm}^{2} \cdot \mathrm{s}^{-1}\right.$ a $35^{0} \mathrm{C}$ comparado a $4,3 \cdot 10^{5} \mathrm{~cm}^{2} \cdot \mathrm{s}^{-1}$ a $55^{0} \mathrm{C}$, calculado com a equação de Wilke-Chang ${ }^{7}$ ) mostram que são diretamente proporcionais à temperatura. Portanto, as taxas de transferência do oxigênio em altas temperaturas são esperadas ser tão boas ou até mesmo melhores que em condições mesofilicas.

Vogelaar et al. (2000), buscando verificar a viabilidade do tratamento biológico aeróbio de águas residuárias na indústria de papel reciclado, analisaram a taxa de transferência de oxigênio em diferentes temperaturas $\left(20^{\circ} \mathrm{C}\right.$ a $\left.55^{\circ} \mathrm{C}\right)$, em águas de abastecimento e de processo desta indústria. Também foi analisada a taxa de transferência de oxigênio no lodo termofílico, a $55^{\circ} \mathrm{C}$. Com os resultados, foi verifícado que na água de abastecimento a taxa de transferência de oxigênio aumentou enquanto a concentração de saturação do oxigênio diminuiu 44\% com o aumento da temperatura de $20^{\circ} \mathrm{C}$ para $55^{\circ} \mathrm{C}$.

Os valores da taxa de transferência de oxigênio, levemente menores na água de processo e no lodo termofilico comparativamente à água de abastecimento, foram causados pelas menores concentrações de saturação de oxigênio nesses líquidos. Os valores dos coeficientes globais de transferência de oxigênio nestes líquidos não diferiram significativamente dos valores encontrados para água de abastecimento (VOGELAAR et al., 2000).

Em geral, foi concluído que a taxa de transferência de oxigênio somente é levemente afetada pela temperatura do líquido. Esse efeito poderia ser ligeiramente positivo, negativo ou nulo, dependendo do diâmetro da bolha e do tipo do reator (VOGELAAR et al., 2000).

No trabalho de Barr et al. (1996), foi feita uma comparação entre a taxa de utilização de oxigênio em reator mesofílico $\left(35^{\circ} \mathrm{C}\right)$ e termofílico $\left(41^{\circ} \mathrm{C}\right.$ a $\left.50^{\circ} \mathrm{C}\right)$. As medidas no reator termofílico foram tomadas a $45^{\circ} \mathrm{C}$. Foi verificada menor média da taxa de utilização de oxigênio durante o período em que o reator operou em alta temperatura. Esse decréscimo pode indicar redução na atividade microbiana. Deve ser ressaltado entretanto que há limitações impostas pela sensibilidade do medidor de oxigênio em temperaturas iguais ou superiores a $45^{\circ} \mathrm{C}$. 


\subsection{Experiências no Departamento de Hidráulica e Saneamento no tratamento}

\section{biológico mesofilico para água residuária das indústrias de papel e celulose}

No Departamento de Hidráulica e Saneamento da Escola de Engenharia de São Carlos (USP) inúmeros trabalhos vêm sendo desenvolvidos visando o tratamento de esgotos sanitários e de águas residuárias industriais, buscando, além da eficiência no tratamento, decréscimos nos custos de implantação e de operação, e, em alguns casos, reuso. Considerando os efluentes da indústria de papel e celulose, em 1991 foi iniciada essa linha de pesquisa, com a abordagem de diferentes pontos no tratamento.

Por exemplo, Carrha em 1991, estudou a remoção de cor de um efluente sintético, com altas concentrações de lignina, utilizando o método eletrolítico, empregando eletrodos de alumínio, aço carbono, aço inoxidável e grafite, em reatores de fluxo descontínuo, para determinação do ponto ótimo de funcionamento.

Em 1993, Guaglianoni também estudou a remoção eletrolítica de cor, porém utilizou efluentes da fase de extração cáustica do processo de branqueạmento e efluentes simulados em laboratório, empregando eletrodos de alumínio e de aço carbono, em reatores de batelada e de escoamento contínuo, variando a densidade de corrente e o tempo de detenção.

Em 1995, Buzinni prosseguiu nesse estudo da remoção eletrolítica de cor em efluentes simulados utilizando eletrodos de alumínio em reator de escoamento contínuo, seguido por câmara de clarificação. Nesse trabalho foi confirmado que o processo eletrolítico é viável tecnicamente para a remoção de cor de águas residuárias provenientes de indústrias de papel e celulose, enfatizando entretanto, a necessidade de outros estudos para otimização do reator de escoamento contínuo.

Lima (1996), buscando maior eficiência no tratamento de efluentes de indústrias de papel, que permitissem também a possibilidade de reuso de água e recuperação de parcela das fibras presentes nesses efluentes, operou uma unidade laboratorial e uma instalação piloto de flotação por ar dissolvido, instaladas junto à São Carlos S/A Indústria de Papel e Embalagens, estudando a influência da aplicação de coagulante, da taxa de aplicação superficial e da quantidade de ar fornecida na distribuição do tamanho das fibras recuperadas, visando a obtenção de flotação seletiva de fibras de maior tamanho. 
Rosa (1997) avaliou os efluentes das etapas de processo e de tratamento de cinco fábricas de celulose integradas ou não com fábricas de papel, verificando a mutagenicidade, através de ensaio de curta duração com Salmonella typhimutium, utilizando o teste de Ames. Dentre os resultados obtidos, de interesse para o presente trabalho, foi demonstrado que os efluentes do primeiro estágio de branqueamento das fábricas kraft e também da fábrica quimiotermomecânica, são potenciais geradores de mutagenicidade. E que as estações de tratamento de efluentes com sistemas biológicos demonstraram-se eficientes em reduzir e até mesmo eliminar a mutagenicidade contida nos efluentes de processo.

Nolasco, em 1998, avaliou a possibilidade de utilização de um sistema de tratamento de águas residuárias da indústria de celulose e papel, por um processo de lodos ativados com recirculação total do lodo excedente, após sua desintegração, como alternativa às formas de tratamento de lodo existentes, através da redução da geração de lodo na própria estação de tratamento de efluentes.

Em 1998, Guaglianoni estudou a degradação anaeróbia de dois compostos organoclorados presentes nos efluentes do processo de branqueamento de uma indústria de papel e celulose: o tetraclorocatecol e tetracloroguaiacol. Sedimentos do Ribeirão de Caldas e marinhos foram dopados com concentrações conhecidas dos compostos.

Nessa linha de pesquisa com organoclorados, foram feitos dois outros trabalhos: Pironel, em 1999, estudou a redução da carga orgânica e a geração de compostos organoclorados relacionados à substituição gradativa de cloro por dióxido de cloro nas seqüências de branqueamento da polpa celulósica, obtendo redução nos valores de cor real, DQO, AOX (halogênios orgânicos adsorvíveis) e toxidade aguda nos filtrados dos estágios da cloração e extração alcalina da indústria Jari Celulose.

Em 2000, Buzinni avaliou durante 635 dias de operação contínua, os desempenhos de dois reatores anaeróbios de fluxo ascendente e manta de lodo (UASB), em escala de bancada, tratando licor negro diluído puro e misturado a cinco organoclorados, atingindo concentração máxima de mistura igual a $15 \mathrm{mg} . \mathrm{L}^{-1}$.

Nalim (2001) utilizou um sistema com reator anaeróbio, seguido por flotação por ar dissolvido e tratamento com membranas, visando a reutilização de água em indústrias de papel e celulose.

Em continuação, dada a importância do tratamento dos efluentes da indústria de papel e celulose, considerando toda a experiência acumulada citada, além das 
experiências obtidas por outros pesquisadores utilizando tratamento termofilico, foi proposto este trabalho, que foi desenvolvido no Laboratório de Processos Biológicos do Departamento de Hidráulica e Saneamento da Escola de Engenharia de São Carlos, Universidade de São Paulo.

\subsection{Considerações gerais sobre o presente trabalho}

A idéia inicial neste experimento era prosseguir na linha de trabalho de Nalim (2001), procurando fechar o circuito de águas na indústria de celulose, com base também nos resultados obtidos nos trabalhos feitos no Departamento de Hidráulica e Saneamento, citados no item anterior.

O trabalho foi feito utilizando um sistema combinado de reatores anaeróbio e aeróbio operando em faixa termofílica. A escolha pelo sistema combinado anaeróbioaeróbio teve por objetivo otimizar o processo de tratamento do efluente, potencializando as vantagens de cada tratamento, baseada em dados da literatura (item 3.4. desta revisão) e em bons resultados obtidos em trabalhos anteriores utilizando o reator anaeróbio UASB (BUZZINI, 2000) e o reator aeróbio de lodos ativados (NOLASCO, 1998) para tratamento de efluente simulado da indústria de pasta celulósica.

Como tratava-se de um primeiro trabalho de avaliação das potencialidades do uso do sistema combinado operado em faixa de temperatura termofílica, foi realizado em escala de bancada.

O substrato foi preparado em laboratório, com licor negro diluído. Na indústria de pasta de celulose não branqueada, o licor negro puro raramente é direcionado à estação de tratamento; em geral, recebe tratamento termoquímico para reaproveitamento de insumos. Entretanto, esse licor pode simular satisfatoriamente o efluente dessas indústrias porque contém os reagentes utilizados no processo da fabricação da pasta de celulose e os subprodutos gerados na decomposição dos constituintes da madeira, como descrito no item 3.2. Além disso, segundo Buzzini (2000), o licor negro já foi empregado por outros pesquisadores como base para a composição de efluente sintético de indústrias integradas de papel e celulose ou apenas de pasta celulósica, mostrando-se adequado.

No caso deste trabalho, o efluente simulou o de fábricas de celulose não branqueada, pois não foram adicionados organoclorados ao substrato. Buscava-se assim, eliminar qualquer tipo de interferência nos resultados pela introdução de compostos 
tóxicos, visto que o objetivo principal do trabalho foi o de verificar a viabilidade do tratamento termofílico do efluente simulado da indústria de pasta de celulose.

A avaliação dos desempenhos dos reatores operando em faixa mesofilica e termofílica foi feita em função da remoção de matéria orgânica expressa em DQO e também das concentrações de ácidos, alcalinidade, composição do biogás do reator anaeróbio, oxigênio disponível no reator aeróbio, bem como exames microbiológicos de ambos os reatores. 


\section{MATERIAL E MÉTODOS}

\footnotetext{
"Estar preparafo para qualquer situaçäo exige que a pessoa seja capaz de cortar um nó... Pois nem tudo pode ser desamarrado."

Henn Frééric Amiel
}

\subsection{Introdução}

Neste capítulo é apresentada a descrição do sistema experimental, bem como o material e os métodos empregados para o monitoramento físico-químico e microbiológico do sistema.

O trabalho experimental foi dividido em várias etapas:

$\rightarrow$ Avaliação da taxa de transferência de oxigênio em água e em água residuária sintética simulando o efluente da indústria de pasta de celulose não branqueada, com DQO de aproximadamente $1400 \mathrm{mg} . \mathrm{L}^{-1}$, no reator de lodos ativados, em diferentes temperaturas $\left(5,15,25,35\right.$ e $\left.45^{0} \mathrm{C}\right)$ e vazões de aeração $\left(15,30,45\right.$ e $\left.60 \mathrm{~L}^{-h^{-1}}\right)$, correspondendo a taxas de aeração de 2,$5 ; 5,0 ; 7,5$ e $10,0 \mathrm{~L} \cdot \mathrm{h}^{-1} \mathrm{~L}^{-1}$.

$\rightarrow$ Paralelamente ao primeiro passo, foi inoculado o reator anaeróbio e mantido em temperatura ambiente, tendo sido a DQO aumentada de $400 \mathrm{mg} . \mathrm{L}^{-1}$ até a DQO de trabalho, em torno de $1400 \mathrm{mg} . \mathrm{L}^{-1}$; e o tempo de detenção reduzido de 40 horas para 24 horas;

$\rightarrow$ Inoculação e partida do reator de lodos ativados;

$\rightarrow$ Aumento gradual da temperatura com monitoramento por meio de análises físico-químicas e exames microbiológicos;

$\rightarrow$ Análises microbiológicas complementares: coloração das filamentosas do reator aeróbio, microscopia eletrônica de varredura e número mais provável de microrganismos metanogênicos em amostras de lodo dos reatores anaeróbio e aeróbio termofilicos; 
$\rightarrow$ Finalmente, um teste com o aumento súbito da temperatura para $55^{\circ} \mathrm{C}$, tendo os reatores sido inoculados em escala de laboratório e monitorados por meio de análises físico-químicas.

\subsection{Aparato Experimental}

\subsubsection{Sistema combinado de tratamento}

O sistema experimental de reatores biológicos em escala de bancada foi montado no Laboratório de Processos Biológicos, Escola de Engenharia de São Carlos. O sistema era composto por um reator anaeróbio de manta de lodo e fluxo ascendente, alimentando, continuamente, um reator aeróbio de lodos ativados (Figura 4.1).

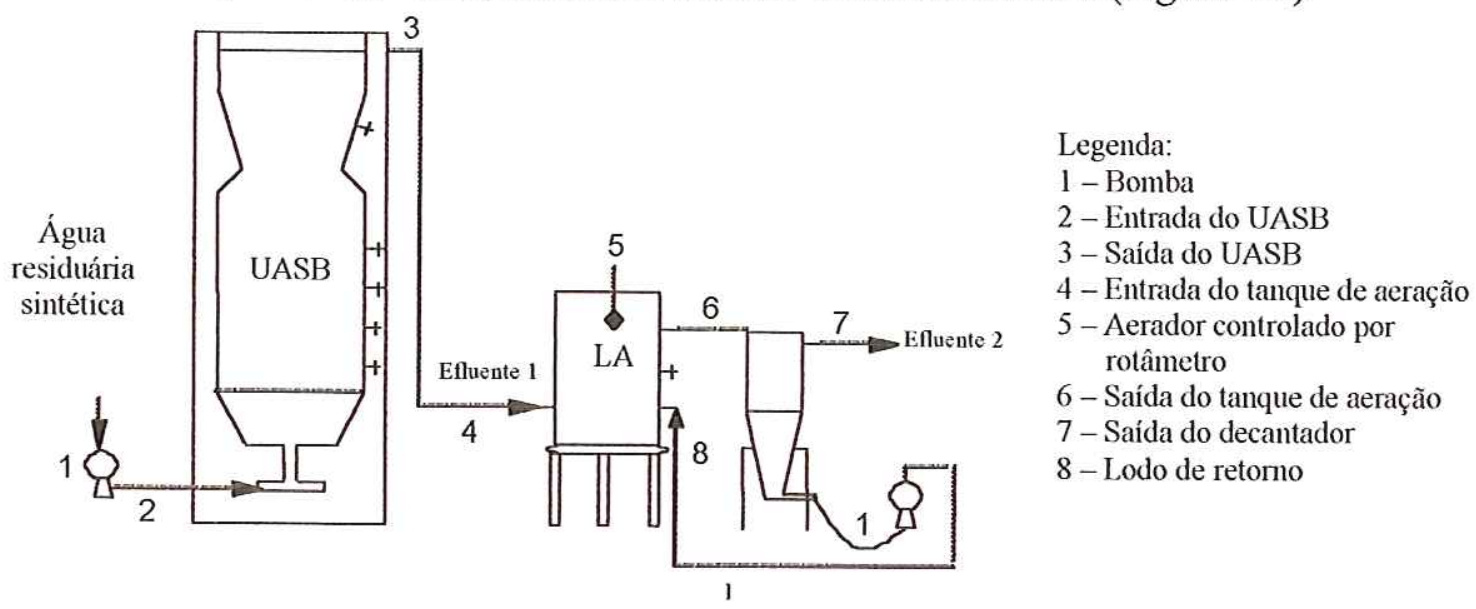

FIGURA 4.1. Fluxograma do sistema de tratamento empregado neste trabalho.

Os reatores foram mantidos em uma cabine construída com madeira, e revestida internamente com isopor, para manter a temperatura. Inicialmente, os reatores foram operados em temperatura ambiente. Posteriormente, o controle foi feito pela utilização de termostato que controlava duas resistências e de ventilador médio, marca Britania B20, com potência de $80 \mathrm{~W}$. O controle da temperatura foi um ponto de grande importância para este trabalho e será discutido posteriormente.

A alimentação dos reatores, bem como a recirculação de lodo no reator aeróbio foi feita utilizando-se bombas dosadoras da Marca Prominent, série Gama 4, tipo 1002, vazão com máxima contrapressão de 2,3 L.h.'-1 e altura de sucção de 6 m.c.a.

\subsubsection{Sistema anaeróbio}

O reator anaeróbio empregado foi o UASB. Este reator foi introduzido no departamento de Hidráulica e Saneamento da Escola de Engenharia de São Carlos pelo 
prof. Eugênio Foresti, em 1987. A partir daí foi utilizado em diversos trabalhos de mestrado e doutorado. Anteriormente a este trabalho, para tratamento de água residuária sintética de indústria de pasta de celulose branqueada e não branqueada foi utilizado no doutoramento de Buzzini (2000).

Este reator, do tipo UASB (Upflow Anaerobic Sludge Blanket), apresentava volume total de 10,5 litros. As faces frontal e dorsal do reator eram de acrílico transparente e as faces laterais de aço inoxidável.

O reator possuía, na lateral, 6 pontos de amostragem, partindo da base, a: $14 \mathrm{~cm}$ (ponto 1), $24 \mathrm{~cm}$ (ponto 2), $34 \mathrm{~cm}$ (ponto 3), $59 \mathrm{~cm}$ (ponto 4) e $73 \mathrm{~cm}$ (ponto 5), de acordo com o esquema apresentado na Figura 4.2.

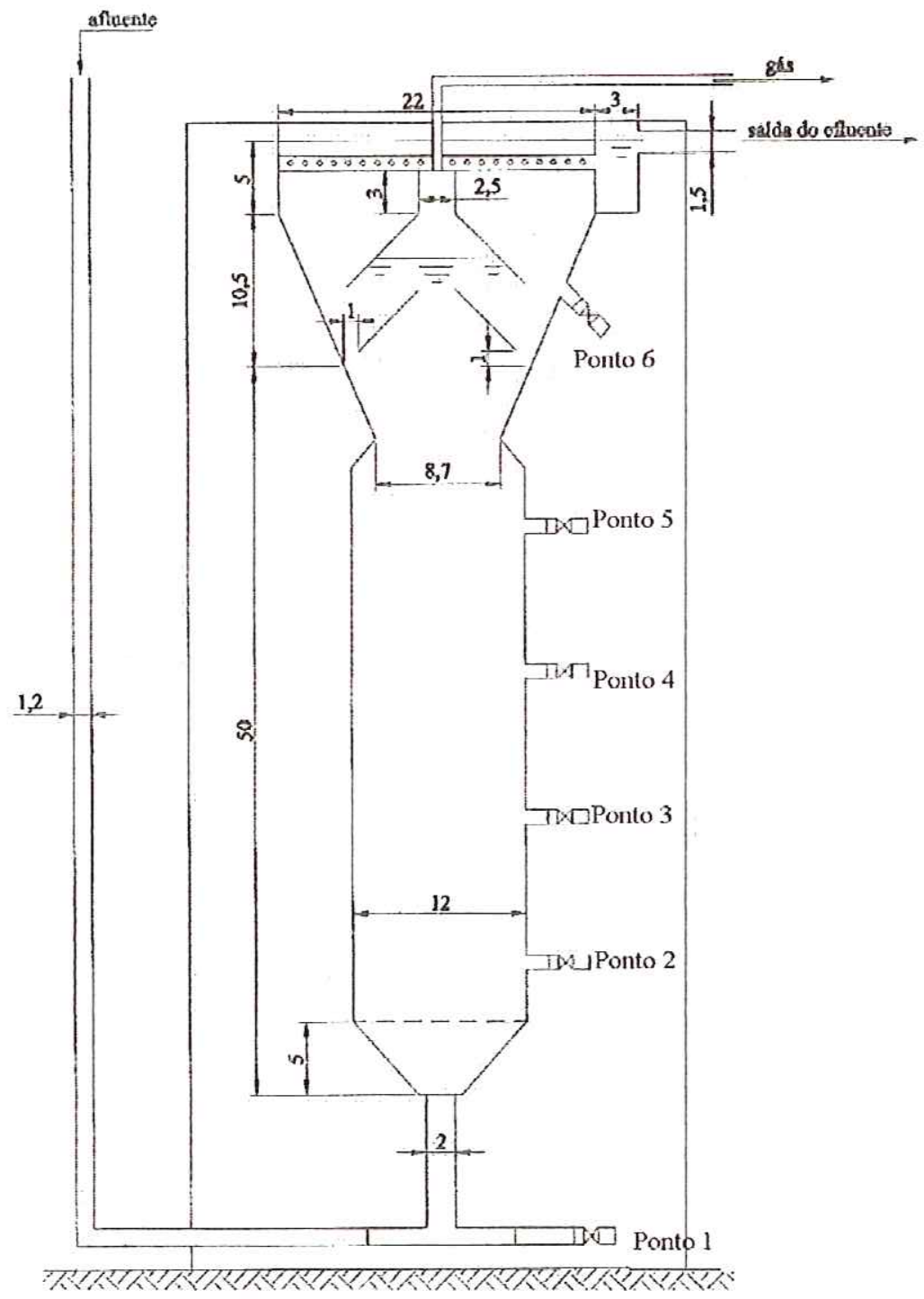

FIGURA 4.2. Esquema do reator UASB empregado e pontos de amostragem. 
As amostras para as análises físico-químicas do efluente foram coletadas na saída do reator UASB até o início da alimentação do reator de lodos ativados, quando passaram a ser coletadas no ponto 6 .

As amostras para análise microbiológica foram sempre coletadas no ponto 2 .

Um selo hídrico externo foi utilizado para permitir a interface gás-líquido.

\subsubsection{Sistema aeróbio}

Esse sistema era composto pelo reator de lodos ativados utilizado no trabalho de Parsekian (2003) e um decantador.

O tanque aeróbio de lodo ativado foi construído em acrílico transparente, com volume de $7 \mathrm{~L}$ e diâmetro de $15 \mathrm{~cm}$.

A aeração utilizada foi a mesma de Parsekian (2003): um tubo de PVC, em cuja extremidade perfurada, foram encaixadas quatro pedras porosas (normalmente empregadas na aeração de pequenos aquários). A vazão de ar era fornecida por uma bomba de aquário, marca Big Air Super Pump A420, freqüência de $60 \mathrm{~Hz}$. O volume de ar fornecido ao reator foi controlado por um rotâmetro montado pela Oficina Mecânica da Escola de Engenharia de São Carlos. As vazões de aeração inicialmente determinadas através de testes de transferência de oxigênio foram de $60 \mathrm{~L} \cdot \mathrm{h}^{-1}$ na faixa mesofilica de operação e de $90 \mathrm{~L} \cdot \mathrm{h}^{-1}$ na faixa termofilica de operação.

$\mathrm{O}$ controle da concentração de oxigênio foi feito por um oxímetro da marca Orion, modelo 850. A sonda do medidor foi mergulhada no tanque de aeração com a extremidade voltada para cima, evitando assim possíveis interferências que as bolhas de ar poderiam causar.

O sedimentador foi o mesmo utilizado por de Parsekian (2003): construído com cone Innhoff, de plástico, com volume total de $2,7 \mathrm{~L}$, com duas saídas: para o efluente tratado e para recirculação do lodo, inicialmente com vazão de $0,2 L \cdot h^{-1}$. Com aproximadamente 20 dias de operação do reator de lodos ativados, a vazão de recirculação do lodo foi aumentada para $0,4 \mathrm{~L} \cdot \mathrm{h}^{-1}$. Na Figura 4.3. é apresentado o esquema do reator aeróbio e do decantador empregados. 


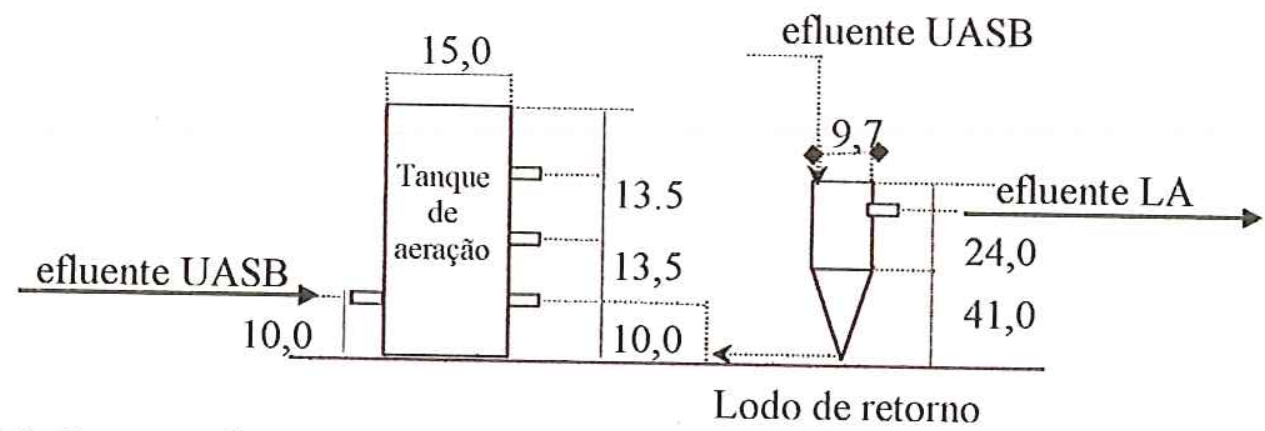

FIGURA 4.3. Esquema do reator de lodos ativados empregado (dimensões em $\mathrm{cm}$ ).

Na Figura 4.4 é apresentada a foto do sistema completo em operação.

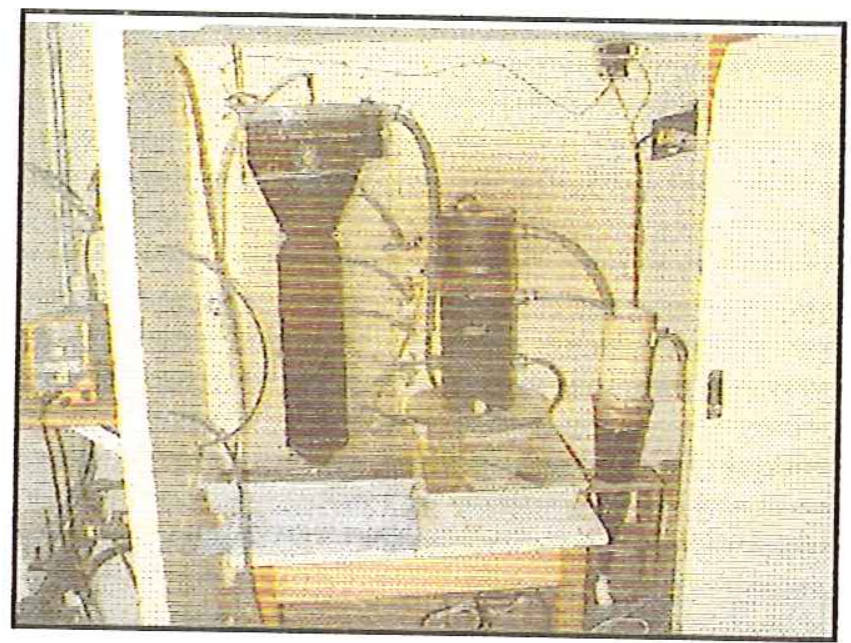

FIGURA 4.4. Sistema completo utilizado neste trabalho.

\section{3. Água residuária sintética}

A água residuária sintética utilizada na alimentação do reator anaeróbio foi preparada conforme BUZZINI (2000). Foram utilizados o licor negro concentrado e o intermediário. Inicialmente, pretendia-se trabalhar com uma única amostra de licor negro durante todo o trabalho experimental, pois, como apresentava carga orgânica elevada, um pequeno volume bastaria para atingir a DQO de trabalho. Desta forma, evitaria-se a introdução de incertezas decorrentes de variações no licor, que poderiam ser naturais ou provocadas por alterações durante o processo industrial de polpação. 
Entretanto, o primeiro licor negro coletado foi o concentrado, com teor de $70 \%$ de sólidos. Esse licor foi de difícil caracterização e causou perda de sólidos no reator UASB.

Optou-se então pela utilização de um licor com menor concentração de sólidos. Foi coletado o licor negro intermediário ${ }^{29}$, e assim buscou-se eliminar os problemas apresentados pelo concentrado. O licor negro intermediário foi coletado duas vezes durante a fase experimental.

O licor negro concentrado e os intermediários foram fornecidos pela indústria Votorantim Celulose e Papel, unidade de Luís Antônio (São Paulo) e estão caracterizados na Tabela 4.1. Esta indústria utiliza o processo Kraft e a madeira digerida é o eucalipto.

TABELA 4.1. Composição do licor negro usado no preparo do água residuária sintética.

\begin{tabular}{|c|c|c|c|}
\hline \multirow{2}{*}{ Parâmetro } & \multicolumn{3}{|c|}{ Licor negro } \\
\hline & Concentrado & Intermediário (1) & Intermediário (2) \\
\hline $\mathrm{pH}$ & 13,6 & 13,6 & 13,0 \\
\hline DQO (mg. $\left.\mathrm{L}^{-1}\right)$ & 350.000 & 278.000 & 233.000 \\
\hline DBO (mg. $\left.\mathrm{L}^{-1}\right)$ & 80.275 & 108.835 & 100.687 \\
\hline Relação DQO/DBO & $1: 4,4$ & $1: 2,6$ & $1: 2,3$ \\
\hline Sulfeto $\left(m g . L^{-1}\right)$ & 4.400 & 1.925 & n.d. \\
\hline Carbono orgânico total & 58.270 & 89.800 & 50.100 \\
\hline $\mathrm{Zn}\left(\mathrm{mg} \cdot \mathrm{L}^{-1}\right)$ & 1,8 & 1,6 & n.d. \\
\hline $\mathrm{Pb}\left(\mathrm{mg} \cdot \mathrm{L}^{-1}\right)$ & n.d. & 4,7 & n.d. \\
\hline $\mathrm{Cd}\left(\mathrm{mg} \cdot \mathrm{L}^{-1}\right)$ & 1,2 & n.d. & n.d. \\
\hline $\mathrm{Ni}\left(\mathrm{mg} \cdot \mathrm{L}^{-1}\right)$ & 4,4 & 2,6 & n.d. \\
\hline $\mathrm{Fe}\left(\mathrm{mg} \cdot \mathrm{L}^{-1}\right)$ & 8,8 & 10,0 & n.d. \\
\hline $\operatorname{Mn}\left(\mathrm{mg} \cdot \mathrm{L}^{-1}\right)$ & 4,6 & 10,3 & n.d. \\
\hline $\mathrm{Cu}\left(\mathrm{mg} . \mathrm{L}^{-1}\right)$ & 1,58 & 0,03 & n.d. \\
\hline $\mathrm{Cr}\left(\mathrm{mg} \cdot \mathrm{L}^{-1}\right)$ & 2,6 & 1,2 & n.d. \\
\hline
\end{tabular}

Determinados volumes do licor, segundo a Tabela 4.2 (página 64) foram diluídos em balão volumétrico de 1,0 L. Posteriormente, o licor diluído foi transferido para um recipiente, recebendo extrato de levedura, cloreto de amônio e fosfato de sódio monobásico, de forma a suprir as quantidades de nitrogênio e fósforo recomendadas para o processo anaeróbio (relação DQO:N:P de 500:5:1). O volume então era completado para 15,0 litros e o pH ajustado com ácido acético até atingir valor igual a 7,0 .

\footnotetext{
${ }^{29}$ Licor negro intermediário é a denominação dada pela indústria de papel e celulose Vororantim (unidade de Luís Antônio) para designar o licor com teor de sólidos em torno de $20 \%$, concentração intenmediária ao licor fraco e ao forte.
} 
Após 153 dias de operação do reator UASB foi adicionado etanol 'a água residuária sintética, A utilização desse composto também seguiu o protocolo de Buzzini (2000) e visou simular os efluentes provenientes das operações de fabricação de celulose, melhorando também a qualidade da água residuária sintética.

Ao longo do experimento ocorreram algumas variações na DQO da água residuária sintética devidas, provavelmente, a material particulado presente no licor negro. As causas deste problema não puderam ser determinadas, não podendo ser contornado, prejudicando assim a manutenção de uma DQO afluente constante no reator anaeróbio.

A alimentação do reator aeróbio foi feita diretamente da saída do reator anaeróbio, por gravidade.

\subsection{Inoculação e operação dos reatores}

\subsubsection{Inoculação dos reatores}

O reator anaeróbio foi inoculado com lodo proveniente de um reator UASB tratando efluente de abatedouro de aves, Avícola Dacar Industrial S.A. (Tietê - São Paulo). Antes da inoculação, o lodo (que estava estocado a $4^{0} \mathrm{C}$ ) foi retirado da geladeira e deixado em repouso por um período de aproximadamente 24 horas, para sua adaptação à temperatura ambiente. A quantidade de lodo utilizada na inoculação foi de 3,0 litros.

Então, o reator anaeróbio foi alimentado com 10 litros de água residuária sintética com DQO em torno de $1400 \mathrm{mg} \cdot \mathrm{L}^{-1}$ e deixado em repouso por aproximadamente 24 horas. Posteriormente foi operado em batelada alimentada, por 10 dias. Após esse período, o reator foi operado de forma contínua, variando-se o tempo de detenção e a carga orgânica de acordo com a Tabela 4.2.

O reator aeróbio de lodos ativados foi inoculado após 60 dias de operação do reator UASB. Foram utilizados 2,0 L de lodo de reator aeróbio da indústria de papel e celulose VCP, Votorantim (Luís Antônio, São Paulo). O reator foi mantido em batelada alimentada com o efluente do reator UASB, por aproximadamente quinze dias. Posteriormente, os reatores foram operados de forma contínua (Tabela 4.3).

Após 60 dias da inoculação do reator aeróbio, foi adicionado no tanque de aeração um volume de 1,0 L de lodo, obtido no reator de lodos ativados da Indústria Faber Castell de corantes (São Carlos - SP). Esta adição de lodo visou aumentar a 
biomassa do reator, buscando melhorar sua eficiência de remoção que estava baixa e com baixo volume de sólidos suspenso voláteis no licor misto.

\subsubsection{Operação dos reatores}

A operação dos reatores foi dividida em duas fases, que por sua vez foram subdivididas em várias etapas de acordo com as alterações efetuadas, quer na DQO afluente, na temperatura e/ou no tempo de detenção hidráulica.

A primeira fase contempla o período em que os reatores foram operados em temperatura mesofilica, adotando a faixa de $(24,0 \pm 2,0)^{0} \mathrm{C}$ a $(42,5 \pm 2,0)^{0} \mathrm{C}$. Esta fase foi subdividida em 8 etapas.

A segunda fase corresponde à operação dos reatores em temperatura termofilica, considerando a faixa de $(47,5 \pm 2,0)^{0} \mathrm{C}$ a $(57,0 \pm 2,0)^{0} \mathrm{C}$. Nessa fase, a subdivisão em cinco etapas contemplou alterações feitas na temperatura e no tempo de detenção hidráulica.

Nas Tabelas 4.2 e 4.3, são apresentadas as duas fases e etapas correspondentes, bem como qual o tipo de licor usado e o volume, a temperatura de operação, o tempo de detenção hidráulica, a taxa de carregamento hidráulico, a taxa de carregamento orgânico e o tempo que os reatores operaram na etapa citada. A Tabela 4.2 contempla o reator UASB e a Tabela 4.3, o de lodos ativados. 
TABELA 4.2 - Fase mesofilica (1), termofilica (2) e etapas correspondentes; tipo e volume de licor negro utilizado; temperatura; tempo de detenção hidráulica; taxa de carregamento hidráulico e orgânico e tempo de duração da etapa no reator UASB.

\begin{tabular}{|c|c|c|c|c|c|c|}
\hline 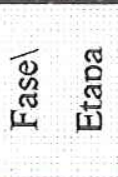 & Tipo de licor e volume & $\begin{array}{c}\text { Temperatura } \\
\left({ }^{\circ} \mathrm{C}\right)\end{array}$ & $\begin{array}{l}\text { TDH } \\
\text { (h) }\end{array}$ & $\begin{array}{c}\text { TCH } \\
\left(\mathrm{m}^{3} \cdot \mathrm{m}^{-3} \cdot \mathrm{d}^{-1}\right)\end{array}$ & $\begin{array}{c}\text { TCO } \\
(\mathrm{KgDQO} \\
\left.\mathrm{dia}^{-1} \cdot \mathrm{m}^{-3}\right)\end{array}$ & $\begin{array}{l}\text { Tempo } \\
\text { (dias) }\end{array}$ \\
\hline \multirow{3}{*}{$1 / 1$} & LNC (10mL:10L) & ambiente & batelada & 0,57 & $0,20-0,27$ & 7 \\
\hline & LNC (14mL:10L) & ambiente & 42 & 0,57 & 0,29 & 3 \\
\hline & LNC (18mL:10L) & ambiente & 42 & 0,57 & 0,38 & 1 \\
\hline \multirow{2}{*}{$1 / 2$} & LNC (20ML:10L) & ambiente & 30 & 0,80 & $0,60-0,78$ & 11 \\
\hline & LNC (25mL:10L) & ambiente & 30 & 0,80 & $0,74-0,84$ & 26 \\
\hline $1 / 3$ & LNI1 (50mL:10L) & ambiente & 20 & 1,20 & $1,46-1,84$ & 34 \\
\hline \multirow{2}{*}{$1 / 4$} & LNI1 (60mL:12L) & ambiente & 20 & 1,20 & $1,47-1,84$ & 28 \\
\hline & LNI1 (60mL:15L) & ambiente & 20 & 1,20 & $1,45-1,79$ & 5 \\
\hline \multirow{2}{*}{$1 / 5$} & LNI1 (50mL:15L:3mL etanol) & ambiente & 20 & 1,20 & $1,45-1,84$ & 17 \\
\hline & LNI1 (50mL:15L:5mL etanol) & ambiente & 20 & 1,20 & 1,18 & 4 \\
\hline \multirow{2}{*}{$1 / 6$} & LNI1 (50mL:15L:5mL etanol) & 35,0 & 20 & 1,20 & 1,35 & 7 \\
\hline & LNI1 (55mL:15L:5mL etanol) & 35,0 & 20 & 1,20 & $1,30-1,63$ & 3 \\
\hline \multirow{4}{*}{$1 / 7$} & LNI1 (55mL:15L:7mL etanol) & 35,0 & 20 & 1,20 & 2,03 & 4 \\
\hline & LNI1 (45mL:15L:7mL etanol) & 35,0 & 20 & 1,20 & 1,03 & 8 \\
\hline & LNI1 (50mL:15L:7mL etanol) & 35,0 & 20 & 1,20 & 1,80 & 6 \\
\hline & LNI1 (45mL:15L:7mL etanol) & 35,0 & 20 & 1,20 & $1,30-1,87$ & 24 \\
\hline $1 / 8$ & LNI1 (45mL:15L:7mL etanol) & 42,5 & 20 & 1,20 & $1,30-1,70$ & 35 \\
\hline $2 / 1$ & LNI1 (45mL:15L:7mL etanol) & 45,0 & 20 & 1,20 & $1,59-1,77$ & 14 \\
\hline $2 / 2$ & LNI1 (45mL:15L:7mL etanol) & 52,0 & 20 & 1,20 & $1,46-1,88$ & 32 \\
\hline $2 / 3$ & LNI2 (45mL:15L:7mL etanol) & 52,0 & 20 & 1,20 & $1,77-1,85$ & 7 \\
\hline \multirow{2}{*}{$2 / 4$} & LNI2 (30mL:15L:7mL etanol) & 52,0 & 20 & 1,20 & 1,46 & 2 \\
\hline & LNI2 (30mL:15L:7mL etanol) & 52,0 & 24 & 1,00 & $1,20-1,77$ & 54 \\
\hline $2 / 5$ & LNI2 (30mL:15L:7mL etanol) & 57,0 & 24 & 1,00 & $1,06-1,29$ & 36 \\
\hline
\end{tabular}

LNC: licor negro concentrado, LNCI1: licor negro concentrado intermediário 1; LNCI2: licor negro concentrado intermediário 2. $\mathrm{T}_{\mathrm{C}}$ : temperatura da Câmara; TCO: taxa de carregamento orgânico. 
TABELA 4.3 - Fase mesofilica (1), termofilica (2) e etapas correspondentes, tipo e volume de licor negro utilizado, temperatura, tempo de detenção hidráulica, taxa de carregamento hidráulico e orgânico e tempo de duração da etapa no reator de lodos ativados.

\begin{tabular}{|c|c|c|c|c|c|c|}
\hline 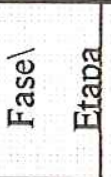 & Tipo de licor e volume & $\begin{array}{c}\text { Temperatura } \\
\left({ }^{\circ} \mathrm{C}\right)\end{array}$ & $\begin{array}{l}\text { TDH } \\
\text { (h) }\end{array}$ & $\begin{array}{c}\text { TCH } \\
\left(\mathrm{m}^{3} \cdot \mathrm{m}^{-3} \cdot \mathrm{d}^{-1}\right)\end{array}$ & $\begin{array}{c}\text { TCO } \\
(\mathrm{KgDQO} \\
\left.\mathrm{dia}^{-1} \cdot \mathrm{m}^{-3}\right)\end{array}$ & $\begin{array}{l}\text { Tempo } \\
\text { (dias) }\end{array}$ \\
\hline \multirow{2}{*}{$1 / 4$} & LNI1 (60mL:12L) & ambiente & 12 & 2,10 & $1,37-1,95$ & 28 \\
\hline & LNI1 (60mL:15L) & ambiente & 12 & 2,10 & $1,52-1,80$ & 5 \\
\hline \multirow{2}{*}{$1 / 5$} & LNI1 (50mL:15L:3mL etanol) & ambiente & 12 & 2,10 & $1,24-2,17$ & 17 \\
\hline & LNI1 (50mL:15L:5mL etanol) & ambiente & 12 & 2,10 & 1,03 & 4 \\
\hline \multirow{2}{*}{$1 / 6$} & LNI1 (50mL:15L:5mL etanol) & 35,0 & 12 & 2,10 & 1,15 & 7 \\
\hline & LNI1 (55mL:15L:5mL etanol) & 35,0 & 12 & 2,10 & $1,13-1,39$ & 3 \\
\hline \multirow{4}{*}{$1 / 7$} & LNI1 (55mL:15L:7mL etanol) & 35,0 & 12 & 2,10 & 2,40 & 4 \\
\hline & LNI1 (45mL:15L:7mL etanol) & 35,0 & 12 & 2,10 & $1,57-4,22$ & 8 \\
\hline & LNI1 (50mL:15L:7mL etanol) & 35,0 & 7 & 3,40 & 4,20 & 6 \\
\hline & LNI1 (45mL:15L:7mL etanol) & 35,0 & 12 & 2,10 & $1,27-1,34$ & 24 \\
\hline $1 / 8$ & LNI1 (45mL:15L:7mL etanol) & 42,5 & 12 & 2,10 & $0,97-1,36$ & 35 \\
\hline $2 / 1$ & LNII (45mL:15L:7mL etanol) & 45,0 & 12 & 2,10 & $0,84-1,32$ & 14 \\
\hline $2 / 2$ & LNI1 (45mL:15L:7mL etanol) & 52,0 & 12 & 2,10 & $0,96-1,34$ & 32 \\
\hline $2 / 3$ & LNI2 (45mL:15L:7mL etanol) & 52,0 & 12 & 2,10 & $1,52-2,62$ & 7 \\
\hline \multirow{2}{*}{$2 / 4$} & LNI2 (30mL:15L:7mL etanol) & 52,0 & 12 & 2,10 & 2,35 & 2 \\
\hline & LNI2 (30mL:15L:7mL etanol) & 52,0 & 8 & 2,84 & $1,54-4,87$ & 54 \\
\hline $2 / 5$ & LNI2 (30mL:15L:7mL etanol) & 57,0 & 8 & 2,84 & $2,57-4,48$ & 36 \\
\hline
\end{tabular}

LNC: licor negro concentrado, LNCI1: licor negro concentrado intermediário 1; LNCI2: licor negro concentrado intermediário 2. $\mathrm{T}_{\mathrm{C}}$ : temperatura da Câmara; TCO: taxa de carregamento orgânico.

\subsubsection{Operações para mamutenção do sistema}

A água residuária sintética para alimentação dos reatores e a limpeza dos tanques afluente do reator anaeróbio e efluente do reator de lodos ativados foram feitas diariamente.

As mangueiras de alimentação e descarte foram limpas semanalmente.

A vazão de alimentação dos reatores era verificada regularmente.

Durante o experimento houve perda da biomassa do reator anaeróbio. Para evitar a entrada desse material no reator aeróbio utilizou-se uma peneira na saída do UASB. Sempre que se fazia necessário, o lodo flotado do reator anaeróbio era retirado.

Não houve descarte de lodo do tanque de aeração do reator aeróbio ao longo do experimento para evitar menor concentração de sólidos no tanque de aeração e conseqüentemente menor idade do lodo. 


\subsection{Monitoramento dos reatores}

Durante todo o procedimento experimental foram coletadas amostras da água residuária sintética, dos efluentes do reator anaeróbio e do reator aeróbio, do licor misto e do decantador.

Estas amostras foram analisadas com a finalidade de verificar-se o desempenho dos reatores. Também foram realizadas, concomitantemente, exames microbiológicos para verificar-se a adaptação e crescimento da microbiota.

\subsubsection{Análises Físico-químicas}

As análises de DQO e sólidos seguiam os procedimentos do "Standard Methods for the Examination of Water and Wastewater" (APHA, 1998).

A leitura da absorbância das amostras de DQO foi feita em espectrofotômetro da marca Hach, modelo DR4000.

As análises de ácidos e de alcalinidade seguiram os protocolos propostos por Dilallo \& Albertson (1961) e modificados por Ripley et al. (1986). Deve-se considerar que por este método a alcalinidade total de uma amostra de reator anaeróbio é composta por dois tipos diferentes de bases: Alcalinidade parcial $(\mathrm{pH}$ inicial menor que 8,0 e maior que 5,75) e Alcalinidade. Intermediária (5,75 - 4.3).

$\mathrm{Na}$ análise de $\mathrm{pH}$, ácidos graxos voláteis e alcalinidade utilizou-se medidor de $\mathrm{pH}$ da marca Micronal B474. Deve-se salientar que a alcalinidade no reator aeróbio não é um parâmetro usual de análise, entretanto, optou-se por essa determinação por diversos motivos: pelo caráter exploratório deste trabalho e pela alcalinidade ser um parâmetro dos modelos IWA; além disso, a alcalinidade tem efeito sobre a cinética global do sistema e também poderia influir na precipitação e remoção de alguns componentes da água residuária sintética, agregando-se ao possível efeito que o aumento de temperatura exerceria sobre o sistema. Deve-se considerar que a alcalinidade também tem efeito sobre a desnitrificação.

Assim, a rotina seguida durante o procedimento experimental está descrita na Tabela 4.4. Deve-se considerar que as análises foram realizadas em duplicata. 
TABELA 4.4 - Análises fisico-quimicas para monitorar o sistema global.

\begin{tabular}{|c|c|c|c|}
\hline Parâmetro & Pontos de de coleta & Freqüência & Método utilizado \\
\hline $\mathrm{pH}$ & $\mathrm{A} 1, \mathrm{E} 1, \mathrm{E} 2$ & diár & Potenciométrico \\
\hline Alcalinidade $(\mathrm{mgCaCO} 3 / \mathrm{L})$ & $\mathrm{Al}, \mathrm{E} 1$ & es/semana & Titulométrico \\
\hline Ácidos voláteis (mg HAc/L) & $\mathrm{A} 1, \mathrm{E} 1, \mathrm{E} 2$ & 2 vezes/semana & Titulométrico \\
\hline DQO (mg. $\left.\mathrm{L}^{-1}\right)$ & $\mathrm{A} 1, \mathrm{E} 1, \mathrm{E} 2$ & 2 vezes/semana & Espectrofotométrico \\
\hline STV, STF (mg.L $\left.\mathrm{L}^{-1}\right)$ & $\mathrm{Al}, \mathrm{E} 1, \mathrm{E} 2, \mathrm{TA}$ & 2 vezes/semana & Gravimétrico \\
\hline SST, SSV (mg. $\left.L^{-1}\right)$ & $\mathrm{A} 1, \mathrm{E} 1, \mathrm{E} 2, \mathrm{TA}$ & 2 vezes/semana & Gravimétrico \\
\hline Oxigênio dissolvido (mg. $\left.\mathrm{L}^{-1}\right)$ & TA & Diariamente & Eletrométrico \\
\hline
\end{tabular}

Obs.: Al: tanque de alimentação do reator UASB; E1: efluente UASB; E2: efluente do tanque de aeração; TA: tanque de aeração (licor misto).

\subsubsection{Análises cromatográficas}

\subsubsection{Análise do Biogás}

Por essa análise foi monitorada a composição dos gases formados no reator anaeróbio. Foi utilizado um cromatógrafo da marca Gow Mac, equipado com detector de condutividade térmica e coluna Porapak Q ( $2 \mathrm{~m} \mathrm{x}$ 1/4"- 80 a $100 \mathrm{mesh})$.

As condições operacionais do Gow Mac foram: vazão do gás de arraste $\left(\mathrm{H}_{2}\right)=$ $60 \mathrm{~mL} / \mathrm{min}$; temperatura do detector $=70^{\circ} \mathrm{C}$; temperatura do injetor $=50^{\circ} \mathrm{C}$; temperatura do forno $=50^{\circ} \mathrm{C}$.

Injetou-se no cromatógrafo $0,50 \mathrm{~mL}$ de amostra do "headspace" do reator.

\subsubsection{Análise de ácidos graxos voláteis}

A análise de ácidos por cromatografia foi desenvolvida pelo grupo técnico da Cromatografia, no Laboratório de Processos Biológicos.

As amostras deste trabalho continham lignina e necessitavam de tratamento prévio para serem injetadas.

Assim, a cada $5 \mathrm{~mL}$ da amostra filtrada foi adicionado $20 \mu \mathrm{L}$ de solução de ácido sulfúrico 1:1 (v/v) e aproximadamente 1 grama de celulose microcristalina. Essa amostra foi agitada por um minuto em agitador de tubos Vórtex e centrifugada a $1800 \mathrm{rpm}$ por 1 minuto. Dois mililitros do sobrenadante foram transferidos para tubo de ensaio.

A partir deste ponto a extração seguia como protocolo desenvolvido pelas técnicas do Laboratório de Cromatografia, pertencente ao Laboratório de Processos Biológicos. Assim, aos 2,0 mL da amostra eram adicionados 1,0g de $\mathrm{NaCl}$ (P.A.), $100 \mu \mathrm{L}$ de solução de $\mathrm{H}_{2} \mathrm{SO}_{4} 1 \mathrm{M}, 100 \mu \mathrm{L}$ de solução de ácido crotônico (700 mg. $\mathrm{L}^{-1}$ ) e 
$0,60 \mathrm{~mL}$ de éter etílico purificado e gelado. Essa amostra era agitada em agitador de tubos (Vórtex) por 1 minuto. Posteriormente a amostra era centrifugada por 1 minuto e armazenada em freezer até o momento da injeção no cromatógrafo.

Retirava-se $1,0 \mu \mathrm{L}$ da fase orgânica da amostra e injetava-se em cromatógrafo a gás HP6890, com detector de ionização de chama a $300^{\circ} \mathrm{C}$, equipado com coluna HP INNOWAX (Cross Linked Polyethylene) com $300 \mathrm{~m}$ x $0,25 \mathrm{~mm}$ e $0,25 \mu \mathrm{m}$ de espessura de filme. O injetor operou a $250^{\circ} \mathrm{C}$, com taxa de "split" de 1:20. Os gases utilizados foram hidrogênio como gás de arraste, nitrogênio como gás auxiliar e ar sintético com fluxos de $30 \mathrm{~mL} \cdot \mathrm{min}^{-1}, 33 \mathrm{~mL} \cdot \mathrm{min}^{-1}$ e $300 \mathrm{~mL} \cdot \mathrm{min}^{-1}$, respectivamente.

A quantificação foi feita pelo método do padrão interno, utilizando o ácido crotônico. Os resultados foram obtidos por comparação com curva de calibração realizada com padrões em concentrações conhecidas e preparados pela mesma metodologia que as amostras.

\subsection{Monitoramento microbiológico}

Periodicamente, de acordo com a Tabela 4.5, a microbiota foi avaliada para verificar-se seu desenvolvimento, composição e as alterações prováveis na diversidade com o aumento da temperatura.

Foram coletadas amostras do ponto 2 do reator anaeróbio (Figura 4.2) e do tanque de aeração do reator de lodos ativados.

Os organismos filamentosos foram caracterizados por colorações, no decorrer do experimento e também foram feitos ensaios, com amostras dos dois reatores, para determinar-se o número mais provável (NMP) das arqueas metanogênicas presentes no lodo.

Os exames citados acima foram feitos por microscopia óptica.

$\mathrm{Na}$ faixa de temperatura termofilica foi feito um exame de microscopia eletrônica de varredura (MEV) a fím de ter-se visões tridimensionais da superfície das células presentes nos reatores anaeróbio e aeróbio, verificando assim a estrutura dos grânulos e flocos, respectivamente.

A freqüência em que houve a coleta das amostras, bem como a justificativa e qual o exame feito estão detalhados na Tabela 4.5. 
TABELA 4.5 - Coleta de amostras para monitoramento microbiológico.

\begin{tabular}{|c|c|c|}
\hline $\begin{array}{l}\text { Fases/ } \\
\text { Etapas }\end{array}$ & Monitoramento & Exame \\
\hline $1 / 1$ & $\begin{array}{l}\text { Alteração no tempo de detenção do reator UASB } \\
\text { para } 42 \text { horas }\end{array}$ & Microscopia óptica \\
\hline $1 / 2$ & $\begin{array}{l}\text { Alteração no tempo de detenção do reator UASB } \\
\text { para } 30 \text { horas e caracterização do inóculo do reator } \\
\text { de lodos ativados }\end{array}$ & Microscopia óptica \\
\hline $1 / 4$ & $\begin{array}{l}\text { Alteração no tempo de detenção do reator UASB } \\
\text { para } 20 \text { horas }\end{array}$ & Microscopia óptica \\
\hline $1 / 7$ & Alteração na temperatura da cabine para $37,5^{\circ} \mathrm{C}$ & Microscopia óptica \\
\hline $1 / 7$ & $\begin{array}{l}\text { Monitoramento do reator UASB na temperatura de } \\
37,5^{\circ} \mathrm{C}\end{array}$ & Microscopia óptica \\
\hline $1 / 7$ & $\begin{array}{l}\text { Monitoramento do reator de lodos ativados na } \\
\text { temperatura de } 37,5^{\circ} \mathrm{C}\end{array}$ & Microscopia óptica \\
\hline $1 / 8$ & Alteração na temperatura da cabine para $42,5^{\circ} \mathrm{C}$ & Microscopia óptica \\
\hline $2 / 1$ & Alteração na temperatura da cabine para $47,5^{\circ} \mathrm{C}$ & Microscopia óptica \\
\hline $2 / 4$ & $\begin{array}{l}\text { Alteração na temperatura da cabine para } 52,0^{\circ} \mathrm{C} \text {. } \\
\text { Foram feitas colorações das amostras do reator } \\
\text { aeróbio porque este ficou sem aeração por } \\
\text { aproximadamente } 36 \text { horas }\end{array}$ & Microscopia óptica \\
\hline $2 / 5$ & $\begin{array}{l}\text { Alteração na temperatura da cabine para } 57,0^{\circ} \mathrm{C} \text { e } \\
\text { coloração das filamentosas }\end{array}$ & Microscopia óptica \\
\hline $2 / 5$ & $\begin{array}{l}\text { Coleta de amostras para monitoramento dos reatores } \\
\text { na temperatura de } 57,0^{\circ} \mathrm{C} \text { visto que haveria corte de } \\
\text { energia e suprimento por meio de gerador por } 5 \text { dias }\end{array}$ & Microscopia óptica \\
\hline $2 / 5$ & $\begin{array}{l}\text { Coleta de amostras para monitoramento dos reatores } \\
\text { na temperatura de } 57,0^{\circ} \mathrm{C} \text { visto que houve queima do } \\
\text { termostato e os reatores ficaram em temperatura de } \\
30^{\circ} \mathrm{C} \text { por aproximadamente } 12 \text { horas. }\end{array}$ & Microscopia óptica \\
\hline$*$ & Fim do experimento & MEV \\
\hline$* *$ & Teste para verificar NMP & Microscopia óptica \\
\hline
\end{tabular}




\subsubsection{Microscopia óptica}

O exame microscópico ótico foi feito utilizando-se um microscópio Olympus BX60, acoplado a uma câmera com captura de imagem e software Image-Pro Plus.

As amostras dos reatores foram coletadas minutos antes do exame. Deve-se considerar que as amostras do reator UASB passavam por um pré-tratamento: foram colocadas em frasco fechado com pérolas de vidro e agitadas manualmente até a maceração dos grânulos.

\subsubsection{Microscopia de varredura}

O preparo das amostras para análise foi feito seguindo o método de Nation (1983), modificado por Araújo.

Foram coletadas amostras do reator anaeróbio e do reator aeróbio.

As amostras foram fixadas em solução tampão de fosfato $0,1 \mathrm{M}(\mathrm{pH} \mathrm{7,3)}$ contendo $2,5 \%$ de glutaraldeído por 12 horas, a $4^{0} \mathrm{C}$.

As amostras foram então lavadas três vezes com tampão fosfato $0,1 \mathrm{M}(\mathrm{pH} 7,3)$, durante 10 minutos.

Posteriormente passaram por um processo de desidratação sucessiva, em séries gradativas de etanol: $50 \%, 70 \%, 80 \%, 90 \%, 95 \%$ e $100 \%$, permanecendo 10 minutos em cada concentração.

As amostras ficavam então submersas em HMDS por 30 segundos, sendo o excesso dessa solução retirado por papel absorvente.

As amostras tratadas foram coladas com esmalte incolor em material suporte e mantidas em estufa a $55^{\circ} \mathrm{C}$, por 1 hora, aproximadamente.

Posteriormente as amostras foram recobertas por uma camada de ouro e examinadas em microscópio eletrônico de varredura Zeiss DSM-960 (20KV).

\subsubsection{Número Mais Provável (NMP)}

Segundo Atlas \& Bartha ${ }^{30}$ (1981) apud Sakamoto (1996) o método do NMP ou da diluição pode ser utilizado para estimar a população total ou para numerar grupos específicos de microrganismos presentes na amostra, capazes de crescer em meio de cultura altamente seletivo, sendo utilizadas de 3 a 10 réplicas por diluição. A amostra é considerada positiva ou negativa.

\footnotetext{
${ }^{30}$ ATLAS, R. M.; BARTHA, R. (1981). Determination of microbial, biomass and activies. In: Microbial ecology Fundamental and applications. P. 81-132.
} 
Essa técnica foi adaptada no Laboratório de Processos Biológicos, para ser utilizada na avaliação da comunidade de anaeróbios estritos em amostras de reatores biológicos, resíduos e amostras ambientais (FATIBELLO, 2000).

Neste trabalho essa técnica foi utilizada para quantificar os grupos microbianos anaeróbios termófilos dos reatores utilizando como substrato específico a água residuária sintética utilizada durante o experimento para alimentar os reatores. Assim, foram montados dois ensaios: com os lodos do reator UASB e do reator de lodos ativados.

Cada lodo foi inoculado em frasco contendo a água residuária sintética descrita no item 4.4, preparada no início deste experimento para avaliar NMP, não esterilizada.

Os frascos lacrados ficaram incubados por 20 dias e após esse período, foi verificado o crescimento (frasco positivo) ou não (frasco negativo), pela presença de turbidez e principalmente, pela formação de produtos. Foi verificada a produção de metano e nos frascos positivos foi feito exame por microscopia óptica.

Para aplicação da técnica, inicialmente foi esterilizado o sistema de filtração em membrana que seria utilizado (Kitassato, copo, suporte, membranas de $0,22 \mu$ m, pipetas e os frascos de antibiótico).

A água residuária sintética foi preparada com DQO de aproximadamente $1400 \mathrm{mg} . \mathrm{L}^{-1}$ e passada pelo sistema de membranas esterilizado. Posteriormente, foi submetida a um fluxo de nitrogênio puro durante 20 minutos. Sob o fluxo desse gás, foram transferidos $9 \mathrm{~mL}$ dessa água residuária sintética para os frascos de antibiótico $(30 \mathrm{~mL})$, sendo fechados com tampa de butila e lacrados.

Amostras de lodo dos reatores foram coletadas e colocadas em frascos de antibiótico com $2 \mathrm{~g}$ de pérolas de vidro, esterilizados.

Foi fluxionado nitrogênio puro nos frascos, por 5 minutos.

Essas amostras de lodo foram maceradas e cada uma transferida para um frasco com a água residuária sintética. $\mathrm{O}$ frasco com a água residuária sintética e amostra foram agitados por 20 minutos, manualmente.

Para a amostra do reator UASB foram feitas diluições até $10^{-6}$ e para a amostra do reator de lodos ativados até $10^{-3}$. Todas as diluições foram feitas em quintuplicata.

Esses frascos foram incubados em estufa a $(57 \pm 2)^{0} \mathrm{C}$, por 20 dias. 
A contagem do NMP das metanogênicas foi feita com a combinação das respostas positivas (produção de metano), utilizando a tabela 9221.IV do APHA (1998).

\subsubsection{Caracterização e quantificação de microrganismos filamentosos}

Para o reator de lodos ativados, o exame microscópico é útil para determinar a natureza física do floco e os tipos de organismos filamentosos presentes. Geralmente, esse tipo de exame fornece informações relativas ao comportamento do reator de lodos ativados nos processos de manuseio e separação de sólidos (JENKINS et al., 1993).

Parker et al. ${ }^{3 l}$ (1971) apud Jenkins et al. (1993) demonstraram que o efeito dos organismos filamentosos é preservar a integridade dos flocos do reator de lodos ativados sob condições de aumento do cisalhamento. Porém, se os organismos filamentosos que fornecem a macroestrutura do floco estão presentes em grandes quantidades, esse número pode interferir na compactação e sedimentação no lodo.

Portanto, é de grande importância, no monitoramento do reator de lodos ativados, determinar quais as morfologias presentes.

Segundo JENKINS et al. (1993), as colorações de Gram e de Neisser são dois dos procedimentos de coloração rotineiramente usados como parte dos métodos de caracterização dos organismos filamentosos. Podem ser ferramentas auxiliares o teste para oxidação a sulfito dos grânulos de enxofre intracelulares, coloração para deteç̧ão de produtos estocados dentro da célula como as poly-ß-hidroxibutirato (PHB) e coloração da bainha.

Os procedimentos adotados para essas colorações são descritos a seguir. De posse de todos os resultados da caracterização, para a identificação dos filamentos é utilizada a chave dicotômica apresentada na Figura 4.5 (página 76).

\subsubsection{Coloração de Gram, modificado do método de Hücker ${ }^{32}$}

Para essa coloração foram utilizadas três soluções, que devem ser preparadas a cada 3 a 6 meses.

Para o preparo da Solução 1 eram misturadas duas soluções (A e B).

\begin{tabular}{ll}
\hline \multicolumn{1}{c}{ Solução A } & \multicolumn{1}{c}{ Solução B } \\
\hline Dissolver $2 \mathrm{~g}$ de violeta cristal em & Dissolver 0,8 g de oxalato de amônio em \\
$20 \mathrm{~mL}$ de etanol $95 \%$ & $80 \mathrm{~mL}$ de água destilada. \\
\hline
\end{tabular}

\footnotetext{
${ }^{31}$ PARKER, D. S., JENKINS, D.; KAUFMAN, W. J. (1971). Physical Conditioning of the activated sludge floc. J. Water Polln. Control Fedn., 43, 1817.

${ }^{32}$ Este é o método de Hücker modificado por JENKINS, D.; RICHARD, M. G.; DAIGGER, G. T. (1993). Mamual on the causes and control of activated sludge bulking and foaming. $2 \mathrm{ed}$. Lewis Publishers, Inc. Michigan.
} 
Solucão 2: dissolver $1 \mathrm{~g}$ de iodo e $2 \mathrm{~g}$ de iodeto de potássio em $300 \mathrm{~mL}$ de água destilada.

Solucão descolorante: etanol 95\%.

Solucão 3: misturar $10 \mathrm{~mL}$ de safranina O (2,5\% peso/volume em etanol 95\%) em $100 \mathrm{~mL}$ de água destilada.

Procedimento:

Colocar uma gota do licor misto em lâmina e deixar secar ao ar;

Cobrir a lâmina com a Solução 1 por 1 minuto e lavar rapidamente com água;

Cobrir a lâmina com a Solução 2 por 1 minuto e lavar muito bem com água;

Para descolorir a amostra, adicionar etanol 95\% gota a gota, durante 25 segundos até eliminar o excesso de violeta cristal;

Cobrir a lâmina com a solução 3 por 1 minuto e lavar muito bem com água, secando com papel;

Examinar a lâmina em óleo de imersão em aumento de 1000 vezes com iluminação direta e não com contraste de fase.

Se o organismo for Gram positivo a coloração será azul violeta e se for Gram negativo negativo, a coloração será vermelha.

\subsubsection{Coloração de Neisser ${ }^{33}$}

Para essa coloração foram utilizadas 2 soluções que deviam ser preparadas a cada 3 a 6 meses.

Para o preparo da Solução 1 eram misturadas 2 partes $(20 \mathrm{~mL})$ da solução A em 1 parte $(10 \mathrm{~mL})$ da solução $\mathrm{B}$ :

\begin{tabular}{ll}
\hline Solução A & Solução B \\
\hline Dissolver 0,1g de azul de metileno em & Misturar 3,3mL de violeta cristal $(10 \%$ \\
$5 \mathrm{~mL}$ de etanol $95 \%, 5 \mathrm{~mL}$ de ácido & peso/volume em etanol $95 \%)$ em $6,7 \mathrm{~mL}$ \\
acético glacial e $100 \mathrm{~mL}$ de água & de etanol $95 \%$ e $100 \mathrm{~mL}$ de água \\
destilada. & destilada. \\
\hline
\end{tabular}

Solucão 2: misturar 33,3 mL de Bismark Brown $\left(\mathrm{C}_{18} \mathrm{H}_{18} \mathrm{~N}_{18}, 1 \%\right.$ peso/volume aquoso) em $66,7 \mathrm{~mL}$ de água destilada.

Procedimento:

Colocar uma gota do licor misto em lâmina e deixar secar ao ar.

\footnotetext{
${ }^{33}$ EIKELBOOM, D. H.; VAN BUIJSEN, H. J. J. (1981). Microscopic sludge investigation manual. TNO Res. Inst. for Env. Hygiene, Delft, The Netherlands. apud JENKINS, D.; RICHARD, M. G.; DAIGGER, G. T. (1993). Manual on the causes and control of activated sludge bulking and foaming. 2 ed. Lewis Publishers, Inc. Michigan.
} 
Cobrir a lâmina com a Solução 1 por 30 segundos e lavar rapidamente com água.

Cobrir a lâmina com a Solução 2 por 1 minuto e lavar muito bem com água e secar com papel.

Examinar a lâmina em óleo de imersão em aumento de 1000 vezes com iluminação direta.

Se o organismo for Neisser positivo a coloração será azul violeta na célula inteira ou em grânulos intracelulares.

Se o organismo for Neisse negativo a coloração será amarelo marron.

\subsubsection{Coloração de Polibetahidroxibutirato (PHB) ${ }^{34}$}

Foram utilizadas 2 soluções.

Solucão 1: dissolver 0,3 g de Sudan Black B (IC) em $100 \mathrm{~mL}$ de etanol $60 \%$.

Solucão 2: dissolver $0,5 \mathrm{~g}$ de safranina $\mathrm{O} \mathrm{em} 100 \mathrm{~mL}$ de água destilada.

Procedimento:

Colocar uma gota do licor misto em lâmina e deixar secar ao ar;

Cobrir a lâmina com a Solução 1 por 10 minutos e caso comece a secar, adicionar mais um pouco da Solução 1;

Lavar a lâmina rapidamente com água;

Cobrir a lâmina com a Solução 2 por 10 segundos, lavar muito bem e secar com papel;

Examinar a lâmina em óleo de imersão, com aumento de 1000 vezes e iluminação direta (e não com contraste de fase).

Grânulos de PHB apresentam-se intracelularmente com a coloração azul-preta enquanto que o citoplasma apresenta-se com coloração rosa clara.

\subsubsection{Coloração de Bainha ${ }^{35}$}

Para essa coloração é utilizado apenas um reagente.

Reagente: dissolver $0,1 \mathrm{~g}$ de violeta cristal em $100 \mathrm{~mL}$ de água destilada.

Procedimento:

Misturar uma gota da amostra de lodos ativados e uma gota da solução de violeta cristal em lâmina; 
Cobrir a lâmina com a lamínula e examinar em microscópio, com aumento de 1000 vezes e iluminação direta.

As células ficam coloridas de violeta escuro, enquanto que as bainhas ficam coloridas de rosa claro.

\subsubsection{Teste de oxidação de enxofre ${ }^{36}$}

Neste teste também foi utilizada apenas uma solução, a ser preparada semanalmente.

Solucão: foi dissolvido 1,0 g. $\mathrm{L}^{-1}$ de tiossulfeto de sódio $\left(\mathrm{Na}_{2} \mathrm{~S} .9 \mathrm{H}_{2} \mathrm{O}\right)$ em $100 \mathrm{~mL}$ de água destilada.

Procedimento:

Misturar uma gota da amostra de lodos ativados e uma gota da solução de sulfeto de sódio;

Deixar secar ao ar por 10 a 20 minutos;

Cobrir com uma lamínula e pressionar levemente para retirar o excesso de solução, que deve ser removida com um papel;

Examinar em microscópio, com aumento de 1000 vezes, usando contraste de fase.

Se o teste for positivo é observada a presença de grânulos intracelulares de coloração amarela (grânulos de enxofre).

\footnotetext{
${ }^{36}$ EIKELBOOM, D. H; VAN BUIJSEN, H. J. J. (1981). Microscopic sludge investigation mamual. TNO Res. Inst. for Env. Hygiene, Delft, The Netherlands. apud JENKINS, D.; RICHARD, M. G.; DAIGGER, G. T. (1993). Mamual on the causes and control of activated sludge bulking and foaming. 2 ed. Lewis Publishers, Inc. Michigan.
} 


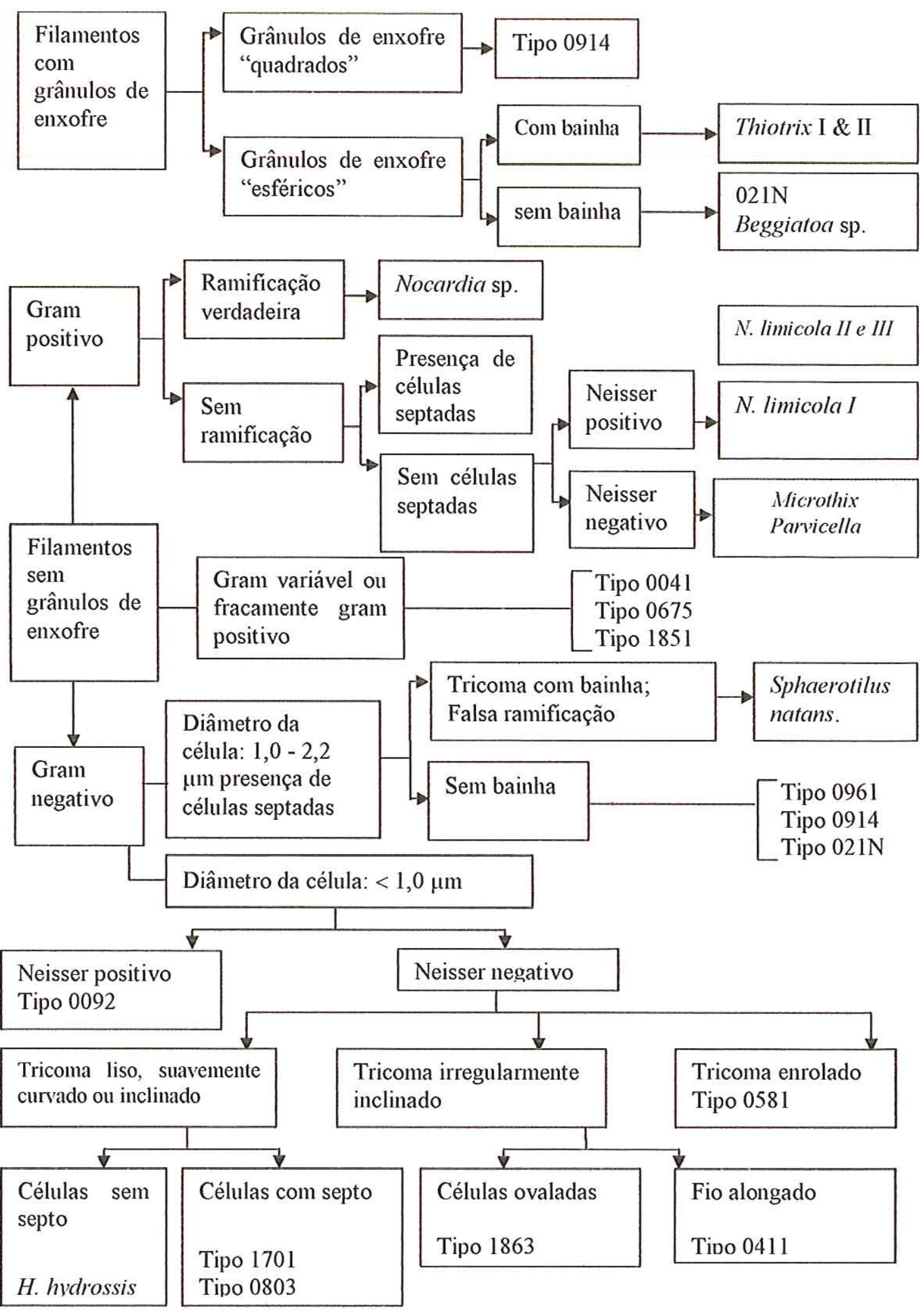

FIGURA 4.5. Chave dicotômica simplificada para identificação de microrganismos filamentosos. Adaptada de Jenkins et al. (1984) e Eikelboom (1975) (Fonte: Bitton, 1994). 


\subsection{Teste de transferência de oxigênio}

Esse teste foi feito em reator de lodo ativado de 6 litros, similar ao utilizado durante a fase experimental deste trabalho com o objetivo de verificar se a transferência de oxigênio em água e na água residuária sintética, descrita no item 4.4, em diferentes temperaturas e vazões de aeração. O teste foi feito sem a presença de biomassa.

A concentração de oxigênio dissolvido foi medida utilizando-se oxímetro da marca ORION, modelo 850, que enviava os dados para um programa de computador.

O tanque foi mantido em cabine climatizada, controlada por termostato, sendo as temperaturas ajustadas em cada teste.

Para a aeração foi empregada bomba e pedras porosas de aquário, sendo a vazão de ar controlada por rotâmetro. Os testes foram feitos em temperaturas de 5, 15, 25, 35 e $45^{\circ} \mathrm{C}$, em vazões de aeração de 15,30 e $45 \mathrm{~L} \cdot \mathrm{h}^{-1}$.

O teste era iniciado na temperatura desejada, removendo-se o oxigênio no líquido (água ou água residuária sintética) com fluxo de nitrogênio. Posteriormente dava-se início à aeração na taxa determinada.

O programa de computador registrava os valores de oxigênio dissolvido, temperatura e tempo em intervalos de dois segundos. Quando o valor do oxigênio dissolvido atingia a saturação, desligava-se a aeração e registrava-se o decaimento desses valores.

Esses dados foram exportados para planilha no Excel, feita pelo aluno de doutorado Neyson Mendonça, do SHS. Nessa planilha, utilizava-se o programa Solver e determinava-se o coeficiente global de transferência de oxigênio (Kla), a concentração de oxigênio e plotava-se um gráfico com os valores.

O programa resolvia a equação 4.1. Como não havia consumo de oxigênio no meio líquido em aeração, a concentração de oxigênio aumentava segundo uma taxa exponencial decrescente. Assim, a concentração tendia assintoticamente até o valor do estado estacionário ou seja, a concentração de saturação.

$$
C=C_{s}\left(C_{s}-C_{o}\right) \cdot e^{-K l a\left(t-t_{o}\right)} \quad \text { Equação } 4.1
$$

Em que:

$\mathrm{C}_{\mathrm{s}}=$ concentração de saturação; $\mathrm{C}_{\mathrm{o}}=$ concentração inicial; Kla $=$ coeficiente global de transferência de oxigênio $\left(\mathrm{min}^{-1}\right) ; \mathrm{t}=$ tempo final; $\mathrm{t}_{\mathrm{o}}=$ tempo inicial.

Na Tabela 4.6. é apresentado um modelo da planilha utilizada no Excel. 
TABELA 4.6. Esquema da planilha do programa Excel utilizada no teste de transferência de oxigênio

\begin{tabular}{|c|c|c|c|c|c|c|c|c|}
\hline 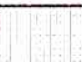 & $\mathrm{A}$ & B & C & $\mathrm{D}$ & $\mathrm{E}$ & $\mathrm{F}$ & $\mathrm{G}$ & $\mathrm{H}$ \\
\hline 1 & \multirow{2}{*}{\multicolumn{6}{|c|}{ 1.ENTRADA DOS DADOS DO MODELO }} & & \\
\hline 2 & & & & & & & & \\
\hline 3 & & & Projecão & SSR & SSE & SST & \multirow[t]{2}{*}{ Residuos } & F.ajuste \\
\hline 4 & $\begin{array}{l}\text { Tempo } \\
\text { (min) }\end{array}$ & $\begin{array}{l}\text { OD Obs. } \\
\left(\mathrm{mO}_{2} \cdot \mathrm{L}^{-1}\right)\end{array}$ & $\begin{array}{l}\mathrm{OD}_{\square \text { alc. }} \\
\left(\mathrm{mO}_{2} \cdot \mathrm{L}^{-1}\right)\end{array}$ & Explicada & Não Explicada & Total & & \\
\hline 5 & $\mathbf{T}_{0}$ & $\mathrm{OD}_{\mathrm{obs} 0}$ & $\begin{array}{l}=\$ B \$ n 5-((\$ B \$ n 5) *(E X P \\
(-\$ D \$ n 5 * A 5)))\end{array}$ & $=(\mathrm{C} 5-\mathrm{SB} \$ \mathrm{n} 5)^{\wedge} 2$ & $=(\mathrm{B} 5-\mathrm{C} 5)^{\wedge} 2$ & $=(\mathrm{B} 5-\$ \mathrm{~B} \$ \mathrm{n} 5)^{\wedge} 2$ & $=\mathrm{B} 5-\mathrm{C} 5$ & $=(\mathrm{B} 5-\mathrm{SC} \operatorname{sn} 2)^{\wedge} 2$ \\
\hline 6 & $\mathrm{~T}_{1}$ & $\mathrm{OD}_{\text {obs } 1}$ & $\begin{array}{l}=\$ B \$ n 5-((\$ B \$ n 5) *(\mathrm{EXP} \\
(-\$ D \$ n 5 * A 6)))\end{array}$ & $=(\mathrm{C} 6-\$ B \$ n 5)^{\wedge} 2$ & $=(\mathrm{B} 6-\mathrm{C} 6)^{\wedge} 2$ & $=(\mathrm{B} 5-\$ \mathrm{~B} \$ \mathrm{n} 5)^{\wedge} 2$ & $=\mathrm{B} 5-\mathrm{C} 5$ & $=(\mathrm{B} 5-\mathrm{SC} \operatorname{Sn} 2)^{\wedge} 2$ \\
\hline 7 & $T_{2}$ & $\mathrm{OD}_{\mathrm{obs} 2}$ & $\begin{array}{l}=\$ \mathrm{~B} \$ \mathrm{n} 5-\left((\$ \mathrm{BB} \$ \mathrm{n} 5)^{*}(\mathrm{EXP}\right. \\
(-\$ D \$ n 5 * \mathrm{~A} 7)))\end{array}$ & $=(\mathrm{C} 7-\mathrm{SB} \$ \mathrm{n} 5)^{\wedge} 2$ & $=(\mathrm{B} 7-\mathrm{C} 7)^{\wedge} 2$ & $=(\mathrm{B} 5-\$ \mathrm{~B} \$ \mathrm{n} 5)^{\wedge} 2$ & $=\mathrm{B} 5-\mathrm{C} 5$ & $=(\mathrm{B} 5-\mathrm{SC} \operatorname{sn} 2)^{\wedge} 2$ \\
\hline 8 & $\ldots$. & & $\cdots$ & & & & & \\
\hline $\mathrm{n}$ & $\mathrm{Tn}$ & $\mathrm{OD}_{\mathrm{obsn}}$ & $\begin{array}{l}=\$ B \$ n 5-\left((\$ B \$ n 5)^{*}(\mathrm{EXP}\right. \\
(-\$ D \$ n 5 * \mathrm{Na})))\end{array}$ & $=(\mathrm{Cn}-\$ \mathrm{~B} \$ \mathrm{Sn} 5)^{\wedge} 2$ & $=(\mathrm{Bn}-\mathrm{Cn})^{\wedge} 2$ & $=(\mathrm{B} 5-\$ \mathrm{~B} \$ \mathrm{n} 5)^{\wedge} 2$ & $=\mathrm{B} 5-\mathrm{C} 5$ & $=(B 5-\$ C \$ n 2)^{\wedge} 2$ \\
\hline n1 & Média(y) & $\begin{array}{l}=\text { MEDIA } \\
\text { (B5:Bn) }\end{array}$ & Soma & $=\mathrm{SOMA}(\mathrm{D} 5: \mathrm{Dn}$ & $=\mathrm{SOMA}(\mathrm{E} 5: \mathrm{Na})$ & $=\mathrm{SOMA}(\mathrm{F} 5: \mathrm{Fn})$ & $\begin{array}{l}=\text { SOMA } \\
(\mathrm{G} 5: \mathrm{Gn})\end{array}$ & $=\mathrm{SOMA}(\mathrm{H} 5: \mathrm{Hn})$ \\
\hline $\mathrm{n} 2$ & $\mathrm{n}$ & $\begin{array}{l}=\text { CONT.NÚM } \\
(\mathrm{A} 5: \mathrm{An})\end{array}$ & $=\mathrm{MÉ} D I A(\mathrm{C} 5: \mathrm{Cn})$ & & & & & \\
\hline
\end{tabular}


TABELA 4.6. Esquema da planilha do programa Excel utilizada no teste de transferência de oxigênio (continuação).

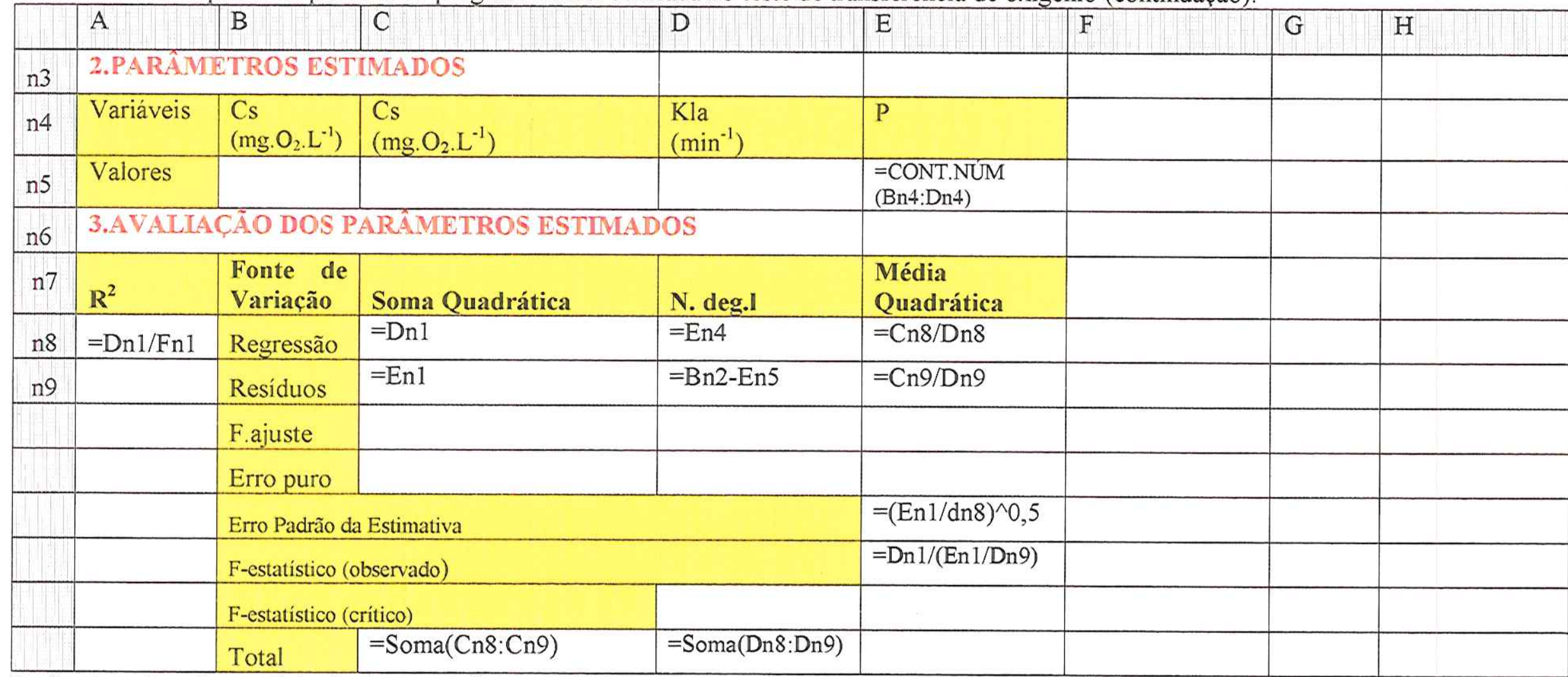

Parâmetros do solver: célula de destino definida (\$En1\$); a célula de destino será minimizada (igual a mínimo); Células variáveis devem conter células que estejam em função da célula de destino e serão no caso: \$B\$n5;\$D\$n5. 


\subsection{Teste do aumento súbito da temperatura}

No presente trabalho optou-se pelo aumento gradual da temperatura, já que o inóculo utilizado era mesofílico e seria utilizado um sistema combinado. Contudo, para verificar o desempenho dos reatores com um rápido aumento da temperatura, foi feito um teste, por período de 50 dias. Se os resultados fossem viáveis, facilitariam novos testes com sistema termofílico em laboratório e também ter-se-ia noção da aplicabilidade do tratamento termofílico em indústrias de pasta de celulose que já utilizam processos de tratamento biológico aeróbio mesofilico, sem necessidade de adaptação gradual do lodo para trabalho na faixa de temperatura termofílica.

Os reatores foram inoculados com lodo mesofilico, em temperatura ambiente $\left(\cong 30^{\circ} \mathrm{C}\right)$ e mantidos em batelada por 24 horas. O reator UASB foi inoculado com $3 \mathrm{~L} \mathrm{de}$ lodo do reator que tratava água residuária da avícola Dacar Industrial S.A. (Tietê - São Paulo) e o reator de lodos ativados foi inoculado com $2,0 \mathrm{~L}$ do reator de lodos ativados da Indústria Volkswagem (São Carlos - São Paulo). A temperatura da cabine foi então ajustada para $57^{\circ} \mathrm{C}$ e os reatores permaneceram em batelada por mais doze dias.

O teste foi dividido em duas etapas de acordo com o aumento na DQO da água residuária sintética (Tabela 4.7) e os reatores foram operados de forma contínua.

TABELA 4.7 - Etapas do teste do aumento súbito da temperatura, tipo e volume de licor utilizado, DQO da água residuária sintética, tempo de detenção hidráulica dos reatores e o tempo de operação em cada etapa.

\begin{tabular}{ccccccc}
\hline \multirow{2}{*}{ Etapas } & \multirow{2}{*}{ Tipo de licor e volume } & $\begin{array}{c}\text { DQO da ARS } \\
\left(\mathrm{mg.L}^{-1}\right)\end{array}$ & \multicolumn{2}{c}{ TDH $(\mathrm{h})$} & Tempo \\
& I & LNI2 & UASB & LA & (dias) \\
\hline II & $(15 \mathrm{~mL}: 15 \mathrm{~L}: 7 \mathrm{~mL}$ etanol $)$ & $492-609$ & 40 & 14 & 26 \\
\hline
\end{tabular}

LNCI2: licor negro concentrado intermediário 2, ARS: água residuária sintética; TDH: tempo de detenção hidráulical LA: lodos ativados 


\section{RESULTADOS E DISCUSSÃO}

"Em momentos dé crise só a imagimịio

O tratamento termofílico anaeróbio já vem sendo estudado há muitos anos no meio acadêmico, entretanto, o estudo do tratamento aeróbio termofílico é relativamente recente. Considerando a aplicação do sistema combinado termofílico (anaeróbioaeróbio), em busca feita em literatura especializada, apenas um artigo foi encontrado. Assim, os resultados obtidos no presente trabalho são fruto de um estudo que objetivou verificar se as vantagens teóricas do sistema termofílico seriam aplicáveis ao efluente da indústria de pasta de celulose não branqueada, nas configurações de reatores escolhidas.

Uma das principais dúvidas em relação à aplicação do tratamento termofilico aeróbio é o suprimento de oxigênio, visto que, a concentração de saturação de oxigênio em alta temperatura é baixa. Assim, para iniciar este capítulo de apresentação e discussão dos resultados serão considerados os resultados obtidos em teste feito em escala de bancada, com água de abastecimento e com a água residuária sintética utilizada, visando analisar as concentrações de saturação do oxigênio dissolvido e suas taxas de transferência em diferentes temperaturas e vazões de aeração.

Posteriormente, serão apresentados e discutidos os resultados obtidos no monitoramento dos reatores, considerando-se duas fases: mesofilica (1) e termofílica (2); de acordo com o item 4.4.2, do capítulo Material e Métodos.

Deve-se considerar que os reatores sofreram ajustes gradativos na taxa de carregamento orgânico na fase 1 e no tempo de detenção hidráulica e temperatura nas duas fases. Assim, cada fase foi dividida em etapas, de acordo com as 
alterações efetuadas.

Esta execução em etapas, do carregamento orgânico e temperatura, visou a adaptação da biomassa às condições termofilicas, visto que os efluentes das indústrias de pasta de celulose podem ser tóxicos aos microrganismos anaeróbios e, de acordo com Speece (1996), pode ocorrer uma potencial adaptação da biomassa a muitos compostos tóxicos, se houver cuidado e paciência para expô-la a concentrações relativamente pequenas no início da operação, atingindo-se gradualmente os valores de trabalho desejados no projeto.

Além disso, considerando-se a elevação da temperatura, no início do trabalho experimental, acreditava-se que aumentos súbitos levariam à lise dos organismos no reator aeróbio, por isso optou-se pelo ajuste gradual.

Assim, são apresentados e discutidos, neste capítulo, os resultados obtidos nas fases mesofílica e termofílica, com uma abordagem geral sobre as condições de operação e problemas encontrados. Posteriormente é apresentada uma avaliação dos resultados obtidos nas análises microscópicas da microbiota dos reatores. Dando prosseguimento à apresentação e discussão dos resultados, são avaliadas as relações e possíveis interferências entre os parâmetros monitorados nas duas fases.

Também são apresentados os resultados obtidos em teste, no qual os reatores foram submetidos a aumento súbito da temperatura. Este teste foi feito em tempo limitado. Finalmente, é apresentado o resumo dos resultados obtidos no presente trabalho com outros encontrados na literatura.

\subsection{Teste de transferência de oxigênio}

Os testes de transferência de oxigênio foram feitos em ausência de biomassa, em água de abastecimento e na água residuária sintética preparada com DQO em torno de $1400 \mathrm{mg} . \mathrm{L}^{-1}$.

Foram testadas diferentes temperaturas $\left(5,15,25,35\right.$ e $\left.45^{\circ} \mathrm{C}\right)$ e diferentes vazões de aeração, controladas por rotâmetro $\left(15,30\right.$ e $\left.45 \mathrm{~L} \cdot \mathrm{h}^{-1}\right)$. Os testes foram feitos em duplicata, sendo que alguns dos resultados apresentados foram cedidos pelo estudante de iniciação científica, Renato Obladen. Não foram testadas temperaturas superiores a $45^{\circ} \mathrm{C}$ devido às limitações do aparelho de medição da concentração de oxigênio dissolvido, cuja temperatura limite de trabalho era de $45^{\circ} \mathrm{C}$. Acima desta temperatura as leituras eram bastante instáveis e portanto, não confiáveis. 
Na Tabela 5.1 e 5.2 são apresentados os valores médios das concentrações de saturação de oxigênio e seus respectivos coeficientes de transferência obtidos no reator com água de abastecimento (Tabela 5.1) e com água residuária sintética (Tabela 5.2).

Conforme esperado pela química, verifica-se a tendência do decréscimo da concentração de saturação à medida que a temperatura é aumentada, nas diferentes vazões de aeração de aeração testadas, tanto na água de abastecimento, quanto na água residuária sintética. Também pode ser verificado que à medida que a concentração de saturação diminui, aumenta o coeficiente de transferência de oxigênio.

Pode ser notado que nas temperaturas de $35^{0} \mathrm{C}$ e vazão de aeração de $30 \mathrm{~L} \cdot \mathrm{h}^{-1}$, a concentração de saturação na água foi levemente maior que a $25^{\circ} \mathrm{C}$, entretanto, o coeficiente de transferência de oxigênio foi menor. $\mathrm{O}$ mesmo ocorreu na água residuária sintética em temperatura de $45^{\circ} \mathrm{C}$ e vazão de aeração de $5 \mathrm{~L} \cdot \mathrm{h}^{-1}$, quando comparado à temperatura de $35^{\circ} \mathrm{C}$ com a mesma aeração. Esta diferença provavelmente é devida a diferença da pressão atmosférica entre os dias em que as análises foram feitas.

TABELA 5.1. Concentrações de saturação e coeficientes de transferência de oxigênio obtido em teste na água utilizando várias temperaturas e vazões de aeração.

\begin{tabular}{ccccccccc}
\hline Parâmetros & \multicolumn{7}{c}{ Vazões de aeração $\left({\left.\mathrm{L} . \mathrm{h}^{-1}\right)}^{-1}\right.$} \\
\cline { 2 - 8 } $\begin{array}{c}\text { Temperaturas } \\
\left({ }^{0} \mathrm{C}\right)\end{array}$ & $\mathrm{CS}$ & & Kla & CS & Kla & CS & Kla \\
\hline 5 & 11,7 & 0,064 & 10,7 & 0,112 & 8,4 & 0,203 \\
15 & 9,1 & 0,090 & 8,4 & 0,147 & 8,4 & 0,204 \\
25 & 6,5 & 0,094 & 6,5 & 0,235 & 7,1 & 0,292 \\
35 & 5,6 & 0,105 & 6,8 & 0,182 & 7,0 & 0,328 \\
45 & 5,2 & 0,143 & - & - & - & - \\
\hline
\end{tabular}

CS - concentração de saturação do oxigênio $\left(\mathrm{mgO}_{2} \cdot \mathrm{L}^{-1}\right) ; \mathrm{Kla}$ - coeficiente de transferência de oxigênio $\left(\min ^{-1}\right)$. Os valores de CS e Kla nesta tabela são valores médios.

TABELA 5.2. Concentrações de saturação e coeficientes de transferência de oxigênio obtido em teste na água residuária sintética utilizando várias temperaturas e vazões de aeração.

\begin{tabular}{cccccccc}
\hline Parâmetros & \multicolumn{7}{c}{ Vazões de aeração $\left({\left.\mathrm{L} . \mathrm{h}^{-1}\right)}\right.$} \\
\cline { 2 - 8 } $\begin{array}{c}\text { Temperaturas } \\
\left({ }^{0} \mathrm{C}\right)\end{array}$ & CS & Kla & CS & Kla & CS & Kla \\
\hline 5 & 9,8 & 0,050 & 10,2 & 0,076 & 10,2 & 0,110 \\
15 & - & - & 8,2 & 0,088 & 7,8 & 0,113 \\
25 & 6,5 & 0,066 & 7,4 & 0,145 & 7,2 & 0,292 \\
35 & 2,4 & 0,186 & 6,4 & 0,243 & 7,0 & 0,339 \\
45 & 5,0 & 0,114 & - & - & - & \\
\hline
\end{tabular}

CS - concentração de saturação do oxigênio $\left(\mathrm{mgO}_{2} \cdot \mathrm{L}^{-1}\right) ; \mathrm{Kla}$ - coeficiente de transferência de oxigênio $\left(\min ^{-1}\right)$. Os valores de CS e Kla nesta tabela são valores médios. 
Esses resultados também estão apresentados nas Figuras 5.1 e 5.2, considerandose os testes em água e na água residuária sintética, respectivamente.

Logo, pelo que foi observado, o oxigênio não é fator limitante para o tratamento aeróbio em altas temperaturas devido ao aumento dos coeficientes de transferência de oxigênio. Esses resultados estão de acordo com os obtidos por Jahren et al. (2002) e Vogelaar et al. (2000).

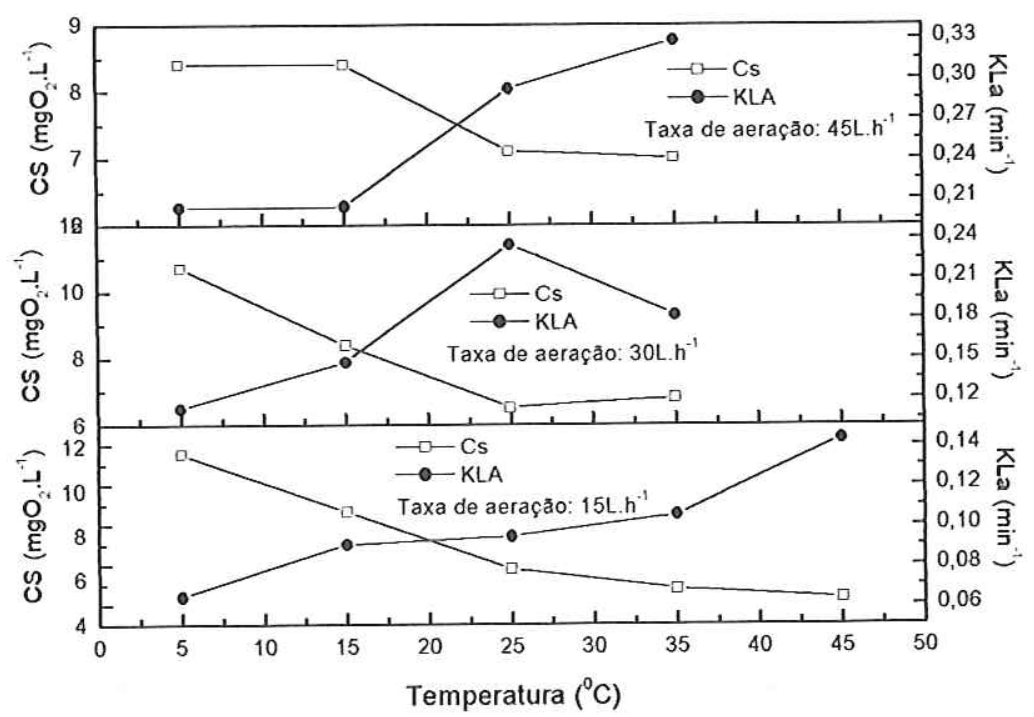

FIGURA 5.1. Valores da concentração de saturação e do coeficiente de transferência do oxigênio, na água, em relação ao aumento de temperatura, considerando as vazões de aeração de 45,30 e $15 \mathrm{~L} \cdot \mathrm{h}^{-1}$.

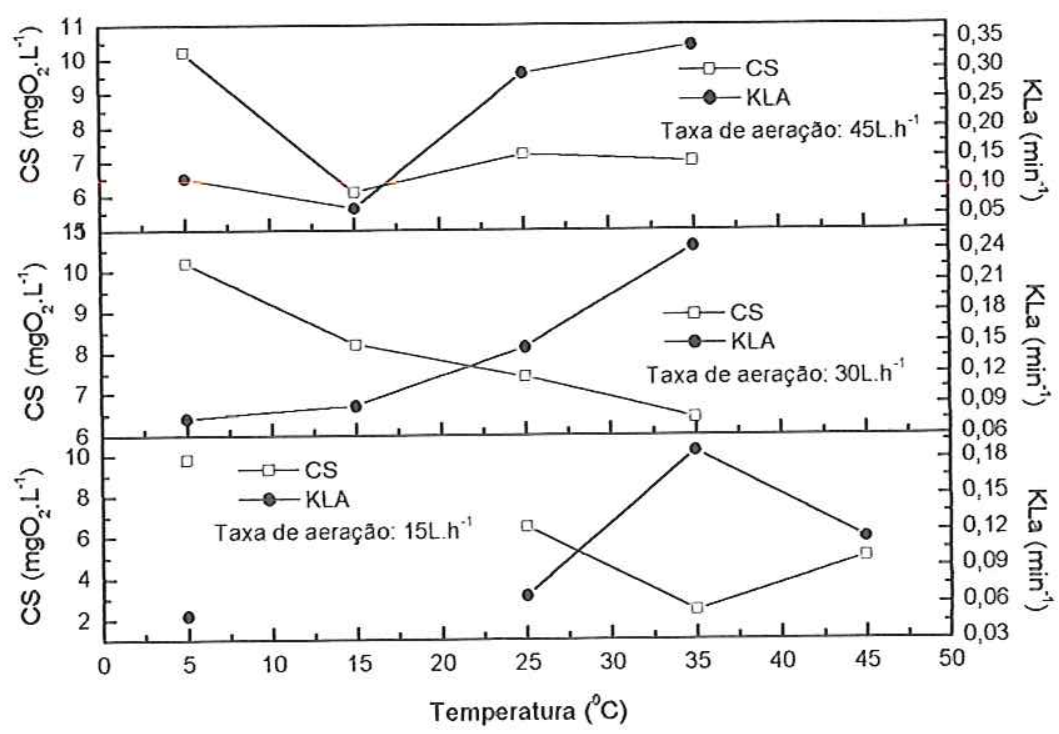

FIGURA 5.2. Valores da concentração de saturação e do coeficiente de transferência do oxigênio, na água residuária sintética, em relação ao aumento de temperatura, considerando as vazões de aeração de 45,30 e $15{\mathrm{~L} . \mathrm{h}^{-1}}^{-}$. 
Na Figura 5.3 são apresentadas as concentrações de saturação e os coeficientes de transferência do oxigênio, considerando-se a temperatura de $35^{\circ} \mathrm{C}$ nos testes com água e com água residuária sintética, em vazão de aeração de $30 \mathrm{~L} \cdot \mathrm{h}^{-1}$. Nota-se que à medida em que a temperatura é aumentada, o comportamento dos parâmetros em ambos os líquidos é similar.

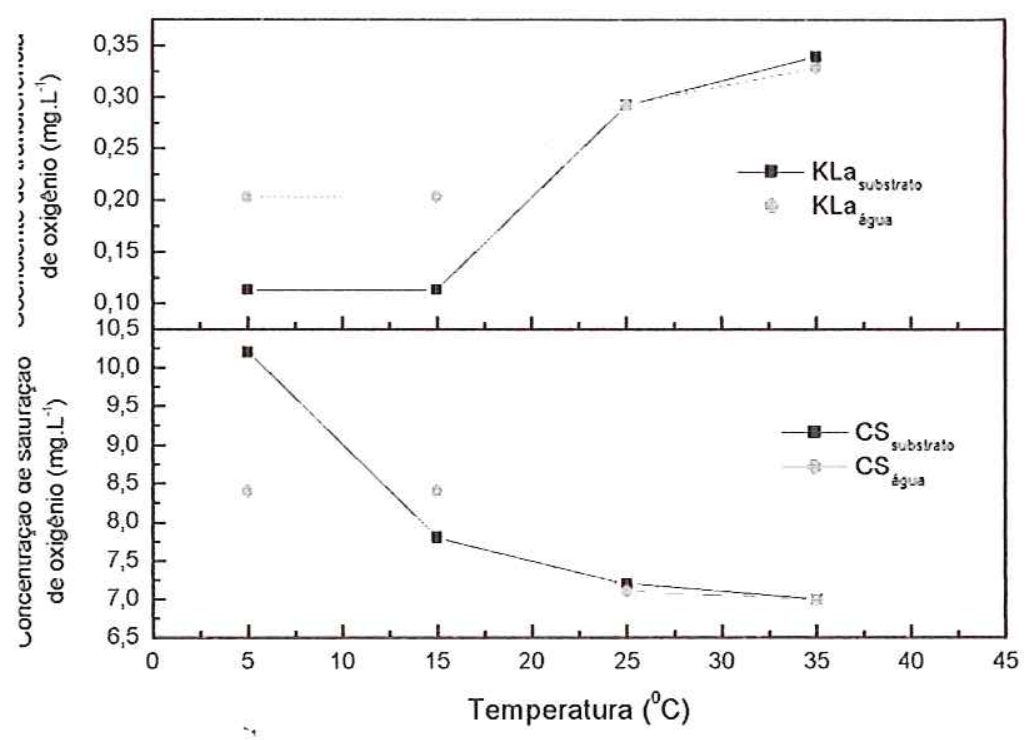

FIGURA 5.3. Valores da concentração de saturação e do coeficiente de transferência do oxigênio na água e na água residuária sintética em relação ao aumento de temperatura, considerando a vazão de aeração de $30 \mathrm{~L} \cdot \mathrm{h}^{-1}$.

\subsection{Monitoramento físico-químico}

\subsubsection{Primeira Fase: Mesofilica}

A primeira fase contempla o período em que os reatores foram operados em temperatura mesofilica, adotando a faixa de $(24,0 \pm 2,0)^{0} \mathrm{C}$ a $(42,5 \pm 2,0)^{0} \mathrm{C}$. Para melhor discussão dos resultados, essa fase, por sua vez, foi subdividida em oito etapas, de acordo com alterações efetuadas na DQO afluente, na temperatura e/ou tempo de detenção hidráulica, como apresentado na Figura 5.4. 


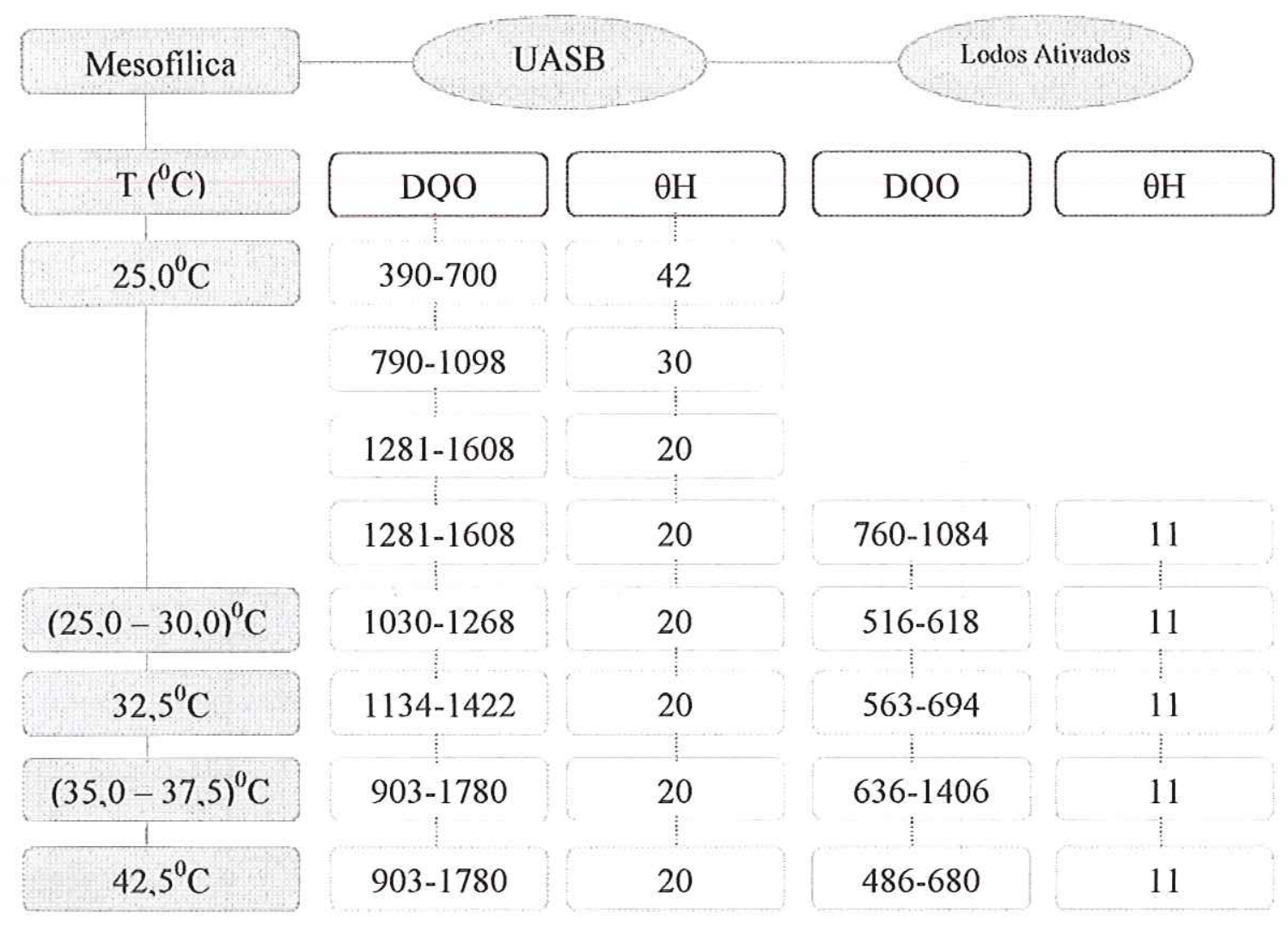

FIGURA 5.4 - Fase mesofílica ( $1^{\text {a }}$ fase): temperatura considerada $\left({ }^{0} \mathrm{C}\right)$, DQO $\left(\mathrm{mg} . \mathrm{L}^{-1}\right) \mathrm{e}$ tempo de detenção hidráulica (h) em cada etapa.

\subsubsection{Primeira etapa mesofilica}

Inicialmente foi operado apenas o reator anaeróbio, inoculado, com 3,0 L de lodo anaeróbio mesofílico. O reator permaneceu em batelada, alimentado com DQO em torno de $400 \mathrm{mg} . \mathrm{L}^{-1}$, por 14 dias.

A divisão em etapas foi considerada com o início da operação do UASB em sistema contínuo. A princípio, foi adotado um tempo de detenção hidráulica de 42 horas e a DQO afluente foi aumentada, atingindo $700 \mathrm{mg} . \mathrm{L}^{-1}$ no final dessa etapa. No período de 25 dias, a eficiência do reator variou na faixa de $51 \%$ a $68 \%$, o pH efluente oscilou entre 7,3 e 7,8. A porcentagem de metano no biogás foi medida aos 22 dias de operação do reator, registrando um valor de $55 \%$.

Os valores médios obtidos na análise de DQO e a eficiência de remoção do reator UASB, bem como os valores obtidos na análise da composição do biogás e do pH afluente e efluente são apresentados nas Figuras 5.5, 5.6, 5.7 e 5.8, respectivamente (páginas 101 a 103). 


\subsubsection{Segunda etapa mesofilica}

O tempo de detenção hidráulica foi então reduzido para 30 horas, iniciando-se assim a segunda etapa, com duração de 41 dias.

A DQO continuou sendo alterada até atingir um valor em torno de $1100 \mathrm{mg} \cdot \mathrm{L}^{-1}$.

A alcalinidade parcial $^{37}$ no reator anaeróbio sofreu ligeira queda no início dessa etapa, de valores em torno de $254 \mathrm{mg} . \mathrm{L}^{-1}$, para $204 \mathrm{mg} . \mathrm{L}^{-1}$, voltando posteriormente a aumentar até valores em torno de $280 \mathrm{mg} . \mathrm{L}^{-1}$ ao final desta etapa. A alcalinidade total variou de 234 a $392 \mathrm{mg} . \mathrm{L}^{-1}$ (Figura 5.8), enquanto os AGV acumularam, passando de concentrações em torno de $30 \mathrm{mg} . \mathrm{L}^{-1}$ para cerca de $40 \mathrm{mg} . \mathrm{L}^{-1}$, mantendo-se estes valores até o final. Assim, o efluente do UASB apresentou média de AGV de (36 \pm 6$) \mathrm{mg} . \mathrm{L}^{-1}$ (Figura 5.8). Este acúmulo de ácidos ocorreu com o aumento do volume do licor no preparo da água residuária sintética, de $20 \mathrm{~mL}$ para $25 \mathrm{~mL}$ que visava o aumento da DQO, que foi em torno de $160 \mathrm{mg} \cdot \mathrm{L}^{-1}$.

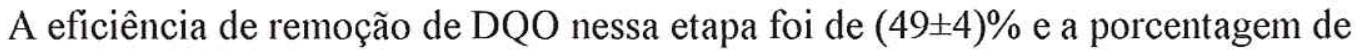
metano no biogás variou de 36\% a 77\% (Figuras 5.6 e 5.7, respectivamente, página 102 .

Comparando esses resultados com os de Buzzini (2000), operando um reator UASB com tempo de detenção de 32 horas e alimentado com um efluente similar, DQO de (1399 \pm 6$) \mathrm{mg} . \mathrm{L}^{-1}$, o desempenho do reator UASB no presente trabalho foi bastante inferior. Considerando os resultados obtidos por aquela autora com o reator 1 , a eficiência de remoção de DQO foi de $(77 \pm 1) \%$, a alcalinidade total oscilou de 720 a $675 \mathrm{mg} \cdot \mathrm{L}^{-1}$ e a concentração de ácidos foi de $(68 \pm 2) \mathrm{mg} \cdot \mathrm{L}^{-1}$.

Tais diferenças podem ser devidas ao lodo utilizado na inoculação e/ou pelo licor negro utilizado. Apesar de ter sido cedido pela mesma indústria (VCP), Buzzini (2000) utilizou em seu trabalho o licor intermediário, com teor de sólidos em torno de $20 \%$. Além disso, outras possíveis diferenças no licor negro podem ser devidas à madeira utilizada à época da coleta do licor e eventuais mudanças no processo de fabricação. Porém, o mais provável seja a diferença no tempo de adaptação do consórcio anaeróbio à água residuária sintética utilizada. No presente trabalho o tempo de adaptação foi relativamente curto (cerca de 63 dias), sendo que no trabalho de Buzzini (2000) foi utilizado um tempo de 126 dias.

\footnotetext{
${ }^{37} \mathrm{~A}$ alcalinidade foi medida como $\mathrm{mgCaCO}{ }^{3} \cdot \mathrm{L}^{-1}$. Para facilitar a apresentação dos resultados, será apresentada apenas como $m g \cdot \mathrm{L}^{-1}$ A alcalinidade parcial ou a bicarbonato é considerada por Ripley et al. (1986) como alcalinidade real de reatores anaeróbios. É obtida pela titulação da amostra com solução padronizada de ácido sulfúrico até obter-se pH igual a 5,75.
} 
No presente trabalho, utilizava-se, até esta etapa na simulação do efluente industrial, o licor negro concentrado, com $70 \%$ de sólidos. Houve grande dificuldade de caracterização deste licor, visto que foi coletado em alta temperatura na fábrica e quando foi resfriado se solidificou. A diluição só foi possível utilizando-se água. Além disso, deve-se considerar que o licor é complexo e a retirada de quantias para obter amostras similares foi muito dificultada.

Somando-se a estes fatores, em 63 dias de operação, houve grande perda de sólidos no reator. Optou-se então pela utilização do licor negro intermediário, sendo feita nova coleta na Indústria VCP - unidade de Luís Antônio.

Os dados monitorados nessa segunda etapa são apresentados na Tabela 5.3, página 90.

\subsubsection{Terceira etapa mesofílica}

A partir do $64^{\circ}$ dia de operação, passou a ser utilizado o licor negro intermediário, iniciando-se assim a terceira etapa.

A DQO foi ajustada para $1400 \mathrm{mg} \cdot \mathrm{L}^{-1}$ e o tempo de detenção hidráulica para 20 horas, valores desejados para esse trabalho.

O valor de DQO escolhido está na faixa da DQO efluente normalmente gerada pelas indústrias de celulose. O tempo de detenção de 20 horas foi escolhido com base nos resultados obtidos por Buzzini (2000). A autora, operando um reator UASB mesofílico alimentado com água residuária sintética com características similares a utilizada neste trabalho, obteve maior eficiência (90\%) com tempo de detenção de 48 horas. Quando o tempo foi diminuído para 24 horas, a eficiência caiu para $76 \%$.

Apesar da diferença de desempenho dos reatores nos dois estudos, como no presente trabalho seria utilizado um pós-tratamento, optou-se pelo menor tempo de detenção, reduzindo-se assim o tempo de tratamento.

A terceira etapa, com duração em torno de 34 dias, apresentou grande variação na DQO afluente, de $1608 \mathrm{mg} . \mathrm{L}^{-1}$ a $1281 \mathrm{mg} . \mathrm{L}^{-1}$ (Figura 5.5, página 101).

O reator UASB apresentou instabilidade e a efíciência de remoção de DQO foi reduzida de valores em torno de 50\%, para aproximadamente 40\%. Posteriormente, a eficiência começou a aumentar atingindo $47 \%$ cerca de uma semana após a queda, mantendo essa efíciência por aproximadamente dez dias. Entretanto, começou a decrescer novamente e, no fim da etapa, apresentou valor de 30\% (Figura 5.6, página 102). 
A porcentagem de metano no biogás variou de $43 \%$ a $91 \%$, entretanto, durante a maior parte desta etapa, manteve-se em torno de 69\% (Figura 5.7, página 102).

Deve-se considerar que nessa etapa, o volume do licor negro utilizado no preparo da água residuária sintética foi dobrado e pode ter inibido a atividade da microbiota por seus efeitos tóxicos. Além disso, o tempo de detenção hidráulica foi reduzido de 30 para 20 horas. Logo, houve a interação de fatores que desestabilizaram a atividade microbiológica no reator, revelada também pelas reduções na porcentagem de metano no biogás.

Apesar da variação na DQO afluente e conseqüente redução na eficiência de

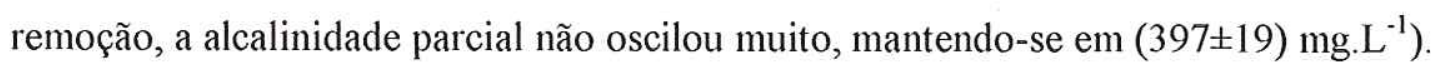

A concentração de AGV nessa etapa foi de (58 12$) \mathrm{mg} \cdot \mathrm{L}^{-1}$.

As concentrações médias de alcalinidade total e AGV desta etapa são apresentados na Figura 5.8, página 103.

Comparando os resultados aos dados de Buzzini (2000), novamente verifica-se a diferença de desempenho dos reatores UASB. Após alteração no tempo de detenção hidráulica de 32 horas para 24 horas, a autora verificou queda de $10 \%$ na eficiência média de remoção, porém o reator manteve-se estável. Deve ser considerado entretanto, que Buzzini (2000) não teve problemas com variação da DQO afluente.

Uma possível explicação para as oscilações na DQO afluente pode ser a presença de material particulado no licor. No experimento de Vogelaar et al. (2002) foi verificado que as altas concentrações de material particulado no afluente dos reatores dificultaram a obtenção de amostras representativas, resultando em grandes flutuações na DQO da água residuária sintética. Entretanto, os autores consideraram excelentes as propriedades de sedimentação dos reatores.

A ausência de avaliação de sólidos totais e suspensos nesta etapa dificultou a obtenção de respostas frente às dificuldades encontradas. Comparando as concentrações de DQO total e filtrada das amostras de água residuária sintética não foi verificada diferença considerável, como pode ser visto na Figura 5.5 (página 101).

Outra explicação seria erro manual na medição do licor, devido a sua viscosidade. Assim, visando evitar erro foram feitas soluções estoque do licor diluído que eram utilizadas no prazo de uma semana. Reservava-se um horário para o preparo destas amostras que eram mantidas em geladeira até o uso. Entretanto, nas análises posteriores as variações na DQO afluente continuaram a ocorrer. 
Os valores obtidos no monitoramento da segunda e da terceira etapa da faixa mesofilica são apresentados na Tabela 5.3.

TABELA 5.3 - Valores dos parâmetros monitorados na segunda $\left(26^{0}\right.$ ao $\left.63^{0} \mathrm{dia}\right)$ e terceira etapa $\left(64^{0}\right.$ ao $\left.104^{0} \mathrm{dia}\right)$.

\begin{tabular}{|c|c|c|c|c|}
\hline Parâmetro & & tapa 2 & & Etapa 3 \\
\hline DQO total ${ }_{\text {afluente }}\left(\mathrm{mg} \cdot \mathrm{L}^{-1}\right)$ & $\begin{array}{l}X \mathrm{Xm}=983 \\
\mathrm{n}=17 \\
\text { Máx }=1100\end{array}$ & $\begin{array}{l}\mathrm{DP}=101 \\
\text { Mín }=790\end{array}$ & $\begin{array}{l}\mathrm{Xm}=1480 \\
\mathrm{n}=11 \\
\text { Máx }=1608\end{array}$ & $\begin{array}{l}\mathrm{DP}=88 \\
\text { Mín = } 1281\end{array}$ \\
\hline DQO filtrada $a_{\text {afluente }}\left(\mathrm{mg} \cdot \mathrm{L}^{-1}\right)$ & $\begin{array}{l}X m=946 \\
n=13 \\
\text { Máx }=1131\end{array}$ & $\begin{array}{c}\mathrm{DP}=128 \\
\text { Mín }=713\end{array}$ & $\begin{array}{l}X m=1470 \\
n=11 \\
\text { Má } x=1700\end{array}$ & $\begin{array}{l}\mathrm{DP}=114 \\
\text { Mín }=1216\end{array}$ \\
\hline DQO total efluente $\left(\mathrm{mg} \cdot \mathrm{L}^{-1}\right)$ & $\begin{array}{l}X m=506 \\
n=18 \\
\text { Máx }=610\end{array}$ & $\begin{array}{c}\mathrm{DP}=66 \\
\mathrm{Min}=396\end{array}$ & $\begin{array}{l}\mathrm{Xm}=809 \\
\mathrm{n}=11 \\
\text { Máx }=908\end{array}$ & $\begin{array}{l}\mathrm{DP}=62 \\
\text { Mín }=688\end{array}$ \\
\hline DQO filtrada efluente $\left(\mathrm{mg} \cdot \mathrm{L}^{-1}\right)$ & $\begin{array}{l}\mathrm{Xm}=461 \\
\mathrm{n}=13 \\
\text { Máx }=546\end{array}$ & $\begin{array}{l}\mathrm{DP}=47 \\
\text { Mín }=384\end{array}$ & $\begin{array}{l}\mathrm{Xm}=781 \\
\mathrm{n}=11 \\
\text { Máx }=884\end{array}$ & $\begin{aligned} \mathrm{DP} & =60 \\
\operatorname{Min} & =638\end{aligned}$ \\
\hline $\begin{array}{l}\text { Eficiência de remoção de } \\
\text { DQO total (\%) }\end{array}$ & $\begin{array}{l}X m=49 \\
n=18 \\
\text { Máx }=54\end{array}$ & $\begin{array}{l}\mathrm{DP}=4 \\
\text { Mín }=40\end{array}$ & $\begin{array}{l}X m=45 \\
n=11 \\
\text { Máx }=52\end{array}$ & $\begin{array}{c}\mathrm{DP}=6 \\
\text { Mín }=30\end{array}$ \\
\hline $\begin{array}{l}\text { Eficiência de remoção de } \\
\text { DQO filtrada (\%) }\end{array}$ & $\begin{array}{l}X m=51 \\
n=18 \\
\text { Máx }=66\end{array}$ & $\begin{array}{l}\mathrm{DP}=8 \\
\text { Mín }=33\end{array}$ & $\begin{array}{l}X m=47 \\
n=11 \\
\text { Máx }=56\end{array}$ & $\begin{array}{c}\mathrm{DP}=6 \\
\text { Mín }=32\end{array}$ \\
\hline $\mathrm{pH}_{\text {afluente }}$ & $\begin{array}{l}\mathrm{n}=14 \\
\text { Máx }=7,6\end{array}$ & Min $=7,0$ & $\begin{array}{l}n=8 \\
\text { Máx }=8,3\end{array}$ & Mín $=6,6$ \\
\hline $\mathrm{pH}_{\text {efluente }}$ & $\begin{array}{l}\mathrm{n}=14 \\
\text { Máx }=7,9\end{array}$ & Mín $=7,2$ & $\begin{array}{l}\mathrm{n}=8 \\
\text { Máx }=8,0\end{array}$ & Mín $=7,8$ \\
\hline Alcalinidade $\left(\mathrm{mg} . \mathrm{L}^{-1}\right)$ & $\begin{array}{l}\mathrm{Xm}=270 \\
\mathrm{n}=11 \\
\text { Máx }=304\end{array}$ & $\begin{array}{c}\mathrm{DP}=36 \\
\text { Min }=204\end{array}$ & $\begin{array}{l}\mathrm{Xm}=397 \\
\mathrm{n}=12 \\
\text { Máx }=424\end{array}$ & $\begin{aligned} \mathrm{DP} & =19 \\
\operatorname{Min} & =365\end{aligned}$ \\
\hline AGV (mg. $\left.L^{-1}\right)$ & $\begin{array}{l}\mathrm{Xm}=36 \\
n=11 \\
\text { Máx }=48\end{array}$ & $\begin{array}{l}\mathrm{DP}=6 \\
\text { Mín }=28\end{array}$ & $\begin{array}{l}X m=59 \\
n=12 \\
\text { Máx }=83\end{array}$ & $\begin{array}{l}\mathrm{DP}=11 \\
\text { Mín }=47\end{array}$ \\
\hline Metano (\%) & $\begin{array}{l}\mathrm{Xm}=63 \\
\text { Máx }=77 \\
\mathrm{n}=12\end{array}$ & $\begin{array}{l}\mathrm{DP}=14 \\
\text { Mín }=36\end{array}$ & $\begin{array}{l}\mathrm{Xm}=69 \\
\text { Máx }=91 \\
\mathrm{n}=13\end{array}$ & $\begin{array}{r}\mathrm{DP}=13 \\
\text { Mín }=43\end{array}$ \\
\hline
\end{tabular}

Xm: média; DP: desvio padrão; Máx e Mín: valores máximo e mínimo no período; n: número de observaçốes.

O reator aeróbio de lodos ativados foi inoculado no final desta terceira etapa, com 2,0 L de lodo da estação de tratamento de lodos ativados da indústria de papel e celulose VCP (Unidade de Luís Antônio), permaneceu em batelada por quinze dias. 
Posteriormente, o sistema de reatores anaeróbio e aeróbio começou a ser operado de forma contínua, com tempo de detenção hidráulica de 20 horas, para o reator UASB, e de 11 horas para o reator de lodos ativados. A alimentação do reator aeróbio pelo efluente do UASB foi feita por gravidade. O efluente do reator aeróbio por sua vez, foi direcionado para decantação. No decantador era feito o retorno ao tanque de aeração de uma parte do lodo sedimentado, correspondendo a vazão de $0,2 \mathrm{~L} \cdot \mathrm{h}^{-1}$.

\subsubsection{Quarta etapa mesofilica}

A quarta etapa marca o início da operação do sistema combinado operando continuamente e durou 28 dias.

A eficiência de remoção do reator UASB permaneceu baixa, $(39 \pm 5) \%$, assim como a do reator de lodos ativados, oscilando entre 15 e $22 \%$, com valores mínimos de $9 \%$ e $11 \%$, com 9 e 19 dias, respectivamente, do início dessa etapa (Figura 5.6, página 102).

Foi verificada baixa concentração de biomassa no reator aeróbio, com valores de SSV de $150 \mathrm{mg} \cdot \mathrm{L}^{-1}$ a $350 \mathrm{mg} \cdot \mathrm{L}^{-1}$. No reator aeróbio, as concentrações efluentes de ST foram de $554 \mathrm{mg} . \mathrm{L}^{-1}$ e de SSV de $62 \mathrm{mg} . \mathrm{L}^{-1}$. Nessa etapa também foi verificada perda de SSV no reator UASB, um valor médio de $885 \mathrm{mg} . \mathrm{d}^{-1}$. Os dados observados de sólidos suspensos totais e voláteis nos reatores são apresentados na Figura 5.9, página 103.

As concentrações de AGV no efluente do reator UASB oscilaram em torno de $60 \mathrm{mg} . \mathrm{L}^{-1}$ no início da quarta etapa, reduzindo-se para cerca de $40 \mathrm{mg} . \mathrm{L}^{-1}$ até o final da mesma. A análise de ácidos no reator de lodos ativados só foi iniciada após treze dias do início da quarta etapa, registrando-se pequena queda de $50 \mathrm{mg} . \mathrm{L}^{-1}$ para aproximadamente $40 \mathrm{mg} . \mathrm{L}^{-1}$. A alcalinidade parcial oscilou entre $298 \mathrm{mg} . \mathrm{L}^{-1} \mathrm{e}$ $448 \mathrm{mg} . \mathrm{L}^{-1}$ no reator UASB. No reator aeróbio entretanto, a alcalinidade foi crescente, $150 \mathrm{mg} . \mathrm{L}^{-1}$ a $400 \mathrm{mg} . \mathrm{L}^{-1}$ no final dessa etapa (Figura 5.8, página 103).

A porcentagem de metano no biogás não foi reduzida, sendo registrados valores de $71 \%$ a $79 \%$ (Figura 5.7, página 102).

No final desta etapa, após dezenove dias de operação do reator de lodos ativados, a vazão de recirculação foi aumentada para dois terços da vazão afluente, cerca de $0,4 \mathrm{~L} \cdot \mathrm{h}^{-1}$. Essa alteração visou aumentar a concentração da biomassa no reator e melhorar sua eficiência. $O$ aumento da recirculação foi feito após análise 
microbiológica, com a finalidade de avaliar-se a qualidade do lodo aeróbio, já que a eficiência era baixa e seu volume, aparentemente, estava decrescendo.

Entretanto, a eficiência de remoção não foi alterada. Uma determinação da Demanda Bioquímica de Oxigênio (DBO) revelou relação DBO/DQO afluente ao reator UASB igual a 0,5 e afluente ao reator de lodos ativados igual a 0,6 .

As concentrações de nitrogênio total na água residuária sintética, efluente do reator UASB e efluente do reator de lodos ativados foram $24,4 \mathrm{mg} . \mathrm{L}^{-1}, 21,5 \mathrm{mg} . \mathrm{L}^{-1} \mathrm{e}$ $3,0 \mathrm{mg} \cdot \mathrm{L}^{-1}$, respectivamente. As concentrações de fósforo apresentaram-se aproximadamente iguais na água residuária sintética e nos efluentes dos reatores anaeróbio e aeróbio, em torno de 10,4 mg. $\mathrm{L}^{-1}$, respectivamente.

Os parâmetros monitorados nessa quarta etapa são apresentados na Tabela 5.4.

TABELA 5.4 - Faixa de variação dos parâmetros monitorados na quarta etapa $\left(105^{\circ}\right.$ ao $146^{\circ}$ dia) na água residuária sintética e nos efluentes dos reatores anaeróbio e aeróbio respectivamente.

\begin{tabular}{|c|c|c|c|c|c|c|}
\hline \multirow[b]{2}{*}{ Parâmetros } & \multicolumn{2}{|c|}{ ARS } & \multicolumn{2}{|c|}{ Efluente UASB } & \multicolumn{2}{|c|}{$\begin{array}{c}\text { Efluente Lodos } \\
\text { ativados }\end{array}$} \\
\hline & $\begin{array}{l}\text { Faixa de } \\
\text { variação } \\
\text { (n) }\end{array}$ & Média $\pm \mathrm{DP}$ & $\begin{array}{l}\text { Faixa de } \\
\text { variação } \\
\text { (n) }\end{array}$ & Média $\pm D P$ & $\begin{array}{l}\text { Faixa de } \\
\text { variação } \\
\text { (n) }\end{array}$ & Média $\pm D P$ \\
\hline $\begin{array}{l}\mathrm{DQO} \\
\left(\mathrm{mg} \cdot \mathrm{L}^{-1}\right)\end{array}$ & $\begin{array}{c}1260-1608 \\
(13)\end{array}$ & $1449 \pm 119$ & $\begin{array}{c}682-1084 \\
(13)\end{array}$ & $884 \pm 101$ & $\begin{array}{c}534-916 \\
(13)\end{array}$ & $733 \pm 88$ \\
\hline $\begin{array}{l}\text { Eficiência de } \\
\text { remoção total } \\
(\%)\end{array}$ & 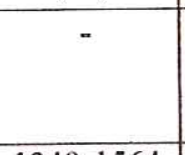 & 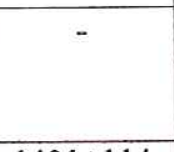 & $\begin{array}{c}32-46 \\
(12)\end{array}$ & $39 \pm 5$ & $\begin{array}{l}9-22 \\
(12)\end{array}$ & $18 \pm 4$ \\
\hline $\begin{array}{l}\mathrm{DQO}_{\text {filtrada }} \\
\left(\mathrm{mg} \cdot \mathrm{L}^{-1}\right)\end{array}$ & $\begin{array}{c}1240-1564 \\
(11)\end{array}$ & $1431 \pm 114$ & $\begin{array}{c}580-988 \\
\text { (11) }\end{array}$ & $788 \pm 102$ & $\begin{array}{c}502-958 \\
(11)\end{array}$ & $720 \pm 112$ \\
\hline $\begin{array}{l}\text { Eficiência de } \\
\text { remoção } \\
\text { filtrada (\%) }\end{array}$ & - & - & $\begin{array}{l}37-54 \\
(11)\end{array}$ & $45 \pm 6$ & $2-15(11)$ & $9 \pm 4$ \\
\hline $\mathrm{pH}$ & $\begin{array}{c}7,1-7,9 \\
(10)\end{array}$ & - & $\begin{array}{c}7,4-7,9 \\
(10)\end{array}$ & - & $\begin{array}{c}7,6-8,5 \\
(8)\end{array}$ & - \\
\hline $\begin{array}{l}\text { Alcalinidade } \\
\left(\mathrm{mg} . \mathrm{L}^{-1}\right)\end{array}$ & $\begin{array}{c}258-457 \\
(11)\end{array}$ & $319 \pm 33$ & $\begin{array}{c}441-569 \\
(11)\end{array}$ & $508 \pm 20$ & $\begin{array}{c}188-543 \\
(6)\end{array}$ & $205 \pm 23$ \\
\hline Ácidos (mg. $\left.\mathrm{L}^{-1}\right)$ & $\begin{array}{c}235-305 \\
(11)\end{array}$ & $270 \pm 19$ & $\begin{array}{c}35-66 \\
(11)\end{array}$ & $53 \pm 10$ & $\begin{array}{c}41-53 \\
(6)\end{array}$ & $46 \pm 5$ \\
\hline ST $\left(\mathrm{mg} \cdot \mathrm{L}^{-1}\right)$ & $1044-1831$ & $1556 \pm 371$ & $786-1425$ & $1204 \pm 289$ & $1144-1459$ & $1306 \pm 132$ \\
\hline STV (mg.L $\left.{ }^{-1}\right)$ & $409-1248$ & $968 \pm 388$ & $401-859$ & $656 \pm 191$ & $700-816$ & $742 \pm 53$ \\
\hline STF (mg.L $\left.L^{-1}\right)$ & $518-635$ & $589 \pm 52$ & $385-649$ & $548 \pm 114$ & $444-643$ & $563 \pm 95$ \\
\hline SST (mg. $\left.L^{-1}\right)$ & $49-129(4)$ & $89 \pm 39$ & $73-97(4)$ & $83 \pm 11$ & $33-109(4)$ & $79 \pm 35$ \\
\hline SSV (mg. $\left.\mathrm{L}^{-1}\right)$ & $40-110(4)$ & $67 \pm 32$ & $55-93(4)$ & $71 \pm 16$ & $26-95(4)$ & $67 \pm 31$ \\
\hline $\mathrm{CH}_{4}(\%)$ & - & - & $71-79(4)$ & $76 \pm 2$ & - & - \\
\hline
\end{tabular}

Obs.: (n): número de observações feitas; DP: desvio padrão. 
No final desta etapa, foi adicionado $1,0 \mathrm{~L}$ de lodo obtido de estação de tratamento por lodos ativados da indústria Faber Castell (item 4.4.1 do capítulo de Material e Métodos) visando o aumento da biomassa no reator, mas não houve aumento na eficiência de remoção.

Para melhorar o desempenho dos reatores foram feitas alterações na água residuária sintética, marcando o início da quinta etapa.

\subsubsection{Quinta etapa mesofílica}

Nessa etapa foram feitas duas alterações importantes: na água residuária sintética e na temperatura.

Na água residuária sintética, introduziu-se o etanol, de acordo com o protocolo de Buzzini (2000), para simular, em parte, o efluente oriundo da fabricação de papel e também melhorar sua qualidade. Uma simulação mais próxima do real exigiria que também fossem adicionadas fibras e amido hidrolisado. Comparando-se os valores do início dessa etapa com os do final da etapa anterior, nota-se que a efíciência de remoção de DQO, como era esperado, aumentou de valores em torno de $34 \%$ para $50 \%$ no reator anaeróbio. Apesar de ter sido registrado aumento na biomassa do reator de lodos ativados, embora insuficiente, de $325 \mathrm{mg} . \mathrm{L}^{-1}$ para $800 \mathrm{mg} . \mathrm{L}^{-1}$, houve queda na eficiência desse reator, de $15 \%$ para $2 \%$.

Entretanto, deve ser considerado que após 37 dias de operação do sistema combinado, a temperatura de trabalho ambiente $\left(\cong 25^{\circ} \mathrm{C}\right)$ foi aumentada para $30^{\circ} \mathrm{C}$, controlada por meio de termostato.

No reator anaeróbio, a porcentagem de metano no biogás permaneceu em torno de $78 \%$ (Figura 5.7 , página 102).

Apesar da concentração de ácidos graxos voláteis na água residuária sintética ter aumentado de $138 \mathrm{mg} . \mathrm{L}^{-1}$ para $188 \mathrm{mg} . \mathrm{L}^{-1}$, no efluente do reator UASB não houve alteração significativa, variando de $40 \mathrm{mg} . \mathrm{L}^{-1}$ a $47 \mathrm{mg} . \mathrm{L}^{-1}$. Deve-se considerar entretanto, que houve consumo da alcalinidade parcial, após a adição do etanol, reduzida de concentrações em torno de $360 \mathrm{mg} . \mathrm{L}^{-1}$ para $205 \mathrm{mg} \cdot \mathrm{L}^{-1}$. Contudo, o $\mathrm{pH}$ foi mantido em torno de 7,5. A concentração média da alcalinidade e AGV nos reatores, bem como a variação do $\mathrm{pH}$ são apresentados na Figura 5.8 (página 103).

A efíciência de remoção de DQO do sistema combinado nessa etapa foi em torno de 55\%, sendo a maior parte devida ao reator UASB. Deve-se ressaltar, 
entretanto, que foi um período curto, devido às mudanças na temperatura e na água residuária sintética, sendo feitas apenas duas amostragens.

Na Tabela 5.5 estão apresentados os resultados obtidos nessa etapa.

TABELA 5.5 - Faixa de variação dos parâmetros monitorados na quinta etapa $\left(147^{\circ}\right.$ ao $\left.158^{0} \mathrm{dia}\right)$.

\begin{tabular}{|c|c|c|c|}
\hline Parâmetros & ARS & Efluente UASB & Efluente LA \\
\hline $\mathrm{DQO}_{\text {total }}\left(\mathrm{mg} \cdot \mathrm{L}^{-1}\right)$ & $1030-1270(2)$ & $515-620(2)$ & $485-605(2)$ \\
\hline Eficiência de remoção (\%) & - & $50-51(2)$ & $2-6(2)$ \\
\hline $\mathrm{DQO}_{\text {filtrada }}\left(\mathrm{mg} \cdot \mathrm{L}^{-1}\right)$ & $1020-1290(2)$ & $460-565(2)$ & $440-545(2)$ \\
\hline Eficiência de remoção (\%) & - & $55-56(2)$ & $3-4(2)$ \\
\hline $\mathrm{pH}$ & $7,2-7,4$ & $7,4-7,6$ & $7,6-7,8$ \\
\hline Alcalinidade (mg. $\left.\mathrm{L}^{-1}\right)$ & $56-77(2)$ & $206-225(2)$ & $112-244(2)$ \\
\hline Ácidos (mg. $\left.\mathrm{L}^{-1}\right)$ & $166-188(2)$ & $45-47(2)$ & $35-50(2)$ \\
\hline ST (mg. $\left.L^{-1}\right)$ & $929-993(2)$ & $767-928(2)$ & $771-1208(2)$ \\
\hline STV (mg. $\left.L^{-1}\right)$ & $575-598$ & $378-560$ & $360-837$ \\
\hline $\operatorname{STF}\left(\mathrm{mg} \cdot \mathrm{L}^{-1}\right)$ & $354-395$ & 368-389 & $371-411$ \\
\hline SST $\left(\mathrm{mg} \cdot \mathrm{L}^{-1}\right)$ & $52(1)$ & $70(1)$ & $80(1)$ \\
\hline SSV $\left(\mathrm{mg} \cdot \mathrm{L}^{-1}\right)$ & 14 & 65 & 30 \\
\hline $\mathrm{CH}_{4}(\%)$ & - & $78-79(2)$ & - \\
\hline
\end{tabular}

Obs.: Os valores entre parênteses (n) se referem ao número de observações.

\subsubsection{Sexta etapa mesofílica}

A temperatura foi ajustada para $32,5^{\circ} \mathrm{C}$ e os reatores permaneceram nessa condição por cerca de dez dias, quando ainda estavam sendo feitas pequenas alterações na água residuária sintética.

A DQO afluente oscilou de $1135 \mathrm{mg} \cdot \mathrm{L}^{-1}$ a $1420 \mathrm{mg} . \mathrm{L}^{-1}$, tendo sua eficiência de remoção no reator anaeróbio variado levemente em torno de $51 \%$, entretanto, no reator aeróbio a eficiência aumentou de $19 \%$ para $33 \%$, apesar de ter sido registrada queda nos SSV do licor misto de $800 \mathrm{mg} . \mathrm{L}^{-1}$ para $430 \mathrm{mg} . \mathrm{L}^{-1}$ (Figuras 5.5 e 5.6, páginas 101 e 102 e Figura 5.9 e 5.10, páginas 103 e 104).

Com o aumento da concentração em $244 \mathrm{mg} . \mathrm{L}^{-1}$ considerando a DQO inicial e final da etapa, acúmulo de AGV em ambos os reatores, de $45 \mathrm{mg} \cdot \mathrm{L}^{-1}$ para $110 \mathrm{mg} . \mathrm{L}^{-1}$ no reator UASB e de $40 \mathrm{mg} . \mathrm{L}^{-1}$ para $90 \mathrm{mg} . \mathrm{L}^{-1}$ no reator aeróbio. A alcalinidade parcial, entretanto, não sofreu alteração significativa, permanecendo com valores em torno de $200 \mathrm{mg} . \mathrm{L}^{-1}$ no reator UASB, sofrendo maior variação no reator de lodos ativados, oscilando de $110 \mathrm{mg} . \mathrm{L}^{-1}$ para $130 \mathrm{mg} . \mathrm{L}^{-1}$ até o final da etapa. $\mathrm{O} \mathrm{pH}$ se manteve em 7,3 no reator anaeróbio e em aproximadamente 7,8 no reator aeróbio (Figura 5.8, pg. 103).

Apesar de não ter havido nenhuma alteração na água residuária sintética no final dessa etapa, em dois dias os sólidos totais da água residuária sintética aumentaram de $1405 \mathrm{mg} . \mathrm{L}^{-1}$ para $1640 \mathrm{mg} . \mathrm{L}^{-1}$, mas sem perda de sólidos nos reatores. No final desse 
período, as concentrações de sólidos voláteis na água residuária sintética e efluente do reator anaeróbio foram quase o dobro dos sólidos fixos, indicativo claro de perda de biomassa. Entretanto, no reator aeróbio as concentrações de sólidos voláteis e fixos foram mais próximas.

A concentração de oxigênio dissolvido no reator aeróbio estava alta, cerca de $5 \mathrm{mg} \cdot \mathrm{L}^{-1}$

A efíciência do sistema combinado nessa etapa aumentou de $61 \%$ para $67 \%$, mantida até o final da etapa.

Os resultados dessa etapa encontram-se resumidos na Tabela 5.6.

TABELA 5.6 - Faixa de variação dos parâmetros monitorados na sexta etapa $\left(159^{\circ}\right.$ ao $\left.168^{0} \mathrm{dia}\right)$.

\begin{tabular}{|c|c|c|c|}
\hline Parâmetros & ARS & Efluente UASB & Efluente LA \\
\hline $\mathrm{DQO}_{\text {total }}\left(\mathrm{mg} \cdot \mathrm{L}^{-1}\right)$ & $1155-1422(3)$ & $563-694(3)$ & $414-464(3)$ \\
\hline $\begin{array}{l}\text { Eficiência de remoção total } \\
\text { (\%) }\end{array}$ & - & $50-52(3)$ & $19-33(3)$ \\
\hline $\mathrm{DQO}_{\text {filltrada }}\left(\mathrm{mg} \cdot \mathrm{L}^{-1}\right)$ & $1414-1134(3)$ & $524-594(3)$ & $405-447(3)$ \\
\hline Eficiência de remoção (\%) & - & $53-58(3)$ & $21-25(2)$ \\
\hline $\mathrm{pH}$ & $7,0-7,4$ & $7,3-7,4$ & $7,8-8,0$ \\
\hline Alcalinidade (mg. $\left.\mathrm{L}^{-1}\right)$ & $65-66(3)$ & $202-206(3)$ & $122-133(3)$ \\
\hline Ácidos $\left(\mathrm{mg} \cdot \mathrm{L}^{-1}\right)$ & $175-215(3)$ & $47-110(3)$ & $34-91(3)$ \\
\hline ST $\left(\mathrm{mg} \cdot \mathrm{L}^{-1}\right)$ & $1405-1637(2)$ & $530-1237(2)$ & $1276-728(2)$ \\
\hline STV (mg. $\left.L^{-1}\right)$ & 851-1096 & $317-1067$ & $607-746$ \\
\hline STF (mg. $\left.L^{-1}\right)$ & $541-554$ & $213-509$ & $460-530$ \\
\hline SST (mg. $\left.L^{-1}\right)$ & $12-51(2)$ & $83-106(2)$ & $22-71(2)$ \\
\hline SSV (mg. $\left.\mathrm{L}^{-1}\right)$ & $10-39$ & $79-88$ & $16-21$ \\
\hline
\end{tabular}

Obs.: Os valores entre parênteses (n) se referem ao número de observaçôes.

\subsubsection{Sétima etapa mesofilica}

Nessa etapa foram feitas várias alterações. A temperatura foi ajustada para $35^{\circ} \mathrm{C}$ e o monitoramento dos dados foi feito após 4 dias.

Houve queda na eficiência de remoção de DQO do reator UASB, justificada pelo estresse sofrido com novo aumento da temperatura, que sofreu aumento gradativo desde a $5^{\mathrm{a}}$ etapa $\left(25\right.$ para $30^{\circ} \mathrm{C}$ na $5^{\mathrm{a}}$ etapa; $32,5^{\circ} \mathrm{C}$ na $6^{\mathrm{a}}$ etapa) e com choque orgânico causado por variação na DQO da água residuária sintética. Não foi possível identificar a alteração no licor negro que permitiu o aumento da concentração orgânica, de valores em torno de $1400 \mathrm{mg} . \mathrm{L}^{-1}$ para $1780 \mathrm{mg} . \mathrm{L}^{-1}$.

Também foi verificada perda de SSV no efluente do reator anaeróbio nesse período inicial, a maior registrada na fase mesofilica (1139 $\left.296 \mathrm{mg} \cdot \mathrm{d}^{-1}\right)$ e leve queda na porcentagem de metano no biogás (79\% para 74\%). No trabalho de Grover et al. (1999) ocorreram baixa concentração de metano no biogás e grande lavagem da 
biomassa (SSV em cerca de 1,7 g.L $\mathrm{L}^{-1}$ ) quando as taxas de carregamento orgânico foram aumentadas. Segundo os autores, o aumento na DQO afluente resultou em um aumento na concentração de lignina e, conseqüentemente, inibição do consórcio microbiano anaeróbio pelo efeito tóxico do licor negro na metanogênese.

Foi feita alteração na água residuária sintética, diminuindo-se a concentração de licor, para reduzir-se a concentração orgânica e permitir a recuperação do reator, evitando perda de sólidos. Entretanto, com a concentração da DQO na água residuária sintética reduzida para $903 \mathrm{mg} . \mathrm{L}^{-1}$ foi verificado aumento em sua concentração de sólidos totais, de $1645 \mathrm{mg} . \mathrm{L}^{-1}$ para $2985 \mathrm{mg} . \mathrm{L}^{-1}$, sendo a maior parte, sólidos voláteis.

Não houve melhora imediata na efíciência de remoção do reator anaeróbio. A eficiência de remoção que havia caído de valores em torno de $50 \%$ para $33 \%$ e mesmo com a diminuição da DQO, continuou caindo até $13 \%$. O reator de lodos ativados, apresentou o maior pico de remoção (73\%). Posteriormente a este resultado, eficiência de remoção caiu para $27 \%$, sendo sucedida por uma eficiência de $69 \%$. Foi verificado que com o choque orgânico, houve aumento de sólidos voláteis no efluente do reator aeróbio, atingindo perda de sólidos suspensos de $3360 \mathrm{mg} \cdot \mathrm{d}^{-1}$. Essa alta quantidade de SS no efluente do reator de lodos ativados provavelmente contribuiu para o aumento da DQO no efluente, reduzindo a qualidade. Isto justificaria também o valor imediatamente posterior de $69 \%$.

A concentração de ácidos foi instável no início dessa etapa, oscilando entre $128 \mathrm{mg} . \mathrm{L}^{-1}$ e $406 \mathrm{mg} . \mathrm{L}^{-1}$, havendo consumo da alcalinidade parcial, ocasionando, redução do $\mathrm{pH}$ efluente para 5,23 no início desse período.

$\mathrm{O}$ controle do $\mathrm{pH}$ foi feito pelo aumento do $\mathrm{pH}$ afluente para valores em torno de 8 e adição de bicarbonato de sódio dentro do reator por meio de seringa $(0,6$ gramas de bicarbonato de sódio por litro do reator UASB), no início desta etapa.

Após aproximadamente uma semana, a temperatura foi aumentada para $37,5^{\circ} \mathrm{C}$. $\mathrm{O}$ pH sofreu ligeira alteração e novamente foi adicionado bicarbonato de sódio pontualmente. Somando-se a esse problema de acidificação, a bomba de alimentação também teve problemas e foi necessário manter os reatores em batelada por um dia.

Como a recuperação do reator anaeróbio estava lenta, houve preocupação com a alimentação do reator aeróbio com o efluente ácido do reator anaeróbio e optou-se pela separação dos reatores. A alimentação do reator de lodos ativados passou a ser feita como a do reator anaeróbio, diretamente do tanque da água residuária sintética. 
Entretanto, por não ser considerado que o reator aeróbio, recebia um afluente já modificado. Assim, houve queda na eficiência do reator aeróbio, de 69\% para 36\%. Também foi verificada uma visível variação no licor misto e grande perda de sólidos.

As concentrações dos ácidos graxos voláteis no efluente do reator anaeróbio foram consumidas (337 mg. $\mathrm{L}^{-1}$ para $180 \mathrm{mg} . \mathrm{L}^{-1}$ ) enquanto no efluente do reator aeróbio houve acúmulo de $\mathrm{AGV}$, de $33 \mathrm{mg} \cdot \mathrm{L}^{-1}$ para $102 \mathrm{mg} \cdot \mathrm{L}^{-1}$. A alcalinidade parcial por sua vez, aumentou de $9 \mathrm{mg} . \mathrm{L}^{-1}$ para $87 \mathrm{mg} . \mathrm{L}^{-1}$ no reator anaeróbio e foi consumida no reator aeróbio, de $232 \mathrm{mg} . \mathrm{L}^{-1}$ para $96 \mathrm{mg} . \mathrm{L}^{-1}$.

Por microscopia óptica dos reatores, nesse período de oscilações, foram observadas a má formação e dispersão do floco aeróbio, entretanto o lodo mostrava-se estabilizado, com presença de aspidiscas e rotíferos. O reator UASB apresentou a presença de muitos bacilos e sarcinas com boa fluorescência. De posse de todos os resultados do monitoramento dos reatores foi concluído que a separação dos reatores foi uma atitude precipitada e ainda agravada pela diminuição do tempo de detenção do reator aeróbio para 7 horas. Assim, imediatamente após a análise microscópica, a alimentação dos reatores voltou a ser contínua e o tempo de detenção do reator de lodos ativados passou a ser de 12 horas.

No final desse período de operação, na faixa de temperatura de $35^{\circ} \mathrm{C}$ a $37,5^{\circ} \mathrm{C}$, as eficiências de remoção de DQO do reator anaeróbio e as do reator aeróbio variaram de $42 \%$ a $61 \%$ e de $22 \%$ a $44 \%$, respectivamente. A eficiência global do sistema foi de $(68 \pm 3) \%$. As concentrações de AGV nos efluentes de ambos os reatores foram reduzidas, apresentando no final desta etapa valores de $69 \mathrm{mg} . \mathrm{L}^{-1}$ para o reator anaeróbio e de $37 \mathrm{mg} . \mathrm{L}^{-1}$ para o aeróbio. A alcalinidade parcial gerada pelo reator UASB apresentou um aumento gradual, atingindo $217 \mathrm{mg} . \mathrm{L}^{-1}$ no final dessa etapa. A porcentagem de metano no biogás variou de $64 \%$ a $78 \%$.

Deve-se considerar que a DQO removida pelo reator aeróbio está abaixo dos valores encontrados no trabalho de Tripathi \& Allen (1999). Os autores, operando um reator SBR alimentado com efluente de indústria de polpa Kraft branqueada, no período de aclimatação, a $35^{\circ} \mathrm{C}$, obtiveram eficiência de remoção de DQO variando de $42 \%$ a $72 \%$, com média de $60 \%$. Esses autores consideraram a eficiência baixa e justificaramna pelas baixas características de sedimentação do lodo durante o período de aclimatação. No presente trabalho, a maior perda de sólidos voláteis no reator aeróbio registrada foi nesta etapa, além das várias mudanças a que os reatores foram submetidos. 
Nolasco (1998) também obteve eficiência de remoção de DQO superior à do presente trabalho. O autor, operando reator de lodos ativados de 6,5 L com tempo de detenção de 8,7 horas, alimentado com água residuária sintética simulando o efluente da indústria de papel, tendo como base o licor negro $\left(\mathrm{DQO}=370 \mathrm{mg} \cdot \mathrm{L}^{-1}\right)$ em temperatura similar, obteve eficiência de remoção de DQO de 65\%, bem como maiores concentrações de SST e de SSV no licor misto $\left(1424 \mathrm{mg} . \mathrm{L}^{-1}\right.$ e $1217 \mathrm{mg} . \mathrm{L}^{-1}$, respectivamente). Além disso, de acordo com Nolasco (1998) as variações nos valores de DQO efluentes foram pequenas mesmo em períodos onde houve aumento da DQO afluente.

Na Tabela 5.7 e Figuras 5.5 a 5.9 (páginas 101 a 104) são apresentadas as faixas de variação dos valores obtidos no monitoramento dos reatores.

TABELA 5.7- Faixa de variação dos parâmetros monitorados na sétima etapa $\left(169^{0}\right.$ ao $210^{\circ}$ dia) nos reatores anaeróbio e aeróbio.

\begin{tabular}{|c|c|c|c|}
\hline Parâmetros & ARS & UASB & Lodos ativados \\
\hline $\mathrm{DQO}_{\text {total }}\left(\mathrm{mg} \cdot \mathrm{L}^{-1}\right)$ & $903-1780(7)$ & $636-1406(7)$ & $326-894(7)$ \\
\hline Eficiência de remoção (\%) & - & $13-61(7)$ & $22-73(7)$ \\
\hline $\mathrm{DQO}_{\text {filltrada }}\left(\mathrm{mg} \cdot \mathrm{L}^{-1}\right)$ & $722-1725(6)$ & $508-1128(6)$ & $262-818(6)$ \\
\hline Eficiência de remoção (\%) & - & $11-62(6)$ & $6-77(6)$ \\
\hline $\mathrm{pH}$ & $7,2-8,7(14)$ & $5,2-7,6(14)$ & $7,1-7,9(10)$ \\
\hline Alcalinidade (mg. $\left.\mathrm{L}^{-1}\right)$ & $154-215(7)$ & $192-290(7)$ & $105-314(7)$ \\
\hline Ácidos $\left(\mathrm{mg} \cdot \mathrm{L}^{-1}\right)$ & $89-214(7)$ & $65-406(7)$ & $33-102(7)$ \\
\hline ST $\left(m g . L^{-1}\right)$ & $512-2985(6)$ & $99-2363(6)$ & $417-1241(6)$ \\
\hline $\operatorname{STV}\left(\mathrm{mg} . \mathrm{L}^{-1}\right)$ & $353-2596(6)$ & $49-1988(6)$ & $221-829$ \\
\hline STF (mg. $\left.\mathrm{L}^{-1}\right)$ & $159-579(6)$ & $51-417(6)$ & $154-571(6)$ \\
\hline SST (mg. $\left.\mathrm{L}^{-1}\right)$ & $41-388(7)$ & $61-162(7)$ & $79-490$ \\
\hline SSV (mg. $\left.\mathrm{L}^{-1}\right)$ & $13-374(7)$ & $28-108(7)$ & $48-452(7)$ \\
\hline $\mathrm{CH}_{4}(\%)$ & - & $64-78(9)$ & - \\
\hline
\end{tabular}

Obs.: Os valores entre parênteses (n) se referem ao número de observações.

\subsubsection{Oitava etapa mesofilica}

A temperatura foi aumentada para $42,5^{\circ} \mathrm{C}$ e o sistema foi operado sob essas condições por 35 dias.

Os reatores que apresentaram resultados de visível recuperação no final da etapa anterior, continuaram apresentando bom desempenho. A eficiência de remoção registrada no UASB foi de $(57 \pm 6) \%$, a alcalinidade parcial de $(239 \pm 34) \mathrm{mg} . \mathrm{L}^{-1}$, porcentagem de metano no biogás de variou de $61 \%$ a $77 \%$, sendo que a concentração de ácidos oscilou de $37 \mathrm{mg} . \mathrm{L}^{-1}$ a $140 \mathrm{mg} . \mathrm{L}^{-1}$.

Entretanto, no reator aeróbio, a eficiência de remoção em torno de $33 \%$, sofreu uma queda para $4 \%$ com 17 dias de operação, na temperatura de $42,5^{\circ} \mathrm{C}$, voltando a 
aumentar posteriormente atingindo valores em torno de $30 \%$ no final dessa etapa.

Nesse período de baixa efíciência de remoção de DQO, as concentrações de SSV no licor misto e no lodo de retorno, diminuíram de $303 \mathrm{mg} . \mathrm{L}^{-1}$ para $47 \mathrm{mg} . \mathrm{L}^{-1}$ e de $268 \mathrm{mg} . \mathrm{L}^{-1}$ para $69 \mathrm{mg} . \mathrm{L}^{-1}$, respectivamente. As concentrações de AGV no efluente

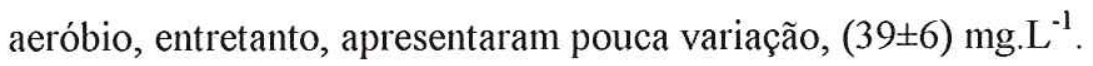

A eficiência global do sistema nessa fase final mesofilica ficou em $(70 \pm 3) \%$. Os resultados da oitava etapa estão apresentados na Tabela 5.8 e Figuras 5.5 a 5.10 (páginas 101 a 104).

TABELA 5.8- Parâmetros monitorados na oitava etapa $\left(211^{0}\right.$ ao $245^{\circ}$ dia) nos reatores anaeróbio e aeróbio respectivamente.

\begin{tabular}{|c|c|c|c|c|c|c|}
\hline \multirow[b]{2}{*}{ Parâmetros } & \multicolumn{2}{|c|}{ ARS } & \multicolumn{2}{|c|}{ UASB } & \multicolumn{2}{|c|}{ Lodos ativados } \\
\hline & $\begin{array}{l}\text { Faixa de } \\
\text { variação } \\
\text { (n) }\end{array}$ & Média $\pm D P$ & $\begin{array}{l}\text { Faixa de } \\
\text { variação } \\
\text { (n) }\end{array}$ & Média $\pm \mathrm{DP}$ & $\begin{array}{l}\text { Faixa de } \\
\text { variação } \\
\text { (n) }\end{array}$ & Média \pm DP \\
\hline $\begin{array}{l}\mathrm{DQO}_{\text {total }} \\
\left(\mathrm{mg} \cdot \mathrm{L}^{-1}\right)\end{array}$ & $\begin{array}{c}1130- \\
1478(9)\end{array}$ & $1360 \pm 130$ & $\begin{array}{l}485-680 \\
\text { (9) }\end{array}$ & $575 \pm 65$ & $\begin{array}{c}360-495 \\
\text { (9) }\end{array}$ & $405 \pm 45$ \\
\hline $\begin{array}{ll}\text { Eficiência } & \text { de } \\
\text { remoção (\%) } & \\
\end{array}$ & - & - & $47-66(9)$ & $57 \pm 6$ & $4-38$ & $29 \pm 10$ \\
\hline $\mathrm{DQO}_{\text {filtrada }}\left(\mathrm{mg} \cdot \mathrm{L}^{-1}\right)$ & $\begin{array}{c}1010-1445 \\
(9)\end{array}$ & $1295 \pm 165$ & $\begin{array}{c}425-595 \\
(9)\end{array}$ & $510 \pm 55$ & $\begin{array}{c}360-460 \\
(9) \\
\end{array}$ & $400 \pm 40$ \\
\hline $\begin{array}{ll}\text { Eficiência } & \text { de } \\
\text { remoção (\%) } & \\
\end{array}$ & - & - & $50-70(9)$ & $60 \pm 7$ & $8-32(9)$ & $25 \pm 10$ \\
\hline $\mathrm{pH}$ & $7,4-8,2$ & - & $7,8-8,1$ & - & $8,1-7,5$ & - \\
\hline $\begin{array}{l}\text { Alcalinidade } \\
\left(\mathrm{mg} \cdot \mathrm{L}^{-1}\right)\end{array}$ & $\begin{array}{l}98-148 \\
(9)\end{array}$ & $122 \pm 18$ & $\begin{array}{l}189-284 \\
(9)\end{array}$ & $239 \pm 34$ & $\begin{array}{c}104-155 \\
(9)\end{array}$ & $131 \pm 17$ \\
\hline Ácidos $\left(\mathrm{mg} \cdot \mathrm{L}^{-1}\right)$ & $\begin{array}{c}134-191 \\
(9)\end{array}$ & $151 \pm 16$ & $\begin{array}{l}37-140 \\
(9)\end{array}$ & $72 \pm 34$ & $\begin{array}{l}31-51 \\
(9)\end{array}$ & $39 \pm 6$ \\
\hline $\begin{array}{l}\left.\text { ST (mg. } L^{-1}\right) \\
\left.\text { STV (mg. } L^{-1}\right) \\
\left.\text { STF (mg. } L^{-1}\right)\end{array}$ & $\begin{array}{c}847-1057 \\
(5) \\
413-843 \\
308-433 \\
\end{array}$ & - & $\begin{array}{c}732-942 \\
(5) \\
280-574 \\
303-471 \\
\end{array}$ & - & $\begin{array}{c}751-921 \\
(5) \\
420-487 \\
297-496 \\
\end{array}$ & - \\
\hline $\begin{array}{l}\left.\text { SST (mg. } L^{-1}\right) \\
\left.\text { SSV (mg. } L^{-1}\right)\end{array}$ & $\begin{array}{c}43-140(5) \\
25-109\end{array}$ & - & $\begin{array}{c}66-126(5) \\
50-87 \\
\end{array}$ & - & $\begin{array}{c}35-99(5) \\
21-62 \\
\end{array}$ & - \\
\hline $\mathrm{CH}_{4}(\%)$ & - & - & $61-77$ & - & - & - \\
\hline
\end{tabular}

Obs.: (n): número de observações feitas; DP: desvio padrão.

\subsubsection{Avaliação do desempenho dos reatores na fase mesofilica}

Esperava-se, nessa primeira fase, bom desempenho do sistema, visto que bons resultados já haviam sido obtidos na operação do reator anaeróbio UASB (Buzzini, 2000) e com o reator aeróbio de lodos ativados (Nolasco, 1998), alimentados por água residuária sintética com características semelhantes.

Entretanto, ambos os reatores operaram aquém das potencialidades individuais. 
O melhor desempenho do reator UASB na fase mesofilica, com boa estabilidade, foi obtido na última etapa (temperatura de $42,5^{\circ} \mathrm{C}$ ) provavelmente devido ao tempo de aclimatação. O reator aeróbio apresentou a melhor eficiência de remoção de DQO na sétima etapa (temperatura de $35^{\circ} \mathrm{C}$ ), mas houve flutuação nos resultados obtidos.

Acreditava-se, no início desse experimento, que aumento súbito da temperatura sobrecarregaria o reator aeróbio e que o ideal seriam aumentos graduais. Esperava-se que o reator UASB permanecesse estável com essa operação.

De modo geral, na fase mesofilica, o reator anaeróbio apresentou o melhor desempenho, no entanto, ambos os reatores mostraram-se bastante instáveis às alterações feitas.

De acordo com trabalho de Schmidt \& Ahring (1994) ${ }^{38}$ citados por Speece (1996) foi verificado que aumentos graduais na temperatura de um reator UASB não foram benéficos quando comparados a aumento súbito para a temperatura desejada. Além disso, segundo Speece (1996), a sensibilidade à temperatura aumenta com a taxa de carregamento. Esse foi outro problema encontrado na primeira fase: as variações da DQO da água residuária sintética, que ocorreram por vezes, simultaneamente à mudança na temperatura.

Vários estudos sugerem que partidas bem sucedidas são necessárias para o estabelecimento de comunidades microbianas adequadas, ajustando-se às funções fisiológicas desejadas (LIU et al., 2002).

De acordo com Liu et al. (2002), baseado em trabalhos de Griffin et al. (1998) e Leclerc et al. (2001), para digestores de resíduos sólidos municipais e matérias orgânicas simples, a fonte de inóculo pode exercer um papel menos significativo que as condições operacionais (por exemplo, temperatura do reator) e além disso, a dinâmica da composição metanogênica é relacionada aos tipos e concentrações de AGV nos reatores. O desempenho provavelmente seria melhor se o tempo de adaptação do lodo tivesse sido maior.

Os resultados obtidos no reator aeróbio também não foram satisfatórios. A qualidade do inóculo utilizado não foi boa, entretanto, na época da inoculação não havia bons inóculos disponíveis. Contudo, no trabalho de Barr et al. (1996) operando reatores de lodos ativados de $5 \mathrm{~L}$ por dois meses a $35^{\circ} \mathrm{C}$ para aclimatação, alimentados com efluente da indústria de polpa Kraft, a eficiência de remoção de DQO foi similar à obtida no presente trabalho, entretanto, com menor faixa de variação $(32,4 \pm 8,0) \%$. O 
tempo de detenção utilizado também era similar ao do presente trabalho, sofrendo variação de 10 para 12 horas. Os autores atribuíram a baixa efíciência de remoção de DQO às baixas concentrações de SSV no licor misto nos reatores, fato também verificado neste trabalho.

Nas Figuras de 5.5 a 5.10 são apresentados os gráficos das oito etapas mesofilicas considerando o monitoramento físico-químico dos reatores: DQO total e filtrada (5.5); eficiência de remoção de DQO total e filtrada (5.6), composição do biogás (5.7); pH (5.8), AGV (5.8), alcalinidade total (5.8) e concentração de sólidos (5.9 e 5.10).

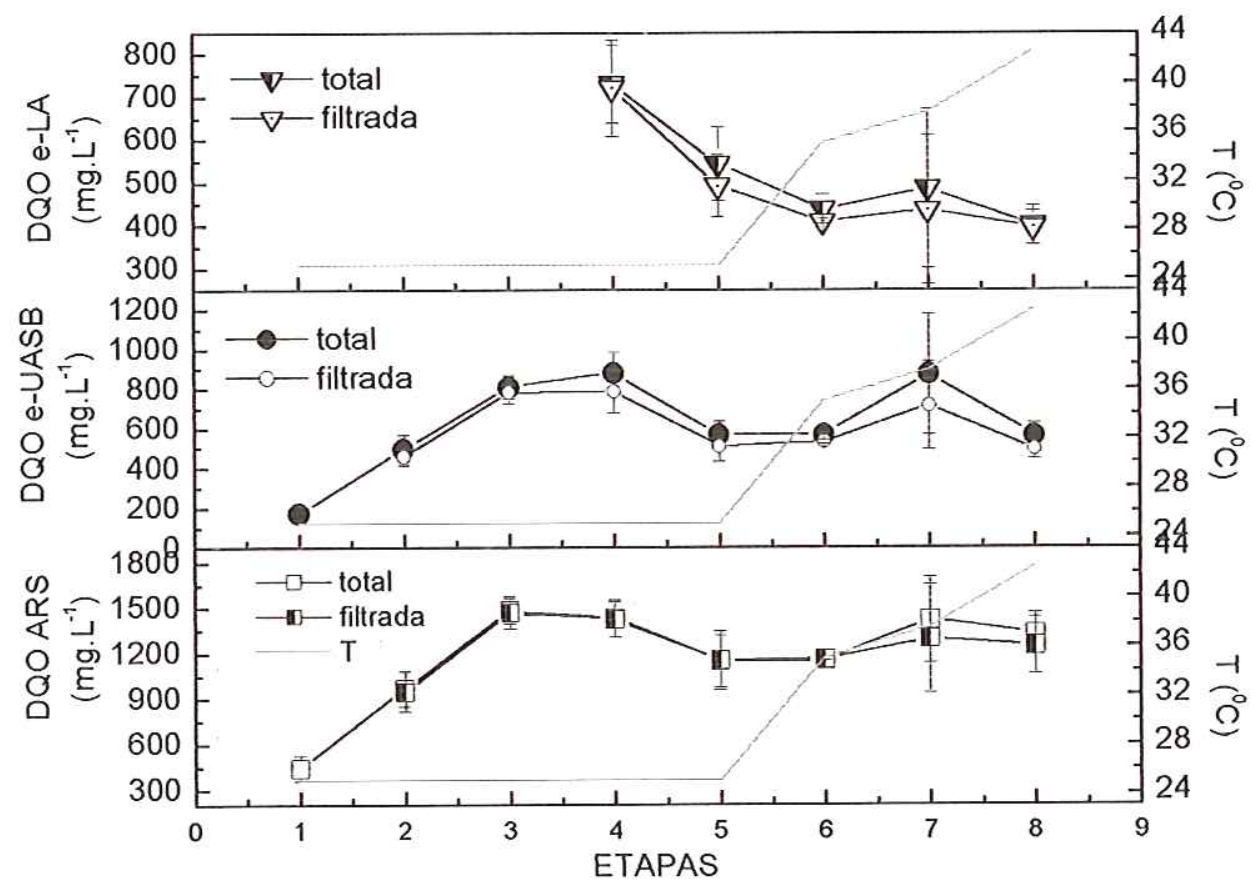

FIGURA 5.5 - Médias da DQO total e filtrada da água residuária sintética (ARS), do efluente do reator UASB (e-UASB) e do efluente do reator de lodos ativados (e-LA) nas 8 etapas da fase mesofilica, considerando as diferentes temperaturas de operação. 


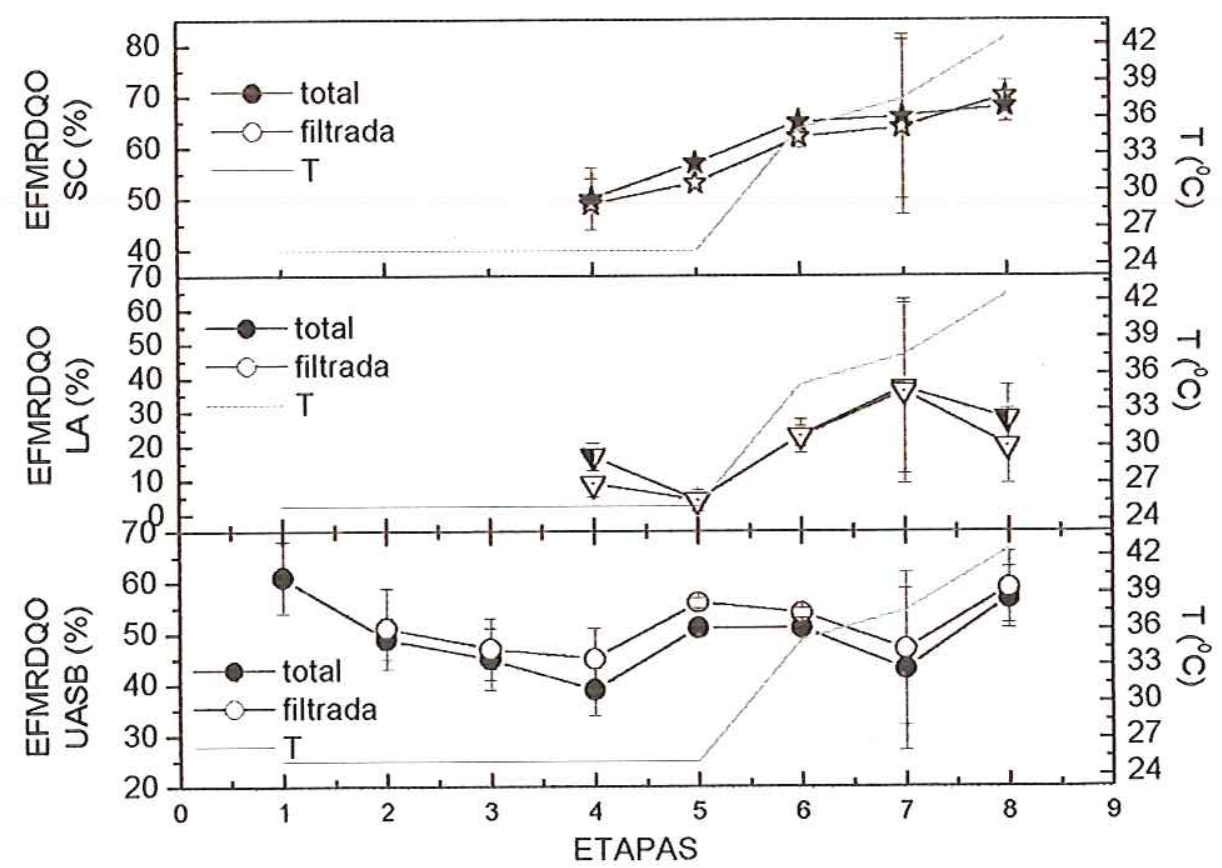

Siglas: EFMRDQO: média da eficiência de remoção de DQO; SC: sistema combinado; T-temperatura.

FIGURA 5.6 - Médias da eficiência de remoção de DQO total e filtrada da água residuária sintética (ARS), do efluente do reator UASB (e-UASB) e do efluente do reator de lodos ativados (e-LA) nas 8 etapas da fase mesofilica, considerando as diferentes temperaturas de operação.

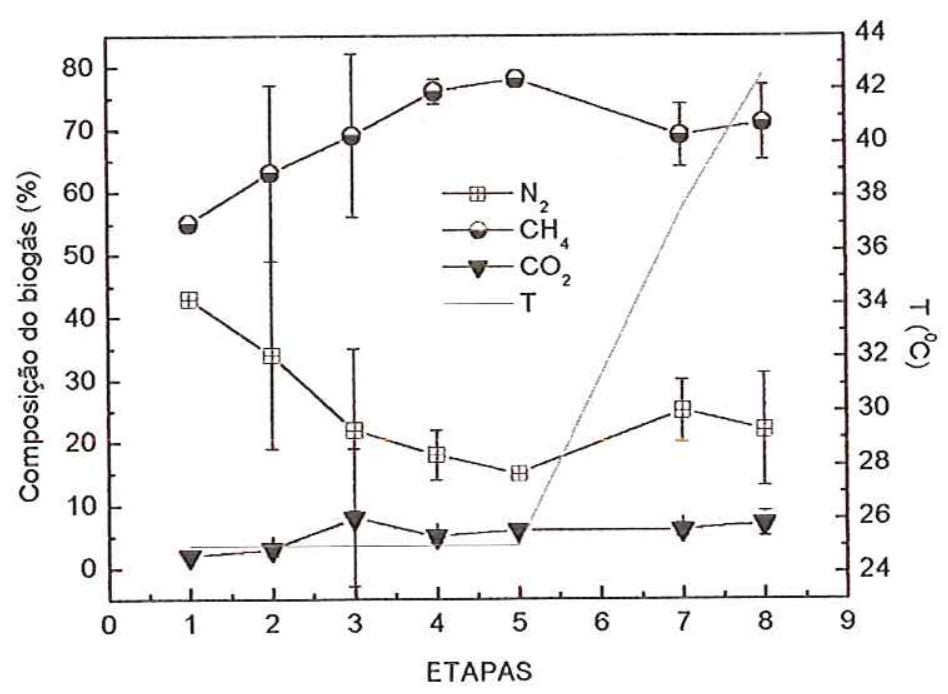

FIGURA 5.7 - Médias das concentrações de nitrogênio $\left(\mathrm{N}_{2}\right)$, Metano $\left(\mathrm{CH}_{4}\right)$ e Gás carbônico $\left(\mathrm{CO}_{2}\right)$ na composição do biogás do reator UASB nas 8 etapas da fase mesofilica, considerando as diferentes temperaturas de operação (T). 


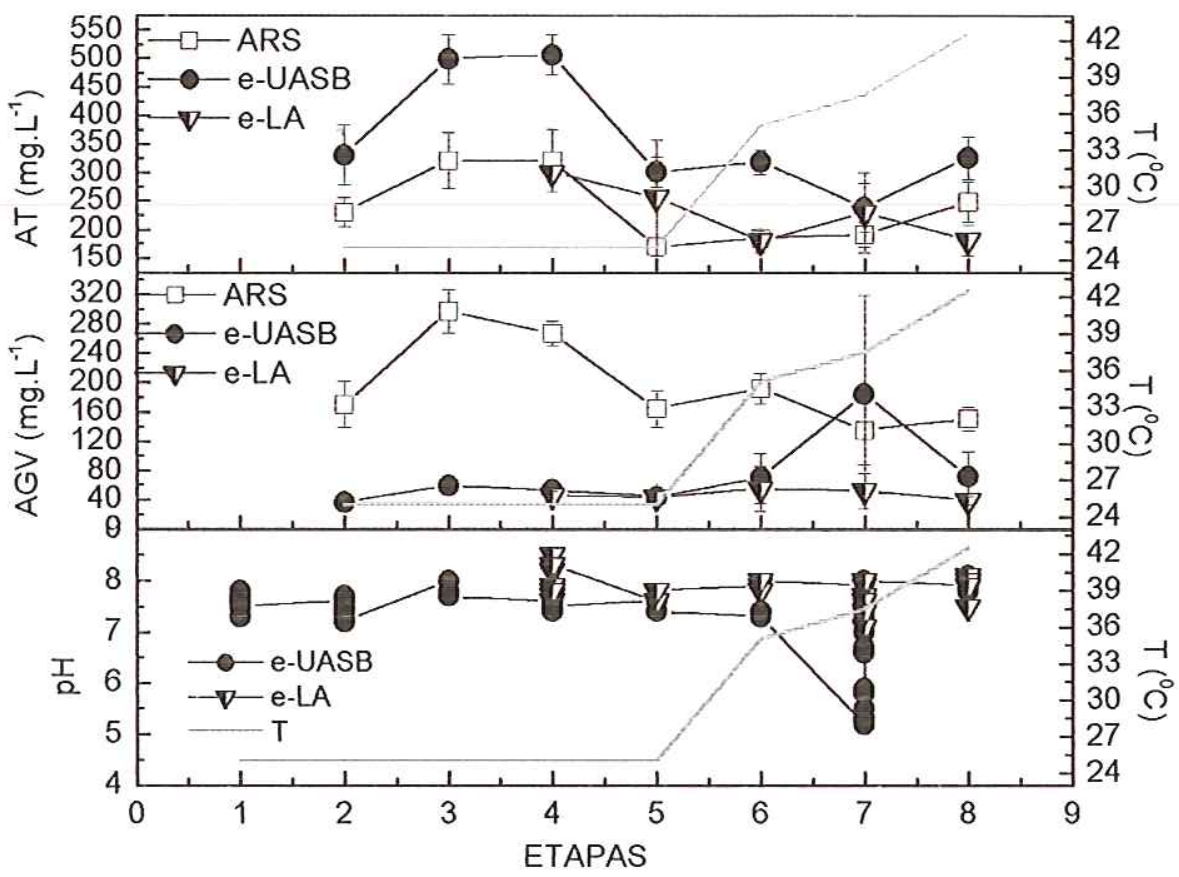

FIGURA 5.8 - Valores de pH e médias das concentrações de ácidos graxos voláteis (AGV) e alcalinidade total (AT) na água residuária sintética (ARS) e efluentes do reator UASB (e-UASB) e do reator de lodos ativados (e-LA) nas 8 etapas da fase mesofilica, considerando as diferentes temperaturas de operação $(\mathrm{T})$.

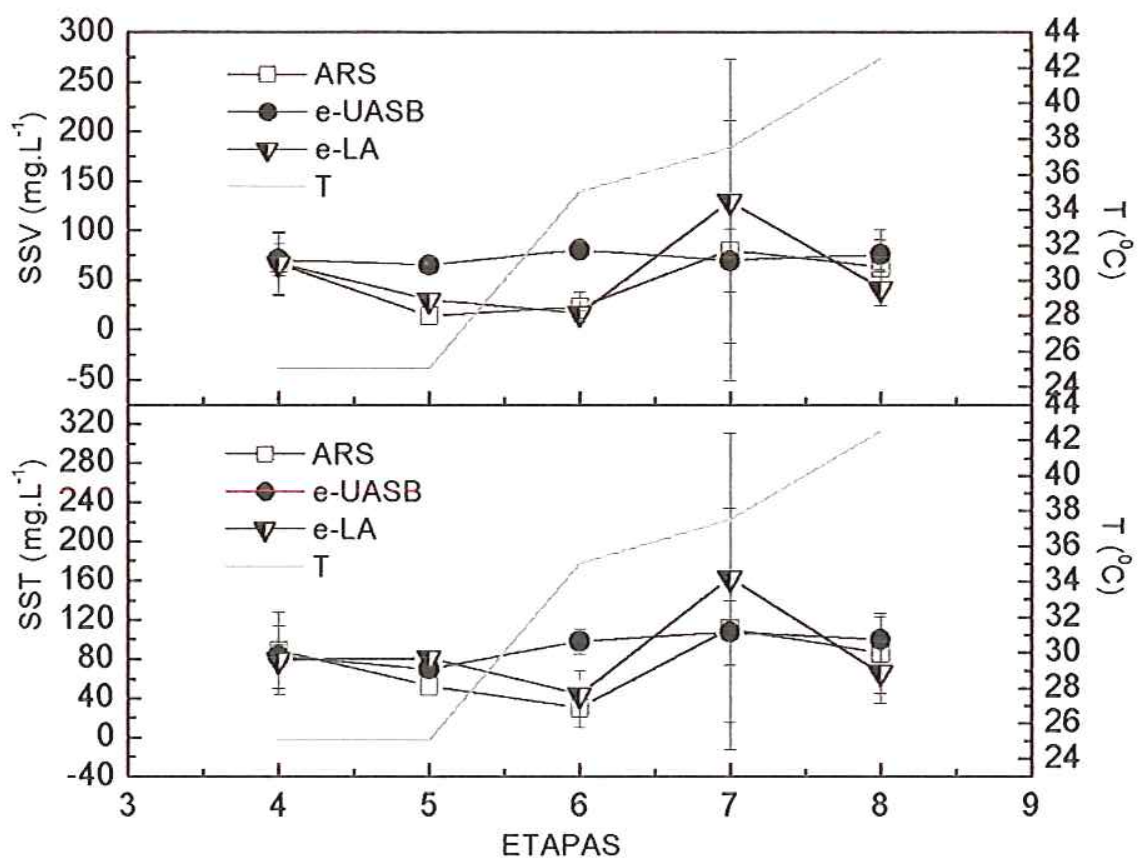

FIGURA 5.9 - Valores médios e desvios das concentrações de sólidos suspensos totais (SST) e sólidos suspensos voláteis (SSV): na água residuária sintética (ARS) e efluentes do reator UASB (e-UASB) e do reator de lodos ativados (e-LA), nas 8 etapas da fase mesofilica, considerando as diferentes temperaturas de operação $(T)$. 


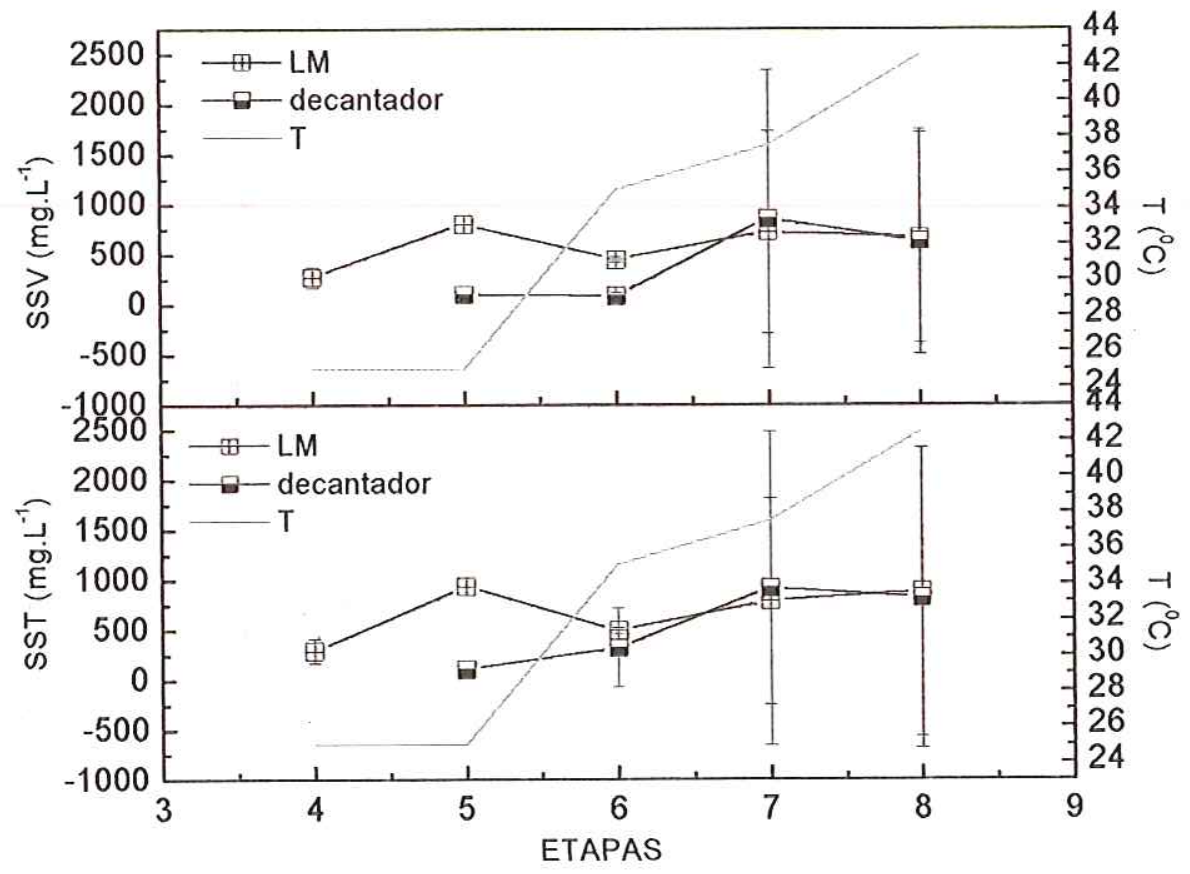

FIGURA 5.10 - Valores médios e desvios das concentrações de sólidos suspensos totais (SST) e sólidos suspensos voláteis (SSV) no licor misto (LM) e decantador do reator aeróbio, nas 8 etapas da fase mesofilica, considerando as diferentes temperaturas de operação (T).

\subsubsection{Segunda Fase: Termofílica}

A segunda fase contempla a operação dos reatores em temperatura termofilica, considerando a faixa de $(45,0 \pm 2,0)^{0} \mathrm{C}$ a $(57,0 \pm 2,0)^{0} \mathrm{C}$. Nessa fase, a subdivisão em cinco etapas foi devida a alterações feitas na temperatura e no tempo de detenção hidráulica, de acordo com a Figura 5.11.

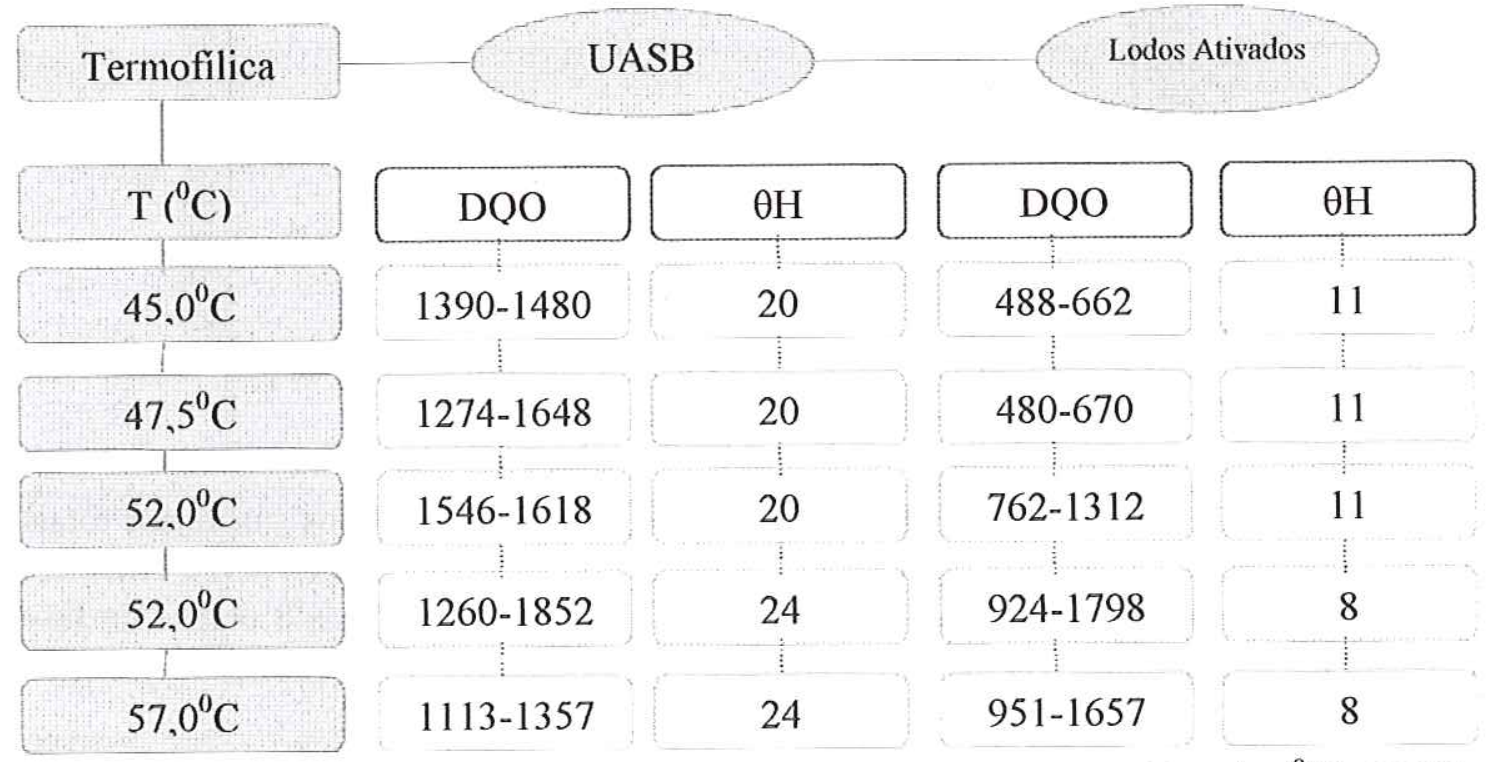

FIGURA 5.11 - Fase termofilica $\left(2^{\mathrm{a}}\right.$ fase): etapas, temperatura considerada $\left({ }^{0} \mathrm{C}\right)$, DQO (mg. $\left.\mathrm{L}^{-1}\right)$ e tempo de detenção hidráulica. 


\subsubsection{Primeira etapa termofilica}

O início da etapa termofilica foi considerado a partir do ajuste da temperatura para $45^{\circ} \mathrm{C}$. As considerações sobre tratamento biológico de água residuária sob condições termofilicas normalmente incluem processos operando em temperaturas de $45^{\circ} \mathrm{C}$ ou maiores (Lapara \& Alleman, 1999). Através de medições feitas em laboratório, foi verificado que no licor misto do reator aeróbio a temperatura registrada era a mesma do termostato $\left(45^{\circ} \mathrm{C}\right)$, entretanto, no reator anaeróbio a temperatura registrada era de $42^{\circ} \mathrm{C}$ ou $43^{\circ} \mathrm{C}$. Portanto, esta faixa de temperatura foi considerada de transição e etapa inicial da fase termofilica, tendo duração de apenas duas semanas.

Comparada à etapa anterior, a eficiência média de remoção do reator anaeróbio foi maior, $(64 \pm 9) \%$, enquanto a do reator aeróbio foi menor $(27 \pm 14) \%$, tendo sofrido maior variação (14 a 42)\%, como pode ser visto pela Figura 5.13, página 116. No trabalho de Tripathi \& Allen (1999) a menor eficiência obtida no reator aeróbio a $45^{\circ} \mathrm{C}$, foi a máxima obtida neste trabalho, $42 \%$.

As concentrações de SSV no licor misto foram extremamente baixas (15 mg. $\mathrm{L}^{-1}$ a $89 \mathrm{mg} . \mathrm{L}^{-1}$ ) enquanto as de SSV no lodo de retorno foram variáveis, atingindo valores bem altos (267 mg. $\mathrm{L}^{-1}$ a $\left.15937 \mathrm{mg} . \mathrm{L}^{-1}\right)$. No efluente do reator aeróbio não foi verificada perda de sólidos como ocorreu no reator anaeróbio, que variou de 716 a 1832 gSSV.d $\mathrm{d}^{-1}$.

A alcalinidade parcial manteve-se em torno de $280 \mathrm{mg} \cdot \mathrm{L}^{-1}$. Também as concentrações de AGV no reator UASB foram ligeiramente menores que na etapa anterior ( $\left.52 \mathrm{mg} . \mathrm{L}^{-1} \pm 12 \mathrm{mg} . \mathrm{L}^{-1}\right)$ enquanto no reator aeróbio permaneceram praticamente constantes (38 mg. $\left.\mathrm{L}^{-1} \pm 7 \mathrm{mg} . \mathrm{L}^{-1}\right)$.

A porcentagem de metano no biogás apresentou variação sutil, de $76 \%$ a $78 \%$.

A variação dos parâmetros monitorados pode ser visualizada nas Figuras de 5.12 a 5.17 , página 115 a 118 .

Sendo essa uma etapa de transição, outros parâmetros foram usados para caracterizar a água residuária sintética e os efluentes dos reatores anaeróbio e aeróbio, determinando-se além dos habituais, DBO, fósforo, nitrogênio amoniacal e carbono. Os valores encontrados são apresentados na Tabela 5.9.

Não foi possível determinar-se a DBO no efluente do reator de lodos ativados não sendo possível portanto a determinação da eficiência de remoção de DBO do reator de lodos ativados. Deve-se considerar entretanto que o reator aeróbio estava instável 
nessa etapa de transição, entre a fase mesofilica e a termofilica, tendo apresentado a menor eficiência de remoção no dia da coleta das amostras para estas análises.

TABELA 5.9 - Caracterização da água residuária sintética e dos efluentes dos reatores na fase de transição do sistema de mesofílico para termofilico.

\begin{tabular}{l|c|c|c}
\hline \multicolumn{1}{c|}{ Parâmetros } & ARS & Efluente UASB & Efluente LA \\
\hline DDO (mg. $\left.\mathrm{L}^{-1}\right)$ & 1396 & 478 & 408 \\
\hline DBO (mg. $\left.\mathrm{L}^{-1}\right)$ & 695 & 260 & - \\
\hline Fósforo $\left(\mathrm{mg} . \mathrm{L}^{-1}\right)$ & 11,6 & 13,6 & 13,3 \\
\hline Nitrogênio amoniacal $\left(\mathrm{mg} . \mathrm{L}^{-1}\right)$ & 23,1 & 23,8 & 5,4 \\
\hline Carbono orgânico total $\left(\mathrm{mg} . \mathrm{L}^{-1}\right)$ & 300,3 & 115,7 & 113,3 \\
\hline
\end{tabular}

As faixas de variação dos valores obtidos nos demais parâmetros monitorados durante toda a etapa são apresentados na Tabela 5.10.

TABELA 5.10 - Faixas de variação dos parâmetros monitorados na primeira etapa termofílica $\left(246^{\circ}\right.$ ao $257^{\circ}$ dia) nos reatores anaeróbio e aeróbio respectivamente

\begin{tabular}{|c|c|c|c|}
\hline Parâmetros & ARS & Efluente UASB & Efluente LA \\
\hline DQO total (mg.L $\left.\mathrm{L}^{-1}\right)$ & $1390-1552(4)$ & $420-662(4)$ & $380-422(4)$ \\
\hline $\begin{array}{l}\text { Eficiência de remoção } \\
(\%)\end{array}$ & - & $52-73(4)$ & $14-42(4)$ \\
\hline DQO filtrada (mg. $\left.\mathrm{L}^{-1}\right)$ & $1212-1472(4)$ & $294-442(4)$ & $350-388(4)$ \\
\hline $\begin{array}{l}\text { Eficiência de remoção } \\
\text { (\%) }\end{array}$ & - & $64-71(4)$ & $11-21(4)$ \\
\hline $\mathrm{pH}$ & $7,5-7,8$ & $7,9-8,0$ & $7,9-8,0$ \\
\hline Alcalinidade (mg. $\left.\mathrm{L}^{-1}\right)$ & $19-118(4)$ & $43-262(4)$ & $21-185(4)$ \\
\hline Ácidos (mg. $\left.\mathrm{L}^{-1}\right)$ & $171-190(4)$ & $41-69(4)$ & $31-48(4)$ \\
\hline ST $\left(\mathrm{mg} \cdot \mathrm{L}^{-1}\right)$ & $1126-2136(4)$ & $886-2077(4)$ & $882-1209(4)$ \\
\hline STV (mg. $\left.\mathrm{L}^{-1}\right)$ & $772-1621$ & $515-1580$ & $455-679$ \\
\hline STF $\left(\mathrm{mg}^{-L^{-1}}\right)$ & $297-515$ & $371-497$ & $334-530$ \\
\hline SST (mg.L $\left.L^{-1}\right)$ & $72-1005(4)$ & $73-171(4)$ & $24-110(4)$ \\
\hline SSV (mg. $\left.L^{-1}\right)$ & $39-899$ (4) & $57-147$ & $9-70$ \\
\hline $\mathrm{CH}_{4}(\%)$ & $=$ & $76-78(3)$ & - \\
\hline
\end{tabular}

Obs.: Os valores entre parênteses (n) se referem ao número de observações.

\subsubsection{Segunda etapa termofílica}

A temperatura foi ajustada para $47,5^{\circ} \mathrm{C}$, assim permanecendo por 34 dias.

Inicialmente houve aumento na eficiência de ambos reatores, do UASB de 52\% para $71 \%$ e do lodos ativados, de $42 \%$ para $58 \%$. Até o final dessa fase, entretanto, as eficiências de remoção dos reatores UASB e de LA, caíram para $62 \%$ e $45 \%$, respectivamente (Figura 5.13, página 116).

As concentrações de AGV acumularam consideravelmente no efluente do reator UASB em relação à etapa anterior (de aproximadamente $41 \mathrm{mg} . \mathrm{L}^{-1}$ para $81 \mathrm{mg} . \mathrm{L}^{-1}$ ), atingindo, até o fim dessa etapa, $120 \mathrm{mg} \cdot \mathrm{L}^{-1}$. No reator aeróbio as concentrações 
sofreram leve decréscimo, mantendo-se em torno de $30 \mathrm{mg} \cdot \mathrm{L}^{-1}$. A alcalinidade parcial foi consumida no reator anaeróbio no início da etapa, queda de $199 \mathrm{mg} . \mathrm{L}^{-1}$ para 127 mg. $L^{-1}$. Entretanto, no final da etapa a alcalinidade parcial já atingia concentrações de $183 \mathrm{mg} . \mathrm{L}^{-1}$. No reator aeróbio, a alcalinidade parcial oscilou de $67 \mathrm{mg} . \mathrm{L}^{-1}$ a $138 \mathrm{mg} . \mathrm{L}^{-1}$ (Figura 5.15, página 117).

Não estava sendo registrada a presença de metano no biogás quando foram verificados produtos de corrosão na junção com a mangueira na saída do biogás. Feita a desobstrução, a medição de metano no biogás ficou impossibilitada pela necessidade do sistema voltar ao equilibrio antes que novas análises fossem feitas.

A eficiência de remoção do sistema combinado nessa etapa variou de $76 \%$ a $88 \%$ (Tabela 5.11).

TABELA 5.11 - Faixas de variação dos parâmetros monitorados na segunda etapa da Fase termofílica $\left(258^{0}\right.$ ao $291^{0}$ dia) nos reatores anaeróbio e aeróbio respectivamente.

\begin{tabular}{|c|c|c|c|}
\hline Parâmetros & ARS & Efluente UASB & Efluente LA \\
\hline DQO total $\left(\mathrm{mg} . \mathrm{L}^{-1}\right)$ & $1274-1648(3)$ & $480-670(3)$ & $202-492(3)$ \\
\hline $\begin{array}{l}\text { Eficiência de remoção } \\
(\%)\end{array}$ & - & $47-71(3)$ & $45-58(3)$ \\
\hline DQO filtrada (mg. $\left.\mathrm{L}^{-1}\right)$ & $1246-1612(3)$ & $332-578(3)$ & $192-300(3)$ \\
\hline $\begin{array}{l}\text { Eficiência de remoção } \\
\text { (\%) }\end{array}$ & - & $54-76(3)$ & $39-50(3)$ \\
\hline $\mathrm{pH}$ & 7,2 & 7,8 & 7,8 \\
\hline $\begin{array}{l}\text { Alcalinidade total } \\
\left(\mathrm{mg} \cdot \mathrm{L}^{-1}\right)\end{array}$ & $205-252(3)$ & $249-320(3)$ & $89-189(3)$ \\
\hline Ácidos (mg. $\left.\mathrm{L}^{-1}\right)$ & $154-202(3)$ & $81-155(3)$ & $29-37(3)$ \\
\hline ST $\left(\mathrm{mg} \cdot \mathrm{L}^{-1}\right)$ & $1218-1381(3)$ & $901-1259(3)$ & $907-2373(3)$ \\
\hline STV (mg. $\left.L^{-1}\right)$ & $798-826$ & $522-688$ & $405-2044$ \\
\hline STF (mg. $\left.L^{-1}\right)$ & $392-560$ & $379-585$ & $330-436$ \\
\hline SST (mg. $\left.L^{-1}\right)$ & $102-316(3)$ & $80-265(3)$ & $44-83(3)$ \\
\hline $\mathrm{SSV}\left(\mathrm{mg} \cdot \mathrm{L}^{-1}\right)$ & $87-242$ & $61-207$ & $40-52$ \\
\hline
\end{tabular}

Obs.: (n): número de observações.

\subsubsection{Terceira etapa termofilica}

A temperatura foi ajustada para $52^{\circ} \mathrm{C}$ e por, uma semana,os reatores foram operados nas mesmas condições da etapa anterior. Entretanto, houve variação da DQO de $1546 \mathrm{mg} . \mathrm{L}^{-1}$ para $1618 \mathrm{mg} . \mathrm{L}^{-1}$ e a eficiência de remoção no reator UASB decresceu de $51 \%$ para $19 \%$, bem como a porcentagem de metano no biogás, reduzida de $43 \%$ para valores abaixo do limite de detecção do aparelho. Também foi registrada perda de SSV no efluente do reator anaeróbio, sendo registrada uma perda de $52 \mathrm{mg} . \mathrm{d}^{-1}$, no início da etapa e uma de $1892 \mathrm{mg} . \mathrm{d}^{-1}$ no fim. 
O reator aeróbio apresentou maior estabilidade e a eficiência sofreu pouca variação, de $53 \%$ para $47 \%$. Apesar dos baixos valores registrados para os SSV no licor misto, foi registrado aumento de $32 \mathrm{mg} . \mathrm{L}^{-1}$ para $470 \mathrm{mg} . \mathrm{L}^{-1}$.

A alcalinidade parcial no efluente do reator anaeróbio foi consumida, de $153 \mathrm{mg} . \mathrm{L}^{-1}$ para $134 \mathrm{mg} . \mathrm{L}^{-1}$, inversamente ao que ocorreu no reator aeróbio, onde a alcalinidade aumentou de $125 \mathrm{mg} . \mathrm{L}^{-1}$ para $208 \mathrm{mg} . \mathrm{L}^{-1}$

Houve acúmulo de AGV nos reatores anaeróbio e aeróbio, de $145 \mathrm{mg} . \mathrm{L}^{-1}$ para $199 \mathrm{mg} . \mathrm{L}^{-1}$ e de $30 \mathrm{mg} . \mathrm{L}^{-1}$ para $48 \mathrm{mg} . \mathrm{L}^{-1}$, respectivamente. Pela análise cromatográfica dos AGV no efluente no dia de menor eficiência do reator anaeróbio foram determinados os ácidos propiônico, isobutírico e isovalérico, em concentrações de 48,9 mg. $\mathrm{L}^{-1} ; 0,3 \mathrm{mg} . \mathrm{L}^{-1}$ e $1,4 \mathrm{mg} . \mathrm{L}^{-1}$, respectivamente.

No trabalho de Dinsdale et al. (1997a) também foi verificada concentração de ácidos graxos voláteis alta, com valores bem superiores aos do presente trabalho, nas condições mesofilica e termofilica. Reatores UASB tratando água residuária da produção de café instantâneo, sob condições mesofílica e termofílica, produziram concentração de AGV no reator mesofílico de $970 \mathrm{mg} . \mathrm{L}^{-1}$, enquanto no termofílico, $1850 \mathrm{mg} . \mathrm{L}^{-1}$. Segundo Dinsdale et al. (1997a), este acúmulo de AGV no processo termofílico foi devido ao processo de conversão do reator de mesofílico para termofílico, feito em um só passo. O controle da acidificação era feito com a adição de bicarbonato de sódio. Como no presente trabalho, foi verificado que o ácido propiônico aparecia em maior concentração.

De acordo com Dinsdale et al. (1997b), baseados em vários autores, reatores UASB termofilicos têm a tendência de acumular ácido propiônico e outros intermediários quando, aparentemente, estão operando em condição estável.

No presente trabalho entretanto, pelos resultados obtidos, principalmente de eficiência de remoção de DQO e porcentagem de metano no biogás, o reator UASB estava instável. A porcentagem de metano no biogás no reator anaeróbio caiu de $43 \%$ para valores abaixo do limite de deteção do método cromatográfico utilizado.

De acordo com Speece (1996) elevadas concentrações de ácido propiônico podem ter efeito de inibição na produção de metano e a concentração deste ácido, nessa etapa, foi a maior registrada durante todo o experimento.

Apesar das concentrações de ácidos serem consideravelmente diferentes às encontradas por Dinsdale et al. (1997a), deve-se considerar que variáveis operacionais 
influenciaram os resultados: águas residuárias diferentes, adaptação do lodo mesofílico para termofilico feita subitamente e não gradualmente.

A acidificação, entretanto, parece ser comum em experimentos utilizando reatores anaeróbios termofílicos. No experimento realizado por Lau \& Fang (1997) em reatores UASB e faixa de temperatura termofilica, também houve necessidade do controle dos altos níveis de ácidos e bicarbonato de sódio também foi utilizado. Rintala \& Lepisto (1997), em reator UASB, operado a $55^{\circ} \mathrm{C}$, tratando água residuária de indústria processadora de vegetais, também verificaram acidificação e conseqüente queda na eficiência de remoção de DQO, de cerca de $50 \%$ para $30 \%$, entre o décimo e o vigésimo dia de operação. No experimento de Rintala \& Lepisto (1997), além da adição de hidróxido de sódio para o controle do $\mathrm{pH}$, reestabalecendo-o para 6,9, também foi feita reinoculação. Foi verificado que a eficiência começou a aumentar, atingindo valores em torno de $60 \%$ dez dias após a reinoculação.

No experimento de Buzzini (2000) operando reatores UASB em faixa mesofílica $\left(30^{0} \mathrm{C} \pm 3^{0} \mathrm{C}\right)$, devido a choque térmico a temperatura se manteve por 6 horas a $(50 \pm 3)^{0} \mathrm{C}$ resultando em acidificação nos reatores. Com o retorno da temperatura para $30^{\circ} \mathrm{C}$ e adição de bicarbonato de sódio os reatores voltaram à estabilidade.

Em relação às concentrações de sólidos totais na água residuária sintética e no efluente do reator anaeróbio foram verificadas reduções de $1665 \mathrm{mg} \cdot \mathrm{L}^{-1}$ para $1308 \mathrm{mg} . \mathrm{L}^{-1}$ e de $1875 \mathrm{mg} . \mathrm{L}^{-1}$ para $746 \mathrm{mg} . \mathrm{L}^{-1}$, respectivamente, do início até o final dessa etapa. Entretanto, no reator aeróbio essas concentrações aumentaram de $1306 \mathrm{mg} . \mathrm{L}^{-1}$ para $1489 \mathrm{mg} \cdot \mathrm{L}^{-1}$.

Nessa etapa, as concentrações de oxigênio dissolvido oscilaram entre $2 \mathrm{mg} . \mathrm{L}^{-1} \mathrm{e}$ $5 \mathrm{mg} . \mathrm{L}^{-1}$, sendo necessário controlar a vazão de ar pelo rotâmetro, para manter os valores acima da concentração adequada para tratamentos biológicos $\left(>1,5 \mathrm{mg} . \mathrm{L}^{-1}\right)$. Tripathi \& Allen (1999) também verificaram queda na concentração de oxigênio quando a temperatura foi aumentada $\left(4,8 \mathrm{mg} \cdot \mathrm{L}^{-1}\right.$ a $35^{0} \mathrm{C}$ para $2,5 \mathrm{mg} \cdot \mathrm{L}^{-1}$ a $\left.60^{0} \mathrm{C}\right)$.

Como foi verificado que a eficiência de remoção de DQO do reator anaeróbio vinha decrescendo desde o final da segunda etapa, e que na terceira a queda foi drástica ( $51 \%$ para $19 \%$ ), além de ser registrado também redução da eficiência de remoção no reator aeróbio, foram feitas alterações buscando-se o equilíbrio do reator UASB, dando início dessa forma a uma nova etapa.

As variações dos parâmetros monitorados nesta etapa podem ser visualizadas na Tabela 5.12 e nas Figuras de 5.12 a 5.17, página 115 a 118 . 
TABELA 5.12 - Faixas de variação dos parâmetros monitorados na terceira etapa da Fase termofilica $\left(292^{\circ}\right.$ ao $298^{\circ}$ dia) nos reatores anaeróbio e aeróbio respectivamente

\begin{tabular}{|c|c|c|c|}
\hline Parâmetros & ARS & Efluente UASB & Efluente LA \\
\hline DQO total (mg. $\left.\mathrm{L}^{-1}\right)$ & $1546-1648(2)$ & $762-1312(2)$ & $356-700(2)$ \\
\hline $\begin{array}{l}\text { Eficiência de remoção } \\
(\%)\end{array}$ & - & $19-51$ & $47-53$ \\
\hline DQO filtrada (mg. $\left.\mathrm{L}^{-1}\right)$ & $1478-1522(2)$ & $556-1076(2)$ & $302-634(2)$ \\
\hline $\begin{array}{l}\text { Eficiência de remoção } \\
(\%)\end{array}$ & - & $29-62$ & $41-46$ \\
\hline $\mathrm{pH}$ & $7.0-7,3(2)$ & $7,3-7,5(2)$ & $7,6-7,9(2)$ \\
\hline $\begin{array}{l}\text { Alcalinidade total } \\
\left(\mathrm{mg} \cdot \mathrm{L}^{-1}\right)\end{array}$ & $241-250(2)$ & $283-299(2)$ & $179-289(2)$ \\
\hline Ácidos $\left(\mathrm{mg} \cdot \mathrm{L}^{-1}\right)$ & $187-195(2)$ & $145-199(2)$ & $30-48(2)$ \\
\hline ST $\left(\mathrm{mg} \cdot \mathrm{L}^{-1}\right)$ & $1308-1665(2)$ & $746-1875(2)$ & $1306-1489(2)$ \\
\hline STV (mg.L $\left.L^{-1}\right)$ & $588-671(2)$ & $477-841(2)$ & $367-854(2)$ \\
\hline STF (mg.L $\left.\mathrm{L}^{-1}\right)$ & $720-994(2)$ & $269-1034(2)$ & $635-939(2)$ \\
\hline $\begin{array}{l}\left.\text { SST (mg. } L^{-1}\right) \\
\left.\text { SSV (mg.L }{ }^{-1}\right)\end{array}$ & $\begin{array}{l}105-198(2) \\
55-82(2)\end{array}$ & $\begin{array}{c}101-265(2) \\
4-152(2)\end{array}$ & $\begin{array}{c}102-204(2) \\
29-94(2)\end{array}$ \\
\hline
\end{tabular}

Obs.: (n): número de observações.

\subsubsection{Quarta etapa termofílica}

Primeiramente, foram feitos ajustes na diluição do licor utilizado no preparo da água residuária sintética, reduzindo de $45 \mathrm{~mL}$ para $30 \mathrm{~mL}$, com conseqüente redução da DQO de concentrações em torno de $1530 \mathrm{mg} . \mathrm{L}^{-1}$ para $1370 \mathrm{mg} . \mathrm{L}^{-1} 1$. Porém, na primeira análise de monitoramento, foi verificado que a eficiência de remoção continuou caindo em ambos os reatores, atingindo $8 \%$ no reator anaeróbio e $20 \%$ no reator aeróbio.

Foi feita então alteração no tempo de detenção hidráulica dos reatores. Para o reator UASB o tempo foi aumentado para 24 horas, visando melhor desempenho. Como o reator aeróbio, antes da última análise, apresentava um bom rendimento, foi sugerida a redução do tempo de detenção hidráulica de 11 para 8 horas.

O reator anaeróbio apresentou aumento na eficiência de remoção de DQO nos primeiros dez dias, contudo, posteriormente, nova queda na eficiência e instalação de instabilidade. No reator aeróbio, inicialmente houve queda na eficiência, mas a recuperação ocorreu em menos de uma semana.

De forma geral, o reator anaeróbio apresentou grande oscilação nos parâmetros monitorados. A eficiência de remoção de DQO oscilou de 3\% a 35\%. A concentração de ácidos variou de $160 \mathrm{mg} . \mathrm{L}^{-1}$ a $340 \mathrm{mg} . \mathrm{L}^{-1}$, sendo o último valor determinado no final da etapa, quando a alcalinidade foi consumida. De modo geral, a alcalinidade parcial variou de $13 \mathrm{mg} . \mathrm{L}^{-1}$ a $278 \mathrm{mg} \cdot \mathrm{L}^{-1}$. Conseqüentemente, o $\mathrm{pH}$ oscilou entre 6,1 e 7,6 por 
todo o período, sendo determinado até 5,1 , quando a alcalinidade foi consumida. A porcentagem de metano no biogás oscilou de $0 \%$ a $19 \%$, apresentando os maiores resultados no final da quarta etapa.

Os ácidos acético e propiônico foram detectados por cromatografia em altos níveis, principalmente do meio para o fim da etapa, variando de $172,3 \mathrm{mg} . \mathrm{L}^{-1}$ a 424,9 mg. $\mathrm{L}^{-1}$ e de 11,6 mg. $\mathrm{L}^{-1}$ a 33,2 mg. $\mathrm{L}^{-1}$, respectivamente. Em menores quantidades e freqüências, foram encontrados os ácidos isobutírico, butírico e isovalérico, em concentrações de $1,5 \mathrm{mg} \cdot \mathrm{L}^{-1} ; 0,1 \mathrm{mg} \cdot \mathrm{L}^{-1}$ a $7,3 \mathrm{mg} \cdot \mathrm{L}^{-1}$ e $0,6 \mathrm{mg} \cdot \mathrm{L}^{-1}$ a $7,6 \mathrm{mg} \cdot \mathrm{L}^{-1}$, respectivamente. De acordo com Speece (1996) sendo o acetato o maior precursor do metano, um sistema anaeróbio em bom funcionamento pode metabolizar eficientemente acetato e removê-lo, resultando em efluente com baixas concentrações.

Correlacionando-se os resultados da análise por cromatografia gasosa, bem como os demais parâmetros monitorados, nota-se o baixo desempenho do reator anaeróbio: a concentração de ácido acético no efluente é alta e a porcentagem de metano no biogás é baixa, bem como a eficiência de remoção de DQO.

Além disso, foi verificada uma perda de sólidos voláteis no efluente do reator anaeróbio que variou de 729 a $3723 \mathrm{mg}^{-\mathrm{d}^{-1}}$. Perda de sólidos em reator anaeróbio também ocorreu no trabalho de Lau \& Fang (1997), quando avaliaram o choque que grânulos de um reator UASB, operado a $55^{\circ} \mathrm{C}$, poderiam sofrer quando a temperatura fosse aumentada subitamente para $65^{\circ} \mathrm{C}$. Pelos resultados, o reator que estava estabilizado com SSV variando de 650 a $850 \mathrm{mg} . \mathrm{L}^{-1}$ no efluente, apresentou valores em torno de $1600 \mathrm{mg} . \mathrm{L}^{-1}$ quando aquecido a $65^{0} \mathrm{C}$. A situação foi regularizada após oito dias. Os autores acreditaram que a lavagem da biomassa pode ser devida à desintegração dos biogrânulos.

Considerando-se o desempenho do reator de lodos ativados, a oscilação na eficiência de remoção de DQO foi mais tênue, variando de $48 \%$ a $68 \%$, exceto no início da etapa, quando apresentou eficiência de 20\%. Tripathi \& Allen (1999), obtiveram eficiência semelhante com reatores seqüenciais em batelada operados em temperatura de $55^{\circ} \mathrm{C}$ tratando efluente de polpa branqueada. Os reatores atingiram eficiência de remoção de DQO variando de $44 \%$ a $65 \%$.

Foi verificada variação na alcalinidade do reator de lodos ativados de $124 \mathrm{mg} . \mathrm{L}^{-1}$ a $279 \mathrm{mg} \cdot \mathrm{L}^{-1}$. A concentração de ácidos também variou, de $24 \mathrm{mg} \cdot \mathrm{L}^{-1}$ a $54 \mathrm{mg} \cdot \mathrm{L}^{-1}$, tendo um pico de $96 \mathrm{mg} . \mathrm{L}^{-1} \mathrm{com} 36$ dias dessa etapa. Pela análise cromatográfica do efluente 
quando houve o pico, apenas o ácido acético foi detectado por cromatografia, em concentração de $0,9 \mathrm{mg} \cdot \mathrm{L}^{-1}$.

Em relação à perda de sólidos, no efluente do reator de lodos ativados, foi

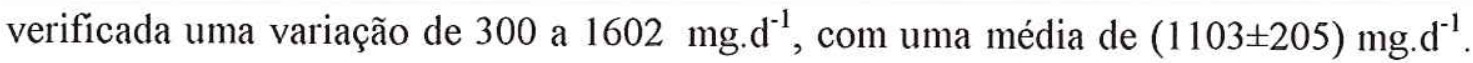
Esta perda aumentou em relação às etapas anteriores, visto que na primeira etapa, as

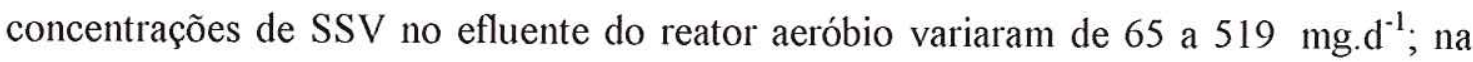

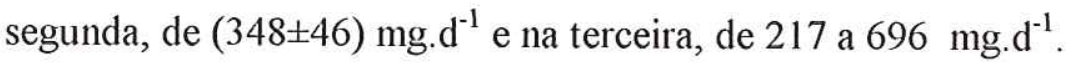

No trabalho de Jahren et al. (2002) tratando licor branco da polpação termomecânica, os valores para SSV no efluente do reator aeróbio foram bem superiores, variando de $220 \mathrm{mg} . \mathrm{L}^{-1}$ a $600 \mathrm{mg} . \mathrm{L}^{-1}$.

A eficiência do sistema nessa etapa foi de $70 \%$, devida, em maior parte, ao reator aeróbio. Provavelmente porque com o baixo desempenho do reator anaeróbio sobrou maior fração de matéria orgânica biodegradável para o reator aeróbio.

Apesar da instabilidade do reator anaeróbio, optou-se pela apresentação na Tabela 5.13, das médias e desvios padrão dos valores do monitoramento dos reatores, sendo também apresentadas as faixas de variação. Estes dados também podem ser visualizados nas Figuras 5.12 a 5.17, página 115 a 118 .

TABELA 5.13- Parâmetros monitorados na quarta etapa da Fase termofilica $\left(299^{\circ}\right.$ ao $354^{0}$ dia) nos reatores anaeróbio e aeróbio.

\begin{tabular}{|c|c|c|c|c|c|c|}
\hline \multirow[b]{2}{*}{ Parâmetros } & \multicolumn{2}{|c|}{ ARS } & \multicolumn{2}{|c|}{$\begin{array}{c}\text { Efluente } \\
\text { UASB }\end{array}$} & \multicolumn{2}{|c|}{$\begin{array}{c}\text { Efluente } \\
\text { Lodos ativados }\end{array}$} \\
\hline & $\begin{array}{c}\text { Faixa de } \\
\text { variação } \\
\text { (n) }\end{array}$ & $\begin{array}{c}\text { Média } \pm \mathbf{D} \\
\mathbf{P}\end{array}$ & $\begin{array}{c}\text { Faixa de } \\
\text { Variação } \\
\text { (n) }\end{array}$ & $\begin{array}{c}\text { Média } \pm \mathbf{D} \\
\mathbf{P}\end{array}$ & $\begin{array}{c}\text { Faixa de } \\
\text { Variação } \\
\text { (n) }\end{array}$ & $\underset{\mathbf{P}}{\text { Média } \pm \mathbf{D}}$ \\
\hline $\begin{array}{l}\text { DQOtotal } \\
\left(\mathrm{mg} \cdot \mathrm{L}^{-1}\right)\end{array}$ & $\begin{array}{c}1260-185 \\
(9)\end{array}$ & $1388 \pm 182$ & $\begin{array}{l}924-1798 \\
\text { (9) }\end{array}$ & $1148 \pm 262$ & $\begin{array}{l}395-598 \\
\text { (9) }\end{array}$ & $485 \pm 64$ \\
\hline $\begin{array}{l}\text { Eficiência de } \\
\text { remoção (\%) }\end{array}$ & - & - & $3-35$ & $18 \pm 11$ & $48-68$ & $57 \pm 7$ \\
\hline $\begin{array}{l}\text { DQOfiltrada } \\
\left(\mathrm{mg}^{-1} \mathrm{~L}^{-1}\right)\end{array}$ & $\begin{array}{l}998-1794 \\
(9)\end{array}$ & $1261 \pm 219$ & $\begin{array}{c}718-1420 \\
\text { (9) }\end{array}$ & $984 \pm 197$ & $\begin{array}{c}324-498 \\
(9)\end{array}$ & $390 \pm 46$ \\
\hline $\begin{array}{l}\text { Eficiência de } \\
\text { remoção (\%) }\end{array}$ & - & - & $13-29$ & $22 \pm 5$ & $47-67$ & $60 \pm 6$ \\
\hline $\mathrm{pH}$ & $7,2-8,5(9)$ & - & $5,1-7,6$ & - & $7,6-8,3$ & - \\
\hline $\begin{array}{l}\text { Alcalinidade } \\
\left(\mathrm{mg} \cdot \mathrm{L}^{-1}\right)\end{array}$ & $\begin{array}{l}149-295 \\
\text { (9) }\end{array}$ & $187 \pm 44$ & $\begin{array}{c}141-479 \\
(9)\end{array}$ & $224 \pm 113$ & $\begin{array}{c}8163-387 \\
(9)\end{array}$ & $261 \pm 86$ \\
\hline Ácidos (mg.L $\left.\mathrm{L}^{-1}\right)$ & $\begin{array}{c}121-219 \\
(9)\end{array}$ & $139 \pm 31$ & $\begin{array}{c}160-340 \\
(9)\end{array}$ & $235 \pm 51$ & $31-96(9)$ & $47 \pm 19$ \\
\hline $\mathrm{ST}\left(\mathrm{mg} \cdot \mathrm{L}^{-1}\right)$ & $444-1600(9)$ & $915 \pm 326$ & $821-1630(9)$ & $1078 \pm 262$ & $760-1116(9)$ & $917 \pm 124$ \\
\hline $\begin{array}{l}\text { STV }\left(m g . L^{-1}\right) \\
\text { STF }\left(m g L^{-1}\right)\end{array}$ & $\begin{array}{c}373-1048(9) \\
71-882(9)\end{array}$ & $\begin{array}{l}549 \pm 227 \\
366 \pm 140\end{array}$ & $\begin{array}{l}349-988(9) \\
275-741(9)\end{array}$ & $\begin{array}{l}622 \pm 209 \\
456+150\end{array}$ & $\begin{array}{l}288-593(9) \\
381-583(9)\end{array}$ & $\begin{array}{c}442 \pm 113 \\
475 \pm 66\end{array}$ \\
\hline SST (mg. $\left.L^{-1}\right)$ & $25-161(9)$ & $88 \pm 51$ & $92-384(9)$ & $173 \pm 79$ & $50-149(9)$ & $\begin{array}{l}410 \pm 66 \\
101 \pm 30\end{array}$ \\
\hline $\operatorname{SSV}\left(\mathrm{mg} \cdot \mathrm{L}^{-1}\right)$ & $21-123(9)$ & $66 \pm 43$ & $69-353(9)$ & $146 \pm 78$ & $24-128(9)$ & $81 \pm 28$ \\
\hline $\mathrm{CH}_{4}(\%)$ & - & - & $0-19(7)$ & - & - & - \\
\hline
\end{tabular}

Obs.: DP: desvio padrão; (n): número de observações. 


\subsubsection{Quinta etapa termofilica}

A temperatura foi aumentada para $57^{\circ} \mathrm{C}$. Esse último ajuste havia sido planejado e foi efetuado porque o reator aeróbio estava respondendo bem na faixa termofílica, apesar dos resultados abaixo do potencial do reator anaeróbio.

O reator anaeróbio continuou instável, sendo que dos parâmetros monitorados

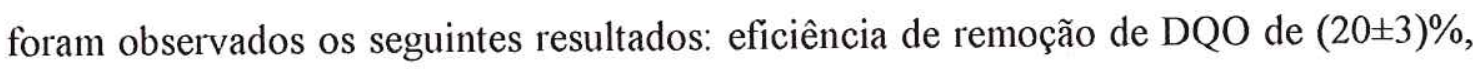
alcalinidade a bicarbonato totalmente consumida na maior parte dessa etapa, entretanto, a concentração de ácidos caiu de $360 \mathrm{mg} . \mathrm{L}^{-1}$ para $237 \mathrm{mg} \cdot \mathrm{L}^{-1}$.

O ácido propiônico foi detectado por cromatografia novamente, em concentrações que variaram de $9,2 \mathrm{mg} \cdot \mathrm{L}^{-1}$ a $47,7 \mathrm{mg} \cdot \mathrm{L}^{-1}$. De acordo com Wiegant et al. ${ }^{39}$ (1986) apud Dinsdale et al. (1997a) sistemas termofílicos têm tendência a acumular altos níveis de ácido propiônico. Também foram detectados os ácidos butírico e isovalérico, em concentrações que variaram de $4,0 \mathrm{mg} . \mathrm{L}^{-1}$ a $57,7 \mathrm{mg} . \mathrm{L}^{-1}$ e $1,8 \mathrm{mg} . \mathrm{L}^{-1}$ a 3,9 mg. $\mathrm{L}^{-1}$, respectivamente. Entretanto, o ácido encontrado em maior quantidade foi o acético, em concentrações que variaram de $112,5 \mathrm{mg} . \mathrm{L}^{-1}$ a $438,2 \mathrm{mg} . \mathrm{L}^{-1}$, confirmando mais uma vez o baixo desempenho do reator anaeróbio e a incapacidade do consórcio microbiano termofilico em converter a água residuária sintética.

Segundo Fernandez \& Forster (1993), organismos anaeróbios termofílicos são mais sensíveis a certos compostos inibitórios que sistemas mesofilicos e, de acordo com Dinsdale et al. (1997a), esta poderia ser a explicação dos baixos níveis de remoção de DQO e os altos níveis de ácidos voláteis.

Houve também muita perda de biomassa nessa etapa de operação do reator UASB, considerando os SSV no afluente e efluente do reator anaeróbio $\left(1505 \pm 238 \mathrm{mgSSV} . \mathrm{d}^{-1}\right.$ durante $5^{\mathrm{a}}$ etapa).

Uma das vantagens atribuídas ao reator UASB é justamente sua capacidade em reter biomassa. Segundo Lepisto \& Rintala (1999), a retenção de biomassa é alcançada pela formação de lodo granular com boas propriedades de sedimentação.

O lodo com o qual o reator UASB foi inoculado apresentava boa granulação, entretanto foi observado, ao longo do experimento, que muitos grânulos se desfizeram ou ficaram ocos. Isto ocorreu provavelmente pela baixa qualidade da água residuária sintética e ainda agravada pelo aumento da temperatura, visto que, de acordo com Lepisto \& Rintala (1999) em consórcio bacteriano anaeróbio imobilizado com a 
formação dos grânulos, a diversidade e a distribuição das bactérias são determinadas por vários fatores físico-químicos e biológicos.

Segundo Speece (1996), três indicadores do processo anaeróbio revelam seu bom ou mau funcionamento: porcentagem de metano no biogás, variação do $\mathrm{pH}$ e concentração de AGV. Nessa etapa da fase termofilica, todos os parâmetros atestaram o mau funcionamento do reator. A porcentagem de metano no biogás oscilou muito (1\% a $70 \%$ ), mantendo-se abaixo de $40 \%$ na maior parte dessa etapa; a concentração de AGV variou de $234 \mathrm{mg} . \mathrm{L}^{-1}$ a $364 \mathrm{mg} . \mathrm{L}^{-1}$, com alta concentração de ácido acético e o pH esteve sempre abaixo de 7.

O reator aeróbio apresentou eficiência de remoção de 43 a $59 \%$, com concentrações de ácidos variando de 45 a $90 \mathrm{mg} . \mathrm{L}^{-1}$ e de alcalinidade de 123 a 295 mg. $\mathrm{L}^{-1}$, como pode ser visto na Tabela 5.14.

No início dessa etapa foram detectadas altas concentrações de ácido acético (394,3 mg. $\left.\mathrm{L}^{-1}\right)$ e baixas de outros ácidos: propiônico, butírico e isovalérico, em concentrações de $20 \mathrm{mg} . \mathrm{L}^{-1} ; 0,4 \mathrm{mg} . \mathrm{L}^{-1}$ e $3,22 \mathrm{mg} . \mathrm{L}^{-1}$, respectivamente. Ao final da etapa as concentrações de ácido acético atingiram cerca de $4,7 \mathrm{mg} \cdot \mathrm{L}^{-1}$.

As concentrações de SSV no licor misto e no lodo de retorno foram as maiores obtidas em todo o experimento, variando de $1570 \mathrm{mg} . \mathrm{L}^{-1}$ a $2940 \mathrm{mg} . \mathrm{L}^{-1}$ e de $2529 \mathrm{mg} . \mathrm{L}^{-1}$ a $4120 \mathrm{mg} . \mathrm{L}^{-1}$, respectivamente. Provavelmente, devido à baixa eficiência de remoção de DQO do reator anaeróbio houve maior fração de biodegradáveis para o consórcio microbiano do reator aeróbio permitindo um aumento da biomassa.

Entretanto, no efluente do reator aeróbio, as concentrações de sólidos suspensos voláteis foram as maiores registradas no experimento, variando de $40 \mathrm{mg} . \mathrm{L}^{-1}$ a $144 \mathrm{mg} . \mathrm{L}^{-1}$, porém abaixo dos valores obtidos por Jahren et al. (2002), como citado na etapa anterior.

No final dessa etapa panes sucessivas no sistema de aquecimento anteciparam o encerramento da operação com o sistema de reatores. Na temperatura de $57^{\circ} \mathrm{C}$ o sistema foi operado por 37 dias.

A variação dos parâmetros monitorados pode ser visualizada na Tabela $5.14 \mathrm{e}$ nas Figuras de 5.12 a 5.17, página 115 a 118. 
TABELA 5.14- Faixa de variação dos parâmetros monitorados na quinta etapa da Fase termofilica $\left(355^{\circ}\right.$ ao $390^{\circ}$ dia) nos reatores anaeróbio e aeróbio respectivamente.

\begin{tabular}{|c|c|c|c|c|c|c|}
\hline \multirow{2}{*}{ Parâmetros } & \multicolumn{2}{|c|}{ ARS } & \multicolumn{2}{|c|}{$\begin{array}{l}\text { Efluente } \\
\text { UASB }\end{array}$} & \multicolumn{2}{|c|}{$\begin{array}{c}\text { Efluente } \\
\text { Lodos ativados }\end{array}$} \\
\hline & $\begin{array}{l}\text { Faixa de } \\
\text { variação }\end{array}$ & $\begin{array}{l}\text { Média } \pm D P \\
\text { (n) }\end{array}$ & $\begin{array}{l}\text { Faixa de } \\
\text { variação }\end{array}$ & $\begin{array}{l}\text { Média } \pm \mathrm{DP} \\
\text { (n) }\end{array}$ & $\begin{array}{l}\text { Faixa de } \\
\text { variação }\end{array}$ & $\begin{array}{l}\text { Média } \pm \text { DP } \\
\text { (n) }\end{array}$ \\
\hline DQO ${ }_{\text {total }}\left(\mathrm{mg} \cdot \mathrm{L}^{-1}\right)$ & $\begin{array}{c}1113-1357 \\
(6)\end{array}$ & $\begin{array}{l}1239 \pm 83 \\
\text { (6) }\end{array}$ & $\begin{array}{l}951-1657 \\
\text { (6) }\end{array}$ & $\begin{array}{l}1124 \pm 274 \\
\text { (6) }\end{array}$ & $\begin{array}{c}416-542 \\
(6)\end{array}$ & $\begin{array}{l}487 \pm 57 \\
(6)\end{array}$ \\
\hline $\begin{array}{l}\text { Eficiência de } \\
\text { remoção (\%) }\end{array}$ & - & - & $13-24(6)$ & $20 \pm 4(6)$ & $43-75(6)$ & $\begin{array}{l}55 \pm 11 \\
(6)\end{array}$ \\
\hline $\begin{array}{l}\mathrm{DQO}_{\text {fittrada }} \\
\left(\mathrm{mg} \cdot \mathrm{L}^{-1}\right)\end{array}$ & $\begin{array}{l}1042-1301 \\
(6)\end{array}$ & $\begin{array}{l}1142 \pm 98 \\
(6)\end{array}$ & $\begin{array}{l}690-940 \\
(6)\end{array}$ & $\begin{array}{c}789 \pm 87 \\
(6)\end{array}$ & $\begin{array}{l}248-419 \\
(6)\end{array}$ & $\begin{array}{l}355 \pm 61 \\
(6)\end{array}$ \\
\hline $\begin{array}{l}\text { Eficiência de } \\
\text { remoção (\%) }\end{array}$ & - & - & $22-39(6)$ & $31 \pm 6(6)$ & $42-69(6)$ & $\begin{array}{l}54 \pm 10 \\
(6)\end{array}$ \\
\hline $\mathrm{pH}$ & $\begin{array}{l}6,0-7,3 \\
(7)\end{array}$ & - & $\begin{array}{l}5,0-6,6 \\
(7)\end{array}$ & - & $\begin{array}{l}7,5-8,1 \\
(7)\end{array}$ & - \\
\hline $\begin{array}{l}\text { Alcalinidade } \\
\left(\mathrm{mg}, \mathrm{L}^{-1}\right)\end{array}$ & $39-79(7)$ & $\begin{array}{l}63 \pm 15 \\
(7)\end{array}$ & $0-47(7)$ & - & $\begin{array}{l}123-295 \\
(7)\end{array}$ & $\begin{array}{l}200 \pm 59 \\
\quad(7)\end{array}$ \\
\hline Ácidos $\left(m g . L^{-1}\right)$ & $\begin{array}{l}97-143 \\
(7)\end{array}$ & $\begin{array}{l}124 \pm 17 \\
\text { (7) }\end{array}$ & $\begin{array}{c}234-364 \\
(7)\end{array}$ & $\begin{array}{l}296 \pm 50 \\
(7)\end{array}$ & $24-90$ & $\begin{array}{l}56 \pm 21 \\
(7)\end{array}$ \\
\hline $\begin{array}{l}\text { ST }\left(m g . L^{-1}\right) \\
\text { STV }\left(m g . L^{-1}\right) \\
\text { STF }\left(m g \cdot L^{-1}\right)\end{array}$ & $\begin{array}{c}705-1073(7) \\
26-576 \\
354-1035\end{array}$ & - & $\begin{array}{c}479-1262(7) \\
29-742 \\
390-1050\end{array}$ & - & $\begin{array}{c}855-1132(7) \\
6-499 \\
394-965\end{array}$ & - \\
\hline $\begin{array}{l}\left.\text { SST (mg. } L^{-1}\right) \\
\left.\text { SSV (mg. } L^{-1}\right)\end{array}$ & $\begin{array}{c}38-189(7) \\
6-170\end{array}$ & - & $\begin{array}{c}140-220(7) \\
4-172\end{array}$ & - & $\begin{array}{c}67-167(7) \\
3-144\end{array}$ & - \\
\hline $\mathrm{CH}_{4}(\%)$ & - & - & $4-70(7)$ & - & - & - \\
\hline
\end{tabular}

Obs.: DP: desvio padrão; (n): número de observações.

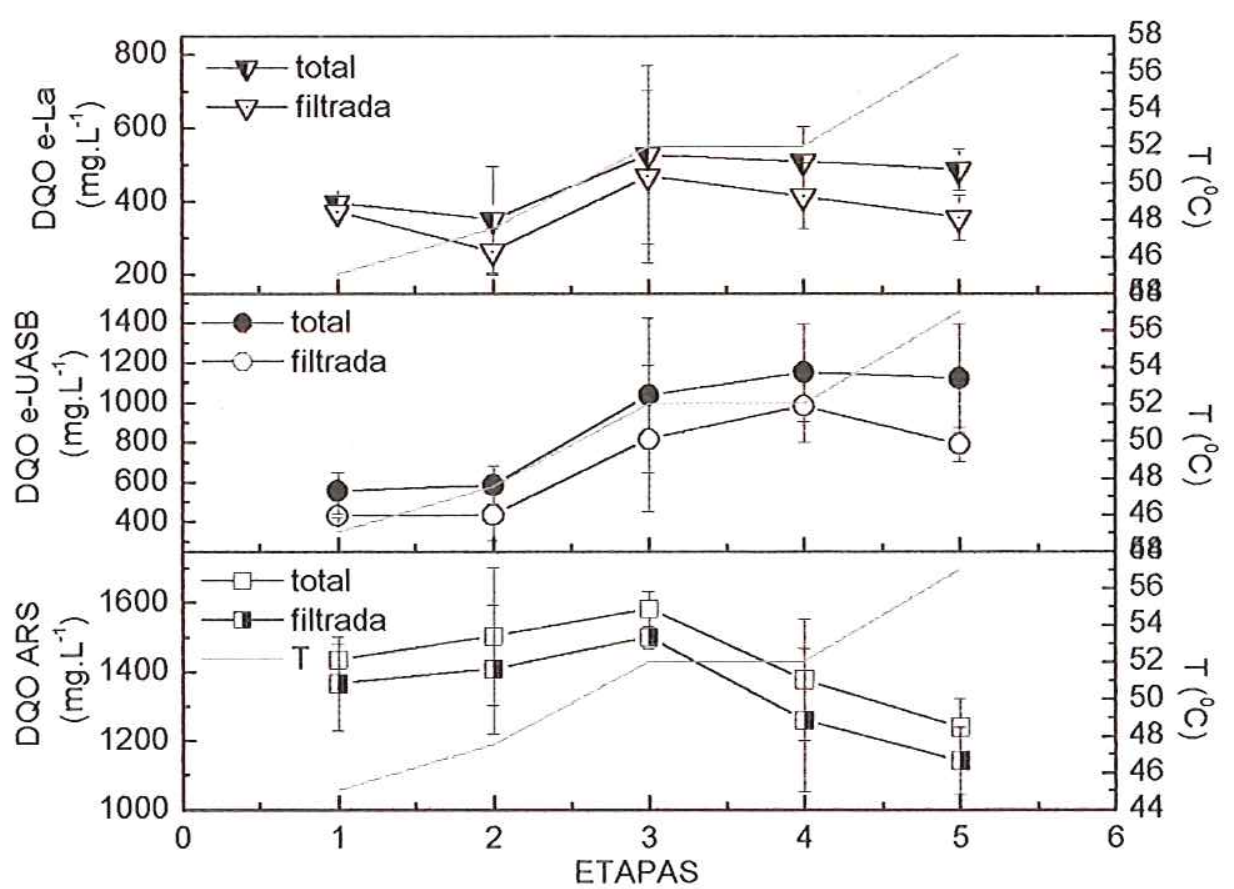

FIGURA 5.12 - Médias da DQO total e filtrada da água residuária sintética (ARS), do efluente do reator UASB (e-UASB) e do efluente do reator de lodos ativados (e-LA) nas 5 etapas da fase termofilica, considerando as diferentes temperaturas de operação. 


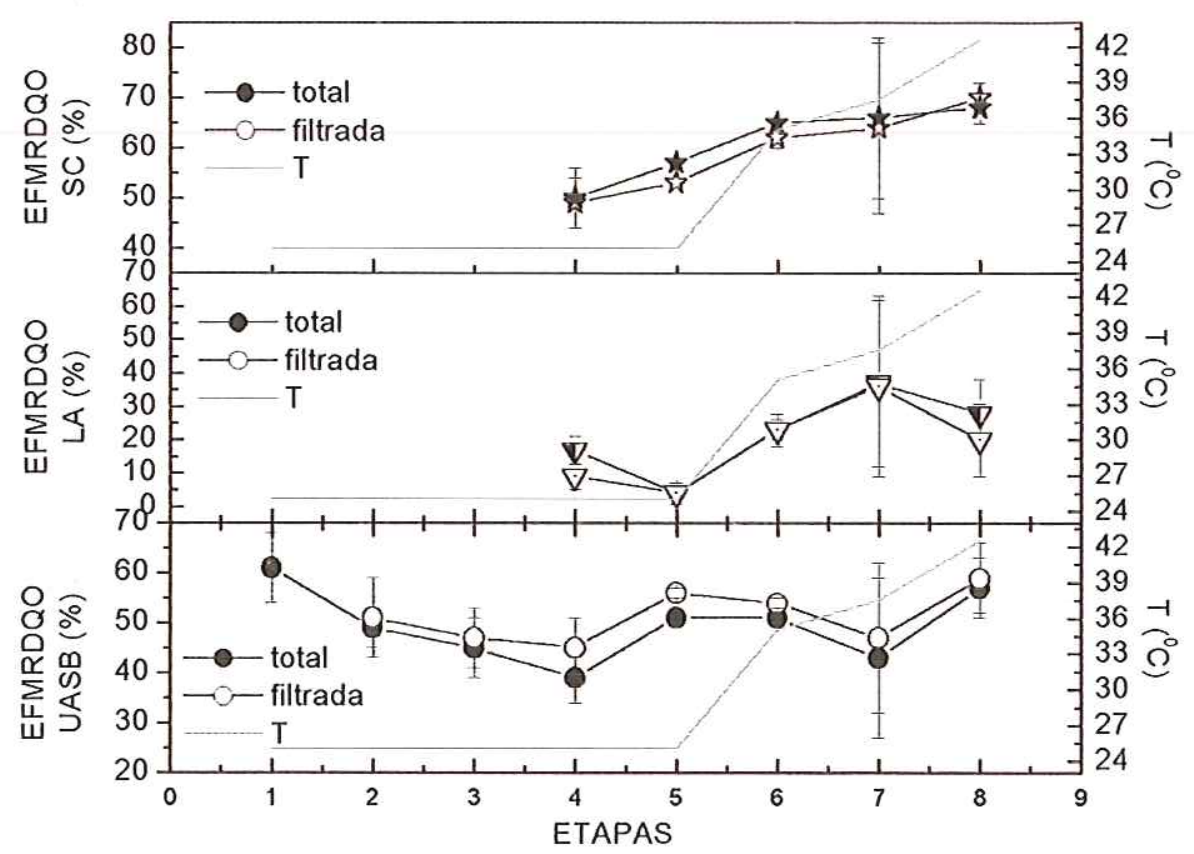

Siglas: EFMRDQO: média da eficiência de remoção de DQO; SC: sistema combinado; T - temperatura.

FIGURA 5.13 - Médias da eficiência de remoção de DQO total e filtrada da água residuária sintética (ARS), do efluente do reator UASB (e-UASB) e do efluente do reator de lodos ativados (e-LA) nas 5 etapas da fase termofilica, considerando as diferentes temperaturas de operação.

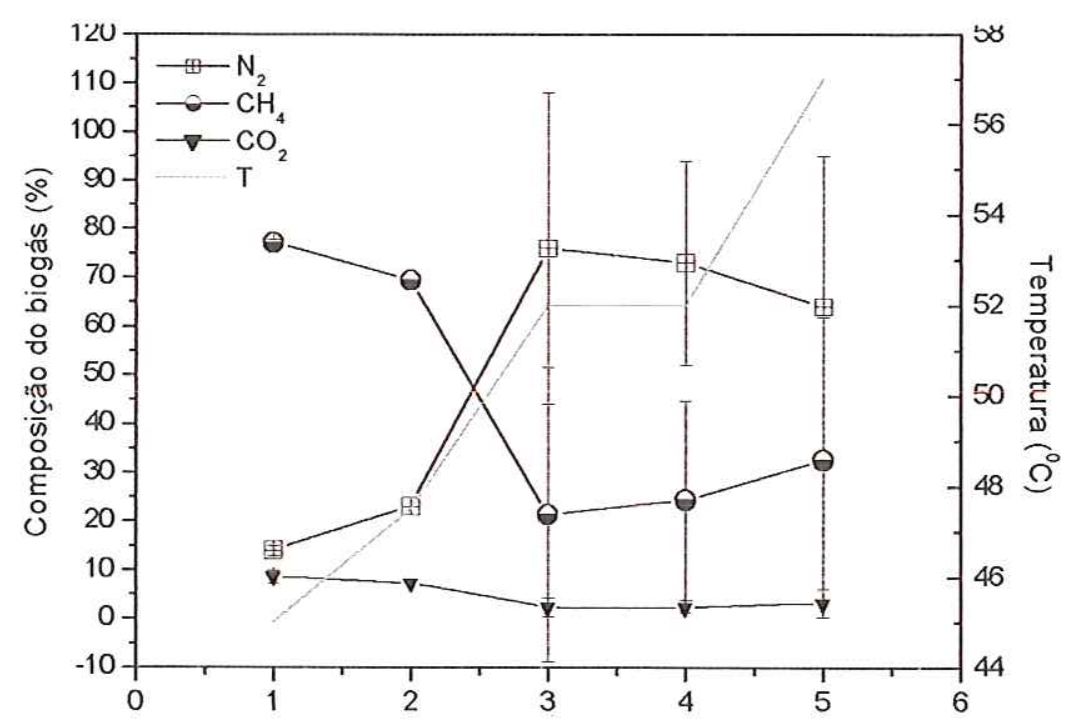

FIGURA 5.14 - Médias das concentrações de nitrogênio $\left(\mathrm{N}_{2}\right)$, Metano $\left(\mathrm{CH}_{4}\right)$ e Gás carbônico $\left(\mathrm{CO}_{2}\right)$ na composição do biogás do reator UASB nas 5 etapas da fase termofilica, considerando as diferentes temperaturas de operação (T). 


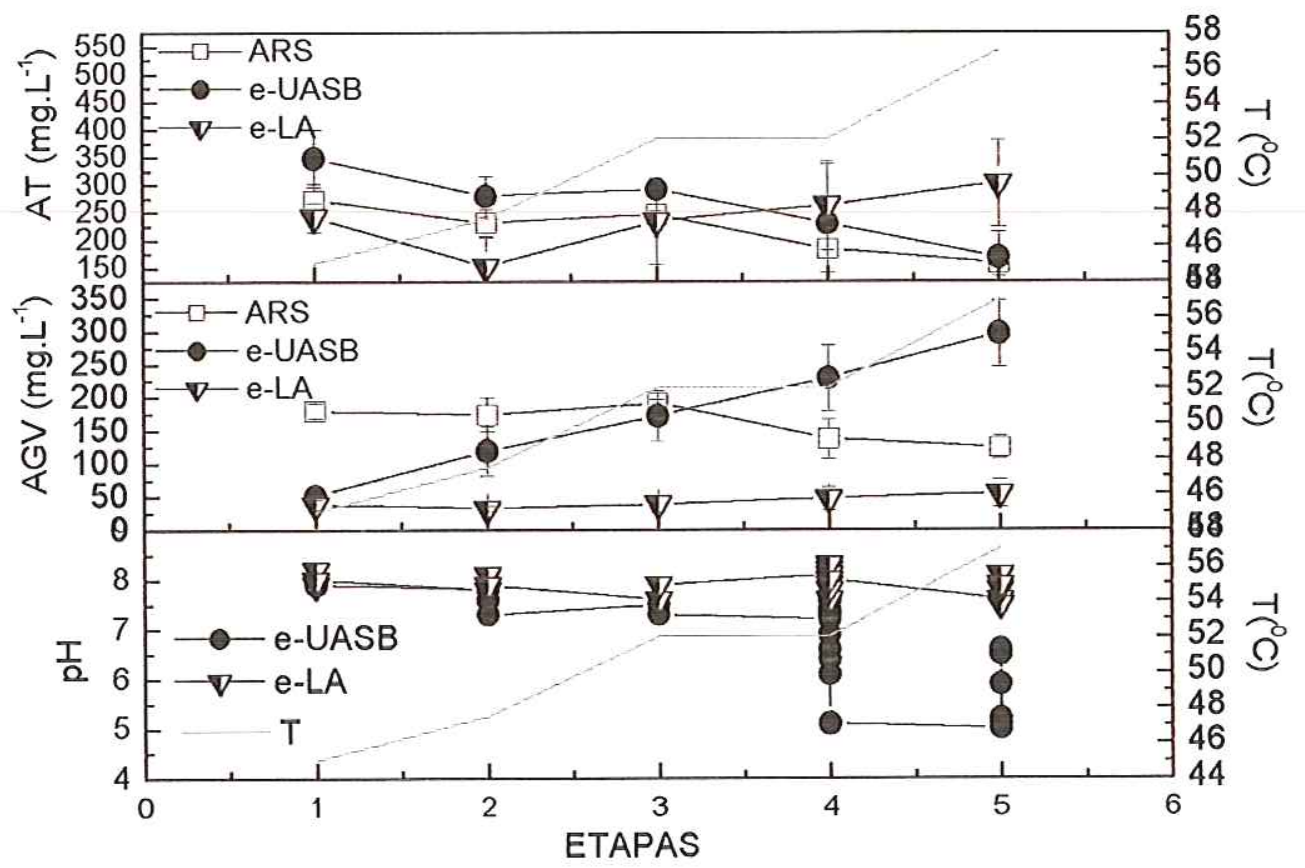

FIGURA 5.15 - Valores de pH e médias das concentrações de ácidos graxos voláteis (AGV) e alcalinidade total (AT) na água residuária sintética (ARS) e efluentes do reator UASB (e-UASB) e do reator de lodos ativados (e-LA) nas 5 etapas da fase termofilica, considerando as diferentes temperaturas de operação $(\mathrm{T})$.

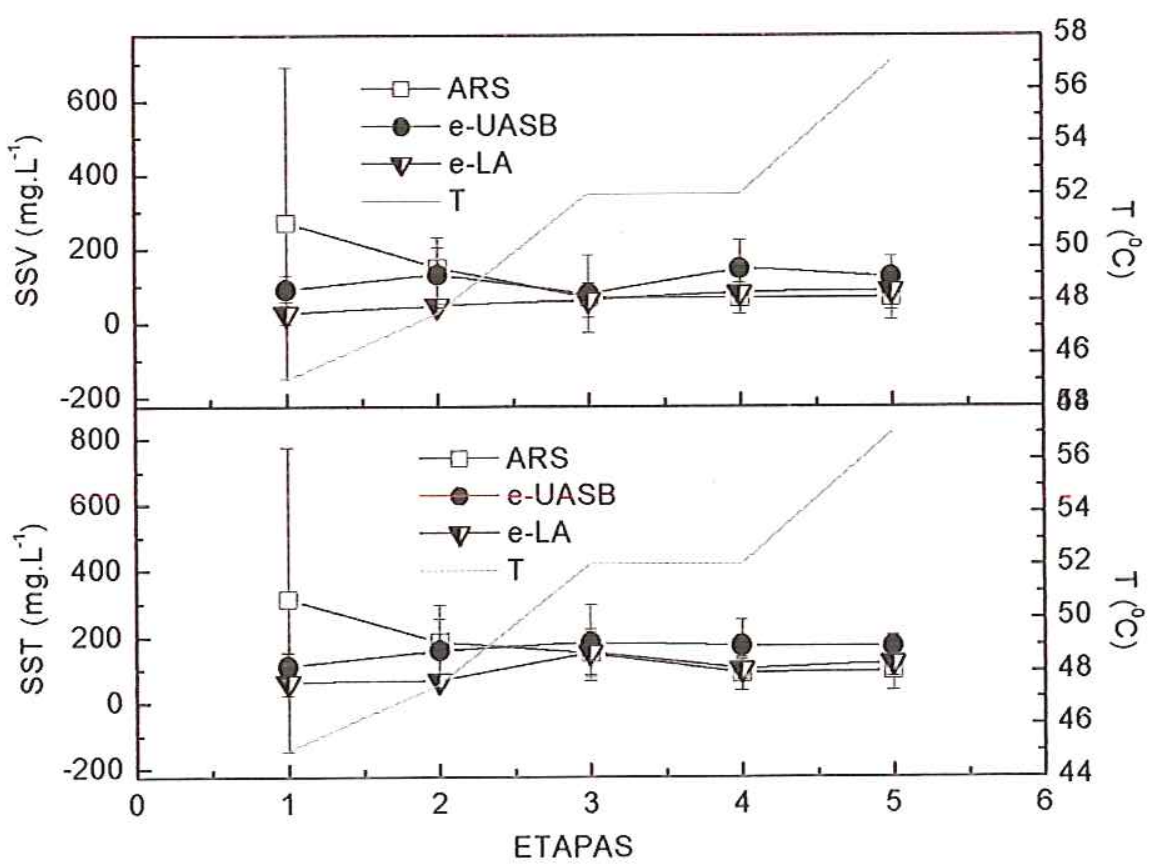

FIGURA 5.16 - Valores médios e desvios das concentrações de sólidos suspensos totais (SST) e sólidos suspensos voláteis (SSV) na água residuária sintética (ARS) e efluentes do reator UASB (e-UASB) e do reator de lodos ativados (e-LA), nas 5 etapas da fase termofilica, considerando as diferentes temperaturas de operação $(\mathrm{T})$. 


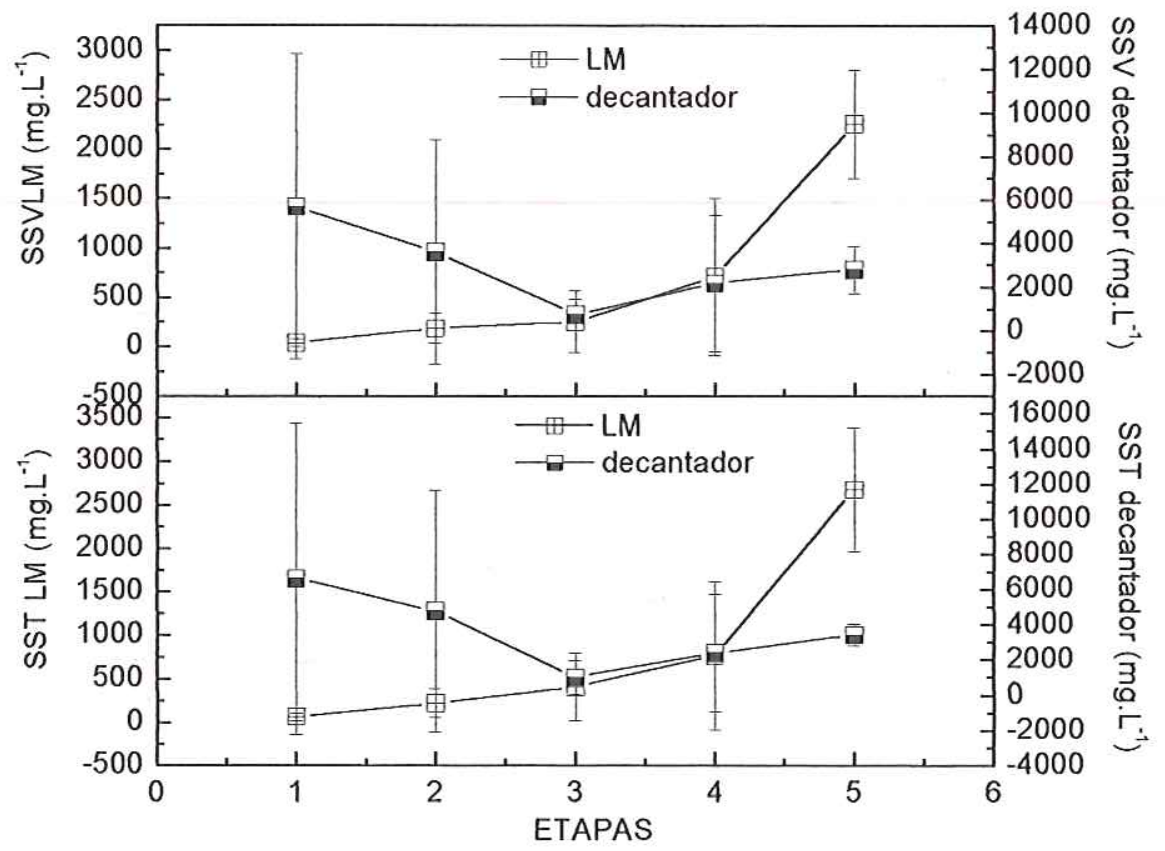

FIGURA 5.17 - Valores médios e desvios das concentrações de sólidos suspensos totais (SST) e sólidos suspensos voláteis (SSV) no licor misto (LM) e decantador do reator aeróbio, nas 5 etapas da fase termofilica, considerando as diferentes temperaturas de operação (T).

\subsubsection{Avaliação do desempenho dos reatores na fase termofílica}

Os resultados revelaram que o reator anaeróbio foi mais instável quando operado na faixa de temperatura termofílica. Após o aumento de $47,5^{\circ} \mathrm{C}$ para $52,0^{\circ} \mathrm{C}$ o reator UASB não retomou a eficiência inicial, mantendo-se instável por 54 dias, diferentemente do comportamento observado por Lau \& Fang (1997), onde o reator UASB com ajuste de temperatura mais drástico, de $55^{\circ} \mathrm{C}$ para $65^{\circ} \mathrm{C}$, retomou a eficiência em aproximadamente 20 dias.

Também foi verificado acúmulo de ácidos em ambos reatores durante a fase termofilica. Essa acidificação pode ser correlacionada a instabilidades na eficiência de remoção de DQO e também na produção de metano. Também foi verificada maior perda de sólidos pelo efluente na fase termofílica.

Lau e Fang (1997) compararam a porcentagem de metano no biogás com a acidificação e com a potencial porcentagem de metano durante a operação de reator anaeróbio a $55^{\circ} \mathrm{C}$ e a $65^{\circ} \mathrm{C}$. Segundo os autores, a leve acidificação a $65^{\circ} \mathrm{C}$ e os valores muito similares encontrados para a potencial porcentagem de metano no biogás, 
indicam que a baixa porcentagem de metano no biogás a $65^{\circ} \mathrm{C}$ foi resultado da incapacidade do consórcio metanogênico converter os ácidos eficientemente em alta temperatura. Além disso, o acúmulo de $\mathrm{AGV}$ pode reduzir o $\mathrm{pH}$ e inibir a reação metanogênica, levando ao fracasso do sistema.

No presente trabalho, como pôde ser visto, ácido propiônico foi detectado em três das quatro etapas termofílicas. De acordo com Speece (1996), baixas concentrações de propionato são indicativos de bom funcionamento do processo anaeróbio, altas, dificuldades em um ou mais passos do metabolismo anaeróbio. Apesar das análises cromatográficas estarem sendo feitas desde a última etapa mesofilica, apenas no final da terceira etapa termofílica é que ácido propiônico passou a ser detectado, coincidindo com o desempenho decrescente do reator.

Nas quarta e quinta etapas termofilicas, ácido acético foi o ácido encontrado em maior concentração. Nessas duas etapas também foi encontrado ácido butírico. De acordo com Ahring et al. (2001), a degradação de butirato parece ser afetada pela concentração de acetato. Em seu experimento foi verificado que durante o período de transição, aumento e decréscimo da concentração de butirato foram acompanhados por acúmulo e conversão de acetato, respectivamente.

Sob condições anaeróbias os carboidratos são primeiramente convertidos pelas acidogênicas em AGV como ácido propiônico e butírico. Estes intermediários são então convertidos pelas acetogênicas em ácido acético e hidrogênio. Finalmente, acetato é convertido pelas metanogênicas acetotróficas em metano. As metanogênicas hidrogenotróficas fazem a conversão a $\mathrm{H}_{2}$ e $\mathrm{CO}_{2}$. O acúmulo de $\mathrm{AGV}$ pode reduzir o $\mathrm{pH}$ e inibir a reação metanogênica, levando ao fracasso do sistema. (LAU \& FANG, 1997). Segundo Lau \& Fang (1997), as metanogênicas acetotróficas não foram tão sensíveis à temperatura de choque como as outras bactérias

No reator anaeróbio houve grande perda de sólidos voláteis e instabilidade operacional na fase termofilica.

No início da fase termofilica foi observado um acúmulo de gás na parte inferior do reator UASB, que permaneceu durante toda esta fase do experimento. Todas estas observações correlacionadas podem ser justificadas por Samson et al. (1990). De acordo com os autores, a pressão hidrodinâmica em reatores UASB pode funcionar como seletora de grânulos. Esta pressão de seleção é definida como a soma da carga hidráulica aplicada e velocidade de produção de gás. O aumento na velocidade 
ascensional do líquido e o volume do gás gerado levam à seleção das partículas componentes do lodo com diferentes propriedades de sedimentação. Logo, partículas mais densas são retidas no reator, enquanto o lodo disperso ou pouco floculento é arrastado para fora. A flotação do lodo pode levar à perda de biomassa e, conseqüentemente, instabilidade no funcionamento de reatores do tipo UASB.

Kosaric et al. (1990) relataram que a flotação é causada pela formação de espaços ocupados por gases no centro do grânulo, criados, provavelmente, pelo decaimento e lise dos microrganismos situados no centro dos grânulos maiores, devido à falta de substrato. Entretanto, de acordo com Speece, (1996) a taxa de decaimento da biomassa termofilica é duas vezes maior que a da mesofilica pela tendência de lise da célula sob condições termofilicas, o que justificaria a presença de gases no interior do grânulo termofílico e sua flotação.

De maneira geral, os resultados obtidos para o reator anaeróbio confirmaram Speece (1996). De acordo com esse autor, a qualidade do efluente de reatores convencionais anaeróbios tratando água residuária das indústrias de polpa e papel foi pior em reatores termofilicos do que nos mesofilicos.

Van Lier et al. (1996) encontraram resultados mais estáveis para reatores UASB termofílicos quando operados com taxa de carregamento moderada $\left(20 \mathrm{kgDQO} \cdot \mathrm{m}^{-3} \cdot \mathrm{d}^{-1}\right.$ a $\left.40 \mathrm{kgDQO} \cdot \mathrm{m}^{-3} \cdot \mathrm{d}^{-1}\right)$. Neste trabalho, os valores da taxa de carregamento orgânico estiveram bem abaixo dos citados pelos autores $\left(0,2 \mathrm{kgDQO} \cdot \mathrm{m}^{-3} \cdot \mathrm{d}^{-1}\right.$ a $\left.2,0 \mathrm{kgDQO} \cdot \mathrm{m}^{-3} \cdot \mathrm{d}^{-1}\right)$.

Considerando-se o reator aeróbio, em relação à concentração de SSV na fase termofílica, foi verificado aumento considerável da biomassa quando comparado à fase mesofilica provavelmente pela maior fração de alimento disponível devido à baixa eficiência de remoção de DQO do reator anaeróbio. Entretanto, também aumentaram as perdas no efluente. Perdas de SSV em efluentes também foram verificadas por JAHREN et al. (2002) e Barr et al. (1996). No presente trabalho, as perdas de SSV não se concentraram em uma única etapa, tendo apresentado como valores mínimo e máximo, $65 \mathrm{mg} . \mathrm{d}^{-1}$ e $1795 \mathrm{mg} . \mathrm{d}^{-1}$, sendo os maiores valores obtidos na quarta etapa e início da quinta. Esses valores ficaram bem abaixo dos encontrados por Jahren et al. (2002) e acima dos obtidos por Barr et al. (1996).

No trabalho de Barr et al. (1996) a concentração de SSV no efluente tratado ficou abaixo de $54 \mathrm{mg} . \mathrm{L}^{-1}\left(42,4 \mathrm{mg} \cdot \mathrm{L}^{-1} \pm 8,4 \mathrm{mg} \cdot \mathrm{L}^{-1}\right)$, indicando boas características de 
sedimentação. Os valores foram comparáveis aos obtidos na fase mesofilica de operação $\left(45,5 \mathrm{mg} \cdot \mathrm{L}^{-1} \pm 11,2 \mathrm{mg} \cdot \mathrm{L}^{-1}\right)$. Tendo operado em temperaturas nas faixas mesofilica $\mathrm{e}$ termofílica, os autores não identificaram turbidez no efluente, nas temperaturas estudadas. Barr et al. (1996) correlacionam a baixa sedimentação e turbidez efluente em muitos trabalhos termofilicos, à pequena idade do lodo (5 a 8 dias) e à configuração de reatores sem retorno dos sólidos do clarificado.

Considerando os resultados obtidos para a concentração de sólidos voláteis no licor misto na faixa termofilica deste trabalho, os valores encontrados foram baixos desde a primeira etapa até a metade da terceira $\left(47,5^{\circ} \mathrm{C}\right.$ a $\left.52,0^{\circ} \mathrm{C}\right)$. A partir daí, os resultados foram satisfatórios, variando de 1570 a $2940 \mathrm{mg} . \mathrm{L}^{-1}$. Concentrações de SSV no licor misto de 1400 a $1700 \mathrm{mg} \cdot \mathrm{L}^{-1}$ foram encontradas por Jahren et al. (2002) e consideradas baixas. Os autores obtiveram esses resultados em reator aeróbio com biofilme e leito móvel, a $55^{\circ} \mathrm{C}$, tratando licor branco de polpação termomecânica. A pequena formação de biomassa poderia ser justificada por duas hipóteses: baixas taxas de carregamento $\left(2,5 \mathrm{~kg}\right.$.DQO. $\mathrm{m}^{-3} \cdot \mathrm{d}^{-1}$ a $3,5 \mathrm{~kg}$.DQO. $\left.\mathrm{m}^{-3} \cdot \mathrm{d}^{-1}\right)$ ou limitação de nutrientes.

De acordo com os autores, a relação DQO:N:P de 100:2,2:0,5 indicou possibilidade de deficiência em nitrogênio ou fósforo no reator, causando baixa produção de lodo e redução na eficiência de remoção. No presente trabalho, não houve adição de nutrientes entre o reator anaeróbio e o aeróbio, sendo o afluente do reator de lodos ativados dependente do desempenho do reator UASB.

Estes resultados se contrapõem aos obtidos por Barr et al. (1996), que verificaram, em elevadas temperaturas, concentração média de $\operatorname{SSV}_{\mathrm{LM}}$ de (1610 191$) \mathrm{mg} . \mathrm{L}^{-1}$, valores comparáveis aos observados neste trabalho, em menores temperaturas, $(1675 \pm 191) \mathrm{mg} \cdot \mathrm{L}^{-1}$.

Considerando-se a análise da concentração de oxigênio dissolvido, esta foi limitada pelo medidor de oxigênio. Barr et al. (1996) também encontraram essa limitação e sugeriram que as análises deveriam ser realizadas a $45^{\circ} \mathrm{C}$.

Zinder (1986) citou que Salkinoja-Salonen et al. (1983) $)^{40}$ atingiram bons resultados na operação de reator de leito fluidizado, termofílico $\left(40^{\circ} \mathrm{C}\right.$ a $\left.60^{\circ} \mathrm{C}\right)$, em escala piloto, alimentado com água residuária da indústria de papel branqueado ou seja, contendo compostos aromáticos clorados.

${ }^{40}$ SALKINOJA-SALONEN, M.; VALO, R.; APAJALAHTI, I. (1983). In: Third Intemacional Symposium on Anaerobic Digestión: Proceedings. Boston, 1983, p. 107. 


\subsection{Efeito da temperatura na comunidade microbiana dos reatores}

\subsubsection{Fase mesofilica}

O monitoramento microbiológico foi feito após cada alteração na temperatura, utilizando microscopia óptica.

\subsubsection{Faixa de temperatura entre 25,0 e $32,5^{\circ} \mathrm{C}$ (etapas 1 a 6 )}

Inicialmente não havia o controle de temperatura na cabine de madeira onde o reator foi montado, entretanto, na sala o controle era feito por meio de ar condicionado, ajustado para $25^{\circ} \mathrm{C}$.

O trabalho experimental foi iniciado com a inoculação apenas do reator anaeróbio. O lodo utilizado como inóculo era granulado, com morfologias celulares diversificadas, com predomínio aparente de Methanosaeta sp. e Methanosarcina sp. (Figura 5.18).

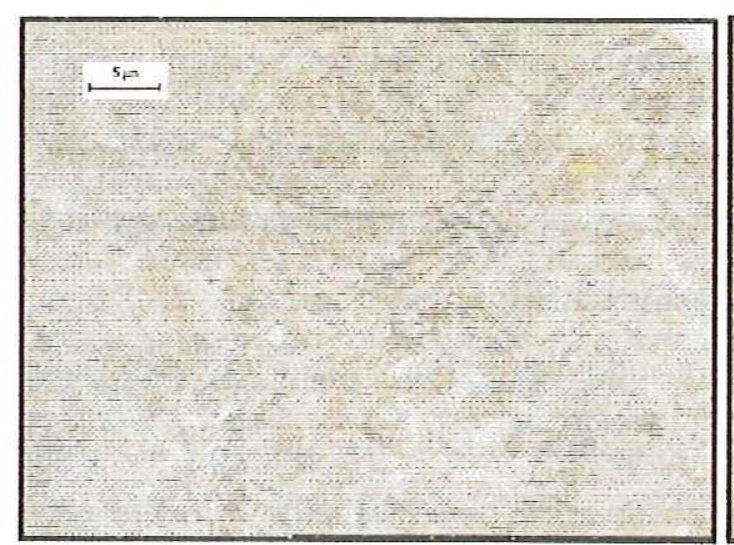

(a)

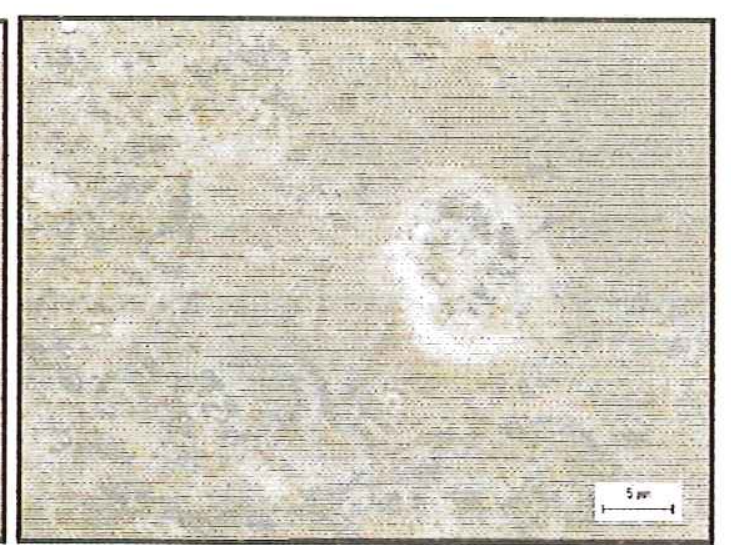

(b)

FIGURA 5.18. Inóculo do reator UASB: Methanosaeta sp. (a) e Methanosarcina sp. (b).

Na segunda etapa da fase mesofílica, após 50 dias do início do trabalho experimental foi feita microscopia para avaliar a adaptação da microbiota anaeróbia ao substrato e às condições operacionais. Nesta etapa o reator UASB estava sendo operado em temperatura ambiente com tempo de detenção de 30 horas. Tal exame revelou a presença de bacilos e sarcinas com fluorescência tênue (Figura 5.19a).

O inóculo do reator de lodos ativados também foi caracterizado. Este inóculo havia sido coletado em reator de lodos ativados mesofílico na estação de tratamento da indústria de papel e celulose VCP - unidade de Luís Antônio/SP. O tanque de aeração 
da VCP era de $330 \mathrm{~m}^{3}$ e o reator operava com tempo de detenção de $3,3 \mathrm{~h}$ e segundo técnicos com efíciência de remoção de DBO superior a $90 \%$. O objetivo da utilização do inóculo da estação desta indústria foi visando otimizar a adaptação do lodo ao efluente do reator anaeróbio.

O reator inoculado foi mantido em batelada alimentada por aproximadamente quinze dias, visto que a qualidade do inóculo utilizado não era boa, por ter sido coletado na época em que a indústria fazia uma parada em seu processo de produção e limpeza de equipamentos, ocasionando portanto, possíveis alterações da microbiota. Deve ser ressaltado que quando foi feita a inoculação deste reator não havia disponibilidade de bons inóculos aeróbios na região.

No inóculo do reator de lodos ativados foram observados protozoários semelhantes a Vorticela sp., filamentos semelhantes a Thiothrix sp., livres natantes e bactérias. Deve-se considerar que, de acordo com Jenkins et al. (1993), flocos de lodos ativados desenvolvidos em águas residuárias industriais freqüentemente exibem uma variedade mais limitada de tipos morfológicos de bactérias, dependendo da composição do resíduo (Figura 5.19b).

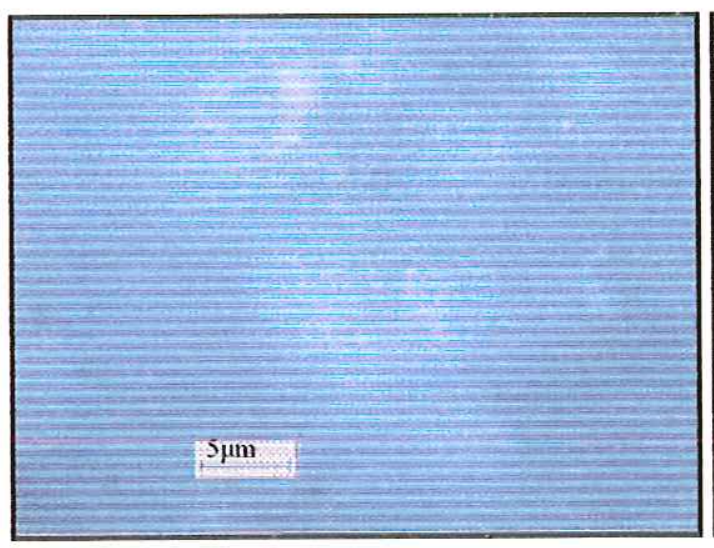

(a)

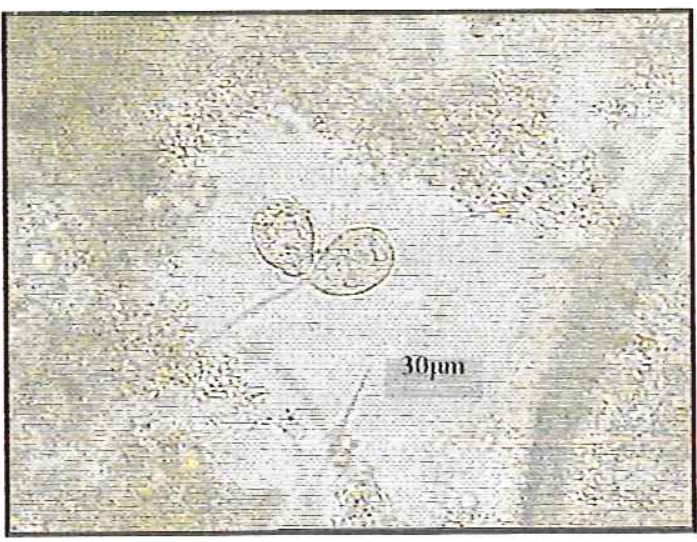

(b)

FIGURA 5.19. Microrganismos visualizados na $2^{\text {a }}$ etapa mesofilica $\left(25^{\circ} \mathrm{C}\right)$ : Bacilos e sarcinas com fluorescência tênue no reator UASB (a) e protozoário semelhante a Vorticella sp., um dos organismos com predomínio aparente no inóculo do reator aeróbio (b).

Os reatores começaram a ser operados em sistema contínuo na quarta etapa mesofílica. Inicialmente, a eficiência de remoção de DQO do reator aeróbio manteve-se baixa mas estável, em torno de $22 \%$. Porém, dez dias após o início da operação do sistema, estes valores começaram a decrescer. Foi verificada uma baixa concentração de biomassa no licor misto do reator, em torno de $340 \mathrm{mg}$. SSV.L ${ }^{-1}$, optou-se por fazer uma 
adição de lodo, obtido da estação de tratamento aeróbio por lodos ativados da indústria de corantes Faber-Castell (São Carlos). O reator não foi mantido em batelada, apenas foi adicionado 1,0L do lodo no tanque de aeração. A qualidade deste lodo também não era a desejada, visto que a diversidade era baixa e havia muita bactéria em suspensão. Também havia ciliados pedunculados semelhantes a Opercularia sp. (Figura 5.20d). A adição deste lodo entretanto, aumentaria a massa microbiana no reator aeróbio antes do ajuste gradual da temperatura. Assim, exames microscópicos para caracterização da microbiota foram feitos nos reatores.

No reator UASB haviam células semelhantes a Methanosaetas sp., que predominavam, poucas sarcinas com fluorescência tênue e bacilos (Figura 5.20a). No trabalho de Buzzini (2000), operando em condições semelhantes, também foram verificadas a presença de bactérias semelhantes às redutoras de sulfato e bacilos fluorescentes.

No reator de lodos ativados foram observados protozoários semelhantes a Euglypha sp. e predominância de flagelados, indicando a presença de alta concentração de matéria orgânica dissolvida. Também foram visualizados alguns ciliados e rotíferos (Figura 5.20b). No inóculo aeróbio havia pouca diversidade com muita bactéria em suspensão e ciliados pedunculados (Figura 5.20c).

Nolasco (1998), operando um reator de lodos ativados alimentado com substrato que tinha como base o licor negro também observou rotíferos e ciliados fixos. Deve-se ressaltar que o autor operou em temperatura de $(22 \pm 2)^{0} \mathrm{C}$ com tempo de detenção hidráulica de 8,7 horas e no presente trabalho, na quarta etapa, o reator de lodos ativados foi operado em temperatura ambiente $\left(25^{\circ} \mathrm{C}\right)$ e tempo de detenção hidráulica de 20 horas. 


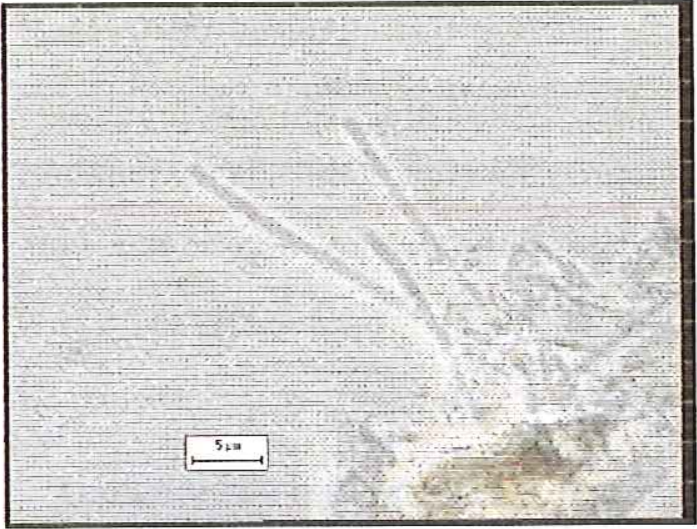

(a)

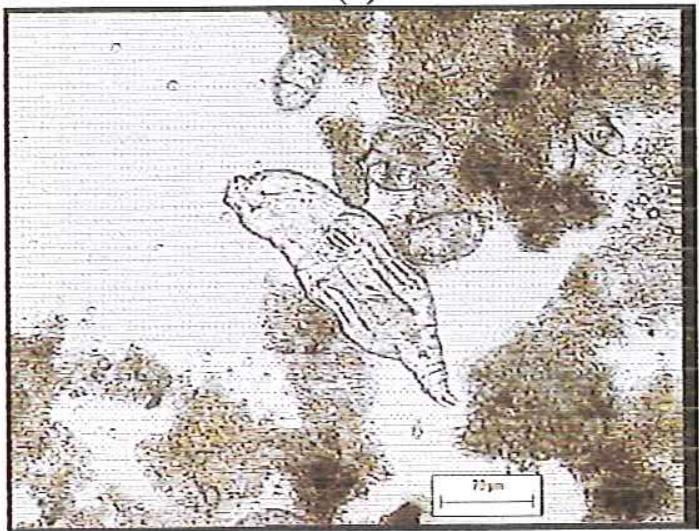

(c)

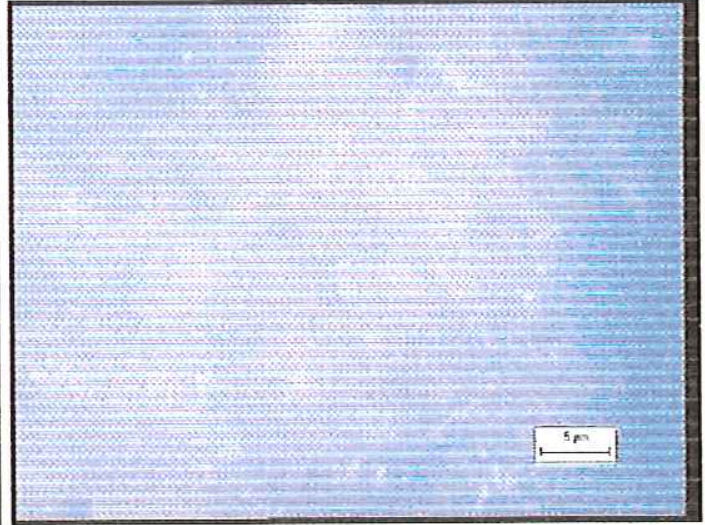

(b)

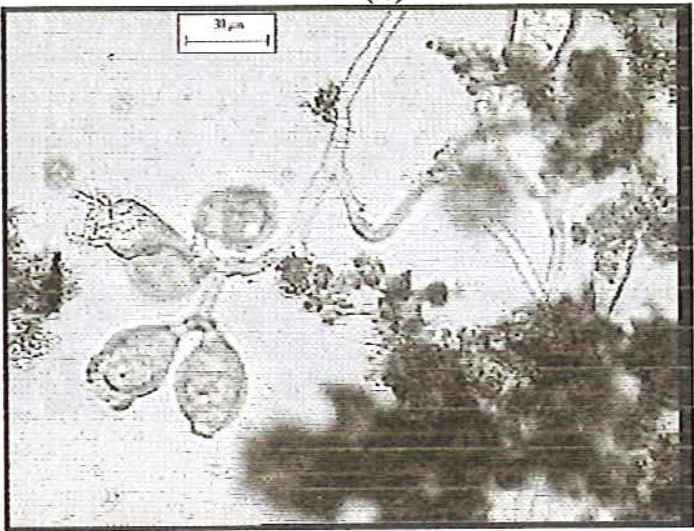

(d)

FIGURA 5.20. Microrganismos visualizados na $4^{\text {a }}$ etapa mesofilica $\left(25^{\circ} \mathrm{C}\right)$ : semelhantes a Methanosaeta sp. (a) e bacilos fluorescentes (b) presentes no reator UASB; Rotífero presente no reator de lodos ativados (c) e ciliados fixos semelhantes a Opercularia sp. no inóculo aeróbio da Faber (d).

\subsubsection{Faixa de temperatura entre $32,5^{\circ} \mathrm{C}$ e $42,5^{\circ} \mathrm{C}$ (etapas 6 a 8 )}

No fim da $5^{\mathrm{a}}$ etapa, com 37 dias de operação do sistema, a temperatura da cabine foi ajustada para $30^{\circ} \mathrm{C}$. Aproximadamente uma semana após, a temperatura foi aumentada para $32,5^{\circ} \mathrm{C}$, sendo os reatores operados por mais 10 dias.

Quatro dias após a alteração na temperatura para $35^{\circ} \mathrm{C}$ houve acidificação no reator anaeróbio ( $7^{\mathrm{a}}$ etapa), provocada por aumento súbito na DQO afluente, provavelmente devido a variação nas características do licor negro utilizado no preparo do substrato, além do estresse provocado pelo aumento da temperatura.

Nova microscopia foi feita aproximadamente 20 dias após ajuste na temperatura para $35^{\circ} \mathrm{C}$. No reator UASB foi revelada a presença de bacilos de diferentes morfologias, e semelhantes aos gêneros Methanosarcina sp. e Methanosaeta sp., com predomínio de bacilos delgados fluorescentes (Figura 5.21).

No reator de lodos ativados estavam presentes rotíferos e ciliados livres natantes semelhantes a Aspidisca sp. e Paramecium sp. Os ciliados usualmente ocorrem sob 
condições de boa formação do floco e geralmente indicam boa atividade operacional dos reatores de lodos ativados (JENKIN et al., 1993). No período inicial desta $7^{\text {a }}$ etapa, apesar das alterações feitas no substrato e temperatura, além da eficiência de remoção do reator UASB ter atingido $13 \%$, o reator de lodos ativados apresentou bom desempenho com efíciência de remoção variando de 69 a $73 \%$. Na Figura 5.22 é apresentada a forma do floco nesta fase de operação.

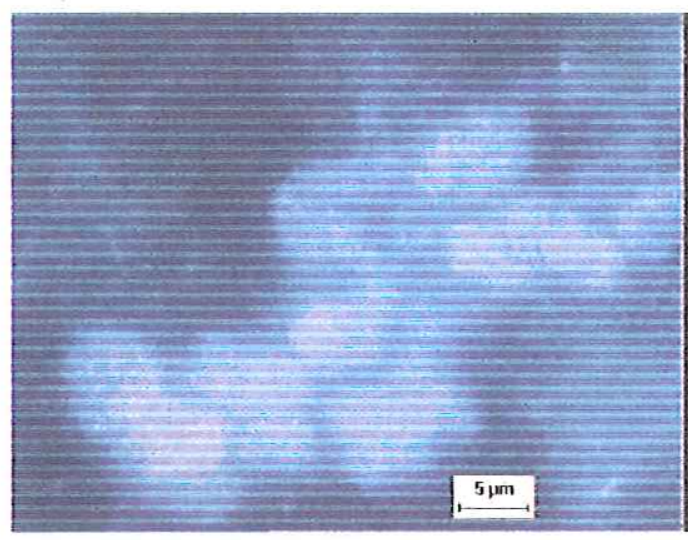

(a)

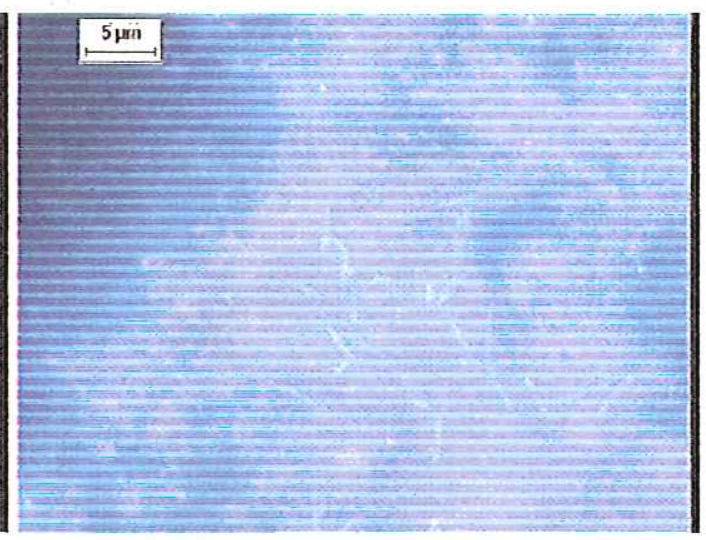

(b)

FIGURA 5.21. Microrganismos visualizados no reator UASB na $7^{\text {a }}$ etapa $\left(35^{\circ} \mathrm{C}\right)$ : semelhantes ao gênero Methanosarcina sp. (a) $e$ bacilos delgados fluorescentes (b).

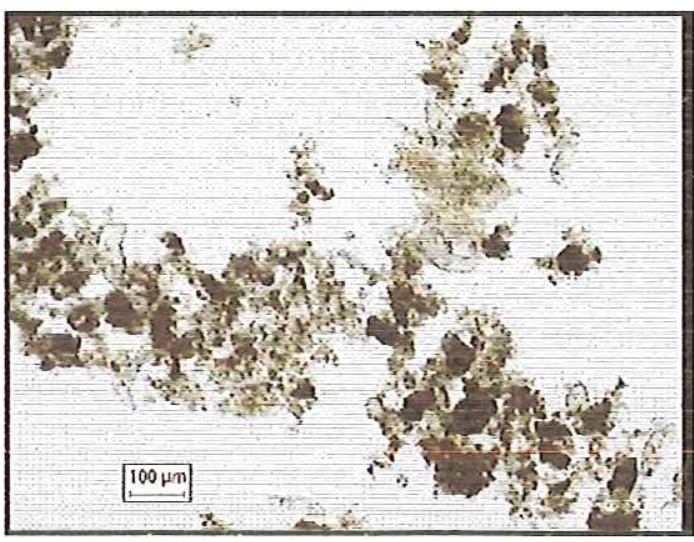

(a)

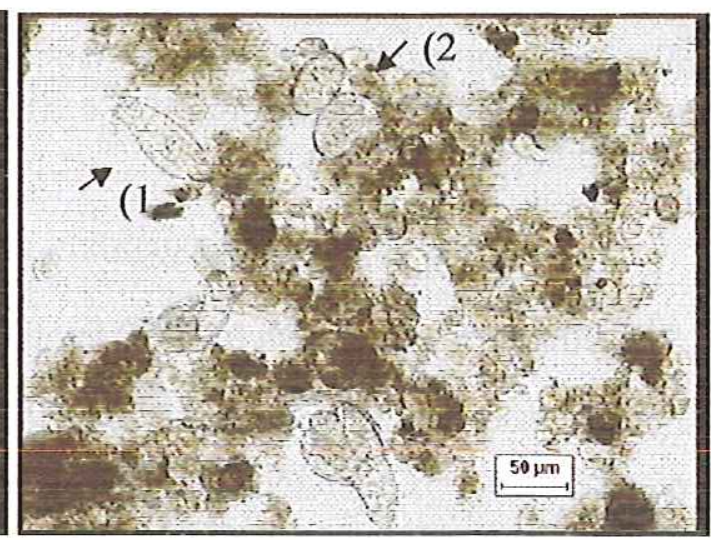

(b)

FIGURA 5.22 . Microrganismos visualizados no reator de lodos ativados na $7^{a}$ etapa $\left(35^{\circ} \mathrm{C}\right)$ : aspecto geral do floco (a); rotíferos (1) e ciliado livre natante semelhante a Aspidisca sp. (2), (b).

Como o reator UASB permaneceu por um período, em torno de 20 dias, com oscilação do $\mathrm{pH}$ efluente e foi registrado um aumento na perda de biomassa no reator aeróbio, optou-se pela separação dos reatores, feita aproximadamente 70 dias após o início da operação do sistema em escoamento contínuo. A intenção era alimentar os reatores com o mesmo substrato, diminuindo-se a DQO afluente. Entretanto, como o 
lote de licor utilizado no preparo do substrato apresentou variação nas características, a carga orgânica não foi a desejada e foi observada quebra do floco aeróbio e perda de biomassa no efluente do reator de lodos ativados (395 mgSSV.L'1).

Esta má formação do floco foi comprovada por microscopia, não documentada. Para uma ação imediata visando a recuperação do reator aeróbio, a operação dos reatores voltou a ser contínua e a vazão de recirculação do reator de lodos ativados foi dobrada.

Após dez dias foi feito exame microscópico do lodo dos reatores para verificar como a microbiota reagiu às alterações e ao ajuste da temperatura para $37,5^{\circ} \mathrm{C}$.

No reator anaeróbio foram verificadas a presença de bacilos, cocos e Methanosaeta sp. (Figura 5.23), enquanto no reator aeróbio a diversidade encontrada foi pequena, destacando-se as da Figura 5.24.

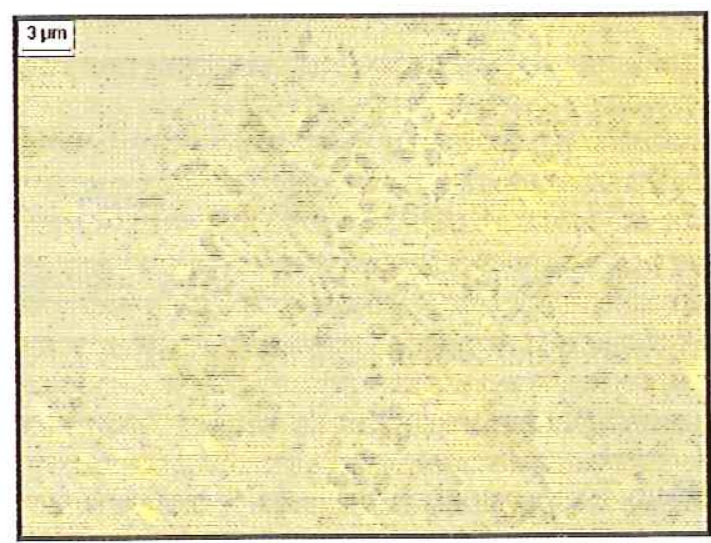

(a)

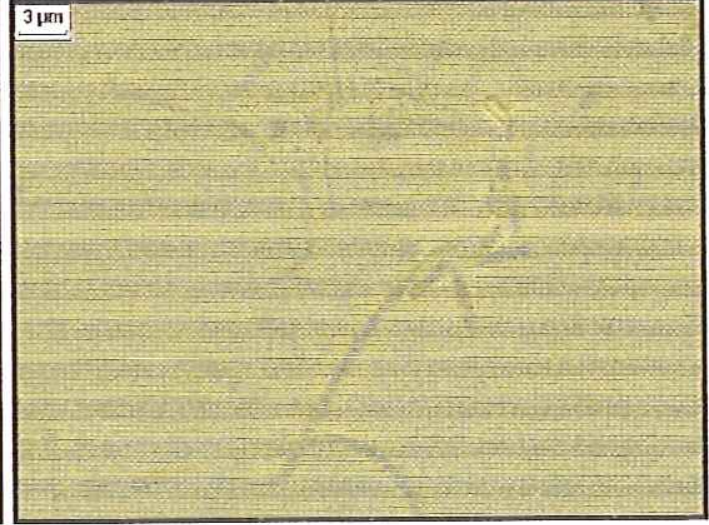

(b)

FIGURA 5.23. Microrganismos visualizados no reator UASB na $7^{\mathrm{a}}$ etapa $\left(37,5^{\circ} \mathrm{C}\right)$ : bacilos curvos (a), Methanosaeta sp. (b).

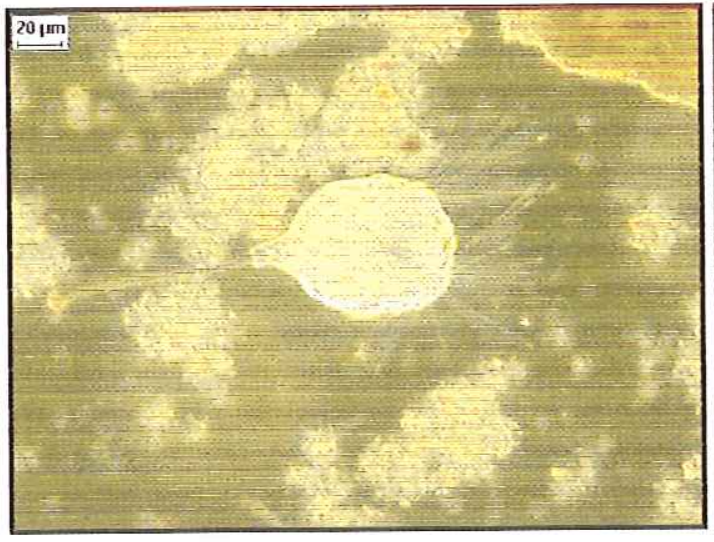

(a)

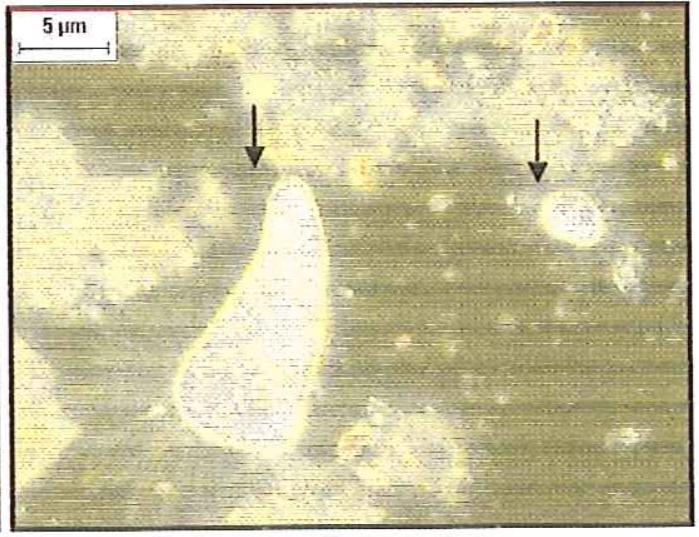

(b)

FIGURA 5.24. Microrganismos visualizados no reator de lodos ativados na $7^{\mathrm{a}}$ etapa $\left(37,5^{\circ} \mathrm{C}\right)$ : ciliado pedunculado semelhante a Acineta sp. (a), protozoário semelhante a Podophrya sp. e Periacineta sp. (b) 
A temperatura foi então ajustada para $42,5^{\circ} \mathrm{C}$ e nova microscopia foi feita após 10 dias de operação. Para o reator UASB este aumento não provocou alteração significativa da microbiota presente, sendo identificados Methanosaeta sp., Methanosarcina sp., bactérias semelhantes às redutoras de sulfato e bacilos de diversas dimensões (Figura 5.25).

Para o reator de lodos ativados entretanto, a mudança provocou alteração nas morfologias microbianas. Foram identificados poucos rotíferos, os protozoários apresentavam-se encistados e os flagelados visualizados apresentam-se ainda com motilidade, mas com a estrutura celular bastante vulnerável.

Segundo Jenkins et al. (1993), alguns organismos, particularmente os ciliados e rotíferos são geralmente os primeiros a ser afetados por materiais tóxicos ou por outros fatores adversos no processo de lodos ativados, como baixas concentrações de oxigênio dissolvido, $\mathrm{pH}$ (fora da média de 6 a 8 ) e alta temperatura. O primeiro sinal visível da toxicidade ou do estresse sofrido é usualmente a diminuição ou cessamento do movimento dos cílios nos organismos ciliados. Protozoários e metazoários geralmente estão ausentes em sistemas de lodos ativados operados em temperatura acima de $40^{\circ} \mathrm{C}$.

No reator aeróbio foram visualizados predominantemente bactérias: cocos, estreptococos e cocobacilos, fundamentando a hipótese de decomposição saprofítica no reator aeróbio. Predominavam nesta etapa os cocos e filamentos semelhantes a Thiothrix sp. e havia pouco material em suspensão. Também foram encontradas Methanosarcina sp., provavelmente provenientes do reator anaeróbio e algumas hifas de fungo. Os flocos encontravam-se abertos e havia pouco material em suspensão (Figura 5.26).

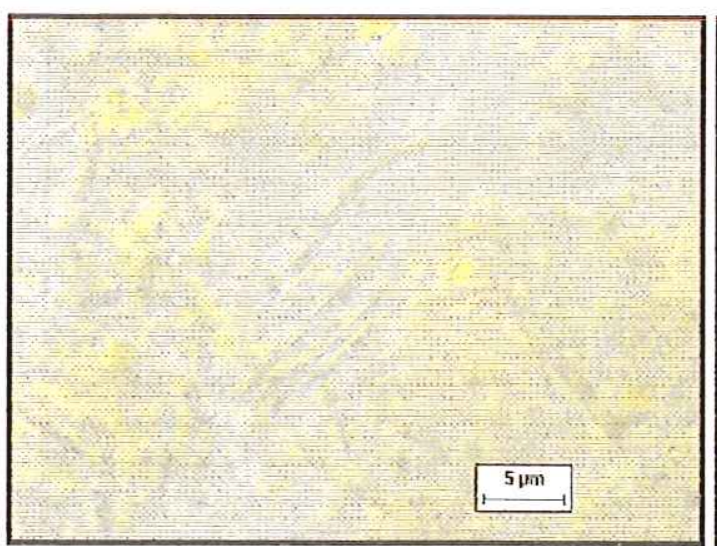

(a)

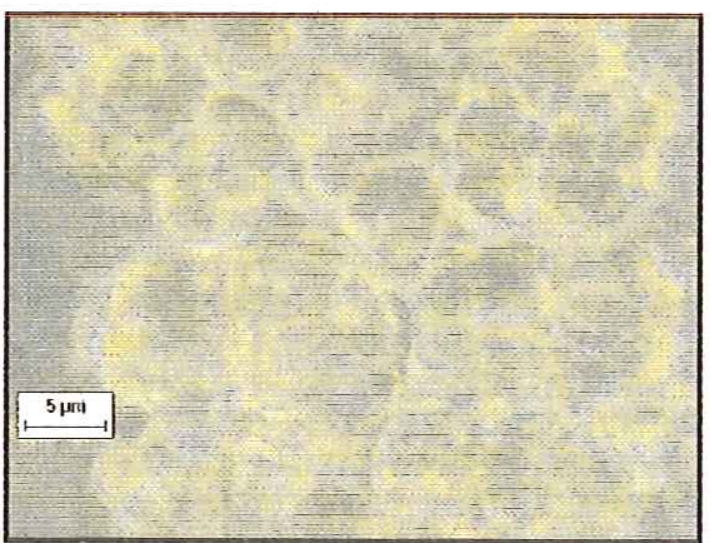

(b)

FIGURA 5.25. Microrganismos visualizados no reator UASB na $8^{\text {a }}$ etapa $\left(42,5^{\circ} \mathrm{C}\right)$ : semelhantes aos gêneros Methanosaeta sp. (a) e Methanosarcina sp.(b). 


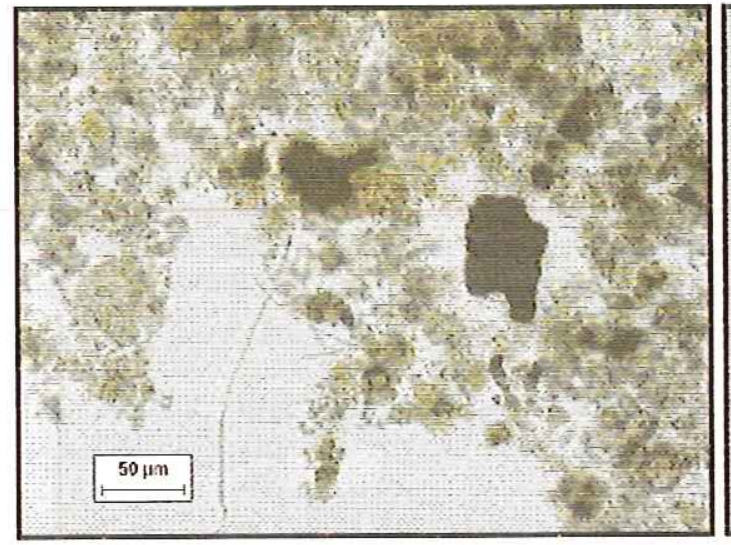

(a)

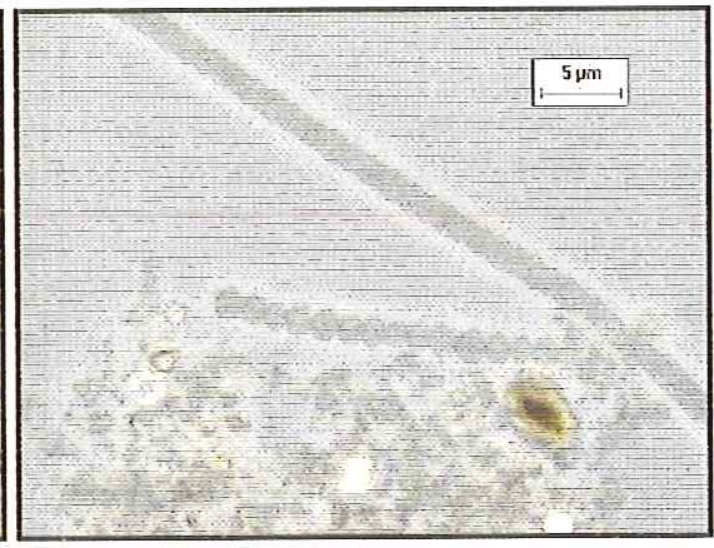

(b)

FIGURA 5.26. Microrganismos visualizados no reator de lodos ativados na $8^{\text {a }}$ etapa $\left(42,5^{\circ} \mathrm{C}\right)$ : aspecto geral do floco (a), estreptococos e filamentos semelhantes a Thiothrix sp. (b).

\subsubsection{Fase Termofilica}

\subsubsection{Faixa de temperatura entre 45 e $57,0^{\circ} \mathrm{C}$ (etapas 1 a 5 )}

A temperatura foi ajustada para $45^{\circ} \mathrm{C}$ e nova microscopia foi feita aproximadamente duas semanas após.

No reator UASB haviam bacilos, grumos semelhantes ao gênero Methanosarcina sp. e Methanosaeta sp., com predomínio dos primeiros. A maioria dos bacilos e Sarcinas encontrados não apresentava boa fluorescência. As células semelhantes ao gênero Methanosaeta sp. agrupavam-se em formas de feixes com vacúolos (Figura 5.27).

Em relação ao exame microscópico anterior, no reator de lodos ativados não houve alteração das morfologias encontradas, apenas um aumento no número de protozoários ciliados. Também havia, aparentemente, maior quantidade de bactérias em suspensão. Além disso, estavam presentes flagelados, tecamebas semelhantes a Euglypha sp., ameba sem carapaça semelhante a Amoeba sp. (Figura 5.28), algumas filamentosas e hifas de fungo. 


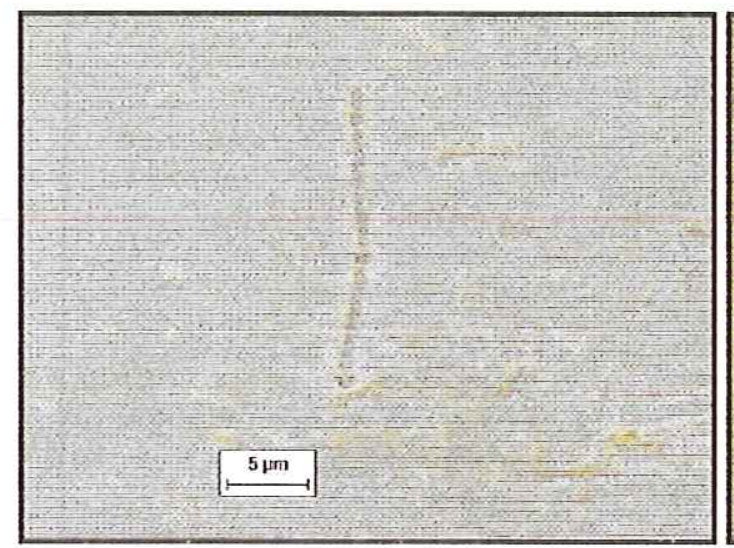

(a)

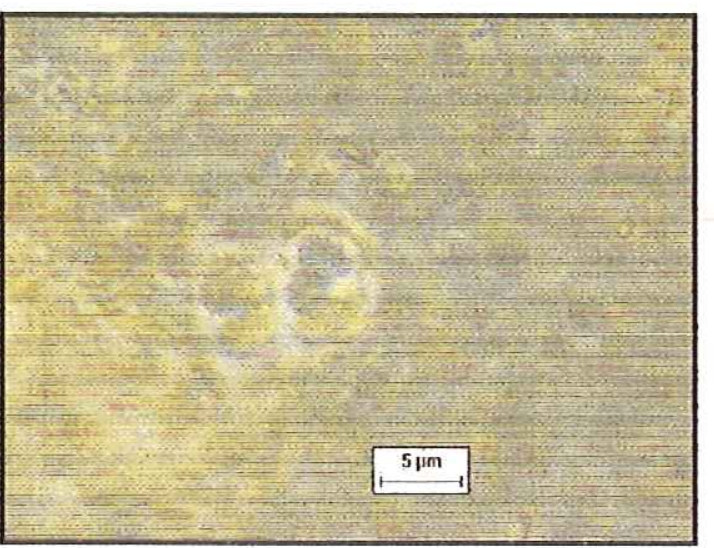

(b)

FIGURA 5.27. Microrganismos visualizados no reator UASB na $1^{\text {a }}$ etapa termofilica $\left(45^{\circ} \mathrm{C}\right)$ : semelhantes aos gêneros Methanosaeta sp. (a), Methanosarcina sp. (b).

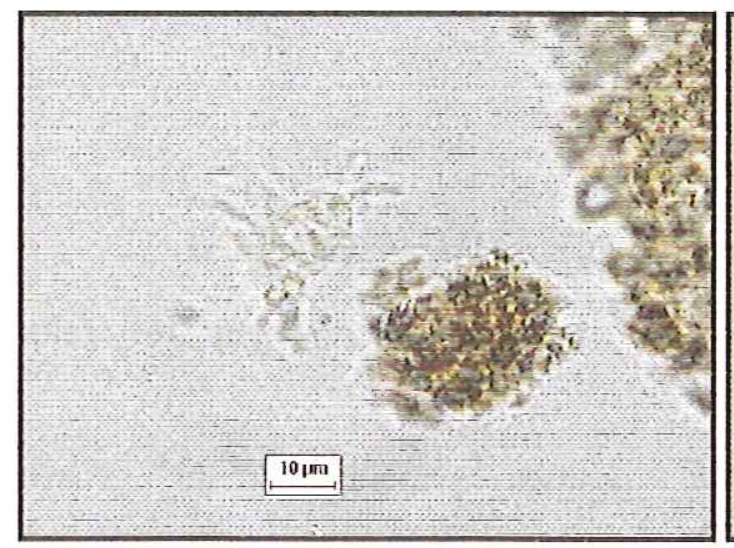

(a)

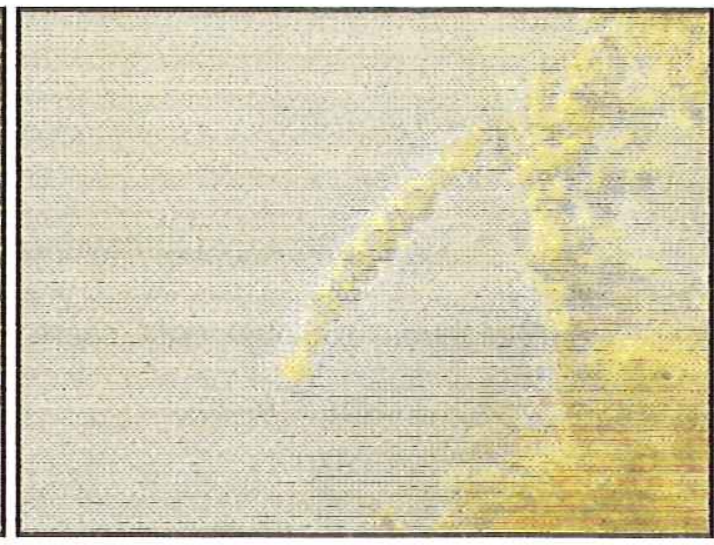

(b)

FIGURA 5.28. Microrganismos visualizados no reator de lodos ativados na $1^{\text {a }}$ etapa termofilica $\left(45^{\circ} \mathrm{C}\right)$ : ameba semelhante ao gênero Amoeba sp.(a) e estreptococos (b).

A temperatura foi aumentada para $52^{\circ} \mathrm{C}$ com 175 dias de operação do sistema. Com 56 dias de operação nesta faixa de temperatura, houve um problema operacional e o reator aeróbio ficou sem aeração por aproximadamente 48 horas. Foi feita uma microscopia para avaliar as condições do reator após este choque. Paralelamente foi avaliada a microbiota do reator UASB.

No reator anaeróbio, aparentemente, predominavam filamentos semelhantes a Methanosaeta sp., porém não havia integridade das células, com morfologia diferente das normalmente encontradas em sistemas anaeróbios (Figura 5.29). 


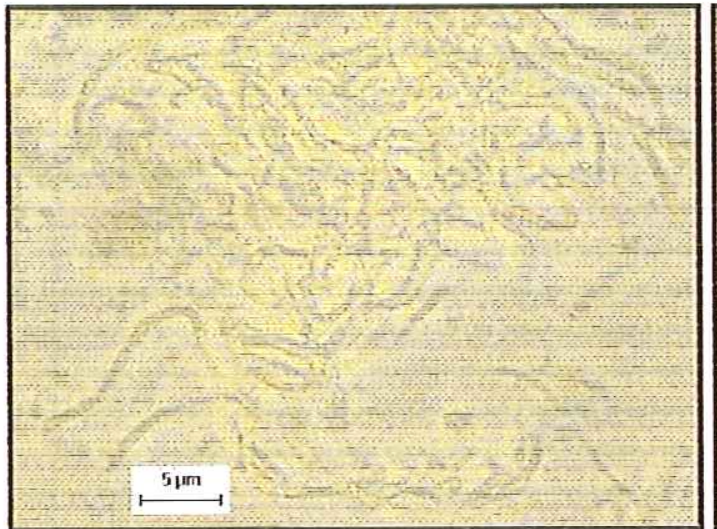

(a)

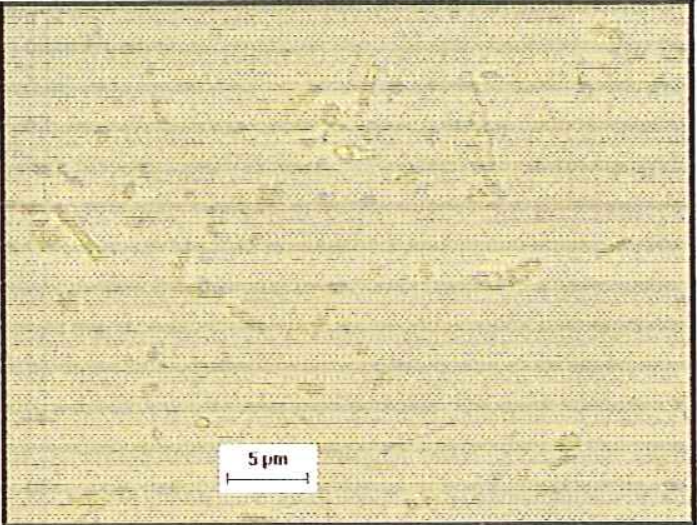

(b)

FIGURA 5.29. Microrganismos visualizados no reator UASB na $4^{\mathrm{a}}$ etapa termofílica $\left(52^{\circ} \mathrm{C}\right)$ : semelhantes ao gênero Methanosaeta sp. (a) e bacilos diversos (b).

No reator de lodos ativados houve ocorrência de organismos filamentosos, que foi resolvido apenas com o aumento da taxa de aeração de 60 para $90 \mathrm{~L} / \mathrm{min}$. Foram observados, a olho nu, polímeros no reator aeróbio, provavelmente uma forma de reação e proteção dos organismos à ausência de oxigênio.

Nas Figuras 5.30 e 5.31 são apresentadas imagens de amostras do reator onde visualiza-se o floco após a ausência de suprimento de oxigênio e as morfologias presentes e a melhora ocorrida apenas com o aumento da taxa de aeração. É interessante salientar que havia o predomínio de duas morfologias de filamentosas.

De acordo com Jenkins et al. (1993) é raro que uma amostra de um reator de lodos ativados com "bulking" contenha somente um tipo de organismo filamentoso, normalmente são vistos três ou mais tipos.

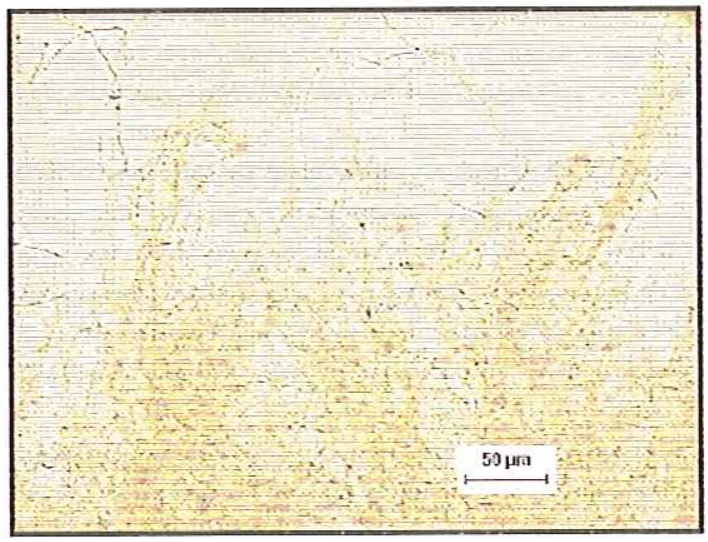

(a)

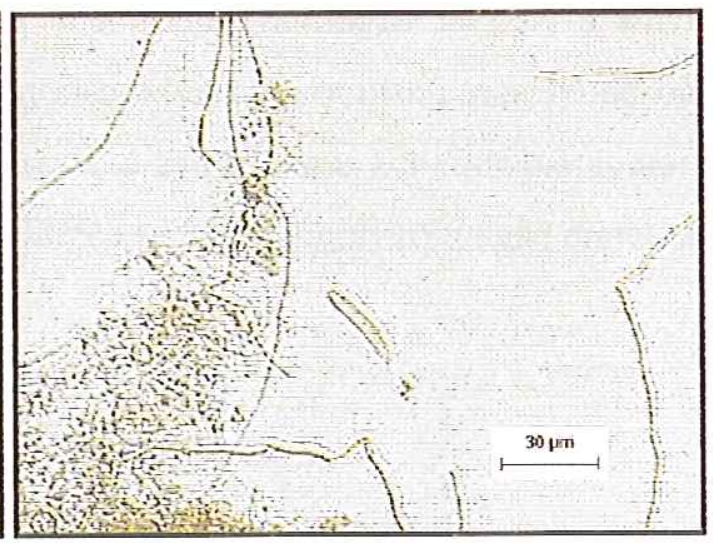

(b)

FIGURA 5.30. Microrganismos visualizados no reator de lodos ativados na $4^{\mathrm{a}}$ etapa termofilica $\left(52^{\circ} \mathrm{C}\right)$ : aspecto geral do floco (a), filamentosas e ciliado (b). 


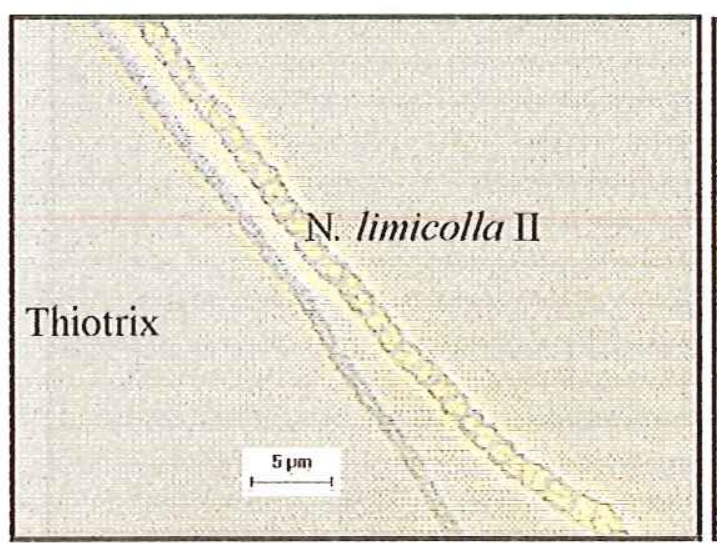

(a)

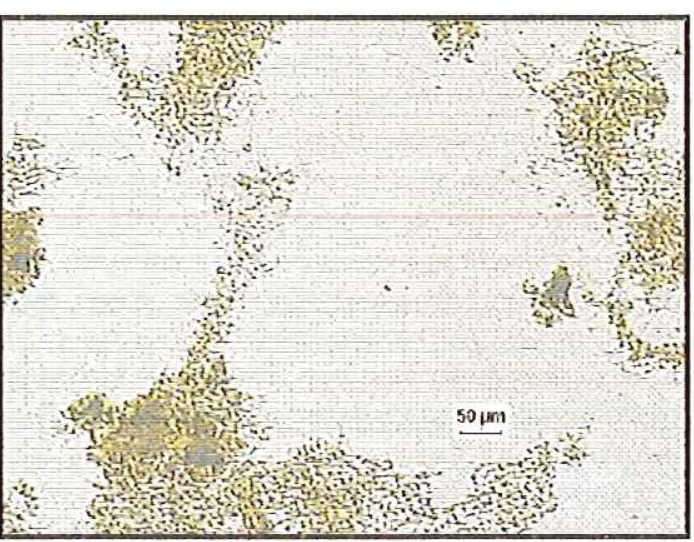

(b)

FIGURA 5.31. Microrganismos visualizados no reator de lodos ativados na $4^{\mathrm{a}}$ etapa termofilica $\left(52^{\circ} \mathrm{C}\right)$ : duas morfologias predominantes após o "bulking", semelhantes a Thiothrix $I$ e $N$. limicola II (a), aspecto geral do floco após aumento da taxa de aeração (b).

Amostras de lodo foram coletadas para exames de coloração de bainha, Neisser, Gram e PHB, com o objetivo de identificação das estruturas filamentosas. Entretanto, esta análise só pôde ser efetuada uma semana após a coleta e as amostras ficaram estocadas em geladeira (Figuras 5.32, 5.33 e 5.34). Alguns dos filamentos corados não fícaram característicos gerando dúvidas na identificação. Possivelmente os filamentos presentes eram Nostocoida limicola II e Thiothrix.

As células da Nostocoida limicola II são claramente septadas, sem bainha e sem grânulos de enxofre, entretanto, grânulos de PHB são comumente observados. Quanto a Neisser e Gram, os resultados são variáveis, a maioria entretanto é Gram negativa. $\mathrm{O}$ filamento Thiothrix II apresenta células septadas e retangulares, Gram negativas, PHB positivas e Neisser negativas, sendo que podem estar presentes grânulos indicando reação de Neisser positivo. A bainha está presente mas é difícil de ser observada. Os filamentos encontrados semelhantes a Thiothrix II apresentam bainha (Figura 5.32 a), sendo Gram negativos (Figura 5.33 a) e PHB positivo (Figura 5.34 a). 


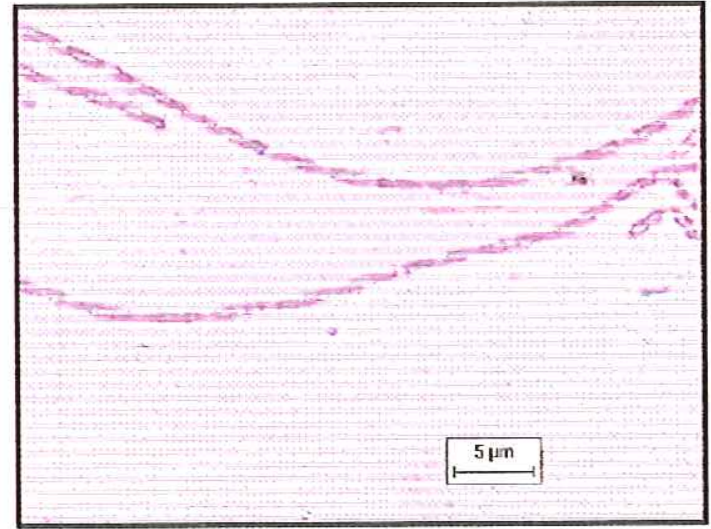

(a)

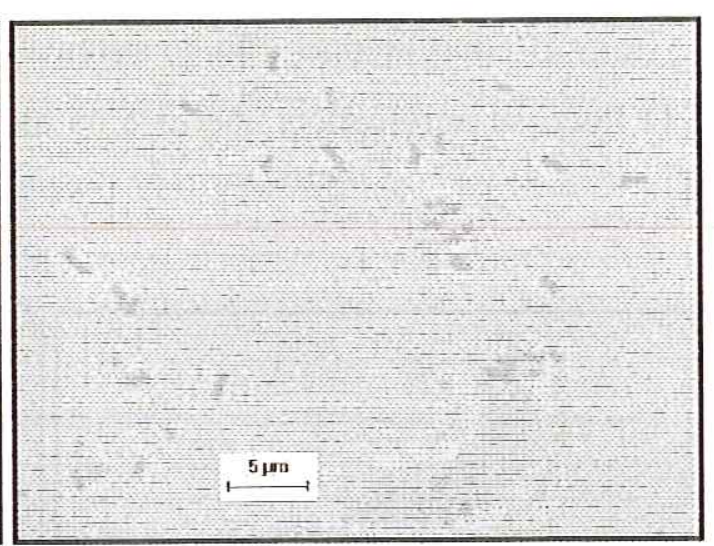

(b)

FIGURA 5.32. Coloração dos organismos filamentosos visualizados no reator de lodos ativados na $4^{\mathrm{a}}$ etapa termofilica $\left(52^{\circ} \mathrm{C}\right)$ : presença de bainha (a), bacilos Gram negativos (b).

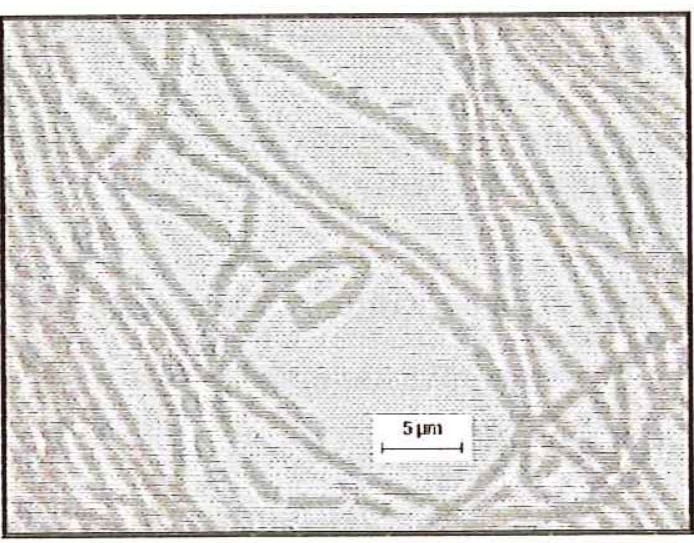

(a)

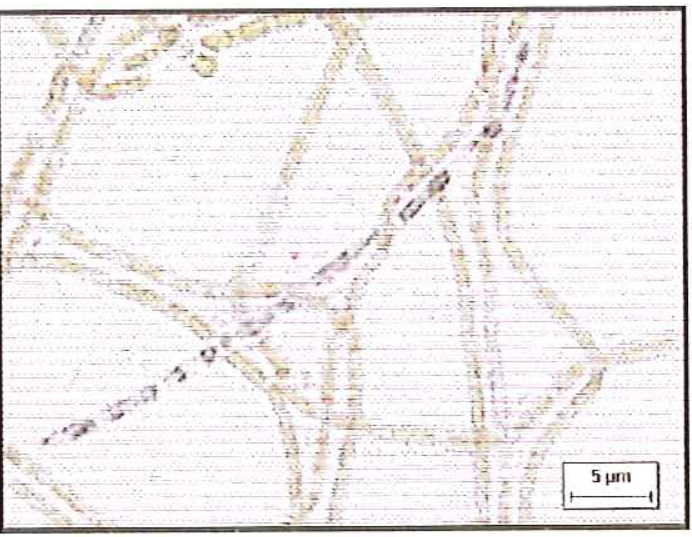

(b)

FIGURA 5.33. Coloração dos organismos filamentosos visualizados no reator de lodos ativados na $4^{\mathrm{a}}$ etapa termofilica $\left(52^{\circ} \mathrm{C}\right)$ : filamentos Gram negativos (a), filamentos Neisser positivo e negativo (b).

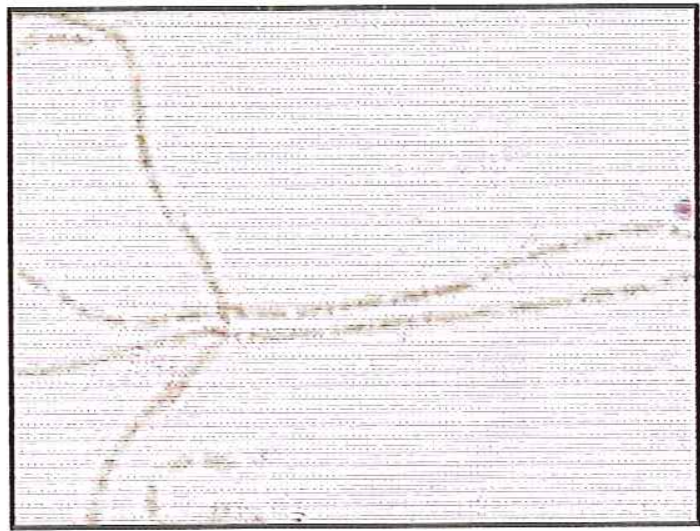

(a)

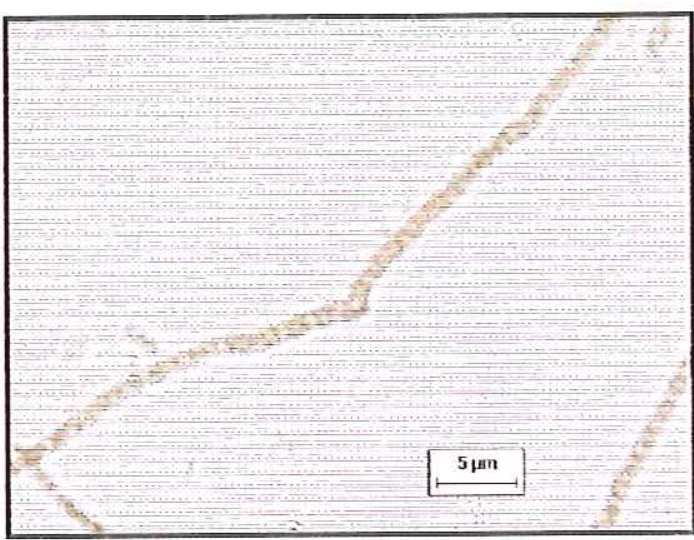

(b)

FIGURA 5.34. Coloração dos organismos filamentosos visualizados no reator de lodos ativados na $4^{\mathrm{a}}$ etapa termofilica $\left(52^{\circ} \mathrm{C}\right)$ : filamento $\mathrm{PHB}$ positivo (a) e filamento $\mathrm{PHB}$ negativo (b). 
Com 236 dias de operação do sistema a temperatura sofreu o último ajuste, para $57^{\circ} \mathrm{C}$. O floco se apresentava aberto e os bacilos eram comuns nas amostras (Figura $5.35)$.

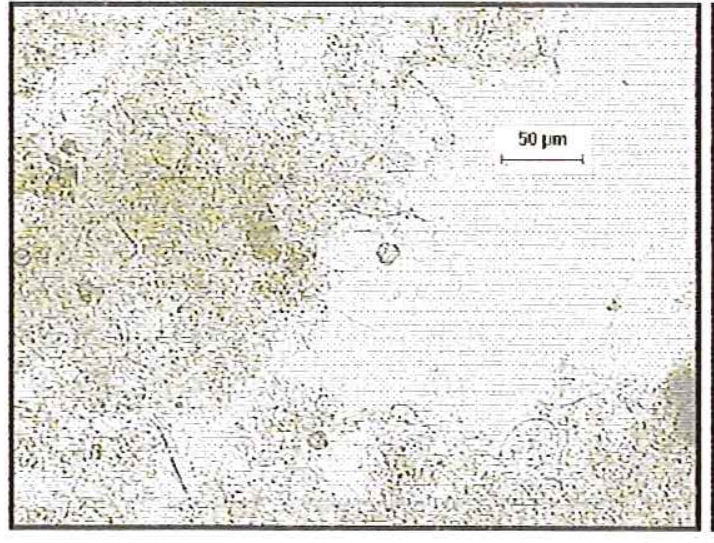

(a)

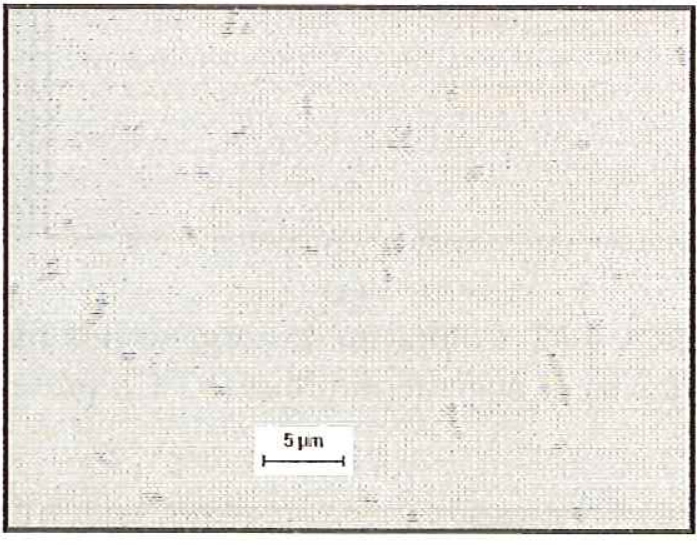

(b)

FIGURA 5.35. Microrganismos visualizados no reator de lodos ativados na $5^{\text {a }}$ etapa termofílica $\left(57^{\circ} \mathrm{C}\right)$ : aspecto geral do floco (a), morfologias variadas de bacilos (b).

Apenas pela microscopia, sem coloração ficava difícil caracterizar os filamentosas. Para identificação dos filamentos foi feita nova coloração logo após a coleta no reator. Esta coloração foi feita duas semanas após a primeira.

Considerando as colorações para bainha, Neisser, Gram, PHB e enxofre, notouse que entre os filamentos havia predomínio de morfologia semelhante a Nocardia sp. A Nocardia sp. é encontrada principalmente dentro do floco, com ramificações freqüentemente presentes, não apresenta bainha (Figura 5.39a), não ocorre em feixes, sendo Gram positiva (Figura 5.36a), Neisser negativa, sendo que apresenta grânulos Neisser positivos (Figura 5.37b) e PHB (Figura 5.38b) são comumente observados (JENKINS et al., 1993). É um microrganismo saprofítico, que pode crescer em diferentes compostos orgânicos, incluindo substratos recalcitrantes, bem como compostos de prontamente degradáveis. A presença de Nocardia sp. é comum em efluentes das indústrias de papel e celulose (TASK FORCE ON WASTEWATER BIOLOGY, 1990).

Foi verificada também a presença significativa de morfologias semelhantes a Thiothrix sp. e N. limicola II. Vários organismos filamentosos, como a Thiothrix sp., tipo $021 N$, Beggiatoa sp. e tipo 0914, podem utilizar o enxofre como uma fonte de energia. $\mathrm{O}$ enxofre está presente no licor negro na forma de sulfeto, como pode ser visto na caracterização apresentada na seção 4.4. de material e métodos. 


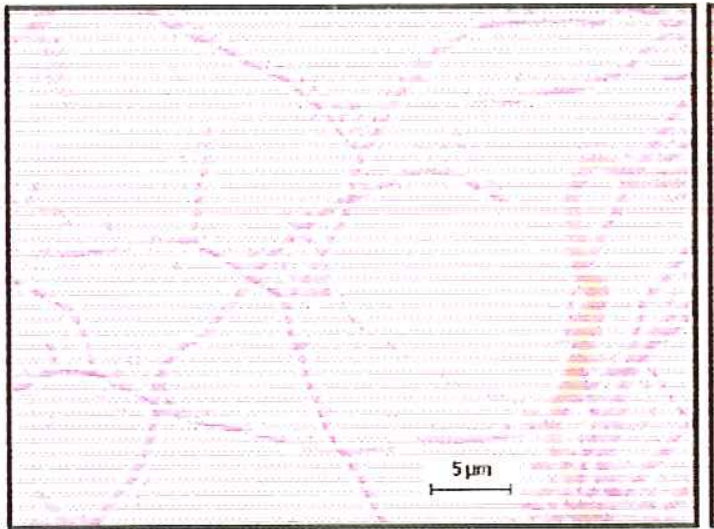

(a)

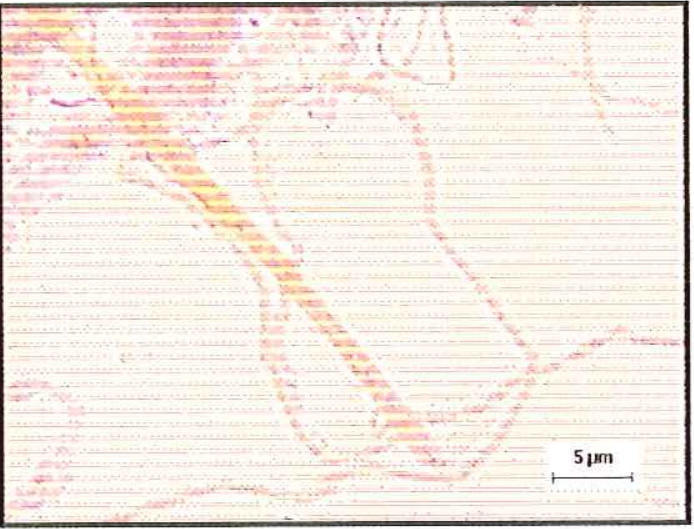

(b)

FIGURA 5.36. Coloração de Gram dos organismos filamentosos presentes no reator de lodos ativados na $5^{\text {a }}$ etapa termofilica $\left(57^{\circ} \mathrm{C}\right)$ : presença abundante de filamento semelhante a Nocardia sp., Gram positiva e de $N$. limicola II, Gram negativa (a) $N$. limicola I e $N$. limicola II, ambas Gram negativas (b).

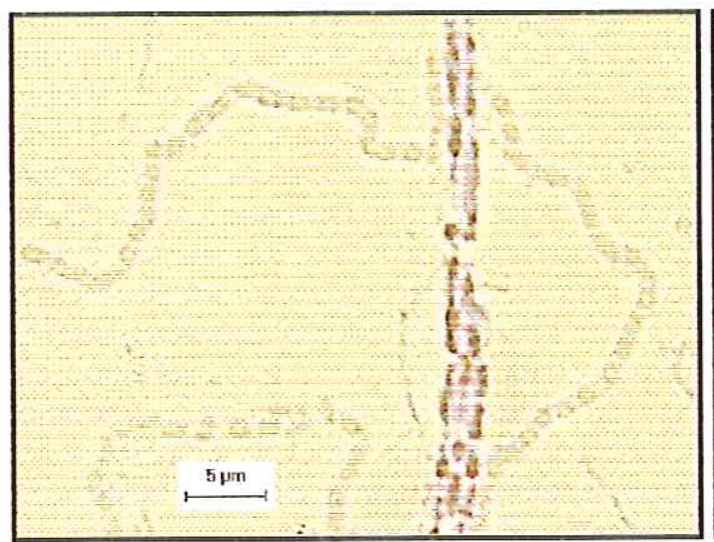

(a)

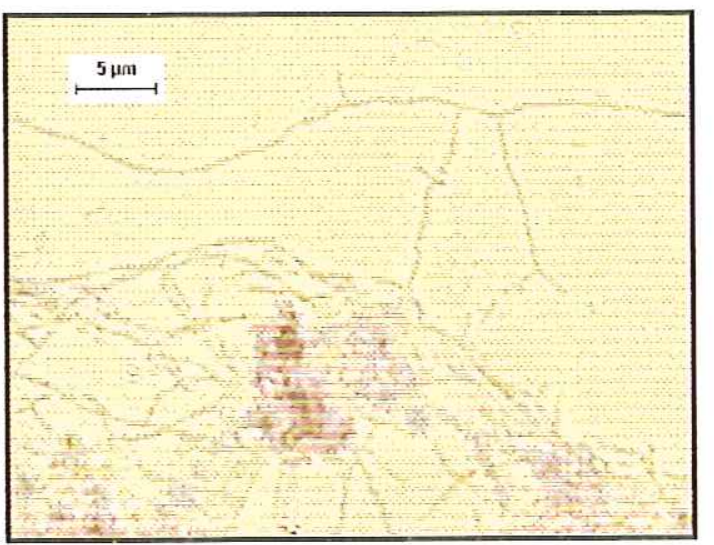

(b)

FIGURA 5.37. Coloração de Neisser dos organismos filamentosos presentes no reator de lodos ativados na $5^{\mathrm{a}}$ etapa termofilica $\left(57^{\circ} \mathrm{C}\right)$ : semelhantes a: Thiothrix I em feixe, Neisser positiva e N. Limicola II, Neisser negativa (a) e Nocardia sp., Neisser positiva de grânulo (b).

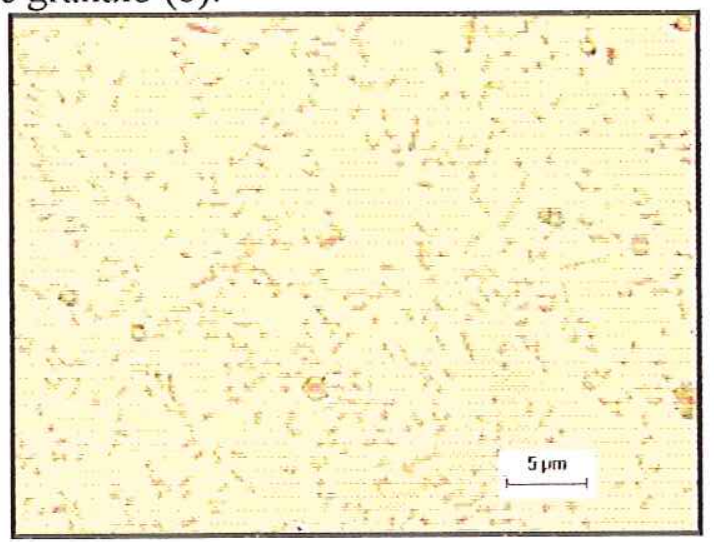

(a)

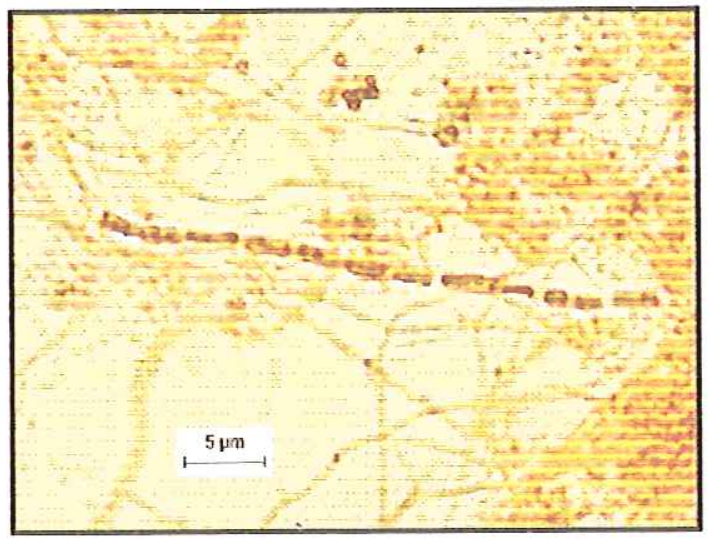

(b)

FIGURA 5.38. Coloração de PHB dos organismos filamentosos presentes no reator de lodos ativados na $5^{\mathrm{a}}$ etapa termofilica $\left(57^{\circ} \mathrm{C}\right)$ : semelhantes a: Bacilos, PHB negativo (a) Nocardia sp. ao fundo, PHB negativa e Thiothrix sp., PHB positiva (b). 


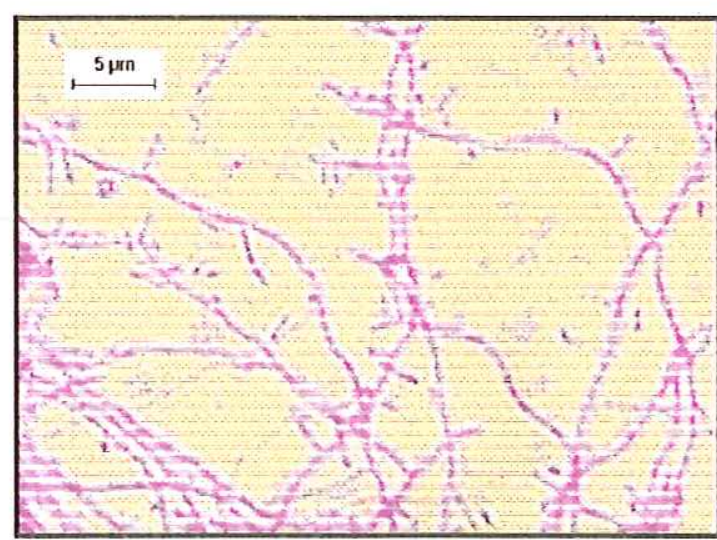

(a)

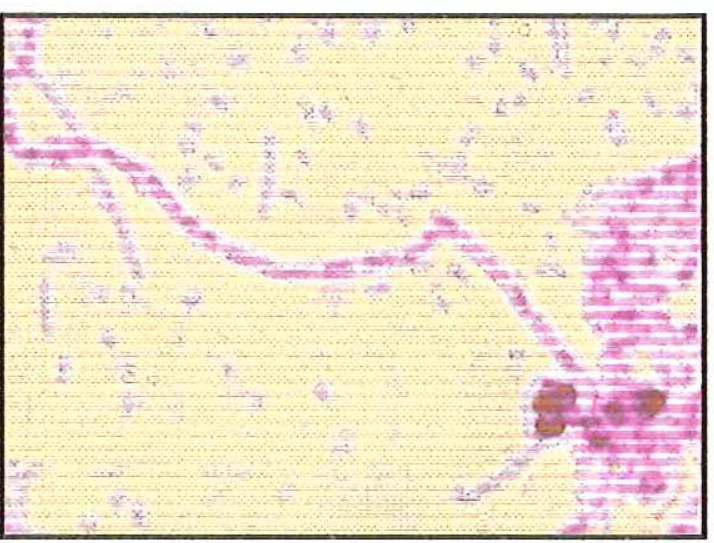

(b)

FIGURA 5.39. Coloração de bainha dos organismos filamentosos presentes no reator de lodos ativados na $5^{\text {a }}$ etapa termofilica $\left(57^{\circ} \mathrm{C}\right)$ : semelhantes a: Nocardia sp., ausência de bainha (a), N. Limicola II, ausência de bainha (b).

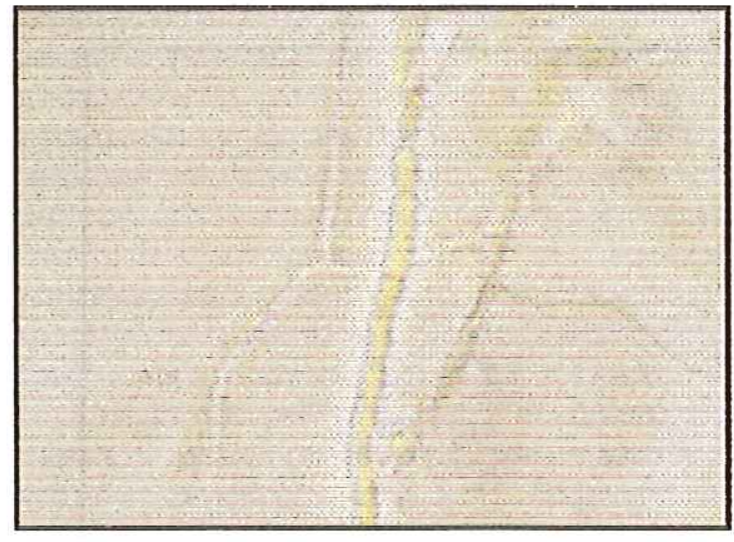

(a)

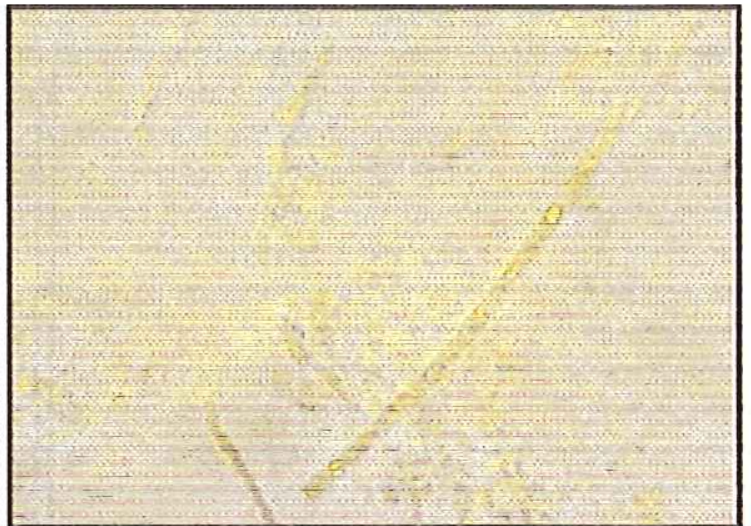

(b)

FIGURA 5.40. Coloração de enxofre dos organismos filamentosos presentes no reator de lodos ativados na $5^{\text {a }}$ etapa termofilica $\left(57^{\circ} \mathrm{C}\right)$ : semelhantes a: $N$. limicola II e Nocardia sp. (a) e Thiothrix sp. (b), ambos filamentos enxofre positivo.

Os reatores operavam nesta temperatura por 31 dias quando foi alterado o suprimento de energia elétrica, sendo utilizado um gerador por cinco dias. Assim, foi feita uma coleta para amostrar os reatores caso houvesse algum problema devido ao corte de energia e suprimento por gerador. Entretanto, como a amostra coletada do reator de lodos ativados não foi imediatamente analisada, somente foi possível caracterizar o floco e algumas morfologias que resistiram à falta de aeração (Figura 5.41).

No exame microscópico da amostra do reator UASB foram verificadas células semelhantes a Methanosarcina sp., Methamosaeta sp. e bacilos. A fluorescência estava mais definida (Figuras 5.42 e 5.43). 


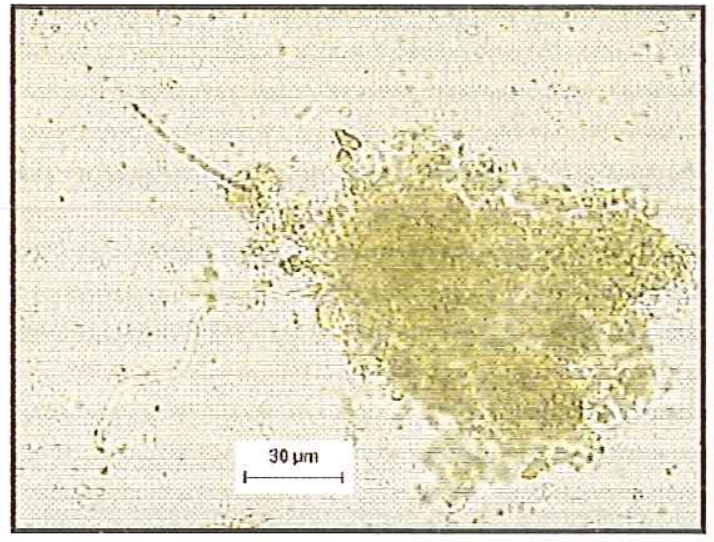

(a)

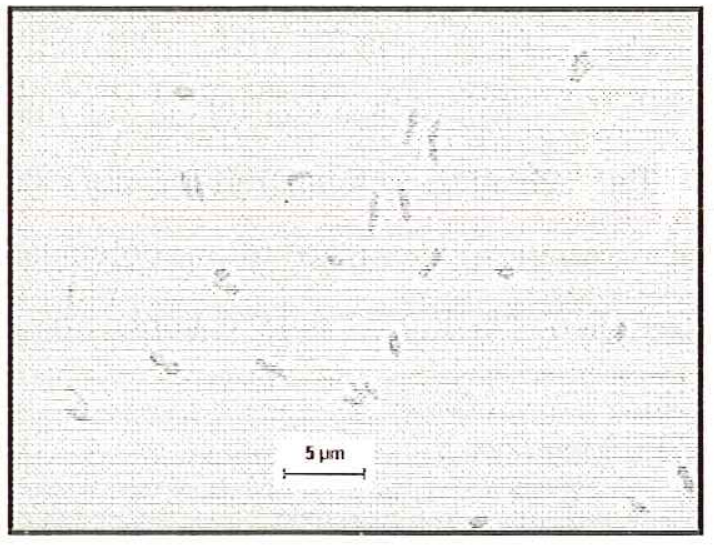

(b)

FIGURA 5.41. Microrganismos visualizados no reator de lodos ativados na $5^{\text {a }}$ etapa termofilica $\left(57^{0} \mathrm{C}\right)$ : aspecto geral do floco (a), predominância de bacilos (b).

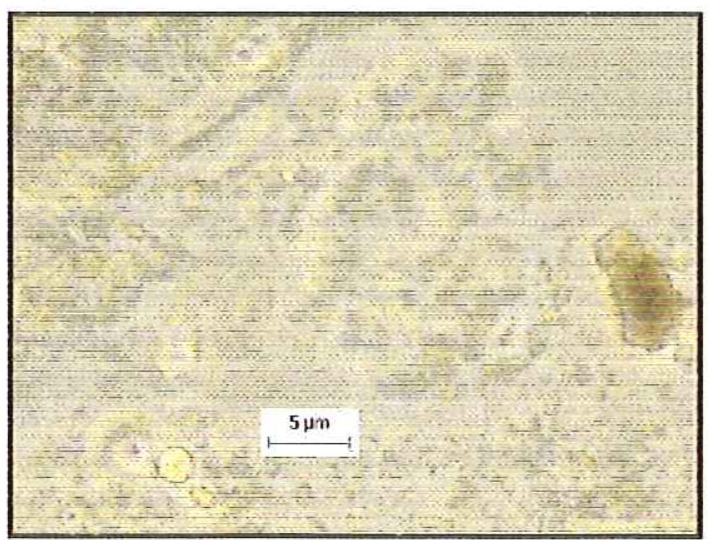

(a)

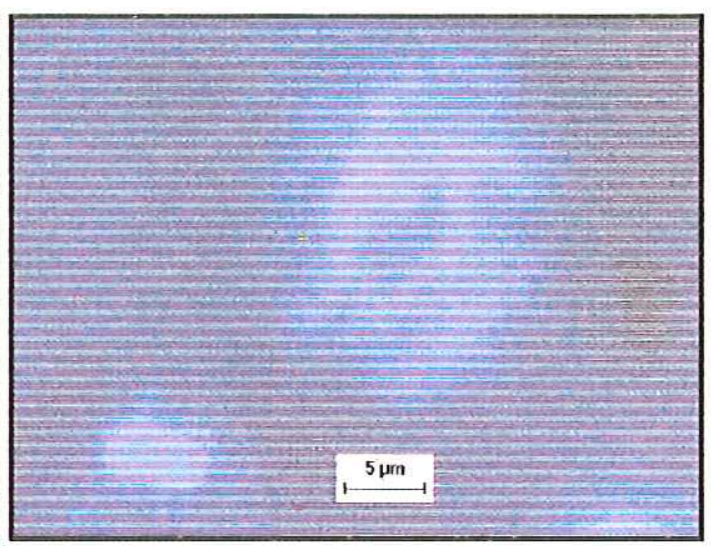

(b)

FIGURA 5.42. Microrganismos visualizados no reator UASB na $5^{\mathrm{a}}$ etapa termofílica $\left(57^{\circ} \mathrm{C}\right)$ : Methanosarcina sp. e respectiva fluorescência (a e b).

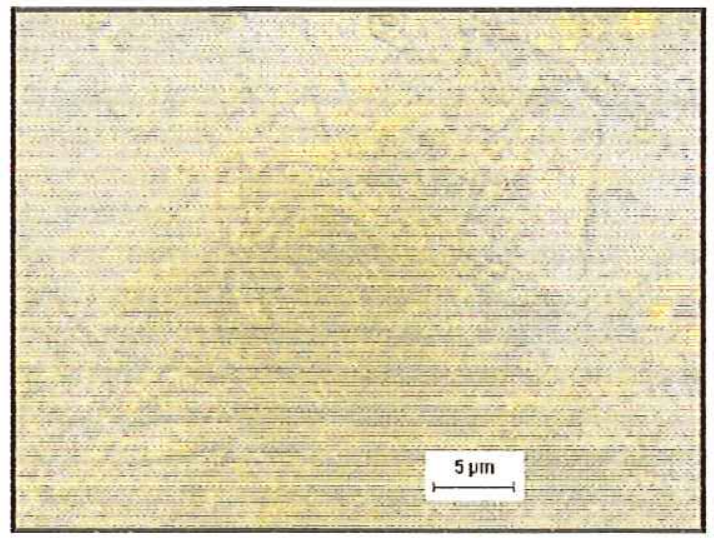

(a)

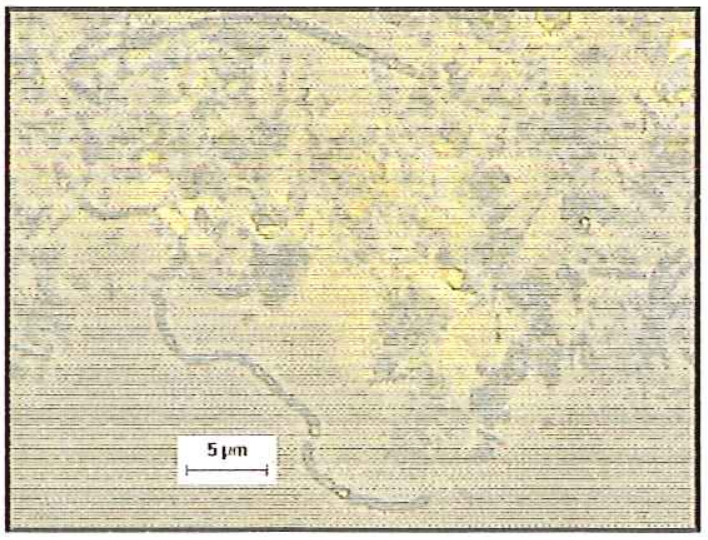

(b)

FIGURA 5.43. Microrganismos visualizados no reator UASB na $5^{\text {a }}$ etapa termofílica $\left(57^{\circ} \mathrm{C}\right)$ : feixe de Methanosaeta sp. (a), filamentos e Methanosaeta sp. (b). 
Após estes quatro dias com suprimento de energia por gerador com conseqüentes oscilações, a resistência que mantinha a temperatura na cabine queimou.

Para manter a temperatura, por 20 horas, foi utilizado um aquecedor de ambientes doméstico. Então, foram coletadas novas amostras dos reatores para exame microscópico. Na Figura 5.44 é apresentada uma das imagens de amostra do reator UASB.

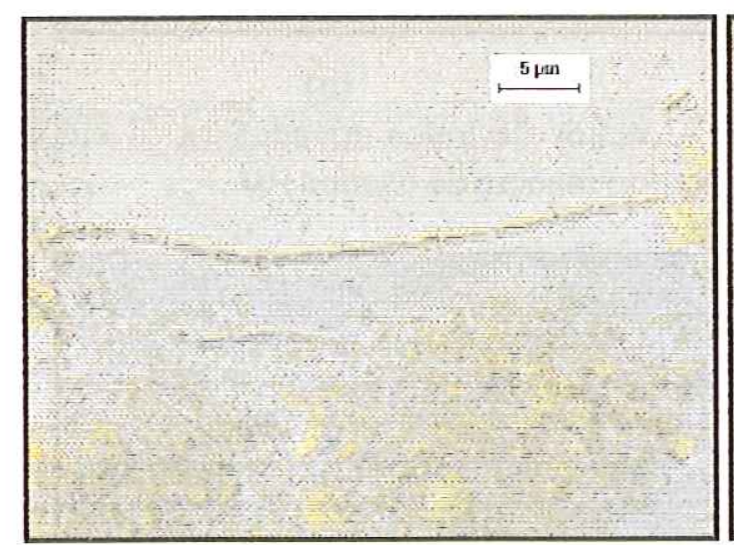

(a)

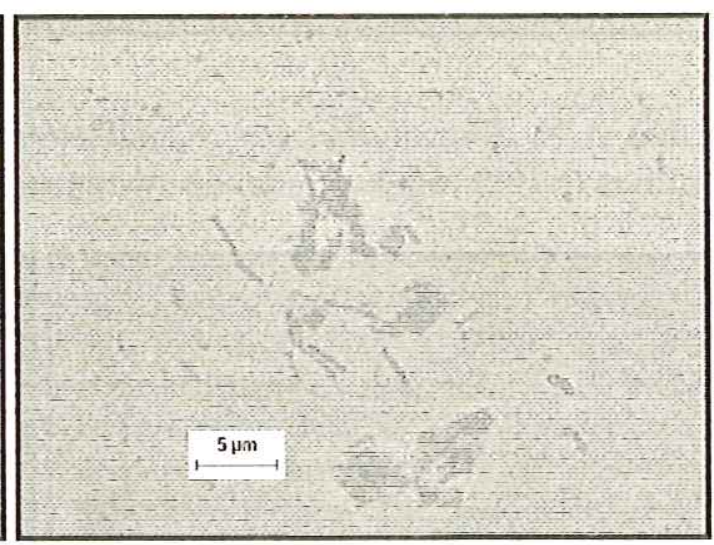

(b)

FIGURA 5.44. Microrganismos visualizados no reator UASB após o choque térmico na $5^{\text {a }}$ etapa termofilica $\left(57^{\circ} \mathrm{C}\right)$ : Methanosaeta sp. (a), bacilos (b).

$\mathrm{Na}$ amostra do reator de lodos ativados foi visualizado um aumento no número de filamentos (Figura 5.45). No floco estavam presentes filamentos semelhantes a Thiothrix e N. limicola II e Nocardia sp., com predomínio dos últimos. O crescimento destes organismos filamentosos, de acordo com Jenkins et al. (1993), é geralmente estimulado pelo uso de aeração uniforme, em reatores de mistura completa, com tanque de aeração alimentado continuamente.

Neste trabalho não foram encontradas algumas bactérias filamentosas que são associadas a baixa concentração de oxigênio dissolvido: tipo 1701, S. natans, $H$. hydrossis e M. parvicella (JENKINS et al., 1993). 


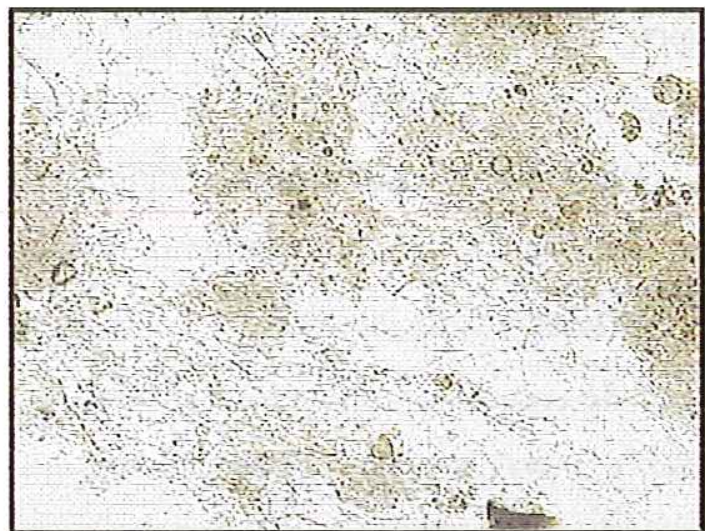

(a)

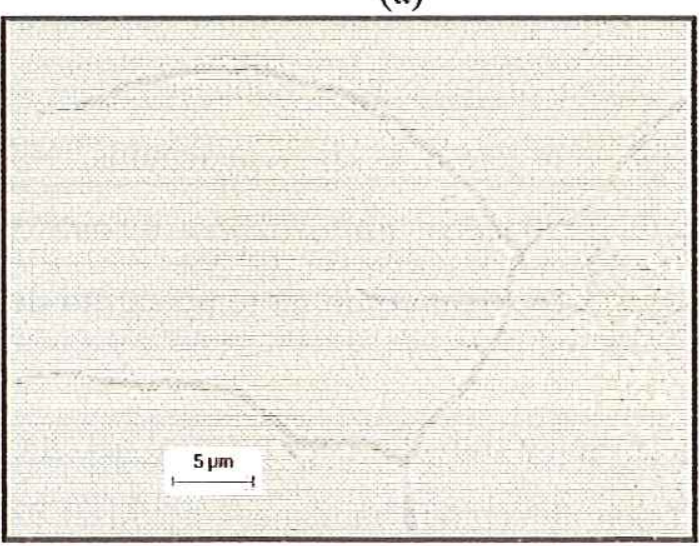

(c)

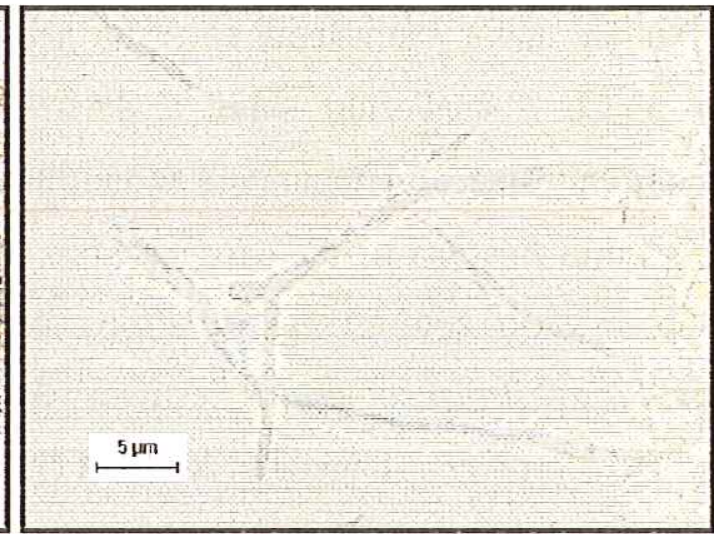

(b)

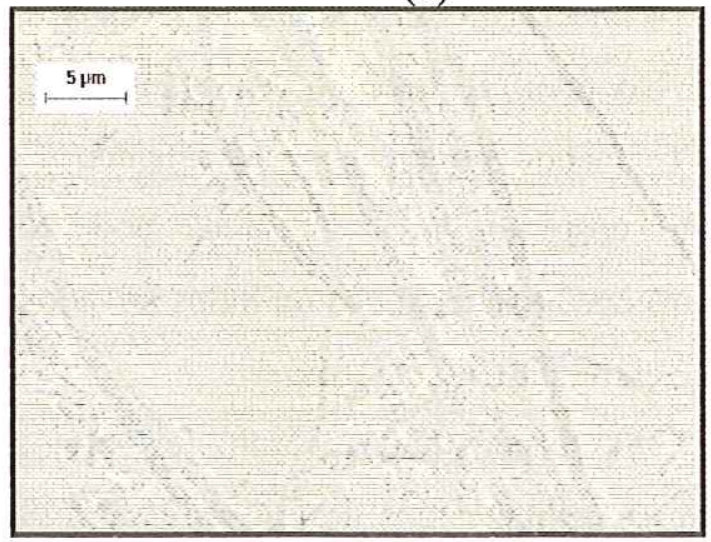

(d)

FIGURA 5.45. Microrganismos visualizados no reator de lodos ativados após choque térmico na $5^{\mathrm{a}}$ etapa termofílica $\left(57^{\circ} \mathrm{C}\right)$ : aspecto geral do floco (a), presença de filamento semelhante a $N$. Limicola II (b), presença de Nocardia sp. e bacilos (c), feixes de Thiothrix sp. (d).

Com 37 dias de operação do sistema a $57^{\circ} \mathrm{C}$ e dois dias após ter sido resolvido o problema da avaria elétrica, houve uma pane no termostato que efetuava o controle da temperatura na cabine. A temperatura ficou abaixo de $57^{\circ} \mathrm{C}$, em torno de $30^{\circ} \mathrm{C}$ graus, por aproximadamente 12 horas e não haveria possibilidade de reajuste da temperatura por aproximadamente 72 horas. Assim foi impossível continuar a operação do sistema, visto que a microbiota de ambos reatores seria submetida a novo choque na temperatura, encerrando-se o experimento.

\subsubsection{Comparação entre as microscopias realizadas nas fases mesofilica e termofilica}

Como pôde ser visto na apresentação dos resultados dos exames microbiológicos na fase termofílica, os bacilos, cocos e filamentos foram os organismos que 
apresentaram maior abundância no reator aeróbio. Segundo Lapara \& Alleman (1999) muito pouco é conhecido sobre a diversidade microbiana dos reatores aeróbios operando em faixa de temperatura termofilica, sendo que apenas foram isolados por pesquisadores Bacillus sp. e microrganismos semelhantes aos bacilos. Suvilampi (2003) baseado em vários autores, também afirma sobre a freqüência de isolamento de espécies de Bacillus e $\beta$-Proteobacteria em estudos recentes de reatores aeróbios termofilicos.

De acordo com Lapara \& Alleman (1999), a microbiota dos reatores biológicos aeróbios termofílicos diferencia-se dos lodos ativados convencionais pela ausência de bactérias nitrificantes, organismos formadores de floco, protozoários e outras formas de vida. No presente trabalho, entretanto, uma pequena diferenciação pôde ser vista a $42,5^{\circ} \mathrm{C}$ quando organismos semelhantes a cocos começaram a ser visualizados. No exame posterior, a $45^{\circ} \mathrm{C}$, ainda podiam ser visualizados protozoários e outros organismos característicos de lodos ativados mesofilicos, bem como na temperatura de $52^{\circ} \mathrm{C}$, entretanto, eram raros.

De forma geral, os resultados obtidos no presente trabalho para o reator aeróbio foram semelhantes aos de Lapara et al. (2001) que detectaram mudanças graduais na estrutura da comunidade bacteriana com o aumento de temperatura, incluindo uma concomitante redução no número de diferentes populações bacterianas.

Tripathi \& Allen (1999) ao avaliarem comunidades microbianas em reatores seqüências em batelada operados em diferentes temperaturas $\left(35,45,55\right.$ e $\left.60^{\circ} \mathrm{C}\right)$ utilizaram técnicas de biologia molecular (método de Victoria et al., 1996 ${ }^{41}$ ) e verificaram que a comunidade microbiana no lodo do SBR operado a $35^{\circ} \mathrm{C}$ era distinta da comunidade do SBR operado a $60^{\circ} \mathrm{C}$. O reator a $60^{\circ} \mathrm{C}$ por sua vez, apresentava uma estrutura da comunidade microbiana muito próxima ou similar a dos reatores operados a $55^{\circ} \mathrm{C}$. De acordo com Tripathi \& Allen (1999) as comunidades microbianas nos reatores operados em altas temperaturas eram mais seletivas e usavam uma limitada faixa dos nutrientes disponíveis, expressos como DQO. No presente trabalho, de modo geral, foi observado no reator aeróbio um aumento da biomassa e uma maior eficiência de remoção de DQO na fase termofilica.

Apesar da bactéria filamentosa tipo 0675 ter sido citada no trabalho de Jenkins et al. (1993) como sendo quase sempre encontrada em lodo de sistemas mesofilicos de tratamento de água residuária de papel, esta morfologia de filamentos não foi observada nas microscopias feitas neste trabalho experimental. Os filamentos predominantes na 
faixa de temperatura termofilica foram Nocardia sp. e Thiotrix sp., sendo o último também encontrado na fase mesofilica.

No reator anaeróbio as morfologias encontradas na fase mesofilica e termofilica foram praticamente as mesmas. Entretanto, na temperatura termofilica a parede celular parecia ser diferenciada e tornou-se comum a presença de vacúolos nas Methanoscieta sp.

Verificou-se também que a freqüência de organismos semelhantes ao gênero Methanosarcina sp. diminuiu nas maiores temperaturas e a fluorescência ficou tênue. Nesta fase houve acúmulo do ácido acético e o gênero Methanosarcina sp. tem menor afinidade por este ácido do que o gênero Methanosaeta sp., porém apresenta maior taxa de utilização específica. Portanto, o predomínio da Methanosarcina sp. é favorecido em altas concentrações de ácido acético (acima de $70 \mathrm{mg} . \mathrm{L}^{-1}$ ). Porém, de acordo com Speece (1996) a cinética é apenas um dos fatores necessários para a predominância.

Assim sendo, outros fatores podem determinar que um ou outro gênero prevaleça, como por exemplo a biodisponibilidade de metais traço como ferro, cobalto e níquel que favorecem o predomínio de Methanosarcina sp. em relação a Methanosaeta sp. (SPEECE, 1996).

Comparando-se os resultados das observações microscópicas do presente trabalho com as de Quarmby \& Forster (1995) há similaridade. Foi verificado em ambos trabalhos, pela microscopia de fluorescência, que havia diferenças sutis entre os tipos de organismos encontrados no lodo termofílico e os que eram encontrados no lodo mesofilico, sendo que os filamentos metanogênicos e os filamentos não fluorescentes foram comuns a todas as amostras.

Foi observado que, a partir da operação em faixa de temperatura termofilica, principalmente considerando a operação em temperatura de $52^{\circ} \mathrm{C}$ e $57^{\circ} \mathrm{C}$, o reator anaeróbio apresentou desempenho abaixo do potencial esperado e a eficiência de remoção de DQO foi decrescendo, com aumento na concentração de AGV.

O mesmo ocorreu no trabalho de Ahring et al. (2001) que avaliaram as populações microbianas em um tanque anaeróbio operado a $55^{\circ} \mathrm{C}$ e a $65^{\circ} \mathrm{C}$ e observaram que quando a temperatura foi aumentada de $55^{\circ} \mathrm{C}$ para $65^{\circ} \mathrm{C}$ houve efeito negativo no desempenho do reator anaeróbio, que estava estável, e na atividade microbiana. O aumento da temperatura operacional levou a um imediato distúrbio do equilíbrio entre fermentativas, microrganismos produtores e consumidores de ácido envolvidos na 
metanogênese, havendo acúmulo inicial e persistente de altas concentrações de AGV com simultânea queda na produção de metano, indicando que o consórcio metanogênico e microrganismos que degradavam ácidos voláteis foram severamente afetados pelo aumento de temperatura e que foram incapazes de balancear a atividade das populações fermentativas. Por outro lado, a alta temperatura operacional não reduziu significativamente a atividade das populações hidrolíticas e fermentativas.

Liu et al. (2002) também verificaram em seu trabalho com reatores de dois estágios termofílico $\left(55^{\circ} \mathrm{C}\right)$ aumento da produção de $\mathrm{AGV}$ e decréscimo na produção de metano diária. Os autores também compararam este reator a outro que operava em temperatura de $37^{\circ} \mathrm{C}$, tendo os resultados sugerido que a quebra da associação sintrófica entre bactérias e metanogênicas foi mais rápida no reator termofílico que no mesofílico.

As Tabelas 5.15 e 5.16 resumem os resultados encontrados nos exames microscópicos considerando três faixas de temperatura: a mesofilica sem controle de temperatura pelo termostato e com o controle e a faixa termofílica. Pode ser visualizada por estas tabelas a freqüência dos microrganismos em cada intervalo de temperatura.

TABELA 5.15. Organismos predominantes no reator UASB nas três faixas de trabalho selecionadas.

\begin{tabular}{|c|c|c|c|}
\hline \multirow[b]{2}{*}{ Morfologias } & \multicolumn{3}{|c|}{ Intervalos de Temperatura } \\
\hline & $\begin{array}{c}\text { Ambiente } \\
\left(25^{\circ} \mathrm{C} \text { a } 30^{\circ} \mathrm{C}\right)\end{array}$ & $\begin{array}{c}\text { Mesofílica } \\
\left(35^{\circ} \mathrm{C} \text { a } 42,5^{\circ} \mathrm{C}\right) \\
\end{array}$ & $\begin{array}{l}\text { Termofílica } \\
\left(45^{\circ} \mathrm{C}-57^{0} \mathrm{C}\right)\end{array}$ \\
\hline $\begin{array}{l}\text { Arqueas metanogênicas } \\
\text { Methanosarcina sp. } \\
\text { Methanosaeta sp. } \\
\text { Esporos de sarcina } \\
\text { Bacilos fluorescentes } \\
\text { Bacilos delgados } \\
\text { Bactérias } \\
\text { com extremidades afiladas } \\
\text { com extremidades arredondadas } \\
\text { Bacilos curvos } \\
\text { Bacilos em cadeia } \\
\text { Cocos } \\
\text { Espirilos } \\
\text { Esporos } \\
\text { Filamentos }\end{array}$ & $\begin{array}{l}4 \\
4 \\
0 \\
2 \\
0 \\
\\
0 \\
2 \\
2 \\
0 \\
0 \\
0 \\
0 \\
3\end{array}$ & $\begin{array}{l}4 \\
3 \\
2 \\
3 \\
4 \\
\\
0 \\
2 \\
2 \\
0 \\
0 \\
0 \\
3 \\
2\end{array}$ & $\begin{array}{l}0 \\
1 \\
4 \\
0 \\
2 \\
0 \\
0 \\
0\end{array}$ \\
\hline
\end{tabular}

Escala qualitativa de frequiência: (0) nenhuma; (1) rara; (2) comum; (3) muito comum; (4) abundante 
TABELA 5.16. Organismos predominantes no reator de lodos ativados nas três faixas de trabalho selecionadas.

\begin{tabular}{|c|c|c|c|c|}
\hline \multirow[t]{2}{*}{ Grupo Funcional } & \multirow{2}{*}{$\begin{array}{c}\text { Espécies } \\
\text { observadas }\end{array}$} & \multicolumn{3}{|c|}{ Intervalos de Temperatura } \\
\hline & & $\begin{array}{c}\text { Ambiente } \\
\left(25^{\circ} \mathrm{C} \text { a } 35^{\circ} \mathrm{C}\right)\end{array}$ & $\begin{array}{c}\text { Mesofílica } \\
\left(35^{\circ} \mathrm{C} \text { a } 45^{\circ} \mathrm{C}\right)\end{array}$ & $\begin{array}{l}\text { Termofílica } \\
\left(45^{0} \mathrm{C}-57^{0} \mathrm{C}\right)\end{array}$ \\
\hline \multirow{3}{*}{$\begin{array}{l}\text { Protozoários } \\
\text { Flagelados } \\
\text { Ciliados livres }\end{array}$} & Nãoidentificads & & & \\
\hline & $\begin{array}{l}\text { Não identificados } \\
\text { Paramecium }\end{array}$ & $\begin{array}{l}2 \\
0\end{array}$ & $\begin{array}{l}1 \\
2\end{array}$ & $\begin{array}{l}0 \\
0\end{array}$ \\
\hline & Aspidisca & 1 & $\begin{array}{l}2 \\
3\end{array}$ & 0 \\
\hline \multirow[t]{2}{*}{ Rizópodes } & Euglypha & 3 & 2 & 0 \\
\hline & Amoeba & 0 & 0 & 0 \\
\hline $\begin{array}{l}\text { Metazoários } \\
\text { (rotíferos) }\end{array}$ & não identificados & 3 & 1 & 0 \\
\hline \multicolumn{5}{|l|}{ Bactérias } \\
\hline Em suspensão & não identificados & 2 & 2 & 2 \\
\hline Cocos & não identificados & 0 & 2 & 3 \\
\hline Bacilos & não identificados & 0 & 0 & 3 \\
\hline \multirow[t]{6}{*}{ Filamentos } & Thiothrix I & 0 & 2 & 3 \\
\hline & Thiothrix II & 0 & 0 & 2 \\
\hline & Nocardia & 0 & 0 & 4 \\
\hline & N.Limicola II & 0 & 0 & 3 \\
\hline & M. Parvicela & 0 & 0 & 1 \\
\hline & $021 N$ & 1 & 2 & 0 \\
\hline
\end{tabular}

Escala qualitativa de frequiência: (0) nenhuma; (1) rara; (2) comum; (3) muito comum; (4) abundante

\subsubsection{Organismos metanogênicos}

Após incubação por 20 dias, a $57^{\circ} \mathrm{C}$, dos frascos contendo inóculo e substrato, foi verificado o crescimento de microrganismos pela formação de biogás, visto que a cor do substrato utilizado(licor negro diluído, seção 4.4 do capítulo Material e métodos) não permitiram observação de turbidez.

Para confirmar a presença ou ausência de produção de metano foram retiradas amostras do biogás dos frascos e injetadas em cromatógrafo a gás. Houve necessidade de eliminar a atenuação do sinal do cromatógrafo (2 para zero) para torná-lo mais sensível à quantificação de metano.

Na Tabela 5.17 são apresentados os resultados da produção de metano nas quintuplicatas das diluições decimais seriadas dos frascos inoculados com lodo anaeróbio (5 diluições) e com lodo aeróbio (3 diluições). A porcentagem de metano no biogás variou de 1 a $3 \%$ em amostras inoculadas com lodo anaeróbio termofilico e em torno de $1 \%$ para amostras inoculadas com lodo aeróbio termofílico.

No exame dos frascos com lodo anaeróbio foi verificado de forma geral o predomínio de Methanosaeta sp. e bacilos, semelhantes a bactérias redutoras de sulfato 
e Dessulfobulbos. Também foram identificados cocos e muitos bacilos com inclusões, que predominaram na diluição de $10^{-2}$ e não foi verificada fluorescência.

Nas maiores diluições os bacilos predominaram e houve redução do aparecimento de Methanosaeta sp. e de bacilos sem inclusões.

Na Tabela 5.18 são apresentados os organismos que predominaram em cada diluição do lodo do reator anaeróbio. Em seguida são apresentados nas Figuras 5.46 e 5.47 fotos dos principais microrganismos visualizados nesta análise de NMP do lodo do reator UASB.

TABELA 5.17. NMP: frascos positivos e negativos em relação à produção de metano com inóculos anaeróbio termófilo (reator UASB) e aeróbio termófilo (reator lodos ativados).

\begin{tabular}{|c|c|c|c|c|c|c|c|c|c|}
\hline \multirow{3}{*}{$\begin{array}{c}\text { Frascos } \\
\text { (repetições) }\end{array}$} & \multicolumn{6}{|c|}{ Reator UASB } & \multirow{2}{*}{\multicolumn{3}{|c|}{$\frac{\text { Reator lodos ativados }}{\text { Diluicóes }}$}} \\
\hline & \multicolumn{6}{|c|}{ Diluições } & & & \\
\hline & $10^{-1}$ & $10^{-2}$ & $10^{-3}$ & $10^{-4}$ & $10^{-5}$ & $10^{-6}$ & $10^{-1}$ & $10^{-2}$ & $10^{-3}$ \\
\hline 1 & + & + & + & - & - & - & - & - & - \\
\hline 2 & + & + & + & + & - & - & + & - & - \\
\hline 3 & + & - & - & - & - & - & - & - & - \\
\hline 4 & - & + & + & - & - & - & + & - & - \\
\hline 5 & + & + & + & - & - & - & - & - & - \\
\hline
\end{tabular}

TABELA 5.18. Microrganismos predominantes nos frascos de contagem com lodo do reator UASB termofílico nas três faixas de trabalho selecionadas.

\begin{tabular}{l|c|c|c|c|c|c}
\hline \multicolumn{1}{c|}{ Morfologias } & \multicolumn{7}{c}{ Diluç̃es } \\
\cline { 2 - 6 } & $\mathbf{1 0}^{-\mathbf{1}}$ & $\mathbf{1 0 ^ { - 2 }}$ & $\mathbf{1 0}^{-\mathbf{3}}$ & $\mathbf{1 0 ^ { - 4 }}$ & $\mathbf{1 0 ^ { - 5 }}$ & $\mathbf{1 0}^{-\mathbf{6}}$ \\
\hline Arqueas metanogênicas & & & & & & \\
Methanosarcina sp. & 1 & 0 & 0 & 0 & 0 & 0 \\
Methanosaeta sp. & 3 & 2 & 0 & 0 & 0 & 0 \\
Bacilos fluorescentes & 0 & 0 & 0 & 0 & 0 & 0 \\
Bacilos curvos & 2 & 2 & 2 & 0 & 0 & 0 \\
Bactérias & 0 & 0 & 0 & 0 & 0 & 0 \\
com extremidades afiladas & 0 & 0 & 0 & 0 & 0 & 0 \\
com extremidades arredondadas & 0 & 0 & 1 & 1 & 0 & 0 \\
Bacilos curvos & 0 & 0 & 2 & 2 & 0 & 0 \\
Bacilos em cadeia & 0 & 2 & 0 & 0 & 0 & 0 \\
Cocos & 0 & 0 & 0 & 0 & 0 & 0 \\
Espirilos & 0 & 0 & 0 & 0 & 0 & 0 \\
Esporos & 0 & 0 & 0 & 0 & 0 & 0 \\
Filamentos &
\end{tabular}

Escala qualitativa de frequiência: (0) nenhuma; (1) rara; (2) comum; (3) muito comum; (4) abundante

Utilizando os dados da Tabela 5.17 e a tabela de probabilidades do APHA (1998) verifica-se que o NMP de arqueas metanogênicas foi igual a $23.10^{4}$ NMP por $100 \mathrm{~mL}$ para o reator anaeróbio e igual a $4.10^{2} \mathrm{NMP}$ por $100 \mathrm{~mL}$ para o reator aeróbio. 


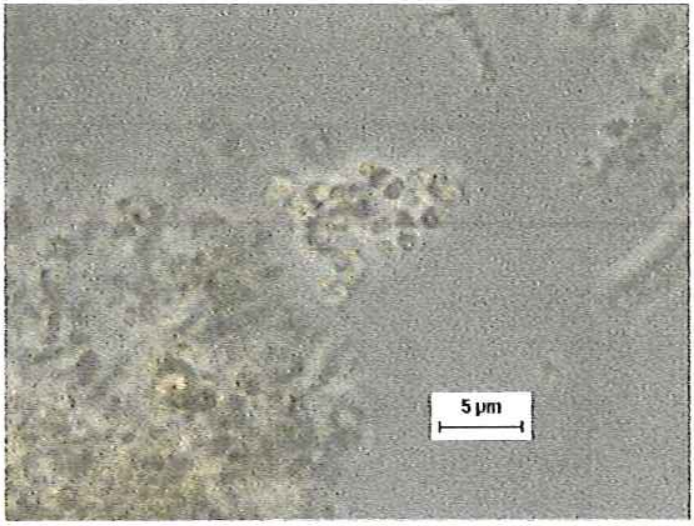

(a)

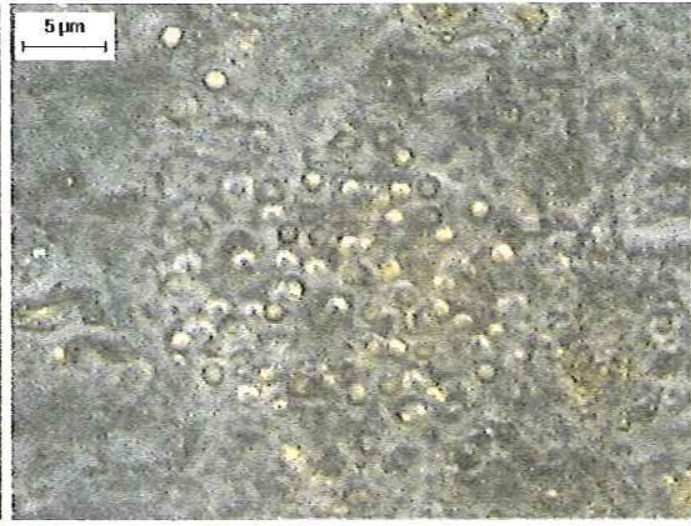

(b)

FIGURA 5.46. Microrganismos visualizados na amostra NMP com inóculo de lodo do reator UASB termofilico: frasco 2 (diluição $10^{-1}$ ); microrganismos semelhantes ao gênero Methanosarcina sp. (a); frasco 7 (diluição $10^{-2}$ ): microrganismos cocóides (b).

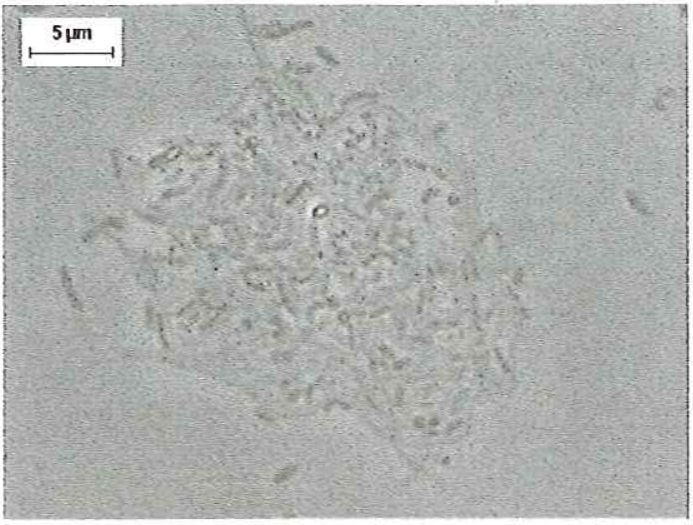

(a)

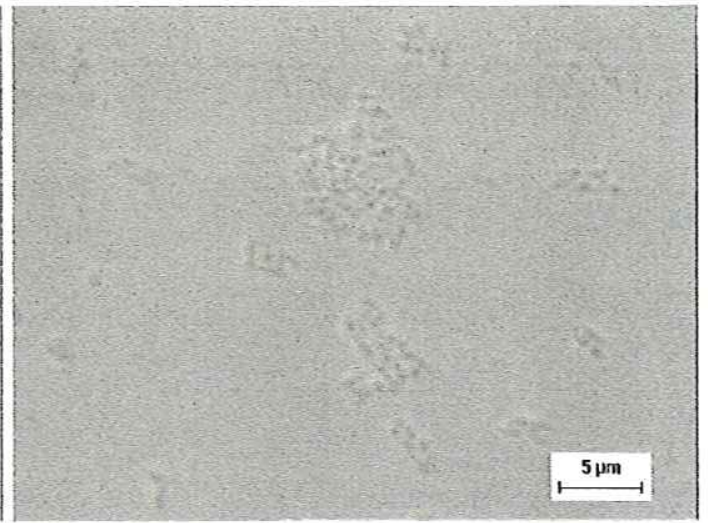

(b)

FIGURA 5.47. Microrganismos visualizados na amostra NMP com inóculo de lodo do reator UASB termofilico, frasco 11 (diluição $10^{-3}$ ): microrganismos semelhantes a Methanosaeta sp. e bacilos, alguns com inclusões (a); frasco 17 (diluição $10^{-4}$ ): bacilos (agrupados e em cadeia), alguns com inclusões (b).

No reator de lodos ativados foi verificada a predominância de bacilos e filamentos delgados, sem fluorescência, sendo comum a ocorrência de bacilos com inclusão. Também foram visualizados microrganismos semelhantes a cocos e bacilos esporulando e algumas morfologias semelhantes a sarcinas, mas não fluorescentes ou com fluorescência tênue, o que era esperado, visto que a condição não era adequada.

Na Tabela 5.19 são apresentadas as freqüências estimadas dos microrganismos encontrados no exame de NMP de frascos inoculados com lodo aeróbio termófilo. Na Figura 5.48 são apresentadas algumas imagens das morfologias dominantes nesta análise. 
TABELA 5.19. Microrganismos predominantes nos frascos de contagem com lodo do reator de lodos ativados termofílico nas três faixas de trabalho selecionadas.

\begin{tabular}{|c|c|c|c|}
\hline \multirow{2}{*}{ Morfologias } & \multicolumn{3}{|c|}{ Diluições } \\
\hline & $10^{-1}$ & $10^{-2}$ & $10^{-3}$ \\
\hline Arqueas metanogênicas & & & \\
\hline Methanosarcina sp. & - & - & - \\
\hline Methanosaeta sp. & 1 & & \\
\hline Bacilos fluorescentes & - & - & - \\
\hline Bacilos curvos & 3 & - & - \\
\hline Bactérias & & & \\
\hline com extremidades afiladas & - & - & - \\
\hline com extremidades arredondadas & - & - & - \\
\hline Bacilos curvos & 2 & - & - \\
\hline Bacilos em cadeia & 1 & - & - \\
\hline Cocos & 1 & - & - \\
\hline Espirilos & - & - & - \\
\hline Esporos & - & - & - \\
\hline Filamentos & 2 & - & - \\
\hline
\end{tabular}

Escala qualitativa de frequiência: (0) nenhuma; (1) rara; (2) comum; (3) muito comum; (4) abundante

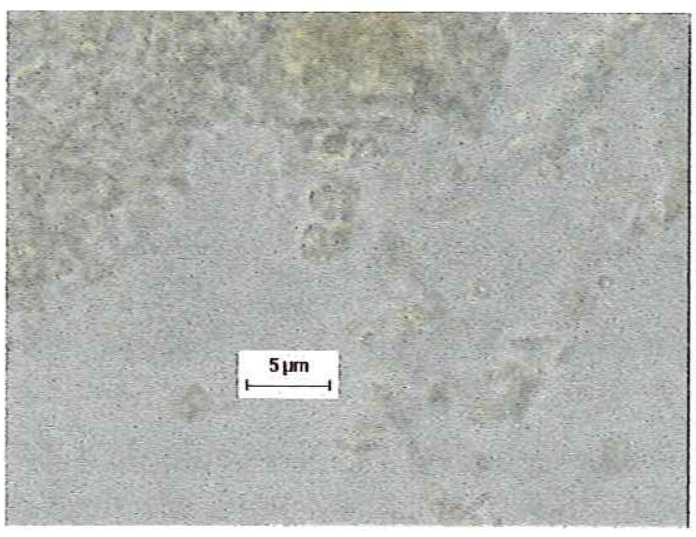

(a)

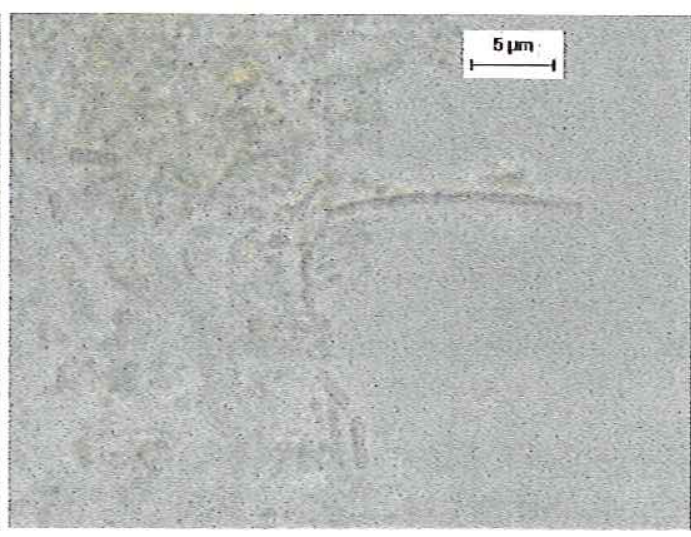

(b)

FIGURA 5.48. Microrganismos visualizados na amostra NMP com inóculo de lodo do reator lodos ativados termofílico, frasco 34 (diluição $10^{-1}$ ): predominância de bacilos, presença de filamentos e sarcinas que não fluorescem (a); frasco 34 (diluição $10^{-1}$ ): bacilos e filamentos delgados (b).

\subsubsection{Microscopia eletrônica de varredura (MEV)}

A microscopia eletrônica de varredura foi feita apenas com lodo termofílico. Tanto nas amostras anaeróbias quanto nas aeróbias foi verificado um número limitado de morfologias.

Quarmby \& Forster (1995) comparando amostras anaeróbias tratadas em faixas de temperatura mesofilicas com amostras tratadas em faixas de temperatura termofilicas pela análise por microscopia eletrônica de varredura, verificou que as amostras ; 
termofílicas tinham um número mais limitado de morfologias comparado às amostras mesofilicas.

Comparando as MEV do lodo termofílico do presente trabalho (Figura 5.50) com as do trabalho de Buzzini (2000) operando um reator UASB mesofilico com água residuária sintética similar, porém com tempo de detenção hidráulico de 40 horas, verificou-se que as estruturas eram comparáveis as do reator em que foram adicionados organoclorados, com morfologias não tão bem definidas quanto as do reator em que os organoclorados não foram adicionados Além disso, no trabalho de Buzzini (2000) espécies semelhantes a Methanosarcina sp. e Methanosaeta sp. foram mais abundantes, o que não aconteceu nas amostras termofilicas deste trabalho.

Liu et al. (2002) analisando lodo anaeróbio, também por MEV, verificaram que espécies de Methanosaeta eram abundantes no interior do lodo do inóculo. Quando estes grânulos foram desintegrados a Methanosaeta sp. foi exposta a altas concentrações de AGV e baixo pH ambiental e sua abundância reduziu rapidamente juntamente com outros microrganismos sintróficos, levando a uma perda de sólidos pelo efluente. De acordo com Liu et al. (2002) a quebra da associação sintrófica entre arqueas metanogênicas e bactérias foi mais rápida no reator termofilico que no reator mesofilico. Isto poderia justificar a grande perda de sólidos que ocorreu no presente trabalho na faixa de temperatura termofilica. Apesar da perda de biomassa também ter ocorrido na faixa de temperatura mesofilica, na faixa de temperatura termofilica a perda foi maior, $(909 \pm 264) \mathrm{mgSSV} . \mathrm{d}^{-1}$ efluente mesofílico comparado a $(1373 \pm 732) \mathrm{mgSSV} . \mathrm{d}^{-1}$ no efluente termofílico.

No exame pôde ser visualizada uma cavidade no grânulo termofilico (Figura 5.49) que provavelmente tenha ocorrido por modificações da organização da camada microbiana do meio dos grânulos termofílicos, como observado por Bochem et al ${ }^{42}$ (1982) citados por Quarmby \& Forster (1995), detalhado no item 3.6.1.1. do capítulo de revisão de literatura. Os autores observaram que o lodo granular termofílico apresenta uma camada do meio com células ovais frouxamente organizadas com o centro formado por bactérias em forma de filamentos e muitas cavidades preenchidas por gás.

${ }^{42}$ BOCHEM, H. P.; SCHOBERT, S. M.; SPREY, B.; WENGLER, P. (1982). Thermophilic biomethanation of acetic acid: morphology and ultrasctructure of a granular consortium. Can. J. Microbiol. 1982. 25, p. 500-510. 


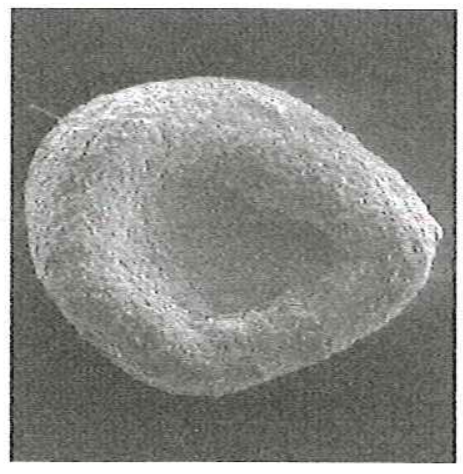

(a)

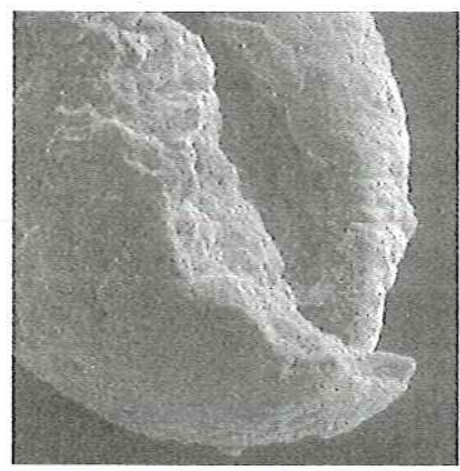

(b)

FIGURA 5.49. Aspecto do grânulo anaeróbio termófilo de reator tratando efluente simulado da indústria de celulose não branqueada. Aumento de 43X (a); aumento de $200 \times(b)$.

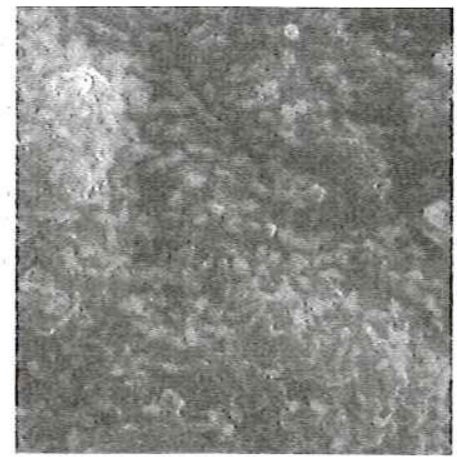

(a)

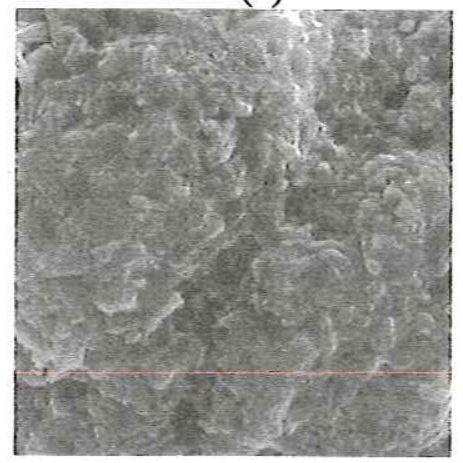

(c)

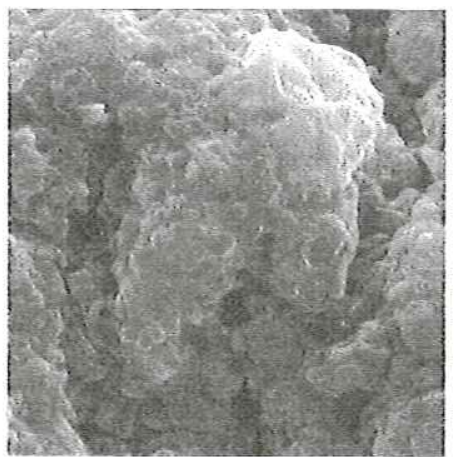

(b)

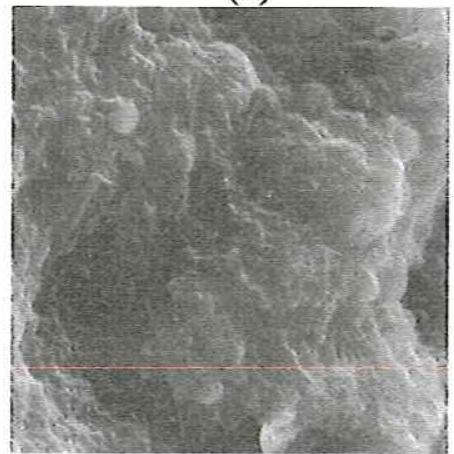

(d)

FIGURA 5.50. MEV - aumento de 5000X: (a) Células em formato de bacilos arredondados (a), células em formato de bacilos e cocos, presença de filamentos (b) e (c), células em formato de $\operatorname{cocos}(\mathrm{d})$.

No exame de microscopia eletrônica do reator de lodos ativados foram visualizados cocos, bacilos e filamentos (Figura 5.51)

Mendonça (2002) visualizou também por MEV estas morfologias em um reator de lodos ativados mesofílico alimentado com efluente sanitário. Segundo a autora estas 
morfologias apareceram raramente porque estavam na maioria das vezes associadas ao floco.

De acordo com Eikelboom (2000) ${ }^{43}$ citado por Mendonça (2002) a abundância destas células livres seria indicadora de escassez de oxigênio ou da presença de componentes tóxicos no afluente do sistema de lodos ativados. Entretanto, por medição do potencial redox do reator de lodos ativados verificou-se que o mesmo estava em condições aeróbias, sendo a abundâncias destas morfologias justificadas, possivelmente, pela elevada temperatura de operação.

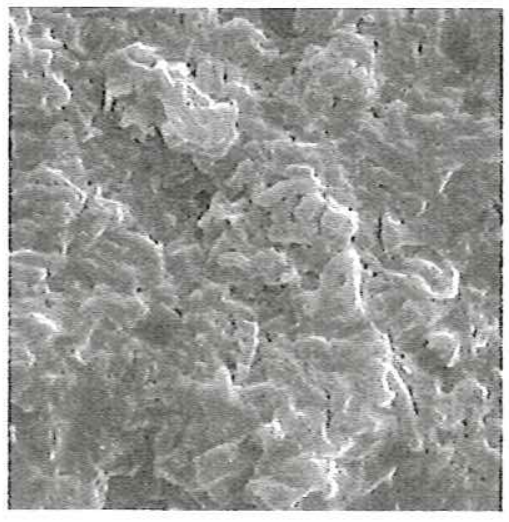

(a)

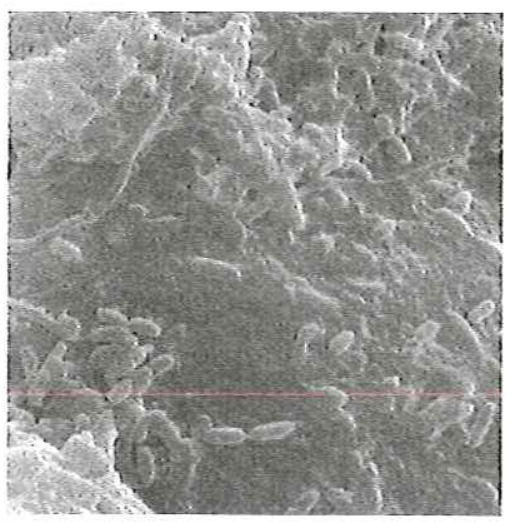

(c)

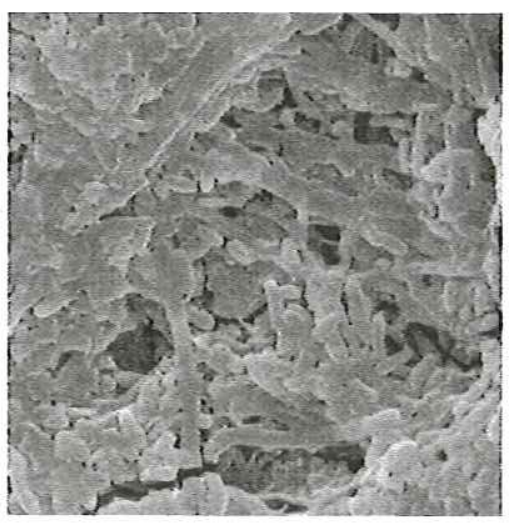

(b)

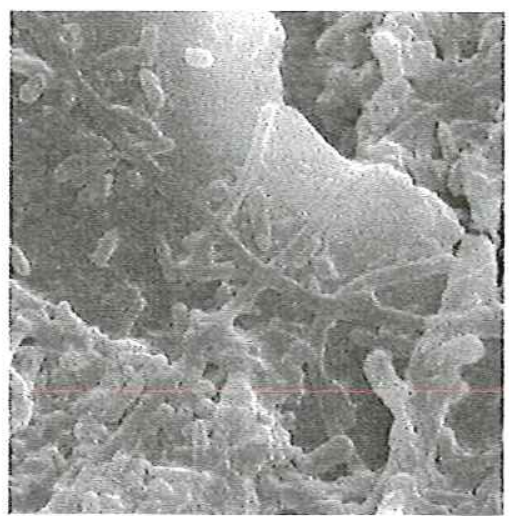

(d)

FIGURA 5.51. MEV - aumento de 5000X: Células em formato de bacilos arredondados (a), células em formato de bacilos e cocos, presença de filamentos (b) e (c), células em formato de $\operatorname{cocos}$ (d).

\footnotetext{
${ }^{43}$ EIKELBOOM, D. H. (2000). Process control of activated sludge plants by microscopic investigation. Manual,
} Asis/IWA, 156p. Londres, Reino Unido. 


\subsection{Efeito da temperatura sobre os parâmetros monitorados}

Esta análise dos efeitos da temperatura nos parâmetros monitorados foi considerada a partir da $5^{a}$ etapa, quando já havia sido feita a adição de etanol na água residuária sintética e também quando a temperatura começou a sofrer ajustes.

\subsubsection{Efeito da temperatura na remoção de DQO}

Na Tabela 5.20 e Figura 5.52 são apresentadas as eficiências obtidas em cada faixa de temperatura, mesofilica e termofilica, considerando as diferentes etapas

Nas primeiras etapas analisadas na fase mesofilica $\left(5^{a}\right.$ e $\left.6^{a}\right)$ nota-se um desempenho praticamente constante do reator anaeróbio e uma baixa eficiência de remoção de DQO do reator aeróbio. Entretanto, apesar deste baixo desempenho do reator aeróbio nestas duas etapas, deve ser considerado que ao longo do período a eficiência de remoção foi crescente.

Considerando a faixa de temperatura de $35,0^{\circ} \mathrm{C}$ a $37,5^{\circ} \mathrm{C}\left(7^{\mathrm{a}}\right.$ etapa da fase mesofilica) observa-se uma grande variação nas eficiências obtidas, indicando uma instabilidade do sistema. O reator de lodos ativados por exemplo, apresentou oscilação na eficiência de remoção de DQO que variou de $22 \%$ a $73 \%$. Deve ser lembrado que nesta etapa foram feitas modificações na água residuária sintética dos reatores e houve alteração no tempo de detenção do reator aeróbio, prejudicando seu desempenho. Além disso, as menores eficiências de remoção do reator UASB correspondem ao período imediatamente após o aumento súbito da DQO afluente (Figura 5.52).

Pela Tabela 5.20 nota-se que as melhores eficiências observadas no reator anaeróbio foram a $47,5^{\circ} \mathrm{C}$ e a $45,0^{\circ} \mathrm{C}$, correspondendo a segunda e primeira etapa da fase termofílica, respectivamente. Considerando o reator aeróbio, as melhores eficiências de remoção foram obtidas a $57^{\circ} \mathrm{C}$, entretanto apresentaram grande variação, de $43 \%$ a $75 \%$. Estes resultados diferem dos obtidos por Tripathi \& Allen (1999) que obtiveram a maior eficiência de remoção (42\% a $72 \%)$ em um reator seqüencial de batelada operado a $35,0^{\circ} \mathrm{C}$. Em temperatura de $55,0^{\circ} \mathrm{C}$ a eficiência obtida em um SBR variou de $42 \%$ a $61 \%$ e a $60^{\circ} \mathrm{C}$, a eficiência variou de $44 \%$ a $65 \%$.

Pela análise do coeficiente de Pearson observa-se que a correlação entre a eficiência de remoção de DQO e o aumento de temperatura é uma cơrrelação negativa $(r=-0,6)$ para o reator anaeróbio e positiva para o reator aeróbio $(r=+0,5)$. Ou seja, as

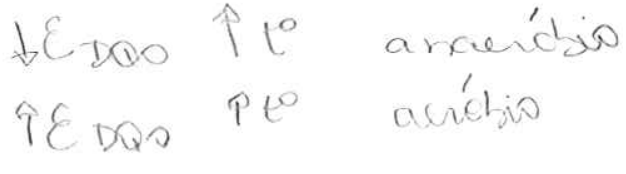


variáveis aumento de temperatura e eficiência de remoção de DQO cresceram em sentidos opostos no reator anaeróbio e no mesmo sentido no reator aeróbio.

Analisando-se a correlação entre a eficiência de remoção do reator UASB e a do reator de lodos ativados encontrou-se correlação negativa na fase termofílica $(r=-0,5)$ e ausência de correlação na fase mesofilica $(r=-0,2)$.

Para essas análises foram considerados todos os dados de eficiência de remoção de DQO obtidos nos reatores no intervalo de temperatura de $30,0^{\circ} \mathrm{C}$ até $57,0^{\circ} \mathrm{C}$.

TABELA 5.20. Faixas de variação das eficiências de remoção de DQO encontradas nos reatores biológicos nos diferentes intervalos de temperatura de trabalho.

\begin{tabular}{|c|c|c|c|c|c|}
\hline \multirow{2}{*}{ 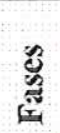 } & \multirow[t]{2}{*}{ Etapas } & \multirow{2}{*}{$\begin{array}{c}\text { Temperatura } \\
\left({ }^{0} \mathrm{C}\right)\end{array}$} & \multicolumn{3}{|c|}{ Eficiência de remoção (\%) } \\
\hline & & & Efluente UASB & Efluente LA & Sistema \\
\hline \multirow{4}{*}{ 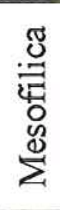 } & 5 & $25,0-30,0$ & $50-51(2)$ & $2-6(2)$ & $52-53$ \\
\hline & 6 & 32,5 & $50-52(3)$ & $19-33(3)$ & $51-67$ \\
\hline & 7 & $35,0-37,5$ & $13-61(7)$ & $0-73(7)$ & $37-81$ \\
\hline & 8 & 42,5 & $47-66(9)$ & $4-38(9)$ & $67-74$ \\
\hline \multirow{5}{*}{ 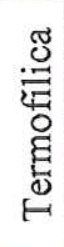 } & 1 & 45,0 & $52-73(4)$ & $14-42(4)$ & $71-75$ \\
\hline & 2 & 47,5 & $47-71(3)$ & $45-58(3)$ & $72-88$ \\
\hline & 3 & 52,0 & $19-51(2)$ & $47-53(2)$ & $57-77$ \\
\hline & 4 & 52,0 & $3-35(10)$ & $20-68(10)$ & $44-70$ \\
\hline & 5 & 57,0 & $13-24(6)$ & $43-75(6)$ & $54-67$ \\
\hline
\end{tabular}

OBS.: os valores entre parênteses representam o número de amostras considerados no intervalo.

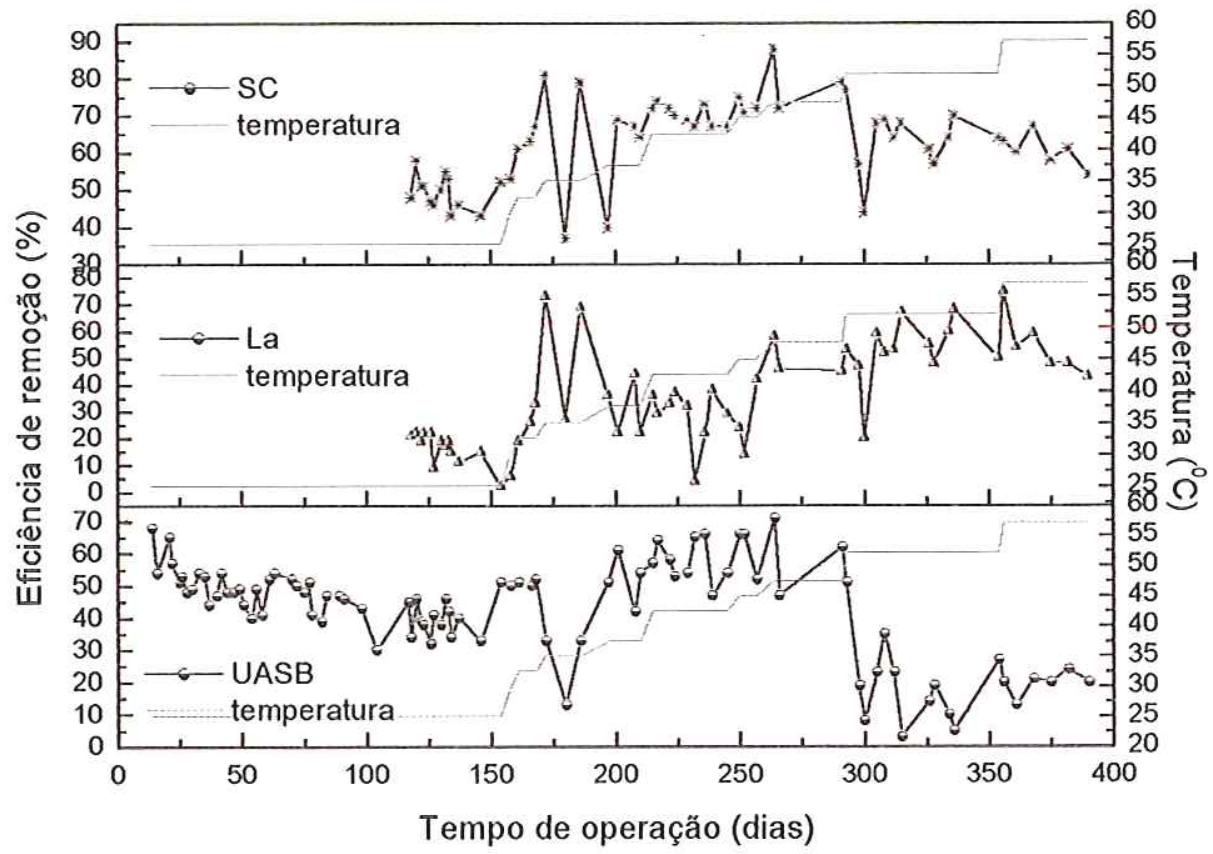

FIGURA 5.52 - Eficiências de remoção de DQO em relação ao tempo de operação, considerando as oito etapas mesofilicas e as cinco etapas termofílicas (SC - sistema combinado, ou seja, eficiência global; La - eficiência do reator de lodos ativados e UASB - eficiência do reator UASB). 


\subsubsection{Efeito da temperatura no $\mathrm{pH}$ e na alcalinidade}

A variação do $\mathrm{pH}$ e da alcalinidade ao longo do tempo encontram-se nas Figuras 5.53 e 5.54. Deve-se ressaltar, que por várias vezes houve controle do $\mathrm{pH}$ afluente e também adição bicarbonato para controle do $\mathrm{pH}$ e alcalinidade.

Avaliando-se então cada etapa, a primeira queda do $\mathrm{pH}$ no reator anaeróbio foi função do aumento da DQO afluente ocorrida concomitantemente com o aumento de temperatura. O reator anaeróbio permaneceu instável por aproximadamente 15 dias (Tabela 5.21 e Figura 5.53). Pode ser verificado na Figura 5.54 que houve consumo da alcalinidade nesta etapa ( $7^{\text {a }}$ etapa).

Nova queda no $\mathrm{pH}$ ocorreu aproximadamente 35 dias após o aumento de temperatura para $52^{\circ} \mathrm{C}$, havendo o consumo da alcalinidade ( $4^{\mathrm{a}}$ etapa termofilica, Tabelas 5.20 e 5.21).

Aplicando-se o coeficiente de Pearson verificou-se que não houve correlação entre o $\mathrm{pH}$ dos reatores na fase mesofilica $(r=0,2)$ e termofilica $(r=0,4)$. Considerandose entretanto o aumento de temperatura em relação ao $\mathrm{pH}$, verificou-se que para o reator aeróbio não houve correlação, enquanto para o reator anaeróbio a correlação foi positiva na fase mesofilica $\left(r_{\mathrm{LA}}=0,6\right)$ e negativa na fase termofilica $\left(r_{\mathrm{LA}}=-0,8\right)$.

Considerando o aumento de temperatura em relação à alcalinidade, verificou-se que somente houve correlação para o reator anaeróbio, na fase termofilica, correlação negativa $\left(\mathrm{r}_{\mathrm{UASB}}=-0,6\right)$.

Neste trabalho, portanto, não houve problemas com o controle de $\mathrm{pH}$ no reator aeróbio, apenas no reator anaeróbio. O mesmo ocorreu no trabalho de Tripathi \& Allen (1999), considerando o tratamento aeróbio, em que os autores não tiveram problemas com pH operando reatores SBR. Segundo Tripathi \& Allen (1999), os resultados de pH efluente aumentaram cerca de $1,5 \mathrm{pH}$ unidades para as amostras retiradas dos reatores nas condições mesofilica e termofílica $\left(35,0^{\circ} \mathrm{C}, 45,0^{\circ} \mathrm{C}, 55,0^{\circ} \mathrm{C}\right.$ e $\left.60,0^{\circ} \mathrm{C}\right)$. Entretanto, segundo os autores, havia tendência de aumento do $\mathrm{pH}$ em temperaturas maiores.

Tripathi \& Allen (1999) relacionam esse aumento de $\mathrm{pH}$ à formação de compostos geradores de alcalinidade e/ou tratamento de ácidos presentes no substrato e efluente. 
TABELA 5.21. Faixa de variação do pH nos efluentes dos reatores biológicos nos diferentes intervalos de temperatura de trabalho.

\begin{tabular}{|c|c|c|c|c|c|}
\hline \multirow{2}{*}{$\begin{array}{l}\text { औे } \\
\text { sू山 }\end{array}$} & \multirow[t]{2}{*}{ Etapas } & \multirow{2}{*}{$\begin{array}{c}\text { Temperatura } \\
\left({ }^{0} \mathrm{C}\right)\end{array}$} & \multicolumn{3}{|c|}{ pH } \\
\hline & & & ARS & Efluente UASB & Efluente LA \\
\hline ర్ & 5 & $25,0-30,0$ & $7,2-7,4(2)$ & $7,4-7,6(2)$ & $7,6-7,8(2)$ \\
\hline 运 & 6 & 32,5 & $7,0-7,4(3)$ & $7,3-7,4(3)$ & $7,8-8,0(3)$ \\
\hline$\underbrace{0}_{0}$ & 7 & $35,0-37,5$ & $7,2-8,7(14)$ & $5,2-8,0(14)$ & $7,1-8,0(14)$ \\
\hline$\Sigma$ & 8 & 42,5 & $7,4-8,2(9)$ & $7,8-8,1(9)$ & $8,1-7,5(9)$ \\
\hline & 1 & 45,0 & $7,5-7,8(9)$ & $7,9-8,0(9)$ & $7,9-8,0(9)$ \\
\hline$\stackrel{0}{=}$ & 2 & 47,5 & $7,2-7,4(4)$ & $7,3-7,8(4)$ & $7,8-8,1(4)$ \\
\hline 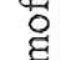 & 3 & 52,0 & $7,0-7,3(2)$ & $7,3-7,5(2)$ & $7,6-7,9(2)$ \\
\hline 0 & 4 & 52,0 & $7,2-8,5(10)$ & $5,1-7,6(10)$ & $7,6-8,3(10)$ \\
\hline & 5 & 57,0 & $6,0-7,3(7)$ & $5,0-6,6(7)$ & $7,5-8,1(7)$ \\
\hline
\end{tabular}

OBS.: os valores entre parênteses representam o número de amostras considerados no intervalo.

TABELA 5.22. Variação das concentrações de alcalinidade total nos efluentes dos reatores biológicos nas diferentes faixas de temperatura operadas.

\begin{tabular}{|c|c|c|c|c|c|}
\hline \multirow{2}{*}{$\begin{array}{l}\mathscr{\tilde { E }} \\
\text { జ्ञ }\end{array}$} & \multirow{2}{*}{ 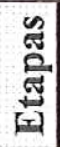 } & \multirow{2}{*}{$\begin{array}{c}\text { Temperatura } \\
\left({ }^{0} \mathrm{C}\right)\end{array}$} & \multicolumn{3}{|c|}{$\operatorname{AT}\left(\mathrm{mg} \mathrm{L}^{-1}\right)$} \\
\hline & & & $\overline{A R S}$ & Efluente UASB & Efluente LA \\
\hline \multirow{4}{*}{ 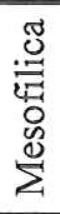 } & 5 & $25,0-30,0$ & $157-188(3)$ & $279-332(3)$ & $140-314(3)$ \\
\hline & 6 & 32,5 & $181-187(3)$ & $297-339(3)$ & $157-190(3)$ \\
\hline & 7 & $35,0-37,5$ & $154-215(7)$ & $192-290(7)$ & $105-314(7)$ \\
\hline & 8 & 42,5 & $204-297(9)$ & $290-382(9)$ & $140-231(9)$ \\
\hline \multirow{5}{*}{ 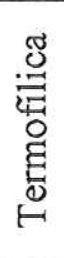 } & 1 & 45,0 & $238-302(4)$ & $271-380(4)$ & $208-263(4)$ \\
\hline & 2 & 47,5 & $205-251(3)$ & $248-320(3)$ & 89-189 (3) \\
\hline & 3 & 52,0 & $241-250(2)$ & $283-299$ (2) & $179-289(2)$ \\
\hline & 4 & 52,0 & $149-295(10)$ & $141-479(10)$ & $163-387(10)$ \\
\hline & 5 & 57,0 & $118-183(7)$ & $126-249(7)$ & $201-416(7)$ \\
\hline
\end{tabular}

OBS.: os valores entre parênteses representam o número de amostras considerados no intervalo. 


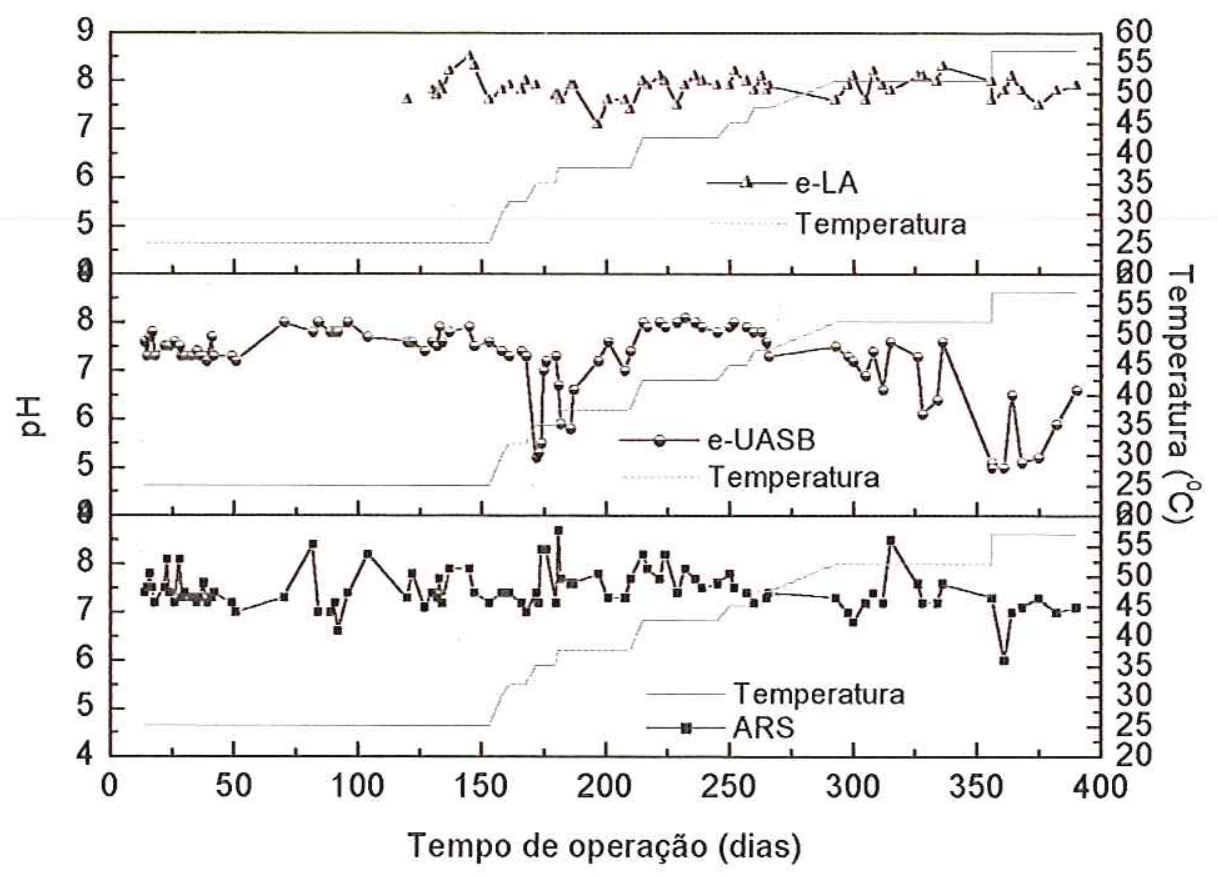

FIGURA 5.53 - Variação do pH na água residuária sintética e nos efluentes dos reatores anaeróbio e aeróbio em relação ao tempo de operação, considerando as oito etapas mesofilicas e as cinco etapas termofilicas.

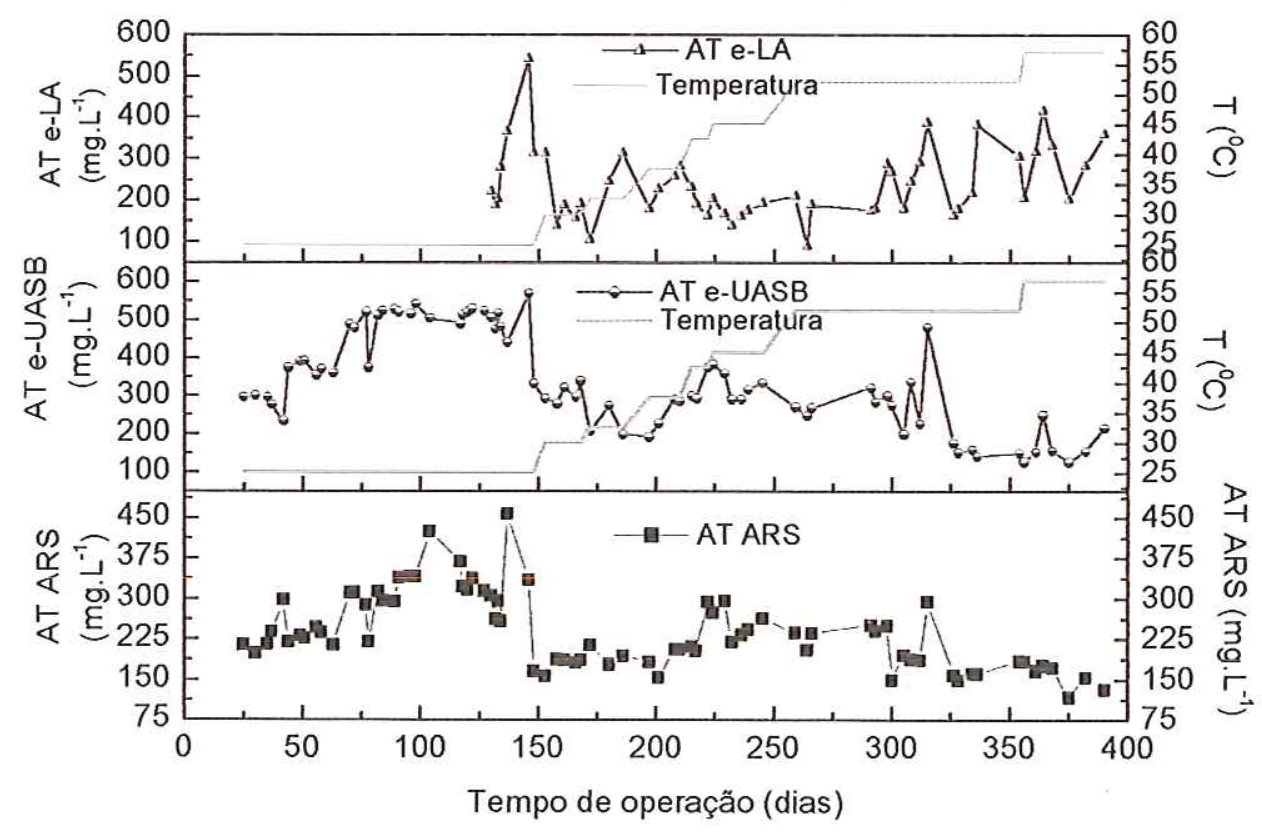

FIGURA 5.54 - Variação das concentrações de alcalinidade total na água residuária sintética e nos efluentes dos reatores UASB e de lodos ativados em relação ao tempo de operação, considerando as oito etapas mesofílicas e as cinco etapas termofílicas.

\subsubsection{Efeito da temperatura na concentração de sólidos suspensos}

Como citado no capítulo Revisão de Literatura, a separação da biomassa formada do efluente tratado em sistemas aeróbios termofilicos é um ponto chave do 
projeto (LAPARA \& ALLEMAN, 1999). Mas, em alguns processos anaeróbios termofílicos, também verifica-se perda de sólidos no efluente, como nos trabalhos de Dinsdale et al. (1997a) e de Lau \& Fang (1997).

$\mathrm{Na}$ quinta etapa da fase mesofilica, ambos reatores perderam sólidos em pequenas concentrações (no reator UASB $18 \mathrm{mgSSV}_{\text {efluente. }} \mathrm{L}^{-1}$ e no reator aeróbio $\left.11 \mathrm{mgSSV}_{\text {efluente. }} \mathrm{L}^{-1}\right)$, entretanto, na sexta etapa apenas foi registrada perda no reator anaeróbio, em concentração de $206 \mathrm{mgSSV}_{\text {efluente. }} \mathrm{L}^{-1}$, durante aproximadamente uma semana de operação, em temperatura de $32,5^{\circ} \mathrm{C}$.

Na sétima etapa, com o aumento da DQO afluente ao reator anaeróbio e a alteração no tempo de detenção hidráulica do reator aeróbio, ocorreu grandes perdas de sólidos em ambos reatores, concentrações de $269 \mathrm{mgSSV}_{\text {efluente. }} \mathrm{L}^{-1}$ no reator anaeróbio e de $429 \mathrm{mgSSV}_{\text {efluente. }} \mathrm{L}^{-1}$ no aeróbio.

$\mathrm{Na}$ oitava etapa apenas o reator anaeróbio perdeu sólidos $\left(102 \mathrm{mgSSV} . \mathrm{L}^{-1}\right)$, porém com desempenho bom e estável.

Nas três primeiras etapas da fase termofilica, as perdas foram pequenas em ambos reatores ( $82 \mathrm{mgSSV}_{\text {efluente }} \mathrm{L}^{-1}$ no UASB e $5 \mathrm{mgSSV}$ efluente. $\mathrm{L}^{-1}$ lodos ativados).

Entretanto, na quarta etapa houve grande perda de biomassa no reator anaeróbio. Inicialmente, essa perda foi reduzida com a alteração do tempo de detenção hidráulica de 20 horas para 24 horas, tendo a perda de sólidos pelo efluente do UASB passado de $93 \mathrm{mgSSV}_{\text {efluente. }} \mathrm{L}^{-1}$ para $3 \mathrm{mgSSV} \mathrm{efluente} \mathrm{L}^{-1}$. Entretanto, em 56 dias de operação a $57^{0} \mathrm{C}$, a perda de sólidos voláteis no reator anaeróbio foi de $854 \mathrm{mg} \cdot \mathrm{L}^{-1}$. O aumento da perda foi ocasionado por aumento súbito da DQO afluente com dezessete dias de operação a $52^{0} \mathrm{C}$, de $1330 \mathrm{mg} \cdot \mathrm{L}^{-1}$ para $1852 \mathrm{mg} \cdot \mathrm{L}^{-1}$.

Na última etapa da fase termofilica ( $5^{a}$ etapa) a perda diminuiu, mas ainda manteve-se alta, apresentando concentração de $575 \mathrm{mgSSV}_{\text {efluente. }} \mathrm{L}^{-1}$ no efluente do reator anaeróbio, sendo de $32 \mathrm{mgSSV}$ efluente. $\mathrm{L}^{-1}$ no efluente do reator aeróbio.

Todos os valores de perdas de biomassa pelo efluente dos reatores, considerando as diferentes etapas da fase mesofilica e da termofilica são apresentados na Tabela 5.23. 
TABELA 5.23. Perda de biomassa pelos reatores (mgSSVefluente. $\mathrm{d}^{-1}$ ).

\begin{tabular}{|c|c|c|c|c|c|c|}
\hline \multirow{3}{*}{ 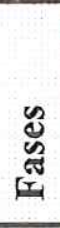 } & \multirow{3}{*}{ 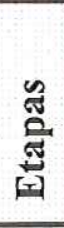 } & \multirow{3}{*}{ Temperatura $\left({ }^{0} \mathrm{C}\right)$} & \multicolumn{4}{|c|}{ Perda de sólidos (mgSSVefluente. $d^{-1}$ ) } \\
\hline & & & \multicolumn{2}{|c|}{ Efluente UASB } & \multicolumn{2}{|c|}{ Efluente LA } \\
\hline & & & $\begin{array}{c}\text { Faixa de } \\
\text { variação (n) }\end{array}$ & Média $\pm D P$ & $\begin{array}{c}\text { Faixa de } \\
\text { variação (n) }\end{array}$ & Média $\pm D P$ \\
\hline \multirow{4}{*}{ 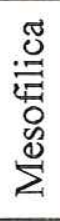 } & 5 & $25,0-30,0$ & $809(1)$ & - & $225(1)$ & - \\
\hline & 6 & 32,5 & $929-1093(3)$ & $1007 \pm 82$ & $90-153(3)$ & $120 \pm 32$ \\
\hline & 7 & $35,0-37,5$ & $349-1350(7)$ & $870 \pm 405$ & $359-3360(7)$ & - \\
\hline & 8 & 42,5 & 618-1091(5) & $945 \pm 192$ & $156-458(5)$ & $310 \pm 127$ \\
\hline \multirow{5}{*}{ 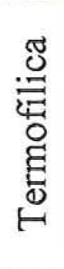 } & 1 & 45,0 & $716-1832(4)$ & $1107 \pm 501$ & $65-519(4)$ & - \\
\hline & 2 & 47,5 & $764-2583(3)$ & $1628 \pm 913$ & 298-388 (3) & $348 \pm 46$ \\
\hline & 3 & 52,0 & $52-1892(2)$ & - & $217-696(2)$ & - \\
\hline & 4 & 52,0 & $729-3723(10)$ & $1538 \pm 821$ & $300-1602(10)$ & $1010 \pm 350$ \\
\hline & 5 & 57,0 & $1225-1817(6)$ & $1505 \pm 238$ & $499-1795(6)$ & $1275 \pm 537$ \\
\hline
\end{tabular}

No trabalho de Lau \& Fang (1997), operando dois reatores UASB com 2,8 litros, em temperatura de $55^{\circ} \mathrm{C}$, por 30 dias, também foram verificadas grandes perdas de biomassa no efluente, $650 \mathrm{mgSSV}$ efluente. $\mathrm{L}^{-1}$ a $850 \mathrm{mgSSV}$ efluente. $\mathrm{L}^{-1}$, atingindo $1600 \mathrm{mgSSV}_{\text {efluente }} \mathrm{L}^{-1}$ quando a temperatura de um dos reatores foi aumentada para $65^{\circ} \mathrm{C}$. Cerca de $30 \%$ da biomassa foi lavada; entretanto, os autores verificaram que a concentração de SSV efluente foi diminuindo gradualmente, voltando à concentração original, em uma semana.

Lau \& Fang (1996) também verificaram lavagem de biogrânulos quando, em outro experimento, aumentaram a temperatura de $37^{\circ} \mathrm{C}$ para $55^{\circ} \mathrm{C}$. Os autores atribuíram essa perda à desintegração dos biogrânulos. No presente trabalho as concentrações de SSV no efluente após o choque orgânico também foram diminuindo até o aumento da temperatura para $57^{\circ} \mathrm{C}$, quando voltaram a aumentar. Deve-se considerar que os reatores são vulneráveis ao aumento de temperatura e o choque orgânico acentuou o impacto.

Considerando-se o reator aeróbio, as concentrações de sólidos suspensos voláteis no licor misto variaram muito nas duas fases de operação, tendo apresentado valores muito baixos na primeira etapa termofilica e somente atingido valores adequados na última etapa (Figura 5.56).

O mesmo foi observado por Tripathi \& Allen (1999), quando o reator SBR operado na faixa de temperatura de $55^{\circ} \mathrm{C}$ e $60^{\circ} \mathrm{C}$ apresentou clara redução nas concentrações de sólidos suspensos do licor misto nos 100 primeiros ciclos de operação. Os autores atribuíram essa redução à deterioração do lodo e sedimentação incompleta 
em altas temperaturas, provocada por mudanças na comunidade microbiana. Entretanto, segundo os autores, quando os microrganismos se aclimataram às novas condições operacionais ou tornaram-se termotolerantes, a situação melhorou e foi possível manter as concentrações de $\mathrm{SS}_{\mathrm{LM}}$ em $1800 \pm 400 \mathrm{mg} \cdot \mathrm{L}^{-1}$.

Analisando-se as correlações entre o aumento de temperatura e a concentração de sólidos suspensos voláteis no efluente, no reator anaeróbio, não foi encontrada correlação na fase mesofilica, mas na fase termofilica, a correlação foi perfeitamente positiva $\left(\mathrm{r}_{\mathrm{UASB}}=+1\right)$. Para o reator aeróbio, não foi encontrada correlação na fase mesofilica e na fase termofílica, o coeficiente de Pearson foi positivo $\left(r_{L A}=+0,5\right)$. Também houve correlação positiva entre o aumento de temperatura e a concentração de sólidos suspensos voláteis no licor misto na fase termofílica $\left(\mathrm{r}_{\mathrm{LA}}=+0,7\right)$; na mesofilica não houve correlação.

Na Tabela 5.24 e Figura 5.55 são apresentados os valores de sólidos suspensos totais e sólidos suspensos voláteis na entrada e saída dos reatores.

TABELA 5.24. Variação das concentrações de sólidos suspensos voláteis e sólidos suspensos totais nas diferentes faixas de temperatura operadas.

\begin{tabular}{|c|c|c|c|c|c|c|c|}
\hline 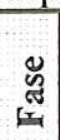 & 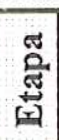 & $\begin{array}{c}\text { Temperatura } \\
\left({ }^{0} \mathrm{C}\right)\end{array}$ & SS & ARS & $\begin{array}{c}\text { Efluente } \\
\text { UASB }\end{array}$ & $\begin{array}{c}\text { Efluente } \\
\text { LA }\end{array}$ & $\mathrm{SSV}_{\text {LM }}$ \\
\hline \multirow{4}{*}{ 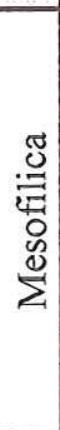 } & 5 & $25,0-30,0$ & $\begin{array}{l}\text { SSV } \\
\text { SST }\end{array}$ & $\begin{array}{l}14 \\
52\end{array}$ & $\begin{array}{l}65 \\
70\end{array}$ & $\begin{array}{l}30 \\
80\end{array}$ & 106 \\
\hline & 6 & 32,5 & $\begin{array}{l}\text { SSV } \\
\text { SST }\end{array}$ & $\begin{array}{l}10-39 \\
12-51\end{array}$ & $\begin{array}{c}79-88 \\
83-106\end{array}$ & $\begin{array}{l}16-21 \\
22-71\end{array}$ & $65-771$ \\
\hline & 7 & $35,0-37,5$ & $\begin{array}{l}\text { SSV } \\
\text { SST }\end{array}$ & $\begin{array}{l}13-374 \\
41-388\end{array}$ & $\begin{array}{c}56-108 \\
103-119\end{array}$ & $\begin{array}{l}14-452 \\
40-490\end{array}$ & $26-4176$ \\
\hline & 8 & 42,5 & $\begin{array}{l}\text { SSV } \\
\text { SST }\end{array}$ & $\begin{array}{l}25-109 \\
43-140\end{array}$ & $\begin{array}{c}50-87 \\
66-126\end{array}$ & $\begin{array}{l}21-61 \\
36-99\end{array}$ & $17-2515$ \\
\hline \multirow{5}{*}{ 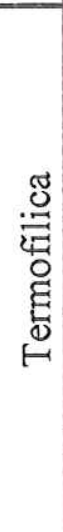 } & 1 & 45,0 & $\begin{array}{l}\text { SSV } \\
\text { SST }\end{array}$ & $\begin{array}{c}39-899 \\
72-1005\end{array}$ & $\begin{array}{l}57-147 \\
73-171 \\
\end{array}$ & $\begin{array}{c}9-70 \\
24-110 \\
\end{array}$ & $15-89$ \\
\hline & 2 & 47,5 & $\begin{array}{l}\text { SSV } \\
\text { SST }\end{array}$ & $\begin{array}{c}87-242 \\
102-316\end{array}$ & $\begin{array}{l}61-207 \\
80-265\end{array}$ & $\begin{array}{l}40-52 \\
44-83\end{array}$ & $74-355$ \\
\hline & 3 & 52,0 & $\begin{array}{l}\text { SSV } \\
\text { SST }\end{array}$ & $\begin{array}{c}55-82 \\
105-198\end{array}$ & $\begin{array}{c}4-152 \\
101-265\end{array}$ & $\begin{array}{c}29-94 \\
102-204\end{array}$ & $32-470$ \\
\hline & 4 & 52,0 & $\begin{array}{l}\text { SSV } \\
\text { SST }\end{array}$ & $\begin{array}{l}21-123 \\
25-161\end{array}$ & $\begin{array}{l}69-353 \\
92-384 \\
\end{array}$ & $\begin{array}{l}24-128 \\
50-149 \\
\end{array}$ & $122-220$ \\
\hline & 5 & 57,0 & $\begin{array}{l}\text { SSV } \\
\text { SST }\end{array}$ & $\begin{array}{c}6-170 \\
38-189\end{array}$ & $\begin{array}{c}4-172 \\
140-220\end{array}$ & $\begin{array}{c}3-144 \\
67-167\end{array}$ & $1570-2940$ \\
\hline
\end{tabular}




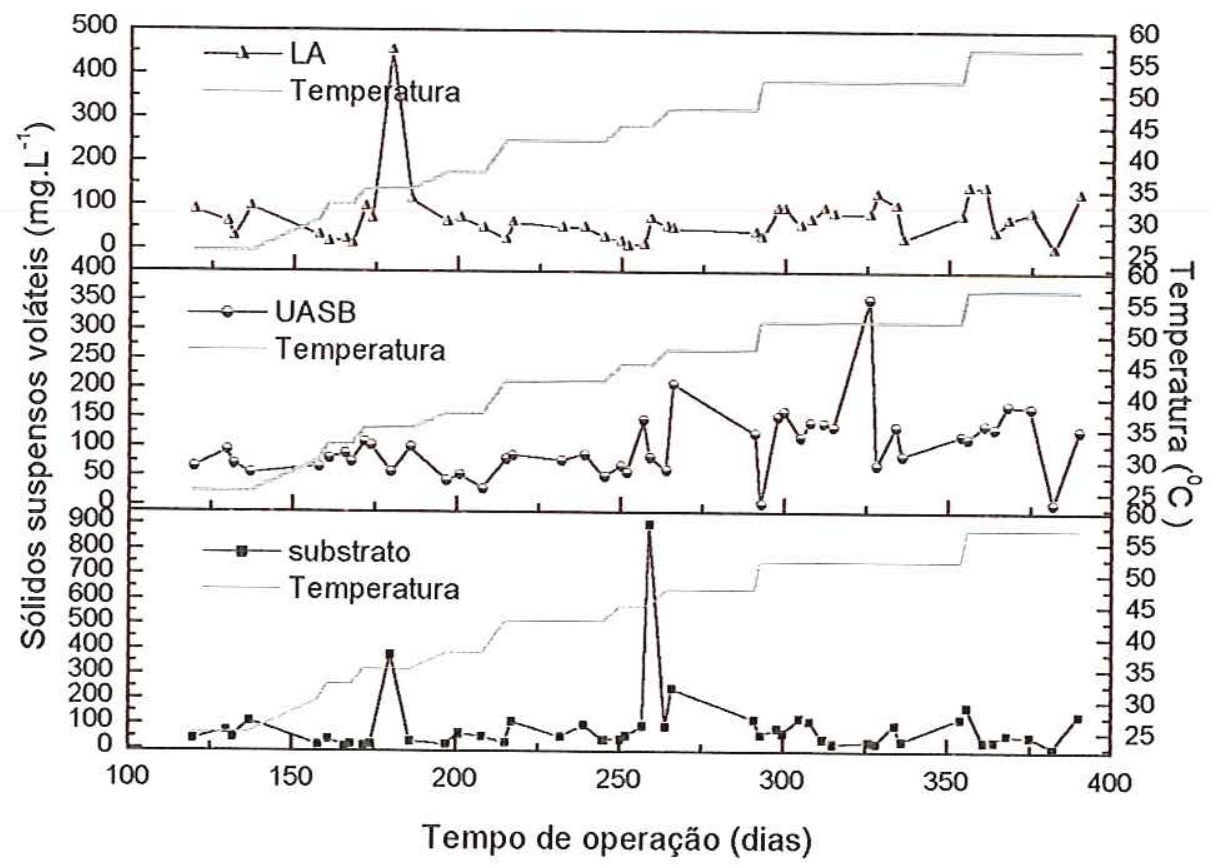

FIGURA 5.55 - Variação de sólidos suspensos voláteis na água residuária sintética e nos efluentes dos reatores anaeróbio e aeróbio em relação ao tempo de operação, considerando as oito etapas mesofilicas e as cinco etapas termofílicas.

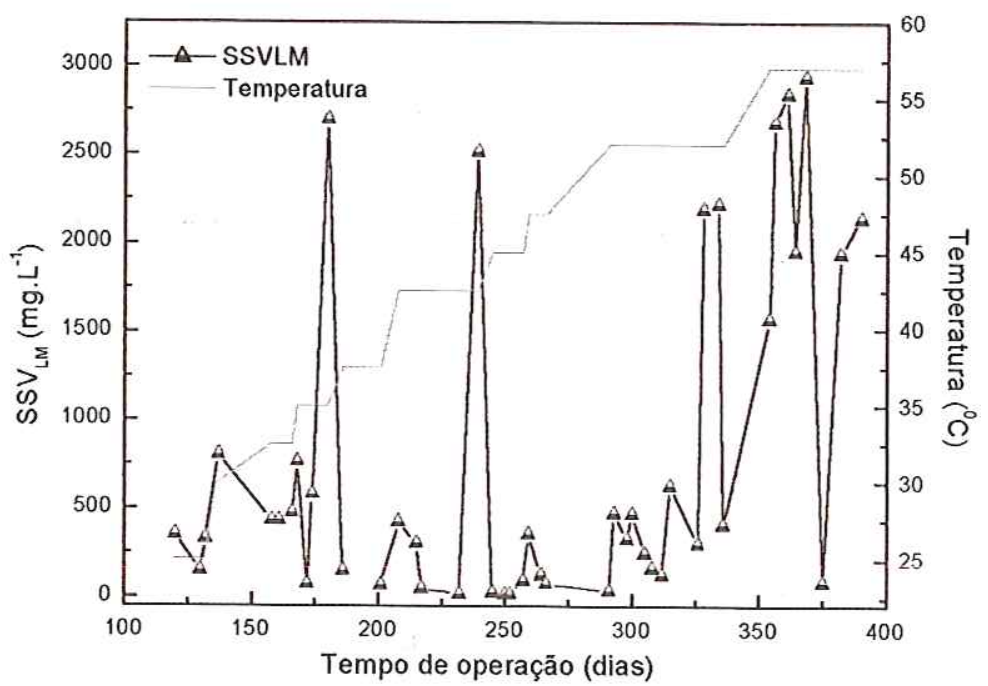

FIGURA 5.56. Variação de sólidos suspensos voláteis no licor misto do reator de lodos ativados em relação ao tempo de operação, considerando as oito etapas mesofilicas e as cinco etapas termofilicas.

\subsubsection{Efeito da temperatura nas concentrações de ácidos graxos voláteis}

A concentração de ácidos graxos se manteve praticamente constante no reator anaeróbio na $5^{\mathrm{a}}$ etapa da fase mesofílica e oscilou no reator aeróbio. No final da $6^{\mathrm{a}}$ etapa mesofilica, a concentração de ácidos aumentou nos dois reatores, assim como a alcalinidade. 
Com o aumento da temperatura para $35,0^{\circ} \mathrm{C}$ e concomitante aumento na DQO da água residuária sintética no início da $7^{\text {a }}$ etapa mesofilica, houve aumento na concentração de ácidos no efluente do reator UASB (110 mg.L $\mathrm{L}^{-1}$ para $\left.406 \mathrm{mg} . \mathrm{L}^{-1}\right)$ porém redução no reator aeróbio $\left(91 \mathrm{mg} . \mathrm{L}^{-1}\right.$ para $\left.41 \mathrm{mg} . \mathrm{L}^{-1}\right)$. O reator anaeróbio permaneceu instável por aproximadamente um mês.

A partir da fase termofilica, os valores de AGV no efluente do reator anaeróbio tornaram-se crescentes, chegando a atingir valores em torno de $350 \mathrm{mg} . \mathrm{L}^{-1}$ (Figura 5.57).

Não houve correlação entre o aumento da temperatura e o aumento da concentração de AGV na fase mesofilica para ambos reatores. Considerando-se a fase termofílica, apenas o reator UASB apresentou correlação positiva $\left(\mathrm{r}_{\mathrm{UASB}}=+0,9\right)$.

As altas concentrações de ácidos graxos voláteis, principalmente propiônico, são freqüentemente associadas a instabilidade de reatores anaeróbios operando em altas temperaturas. Ahring et al. (2001), realizaram experimento para verificar se o aumento de temperatura, de 55 para $65^{\circ} \mathrm{C}$, em um reator termofilico anaeróbio, teria efeitos sobre seu desempenho e na dinâmica da população microbiana. Foi verificado que o aumento na temperatura operacional teve efeito negativo no desempenho do reator e causou mudanças na estrutura da comunidade microbiana, com imediato distúrbio no balanço entre microrganismos, acúmulo inicial e persistente de altas concentrações de ácidos e simultânea redução na produção de metano.

De acordo com o trabalho de Ahring et al. (2001) foi verificado que o consórcio microbiano que degradava os ácidos e as metanogênicas foram severamente afetados pelo aumento da temperatura, sendo incapazes de contrabalançar a atividade das populações fermentativas. Entretanto, a eficiência dos microrganismos hidrolíticos e fermentativos não foi significativamente afetada. Também foi verificado que o acetato somente acumulou por um curto período, refletindo que, na verdade, as populações microbianas presentes foram capazes de assumir a atividade das arqueas metanogênicas utilizadoras de acetato.

No presente trabalho foi verificado que o aumento gradativo da temperatura prejudicou o desempenho do reator anaeróbio. Em relação à concentração de AGV a instabilidade foi revelada principalmente na fase termofilica, em que provavelmente houve desbalanceamento entre as comunidades microbianas e conseqüentemente excesso na concentração de AGV, levando a acidificação do reator UASB. 
As análises cromatográficas para identificação dos ácidos nos efluentes foram feitas a partir da oitava etapa da fase mesofilica, mas, apenas a partir da terceira etapa termofílica os ácidos começaram a ser registrados em concentrações consideráveis no efluente do reator anaeróbio, como pode ser visto na Figura 5.58.

$\mathrm{Na}$ quarta etapa termofílica, quando o reator UASB operava em faixa de temperatura de $52,0^{\circ} \mathrm{C}$ e tempo de detenção de 24 horas, começou a haver acúmulo de ácido acético que passou a ser detectado em concentrações de $129 \mathrm{mg} . \mathrm{L}^{-1}$ a $463 \mathrm{mg} . \mathrm{L}^{-1}$. Deve-se ressaltar que esse ácido era adicionado na água residuária sintética, mas não havia sido detectado em análises anteriores. Até o encerramento do experimento havia um desbalanceamento e o consórcio microbiano não foi capaz de utilizar o ácido acético (Figura 5.58)

O ácido propiônico também passou a ser detectado na maior parte das amostras do efluente do UASB a partir da terceira etapa da fase termofilica (Figura 5.58).

De acordo com van Lier et al. (1993), a oxidação termofílica do propionato parece ser muito sensível ao aumento na concentração de acetato. Aplicando-se o coeficiente de Pearson, considerando-se como variáveis as concentrações de ácido propiônico e de acético no efluente do UASB, a partir da metade da $4^{\text {a }}$ etapa termofílica foi verificada correlação positiva $\left(\mathrm{r}_{\mathrm{UASB}}=+0,7\right)$. Os ácidos butírico e o isovalérico também foram detectados nessa faixa de temperatura, porém em concentrações bem menores, de 0,1 mg. $\mathrm{L}^{-1}$ a 7,3 mg. $\mathrm{L}^{-1}$ e $0,6 \mathrm{mg} \cdot \mathrm{L}^{-1}$ a $7,6 \mathrm{mg} \cdot \mathrm{L}^{-1}$, respectivamente.

Comparando a Figura 5.58 e as concentrações de ácidos graxos voláteis apresentadas na Tabela 5.25 verifica-se que na fase mesofilica e início da termofílica as concentrações de AGV no efluente do reator UASB, em geral, foram baixas e nenhum ácido foi detectado por cromatografia gasosa. A partir da terceira etapa da fase termofilica entretanto, a concentração dos AGV aumenta consideravelmente e ácidos como o acético, propiônico, isovalérico e butírico passam a ser determinados por cromatografia.

No efluente do reator de lodos ativados, foram detectados ácidos por cromatografia gasosa, imediatamente após a mudança de temperatura de $52^{\circ} \mathrm{C}$ para $57^{0} \mathrm{C}$. Foram identificados os ácidos acético, propiônico, butírico e isovalérico, em concentrações de $394 \mathrm{mg} . \mathrm{L}^{-1}, 20 \mathrm{mg} . \mathrm{L}^{-1}, 0,4 \mathrm{mg} . \mathrm{L}^{-1}$ e $3,2 \mathrm{mg} \cdot \mathrm{L}^{-1}$, respectivamente (Figura 5.59b). 
Também foi detectado ácido acético nos dois últimos dias de operação na fase termofilica, em concentrações de 4,6 mg. $\mathrm{L}^{-1}$ e $4,8 \mathrm{mg} \cdot \mathrm{L}^{-1}$. Comparando-se as concentrações encontradas no efluente do reator aeróbio com as do reator UASB, apresentadas na Figura 5.58, verifica-se considerável redução.

De acordo com o trabalho de Mason (1986) não foram verificados ácidos graxos voláteis sob concentrações suficientes de oxigênio em um biorreator aeróbio termofílico em escala de bancada. Quando o oxigênio foi limitado, cada AGV variou com o tempo de residência, exceto o ácido acético, que foi produzido em altas concentrações, cerca de cinco a dez vezes maior que as de outros ácidos.

De acordo com Chu et al. (1996), ácido acético foi o predominante nos AGV na digestão aeróbia termofílica. Os resultados encontrados no presente trabalho estão de acordo com essa afirmação.

As concentrações de AGV no efluente dos reatores podem ser visualizados na Tabela 5.25.

TABELA 5.25. Variação das concentrações de AGV nos efluentes dos reatores biológicos nas diferentes faixas de temperatura operadas.

\begin{tabular}{|c|c|c|c|c|c|}
\hline \multirow{2}{*}{ 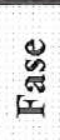 } & \multirow{2}{*}{ 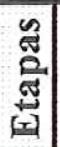 } & \multirow{2}{*}{$\begin{array}{c}\text { Temperatura } \\
\left({ }^{0} \mathrm{C}\right)\end{array}$} & \multicolumn{3}{|c|}{ AGV (mg. $\left.L^{-1}\right)$} \\
\hline & & & ARS & Efluente UASB & Efluente LA \\
\hline \multirow{4}{*}{ 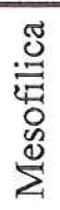 } & 5 & $25,0-30,0$ & $166-188(2)$ & $45-47(2)$ & $35-50(2)$ \\
\hline & 6 & 32,5 & $175-215(3)$ & $47-110(3)$ & $34-91(3)$ \\
\hline & 7 & $35,0-37,5$ & $89-214(7)$ & $65-406(7)$ & $33-102(7)$ \\
\hline & 8 & 42,5 & $134-191(9)$ & $37-140(9)$ & $31-51(9)$ \\
\hline \multirow{5}{*}{ 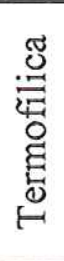 } & 1 & 45,0 & $171-190(9)$ & $41-69(9)$ & $31-48(9)$ \\
\hline & 2 & 47,5 & $154-202(3)$ & $81-155(3)$ & $29-37(3)$ \\
\hline & 3 & 52,0 & $187-195(2)$ & $145-199(2)$ & $30-48(2)$ \\
\hline & 4 & 52,0 & $121-219(9)$ & $160-340(9)$ & $31-96(9)$ \\
\hline & 5 & 57,0 & $97-143(7)$ & $234-364(7)$ & $24-90(7)$ \\
\hline
\end{tabular}

OBS.: os valores entre parênteses representam o número de amostras considerados no intervalo. 


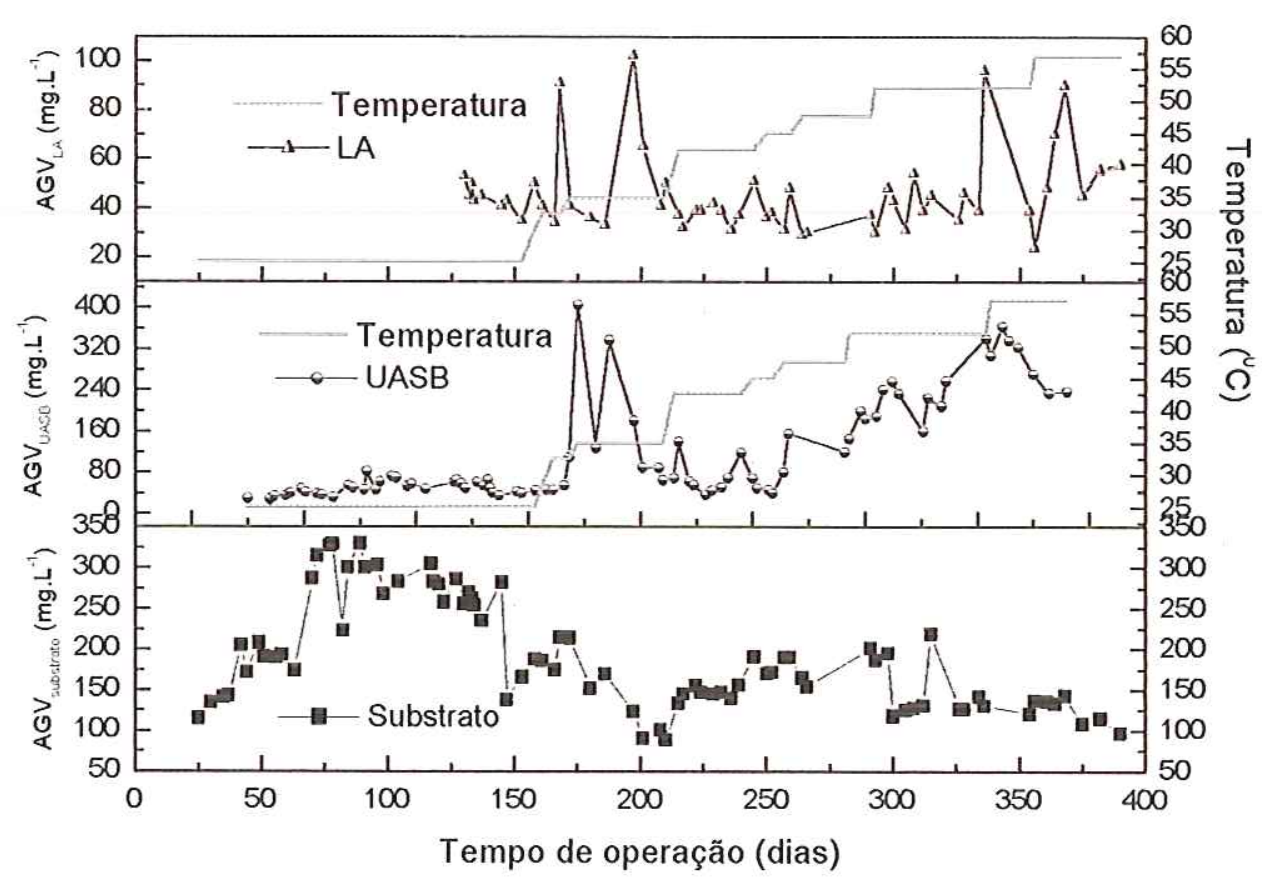

FIGURA 5.57. Variações de concentrações de AGV na água residuária sintética e nos efluentes dos reatores biológicos em relação ao tempo de operação, considerando as oito etapas mesofilicas e as cinco termofilicas.

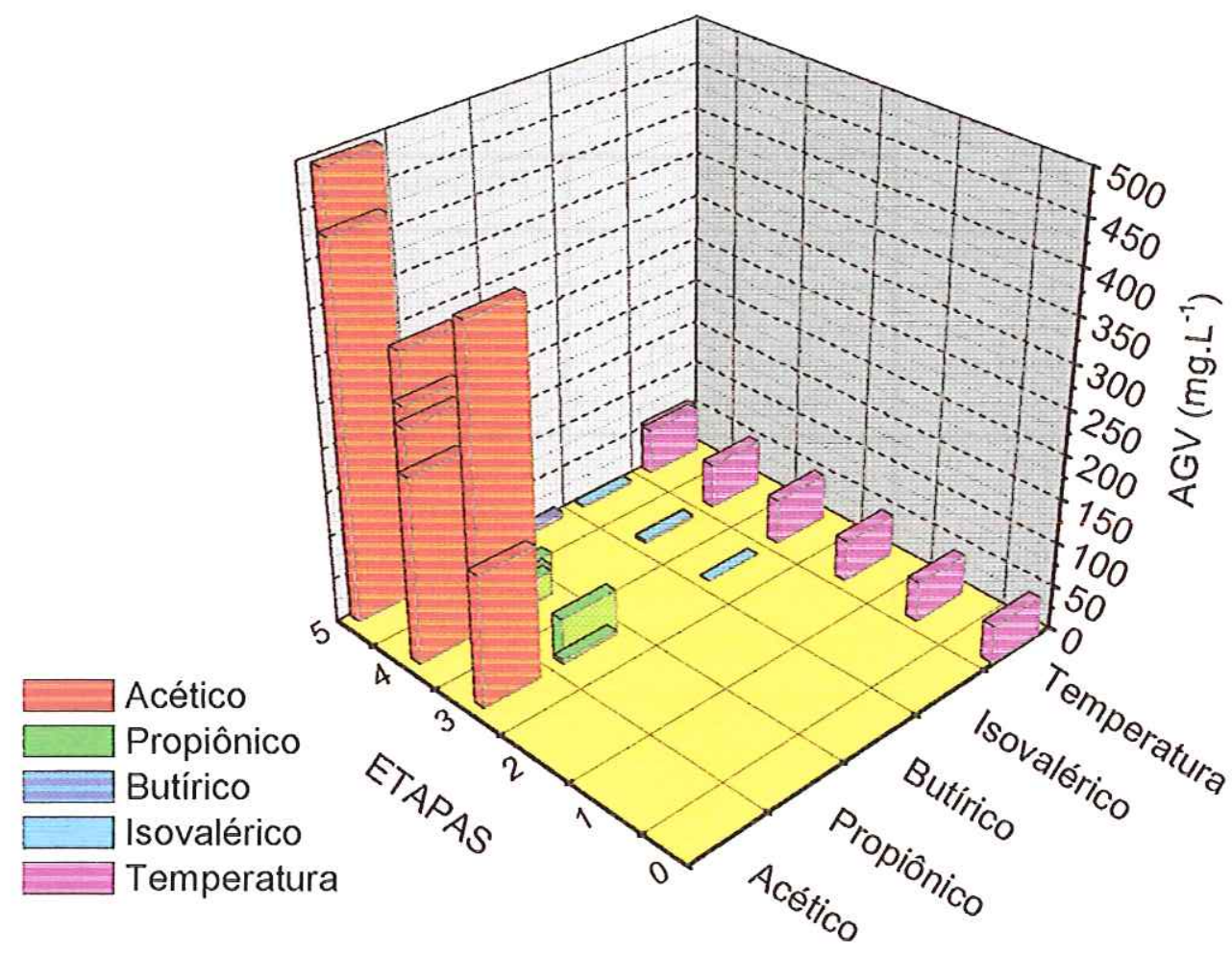

FIGURA 5.58. Concentrações de ácidos determinados por cromatografia gasosa em amostras do efluente do reator UASB na oitava etapa mesofilica (etapa 0 ) e nas 5 etapas termofilicas. 


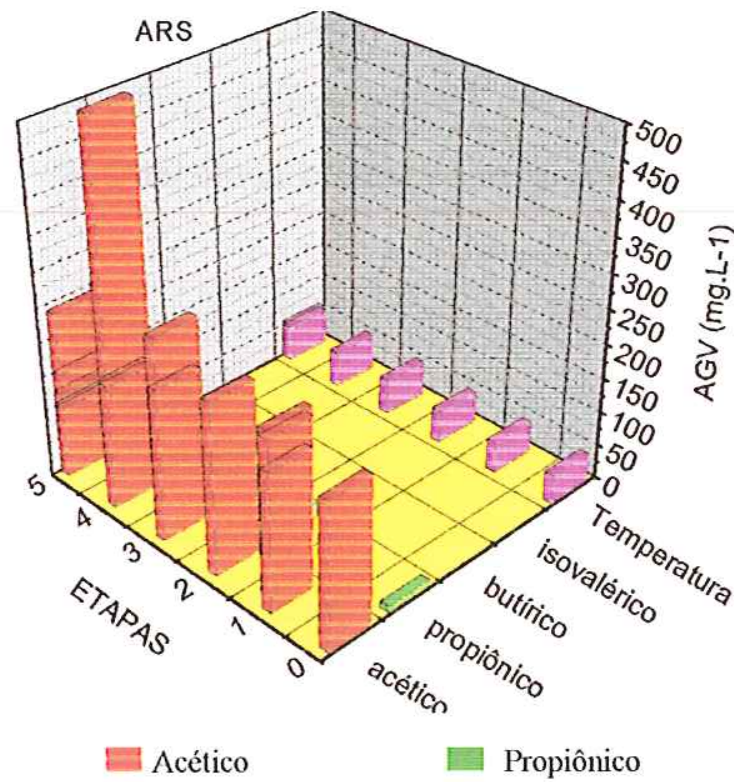

(a)

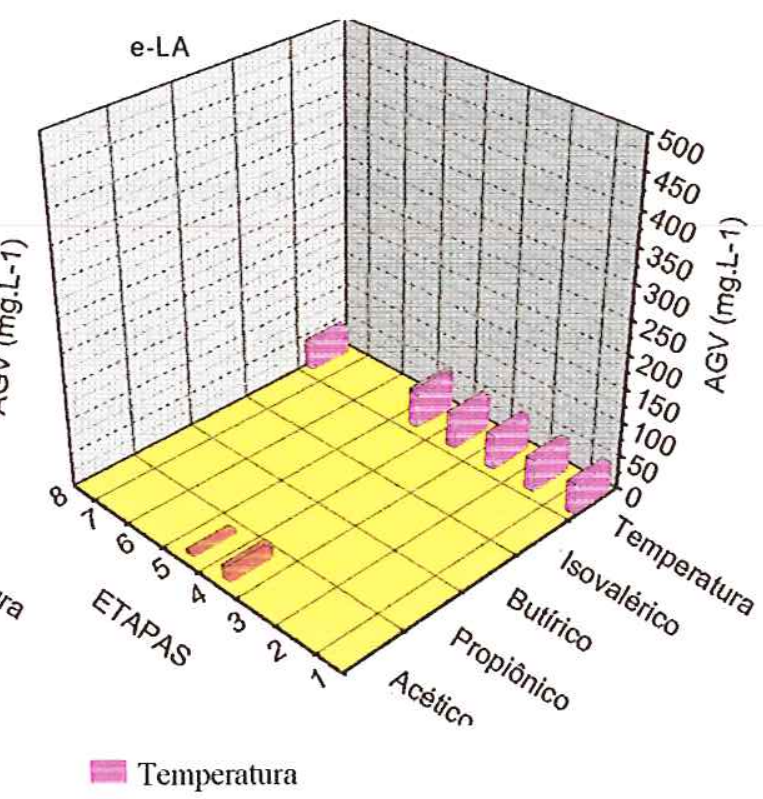

(b)

FIGURA 5.59. Concentrações de ácidos determinados por cromatografia gasosa em amostras da água residuária sintética (a) e do efluente do reator de lodos ativados (b) na oitava etapa mesofilica (etapa 0 ) e nas 5 etapas termofilicas.

Os valores das concentrações dos ácidos representados nas Figuras são maiores que os valores obtidos por titulometria porque há muita perda neste método e a detecção por cromatografia também é mais sensível.

\subsubsection{Efeito da temperatura na composição do biogás}

A primeira queda na porcentagem de metano no biogás ocorreu quando a temperatura foi aumentada de $30,0^{\circ} \mathrm{C}$ para $32,5^{\circ} \mathrm{C}$. Entretanto, deve ser lembrado que essa ocorrência coincidiu com o aumento súbito da DQO afluente ao reator anaeróbio, que recuperou-se em uma semana. A instabilidade na porcentagem de metano começou na fase termofilica, quando a temperatura foi aumentada para $52,0^{\circ} \mathrm{C}$. O reator começou a se recuperar no final da terceira fase termofilica. Quando a temperatura foi aumentada para $57,0^{\circ} \mathrm{C}$ ocorreram novas quedas da porcentagem de metano no biogás e instabilidade até o final da operação.

No trabalho de Lau \& Fang (1997), os microrganismos termofilicos perderam a atividade metanogênica depois de expostos a aumento de $10^{\circ} \mathrm{C}$ na temperatura, entretanto, recuperaram completamente essa atividade oito dias após a temperatura ser retornada para $55^{\circ} \mathrm{C}$. No presente trabalho, apesar da variação na temperatura ter sido gradativa, a concentração de metano oscilou muito, talvez pelos novos ajustes de temperatura. 
Considerando-se o aumento de temperatura de $30,0^{\circ} \mathrm{C}$ para $42,5^{\circ} \mathrm{C}$ em relação à porcentagem de metano no biogás, o coeficiente de Pearson foi positivo $\left(r_{\mathrm{UASB}}=+0,5\right)$. $\mathrm{Na}$ fase termofílica, aumento da temperatura de $45,0^{\circ} \mathrm{C}$ para $57,0^{\circ} \mathrm{C}$, o coeficiente de Pearson foi negativo ( $\left.\mathrm{r}_{\mathrm{UASB}}=-0,5\right)$.

Os resultados obtidos por Ahring et al. (1994), operando reator anaeróbio, revelaram que quando a temperatura foi aumentada de $55^{\circ} \mathrm{C}$ para $60^{\circ} \mathrm{C}$ o consórcio metanogênico foi severamente afetado, sendo incapaz de equilibrar ou balancear a atividade das populações fermentativas.

No presente trabalho, na faixa termofilica a porcentagem de metano no biogás tornou-se instável, sendo que o ácido propiônico passou a ser detectado no efluente do reator anaeróbio a partir do aumento da temperatura para $55^{\circ} \mathrm{C}$.

As porcentagens de nitrogênio, metano e gás carbônico obtidas no monitoramento do biogás nas fases mesofilica e termofilica são apresentadas na Tabela 5.26 e Figura 5.60.

Como pode ser observado na Figura 5.60 as porcentagens de nitrogênio na composição do biogás nas três últimas etapas termofílicas aumentaram consideravelmente.

TABELA 5.26. Variação das concentrações no biogás nas diferentes faixas de temperatura operadas.

\begin{tabular}{|c|c|c|c|c|c|}
\hline \multirow{2}{*}{$\begin{array}{l}\text { E } \\
\text { s }\end{array}$} & \multirow{2}{*}{ 泀 } & \multirow{2}{*}{$\begin{array}{c}\text { Temperatura } \\
\left({ }^{0} \mathrm{C}\right)\end{array}$} & \multicolumn{3}{|c|}{$\mathrm{CH}_{4}(\%)$} \\
\hline & & & $\mathrm{N}_{2}$ & $\mathrm{CH}_{4}$ & $\mathrm{CO}_{2}$ \\
\hline త్ర్ల & 5 & $25,0-30,0$ & $15-16(2)$ & $78-79(2)$ & $6-7(2)$ \\
\hline 댕 & 7 & $35,0-37,5$ & $16-31(9)$ & $64-78(9)$ & $4-8(9)$ \\
\hline$\sum^{\circ}$ & 8 & 42,5 & $13-35(6)$ & $61-77(6)$ & $4-10(6)$ \\
\hline త్ర & 1 & 45,0 & $14-23(4)$ & $69-78(4)$ & $7-9(4)$ \\
\hline 贾 & 3 & 52,0 & $53-99(2)$ & $0-43(2)$ & $1-4(2)$ \\
\hline E & 4 & 52,0 & $78-96(5)$ & $3-19(5)$ & $1-3(5)$ \\
\hline$\stackrel{\oplus}{\oplus}$ & 5 & 57,0 & $23-96(10)$ & $1-70(10)$ & $0-8(10)$ \\
\hline
\end{tabular}

OBS.: os valores entre parênteses representam o número de amostras considerados no intervalo. 


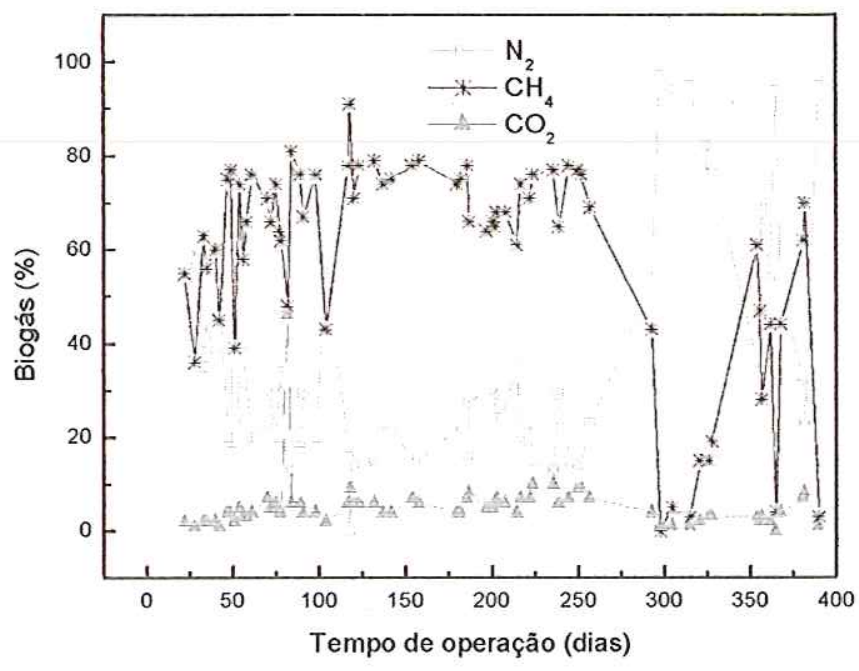

FIGURA 5.60. Variação das porcentagens de $\mathrm{N}_{2}, \mathrm{CH}_{4}$ e $\mathrm{CO}_{2}$ no biogás do reator biológico anaeróbio durante o tempo de operação, considerando as oito etapas mesofilicas e as cinco termofílicas.

\subsection{Teste do aumento súbito da temperatura}

A melhor maneira de se fazer a adaptação de lodo mesofilico para termofilico ainda não está bem determinada. De acordo com Kim \& Speece (2002), vários estudos foram feitos para determinar qual o melhor procedimento para dar partida em reatores termofílicos em relação ao aumento de temperatura e qual a melhor fonte de inóculo a ser utilizada.

Em relação ao aumento da temperatura, a maioria dos trabalhos utiliza o aumento gradual para reatores anaeróbios e aeróbios (TRIPATHI \& ALLEN, 1999), entretanto, o aumento súbito da temperatura também é utilizado para reatores anaeróbios (VAN Lier et $a l^{44}$, 1992 apud KIM \& SPEECE, 2002a; DINSDALE et al., 1997a) e aeróbios (JAHREN et al., 2002).

De acordo Zinder (1986), reatores inoculados com lodo mesofílico, submetidos a aumento súbito da temperatura, para operarem na faixa termofilica necessitam ter suas concentrações de alcalinidade aumentadas para manter o $\mathrm{pH}$ neutro até que ocorra a estabilização.

Neste teste os reatores foram inoculados em temperatura ambiente e mantidos em batelada por 24 horas. Posteriormente a temperatura foi ajustada para $57^{\circ} \mathrm{C}$ e os reatores permaneceram em batelada alimentada por mais doze dias. 
O sistema começou a ser operado de forma contínua, sendo o tempo de detenção utilizado de 40 horas para o reator anaeróbio e de 14 horas para o aeróbio.

Nos primeiros vinte e seis dias foi utilizado volume de $15 \mathrm{~mL}$ do licor negro para $15 \mathrm{~L}$ de água e a DQO afluente variou de $492 \mathrm{mg} \cdot \mathrm{L}^{-1}$ a $609 \mathrm{mg} \cdot \mathrm{L}^{-1}$. Nesse período as eficiências de remoção de DQO do reator anaeróbio variaram de $28 \%$ a $48 \%$ e a do aeróbio de $35 \%$ a $44 \%$, portanto as eficiências do sistema oscilaram de $59 \%$ a $66 \%$.

No reator UASB, as concentrações de AGV variaram de $64 \mathrm{mg} . \mathrm{L}^{-1}$ a $84 \mathrm{mg} . \mathrm{L}^{-1}$, enquanto para o reator de lodos ativados, de $20 \mathrm{mg} \cdot \mathrm{L}^{-1}$ a $66 \mathrm{mg} \cdot \mathrm{L}^{-1}$. O pH foi reduzido em ambos reatores; 7,0 para 6,4 no reator anaeróbio e de 8,2 para 7,3 no reator aeróbio. A concentração de alcalinidade parcial, inicialmente de $29 \mathrm{mg} . \mathrm{L}^{-1}$, atingiu $14 \mathrm{mg} . \mathrm{L}^{-1}$ no final da etapa no reator UASB enquanto a alcalinidade total variou de $41 \mathrm{mg} . \mathrm{L}^{-1}$ a 57 $m g . L^{-1}$. No reator de lodos ativados, a alcalinidade total sofreu pouca variação, de $56 \mathrm{mg} \cdot \mathrm{L}^{-1}$ a $62 \mathrm{mg} \cdot \mathrm{L}^{-1}$.

A porcentagem de metano no biogás oscilou muito nesse período. Inicialmente foi registrado valor de $4 \%$, posteriormente atingiu valores de $49 \%, 5 \%$, atingindo $38 \%$ no final desta primeira etapa.

Nos primeiros vinte e seis dias, o reator UASB registrou ligeira perda de SSV (31 mg. $\mathrm{L}^{-1}$ ), concentrada no segundo dia de análise. As perdas no reator aeróbio foram menores, no primeiro dia de análise $\left(7 \mathrm{mg} . \mathrm{L}^{-1}\right)$. Entretanto, apesar dos valores registrados para SSV no lodo de retorno atingiram de $1592 \mathrm{mg} . \mathrm{L}^{-1}$, no licor misto foram de $204 \mathrm{mg} . \mathrm{L}^{-1}$, no primeiro dia de análise. Esses valores decresceram para $667 \mathrm{mg} . \mathrm{L}^{-1} \mathrm{e}$ posteriormente para $428 \mathrm{mg} . \mathrm{L}^{-1}$, no lodo de retorno, e de $76 \mathrm{mg} . \mathrm{L}^{-1}$ para $14 \mathrm{mg} . \mathrm{L}^{-1}$ no licor misto, até o final da etapa.

Posteriormente, a concentração de licor negro utilizada no preparo do substrato foi dobrada, e o sistema foi operado por mais vinte e quatro dias. A DQO afluente variou de $716 \mathrm{mg} \cdot \mathrm{L}^{-1}$ a $1385 \mathrm{mg} . \mathrm{L}^{-1}$. Com o ajuste, a eficiência no reator anaeróbio caiu de $48 \%$ para $8 \%$, tendo variado de $21 \%$ a $39 \%$ até o final da etapa. O reator aeróbio, por sua vez, com a queda na efíciência do reator UASB, apresentou melhora, atingindo $71 \%$ de eficiência de remoção de DQO. Depois a eficiência foi sendo reduzida, atingindo $41 \%$ até o final da etapa.

Entretanto, uma análise global da eficiência do reator aeróbio nessa segunda etapa, revela valores maiores que os obtidos na primeira etapa. Esses resultados divergem dos obtidos por JAHREN et al. (2002), com reator aeróbio termofílico inoculado com lodo mesofílico de estação de tratamento mesofílica de água residuária 
da indústria de papel, obtiveram remoção inicial de DQO similar às obtidas depois que o lodo estava adaptado à temperatura. Esses resultados sugeriram que os microrganismos termofílicos ou termotolerantes aeróbios estão presentes em processos mesofilicos em altas concentrações.

No presente trabalho o conjunto de reatores operou com eficiência de $61 \%$ a $73 \%$.

Houve perda de SV no reator UASB no início e final dessa etapa, de $64 \mathrm{mg} . \mathrm{L}^{-1} \mathrm{e}$ $37 \mathrm{mg} . \mathrm{L}^{-1}$, respectivamente. No reator de lodos ativados foi registrada pequena perda de sólidos, cerca de $18 \mathrm{mg} . \mathrm{L}^{-1}$, no meio da etapa. Os SSV no licor misto continuaram baixos, variando de $138 \mathrm{mg} . \mathrm{L}^{-1}$ a $315 \mathrm{mg} . \mathrm{L}^{-1}$, enquanto no lodo de retorno os valores variaram de $80 \mathrm{mg} . \mathrm{L}^{-1}$ a $294 \mathrm{mg} \cdot \mathrm{L}^{-1}$.

A porcentagem de metano, inicialmente de $71 \%$, foi reduzida para $19 \%, 9 \%$, atingindo no final da etapa, 5\%. Van $\operatorname{Lier}^{51}$ (1992), citado por Kim \& Speece (2002), testaram a partida de reatores UASB termofilicos (temperaturas de 46,55 e $64^{\circ} \mathrm{C}$ ) com aumento súbito da temperatura para $55^{\circ} \mathrm{C}$ e observaram queda inicial na taxa de produção de metano. De acordo com van Lier et al. (1997), como descrito no trabalho de van Lier et al. (1992), geralmente, aumento na temperatura, alterando a faixa mesofilica para a termofilica, resulta, imediatamente, em mudança nas subpopulações metanogênicas. Organismos mesofilicos morrem rapidamente em temperaturas que excedem a máxima temperatura de crescimento dessas bactérias. Sob condições termofílicas não há competição entre mesófilos e termófilos.

A concentração da alcalinidade a bicarbonato no reator UASB aumentou para $31 \mathrm{mg} . \mathrm{L}^{-1}$ no início da etapa, mas ficou abaixo dos limites de detecção na metade do período, atingindo valores de $21 \mathrm{mg} . \mathrm{L}^{-1}$, até o final da etapa. Essa redução da alcalinidade no reator anaeróbio, onde foi registrado $\mathrm{pH}$ de 5,1 , provavelmente esteve correlacionada a aumento da concentração de AGV de $115 \mathrm{mg} . \mathrm{L}^{-1}$ para $202 \mathrm{mg} . \mathrm{L}^{-1}$. No reator de lodos ativados a alcalinidade parcial foi crescente, de $45 \mathrm{mg} . \mathrm{L}^{-1}$ a $111 \mathrm{mg} . \mathrm{L}^{-1}$, apenas apresentando queda para $53 \mathrm{mg} \cdot \mathrm{L}^{-1}$ concomitante à do reator UASB. No reator aeróbio foram registradas concentrações de $47 \mathrm{mg} . \mathrm{L}^{-1}$ a $78 \mathrm{mg} . \mathrm{L}^{-1}$ de $\mathrm{AGV}$, tendo o $\mathrm{pH}$ variado de 7,5 a 8,2 .

A diversidade microbiana aeróbia foi menor no reator de lodos ativados com aumento súbito da temperatura de operação. 
Comparando-se os dois reatores no teste de aumento súbito da temperatura, o desempenho do reator aeróbio foi melhor que o do anaeróbio. De acordo com Speece (1996), processos anaeróbios são comumente considerados mais sensíveis a mudanças repentinas nas condições ambientais que os aeróbios.

Entretanto, a perda do lodo no reator anaeróbio não foi tão significativa quanto a ocorrida na fase termofilica, considerando o aumento gradual de temperatura.

Na figura 5.61 são apresentados todos os resultados obtidos no monitoramento dos reatores durante o teste do aumento súbito de temperatura. São apresentados, paralelamente, os gráficos das variações de concentrações de DQO (mg. $\left.L^{-1}\right)$, pH, eficiência de remoção de DQO (\%), ácidos graxos voláteis $\left(\mathrm{mg} \cdot \mathrm{L}^{-1}\right)$, sólidos suspensos voláteis nos efluentes dos reatores $\left(\mathrm{mg} \cdot \mathrm{L}^{-1}\right)$, alcalinidade total $\left(\mathrm{mg} . \mathrm{L}^{-1}\right)$, sólidos suspensos voláteis no licor misto e no lodo de retorno e porcentagem de metano no biogás do reator anaeróbio.
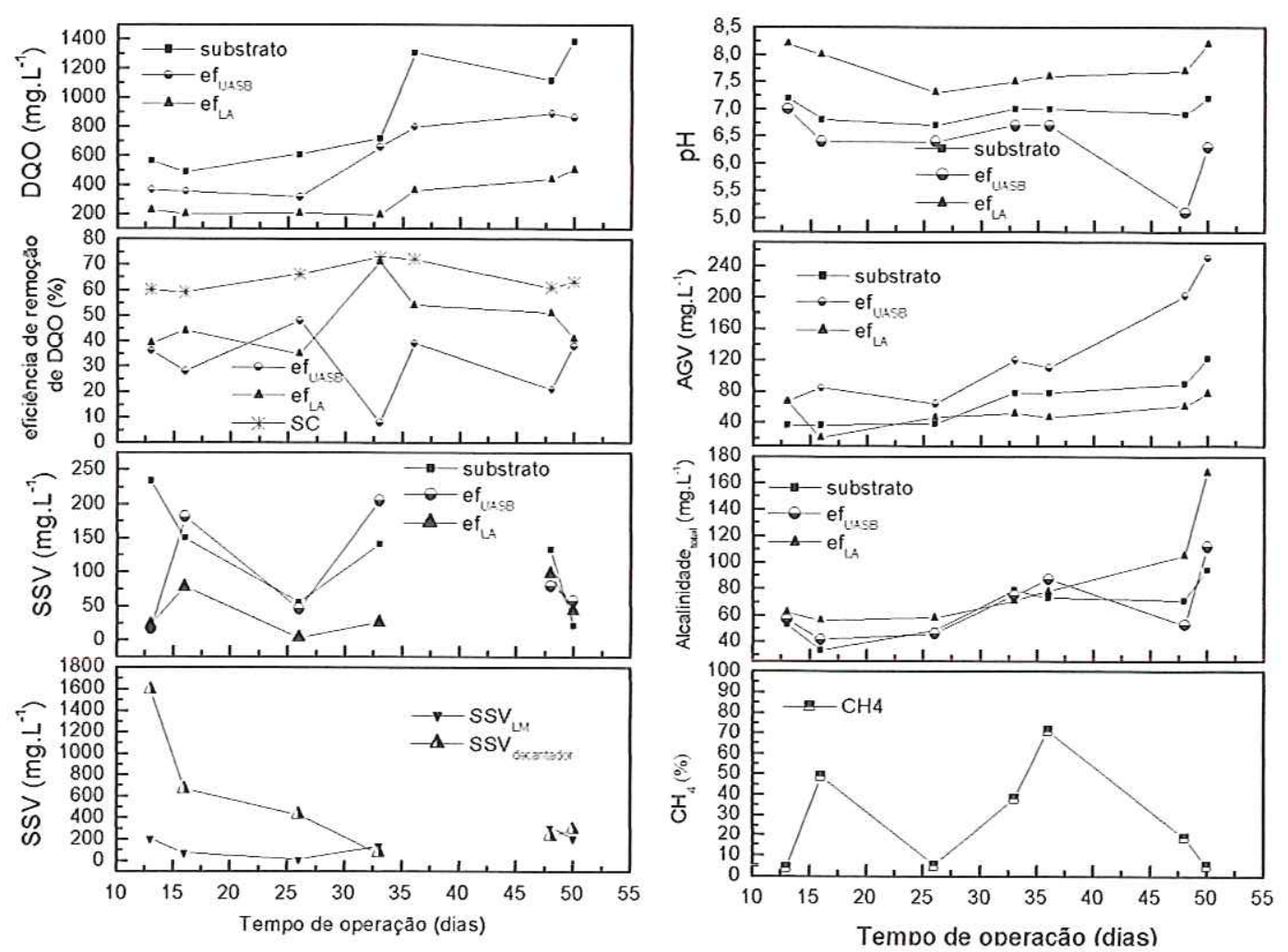

FIGURA 5.61. Resultados do monitoramento dos reatores UASB e de lodos ativados no teste do aumento súbito da temperatura. 


\subsection{Comparação entre os reatores operando nas fases mesofilica e termofilica}

Na literatura é possível encontrar trabalhos em que foram utilizados reatores termofilicos anaeróbios ou aeróbios. Como citado por Barr et al. (1996), na revisão de literatura do presente trabalho, a comparação entre artigos é dificultada pelas diferentes condições operacionais utilizadas, bem como outras variáveis no processo. Entretanto, apresenta-se nas Tabelas 5.27 e 5.28 um resumo dos resultados obtidos no presente trabalho, considerando-se as fases mesofilica e termofilica, respectivamente, e, na Tabela 5.29 apresentados alguns trabalhos para comparação.

Deve-se ressaltar que foram consideradas na Tabela 5.27, para a faixa de temperatura mesofilica, apenas os resultados a partir da metade da $7^{\mathrm{a}}$ etapa até a $8^{\mathrm{a}}$ e na Tabela 5.28, para a faixa de temperatura termofilica, a $4^{\mathrm{a}}$ e $5^{\mathrm{a}}$ etapa, visto que nestes períodos os reatores não passaram por nenhuma alteração no substrato ou no tempo de detenção, apenas na temperatura.

Na fase mesofilica, o afluente ao reator UASB foi uma água residuária sintética preparada pela diluição de $45 \mathrm{~mL}$ de licor negro intermediário para 15 litros de água de abastecimento. O tempo de detenção utilizado no reator anaeróbio foi de 20 horas e, no aeróbio, de 11 horas.

$\mathrm{Na}$ fase termofílica a água residuária sintética estava sendo preparada pela diluição de $30 \mathrm{~mL}$ de licor em 15 litros de água de abastecimento. $\mathrm{O}$ tempo de detenção utilizado no reator UASB foi de 24 horas e no aeróbio, de 8 horas. 
TABELA 5.27. Resumo dos resultados monitorados na fase mesofilica $\left(37,5^{\circ} \mathrm{C}\right.$ a $\left.42,5^{\circ} \mathrm{C}\right)$.

\begin{tabular}{|c|c|c|c|c|c|c|}
\hline \multirow{3}{*}{ Parâmetros } & \multicolumn{6}{|c|}{ Mesofilica $\left(37,5^{\circ} \mathrm{C}\right.$ a $\left.42,5^{0} \mathrm{C}\right)$} \\
\hline & \multicolumn{2}{|c|}{ Substrato } & \multicolumn{2}{|c|}{$\begin{array}{c}\text { Efluente } \\
\text { UASB }\end{array}$} & \multicolumn{2}{|c|}{$\begin{array}{c}\text { Efluente } \\
\text { Lodos ativados }\end{array}$} \\
\hline & $\begin{array}{l}\text { Faixa de } \\
\text { variação }\end{array}$ & $\begin{array}{c}\text { Média } \pm D P \\
\text { (n) }\end{array}$ & $\begin{array}{l}\text { Faixa de } \\
\text { variação }\end{array}$ & $\begin{array}{l}\text { Média } \pm \mathrm{DP} \\
\text { (n) }\end{array}$ & $\begin{array}{l}\text { Faixa de } \\
\text { variação }\end{array}$ & $\begin{array}{c}\text { Média } \pm D P \\
\text { (n) }\end{array}$ \\
\hline $\begin{array}{l}\mathrm{DQO}_{\text {total }} \\
\left(\mathrm{mg} \cdot \mathrm{L}^{-1}\right)\end{array}$ & $1130-1634$ & $\begin{array}{c}1368 \pm 154 \\
(12)\end{array}$ & $486-680$ & $593 \pm 65$ & $360-500$ & $\begin{array}{c}418 \pm 55 \\
(12)\end{array}$ \\
\hline $\begin{array}{l}\text { Eficiência de } \\
\text { remoção (\%) }\end{array}$ & - & - & $42-66$ & $56 \pm 7(12)$ & $4-44$ & $29 \pm 11$ \\
\hline $\begin{array}{l}\mathrm{DQO}_{\text {filtrada }} \\
\left(\mathrm{mg} \cdot \mathrm{L}^{-1}\right)\end{array}$ & $1008-1596$ & $\begin{array}{c}1307 \pm 176 \\
(12)\end{array}$ & $426-602$ & $\begin{array}{c}521 \pm 57 \\
(12)\end{array}$ & $358-476$ & $\begin{array}{c}401 \pm 42 \\
(12)\end{array}$ \\
\hline $\begin{array}{l}\text { Eficiência de } \\
\text { remoção (\%) }\end{array}$ & - & - & $48-69$ & $60 \pm 7(12)$ & $6-38$ & $24 \pm 11$ \\
\hline $\mathrm{pH}$ & $7,3-8,2$ & (12) & $7,0-8,1$ & (12) & $7,4-8,1$ & (12) \\
\hline $\begin{array}{l}\text { Alcalinidade } \\
\left(\mathrm{mg} . \mathrm{L}^{-1}\right)\end{array}$ & $154-297$ & $\begin{array}{l}234 \pm 42 \\
(12)\end{array}$ & $227-382$ & $\begin{array}{c}312 \pm 44 \\
(12)\end{array}$ & $140-281$ & $\begin{array}{c}199 \pm 43 \\
(12)\end{array}$ \\
\hline $\begin{array}{l}\text { Ácidos } \\
\left(\mathrm{mg} \cdot \mathrm{L}^{-1}\right)\end{array}$ & $89-191$ & $\begin{array}{c}137 \pm 29 \\
(12)\end{array}$ & $37-140$ & $\begin{array}{c}74 \pm 30 \\
(12)\end{array}$ & $31-65$ & $\begin{array}{l}42 \pm 9 \\
(12)\end{array}$ \\
\hline ST $\left(m g . L^{-1}\right)$ & $847-1151$ & $1043 \pm 110$ & $99-1001$ & $788 \pm 289$ & $417-983$ & $804 \pm 174$ \\
\hline STV (mg. $\left.L^{-1}\right)$ & $413-843$ & $645 \pm 150$ & $49-584$ & $447 \pm 188$ & $221-649$ & $428 \pm 123$ \\
\hline STF $\left(m g \cdot L^{-1}\right)$ & $308-579$ & $398 \pm 85$ & $51-471$ & $341 \pm 133$ & $196-574$ & $375 \pm 116$ \\
\hline SST (mg. $\left.L^{-1}\right)$ & $43-140$ & $82 \pm 32$ & $61-126$ & $94 \pm 25$ & $35-122$ & $77 \pm 31$ \\
\hline SSV (mg. $\left.L^{-1}\right)$ & $17-109$ & $55 \pm 33$ & $28-87$ & $63 \pm 22$ & $21-71$ & $49 \pm 17$ \\
\hline SSVLM & - & - & - & - & $17-423$ & $167 \pm 162$ \\
\hline SSVdec & - & - & - & - & $22-268$ & $105 \pm 79$ \\
\hline $\mathrm{CH}_{4}(\%)$ & - & - & $61-78$ & $70 \pm 6$ & - & - \\
\hline
\end{tabular}

Obs.: DV: desvio padrão. Os valores entre parênteses (n) se referem ao número de observações. 
TABELA 5.28. Resumo dos resultados monitorados na fase termofilica $\left(52,0^{\circ} \mathrm{C}\right.$ a $\left.57,0^{\circ} \mathrm{C}\right)$.

\begin{tabular}{|c|c|c|c|c|c|c|}
\hline \multirow{3}{*}{ Parâmetros } & \multicolumn{6}{|c|}{ Termofilica $\left(52^{0} \mathrm{C}\right.$ a $\left.57^{0} \mathrm{C}\right)$} \\
\hline & \multicolumn{2}{|c|}{ Substrato } & \multicolumn{2}{|c|}{$\begin{array}{c}\text { Efluente } \\
\text { UASB }\end{array}$} & \multicolumn{2}{|c|}{$\begin{array}{c}\text { Efluente } \\
\text { Lodos ativados }\end{array}$} \\
\hline & $\begin{array}{l}\text { Faixa de } \\
\text { variação } \\
\end{array}$ & $\begin{array}{c}\text { Média } \pm \text { DP } \\
\text { (n) }\end{array}$ & $\begin{array}{l}\text { Faixa de } \\
\text { variação } \\
\end{array}$ & $\begin{array}{c}\text { Média } \pm \mathrm{DP} \\
\text { (n) }\end{array}$ & $\begin{array}{l}\text { Faixa de } \\
\text { variação } \\
\end{array}$ & $\begin{array}{c}\text { Média } \pm \mathrm{DP} \\
\text { (n) }\end{array}$ \\
\hline $\begin{array}{l}\mathrm{DQO}_{\text {total }} \\
\left(\mathrm{mg} \cdot \mathrm{L}^{-1}\right)\end{array}$ & $1113-1852$ & $\begin{array}{c}1328 \pm 165 \\
(15)\end{array}$ & 924-1798 & $\begin{array}{c}1138 \pm 257 \\
(15)\end{array}$ & $395-598$ & $\begin{array}{c}486 \pm 59 \\
(15)\end{array}$ \\
\hline $\begin{array}{l}\text { Eficiência de } \\
\text { remoção (\%) }\end{array}$ & - & - & $3-35$ & $18 \pm 8(15)$ & $43-75$ & $56 \pm 9(15)$ \\
\hline $\begin{array}{l}\mathrm{DQO}_{\text {filtrada }} \\
\left(\mathrm{mg} \cdot \mathrm{L}^{-1}\right)\end{array}$ & $\begin{array}{c}998-1794 \\
(15)\end{array}$ & $1213 \pm 186$ & $690-1420$ & $\begin{array}{c}906 \pm 186 \\
(15)\end{array}$ & $248-498$ & $\begin{array}{c}376 \pm 54 \\
(15)\end{array}$ \\
\hline $\begin{array}{l}\text { Eficiência de } \\
\text { remoção (\%) }\end{array}$ & - & - & $13-39$ & $26 \pm 7(15)$ & $42-69$ & $57 \pm 8(15)$ \\
\hline $\mathrm{pH}$ & $6,0-8,5$ & (16) & $5,0-7,6$ & (16) & $7,5-8,3$ & (16) \\
\hline $\begin{array}{l}\text { Alcalinidade } \\
\left(\mathrm{mg} \cdot \mathrm{L}^{-1}\right)\end{array}$ & $118-295$ & $\begin{array}{c}174 \pm 38 \\
(16)\end{array}$ & $126-479$ & $\begin{array}{c}200 \pm 92 \\
(16)\end{array}$ & $163-416$ & $\begin{array}{c}279 \pm 83 \\
(16)\end{array}$ \\
\hline $\begin{array}{l}\text { Ácidos } \\
\left(\mathrm{mg} \cdot \mathrm{L}^{-1}\right)\end{array}$ & $97-219$ & $\begin{array}{c}133 \pm 26 \\
(16)\end{array}$ & $160-364$ & $\begin{array}{c}261 \pm 58 \\
(16)\end{array}$ & $24-96$ & $\begin{array}{c}51 \pm 20 \\
(16)\end{array}$ \\
\hline ST (mg. $\left.L^{-1}\right)$ & $444-1600$ & $878 \pm 248$ & $479-1630$ & $1012 \pm 265$ & $760-1132$ & $938 \pm 110$ \\
\hline STV (mg. $\left.L^{-1}\right)$ & $26-1048$ & $457 \pm 210$ & $29-988$ & $528 \pm 243$ & $6-578$ & $403 \pm 226$ \\
\hline STF $\left(m g \cdot L^{-1}\right)$ & $71-1035$ & $445 \pm 226$ & $275-1050$ & $484 \pm 199$ & $381-965$ & $535 \pm 150$ \\
\hline SST (mg. $\left.L^{-1}\right)$ & $25-189$ & $92 \pm 54$ & $92-384$ & $171 \pm 65$ & $50-167$ & $109 \pm 35$ \\
\hline SSV (mg. $\left.L^{-1}\right)$ & $6-170$ & $67 \pm 51$ & $4-353$ & $135 \pm 71$ & 3-144 & $83 \pm 41$ \\
\hline SSVLM & - & - & - & - & $80-2940$ & $1296 \pm 1088$ \\
\hline SSVdec & & & & & $40-10120$ & $2492 \pm 2535$ \\
\hline $\mathrm{CH}_{4}(\%)$ & - & - & 0-77 & $34 \pm 28$ & - & - \\
\hline
\end{tabular}

Obs.: DV: desvio padrão. Os valores entre parênteses (n) se referem ao número de observações. 
TABELA 5.29. Comparação entre trabalhos com reatores aeróbios operando em faixas de temperatura mesofilica e termofilica.

\begin{tabular}{|c|c|c|c|c|c|c|c|}
\hline Processo & $\begin{array}{l}\mathrm{T} \\
\left({ }^{0} \mathrm{C}\right)\end{array}$ & Escala & Substrato & $\begin{array}{c}\mathrm{\theta H} \\
\text { (horas) }\end{array}$ & $\varepsilon_{\mathrm{DQO}} \%$ & Observação & Referência \\
\hline LA & 35 & $\begin{array}{l}\mathrm{Lab} \\
(5 \mathrm{~L})\end{array}$ & Efluente de polpa Kraft & 12 a 4 & $64 \pm 8,2$ & $\begin{array}{l}\varepsilon_{\mathrm{DBO}} \% \text {, SSVLM e SSVefluente comparáveis a } \\
\text { condições mesofilicas. Não foram verificados } \\
\text { turbidez efluente e problemas com sedimentação do } \\
\text { lodo }\end{array}$ & $\begin{array}{l}\text { Barr et al. } \\
(1996)\end{array}$ \\
\hline $\begin{array}{l}\mathrm{SBR}_{1} \\
\mathrm{SBR}_{2} \\
\mathrm{SBR}_{3} \\
\mathrm{SBR}_{4}\end{array}$ & $\begin{array}{l}35 \\
45 \\
55 \\
60\end{array}$ & $\begin{array}{l}\text { Lab } \\
(2 \mathrm{~L})\end{array}$ & $\begin{array}{l}\text { Efluente do branqueamento } \\
\text { do papel (Indústria Domtar) }\end{array}$ & 12 & $\begin{array}{l}64 \pm 8,2 \\
63 \pm 8,0 \\
52 \pm 8,0 \\
50 \pm 6,0\end{array}$ & Aumento gradual da temperatura. & $\begin{array}{l}\text { Tripathi \& } \\
\text { Allen } \\
(1999)\end{array}$ \\
\hline $\begin{array}{l}\mathrm{SBR}_{1} \\
\mathrm{SBR}_{2} \\
\mathrm{SBR}_{3} \\
\mathrm{SBR}_{4}\end{array}$ & $\begin{array}{l}35 \\
45 \\
55 \\
60\end{array}$ & $\begin{array}{l}\text { Lab } \\
(2 \mathrm{~L})\end{array}$ & $\begin{array}{l}\text { Efluente do branqueamento } \\
\text { do papel (Indústria } \\
\text { ALPAC) }\end{array}$ & 12 & $\begin{array}{l}70 \pm 9,7 \\
68 \pm 10,5 \\
54 \pm 9,6 \\
56 \pm 15,0\end{array}$ & Aumento gradual da temperatura. & $\begin{array}{l}\text { Tripathi \& } \\
\text { Allen } \\
(1999)\end{array}$ \\
\hline $\begin{array}{l}\text { Reator de } \\
\text { biofilme e } \\
\text { leito móvel } \\
\text { Kaldnes } \\
\text { (MBBR) }\end{array}$ & 55 & $\begin{array}{l}\text { Lab } \\
(8,55 \mathrm{~L})\end{array}$ & $\begin{array}{l}\text { Licor branco de polpagem } \\
\text { termomecânica }\end{array}$ & 30 a 14 & $60-65$ & $\begin{array}{l}\text { A taxa de remoção aumentou linerarmente com a } \\
\text { TCO e não havia sinais que a TCOmáxima havia } \\
\text { sido atingida }\end{array}$ & $\begin{array}{l}\text { Jahren et } \\
\text { al. (2002) }\end{array}$ \\
\hline
\end{tabular}


TABELA 5.29. Comparação entre trabalhos com reatores anaeróbios operando em faixa de temperatura mesofilica e termofilica (continuação).

\begin{tabular}{|c|c|c|c|c|c|c|c|}
\hline Processo & $\begin{array}{l}\mathrm{T} \\
\left({ }^{\circ} \mathrm{C}\right)\end{array}$ & Escala & Substrato & $\begin{array}{c}\theta \mathrm{H} \\
\text { (horas) }\end{array}$ & $\begin{array}{l}\varepsilon_{\mathrm{DQO}} \\
\%\end{array}$ & Observação & Referência \\
\hline $\begin{array}{l}\text { Filtro } \\
\text { anaeróbio }\end{array}$ & $\begin{array}{l}35 \\
55\end{array}$ & $\begin{array}{l}1,52 \mathrm{~L} \\
1,55 \mathrm{~L}\end{array}$ & $\begin{array}{l}\text { Simulado: indústria de } \\
\text { papel }\end{array}$ & $\begin{array}{c}11,7 \mathrm{a} \\
26,2\end{array}$ & & $\begin{array}{l}\text { A taxa de produção específica foi maior no digestor } \\
\text { termofilico em todos os } \theta_{\mathrm{H}} \text { comparado ao digestor } \\
\text { mesofilico. Metano diminuiu com o aumento do } \theta^{\mathrm{H}} \text { e } \\
\text { AGV aumentou sistema mesofilico }\end{array}$ & $\begin{array}{l}\text { Ahn \& } \\
\text { Forster } \\
(2002 a)\end{array}$ \\
\hline $\begin{array}{l}\text { Filtro } \\
\text { anaeróbio }\end{array}$ & $\begin{array}{l}35 \\
55\end{array}$ & $\begin{array}{l}1,52 \mathrm{~L} \\
1,55 \mathrm{~L}\end{array}$ & $\begin{array}{l}\text { Simulado: indústria de } \\
\text { papel }\end{array}$ & $\begin{array}{c}25 \\
24,7\end{array}$ & & $\begin{array}{l}\text { A biomassa no digestor termofilico é menos } \\
\text { susceptivel a flutuações na temperatura que no digestor } \\
\text { mesofilico. Ambos reatores são capazes de recuperar a } \\
\text { eficiência depois que a temperatura é reajustada para as } \\
\text { condições ótimas. }\end{array}$ & $\begin{array}{l}\text { Ahn \& } \\
\text { Forster } \\
(2002 b)\end{array}$ \\
\hline UASB & 35 & $5 \mathrm{~L}$ & $\begin{array}{l}\text { Efluente indústria de café } \\
\text { instantâneo } \\
\text { Efluente indústria de café } \\
\text { instantâneo }\end{array}$ & $\begin{array}{l}48 \\
36 \\
24 \\
18 \\
48 \\
36 \\
24 \\
18\end{array}$ & $\begin{array}{l}78 \\
78 \\
77 \\
- \\
70 \\
73 \\
70 \\
68\end{array}$ & $\begin{array}{l}\text { A cada redução no } \theta_{\mathrm{H}} \text { havia um aumento na TCO } \\
\text { sendo os valores de } 5 ; 6,6 ; 10 \text {; e } 11,4 \mathrm{KgDQO} \cdot \mathrm{m}^{-3} \cdot \mathrm{d}^{-1} \text {, } \\
\text { respectivamente. Nesta última TCO o reator mesofilico } \\
\text { entrou em colapso. A concentração de AGV no reator } \\
\text { mesofilico foi de } 35,17,15 \mathrm{mg} \cdot \mathrm{L}^{-1} \text { para } \theta_{\mathrm{H}} \text { de } 48,36 \text {, } \\
24 \text { e } 18 \text {, respectivamente. No reator termofilico estas } \\
\text { concentrações foram de } 122,99,80 \text { e } 97 \mathrm{mg} \cdot \mathrm{L}^{-1} \text {, } \\
\text { respectivamente. }\end{array}$ & $\begin{array}{l}\text { Dinsdale et } \\
\text { al. (1997a) }\end{array}$ \\
\hline
\end{tabular}

*O efluente do reator UASB era utilizado para alimentar o reator de LA para o qual estão especificadas as condições operacionais. 


\section{CONCLUSÕES}

"A úmica maneira de descobrir os limites do possivel é ir além deles, para o impossível Anthurc. Clarke

O principal objetivo deste trabalho foi verificar a aplicabilidade de sistema de reatores (anaeróbio-aeróbio) inoculados com lodos mesofilicos e gradualmente adaptados, à faixa de temperatura termofílica, para tratar efluente simulado de indústria de pasta de celulose não branqueada. Logo, as conclusões são apresentadas considerando as duas faixas de temperatura de trabalho.

\section{Monitoramento físico-químico:}

- A concentração de oxigênio dissolvido não é parâmetro limitante para o tratamento aeróbio termofilico. Em alta temperatura a concentração de saturação diminui porém aumenta o coeficiente de transferência de oxigênio tornando possível a operação de processos aeróbios;

- Na faixa mesofilica $\left(37,5\right.$ a $\left.42,5^{\circ} \mathrm{C}\right)$ a eficiência do sistema foi de $(69 \pm 3) \%$, com maior eficiência do reator anaeróbio $(56 \pm 7) \%$ e produção de metano estável, aproximadamente $75 \%$;

- Na faixa termofilica $\left(45,0\right.$ a $\left.52,0^{\circ} \mathrm{C}\right)$, com os reatores UASB e de lodos ativados operando com tempo de detenção hidráulica de $20 \mathrm{~h}$ e de $11 \mathrm{~h}$, respectivamente, as eficiências de remoção de DQO do sistema variaram de $57 \%$ a $88 \%$;

- O reator UASB apresentou alcalinidade total efluente variando de $249 \mathrm{mg} . \mathrm{L}^{-1}$ a $382 \mathrm{mg} . \mathrm{L}^{-1}$; concentração de ácidos graxos variando de $41 \mathrm{mg} . \mathrm{L}^{-1}$ a $199 \mathrm{mg} . \mathrm{L}^{-1} \mathrm{e}$ o $\mathrm{pH}$, de 7,3 a 8,0 .

- A porcentagem de metano no biogás foi decrescendo com o aumento de temperatura, de $77 \%$ a valores abaixo do limite de deteção do método. 
- No reator de lodos ativados a efíciência de remoção de DQO variou de $14 \%$ a $58 \%$ e o $\mathrm{pH}$, na faixa de 7,6 a 8,2 .

- A concentração de sólidos suspensos voláteis no licor misto foi baixa variando de $15 \mathrm{mg} . \mathrm{L}^{-1}$ a $470 \mathrm{mg} . \mathrm{L}^{-1}$, sendo o maior valor obtido quando o reator operava em temperatura de $52^{\circ} \mathrm{C}$;

- Na última etapa termofílica, com os reatores UASB e de lodos ativados operando com tempo de detenção hidráulica de $24 \mathrm{~h}$ e $8 \mathrm{~h}$, respectivamente, as eficiências de remoção de DQO do sistema variaram de 54\% a 70\%;

- O reator UASB apresentou eficiências de remoção de DQO de $3 \%$ a 35\%, com grande perda de sólidos suspensos voláteis no efluente, cerca de (1505 \pm 238$) \mathrm{mgSSV} . \mathrm{d}^{-1}$.

- No reator aeróbio, as eficiências de remoção de DQO variaram de $43 \%$ a $75 \%$, e a perda de sólidos suspensos voláteis pelo efluente foi menor que a do reator anaeróbio, cerca de $(1275 \pm 537) \mathrm{mgSSV} . \mathrm{d}^{-1}$.

- As concentrações de sólidos suspensos voláteis no licor misto aumentaram com o aumento da temperatura, variando de $122 \mathrm{mg} . \mathrm{L}^{-1}$ a $2940 \mathrm{mg} . \mathrm{L}^{-1}$, provavelmente pela maior disponibilidade de alimento, visto que a efíciência do reator anaeróbio foi reduzida em maiores temperaturas.

- Monitoramento microbiológico:

- No reator anaeróbio, as morfologias encontradas nas fases mesofilica e termofílica foram praticamente as mesmas, porém, na termofílica, diminuiu a freqüência de Methanosarcina sp. e tornou-se comum a presença de vacúolos em Methanosaeta sp., bem como sua parede celular parecia estar diferenciada;

- Bacilos e Methanosaeta sp. foram predominantes nas duas fases de operação;

- No reator aeróbio foi verificada diferenciação na microbiota a partir da temperatura de $42,5^{\circ} \mathrm{C}$ com a presença de morfologias semelhantes a cocos;

- A partir da temperatura de $45,0^{\circ} \mathrm{C}$, protozoários e outros organismos característicos de lodos ativados mesofilicos não foram identificados;

- No reator aeróbio, na fase termofílica, predominaram bacilos, cocos e filamentos;

- No teste para verificar organismos metanogênicos em amostras de lodo do reator UASB e do reator de lodos ativạdos incubados na água residuária sintética a $57^{\circ} \mathrm{C}$ por 50 dias verificou-se que nos frascos inoculados com lodo anaeróbio 
predominaram Methanosceta sp. e bacilos, enquanto nos frascos inoculados com lodo aeróbio predominaram bacilos e filamentos delgados;

- Por microscopia eletrônica de varredura foram verificadas as mesmas morfologias nas amostras de lodo anaeróbio e aeróbio, em número limitado e sem boa definição.

- Teste do aumento súbito da temperatura:

- Com a operação dos reatores tendo a temperatura sido aumentada subitamente obteve-se eficiência de remoção do sistema variando de 59\% a 73\%. Também foi verificada uma menor diversidade microbiana e um melhor desempenho do reator de lodos ativados. 


\title{
7. RECOMENDAÇÕES
}

\author{
$\mathcal{N}$ unca é tarde para tentar o desconfiecido, munca é \\ tarde para se ir mais além. \\ (Gabriele D'Annumunzio, poeta itafiano - 1863-1938)
}

Tendo sido este um primeiro trabalho sobre sistemas termofilicos tratando água residuária sintética da indústria de pasta de celulose não branqueada e com resultados considerados bons, há sugestões para trabalhos futuros. A princípio, são apresentadas algumas sugestões de trabalhos de fundamentação:

- Estudo das interações químicas no floco do reator aeróbio termofílico, verificando quais as reações predominantes e o que pode ser feito para melhorar sua capacidade de sedimentação, evitando a turbidez efluente e melhorando, por conseqüência, o desempenho do reator;

- Estudos microbiológicos do grânulo e do floco termofílicos, verificando quais as morfologias predominantes e a melhor maneira de favorecê-las, para operações mais estáveis dos reatores;

- Melhorar as formas de aeração do sistema, bem como suas configurações, evitando maior custo em possível aumento da aeração em reatores termofílicos aeróbios para manutenção das concentrações do oxigênio dissolvido.

Algumas alterações operacionais são também sugeridas:

- Encontrar configuração adequada de reator anaeróbio para que possa ser implementado o sistema de tratamento anaeróbio-aeróbio termofílico. Talvez a configuração de um filtro anaeróbio seja mais eficaz para reter os grânulos termofílicos, evitando a perda efluente;

- Iniciar a operação dos reatores com aumento súbito da temperatura, permitindo um maior período para estabilização dos reatores; 
- Testar a operação do reator aeróbio em regime de batelada para verificar se a melhora a sedimentação e conseqüentemente a concentração de sólidos suspensos voláteis no licor misto

- Outras configurações do reator aeróbio também poderiam ser testadas, buscando minimizar a perda de biomassa. Pode-se utilizar, por exemplo, aeróbio com biomassa imobilizada ou aeróbio com membrana;

- Fazer um balanço de sólidos nos reatores;

- Pretendia-se implantar, após o tratamento biológico, um sistema de eletroflotação para melhorar a qualidade do efluente, verificando a possibilidade de reuso. Infelizmente isto não foi possível devido ao encerramento do tratamento biológico antes do esperado, por problemas operacionais para manter o controle da temperatura. Portanto, fica a sugestão para trabalhos futuros. 


\section{REFERÊNCIAS BIBLIOGRÁFICAS}

AHN, J.-H.; FORSTER C.F. (2000). Kinetic analyses of the operation of mesophilic and thermophilic anaerobic filters treating a simulated starch wastewater. Process Biochemistry, 36: 19-23.

Q AHN, J.-H.; FORSTER C.F. (2002a). The effect of temperature variations on the performance of mesophilic and thermophilic anaerobic filters treating a simulated papermill wastewater. Process Biochemistry, 37: 589-594.

8 AHN, J.H.; FORSTER, C.F.(2002b). A comparison of mesophilic and thermophilic anaerobic upflow filters.treating paper pulp liquors. Process Biochemistry. 38: 257262.

AHRING, B.K.; IBRAHIM, A.A.; MLADENOVSKA, S. (2001). Effect of temperature increase from 55 to $65^{\circ} \mathrm{C}$ on performance and microbial population dynamics of anaerobic reactor treating cattle manure. Water Research. 35(10): 2446-2452.

ALEXIOU, I. E.; ANDERSON, G. K.; EVISON, L. M. (1994). Design of preacidification reactors for the anaerobic treatment of industrial wastewaters. Water Sci. Technol. 29(9), 199-204.

AN, H.; QIAN, Y.; GU, X.; TANG, W. Z. (1996).Biological Treatment of dye wastewaters using an anaerobic-oxic system. Chemosphere, 33(12): 2533-2542.

APHA - Standard Methods for the Examination of Water and Wastewater. (1998). American Public Health Association, American Water Works Association, Water Pollution Control Federation. 12. ed. New York.

ARAÚJO, J. C. (1994). Acompanhamento da evolução do biofilme e caracterização química e biológica em reator de leito fluidificado tratando esgoto sanitário e sintético. Dissertação (Mestrado) - Escola de Engenharia de São Carlos, Universidade de São Paulo.

BARR, T.A.; TAYLOR, J.M.; DUFF, S.J.B. (1996). Effect of HRT, SRT and temperature on the performance of activated sludge reactors treating bleached kraft mill effluent. War Res. 30(4): 799-810. 
BITTON, GABRIEL. (1995). Wastewater microbiology. Wiley-Liss, New York, 478 p.

BNDES. (2003). O setor de papel e celulose no Brasil e no mundo. Disponível em: $<$ http://www.bndes.gov.br/conhecimento/relato/rel52b.pdf $>$. Acesso em: 25 de novembro.

BROCK, T. D. (1986). Thermophiles: General, Molecular and Applied Biology, T.D.Brock (Ed.). Wiley-Interscience, New York, 316p.

BROCK, T.D.; MADIGAN, M.T. (1988). Biology of microorganisms. Prentice Hall. Englewood Cliffs, New Jersey.

BUZZINI, A P. (1995). Avaliação preliminar de um sistema de eletroflotação para a remoção de cor de efluentes de industrias de papel e celulose. Dissertação. Universidade de São Paulo - Escola de Engenharia de São Carlos. São Carlos. 178 p.

BUZZINI, A P. (2000). Tratamento de águas residuárias simuladas de indístrias de pasta celulósica não branqueada e branqueada. Tese (doutorado). Universidade de São Paulo - Escola de Engenharia de São Carlos. São Carlos. 165 p.

CAMPOS, J. R. (1999). Tratamento de esgotos sanitários por processo anaeróbio e disposição controlada no solo. (coordenador). RJ, projeto PROSAB/ABES. 464p.

CAPO, P. (1998). Legislação ambiental e novas tecnologias de tratamento de resíduos de processo. O Papel: revista mensal de tecnologia em celulose e papel, ano LIX, n. 12:. 42-47, dezembro.

CARRHA, L. R. (1991). Avaliação do processo eletrolítico para remoção de cor devida a lignina. Dissertação. Universidade de São Paulo - Escola de Engenharia de São Carlos. São Carlos. 178 p.

CHERNICHARO, C. A. L. (1997). Reatores Anaeróbios. Departamento de Engenharia Sanitária e Ambiental - UFMG. Belo Horizonte. 246pp.

CHU, A.; MAVINIC, D.S.; RAMEY, W. D.; KELLY, H. G. (1996). A biochemical model describing volatile fatty acid metabolism in thermophilic aerobic digestion of wastewater sludge. Wat. Res. 30(8): 1759-1770.

CORSON, W. H. (1996). Manual global de ecologia: o que você pode fazer a respeito da crise do meio ambiente. Tradução de Alexandre Gomes Camaru. $2^{a}$ ed. São Paulo. Editora Augustus.

D'SOUZA, C. P.; BALASUBRAMANYA, R. H. (1999). Microbial ecology of solid cellulosic materials during aerobic digestion and anaerobic fermentation. Bioresource technology, 69: 285-287. Elsevier Science Ltda. Grã-Bretanha. 
DANGCONG, P.; QITING, J. (1993). Anaerobic digestion of alkaline black liquor using an upflow anaerobic sludge blanket reactor. J Chem.Tech Biotechnol, 58: 8993.

DILALLO, R.; ALBERTSON, O. E. (1961). Volatile acids by direct titration. Journal Water Pollution Control Federation. 33(4): 350-364.

DINSDALE, R.M.; HAWKES, F.R.; HAWKES, D. L. (1997a). Comparison of Mesophilic and thermophilic upflow anaerobic sludge blanket reactors treating instant coffee production wastewater. Water Research., 31(1): 163-169.

DINSDALE, R.M.; HAWKES, F.R.; HAWKES, D. L. (1997b). Mesophilic and thermophilic anaerobic digestion with thermophilic pre-acidification of instantcoffee production wastewater. Water Research., 31(8): 1931-1938.

ESCADA, M. A. S. (1991). Determinação de parâmetros característicos de filtração de suspensões fibrosas. Dissertação. Universidade de São Paulo - Escola de Engenharia de São Carlos. São Carlos. 126 p.

FALKENMARK, M. (1997). Terra, patrimônio comum: a ciência a serviço do meio ambiente e do desenvolvimento. Tradução de Abreu, E. S. Nobel.

FATIBELlO, S. H. S. A. (2000) Avaliação da atividade microbiana anaeróbia de sedimentos lacustre e de lodos de um biodigestor anaeróbio termofílico na degradação de tricloroetileno (TCE). Dissertação. Universidade de São Paulo Escola de Engenharia de São Carlos. São Carlos. 225p.

FERNANDEZ, N.; FORSTER, C. F. (1993b). A study of the operation of mesophilic and thermophilic anaerobic filters treating a synthetic coffee waste. Bioresource Technol. 45, 223-227.

FIGUEROA, F. E. V. (1996). Avaliação econômica de ambientes naturais. O caso das áreas alagadas. Uma proposta para a represa do Lobo (Broa). Itirapina - SP. Dissertação. Universidade de São Paulo - Escola de Engenharia de São Carlos. São Carlos. 143p.

FORESTI, E. (1987). Efeitos da concentração inicial do substrato no desempenho de reatores anaeróbios de fluxo ascendente com manta de lodo). São Carlos/SP, 1987. 147p. Tese (Livre Docência) - Escola de Engenharia de São Carlos, Universidade de São Paulo.

FORSTER, C. F. (1991). Anaerobic upflow sludge blanket reactors: aspects of their microbiology and their chemistry. J. Biotechnology. 1991. 17: 221-232. 
GAVALA, H. N.; YENAL, U.; SKIADAS, I.V.; WESTERMANN, P.; AHRING, B.K.(2001). Mesophilic and thermophilic anaerobic digestion of primary and secondary sludge. Effect of pre-treatment at elevated temperature. Water Research. Article in press, p. 1-12.

- GEOTRACK. (2003). Tragédia ecológica: UFV é chamada para dimensionar os danos ao meio ambiente causados pelo vazamento de resíduos químicos no rio Pomba, em MinasGerais. Disponível em:<http://www.geotrack.hpg.ig.com.br/pnov090.pdf>. Acesso em: 25 de novembro.

GROVER, R.; MARWAHA, S.S.; KENNEDY, J. F. (1999). Studies on the use o na anaerobic baffled reactor for the continuous anaerobic digestion of pulp and paper mill black liquors. Process Biochemistry, 34: 653-657.

GUAGLiANONI, L. G. (1993). Remoção de cor por processo eletrolítico em águas residuárias contendo lignina. Dissertação. Universidade de São Paulo - Escola de Engenharia de São Carlos. São Carlos. 186 p.

GUAGLIANONI, L. G. (1998). A remoção dos compostos organoclorados Tetraclorocatecol e Tetracloroguaiacol contidos em efluentes da indisstria de papel e celulose. Tese (doutorado). Universidade de São Paulo - Escola de Engenharia de São Carlos. São Carlos. 103 p.

GUERRERO, L; OMIL, F.; MÉNDEZ, R.; LEMA, J.M. (1999). Anaerobic hydrolysis and acidogenesis of wastewaters from food industries with high content of organic solids and protein. Water Research. 33(15): 3281-3290.

GUIOT, S.R.; PAUSS, A.; COSTERTON, J.W. (1992). A structured model of the anaerobic granule consortium. Water Science Technology. 25:1-10.

JAHREN, S. J.; ODEGAARD, H. (1999). Treatment of thermomechanical pulping (TMP) whitewater in thermopilic $\left(55^{\circ} \mathrm{C}\right)$ anaerobic-aerobic moving bed biofilm reactors. Water Science Technology. 40(8): 81-89.

JAHREN, S. J.; RINTALA, J. A. (1997). The closure of water circuits by internal thermophilic (55 and 700C) anaerobic treatment in the thermomechanical pulping process. Water Science Technology. 35(2-3): 49-56.

JAHREN, S. J.; RINTALA, J. A.; ODEGAARD, H. (1999). Anaerobic thermophilic $\left(55^{\circ} \mathrm{C}\right)$ treatment of TMP whitewater in reactors based on biomass attachment and entrapment. Water Science Technology. 40(11-12): 67-75. 
JAHREN, S.; RINTALA, J.A.; ØDEGAARD, H. (2002). Aerobic moving bed biofilm reactor treating thermomechanical pulping whitewater under thermophilic conditions. Water Research. 36: 1067-1075.

JEAN, R. (1997). Avaliação da atividade mutagênica de efluentes de indístrias de celulose determinada por ensaio de curta duração com Salmonella typhimurium :teste de Ames. Dissertação. Universidade de São Paulo - Escola de Engenharia de São Carlos. São Carlos. $215 \mathrm{p}$

JENKINS, D.; RICHARD, M. G.; DAIGGER, G. T. (1993). Manual on the causes and control of activated sludge bulking and foaming. 2 ed. Lewis Publishers, Inc. Michigan.

KATO, M. T.; ANDRADE NETO, C. O.; CHERNICHARO, C. A L.; FORESTI, E.; CYBIS, L. F. (1999). Configurações de reatores anaeróbios. In: CAMPOS, J. R. (1999). Tratamento de esgotos sanitários por processo anaeróbio e disposição controlada no solo. (coordenador). Cap. 3, p. 53-99, projeto PROSAB/ABES.

KIM, M.; AHN, Y.; SPEECE, R.E. (2002b). Comparative process stability and efficiency of anaerobic digestion; mesophilic vc. thermophilic. Water Research., 36: 4369-4385.

KIM, M.; SPEECE, R.E. (2002a). Aerobic waste activated sludge (WAS) for start-up seed of mesophilic and thermophilic anaerobic digestion. Water Research., 36: 3860-3866.

KORTEKAAS, S.; SOTO, M., VICENT, T.; FIELD, J.A.; LETTINGA, G. (1995). Contribution of extractives to methanogenic toxicity of hemp black liquor. Journal of fermentation and bioengineering. 80(4): 383-388.

KOSARIC, N.; BLASZCZYK, R.; ORPHAN, L.; VALLADARES, J. (1990). The characteristics of granules from uplfow anaerobic sludge blanket reactors. Water Research. 24: 1473-1477.

LANGWORTHY, T. A.; POND, J. L. (1986). Membranes and lipids of thermophiles. In: Thermophiles: General, Molecular and Applied Biology, T.D.Brock (Ed.). WileyInterscience, New York, p. 75-106.

LAPARA, T. M.; ALLEMAN, J. E. (1999). Thermophilic aerobic biological wastewater treatment. Water Research. 33(4): 895-908.

LAPARA, T. M.; NAKATSU, C. H.; PANTEA, L. M.; ALLEMAN, J. E. (2001). Aerobic biological treatment of a pharmaceutical wastewater: effect of temperature on COD removal and bacterial community development. Water Research. 35(18): 4417-4425.

LAU, E.W.C.; FANG, H.H.P. (1997). Effect of temperature shock to thermophilic granules. Water Research., 31(10): 2626-2632.

LENS, P. M.; D E BEER, D.; CRONENBER, C.H.; HOUWEN, F.P.; OTTENGRAF, S. P. P.; VERSTRAETE, W. (1993). Heterogenous distribution of microbial activity 
in methanogenic aggregates: pH and glucose microprofiles. App. Envirn. Microbiol. 59: $3803-3815$.

LEPISTO, R.; RINTALA, J. (1997). The effect of extreme temperatures $\left(70-80^{\circ} \mathrm{C}\right)$ on the effluent quality and sludge characteristics of UASB reactors. Water Science Technology. 36(6-7): 325-332.

LEPISTO, R.; RINTALA, J. (1999). The extreme thermophilic $\left(70^{0} \mathrm{C}\right)$, VFA-FED UASB reactor: performance, temperature response, load potential, and comparison with 35 and $55^{\circ} \mathrm{C}$ UASB reactors. Water Research. 33(14): 3162-3170.

LETTINGA, G., FIELD, J.A., ALVAREZ, R.S., VANLIER, J.B., RINTALA, J.B. (1991). Future perspectives for the anaerobic treatment of forest industry wastewaters. Water Sci. Technol. 24: 91-102.

LETTINGA, G., HULSHOFF POL, L.W. (1991). UASB process design for various waste waters. Water Sci. Technol. 24(8): 87-107.

LIAO, B.Q; ALLEN, D. G.; DROPPO, I. G.; LEPPARD, G. G.; LISS, S. N. (2001). Surface properties of sludge and their role in bioflocculation and settleability. Water Res. 2001;35(2):339-50.

LIMA, M. R. A. (1996). Emprego da flotação por ar dissolvido no tratamento das águas residuárias de uma indústria de papel visando a recuperação de fibras. Dissertação. Universidade de São Paulo - Escola de Engenharia de São Carlos. São Carlos. 102 p.

LIU, W-T; CHAN; O-C; FANG, H. H. P. (2002). Microbial community dynamics during start-up of acidogenic anaerobic reactors. Water Research, 36: 3203-3210.

MADIGAN, T., MARTINKO, J. \& PARKER, J. (1998). In: Brock T.D. (ed.) Biology of Microorganisms. 8th edition. Prentice Hall International, Inc. New Jersey. 986 p.

- MAIA, J. N. (2001). Indístria da celulose - pasta e papel: Notas sobre os seus processos tecnológicos, a envolvente Européia e a situação em Portugal. Disponível em: $<$ http://www.iscte.pt/gei/PT-II-cel-2002.pdf $>$. Acesso em: 25 de novembro.

MARTOS, H. L.; MAIA, N. B. (1997). Indicadores ambientais Esalq. 266p. Cap. 1. Recursos naturais não renováveis e desenvolvimento sustentável. Landim, P. M. Barbosa. p. 9-22.

MASON, C. A. (1986). Microbial death lysis and cryptic growth: fundamental and applied aspects. Diss. ETH. N. 8150. Swiss Federal Institute of Thechnology. Zurich. 
MENDONÇA, L. C. (2002). Microbiologia de sistema de lodos ativados como póstratamento de efluente de reator anaeróbio de leito expandido. Tese (doutorado). Universidade de São Paulo - Escola de Engenharia de São Carlos. São Carlos. 219 p.

MORGAN, J. W.; FORSTER, C. F.; EVISON, L. A. (1990). A comparative study of the nature of biopolymers extracted from anaerobic and activated sludges. Wat. Res. 24: 743-750.

NALIM, L. (2001). Tratamento biológico e Físico-químico para reuso dos efluentes do estágio de branqueamento de polpa celulósica. Dissertação. Universidade de São Paulo - Escola de Engenharia de São Carlos. São Carlos.

NOLASCO, M. A. (1998). Redıção da prodıção de lodo no tratamento aeróbio de efluentes da indístria de celulose e papel. Tese (doutorado). Universidade de São Paulo - Escola de Engenharia de São Carlos. São Carlos. 176 p.

PARSEKIAN, M. P. S. (2003). Balanço de nitrogênio e fósforo em sistema de tratamento ateróbio precedido de reator UASB, empregando recirculação total e lise celular: Doutorado (tese). Universidade de São Paulo - Escola de Engenharia de São Carlos. São Carlos. 223 p.

PELCZAR JR., M.; REID, R.; CHAN, E. C. S. (1980). Microbiologia. Tradutor: PEREIRA, M. A. M. vol. 1. São Paulo, São Paulo. McGraw-Hill. 566p.

PIRONEL, A L. (1999). Avaliação dos efluentes de uma planta de branqueamento de celulose Kraft para diferentes níveis de substituição do cloro pelo dióxido de cloro. Dissertação. Universidade de São Paulo - Escola de Engenharia de São Carlos. São Carlos. 113 p.

PORTO, M. F. A. (1991). Estabelecimento de Parâmetros de Controle da Poluição. Hidrologia Ambiental PORTO, R. L. L. Coleção ABRH de Recursos Hídricos EDUSP/ABRH, v. 3, 1991. São Paulo.

QUARMBY, J.; FORSTER C.F. (1995). A comparative study of the structure of thermophilic and mesophilic anaerobic granules. Enzyme and Microbial Technology. 17:493-498.

REALI, M. A. P.; DANIEL, L. A.; CAMPOS, J. R. (1999). Conceitos gercis sobre técnicas de tratamento de águas de abastecimento, esgotos sanitários e desinfecção. São Carlos. 
REIS, C. M. D. F. S. (1997). A ecogestão na indístria de celulose e papel e sua relação com o orgão de controle ambiental do Estado de São Paulo. Dissertação. Escola de Engenharia de São Carlos - Universidade de São Paulo. São Carlos/SP.

( REZENDE, A. A.P.;. MATOS, A. T.; SILVA, C. M. (2000). Utilização do efluente de indústria de celulose e papel em irrigação - uma revisão. 330. Congresso Anual de Celulose e Papel. ABTCP. 23 a 26 de outubro.

RINTALA, J. A.; LEPISTÖ, S. S. (1997). Pilot-scale thermopphilic anaerobic treatment of wastewater from seasonal vegetable processing industry. Water Science Technology. 36(23): 279-285.

RIPLEY, L. E.; BOYLE, W. C.; CONVERSE, J. C. (1986). Improved alkalimetric monitoring for anaerobic digestion of high-strenght wastes. Journal W. P. C. F., 58: 406-411.

ROSA, J. (1997). Avaliação da atividade mutagênica de efluentes de indístrias de celulose determinada por ensaio de curta duração com "Salmonella typhimurium": teste de Ames. Dissertação (mestrado). Escola de Engenharia de São Carlos - Universidade de São Paulo. São Carlos - SP. 215p.

SAKAMOTO, I. K. (1996). Comportamento do consórcio microbiano existente em um lodo anaeróbio granulado metanogênico, submetido a adições crescentes de sulfato. Dissertação (mestrado). Escola de Engenharia de São Carlos - Universidade de São Paulo. São Carlos SP. 150p.

SAMSON, R.; PAUSS, A.; GUIOT, S. R. (1990). Immobilized systems in anaerobic digestion process. p. 153-190. In: R. D. Tyagi \& K. Vembu (ed.). Wastewater treatment by immobilized cells. CRC Press. Boca Raton, FL.

SAUNAMÄKI, R. (1997). Activated sludge plants in Finland. Water Sci Technol. 35(23):235-43.

SIERRA-ALVAREZ, R., FIELD, J. A., KORTEKAAS, S., LETTINGA,G. (1994). Overview of the anaerobic toxicity caused by organic forest industry wastewater pollutants. Wat. Sci. Tech., 29: 353-363.

SIERRA-ALVAREZ, R; LETTINGA, G. (1991).The methanogenic toxicity of wastewater lignins and lignin related compounds. J. Chem. Technol. Biotechnol., 50: $443-455$.

SIKKEMA, J., DE BONT, J. A.M.; POOLMAN, B. (1994). Interactions of cyclic hydrocarbons with biological membranes. J. Biol. Chem., 269: 8022-8028. 
SOUZA, M. E., FUZARO, G. \& POLEGATO, A. R. (1992). Thermophilic Anaerobic Digestion of Vinasse in Pilot Plant UASB Reactor. Water Science and Technology, 25(7): 191-200.

SOUZA, M. P. (1997). Notas de aula: SHS 851 - Análise e Gestão Ambiental. Programa de Pós-graduação em Hidráulica e Saneamento. Departamento de Hidráulica e Saneamento. Escola de Engenharia de São Carlos/Universidade de São Paulo.

SPEECE, R.E. (1996). Anaerobic biotechnology for industrial wastewaters. Archae Press. Nashvilee, Tennessee. 394p.

SPRINGER, A. M. (1993) Industrial environmental control pulp and paper industry. $2^{\text {a }}$ edição. Tappi Press. Atlanta, Estados Unidos da América. 699p.

SUNDARAM, T. K. (1986). Physiology and growth of thermophilic bacteria. In Brock, T. D. (ed.). Thermophiles: general molecular and applied microbiology. Wiley, New York, p. 75-106.

SUVILAMPI, JUHANI (2003). Aerobic Wastewater Treatment under High and Varying Temperatures: Thermophilic Process Performance and Effluent Quality. Jyväskylä, 2003. 59p. (dissertação). Department of Biological and Environmental Science, University of Jyväskylä.

TASK FORCE ON WASTEWATER BIOLOGY (1990). Wastewater biology: the microlife. Special publication. In: Actinomycetes. Cap.3. p. 21-38.

TEZEL, U.; GUVEN, E.; ERGUDER, T. H.; DEMIRER, G. N. (2001). Sequential (anaerobic/aerobic) biological treatment of Dalaman SEKA Pulp and Paper Industry efluent. Waste Management. 21: 717-724.

THOMPSON, G.; SWAIN, J. ; KAY, M.; FORSTER, C.F. (2001). The treatment of pulp and paper mill effluent: a review. Bioresource Technology, 77: 275-286.

TRIPATHI, C. S.; ALLEN, D. G. (1999). Comparison of Mesophilic and Thermophilic aerobic biological treatment in sequencing batch reactors treating bleached kraft pulp mill effluent. Water Research, 33(3): 836-846, out.

UC. (2003). Propriedades termofísicas de licores celulósicos. Disponível em: $<$ http://www.eq.UC.pt/ eqlamf/liqu.html $>$. Acesso em: 25 de novembro.

VAN LIER, J. B.; REBAC, S.; LETTINGA, G. (1997). High-rate anaerobic wastewater treatment under psychrophilic and thermophilic conditions. Water Science Technology. 35(10): 199-206. 
VAN LIER, J.B.; MARTIN, J.L.S.; LETTINGA, G. (1996). Effect of temperature on the anaerobic thermophilic conversion of volatile fatty acids by dispersed and granular sludge. Water Research. 30(1): 199-207.

VAN LIER, J. B.; GROLLE K, C. F.; FRIJTERS, C. T. M. J.; STAMS, A. J. M.; LETTINGA, G. (1993) Effect of acetate, propionate, and butyrate on the thermophilic anaerobic degradation of propionate by methanogenic sludge and defined cultures. Appl. Environ. Microbiol. 59: 1003-1011.

VAZOLLER, R. F. (1995). Avaliação do ecossistema microbiano de um biodigestor anaeróbio de fluxo ascendente e manta de lodo, operado com vinhaça sob condições termofílicas. Tese (doutorado). Universidade de São Paulo - Escola de Engenharia de São Carlos. São Carlos. 259p.

VOGELAAR, J. C. T.; KLAPWIJK, A.; LIER, J. B.; RULKENS, W.H. (2000). Temperature effects on the oxygen transfer rate between 20 and $55^{\circ} \mathrm{C}$. Water Research, 34(3): 1037-1041.

VOGELAAR, J.C.T.; BOUWHUIS, E.; KLAPWIJK, A.; SPANJERS, H.; LIER, J.B.VAN (2002). Mesophilic and Thermophilic activated sludge post-treatment of paper Mill process water. Water Research, 36: 1869-1879.

VON SPERLING, M.; VAN HAANDEL, A. C.; JORDÃO, E. P.; CAMPOS, J. R.; CYBIS, L. F.; AISSE, M. M.; SOBRINHO, P. A. (2001). Pós-tratamento de efluentes de reatores anaeróbios por sistemas de lodos ativados. In: CHERNICHARO, C. A. L (coordenador). Pós-tratamento de efluentes de reatores ancaeróbios. Cap. 5, p. 279-331.

ZINDER, S.H. (1986). Thermophilic waste treatment systems. In: Thermophiles: General, Molecular and Applied Biology, T.D.Brock (Ed.). Wiley-Interscience, New York, p. 257-277.

ZINDER, S.H. (1990). Conversion of acetic acid to methane by thermophiles. FEMS Microbial. Rev. 75: 125-138.

ZITA. A.; HERMANSSON, M. (1997). Effects of bacterial cell surface structures and hydrophobicity on attachment to activated sludge flocs. Appl. Environ. Microbiol. 63(3):1168-70. 
Anexos 
TABELA A1. Concentrações de DQO monitorados nos reatores na fase mesofílica: $1^{\text {a }}$ a $2^{-1}$ etapa.

\begin{tabular}{|c|c|c|c|c|c|c|c|c|c|}
\hline \multirow[b]{2}{*}{ 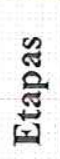 } & \multirow{2}{*}{$\begin{array}{c}\text { Tipo de licore } \\
\text { volume }\end{array}$} & \multirow{2}{*}{$\begin{array}{c}\mathrm{T} \\
\left({ }^{0} \mathrm{C}\right)\end{array}$} & \multirow{2}{*}{$\begin{array}{l}\text { Tempo } \\
\text { (dia) }\end{array}$} & \multicolumn{3}{|c|}{ DQO total (mg. $\left.\mathrm{L}^{-1}\right)$} & \multicolumn{3}{|c|}{ DQO filtrada (mg. $\left.\mathrm{L}^{-1}\right)$} \\
\hline & & & & ARS & e-UASB & e-LA & ARS & e-UASB & e-LA \\
\hline \multirow[t]{5}{*}{1} & LNC (10mL:10L) & 25 & 14 & 390 & 125 & - & - & - & - \\
\hline & LNC (10mL:10L) & 25 & 16 & 361 & 165 & - & - & - & - \\
\hline & LNC (14mL:10L) & 25 & 21 & 487 & 170 & - & - & - & - \\
\hline & LNC (14mL:10L) & 25 & 22 & 535 & 233 & - & - & - & - \\
\hline & LNC (18mL:10L) & 25 & 25 & 700 & 343 & - & - & - & - \\
\hline \multirow[t]{17}{*}{2} & LNC (20ML: 10L) & 25 & 26 & 846 & 396 & - & - & - & - \\
\hline & LNC (20ML: 10L) & 25 & 28 & 790 & 413 & - & 770 & 408 & - \\
\hline & LNC (20ML: 10L) & 25 & 30 & 830 & 423 & - & 909 & 448 & - \\
\hline & LNC (20ML:10L) & 25 & 33 & 951 & 437 & - & 830 & 441 & - \\
\hline & LNC (20ML:10L) & 25 & 35 & 1030 & 481 & - & 907 & 434 & - \\
\hline & LNC (20ML:10L) & 25 & 37 & 841 & 475 & - & 713 & 478 & - \\
\hline & LNC (25mL:10L) & 25 & 40 & 1085 & 575 & - & & & - \\
\hline & LNC (25mL:10L) & 25 & 42 & 1062 & 487 & - & 1131 & 384 & - \\
\hline & LNC (25mL:10L) & 25 & 44 & 971 & 509 & - & 1121 & 464 & - \\
\hline & LNC (25mL: 10L) & 25 & 47 & 1100 & 575 & - & & & - \\
\hline & LNC (25mL: 10L) & 25 & 49 & 1068 & 549 & - & 1047 & 429 & - \\
\hline & LNC (25mL: 10L) & 25 & 51 & 1098 & 610 & - & 1072 & 546 & - \\
\hline & LNC (25mL: 10L) & 25 & 54 & 972 & 588 & - & 900 & 498 & - \\
\hline & LNC (25mL:10L) & 25 & 56 & 976 & 494 & - & 940 & 438 & - \\
\hline & LNC (25mL: 10L) & 25 & 58 & 998 & 590 & - & 966 & 494 & - \\
\hline & LNC (25mL: 10L) & 25 & 61 & 1044 & 504 & - & - & - & - \\
\hline & LNC (25mL: 10L) & 25 & 63 & 1056 & 490 & - & 998 & 530 & - \\
\hline
\end{tabular}


TABELA A2. Concentrações de DQO monitorados nos reatores na fase mesofílica: $3^{\underline{a}}$ a $4^{\mathrm{a}}$ etapa.

\begin{tabular}{|c|c|c|c|c|c|c|c|c|c|}
\hline \multirow{2}{*}{ 芯 } & \multirow{2}{*}{$\begin{array}{c}\text { Tipo de } \\
\text { licore volume }\end{array}$} & \multirow{2}{*}{$\begin{array}{c}\mathrm{T} \\
\left({ }^{\circ} \mathrm{C}\right)\end{array}$} & \multirow{2}{*}{$\begin{array}{c}\text { Tempo } \\
\text { (dia) }\end{array}$} & \multicolumn{3}{|c|}{ DQO total $\left(\mathrm{mg} \cdot \mathrm{L}^{-1}\right)$} & \multicolumn{3}{|c|}{ DQO filtrada (mg. $\left.L^{-1}\right)$} \\
\hline & & & & ARS & e-UASB & e-LA & ARS & e-UASB & e-LA \\
\hline \multirow[t]{14}{*}{3} & $\begin{array}{c}\text { LNI1 } \\
(50 \mathrm{~mL}: 10 \mathrm{~L})\end{array}$ & 25 & 70 & 1448 & 688 & - & 1436 & 638 & - \\
\hline & $\begin{array}{c}\text { LNI1 } \\
\text { (50mL:10L) }\end{array}$ & 25 & 72 & 1522 & 758 & - & 1514 & 790 & - \\
\hline & $\begin{array}{c}\text { LNII } \\
\text { (50mL:10L) }\end{array}$ & 25 & 75 & 1508 & 784 & - & 1500 & 782 & - \\
\hline & LNI1 & & & & & & & & \\
\hline & $\begin{array}{c}\text { (50mL:10L) } \\
\text { LNI1 }\end{array}$ & 25 & 77 & 1700 & 782 & - & 1608 & 784 & - \\
\hline & (50mL:10L) & 25 & 78 & 1544 & 908 & - & 1516 & 884 & - \\
\hline & $\begin{array}{c}\text { LNII } \\
\text { (50mL:10L) }\end{array}$ & 25 & 82 & 1398 & 852 & - & 1396 & 784 & - \\
\hline & $\begin{array}{c}\text { LNI1 } \\
\text { (50mL:10L) }\end{array}$ & 25 & 84 & 1550 & 822 & - & 1474 & 756 & - \\
\hline & LNII & & & & & & & & \\
\hline & $\begin{array}{c}\text { (50mL:10L) } \\
\mathrm{LNH}\end{array}$ & 25 & 89 & 1492 & 776 & - & 1468 & 758 & - \\
\hline & (50mL:10L) & 25 & 91 & 1500 & 804 & - & 1432 & 776 & - \\
\hline & $\begin{array}{c}\text { LNII } \\
\text { (50mL:10L) }\end{array}$ & 25 & 98 & 1481 & 832 & - & 1466 & 807 & - \\
\hline & LNII & & & & & & & & \\
\hline & (50mL:10L) & 25 & 104 & 1281 & 892 & - & 1216 & 832 & - \\
\hline \multirow[t]{17}{*}{4} & $\begin{array}{c}\text { LNII } \\
(60 \mathrm{~mL}: 12 \mathrm{~L})\end{array}$ & 25 & 117 & 1502 & 820 & - & 1478 & 786 & - \\
\hline & $\begin{array}{c}\text { LNI1 } \\
(60 \mathrm{~mL}: 12 \mathrm{~L})\end{array}$ & 25 & 118 & 1476 & 976 & 774 & 1454 & 832 & 728 \\
\hline & LNI1 & 25 & 120 & 1266 & 682 & 534 & 1260 & 580 & 502 \\
\hline & $\begin{array}{c}\text { (60mL:12L) } \\
\text { LNI1 }\end{array}$ & 25 & 120 & & & & & & \\
\hline & $(60 \mathrm{~mL}: 12 \mathrm{~L})$ & 25 & 122 & 1524 & 926 & 746 & 1498 & 860 & 734 \\
\hline & $\begin{array}{c}\text { LNI1 } \\
\text { (60mL:12L) }\end{array}$ & 25 & 123 & 1566 & 974 & 762 & & & \\
\hline & LNII & & & & & & & & \\
\hline & $\begin{array}{c}\text { (60mL:12L) } \\
\text { LNII }\end{array}$ & 25 & 126 & 1338 & 908 & 712 & & & \\
\hline & (60mL:12L) & 25 & 127 & 1526 & 866 & 786 & 1462 & 776 & 762 \\
\hline & $\begin{array}{c}\text { LNI1 } \\
\text { (60mL:12L) }\end{array}$ & 25 & 130 & 1392 & 870 & 702 & 1362 & 748 & 696 \\
\hline & LNII & & & & & & & & \\
\hline & (60mL:12L) & 25 & 132 & 1550 & 844 & 702 & 1512 & 702 & 666 \\
\hline & (60mL:15L) & 25 & 133 & 1564 & 900 & 728 & 1522 & 836 & 744 \\
\hline & $\begin{array}{c}\text { LNI1 } \\
(60 \mathrm{~mL} \cdot 15 \mathrm{~L})\end{array}$ & 25 & 134 & 1332 & 884 & 754 & 1318 & 808 & 742 \\
\hline & $\begin{array}{c}\text { (60mL:15L) } \\
\text { LNII }\end{array}$ & & & & & & 1318 & 808 & 742 \\
\hline & $(60 \mathrm{~mL}: 15 \mathrm{~L})$ & 25 & 137 & 1268 & 760 & 680 & 1240 & 752 & 672 \\
\hline & $\begin{array}{c}\text { LNI1 } \\
\text { (60mL:15L) }\end{array}$ & 25 & 146 & 1608 & 1084 & 916 & 1564 & 988 & 958 \\
\hline
\end{tabular}


TABELA A3. Concentrações de DQO monitorados nos reatores na fase mesofilica: $5^{\mathbf{a}}$ a $8^{\text {a }}$ etapa.

\begin{tabular}{|c|c|c|c|c|c|c|c|c|c|}
\hline \multirow[b]{2}{*}{ 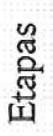 } & \multirow{2}{*}{$\begin{array}{l}\text { Tipo de licor e } \\
\text { volume }\end{array}$} & \multirow{2}{*}{$\begin{array}{c}\mathrm{T} \\
\left({ }^{\circ} \mathrm{C}\right)\end{array}$} & \multirow{2}{*}{$\begin{array}{l}\text { Tempo } \\
\text { (dia) }\end{array}$} & \multicolumn{3}{|c|}{ DQO total (mg. $\left.\mathrm{L}^{-1}\right)$} & \multicolumn{3}{|c|}{ DQO filtrada (mg.L $\left.\mathrm{L}^{-1}\right)$} \\
\hline & & & & ARS & e-UASB & e-LA & ARS & e-UASB & $\begin{array}{l}\text { e- } \\
\text { LA }\end{array}$ \\
\hline \multirow[t]{2}{*}{$\mathbf{5}$} & $\begin{array}{l}\text { LNI1 (50mL:15L:3mL } \\
\text { etanol) }\end{array}$ & 25 & 154 & 1290 & 618 & 604 & 1218 & 564 & 544 \\
\hline & $\begin{array}{l}\text { LNI1 (50mL:15L:5mL } \\
\text { etanol) }\end{array}$ & 30 & 158 & 1030 & 516 & 484 & 1018 & 458 & 442 \\
\hline \multirow[t]{3}{*}{6} & $\begin{array}{l}\text { LNI1 (50mL:15L:5mL } \\
\text { etanol) }\end{array}$ & 32,5 & 161 & 1178 & 576 & 464 & 1170 & 524 & 414 \\
\hline & $\begin{array}{l}\text { LNII (55mL:15L:7mL } \\
\text { etanol) }\end{array}$ & 32,5 & 166 & 1155 & 563 & 414 & 1134 & 541 & 405 \\
\hline & $\begin{array}{l}\text { LNI1 (55mL: } 15 \mathrm{~L}: 7 \mathrm{~mL} \\
\text { etanol) }\end{array}$ & 32,5 & 168 & 1422 & 694 & 463 & 1414 & 594 & 447 \\
\hline \multirow[t]{7}{*}{7} & $\begin{array}{c}\text { LNI1 (55mL:15L:7mL } \\
\text { eanol) }\end{array}$ & 35 & 172 & 1780 & 1201 & 329 & 1725 & 1128 & 262 \\
\hline & $\begin{array}{c}\text { LNII (45mL:15L:7mL } \\
\text { etanol) }\end{array}$ & 35 & 180 & 903 & 783 & 569 & 899 & 732 & 504 \\
\hline & $\begin{array}{l}\text { LNII (45mL:15L:7mL } \\
\text { etanol) }\end{array}$ & 35 & 186 & 1578 & 1051 & 326 & 1604 & 976 & 304 \\
\hline & $\begin{array}{c}\text { LNI1 (45mL: } 15 \mathrm{~L}: 7 \mathrm{~mL} \\
\text { etanol) }\end{array}$ & 37,5 & 197 & 1488 & 1406 & 894 & 722 & 642 & 818 \\
\hline & $\begin{array}{c}\text { LNII (45mL:15L:7mL } \\
\text { etanol) }\end{array}$ & 37,5 & 201 & 1634 & 638 & 500 & 1596 & 602 & 386 \\
\hline & $\begin{array}{l}\text { LNI1 (45mL:15L:7mL } \\
\text { etanol) }\end{array}$ & 37,5 & 208 & 1142 & 668 & 374 & 1120 & 578 & 358 \\
\hline & $\begin{array}{l}\text { LNII (45mL:15L:7mL } \\
\text { etanol) }\end{array}$ & 37,5 & 210 & 1396 & 636 & 498 & 1304 & 508 & 476 \\
\hline \multirow[t]{9}{*}{8} & $\begin{array}{l}\text { LNII (45mL:15L:7mL } \\
\text { etanol) }\end{array}$ & 42,5 & 215 & 1454 & 626 & 402 & 1404 & 558 & 390 \\
\hline & $\begin{array}{l}\text { LNII (45mL:15L:7mL } \\
\text { etanol) }\end{array}$ & 42,5 & 217 & 1478 & 538 & 380 & 1426 & 484 & 386 \\
\hline & $\begin{array}{c}\text { LNII (45mL: } 15 \mathrm{~L}: 7 \mathrm{~mL} \\
\text { etanol) }\end{array}$ & 42,5 & 222 & 1264 & 536 & 360 & 1194 & 536 & 366 \\
\hline & $\begin{array}{c}\text { LNI1 (45mL:15L:7mL } \\
\text { etanol) }\end{array}$ & 42,5 & 224 & 1454 & 680 & 430 & 1444 & 596 & 458 \\
\hline & $\begin{array}{l}\text { LNI1 (45mL:15L:7mL } \\
\text { etanol) }\end{array}$ & 42,5 & 229 & 1196 & 552 & 376 & 1008 & 480 & 364 \\
\hline & $\begin{array}{l}\text { LNII (45mL:15L:7mL } \\
\text { etanol) }\end{array}$ & 42,5 & 232 & 1476 & 514 & 494 & 1446 & 446 & 458 \\
\hline & $\begin{array}{l}\text { LN11 (45mL:15L:7mL } \\
\text { etanol) }\end{array}$ & 42,5 & 236 & 1414 & 486 & 378 & 1340 & 426 & 390 \\
\hline & $\begin{array}{c}\text { LNI1 }(45 \mathrm{~mL}: 15 \mathrm{~L}: 7 \mathrm{~mL} \\
\text { etanol) }\end{array}$ & 42,5 & 239 & 1130 & 600 & 374 & 1072 & 530 & 360 \\
\hline & $\begin{array}{c}\text { LNII (45mL:15L:7mL } \\
\text { etanol) }\end{array}$ & 42,5 & 245 & 1380 & 636 & 454 & 1334 & 506 & 420 \\
\hline
\end{tabular}


TABELA A4. Concentrações de DQO monitorados nos reatores na fase termofilica: $1^{\text {a }}$ a $5^{\mathrm{a}}$ etapa.

\begin{tabular}{|c|c|c|c|c|c|c|c|c|c|}
\hline \multirow{2}{*}{$\begin{array}{l}\text { 芯 } \\
\text { 己 } \\
\text { 岃 }\end{array}$} & \multirow{2}{*}{$\begin{array}{c}\text { Tipo de licor e } \\
\text { volume }\end{array}$} & \multirow{2}{*}{$\begin{array}{c}\mathrm{T} \\
\left({ }^{0} \mathrm{C}\right)\end{array}$} & \multirow{2}{*}{$\begin{array}{l}\text { Tempo } \\
\text { (dia) }\end{array}$} & \multicolumn{3}{|c|}{ DQO total (mg. $\left.\mathrm{L}^{-1}\right)$} & \multicolumn{3}{|c|}{ DQO filtrada (mg. $\left.\mathrm{L}^{-1}\right)$} \\
\hline & & & & ARS & $e$-UASB & e-LA & ARS & e-UASB & e-LA \\
\hline \multirow[t]{3}{*}{1} & $\begin{array}{l}\text { LNII (45mL:15L:7mL } \\
\text { etanol) }\end{array}$ & 45 & 250 & 1480 & 512 & 380 & 1472 & 424 & 388 \\
\hline & $\begin{array}{l}\text { LNI1 (45mL:15L:7mL } \\
\text { etanol) }\end{array}$ & 45 & 252 & 1434 & 488 & 420 & 1412 & 424 & 376 \\
\hline & $\begin{array}{c}\text { LNI1 (45mL:15L:7mL } \\
\text { etanol) }\end{array}$ & 45 & 257 & 1390 & 662 & 384 & 1212 & 442 & 350 \\
\hline \multirow[t]{3}{*}{2} & $\begin{array}{c}\text { LNI1 (45mL:15L:7mL } \\
\text { etanol) }\end{array}$ & 47,5 & 264 & 1648 & 480 & 202 & 1612 & 384 & 192 \\
\hline & $\begin{array}{l}\text { LNI1 (45mL:15L:7mL } \\
\text { etanol) }\end{array}$ & 47,5 & & 1274 & 670 & 360 & 1246 & 578 & 298 \\
\hline & $\begin{array}{c}\text { LNI1 (45mL:15L:7mL } \\
\text { etanol) }\end{array}$ & 47,5 & 291 & 1586 & 604 & 492 & 1366 & 332 & 300 \\
\hline \multirow[t]{2}{*}{3} & $\begin{array}{l}\text { LNI1 (45mL:15L:7mL } \\
\text { etanol) }\end{array}$ & 52 & 293 & 1546 & 762 & 356 & 1478 & 556 & 302 \\
\hline & $\begin{array}{c}\text { LNI1 (45mL:15L:7mL } \\
\text { etanol) }\end{array}$ & 52 & 298 & 1618 & 1312 & 700 & 1522 & 1076 & 634 \\
\hline \multirow[t]{10}{*}{4} & $\begin{array}{c}\text { LNI2 (30mL:15L:7mL } \\
\text { etanol) }\end{array}$ & 52 & 300 & 1278 & 1176 & 720 & 1246 & 992 & 640 \\
\hline & $\begin{array}{c}\text { LNI2 (30mL:15L:7mL } \\
\text { etanol) }\end{array}$ & 52 & 305 & 1348 & 1042 & 432 & 1196 & 904 & 368 \\
\hline & $\begin{array}{c}\text { LNI2 (30mL:15L: } 7 \mathrm{~mL} \\
\text { etanol) }\end{array}$ & 52 & 308 & 1424 & 924 & 446 & 998 & 718 & 384 \\
\hline & $\begin{array}{c}\text { LNI2 (30mL:15L:7mL } \\
\text { etanol) }\end{array}$ & 52 & 312 & 1278 & 986 & 466 & 1216 & 922 & 392 \\
\hline & $\begin{array}{c}\text { LNI2 (30mL:15L:7mL } \\
\text { ctanol) }\end{array}$ & 52 & 315 & 1852 & 1798 & 598 & 1794 & 1420 & 498 \\
\hline & $\begin{array}{c}\text { LNI2 (30mL:15L:7mL } \\
\text { etanol) }\end{array}$ & 52 & 326 & 1321 & 1138 & 517 & 1260 & 996 & 395 \\
\hline & $\begin{array}{c}\text { LNI2 (30mL:15L:7mL } \\
\text { etanol) }\end{array}$ & 52 & 328 & 1301 & 1057 & 553 & 1225 & 960 & 395 \\
\hline & $\begin{array}{c}\text { LN2 (30mL:15L:7mL } \\
\text { etanol) }\end{array}$ & 52 & 334 & 1260 & 1128 & 451 & 1113 & 909 & 324 \\
\hline & $\begin{array}{c}\text { LNI2 (30mL:15L:7mL } \\
\text { etanol) }\end{array}$ & 52 & 336 & 1316 & 1250 & 395 & 1301 & 1138 & 375 \\
\hline & $\begin{array}{c}\text { LNI2 (30mL:15L:7mL } \\
\text { etanol) }\end{array}$ & 52 & 354 & 1388 & 1011 & 502 & 1245 & 889 & 380 \\
\hline \multirow[t]{6}{*}{5} & $\begin{array}{l}\text { LNI2 (30mL:15L:7mL } \\
\text { etanol) }\end{array}$ & 57 & 356 & 1113 & 1657 & 416 & 1042 & 808 & 248 \\
\hline & $\begin{array}{c}\text { LNI2 (30mL:15L:7mL } \\
\text { etanol) }\end{array}$ & 57 & 361 & 1357 & 1174 & 538 & 1301 & 940 & 350 \\
\hline & $\begin{array}{c}\text { LNI2 (30mL: } 15 \mathrm{~L}: 7 \mathrm{~mL} \\
\text { etanol) }\end{array}$ & 57 & 368 & 1283 & 1017 & 419 & 1201 & 777 & 394 \\
\hline & $\begin{array}{c}\text { LNI2 (30mL:15L:7mL } \\
\text { etanol) }\end{array}$ & 57 & 375 & 1222 & 981 & 511 & 1119 & 797 & 389 \\
\hline & $\begin{array}{c}\text { LNI2 (30mL:15L:7mL } \\
\text { etanol) }\end{array}$ & 57 & 382 & 1268 & 961 & 496 & 1140 & 690 & 332 \\
\hline & $\begin{array}{c}\text { LNI2 (30mL:15L:7mL } \\
\text { etanol) }\end{array}$ & 57 & 390 & 1191 & 951 & 542 & 1048 & 721 & 419 \\
\hline
\end{tabular}


TABELA A5. Valores de eficiência de remoção de DQO monitorados nos reatores na fase mesofilica: $1^{\mathrm{a}}$ a $2^{2}$ etapa.

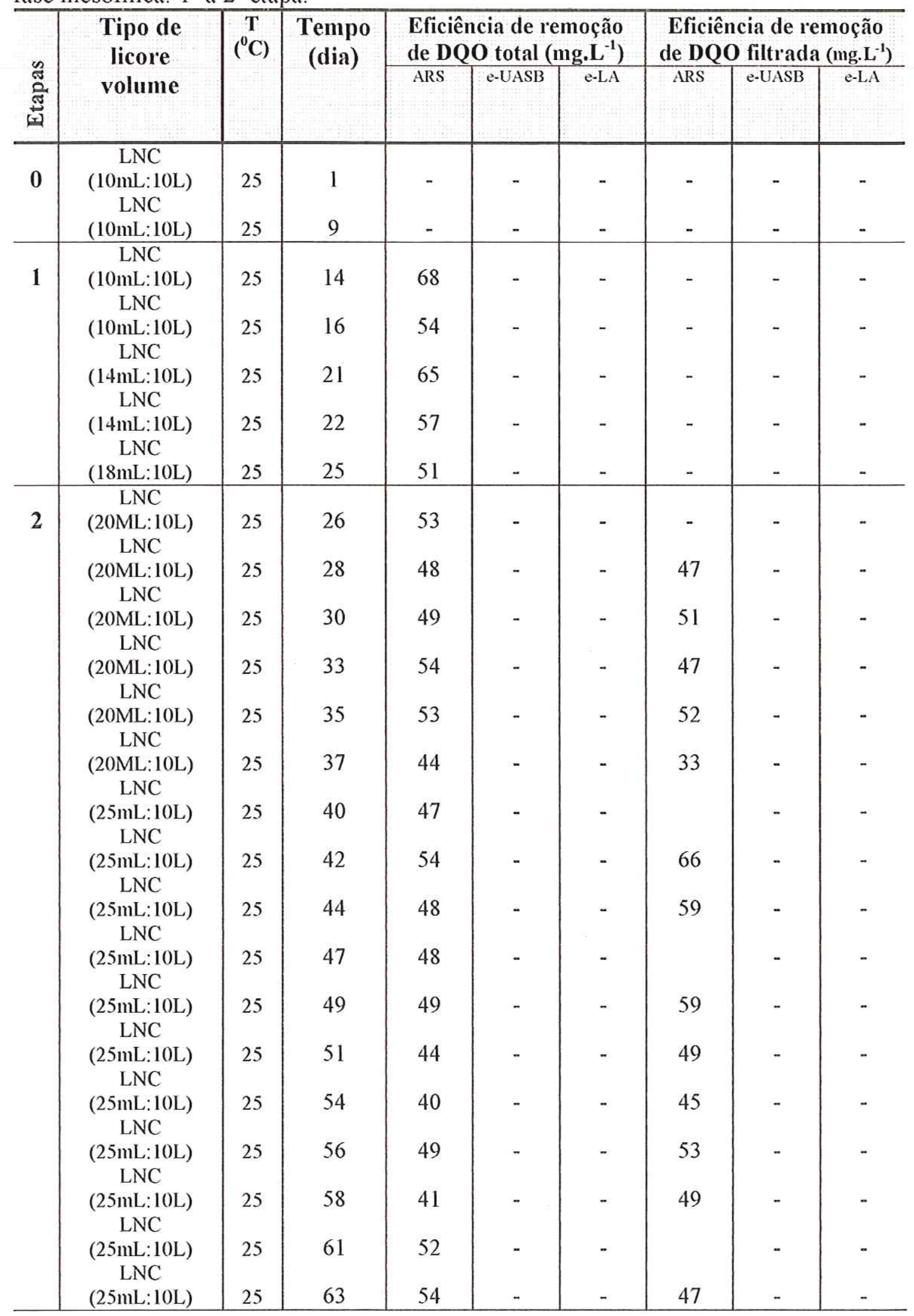


TABELA A6. Valores de eficiência de remoção de DQO monitorados nos reatores na fase mesofilica: $3^{\mathrm{a}}$ a $4^{\mathrm{a}}$ etapa.

\begin{tabular}{|c|c|c|c|c|c|c|c|c|c|}
\hline \multirow[b]{2}{*}{ 营 } & \multirow{2}{*}{$\begin{array}{l}\text { Tipo de } \\
\text { licore } \\
\text { volume }\end{array}$} & \multirow[t]{2}{*}{$\begin{array}{c}\mathrm{T} \\
\left({ }^{0} \mathrm{C}\right)\end{array}$} & \multirow[t]{2}{*}{$\begin{array}{l}\text { Tempo } \\
\text { (dia) }\end{array}$} & \multicolumn{3}{|c|}{$\begin{array}{l}\text { Eficiência de remoção } \\
\text { de DQO total }\left(\mathrm{mg.L}^{-1}\right)\end{array}$} & \multicolumn{3}{|c|}{$\begin{array}{l}\text { Eficiência de remoção } \\
\left.\text { de DQO filtrada (mg. } \mathrm{L}^{-1}\right)\end{array}$} \\
\hline & & & & ARS & $e-U A S B$ & e-LA & ARS & e-UASB & e-LA \\
\hline \multirow[t]{14}{*}{3} & $\begin{array}{c}\text { LNI1 } \\
\text { (50mL:10L) } \\
\text { LNI1 }\end{array}$ & 25 & 70 & 52 & - & - & 56 & - & - \\
\hline & (50mL:10L) & 25 & 72 & 50 & - & - & 48 & - & - \\
\hline & $\begin{array}{c}\text { LNII } \\
\text { (50mL:10L) }\end{array}$ & 25 & 75 & 48 & - & - & 48 & - & - \\
\hline & LNI1 & & & & & & & & \\
\hline & $\begin{array}{c}\text { (50mL:10L) } \\
\text { LNII }\end{array}$ & 25 & 77 & 51 & - & - & 54 & - & - \\
\hline & (50mL:10L) & 25 & 78 & 41 & - & - & 42 & - & - \\
\hline & $\begin{array}{c}\text { LNII } \\
\text { (50mL:10L) }\end{array}$ & 25 & 82 & 39 & - & - & 44 & - & \\
\hline & LNII & & & & & & & & - \\
\hline & (50mL:10L) & 25 & 84 & 47 & - & - & 49 & - & - \\
\hline & $\begin{array}{c}\text { LNI1 } \\
\text { (50mL:10L) }\end{array}$ & 25 & 89 & 47 & - & - & 49 & - & - \\
\hline & LNII & & & & & & & & \\
\hline & $\begin{array}{c}\text { (50mL:10L) } \\
\text { LNI1 }\end{array}$ & 25 & 91 & 46 & - & - & 46 & - & - \\
\hline & (50mL:10L) & 25 & 98 & 43 & - & - & 46 & - & - \\
\hline & $\begin{array}{c}\text { LNI1 } \\
\text { (50mL:10L) }\end{array}$ & 25 & 104 & 30 & - & - & 32 & - & \\
\hline \multirow{19}{*}{4} & LNI1 & & & & & & & & \\
\hline & $\begin{array}{c}\text { (60mL:12L) } \\
\text { LNI1 }\end{array}$ & 25 & 117 & 45 & - & - & 47 & - & - \\
\hline & $(60 \mathrm{~mL}: 12 \mathrm{~L})$ & 25 & 118 & 34 & 21 & 48 & 43 & 13 & 50 \\
\hline & $\begin{array}{c}\text { LNIl } \\
\text { (60mL:12L) }\end{array}$ & 25 & 120 & 46 & 22 & 58 & 54 & 13 & 60 \\
\hline & LNI1 & & & & & & & & \\
\hline & (60mL:12L) & 25 & 122 & 39 & 19 & 51 & 43 & 15 & 51 \\
\hline & $\begin{array}{c}\text { LNII } \\
\text { (60mL:12L) }\end{array}$ & 25 & 123 & 38 & 22 & 51 & - & - & - \\
\hline & LNI1 & & & & & & & & \\
\hline & (60mL:12L) & 25 & 126 & 32 & 22 & 47 & - & - & - \\
\hline & (60mL:12L) & 25 & 127 & 41 & 9 & 46 & 49 & 2 & 50 \\
\hline & $\begin{array}{c}\text { LNII } \\
(60 \mathrm{~m} \cdot 12 \mathrm{~L})\end{array}$ & 25 & 130 & 38 & & & 45 & 7 & 40 \\
\hline & & 25 & & 38 & 19 & 50 & 45 & 1 & 49 \\
\hline & (60mL:12L) & 25 & 132 & 46 & 17 & 55 & 54 & 5 & 56 \\
\hline & $\begin{array}{c}\text { LNII } \\
(60 \mathrm{~mL}: 15 \mathrm{~L})\end{array}$ & 25 & 133 & 42 & 19 & 53 & 45 & 11 & 51 \\
\hline & LNII & & & & & & & & \\
\hline & (60mL:15L) & 25 & 134 & 34 & 15 & 43 & 39 & 8 & 44 \\
\hline & $\begin{array}{c}\text { LNII } \\
(60 \mathrm{~mL}: 15 \mathrm{~L})\end{array}$ & 25 & 137 & 40 & 11 & 46 & 39 & 11 & 46 \\
\hline & LNI1 & & & & & & & & \\
\hline & $(60 \mathrm{~mL}: 15 \mathrm{~L})$ & 25 & 146 & 33 & 15 & 43 & 37 & 3 & 39 \\
\hline
\end{tabular}


TABELA A7. Valores de eficiência de remoção de DQO monitorados nos reatores na fase mesofilica: $5^{\mathbf{a}}$ a $8^{\mathrm{a}}$ etapa.

\begin{tabular}{|c|c|c|c|c|c|c|c|c|c|}
\hline \multirow{2}{*}{ 总 } & \multirow[t]{2}{*}{$\begin{array}{c}\text { Tipo de licor e } \\
\text { volume }\end{array}$} & \multirow[t]{2}{*}{$\begin{array}{c}\mathrm{T} \\
\left({ }^{0} \mathrm{C}\right)\end{array}$} & \multirow[t]{2}{*}{$\begin{array}{l}\text { Tempo } \\
\text { (dia) }\end{array}$} & \multicolumn{3}{|c|}{$\begin{array}{l}\text { Eficiência de remoção } \\
\left.\text { de DQO total (mg. } L^{-1}\right)\end{array}$} & \multicolumn{3}{|c|}{$\begin{array}{l}\text { Eficiência de remoção } \\
\left.\text { de DQO filtrada (mg. } \mathrm{L}^{-1}\right)\end{array}$} \\
\hline & & & & ARS & e-UASB & e-LA & ARS & e-UASB & e-LA \\
\hline 5 & \multirow{2}{*}{$\begin{array}{c}\text { LNII (50mL:15L:3mL } \\
\text { etanol) } \\
\text { LNII (50mL: } 15 \mathrm{~L}: 5 \mathrm{~mL} \\
\text { etanol) }\end{array}$} & 25 & 154 & 51 & 2 & 52 & 56 & 4 & 58 \\
\hline & & 30 & 158 & 50 & 6 & 53 & 55 & 3 & 57 \\
\hline \multirow[t]{3}{*}{6} & \multirow{3}{*}{$\begin{array}{c}\text { LNI1 (50mL: } 15 \mathrm{~L}: 5 \mathrm{~mL} \\
\text { etanol) } \\
\text { LNI1 }(55 \mathrm{~mL}: 15 \mathrm{~L}: 7 \mathrm{~mL} \\
\text { etanol) } \\
\text { LNII }(55 \mathrm{~mL}: 15 \mathrm{~L}: 7 \mathrm{~mL} \\
\text { etanol) }\end{array}$} & 32,5 & 161 & 51 & 19 & 61 & 55 & 21 & 65 \\
\hline & & 32,5 & 166 & 50 & 26 & 63 & 53 & 25 & 65 \\
\hline & & 32,5 & 168 & 52 & 33 & 67 & 58 & 25 & 68 \\
\hline \multirow[t]{7}{*}{7} & $\begin{array}{l}\text { LNII (55mL:15L:7mL } \\
\text { etanol) }\end{array}$ & 35 & 172 & 33 & 73 & 81 & 35 & 77 & 85 \\
\hline & $\begin{array}{c}\text { LNII (45mL:15L:7mL } \\
\text { etanol) }\end{array}$ & 35 & 180 & 13 & 27 & 37 & 19 & 31 & 44 \\
\hline & $\begin{array}{l}\text { LNII (45mL: } 15 \mathrm{~L}: 7 \mathrm{~mL} \\
\text { etanol) }\end{array}$ & 35 & 186 & 33 & 69 & 79 & 39 & 69 & 81 \\
\hline & $\begin{array}{c}\text { LNI1 (45mL: } 15 \mathrm{~L}: 7 \mathrm{~mL} \\
\text { etanol) }\end{array}$ & 37,5 & 197 & 51 & 36 & 40 & 11 & & \\
\hline & $\begin{array}{c}\text { LNI1 } \\
\begin{array}{c}(45 \mathrm{~mL}: 15 \mathrm{~L}: 7 \mathrm{~mL} \\
\text { etanol) }\end{array}\end{array}$ & 37,5 & 201 & 61 & 22 & 69 & 62 & 36 & 76 \\
\hline & $\begin{array}{c}\text { LNI1 (45mL:15L:7mL } \\
\text { efanol) }\end{array}$ & 37,5 & 208 & 42 & 44 & 67 & 48 & 38 & 68 \\
\hline & $\begin{array}{c}\text { LNI1 (45mL:15L:7mL } \\
\text { (tanol) }\end{array}$ & 37,5 & 210 & 54 & 22 & 64 & 61 & 6 & 63 \\
\hline \multirow[t]{9}{*}{8} & $\begin{array}{c}\text { LNII (45mL:15L:7mL } \\
\text { (tanol) }\end{array}$ & 42,5 & 215 & 57 & 36 & 72 & 60 & 30 & 72 \\
\hline & $\begin{array}{c}\text { LN11 (45mL:15L:7mL } \\
\text { etanol) }\end{array}$ & 42,5 & 217 & 64 & 29 & 74 & 66 & 20 & 73 \\
\hline & $\begin{array}{l}\text { LNII (45mL: } 15 \mathrm{~L}: 7 \mathrm{~mL} \\
\text { etanol) }\end{array}$ & 42,5 & 222 & 58 & 33 & 72 & 55 & 32 & 69 \\
\hline & $\begin{array}{c}\text { LNII (45mL: } 15 \mathrm{~L}: 7 \mathrm{~mL} \\
\text { etanol) }\end{array}$ & 42,5 & 224 & 53 & 37 & 70 & 59 & 23 & 68 \\
\hline & $\begin{array}{c}\text { LNII }(45 \mathrm{~mL}: 15 \mathrm{~L}: 7 \mathrm{~mL} \\
\text { etanol) }\end{array}$ & 42,5 & 229 & 54 & 32 & 69 & 52 & 24 & 64 \\
\hline & $\begin{array}{c}\text { LNII (45mL: } 15 \mathrm{~L}: 7 \mathrm{~mL} \\
\text { etanol) }\end{array}$ & 42,5 & 232 & 65 & 4 & 67 & 69 & & 68 \\
\hline & $\begin{array}{c}\text { LNI1 (45mL: } 15 \mathrm{~L}: 7 \mathrm{~mL} \\
\text { etanol) }\end{array}$ & 42,5 & 236 & 66 & 22 & 73 & 68 & 8 & 71 \\
\hline & $\begin{array}{c}\text { LNI1 (45mL:15L:7mL } \\
\text { etanol) }\end{array}$ & 42,5 & 239 & 47 & 38 & 67 & 51 & 32 & 66 \\
\hline & $\begin{array}{c}\text { LN11 } \begin{array}{c}(45 \mathrm{~mL}: 15 \mathrm{~L}: 7 \mathrm{~mL} \\
\text { etanol) }\end{array}\end{array}$ & 42,5 & 245 & 54 & 29 & 67 & 62 & 17 & 69 \\
\hline
\end{tabular}


TABELA A8. Valores de eficiência de remoção de DQO monitorados nos reatores na fase termofilica: $1^{\underline{a}}$ a $5^{\frac{a}{2}}$ etapa.

\begin{tabular}{|c|c|c|c|c|c|c|c|c|c|}
\hline \multirow{2}{*}{ 荧 } & \multirow{2}{*}{$\begin{array}{l}\text { Tipo de licor e } \\
\text { volume }\end{array}$} & \multirow{2}{*}{$\begin{array}{c}\mathrm{T} \\
\left({ }^{0} \mathrm{C}\right)\end{array}$} & \multirow{2}{*}{$\begin{array}{l}\text { Tempo } \\
\text { (dii) }\end{array}$} & \multicolumn{3}{|c|}{ DQO total $\left(\mathrm{mg} . \mathrm{L}^{-1}\right)$} & \multicolumn{3}{|c|}{ DQO filtrada (mg. $\left.\mathrm{L}^{-1}\right)$} \\
\hline & & & & ARS & e-UASB & e-LA & ARS & e-UASB & e-LA \\
\hline \multirow[t]{3}{*}{1} & $\begin{array}{c}\text { LNI1 (45mL: } 15 \mathrm{~L}: 7 \mathrm{~mL} \\
\text { etanol) }\end{array}$ & 45 & 250 & 66 & 24 & 75 & 71 & 11 & 75 \\
\hline & $\begin{array}{c}\text { LNII (45mL:15L:7mL } \\
\text { etanol) }\end{array}$ & 45 & 252 & 66 & 14 & 71 & 70 & 11 & 73 \\
\hline & $\begin{array}{c}\text { LNII } \\
\begin{array}{c}(45 \mathrm{~mL}: 15 \mathrm{~L}: 7 \mathrm{~mL} \\
\text { etanol) }\end{array}\end{array}$ & 45 & 257 & 52 & 42 & 72 & 64 & 21 & 71 \\
\hline \multirow[t]{3}{*}{2} & $\begin{array}{c}\text { LNII (45mL:15L:7mL } \\
\text { etanol) }\end{array}$ & 47,5 & 264 & 71 & 58 & 88 & 76 & 50 & 88 \\
\hline & $\begin{array}{c}\text { LNI1 (45mL: } 15 \mathrm{~L}: 7 \mathrm{~mL} \\
\text { etanol) }\end{array}$ & 47,5 & 266 & 47 & 46 & 72 & 54 & 48 & 76 \\
\hline & $\begin{array}{c}\text { LNI1 (45mL:15L:7mL } \\
\text { etanol) }\end{array}$ & 47,5 & 291 & 62 & 45 & 79 & 64 & 39 & 78 \\
\hline \multirow[t]{2}{*}{3} & $\begin{array}{c}\text { LNI1 (45mL:15L:7mL } \\
\text { etanol) }\end{array}$ & 52 & 293 & 51 & 53 & 77 & 62 & 46 & 80 \\
\hline & $\begin{array}{c}\text { LNII ( } \begin{array}{c}45 \mathrm{~mL}: 15 \mathrm{~L}: 7 \mathrm{~mL} \\
\text { etanol) }\end{array} \\
\end{array}$ & 52 & 298 & 19 & 47 & 57 & 29 & 41 & 58 \\
\hline \multirow[t]{10}{*}{4} & $\begin{array}{c}\text { LNI2 (30mL:15L:7mL } \\
\text { etanol) }\end{array}$ & 52 & 300 & 8 & 20 & 44 & 39 & 35 & 49 \\
\hline & $\begin{array}{c}\text { LNI2 (30mL:15L:7mL } \\
\text { etanol) }\end{array}$ & 52 & 305 & 23 & 59 & 68 & 24 & 59 & 69 \\
\hline & $\begin{array}{c}\text { LNI2 (30mL:15L:7mL } \\
\text { etanol) }\end{array}$ & 52 & 308 & 35 & 52 & 69 & 28 & 47 & 62 \\
\hline & $\begin{array}{c}\text { LN12 (30mL:15L:7mL } \\
\text { etanol) }\end{array}$ & 52 & 312 & 23 & 53 & 64 & 24 & 57 & 68 \\
\hline & $\begin{array}{c}\text { LN12 (30mL:15L:7mL } \\
\text { etanol) }\end{array}$ & 52 & 315 & 3 & 67 & 68 & 21 & 65 & 72 \\
\hline & $\begin{array}{c}\text { LNI2 (30mL:15L:7mL } \\
\text { tanol) }\end{array}$ & 52 & 326 & 14 & 55 & 61 & 21 & 60 & 69 \\
\hline & $\begin{array}{c}\text { LNI2 (30mL:15L:7mL } \\
\text { etanol) }\end{array}$ & 52 & 328 & 19 & 48 & 57 & 22 & 59 & 68 \\
\hline & $\begin{array}{l}\text { LNI2 (30mL:15L:7mL } \\
\text { tanol) }\end{array}$ & 52 & 334 & 10 & 60 & 64 & 18 & 64 & 71 \\
\hline & $\begin{array}{c}\text { LNI2 (30mL:15L:7mL } \\
\text { etanol) }\end{array}$ & 52 & 336 & 5 & 68 & 70 & 13 & 67 & 71 \\
\hline & $\begin{array}{c}\text { LNI2 (30mL: } 15 \mathrm{~L}: 7 \mathrm{~mL} \\
\text { etanol) }\end{array}$ & 52 & 354 & 27 & 50 & 64 & 29 & 57 & 69 \\
\hline \multirow[t]{6}{*}{5} & $\begin{array}{c}\text { LN12 (30mL: } 15 \mathrm{~L}: 7 \mathrm{~mL} \\
\text { etanol) }\end{array}$ & 57 & 356 & 20 & 75 & 63 & 22 & 69 & 76 \\
\hline & $\begin{array}{c}\text { LNI2 (30mL:15L:7mL } \\
\text { tanol) }\end{array}$ & 57 & 361 & 13 & 54 & 60 & 28 & 63 & 73 \\
\hline & $\begin{array}{l}\text { LN12 (30mL:15L:7mL } \\
\text { etanol) }\end{array}$ & 57 & 368 & 21 & 59 & 67 & 35 & 49 & 67 \\
\hline & $\begin{array}{c}\text { LNI2 (30mL:15L:7mL } \\
\text { etanol) }\end{array}$ & 57 & 375 & 20 & 48 & 58 & 29 & 51 & 65 \\
\hline & $\begin{array}{l}\text { LNI2 (30mL:15L:7mL } \\
\text { ctanol) }\end{array}$ & 57 & 382 & 24 & 48 & 61 & 39 & 52 & 71 \\
\hline & $\begin{array}{l}\text { LNI2 (30mL:15L:7mL } \\
\text { etanol) }\end{array}$ & 57 & 390 & 20 & 43 & 54 & 31 & 42 & 60 \\
\hline
\end{tabular}


TABELA A9. Valores de $\mathrm{pH}$ monitorados nos efluentes dos reatores na fase mesofilica: $1^{\mathrm{a}}$ a $6^{\mathrm{a}}$ etapa.

\begin{tabular}{|c|c|c|c|c|c|c|c|}
\hline \multirow[b]{2}{*}{ 芯 } & \multirow[t]{2}{*}{ Tipo de licor e volume } & \multirow{2}{*}{$\begin{array}{c}\mathrm{T} \\
\left({ }^{0} \mathrm{C}\right)\end{array}$} & \multirow{2}{*}{$\begin{array}{l}\text { Data da } \\
\text { coleta }\end{array}$} & \multirow{2}{*}{$\begin{array}{l}\text { Tempo de } \\
\text { operação } \\
\text { (dia) }\end{array}$} & \multicolumn{3}{|c|}{$\mathrm{pH}$} \\
\hline & & & & & ARS & e-UASB & e-LA \\
\hline \multirow[t]{8}{*}{1} & LNC (10mL:10L) & 25,0 & $10 / 04 / 02$ & 14 & 7,4 & 7,6 & \\
\hline & LNC (10mL:10L) & 25,0 & $11 / 04 / 02$ & 15 & 7,5 & 7,3 & \\
\hline & LNC (10mL:10L) & 25,0 & $12 / 04 / 02$ & 16 & 7,8 & 7,7 & \\
\hline & LNC (10mL:10L) & 25,0 & $13 / 04 / 02$ & 17 & 7,5 & 7,8 & \\
\hline & LNC (10mL:10L) & 25,0 & $14 / 04 / 02$ & 18 & 7,2 & 7,3 & \\
\hline & LNC (14mL:10L) & 25,0 & $18 / 04 / 02$ & 22 & 7,5 & 7,5 & \\
\hline & LNC (14mL:10L) & 25,0 & $19 / 04 / 02$ & 23 & 8,1 & 7,5 & \\
\hline & LNC (14mL:10L) & 25,0 & $20 / 04 / 02$ & 24 & 7,4 & 7,5 & \\
\hline \multirow[t]{13}{*}{2} & LNC (20ML:10L) & 25,0 & $22 / 04 / 02$ & 26 & 7,2 & 7,6 & \\
\hline & LNC (20ML:10L) & 25,0 & $24 / 04 / 02$ & 28 & 8,1 & 7,5 & \\
\hline & LNC (20ML:10L) & 25,0 & $25 / 04 / 02$ & 29 & 7,3 & 7,3 & \\
\hline & LNC (20ML:10L) & 25,0 & $26 / 04 / 02$ & 30 & 7,4 & 7,3 & \\
\hline & LNC (20ML:10L) & 25,0 & $29 / 04 / 02$ & 33 & 7,3 & 7,3 & \\
\hline & LNC (20ML:10L) & 25,0 & $01 / 05 / 02$ & 35 & 7,2 & 7,4 & \\
\hline & LNC (20ML:10L) & 25,0 & $02 / 05 / 02$ & 36 & 7,3 & 7,3 & \\
\hline & LNC (20ML:10L) & 25,0 & $04 / 05 / 02$ & 38 & 7,6 & 7,3 & \\
\hline & LNC (20ML:10L) & 25,0 & $05 / 05 / 02$ & 39 & 7,2 & 7,2 & \\
\hline & LNC (20ML:10L) & 25,0 & 07/05/02 & 41 & 7,3 & 7,7 & \\
\hline & LNC (25mL:10L) & 25,0 & $08 / 05 / 02$ & 42 & 7,4 & 7,3 & \\
\hline & LNC (25mL:10L) & 25,0 & $15 / 05 / 02$ & 49 & 7,2 & 7,3 & \\
\hline & LNC (25mL:10L) & 25,0 & $17 / 05 / 02$ & 51 & 7,0 & 7,2 & \\
\hline \multirow[t]{8}{*}{3} & LNI1 (50mL:10L) & 25,0 & $05 / 06 / 02$ & 70 & 7,3 & 8,0 & \\
\hline & LNIl (50mL:10L) & 25,0 & $17 / 06 / 02$ & 82 & 8,4 & 7,8 & \\
\hline & LNI1 (50mL:10L) & 25,0 & $19 / 06 / 02$ & 84 & 7,0 & 8,0 & \\
\hline & LNI1 (50mL: 10L) & 25,0 & $24 / 06 / 02$ & 89 & 7,0 & 7,8 & \\
\hline & LNI1 (50mL:10L) & 25,0 & $26 / 06 / 02$ & 91 & 7,2 & 7,8 & \\
\hline & LNI1 (50mL:10L) & 26,0 & $27 / 06 / 02$ & 92 & 6,6 & 7,8 & \\
\hline & LNI1 (50mL:10L) & 25,0 & $02 / 07 / 02$ & 96 & 7,4 & 8,0 & \\
\hline & LNI1 (50mL:10L) & 25,0 & $10 / 07 / 02$ & 104 & 8,2 & 7,7 & \\
\hline \multirow[t]{10}{*}{4} & LNI1 (60mL:12L) & 25,0 & $26 / 07 / 02$ & 120 & 7,3 & 7,6 & 7,6 \\
\hline & LNI1 (60mL:12L) & 25,0 & $28 / 07 / 02$ & 122 & 7,8 & 7,6 & \\
\hline & LNI1 (60mL:12L) & 25,0 & $02 / 08 / 02$ & 127 & 7,1 & 7,4 & \\
\hline & LNI1 (60mL:12L) & 25,0 & 05/08/02 & 130 & 7,4 & 7,6 & 7,8 \\
\hline & LNII (60mL:12L) & 25,0 & 07/08/02 & 132 & 7,3 & 7,5 & 7,7 \\
\hline & LNI1 (60mL:15L) & 25,0 & $08 / 08 / 02$ & 133 & 7,7 & 7,9 & 7,9 \\
\hline & LNI1 (60mL:15L) & 25,0 & 09/08/02 & 134 & 7,2 & 7,6 & 7,8 \\
\hline & LNII (60mL:15L) & 25,0 & $12 / 08 / 02$ & 137 & 7,9 & 7,8 & 8,2 \\
\hline & LNII (60mL:15L) & 25,0 & $20 / 08 / 02$ & 146 & 7,9 & 7,9 & 8,5 \\
\hline & LNI1 (45mL:15L:4mL etanol) & 25,0 & $22 / 08 / 02$ & 147 & 7,4 & 7,5 & 8,3 \\
\hline \multirow[t]{2}{*}{5} & LNI1 (50mL:15L:3mL etanol) & 25,0 & $29 / 08 / 02$ & 154 & 7,2 & 7,6 & 7,6 \\
\hline & LNI1 (50mL:15L:5mL etanol) & 30,0 & $02 / 09 / 02$ & 158 & 7,4 & 7,4 & 7,8 \\
\hline \multirow[t]{3}{*}{6} & LNI1 (50mL:15L:5mL etanol) & 32,5 & $05 / 09 / 02$ & 161 & 7,4 & 7,3 & 7,9 \\
\hline & LNI1 (55mL:15L:7mL etanol) & 32,5 & $10 / 09 / 02$ & 166 & 7,2 & 7,4 & 7,8 \\
\hline & LNII (55mL:15L:7mL etanol) & 32,5 & $12 / 09 / 02$ & 168 & 7,0 & 7,3 & 8,0 \\
\hline
\end{tabular}


TABELA A10. Valores de $\mathrm{pH}$ monitorados nos efluentes dos reatores na fase mesofílica: $7^{\mathrm{a}}$ a $8^{\mathrm{a}}$ etapa.

\begin{tabular}{|c|c|c|c|c|c|c|c|}
\hline \multirow{2}{*}{$\begin{array}{l}\text { 总 } \\
\text { 焉 }\end{array}$} & \multirow{2}{*}{ Tipo de licor e volume } & \multirow{2}{*}{$\begin{array}{c}\mathrm{T} \\
\left({ }^{0} \mathrm{C}\right)\end{array}$} & \multirow{2}{*}{$\begin{array}{l}\text { Data da } \\
\text { coleta }\end{array}$} & \multirow{2}{*}{$\begin{array}{l}\text { Tempo de } \\
\text { operação } \\
\text { (dia) }\end{array}$} & \multicolumn{3}{|c|}{$\overline{\mathrm{pH}}$} \\
\hline & & & & & ARS & e-UASB & e-LA \\
\hline \multirow[t]{14}{*}{7} & LNI1 (55mL:15L:7mL etanol) & 35,0 & $16 / 09 / 02$ & 172 & 7,4 & 5,2 & 7,9 \\
\hline & LNII (55mL:15L:7mL etanol) & 35,0 & $17 / 09 / 02$ & 173 & 7,2 & 5,3 & \\
\hline & LNI1 (55mL:15L:7mL etanol) & 35,0 & $18 / 09 / 02$ & 174 & 8,3 & 5,5 & \\
\hline & LNI1 (55mL:15L:7mL etanol) & 35,0 & $19 / 09 / 02$ & 175 & 8,3 & 7,0 & \\
\hline & LNI1 (55mL:15L:7mL etanol) & 35,0 & $20 / 09 / 02$ & 176 & 8,3 & 7,2 & \\
\hline & LNI1 (45mL:15L:7mL etanol) & 35,0 & $24 / 09 / 02$ & 180 & 7,2 & 7,3 & 7,7 \\
\hline & LNII (45mL:15L:7mL etanol) & 37,5 & $25 / 09 / 02$ & 181 & 8,7 & 6,7 & 7,7 \\
\hline & LNI1 (45mL:15L:7mL etanol) & 37,5 & $26 / 09 / 02$ & 182 & 7,7 & 5,9 & 7,6 \\
\hline & LNI1 (45mL:15L:7mL etanol) & 35,0 & $30 / 09 / 02$ & 186 & 7,6 & 5,8 & 7,9 \\
\hline & LNI1 (45mL:15L:7mL etanol) & 37,5 & $01 / 10 / 02$ & 187 & 7,6 & 6,6 & 7,9 \\
\hline & LNI1 (45mL:15L:7mL etanol) & 37,5 & $11 / 10 / 02$ & 197 & 7,8 & 7,2 & 7,1 \\
\hline & LNI1 (45mL:15L:7mL etanol) & 37,5 & $15 / 10 / 02$ & 201 & 7,3 & 7,6 & 7,6 \\
\hline & LNI1 (45mL:15L:7mL etanol) & 37,5 & $22 / 10 / 02$ & 208 & 7,3 & 7,0 & 7,6 \\
\hline & LNI1 (45mL:15L:7mL etanol) & 37,5 & $24 / 10 / 02$ & 210 & 7,7 & 7,4 & 7,4 \\
\hline \multirow[t]{9}{*}{8} & LNI1 (45mL:15L:7mL etanol) & 42,5 & $29 / 10 / 02$ & 215 & 8,2 & 8,0 & 8,0 \\
\hline & LNI1 (45mL:15L:7mL etanol) & 42,5 & $31 / 10 / 02$ & 217 & 7,9 & 7,9 & 7,9 \\
\hline & LNI1 (45mL:15L:7mL etanol) & 42,5 & $05 / 11 / 02$ & 222 & 7,7 & 8,0 & 8,1 \\
\hline & LNI1 (45mL:15L:7mL etanol) & 42,5 & $07 / 11 / 02$ & 224 & 8,2 & 7,9 & 8,0 \\
\hline & LNI1 (45mL:15L:7mL etanol) & 42,5 & $12 / 11 / 02$ & 229 & 7,4 & 8,0 & 7,5 \\
\hline & LNI1 (45mL:15L:7mL etanol) & 42,5 & $15 / 11 / 02$ & 232 & 7,9 & 8,1 & 7,9 \\
\hline & LNI1 (45mL:15L:7mL etanol) & 42,5 & $19 / 11 / 02$ & 236 & 7,7 & 8,0 & 8,1 \\
\hline & LNII (45mL:15L:7mL etanol) & 42,5 & $22 / 11 / 02$ & 239 & 7,5 & 7,9 & 8,0 \\
\hline & LNI1 (45mL:15L:7mL etanol) & 42,5 & $28 / 11 / 02$ & 245 & 7,6 & 7,8 & 7,9 \\
\hline \multirow[t]{14}{*}{7} & LNII (55mL:15L:7mL etanol) & 35,0 & $16 / 09 / 02$ & 172 & 7,4 & 5,2 & 7,9 \\
\hline & LNII (55mL:15L:7mL etanol) & 35,0 & $17 / 09 / 02$ & 173 & 7,2 & 5,3 & \\
\hline & LNI1 (55mL:15L:7mL etanol) & 35,0 & $18 / 09 / 02$ & 174 & 8,3 & 5,5 & \\
\hline & LNI1 (55mL:15L:7mL etanol) & 35,0 & $19 / 09 / 02$ & 175 & 8,3 & 7,0 & \\
\hline & LNI1 (55mL:15L:7mL etanol) & 35,0 & $20 / 09 / 02$ & 176 & 8,3 & 7,2 & \\
\hline & LNI1 (45mL:15L:7mL etanol) & 35,0 & $24 / 09 / 02$ & 180 & 7,2 & 7,3 & 7,7 \\
\hline & LNI1 (45mL:15L:7mL etanol) & 37,5 & $25 / 09 / 02$ & 181 & 8,7 & 6,7 & 7,7 \\
\hline & LNI1 (45mL:15L:7mL etanol) & 37,5 & $26 / 09 / 02$ & 182 & 7,7 & 5,9 & 7,6 \\
\hline & LNI1 (45mL:15L:7mL etanol) & 35,0 & $30 / 09 / 02$ & 186 & 7,6 & 5,8 & 7,9 \\
\hline & LNI1 (45mL:15L:7mL etanol) & 37,5 & $01 / 10 / 02$ & 187 & 7,6 & 6,6 & 7,9 \\
\hline & LNI1 (45mL:15L:7mL etanol) & 37,5 & $11 / 10 / 02$ & 197 & 7,8 & 7,2 & 7,1 \\
\hline & LNI1 (45mL:15L:7mL etanol) & 37,5 & $15 / 10 / 02$ & 201 & 7,3 & 7,6 & 7,6 \\
\hline & LNI1 (45mL:15L:7mL etanol) & 37,5 & $22 / 10 / 02$ & 208 & 7,3 & 7,0 & 7,6 \\
\hline & LNI1 (45mL:15L:7mL etanol) & 37,5 & $24 / 10 / 02$ & 210 & 7,7 & 7,4 & 7,4 \\
\hline \multirow[t]{6}{*}{8} & LNI1 (45mL:15L:7mL etanol) & 42,5 & $29 / 10 / 02$ & 215 & 8,2 & 8,0 & 8,0 \\
\hline & LNI1 (45mL:15L:7mL etanol) & 42,5 & $31 / 10 / 02$ & 217 & 7,9 & 7,9 & 7,9 \\
\hline & LNI1 (45mL:15L:7mL etanol) & 42,5 & $05 / 11 / 02$ & 222 & 7,7 & 8,0 & 8,1 \\
\hline & LNI1 (45mL:15L:7mL etanol) & 42,5 & $07 / 11 / 02$ & 224 & 8,2 & 7,9 & 8,0 \\
\hline & LNI1 (45mL:15L:7mL etanol) & 42,5 & $12 / 11 / 02$ & 229 & 7,4 & 8,0 & 7,5 \\
\hline & LNI1 (45mL:15L:7mL etanol) & 42,5 & $15 / 11 / 02$ & 232 & 7,9 & 8,1 & 7,9 \\
\hline
\end{tabular}


TABELA A11. Valores de $\mathrm{pH}$ monitorados nos efluentes dos reatores na fase termofílica: $1^{\underline{a}}$ a $5^{\text {a }}$ etapa.

\begin{tabular}{|c|c|c|c|c|c|c|c|}
\hline \multirow{2}{*}{ 蛋 } & \multirow[t]{2}{*}{ Tipo de licor e volume } & \multirow{2}{*}{$\begin{array}{c}\mathrm{T} \\
\left({ }^{0} \mathrm{C}\right)\end{array}$} & \multirow{2}{*}{$\begin{array}{c}\text { Data da } \\
\text { coleta }\end{array}$} & \multirow{2}{*}{$\begin{array}{l}\text { Tempo de } \\
\text { operação } \\
\text { (dia) }\end{array}$} & \multicolumn{3}{|c|}{ pH } \\
\hline & & & & & ARS & e-UASB & e-LA \\
\hline \multirow[t]{3}{*}{1} & LNI1 (45mL:15L:7mL etanol) & 45,0 & $03 / 12 / 02$ & 250 & 7,8 & 7,9 & 7,9 \\
\hline & LNI1 (45mL:15L:7mL etanol) & 45,0 & $05 / 12 / 02$ & 252 & 7,5 & 8,0 & 8,2 \\
\hline & LNI1 (45mL:15L:7mL etanol) & 45,0 & $10 / 12 / 02$ & 257 & 7,4 & 7,9 & 8,0 \\
\hline \multirow[t]{4}{*}{2} & LNI1 (45mL:15L:7mL etanol) & 47,5 & $13 / 12 / 02$ & 264 & 7,2 & 7,8 & 7,8 \\
\hline & LNI1 (45mL:15L:7mL etanol) & 47,5 & $16 / 12 / 02$ & 263 & & 7,8 & 8,1 \\
\hline & LNI1 (45mL:15L:7mL etanol) & 47,5 & $18 / 12 / 02$ & 265 & 7,3 & 7,6 & 7,8 \\
\hline & LNI1 (45mL:15L:7mL etanol) & 47,5 & $19 / 12 / 02$ & 266 & 7,4 & 7,3 & 7,9 \\
\hline \multirow[t]{2}{*}{3} & LNI1 (45mL:15L:7mL etanol) & 52,0 & $15 / 01 / 03$ & 293 & 7,3 & 7,5 & 7,6 \\
\hline & LNII (45mL:15L:7mL etanol) & 52,0 & $20 / 01 / 03$ & 298 & 7,0 & 7,3 & 7,9 \\
\hline \multirow[t]{10}{*}{4} & LNI2 (30mL:15L:7mL etanol) & 52,0 & $22 / 01 / 03$ & 300 & 6,8 & 7,2 & 8,1 \\
\hline & LNI2 (30mL:15L:7mL etanol) & 52,0 & $27 / 01 / 03$ & 305 & 7,2 & 6,9 & 7,6 \\
\hline & LNI2 (30mL:15L:7mL etanol) & 52,0 & $30 / 01 / 03$ & 308 & 7,4 & 7,4 & 8,2 \\
\hline & LNI2 (30mL:15L:7mL etanol) & 52,0 & $03 / 02 / 03$ & 312 & 7,2 & 6,6 & 7,9 \\
\hline & LNI2 (30mL:15L:7mL etanol) & 52,0 & $06 / 02 / 03$ & 315 & 8,5 & 7,6 & 7,8 \\
\hline & LNI2 (30mL:15L:7mL etanol) & 52,0 & $17 / 02 / 03$ & 326 & 7,6 & 7,3 & 8,1 \\
\hline & LNI2 (30mL:15L:7mL etanol) & 52,0 & $19 / 02 / 03$ & 328 & 7,2 & 6,1 & 8,1 \\
\hline & LNI2 (30mL:15L:7mL etanol) & 52,0 & $25 / 02 / 03$ & 334 & 7,2 & 6,4 & 8,0 \\
\hline & LNI2 (30mL:15L:7mL etanol) & 52,0 & $26 / 02 / 03$ & 336 & 7,6 & 7,6 & 8,3 \\
\hline & LNI2 (30mL:15L:7mL etanol) & 52,0 & $17 / 03 / 03$ & 354 & 7,3 & 5,1 & 8,0 \\
\hline \multirow[t]{7}{*}{5} & LNI2 (30mL:15L:7mL etanol) & 57,0 & $20 / 03 / 03$ & 356 & 7,3 & 5,0 & 7,6 \\
\hline & LNI2 (30mL:15L:7mL etanol) & 57,0 & $25 / 03 / 03$ & 361 & 6,0 & 5,0 & 7,8 \\
\hline & LNI2 (30mL:15L:7mL etanol) & 57,0 & $28 / 03 / 03$ & 364 & 7,0 & 6,5 & 8,1 \\
\hline & LNI2 (30mL:15L:7mL etanol) & 57,0 & $01 / 04 / 03$ & 368 & 7,1 & 5,1 & 7,8 \\
\hline & LNI2 (30mL:15L:7mL etanol) & 57,0 & $08 / 04 / 03$ & 375 & 7,3 & 5,2 & 7,5 \\
\hline & LNI2 (30mL:15L:7mL etanol) & 57,0 & $15 / 04 / 03$ & 382 & 7,0 & 5,9 & 7,8 \\
\hline & LNI2 (30mL:15L:7mL etanol) & 57,0 & $23 / 04 / 03$ & 390 & 7,1 & 6,6 & 7,9 \\
\hline
\end{tabular}


TABELA A12. Concentrações de ácidos graxos voláteis monitorados nos efluentes dos reatores na fase mesofilica: $2^{\underline{a}}$ a $6^{\underline{a}}$ etapa.

\begin{tabular}{|c|c|c|c|c|c|c|c|}
\hline \multirow[b]{2}{*}{ 胥 } & \multirow[t]{2}{*}{ Características do licor } & \multirow{2}{*}{$\begin{array}{c}T \\
(0 \mathrm{C})\end{array}$} & \multirow{2}{*}{$\begin{array}{l}\text { Data da } \\
\text { coleta }\end{array}$} & \multirow{2}{*}{$\begin{array}{c}\text { Tempo de } \\
\text { operação } \\
\text { (dias) }\end{array}$} & \multicolumn{3}{|c|}{ Ácidos } \\
\hline & & & & & ARS & e-UASB & e-LA \\
\hline \multirow[t]{11}{*}{2} & LNC (20ML:10L) & 25 & $21 / 04 / 02$ & 25 & 115 & 30 & - \\
\hline & LNC (20ML:10L) & 25 & $26 / 04 / 02$ & 30 & 135 & nd & - \\
\hline & LNC (20ML:10L) & 25 & $01 / 05 / 02$ & 35 & 141 & 28 & - \\
\hline & LNC (20ML:10L) & 25 & $03 / 05 / 02$ & 37 & 143 & 34 & - \\
\hline & LNC (25mL:10L) & 25 & $08 / 05 / 02$ & 42 & 205 & 36 & - \\
\hline & LNC (25mL:10L) & 25 & $10 / 05 / 02$ & 44 & 172 & 41 & - \\
\hline & LNC (25mL:10L) & 25 & $15 / 05 / 02$ & 49 & 208 & 48 & - \\
\hline & LNC (25mL:10L) & 25 & $17 / 05 / 02$ & 51 & 191 & 42 & - \\
\hline & LNC (25mL:10L) & 25 & $22 / 05 / 02$ & 56 & 190 & 39 & - \\
\hline & LNC (25mL:10L) & 25 & $24 / 05 / 02$ & 58 & 193 & 37 & - \\
\hline & LNC (25mL:10L) & 25 & $29 / 05 / 02$ & 63 & 174 & 32 & - \\
\hline \multirow[t]{11}{*}{3} & LNI1 (50mL:10L) & 25 & $05 / 06 / 02$ & 70 & 287 & 55 & - \\
\hline & LNI1 (50mL:10L) & 25 & $07 / 06 / 02$ & 72 & 315 & 51 & - \\
\hline & LNI1 (50mL:10L) & 25 & $12 / 06 / 02$ & 77 & 327 & 47 & - \\
\hline & LNI1 (50mL:10L) & 25 & $13 / 06 / 02$ & 78 & 329 & 83 & - \\
\hline & LNI1 (50mL:10L) & 25 & $17 / 06 / 02$ & 82 & 223 & 46 & - \\
\hline & LNII (50mL:10L) & 25 & $19 / 06 / 02$ & 84 & 300 & 62 & - \\
\hline & LNII (50mL:10L) & 25 & $24 / 06 / 02$ & 89 & 330 & 73 & - \\
\hline & LNI1 (50mL:10L) & 25 & $26 / 06 / 02$ & 91 & 300 & 70 & - \\
\hline & LNI1 (50mL:10L) & 25 & $02 / 07 / 02$ & 96 & 303 & 54 & - \\
\hline & LNI1 (50mL:10L) & 25 & $04 / 07 / 02$ & 98 & 268 & 58 & - \\
\hline & LNII (50mL:10L) & 25 & $10 / 07 / 02$ & 104 & 283 & 48 & - \\
\hline \multirow[t]{11}{*}{4} & LNII (60mL:12L) & 25 & $23 / 07 / 02$ & 117 & 305 & 61 & - \\
\hline & LNI1 (60mL:12L) & 25 & $24 / 07 / 02$ & 118 & 283 & 66 & - \\
\hline & LNI1 (60mL:12L) & 25 & $26 / 07 / 02$ & 120 & 280 & 59 & - \\
\hline & LNI1 (60mL:12L) & 25 & $28 / 07 / 02$ & 122 & 258 & 50 & - \\
\hline & LNI1 (60mL:12L) & 25 & $02 / 08 / 02$ & 127 & 286 & 61 & - \\
\hline & LNI1 (60mL:12L) & 25 & $05 / 08 / 02$ & 130 & 256 & 55 & 53 \\
\hline & LNI1 (60mL:12L) & 25 & $07 / 08 / 02$ & 132 & 270 & 66 & 45 \\
\hline & LNI1 (60mL:15L) & 25 & $08 / 08 / 02$ & 133 & 262 & 50 & 50 \\
\hline & LNI1 (60mL:15L) & 25 & $09 / 08 / 02$ & 134 & 254 & 41 & 43 \\
\hline & LNI1 (60mL:15L) & 25 & $12 / 08 / 02$ & 137 & 235 & 35 & 45 \\
\hline & LNII (60mL:15L) & 25 & $20 / 08 / 02$ & 145 & 282 & 43 & 41 \\
\hline \multirow[t]{3}{*}{5} & $\begin{array}{l}\text { LNI1 (50mL:15L:3mL } \\
\text { etanol) }\end{array}$ & 25 & $22 / 08 / 02$ & 147 & 138 & 40 & 43 \\
\hline & $\begin{array}{l}\text { LNI1 (50mL:15L:3mL } \\
\text { etanol) }\end{array}$ & 25 & $28 / 08 / 02$ & 153 & 166 & 45 & 35 \\
\hline & $\begin{array}{l}\text { LNII (50mL:15L:5mL } \\
\text { etanol) }\end{array}$ & 30 & $02 / 09 / 02$ & 158 & 188 & 47 & 50 \\
\hline \multirow{4}{*}{6} & LNI1 (50mL:15L:5mL & & & & & & \\
\hline & etanol) & 32,5 & $05 / 09 / 02$ & 161 & 186 & 47 & 41 \\
\hline & $\begin{array}{l}\text { LNII (55mL:15L:7mL } \\
\text { etanol) }\end{array}$ & 32,5 & $10 / 09 / 02$ & 166 & 175 & 55 & 34 \\
\hline & $\begin{array}{c}\text { LNII (55mL:15L:7mL } \\
\text { etanol) }\end{array}$ & 32,5 & $12 / 09 / 02$ & 168 & 215 & 110 & 91 \\
\hline
\end{tabular}


TABELA A13. Concentrações de ácidos graxos voláteis monitorados nos efluentes dos reatores na fase mesofilica ( $7^{\mathrm{a}}$ a $8^{\mathrm{a}}$ etapa) e fase termofilica ( $1^{\mathrm{a}}$ a $3^{\mathrm{a}}$ etapa).

\begin{tabular}{|c|c|c|c|c|c|c|c|}
\hline \multirow[b]{2}{*}{ 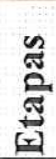 } & \multirow[t]{2}{*}{ Características do licor } & \multirow{2}{*}{$\begin{array}{c}T \\
(0 \mathrm{C})\end{array}$} & \multirow{2}{*}{$\begin{array}{c}\text { Data da } \\
\text { coleta }\end{array}$} & \multirow{2}{*}{$\begin{array}{l}\text { Tempo de } \\
\text { operação } \\
\text { (dias) }\end{array}$} & \multicolumn{3}{|c|}{ Ácidos } \\
\hline & & & & & ARS & e-UASB & e-LA \\
\hline \multirow[t]{8}{*}{7} & $\begin{array}{l}\text { LNI1 (55mL:15L:7mL } \\
\text { etanol) } \\
\text { LNI1 (45mL:15L:7mL }\end{array}$ & 35 & $16 / 09 / 02$ & 172 & 214 & 406 & 41 \\
\hline & etanol) & 35 & $24 / 09 / 02$ & 180 & 152 & 128 & 36 \\
\hline & $\begin{array}{l}\text { LNII (50mL:15L: } 7 \mathrm{~mL} \\
\text { etanol) }\end{array}$ & 35 & $30 / 09 / 02$ & 186 & 170 & 337 & 33 \\
\hline & $\begin{array}{l}\text { LNI1 (45mL:15L:7mL } \\
\text { etanol) }\end{array}$ & 35 & $11 / 10 / 02$ & 197 & 124 & 180 & 102 \\
\hline & $\begin{array}{c}\text { LNII (45mL:15L:7mL } \\
\text { etanol) }\end{array}$ & 35 & $15 / 10 / 02$ & 201 & 91 & 90 & 65 \\
\hline & LNI1 (45mL:15L:7mL & & & & & & \\
\hline & etanol) & 35 & $22 / 10 / 02$ & 208 & 101 & 89 & 41 \\
\hline & $\begin{array}{l}\text { etanol) } \\
\end{array}$ & 35 & $24 / 10 / 02$ & 210 & 89 & 65 & 50 \\
\hline \multirow[t]{10}{*}{8} & $\begin{array}{l}\text { LNI1 (45mL:15L:7mL } \\
\text { etanol) } \\
\end{array}$ & 42,5 & $29 / 10 / 02$ & 215 & 134 & 69 & 37 \\
\hline & etanol) & 42,5 & $31 / 10 / 02$ & 217 & 145 & 140 & 32 \\
\hline & $\begin{array}{l}\text { LNII (45mL:15L:7mL } \\
\text { etanol) }\end{array}$ & 42,5 & $05 / 11 / 02$ & 222 & 155 & 62 & 39 \\
\hline & $\begin{array}{l}\text { LNI1 (45mL:15L:7mL } \\
\text { etanol) }\end{array}$ & 42,5 & $07 / 11 / 02$ & 224 & 147 & 56 & 39 \\
\hline & LNI1 (45mL:15L:7mL & & & & & & \\
\hline & $\begin{array}{c}\text { etanol) } \\
\end{array}$ & 42,5 & $12 / 11 / 02$ & 229 & 145 & 37 & 42 \\
\hline & etanol) & 42,5 & $15 / 11 / 02$ & 232 & 147 & 45 & 39 \\
\hline & $\begin{array}{l}\text { LNI1 (45mL:15L:7mL } \\
\text { etanol) }\end{array}$ & 42,5 & $19 / 11 / 02$ & 236 & 140 & 52 & 31 \\
\hline & $\begin{array}{c}\text { LNIl (45mL:15L:7mL } \\
\text { etanol) }\end{array}$ & 42,5 & $22 / 11 / 02$ & 239 & 156 & 69 & 37 \\
\hline & $\begin{array}{c}\text { LNI1 (45mL: } 15 \mathrm{~L}: 7 \mathrm{~mL} \\
\text { etanol) }\end{array}$ & & $28 / 11 / 02$ & & & & 51 \\
\hline \multirow[t]{4}{*}{1} & $\begin{array}{l}\text { LNI1 (45mL: } 15 \mathrm{~L}: 7 \mathrm{~mL} \\
\text { etanol) }\end{array}$ & 45 & $03 / 12 / 02$ & 250 & 171 & 69 & 36 \\
\hline & $\begin{array}{l}\text { LNII (45mL:15L:/mL } \\
\text { etanol) }\end{array}$ & 45 & $05 / 12 / 02$ & 252 & 172 & 50 & 38 \\
\hline & $\begin{array}{l}\text { LNI1 (45mL:15L:7mL } \\
\text { etanol) }\end{array}$ & 45 & $10 / 12 / 02$ & 257 & 190 & 47 & 31 \\
\hline & $\begin{array}{l}\text { LNI1 (45mL:15L:7mL } \\
\text { etanol) }\end{array}$ & 45 & & & 190 & 41 & 48 \\
\hline \multirow[t]{3}{*}{2} & $\begin{array}{l}\text { LNII (45mL:15L:7mL } \\
\text { etanol) } \\
\text { LNII (45mL:15L:7mL }\end{array}$ & 47,5 & $17 / 12 / 02$ & 264 & 165 & 81 & 29 \\
\hline & etanol) & 47,5 & $19 / 12 / 02$ & 266 & 154 & 155 & 30 \\
\hline & $\begin{array}{l}\text { LNII (45mL:15L:7mL } \\
\text { etanol) }\end{array}$ & 47,5 & $13 / 01 / 02$ & 291 & 201 & 120 & 37 \\
\hline \multirow[t]{2}{*}{3} & $\begin{array}{l}\text { LNII (45mL:15L:7mL } \\
\text { etanol) }\end{array}$ & 52 & $15 / 01 / 02$ & 293 & 187 & 145 & 30 \\
\hline & $\begin{array}{l}\text { LNI1 (45mL:15L:7mL } \\
\text { etanol) }\end{array}$ & 52 & & 298 & 195 & 199 & 48 \\
\hline
\end{tabular}


TABELA A14. Concentrações de ácidos graxos voláteis monitorados nos efluentes dos reatores na fase termofilica ( $4^{\mathrm{a}}$ a $5^{\mathrm{a}}$ etapa).

\begin{tabular}{|c|c|c|c|c|c|c|c|}
\hline \multirow[b]{2}{*}{ 总 } & \multirow{2}{*}{ Características do licor } & \multirow{2}{*}{$\begin{array}{c}\mathrm{T} \\
(0 \mathrm{C})\end{array}$} & \multirow{2}{*}{$\begin{array}{c}\text { Data da } \\
\text { coleta }\end{array}$} & \multirow{2}{*}{$\begin{array}{l}\text { Tempo de } \\
\text { operação } \\
\text { (dias) }\end{array}$} & \multicolumn{3}{|c|}{ Ácidos } \\
\hline & & & & & ARS & e-UASB & e-LA \\
\hline \multirow[t]{11}{*}{4} & $\begin{array}{l}\text { LNI2 (30mL:15L:7mL } \\
\text { etanol) }\end{array}$ & 52 & $22 / 01 / 02$ & 300 & 118 & 184 & 43 \\
\hline & $\begin{array}{c}\text { LNI2 (30mL:15L:7mL } \\
\text { etanol) }\end{array}$ & 52 & & 305 & 126 & 189 & 31 \\
\hline & $\begin{array}{c}\text { LNI2 (30mL:15L:7mL } \\
\text { etanol) }\end{array}$ & 52 & $30 / 01 / 02$ & 308 & 128 & 240 & 54 \\
\hline & LNI2 (30mL:15L:7mL & & & & & & \\
\hline & $\begin{array}{c}\text { etanol) } \\
\text { LNI2 (30mL:15L:7mL }\end{array}$ & 52 & $03 / 02 / 02$ & 312 & 131 & 257 & 39 \\
\hline & etanol) & 52 & $06 / 02 / 02$ & 315 & 219 & 233 & 45 \\
\hline & $\begin{array}{l}\text { LNI2 (30mL: } 15 \mathrm{~L}: 7 \mathrm{~mL} \\
\text { etanol) }\end{array}$ & 52 & $17 / 02 / 02$ & 326 & 127 & 160 & 35 \\
\hline & $\begin{array}{l}\text { LNI2 (30mL:15L:7mL } \\
\text { etanol) }\end{array}$ & 52 & $19 / 02 / 03$ & 328 & 127 & 225 & 46 \\
\hline & $\begin{array}{l}\text { LNI2 (30mL:15L:7mL } \\
\text { etanol) }\end{array}$ & 52 & $25 / 02 / 03$ & 334 & 142 & 209 & 39 \\
\hline & $\begin{array}{l}\text { LNI2 (30mL:15L:7mL } \\
\text { etanol) }\end{array}$ & 52 & $27 / 02 / 03$ & 336 & 131 & 258 & 96 \\
\hline & $\begin{array}{l}\text { LNI2 (30mL:15L:7mL } \\
\text { etanol) }\end{array}$ & & $17 / 03 / 03$ & 354 & 121 & 340 & 39 \\
\hline \multirow[t]{7}{*}{5} & $\begin{array}{l}\text { LNI2 (30mL:15L:7mL } \\
\text { etanol) }\end{array}$ & 57 & $20 / 03 / 03$ & 356 & 137 & 307 & 24 \\
\hline & $\begin{array}{l}\text { LNI2 (30mL:15L:7mL } \\
\text { etanol) }\end{array}$ & 57 & $25 / 03 / 03$ & 361 & 136 & 364 & 48 \\
\hline & $\begin{array}{l}\text { LNI2 (30mL:15L:7mL } \\
\text { etanol) }\end{array}$ & 57 & $28 / 03 / 03$ & 364 & 134 & 336 & 70 \\
\hline & $\begin{array}{l}\text { LNI2 (30mL:15L:7mL } \\
\text { etanol) }\end{array}$ & 57 & $01 / 04 / 03$ & 368 & 143 & 323 & 90 \\
\hline & $\begin{array}{l}\text { LNI2 (30mL:15L:7mL } \\
\text { etanol) }\end{array}$ & 57 & $08 / 04 / 03$ & 375 & 108 & 271 & 45 \\
\hline & $\begin{array}{l}\text { LNI2 (30mL:15L:7mL } \\
\text { etanol) }\end{array}$ & 57 & $15 / 04 / 03$ & 382 & 115 & 234 & 55 \\
\hline & $\begin{array}{l}\text { LNI2 (30mL:15L:7mL } \\
\text { etanol) }\end{array}$ & 57 & $23 / 04 / 03$ & 390 & 97 & 237 & 57 \\
\hline
\end{tabular}


TABELA A15. Concentrações de alcalinidade monitorados nos reatores na fase mesofilica: $2^{\underline{a}}$ a $3^{\underline{a}}$ etapa.

\begin{tabular}{|c|c|c|c|c|c|c|c|c|c|}
\hline \multirow[b]{2}{*}{ 总 } & \multirow[t]{2}{*}{$\begin{array}{c}\text { Tipo de licore } \\
\text { volume }\end{array}$} & \multirow[t]{2}{*}{$\begin{array}{c}\mathrm{T} \\
\left({ }^{0} \mathrm{C}\right)\end{array}$} & \multirow[t]{2}{*}{$\begin{array}{l}\text { Tempo } \\
\text { (dia) }\end{array}$} & \multicolumn{3}{|c|}{$\begin{array}{c}\text { Alcalinidade parcial } \\
\left(\mathrm{mg}^{-\mathrm{L}^{-1}}\right)\end{array}$} & \multicolumn{3}{|c|}{$\begin{array}{l}\text { Alcalinidade total } \\
\text { filtrada }\left(\mathrm{mg} \cdot \mathrm{L}^{-1}\right)\end{array}$} \\
\hline & & & & ARS & e-UASB & e-LA & ARS & e-UASB & e-LA \\
\hline \multirow[t]{15}{*}{2} & $\begin{array}{c}\text { LNC } \\
\text { (18mL:10L) } \\
\text { LNC }\end{array}$ & 25 & 25 & 119 & 254 & - & 214 & 296 & - \\
\hline & (20ML:10L) & 25 & 30 & 97 & 258 & - & 198 & 300 & - \\
\hline & $\begin{array}{c}\text { LNC } \\
\text { (20ML:10L) }\end{array}$ & 25 & 35 & 102 & 239 & - & 216 & 296 & - \\
\hline & $\mathrm{LNC}$ & & & & & & & & \\
\hline & (20ML:10L) & 25 & 37 & 135 & 204 & - & 238 & 276 & - \\
\hline & (25mL:10L) & 25 & 42 & 91 & 232 & - & 298 & 233 & - \\
\hline & $\begin{array}{c}\text { LNC } \\
\text { (25) } 10 \mathrm{~L}\end{array}$ & 25 & A & & & & & 274 & \\
\hline & $\begin{array}{l}\text { (25mL:I0L) } \\
\text { LNC }\end{array}$ & 25 & 44 & 94 & 299 & - & 221 & $3 / 4$ & - \\
\hline & (25mL:10L) & 25 & 49 & 92 & 304 & - & 232 & 390 & - \\
\hline & $\begin{array}{c}\text { LNC } \\
(25 \mathrm{~mL} \cdot 10 \mathrm{~L})\end{array}$ & 25 & 51 & 86 & 322 & - & 227 & 302 & \\
\hline & LNC & & & & & & 221 & של & - \\
\hline & (25mL:10L) & 25 & 56 & 110 & 288 & - & 247 & 354 & - \\
\hline & $\begin{array}{c}\mathrm{LNC} \\
(25 \mathrm{~mL} \cdot 10 \mathrm{~L})\end{array}$ & 25 & 58 & 103 & 295 & - & 238 & 370 & \\
\hline & LNC & & & & & & & & \\
\hline & (25mL:10L) & 25 & 63 & 94 & 281 & - & 214 & 359 & - \\
\hline \multirow[t]{15}{*}{3} & $\begin{array}{c}\text { LNII } \\
\text { (50mL:10L) }\end{array}$ & 25 & 70 & 105 & 407 & - & 312 & 488 & - \\
\hline & $\begin{array}{l}\text { LNI1 } \\
\text { (50mL:10L) }\end{array}$ & 25 & 72 & 96 & 405 & - & 311 & 478 & - \\
\hline & LNI1 & & & & & & & & \\
\hline & (50mL:10L) & 25 & 77 & 94 & 422 & - & 289 & 520 & - \\
\hline & $\begin{array}{l}\text { LNII } \\
\text { (50mL:10L) }\end{array}$ & 25 & 78 & 79 & 369 & - & 221 & 374 & - \\
\hline & LNI1 & & & & & & & & \\
\hline & (50mL:10L) & 25 & 82 & 159 & 389 & - & 313 & 511 & - \\
\hline & $\begin{array}{c}\text { LNII } \\
(50 \mathrm{~mL}: 10 \mathrm{~L})\end{array}$ & 25 & 84 & 91 & 424 & - & 296 & 523 & - \\
\hline & LNI1 & & & & & & & & \\
\hline & $\begin{array}{l}\text { (50mL:10L) } \\
\text { LNI1 }\end{array}$ & 25 & 89 & 79 & 404 & - & 295 & 527 & - \\
\hline & $(50 \mathrm{~mL}: 10 \mathrm{~L})$ & 25 & 91 & 129 & 382 & - & 340 & 520 & - \\
\hline & $\begin{array}{c}\text { LNI1 } \\
(50 \mathrm{~mL}: 10 \mathrm{~L})\end{array}$ & 25 & 96 & 133 & 404 & - & 341 & 516 & - \\
\hline & LNI1 & & & & & & & & \\
\hline & (50mL:10L) & 25 & 98 & 122 & 391 & - & 340 & 541 & - \\
\hline & $\begin{array}{c}\text { LNII } \\
(50 \mathrm{~mL}: 10 \mathrm{~L})\end{array}$ & 25 & 104 & 250 & 365 & - & 424 & 503 & - \\
\hline
\end{tabular}


TABELA A16. Concentrações de alcalinidade monitorados nos reatores na fase mesofilica: $4^{\mathrm{a}}$ a $8^{\mathrm{a}}$ etapa.

\begin{tabular}{|c|c|c|c|c|c|c|c|c|c|}
\hline \multirow{2}{*}{ 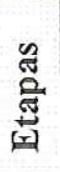 } & \multirow[t]{2}{*}{$\begin{array}{l}\text { Tipo de licore } \\
\text { volume }\end{array}$} & \multirow[t]{2}{*}{$\stackrel{\mathrm{T}}{\left({ }^{0} \mathrm{C}\right)}$} & \multirow{2}{*}{$\begin{array}{c}\text { Temp } \\
\text { o } \\
\text { (dia) }\end{array}$} & \multicolumn{3}{|c|}{$\begin{array}{l}\text { Alcalinidade parcial } \\
\left.\text { (mg.L } \mathrm{L}^{-1}\right)\end{array}$} & \multicolumn{3}{|c|}{$\begin{array}{l}\text { Alcalinidade total } \\
\text { filtrada }\left(\mathrm{mg}^{\left.-\mathrm{L}^{-1}\right)}\right.\end{array}$} \\
\hline & & & & ARS & $\mathrm{e}$-UASB & e-LA & ARS & e-UASB & e-LA \\
\hline \multirow[t]{12}{*}{4} & LNI1 (60mL:12L) & 25 & 117 & 181 & 408 & - & 370 & 489 & - \\
\hline & LNIl (60mL:12L) & 25 & 118 & 131 & 366 & - & 323 & 513 & - \\
\hline & LNI1 (60mL:12L) & 25 & 120 & 133 & 389 & - & 318 & 520 & - \\
\hline & LNI1 (60mL:12L) & 25 & 122 & 150 & 349 & - & 339 & 529 & - \\
\hline & LNI1 (60mL:12L) & 25 & 127 & 122 & 436 & - & 314 & 524 & - \\
\hline & LNI1 (60mL:12L) & 25 & 130 & 133 & 447 & 162 & 305 & 506 & 222 \\
\hline & LNI1 (60mL:12L) & 25 & 132 & 96 & 342 & 131 & 262 & 475 & 188 \\
\hline & LNI1 (60mL:15L) & 25 & 133 & 106 & 393 & 157 & 297 & 517 & 202 \\
\hline & LNI1 (60mL:15L) & 25 & 134 & 82 & 356 & 206 & 258 & 482 & 279 \\
\hline & LNII (60mL:15L) & 25 & 137 & 311 & 298 & 267 & 457 & 441 & 366 \\
\hline & LNIl (60mL:15L) & 25 & 146 & 126 & 422 & 400 & 335 & 569 & 543 \\
\hline & $\begin{array}{c}\text { LNI1 (50mL:15L:3mL } \\
\text { etanol) }\end{array}$ & & 148 & 70 & 204 & 244 & 166 & 332 & 314 \\
\hline \multirow[t]{2}{*}{5} & $\begin{array}{l}\text { LNI1 (50mL: } 15 \mathrm{~L}: 3 \mathrm{~mL} \\
\text { etanol) }\end{array}$ & 35 & 154 & 56 & 206 & 244 & 157 & 293 & 314 \\
\hline & $\begin{array}{c}\text { LNI1 (50mL:15L:5mL } \\
\text { etanol) }\end{array}$ & 35 & 158 & 77 & 225 & 112 & 188 & 279 & 140 \\
\hline \multirow[t]{3}{*}{6} & $\begin{array}{l}\text { LNI1 (50mL: } 15 \mathrm{~L}: 5 \mathrm{~mL} \\
\text { etanol) }\end{array}$ & 6 & 161 & 66 & 204 & 127 & 187 & 321 & 188 \\
\hline & $\begin{array}{l}\text { LNI1 (55mL:15L:7mL } \\
\text { etanol) }\end{array}$ & & 166 & 65 & 206 & 122 & 181 & 297 & 157 \\
\hline & $\begin{array}{c}\text { LNI1 (55mL:15L:7mL } \\
\text { etanol) }\end{array}$ & & 168 & 65 & 202 & 133 & 187 & 339 & 190 \\
\hline \multirow[t]{7}{*}{7} & $\begin{array}{c}\text { LNI1 (55mL: } 15 \mathrm{~L}: 7 \mathrm{~mL} \\
\text { etanol) }\end{array}$ & 7 & 172 & 80 & 0 & 206 & 215 & 206 & 105 \\
\hline & $\begin{array}{l}\text { LNI1 (45mL:15L:7mL } \\
\text { etanol) }\end{array}$ & & 180 & 75 & 173 & 176 & 178 & 274 & 244 \\
\hline & $\begin{array}{l}\text { LNI1 (45mL:15L:7mL } \\
\text { etanol) }\end{array}$ & & 186 & 87 & 9 & 232 & 194 & 199 & 314 \\
\hline & $\begin{array}{c}\text { LNI1 (45mL: } 15 \mathrm{~L}: 7 \mathrm{~mL} \\
\text { etanol) }\end{array}$ & & 197 & 96 & 87 & 96 & 183 & 192 & 178 \\
\hline & $\begin{array}{l}\text { LNI1 (45mL:15L:7mL } \\
\text { etanol) }\end{array}$ & & 201 & 84 & 136 & 155 & 154 & 227 & 227 \\
\hline & $\begin{array}{l}\text { LNI1 (45mL: } 15 \mathrm{~L}: 7 \mathrm{~mL} \\
\text { etanol) }\end{array}$ & 37,5 & 208 & 108 & 171 & 124 & 206 & 290 & 258 \\
\hline & $\begin{array}{c}\text { LNI1 (45mL:15L:7mL } \\
\text { etanol) }\end{array}$ & 37,5 & 210 & 107 & 158 & 173 & 207 & 286 & 281 \\
\hline \multirow[t]{10}{*}{8} & $\begin{array}{c}\text { LNI1 (45mL: } 15 \mathrm{~L}: 7 \mathrm{~mL} \\
\text { etanol) }\end{array}$ & 42,5 & 215 & 109 & 217 & 134 & 211 & 299 & 231 \\
\hline & $\begin{array}{l}\text { LNI1 (45mL:15L:7mL } \\
\text { etanol) }\end{array}$ & 42,5 & 217 & 98 & 189 & 149 & 204 & 293 & 190 \\
\hline & $\begin{array}{l}\text { LNII (45mL:15L:7mL } \\
\text { etanol) }\end{array}$ & 42,5 & 222 & 140 & 274 & 113 & 295 & 375 & 164 \\
\hline & $\begin{array}{l}\text { LNI1 (45mL: } 15 \mathrm{~L}: 7 \mathrm{~mL} \\
\text { etanol) }\end{array}$ & 42,5 & 224 & 138 & 281 & 155 & 274 & 382 & 202 \\
\hline & $\begin{array}{l}\text { LNI1 (45mL:15L:7mL } \\
\text { etanol) }\end{array}$ & 42,5 & 229 & 148 & 284 & 122 & 297 & 359 & 168 \\
\hline & $\begin{array}{l}\text { LNI1 (45mL:15L:7mL } \\
\text { etanol) }\end{array}$ & 42,5 & 232 & 101 & 226 & 104 & 220 & 290 & 140 \\
\hline & $\begin{array}{c}\text { LNI1 (45mL:15L:7mL } \\
\text { etanol) }\end{array}$ & 42,5 & 236 & 121 & 211 & 125 & 234 & 290 & 161 \\
\hline & $\begin{array}{c}\text { LNI1 (45mL:15L:7mL } \\
\text { etanol) }\end{array}$ & 42,5 & 239 & 118 & 226 & 129 & 243 & 315 & 176 \\
\hline & $\begin{array}{c}\text { LNI1 (45mL:15L:7mL } \\
\text { etanol) }\end{array}$ & 42,5 & 245 & 124 & 244 & 146 & 263 & 333 & 193 \\
\hline & $\begin{array}{l}\text { LNI1 (45mL: } 15 \mathrm{~L}: 7 \mathrm{~mL} \\
\text { etanol) }\end{array}$ & 45 & 257 & 97 & 199 & 158 & 238 & 271 & 208 \\
\hline
\end{tabular}


TABELA A17. Concentrações de alcalinidade monitorados nos reatores na fase mesofilica: $4^{\mathrm{a}}$ a $8^{\mathrm{a}}$ etapa.

\begin{tabular}{|c|c|c|c|c|c|c|c|c|c|}
\hline \multirow{2}{*}{ 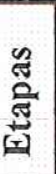 } & \multirow[t]{2}{*}{$\begin{array}{c}\text { Tipo de licore } \\
\text { volume }\end{array}$} & \multirow[t]{2}{*}{$\begin{array}{c}\mathrm{T} \\
\left({ }^{0} \mathrm{C}\right)\end{array}$} & \multirow{2}{*}{$\begin{array}{c}\text { Temp } \\
0 \\
\text { (dia) }\end{array}$} & \multicolumn{3}{|c|}{$\begin{array}{l}\text { Alcalinidade parcial } \\
\left(\mathrm{mg} . \mathrm{L}^{-1}\right)\end{array}$} & \multicolumn{3}{|c|}{$\begin{array}{l}\text { Alcalinidade total } \\
\text { filtrada }\left(\mathrm{mg} . \mathrm{L}^{-1}\right)\end{array}$} \\
\hline & & & & ARS & e-UASB & $\mathrm{e}-\mathrm{LA}$ & ARS & e-UASB & $\mathrm{e}-\mathrm{LA}$ \\
\hline \multirow[t]{12}{*}{4} & LNI1 (60mL:12L) & 25 & 117 & 181 & 408 & - & 370 & 489 & - \\
\hline & LNI1 (60mL:12L) & 25 & 118 & 131 & 366 & - & 323 & 513 & - \\
\hline & LNI1 (60mL:12L) & 25 & 120 & 133 & 389 & - & 318 & 520 & - \\
\hline & LNII (60mL:12L) & 25 & 122 & 150 & 349 & - & 339 & 529 & - \\
\hline & LNII (60mL:12L) & 25 & 127 & 122 & 436 & - & 314 & 524 & - \\
\hline & LNII (60mL:12L) & 25 & 130 & 133 & 447 & 162 & 305 & 506 & 222 \\
\hline & LNI1 (60mL:12L) & 25 & 132 & 96 & 342 & 131 & 262 & 475 & 188 \\
\hline & LNI1 (60mL:15L) & 25 & 133 & 106 & 393 & 157 & 297 & 517 & 202 \\
\hline & LNI1 (60mL:15L) & 25 & 134 & 82 & 356 & 206 & 258 & 482 & 279 \\
\hline & LNI1 (60mL:15L) & 25 & 137 & 311 & 298 & 267 & 457 & 441 & 366 \\
\hline & LNI1 (60mL:15L) & 25 & 146 & 126 & 422 & 400 & 335 & 569 & 543 \\
\hline & $\begin{array}{c}\mathrm{LNII}(50 \mathrm{~mL}: 15 \mathrm{~L}: 3 \mathrm{~mL} \\
\text { etanol) }\end{array}$ & & 148 & 70 & 204 & 244 & 166 & 332 & 314 \\
\hline \multirow[t]{2}{*}{5} & $\begin{array}{l}\text { LNI1 (50mL:15L:3mL } \\
\text { tanol) }\end{array}$ & 5 & 154 & 56 & 206 & 244 & 157 & 293 & 314 \\
\hline & $\begin{array}{c}\text { LNII (50mL: } 15 \mathrm{~L}: 5 \mathrm{~mL} \\
\text { etanol) }\end{array}$ & & 158 & 77 & 225 & 112 & 188 & 279 & 140 \\
\hline \multirow[t]{3}{*}{6} & $\begin{array}{c}\text { LNI1 (50mL: } 15 \mathrm{~L}: 5 \mathrm{~mL} \\
\text { tanol) }\end{array}$ & 6 & 161 & 66 & 204 & 127 & 187 & 321 & 188 \\
\hline & $\begin{array}{c}\text { LNII (55mL:15L:7mL } \\
\text { etanol) }\end{array}$ & & 166 & 65 & 206 & 122 & 181 & 297 & 157 \\
\hline & $\begin{array}{l}\text { LNI1 (55mL:15L:7mL } \\
\text { etanol) }\end{array}$ & & 168 & 65 & 202 & 133 & 187 & 339 & 190 \\
\hline \multirow[t]{8}{*}{7} & $\begin{array}{c}\text { LNI1 (55mL:15L:7mL } \\
\text { etanol) }\end{array}$ & 7 & 172 & 80 & 0 & 206 & 215 & 206 & 105 \\
\hline & $\begin{array}{c}\text { LNII }(45 \mathrm{~mL}: 15 \mathrm{~L}: 7 \mathrm{~mL} \\
\text { etanol) }\end{array}$ & & 180 & 75 & 173 & 176 & 178 & 274 & 244 \\
\hline & $\begin{array}{c}\text { LNI1 }(45 \mathrm{~mL}: 15 \mathrm{~L}: 7 \mathrm{~mL} \\
\text { etanol) }\end{array}$ & & 186 & 87 & 9 & 232 & 194 & 199 & 314 \\
\hline & $\begin{array}{c}\text { LNI1 (45mL:15L:7mL } \\
\text { etanol) }\end{array}$ & & 197 & 96 & 87 & 96 & 183 & 192 & 178 \\
\hline & LNII (45mL:15L:7mL & & & & & & & & \\
\hline & etanol) & & 201 & 84 & 136 & 155 & 154 & 227 & 227 \\
\hline & 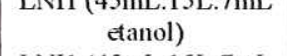 & 37,5 & 208 & 108 & 171 & 124 & 206 & 290 & 258 \\
\hline & $\begin{array}{c}\text { LNII (45mL:15L:7mL } \\
\text { etanol) }\end{array}$ & 37,5 & 210 & 107 & 158 & 173 & 207 & 286 & 281 \\
\hline \multirow[t]{12}{*}{8} & $\begin{array}{c}\text { LNII (45mL:15L:7mL } \\
\text { etanol) }\end{array}$ & 42,5 & 215 & 109 & 217 & 134 & 211 & 299 & 231 \\
\hline & $\begin{array}{c}\text { LNI1 (45mL: } 15 \mathrm{~L}: 7 \mathrm{~mL} \\
\text { etanol) }\end{array}$ & 42,5 & 217 & 98 & 189 & 149 & 204 & 293 & 190 \\
\hline & LNI1 (45mL:15L:7mL & 125 & 222 & 140 & 274 & 113 & 205 & $=$ & (c) \\
\hline & LNI1 (45mL:15L:7mL & 72,3 & & 140 & 214 & 115 & 290 & $3 / 17$ & 104 \\
\hline & etanol) & 42,5 & 224 & 138 & 281 & 155 & 274 & 382 & 202 \\
\hline & $\begin{array}{c}\text { LNII (45mL:15L:7mL } \\
\text { etanol) }\end{array}$ & 42,5 & 229 & 148 & 284 & 122 & 297 & 359 & 168 \\
\hline & $\begin{array}{c}\text { LNII (45mL:15L:7mL } \\
\text { etanol) }\end{array}$ & 42,5 & 232 & 101 & 226 & 104 & 220 & 290 & 140 \\
\hline & $\begin{array}{c}\text { LNI1 (45mL:15L:7mL } \\
\text { etanol) }\end{array}$ & 42,5 & 236 & 121 & 211 & 125 & 234 & 290 & 161 \\
\hline & LNII (45mL: $15 \mathrm{~L}: 7 \mathrm{~mL}$ & 42.5 & 239 & 118 & 226 & 129 & 243 & 335 & 176 \\
\hline & LNI1 (45mL:15L:7mL & & & & & & & & \\
\hline & etanol) & 42,5 & 245 & 124 & 244 & 146 & 263 & 333 & 193 \\
\hline & 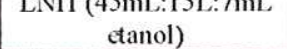 & 45 & 257 & 97 & 199 & 158 & 238 & 271 & 208 \\
\hline
\end{tabular}


TABELA A18. Concentrações de alcalinidade monitorados nos reatores na fase termofílica: $1^{\underline{a}}$ a $5^{\mathbf{a}}$ etapa.

\begin{tabular}{|c|c|c|c|c|c|c|c|c|c|}
\hline \multirow{2}{*}{ 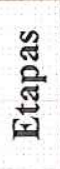 } & \multirow[t]{2}{*}{$\begin{array}{l}\text { Tipo de licore } \\
\text { volume }\end{array}$} & \multirow[t]{2}{*}{$\begin{array}{c}\mathrm{T} \\
\left({ }^{0} \mathrm{C}\right)\end{array}$} & \multirow{2}{*}{$\begin{array}{c}\text { Temp } \\
0 \\
\text { (dia) }\end{array}$} & \multicolumn{3}{|c|}{$\begin{array}{l}\text { Alcalinidade parcial } \\
\left(\mathrm{mg} . \mathrm{L}^{-1}\right)\end{array}$} & \multicolumn{3}{|c|}{$\begin{array}{l}\text { Alcalinidade total } \\
\left.\text { filtrada (mg. } \mathrm{L}^{-1}\right)\end{array}$} \\
\hline & & & & ARS & e-UASB & e-LA & ARS & e-UASB & e-LA \\
\hline 1 & $\begin{array}{c}\begin{array}{c}\text { LNII (45mL:15L:7mL } \\
\text { ctanol) }\end{array} \\
\end{array}$ & 45 & 257 & 97 & 199 & 158 & 238 & 271 & 208 \\
\hline \multirow[t]{3}{*}{2} & $\begin{array}{c}\text { LNI1 (45mL: } 15 \mathrm{~L}: 7 \mathrm{~mL} \\
\text { etanol) }\end{array}$ & 47,5 & 264 & 76 & 155 & 67 & 205 & 248 & 89 \\
\hline & $\begin{array}{c}\text { LNII (45mL: } 15 \mathrm{~L}: 7 \mathrm{~mL} \\
\text { etanol) }\end{array}$ & 47,5 & 266 & 104 & 126 & 138 & 237 & 268 & 189 \\
\hline & $\begin{array}{c}\text { LNII ( } \begin{array}{c}45 \mathrm{~mL}: 15 \mathrm{~L}: 7 \mathrm{~mL} \\
\text { etanol) }\end{array} \\
\end{array}$ & 47,5 & 291 & 95 & 183 & 124 & 251 & 320 & 176 \\
\hline \multirow[t]{2}{*}{3} & $\begin{array}{c}\text { LNI1 (45mL:15L:7mL } \\
\text { etanol) }\end{array}$ & 52 & 293 & 98 & 153 & 125 & 241 & 283 & 179 \\
\hline & $\begin{array}{c}\text { LNII ( } \begin{array}{c}(45 \mathrm{~mL}: 15 \mathrm{~L}: 7 \mathrm{~mL} \\
\text { etanol) }\end{array} \\
\end{array}$ & 52 & 298 & 95 & 134 & 208 & 250 & 299 & 289 \\
\hline \multirow[t]{10}{*}{4} & $\begin{array}{c}\text { LNI2 (30mL:15L:7mL } \\
\text { etanol) }\end{array}$ & 52 & 300 & 57 & 122 & 196 & 149 & 275 & 268 \\
\hline & $\begin{array}{l}\text { LNI2 (30mL: } 15 \mathrm{~L}: 7 \mathrm{~mL} \\
\text { etanol) }\end{array}$ & 52 & 305 & 94 & 57 & 124 & 196 & 198 & 179 \\
\hline & $\begin{array}{l}\text { LNI2 (30mL: } 15 \mathrm{~L}: 7 \mathrm{~mL} \\
\text { etanol) }\end{array}$ & 52 & 308 & 92 & 152 & 171 & 187 & 335 & 246 \\
\hline & $\begin{array}{c}\text { LNI2 (30mL: } 15 \mathrm{~L}: 7 \mathrm{~mL} \\
\text { etanol) }\end{array}$ & 52 & 312 & 83 & 46 & 204 & 186 & 226 & 292 \\
\hline & $\begin{array}{c}\text { LNI2 (30mL:15L: } 7 \mathrm{~mL} \\
\text { etanol) }\end{array}$ & 52 & 315 & 161 & 278 & 275 & 295 & 479 & 387 \\
\hline & $\begin{array}{c}\text { LNI2 (30mL: } 15 \mathrm{~L}: 7 \mathrm{~mL} \\
\text { etanol) }\end{array}$ & 52 & 326 & 69 & 60 & 127 & 158 & 176 & 163 \\
\hline & $\begin{array}{c}\text { LNI2 (30mL:15L:7mL } \\
\text { etanol) }\end{array}$ & 52 & 328 & 59 & 13 & 137 & 149 & 151 & 178 \\
\hline & $\begin{array}{c}\text { LNI2 (30mL:15L:7mL } \\
\text { efanol) }\end{array}$ & 52 & 334 & 67 & 22 & 156 & 162 & 158 & 218 \\
\hline & $\begin{array}{c}\text { LNI2 (30mL:15L:7mL } \\
\text { ctanol) }\end{array}$ & 52 & 336 & 75 & 155 & 279 & 160 & 141 & 382 \\
\hline & $\begin{array}{c}\text { LNI2 (30mL: } 15 \mathrm{~L}: 7 \mathrm{~mL} \\
\text { etanol) }\end{array}$ & 52 & 354 & 87 & 0 & 228 & 185 & 149 & 305 \\
\hline \multirow[t]{7}{*}{5} & $\begin{array}{c}\text { LNI2 (30mL:15L:7mL } \\
\text { etanol) }\end{array}$ & 57 & 356 & 79 & 0 & 136 & 183 & 126 & 205 \\
\hline & $\begin{array}{c}\text { LN12 (30mL:15L:7mL } \\
\text { etanol) }\end{array}$ & 57 & 361 & 61 & 0 & 215 & 167 & 152 & 317 \\
\hline & $\begin{array}{l}\text { LNI2 (30mL:15L:7mL } \\
\text { etanol) }\end{array}$ & 57 & 364 & 79 & 33 & 295 & 176 & 249 & 416 \\
\hline & $\begin{array}{l}\text { LNI2 (30mL: } 15 \mathrm{~L}: 7 \mathrm{~mL} \\
\text { etanol) }\end{array}$ & 57 & 368 & 69 & 0 & 222 & 172 & 156 & 332 \\
\hline & $\begin{array}{l}\text { LNI2 (30mL: } 15 \mathrm{~L}: 7 \mathrm{~mL} \\
\text { etanol) }\end{array}$ & 57 & 375 & 39 & 0 & 123 & 118 & 126 & 201 \\
\hline & $\begin{array}{c}\text { LNI2 (30mL:15L:7mL } \\
\text { etanol) }\end{array}$ & 57 & 382 & 57 & 5 & 182 & 154 & 154 & 283 \\
\hline & $\begin{array}{c}\text { LN12 (30mL:15L:7mL } \\
\text { etanol) }\end{array}$ & 57 & 390 & 54 & 47 & 230 & 133 & 215 & 359 \\
\hline
\end{tabular}


TABELA A19. Composição do biogás do reator UASB monitorada na fase mesofilica: $1^{\underline{a}}$ a $3^{\underline{a}}$ etapa.

\begin{tabular}{|c|c|c|c|c|c|c|c|c|c|}
\hline \multirow{2}{*}{ 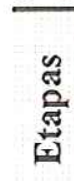 } & \multirow[t]{2}{*}{$\begin{array}{c}\text { Tipo de licore } \\
\text { volume }\end{array}$} & \multirow[t]{2}{*}{$\begin{array}{c}\mathrm{T} \\
\left({ }^{0} \mathrm{C}\right)\end{array}$} & \multirow[t]{2}{*}{$\begin{array}{l}\text { Tempo } \\
\text { (dia) }\end{array}$} & \multicolumn{3}{|c|}{$\begin{array}{l}\text { Alcalinidade parcial } \\
\qquad\left(\mathrm{mg} . \mathrm{L}^{-1}\right)\end{array}$} & \multicolumn{3}{|c|}{$\begin{array}{l}\text { Alcalinidade total } \\
\text { filtrada }\left(\mathrm{mg} \cdot \mathrm{L}^{-1}\right)\end{array}$} \\
\hline & & & & ARS & e-UASB & e-LA & ARS & e-UASB & e-LA \\
\hline 1 & $\begin{array}{c}\text { LNC } \\
(14 \mathrm{~mL}: 10 \mathrm{~L})\end{array}$ & 25 & 22 & 43 & 55 & 2 & 9,2 & 11,7 & 0,8 \\
\hline \multirow[t]{16}{*}{2} & $\begin{array}{c}\text { LNC } \\
\text { (20ML:10L) }\end{array}$ & 25 & 28 & 62 & 36 & 1 & 13,2 & 7,9 & 0,7 \\
\hline & $\begin{array}{c}\text { LNC } \\
\text { (20ML:10L) }\end{array}$ & 25 & 33 & 35 & 63 & 2 & 7,9 & 14,1 & 0,9 \\
\hline & LNC & & & & & & & & \\
\hline & $\begin{array}{c}\text { (20ML:10L) } \\
\text { LNC }\end{array}$ & 25 & 35 & 43 & 56 & 2 & 8,1 & 10,5 & 0,7 \\
\hline & (25mL:10L) & 25 & 40 & 38 & 60 & 2 & 7,1 & 10,9 & 0,8 \\
\hline & (25mL:10L) & 25 & 42 & 54 & 45 & 1 & 11,3 & 9,5 & 0,7 \\
\hline & LNC & & & & & & & & \\
\hline & (25mL:10L) & 25 & 47 & 20 & 75 & 4 & 4,6 & 16,0 & 1,4 \\
\hline & $\begin{array}{c}\text { LNC } \\
(25 \mathrm{~mL}: 10 \mathrm{~L})\end{array}$ & 25 & 49 & 19 & 77 & 4 & 3,9 & 14,4 & 1,1 \\
\hline & LNC & & & & & & & & \\
\hline & (25mL:10L) & 25 & 51 & 59 & 39 & 2 & 10,2 & 6,8 & 0,7 \\
\hline & (25mL:10L) & 25 & 54 & 21 & 74 & 5 & 4,0 & 12,6 & 1,2 \\
\hline & $\begin{array}{c}\text { LNC } \\
(25 \mathrm{~mL}: 10 \mathrm{~L})\end{array}$ & 25 & 56 & 39 & 58 & 3 & 5.8 & 138 & 11 \\
\hline & LNC & & & & & & & & 1,1 \\
\hline & (25mL:10L) & 25 & 58 & 31 & 66 & 3 & 5,1 & 10,2 & 0,9 \\
\hline & $\begin{array}{c}\text { LNC } \\
\text { (25mL:10L) }\end{array}$ & 25 & 61 & 20 & 76 & 4 & 4,0 & 14,1 & 1,2 \\
\hline \multirow{18}{*}{3} & LNI1 & & & & & & & & \\
\hline & $\begin{array}{c}\text { (50mL:10L) } \\
\text { LNI1 }\end{array}$ & 25 & 70 & 22 & 71 & 7 & 5,4 & 16,5 & 2,1 \\
\hline & $\begin{array}{c}\text { (50mL:10L) } \\
\text { LNI1 }\end{array}$ & 25 & 72 & 29 & 66 & 5 & 5,5 & 11,9 & 1,3 \\
\hline & (50mL:10L) & 25 & 75 & 20 & 74 & 6 & 4,6 & 16,0 & 1,7 \\
\hline & $\begin{array}{c}\text { LNI1 } \\
\text { (50mL:10L) }\end{array}$ & 25 & 77 & 31 & 64 & 4 & 6.6 & 13,2 & 13 \\
\hline & $\begin{array}{c}\text { (50mL:10L) } \\
\text { LNI1 }\end{array}$ & & & & & & & & \\
\hline & (50mL:10L) & 25 & 78 & 34 & 62 & 4 & 8,9 & 15,9 & 1,5 \\
\hline & $\begin{array}{c}\text { LNI1 } \\
\text { (50mL:10L) }\end{array}$ & 25 & 82 & 6 & 48 & 46 & 0,5 & 1,0 & 1,1 \\
\hline & LNII & & & & & & & & \\
\hline & (50mL:10L) & 25 & 84 & 13 & 81 & 6 & 3,4 & 19,2 & 1,9 \\
\hline & $\begin{array}{c}\text { LNIl } \\
\text { (50mL:10L) }\end{array}$ & 25 & 89 & 18 & 76 & 6 & 3,9 & 15,2 & 1,6 \\
\hline & LNI1 & & & & & & & & \\
\hline & $\begin{array}{c}\text { (50mL:10L) } \\
\text { LNII }\end{array}$ & 25 & 91 & 29 & 67 & 4 & 6,2 & 13,8 & 1,3 \\
\hline & (50mL:10L) & 26 & 98 & 20 & 76 & 4 & 4,0 & 14,1 & 1,2 \\
\hline & $\begin{array}{c}\text { LNI1 } \\
\text { (50mL:10L) }\end{array}$ & 27 & 104 & 55 & 43 & 2 & 11,2 & 8,8 & 0.9 \\
\hline & LNI1 & & & & & & & & \\
\hline & (50mL:10L) & 25 & 117 & 17 & 78 & 6 & 3,7 & 18,5 & 1,0 \\
\hline & (50mL:10L) & 25 & 118 & 0 & 91 & 9 & 0,4 & 4,4 & 0,8 \\
\hline
\end{tabular}


TABELA A20. Composição do biogás do reator UASB monitorada na fase mesofílica: $4^{\mathrm{a}}$ a $8^{\mathrm{a}}$ etapa.

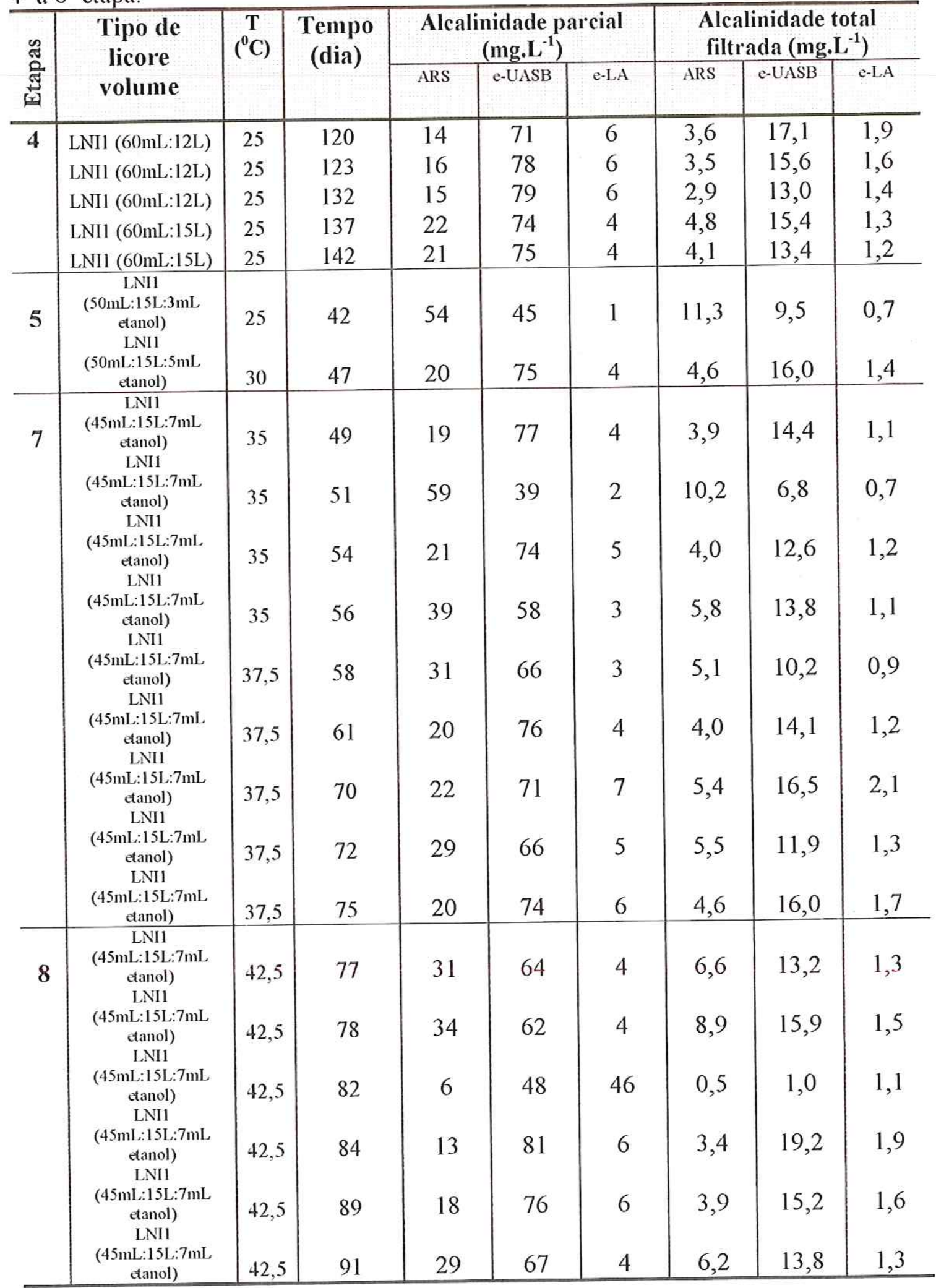


TABELA A21. Composição do biogás do reator UASB monitorada na fase termofilica: $1^{\mathrm{a}}$ a $5^{\mathrm{a}}$ etapa.

\begin{tabular}{|c|c|c|c|c|c|c|c|c|c|}
\hline \multirow{2}{*}{ 离 } & \multirow[t]{2}{*}{$\begin{array}{l}\text { Tipo de licore } \\
\text { volume }\end{array}$} & \multirow[t]{2}{*}{$\begin{array}{c}\mathrm{T} \\
\left({ }^{0} \mathrm{C}\right)\end{array}$} & \multirow[t]{2}{*}{$\begin{array}{l}\text { Tempo } \\
\text { (dia) }\end{array}$} & \multicolumn{3}{|c|}{$\begin{array}{c}\text { Alcalinidade parcial } \\
\left(\mathrm{mg} . \mathrm{L}^{-1}\right)\end{array}$} & \multicolumn{3}{|c|}{$\begin{array}{l}\text { Alcalinidade total } \\
\text { filtrada }\left(\mathrm{mg} . \mathrm{L}^{-1}\right)\end{array}$} \\
\hline & & & & ARS & e-UASB & e-LA & ARS & e-UASB & $e-L A$ \\
\hline \multirow[t]{4}{*}{1} & \multirow{4}{*}{$\begin{array}{c}\text { LNII (45mL: } 15 \mathrm{~L}: 7 \mathrm{~mL} \\
\text { etanol) } \\
\text { LNII (45mL: } 15 \mathrm{~L}: 7 \mathrm{~mL} \\
\text { etanol) } \\
\text { LNII (45mL:15L:7mL } \\
\text { etanol) } \\
\text { LNII (45mL: } 15 \mathrm{~L}: 7 \mathrm{~mL} \\
\text { etanol) }\end{array}$} & 45 & 245 & 15 & 78 & 7 & 3,5 & 16,2 & 1,9 \\
\hline & & 45 & 250 & 14 & 77 & 9 & 3,8 & 19,4 & 2,7 \\
\hline & & 45 & 252 & 14 & 76 & 9 & 3,0 & 14,2 & 2,1 \\
\hline & & 45 & 257 & 23 & 69 & 7 & 5,6 & 15,9 & 2,1 \\
\hline \multirow[t]{2}{*}{3} & \multirow{2}{*}{\begin{tabular}{|c|} 
LNI1 (45mL: $15 \mathrm{~L}: 7 \mathrm{~mL}$ \\
etanol) \\
LNI1 \\
$\begin{array}{c}(45 \mathrm{~mL}: 15 \mathrm{~L}: 7 \mathrm{~mL} \\
\text { etanol) }\end{array}$
\end{tabular}} & 52 & 293 & 53 & 43 & 4 & 11,8 & 9,6 & 1,2 \\
\hline & & 52 & 298 & 99 & 0 & 1 & 23,5 & 0,4 & 0,7 \\
\hline \multirow[t]{5}{*}{4} & \multirow{5}{*}{ 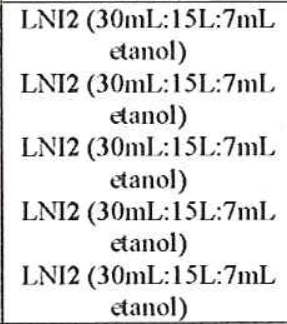 } & 52 & 305 & 94 & 5 & 1 & 22,6 & 1,6 & 0,7 \\
\hline & & 52 & 315 & 96 & 3 & 1 & 25,0 & 1,3 & 0,6 \\
\hline & & 52 & 321 & 83 & 15 & 2 & 18,4 & 3,8 & 0,9 \\
\hline & & 52 & 326 & 82 & 15 & 3 & 18,3 & 3,7 & 1,0 \\
\hline & & 52 & 328 & 78 & 19 & 3 & 22,3 & 5,8 & 1,2 \\
\hline \multirow[t]{10}{*}{5} & $\begin{array}{c}\text { LNI2 (30mL:15L:7mL } \\
\text { etanol) }\end{array}$ & 52 & 354 & 36 & 61 & 3 & 8,1 & 13,6 & 1,1 \\
\hline & $\begin{array}{l}\text { LN12 (30mL:15L:7mL } \\
\text { etanol) }\end{array}$ & 52 & 356 & 51 & 47 & 2 & 11,7 & 10,8 & 1,0 \\
\hline & $\begin{array}{l}\text { LNI2 (30mL:15L:7mL } \\
\text { etanol) }\end{array}$ & 57 & 357 & 69 & 28 & 3 & 17,4 & 7,4 & 1,3 \\
\hline & $\begin{array}{l}\text { LN12 (30mL:15L:7mL } \\
\text { etanol) }\end{array}$ & 57 & 362 & 54 & 44 & 2 & 12,4 & 10,1 & 1,0 \\
\hline & $\begin{array}{l}\text { LNI2 (30mL:15L:7mL } \\
\text { etanol) }\end{array}$ & 57 & 365 & 95 & 4 & 0 & 12,0 & 1,0 & 0,5 \\
\hline & $\begin{array}{c}\mathrm{LNI2}(30 \mathrm{~mL}: 15 \mathrm{~L}: 7 \mathrm{~mL} \\
\text { etanol) }\end{array}$ & 57 & 368 & 52 & 44 & 4 & 12,1 & 10,4 & 1,3 \\
\hline & $\begin{array}{c}\text { LNI2 (30mL:15L:7mL } \\
\text { etanol) }\end{array}$ & 57 & 381 & 32 & 62 & 7 & 7,0 & 13,0 & 1,8 \\
\hline & $\begin{array}{l}\text { LNI2 (30mL:15L:7mL } \\
\text { etanol) }\end{array}$ & 57 & 382 & 23 & 70 & 8 & 5,1 & 14,7 & 2,0 \\
\hline & $\begin{array}{l}\text { LNI2 (30mL:15L:7mL } \\
\text { etanol) }\end{array}$ & 57 & 390 & 96 & 3 & 1 & 22,9 & 1,1 & 0,7 \\
\hline & $\begin{array}{l}\text { LN12 (30mL:15L:7mL } \\
\text { etanol) }\end{array}$ & 57 & 402 & 94 & 1 & 1 & 21,6 & 0,7 & 0,6 \\
\hline
\end{tabular}


TABELA A22. Sólidos totais, sólidos totais voláteis e sólidos totais fixos na água residuária sintética e efluente dos reatores anaeróbio e aeróbio: fase mesofilica ( $4^{\mathrm{a}}$ etapa a $8^{\text {a }}$ etapa) e fase termofilica ( $1^{\text {a }}$ etapa).

\begin{tabular}{|c|c|c|c|c|c|c|c|c|c|c|c|}
\hline \multirow[b]{2}{*}{ n } & \multirow[t]{2}{*}{ Tipo de licore volume } & \multirow{2}{*}{$\begin{array}{c}\text { Tempo } \\
\text { (dia) }\end{array}$} & \multicolumn{3}{|c|}{ ST } & \multicolumn{3}{|c|}{ STV } & \multicolumn{3}{|c|}{ STF } \\
\hline & & & ARS & $\begin{array}{c}\mathrm{e}- \\
\mathrm{UASB}\end{array}$ & $\mathrm{e}-\mathrm{LA}$ & ARS & $\begin{array}{c}\mathrm{e}- \\
\text { UASB }\end{array}$ & $\mathrm{e}-\mathrm{L} A$ & ARS & $\begin{array}{c}e \cdot \\
\text { UASB }\end{array}$ & e-LA \\
\hline 4 & $\begin{array}{c}\text { LNI1 (60mL:12L) } \\
\text { LNI1 (60mL:12L) } \\
\text { LNI1 (60mL:15L) } \\
\text { LNI1 (60mL:15L) } \\
\text { LNI1 (50mL:15L:5mL } \\
\text { etanol) }\end{array}$ & $\begin{array}{l}118 \\
130 \\
137 \\
146 \\
\\
158\end{array}$ & $\begin{array}{l}1831 \\
1829 \\
1521 \\
1044 \\
993 \\
\end{array}$ & $\begin{array}{l}1242 \\
1364 \\
1425 \\
786 \\
767 \\
\end{array}$ & $\begin{array}{l}1343 \\
1459 \\
1276 \\
1144 \\
771 \\
\end{array}$ & $\begin{array}{l}1210 \\
1248 \\
1003 \\
409 \\
598 \\
\end{array}$ & $\begin{array}{l}651 \\
715 \\
859 \\
401 \\
\\
378 \\
\end{array}$ & $\begin{array}{l}707 \\
816 \\
746 \\
700 \\
\\
360\end{array}$ & $\begin{array}{l}621 \\
581 \\
518 \\
635 \\
\\
395\end{array}$ & $\begin{array}{l}591 \\
649 \\
566 \\
385 \\
\\
389 \\
\end{array}$ & $\begin{array}{l}636 \\
643 \\
530 \\
444 \\
411 \\
\end{array}$ \\
\hline 6 & $\begin{array}{c}\text { LNI1 (50mL: } 15 \mathrm{~L}: 5 \mathrm{~mL} \\
\text { etanol) } \\
\text { LNI1 (55mL:15L:7mL } \\
\text { etanol) } \\
\text { LNI1 (55mL:15L:7mL } \\
\text { etanol) }\end{array}$ & $\begin{array}{l}160 \\
166 \\
168 \\
\end{array}$ & $\begin{array}{l}929 \\
1405 \\
1637 \\
\end{array}$ & $\begin{array}{r}928 \\
530 \\
1237 \\
\end{array}$ & $\begin{array}{l}1208 \\
1276 \\
728 \\
\end{array}$ & $\begin{array}{l}575 \\
851 \\
1096 \\
\end{array}$ & $\begin{array}{c}560 \\
317 \\
1067 \\
\end{array}$ & $\begin{array}{l}837 \\
746 \\
607 \\
\end{array}$ & $\begin{array}{l}354 \\
554 \\
541 \\
\end{array}$ & $\begin{array}{l}368 \\
213 \\
509 \\
\end{array}$ & $\begin{array}{l}371 \\
530 \\
460 \\
\end{array}$ \\
\hline 7 & $\begin{array}{c}\text { LNI1 (55mL:15L:7mL } \\
\text { etanol) } \\
\text { LNI1 (45mL:15L:7mL } \\
\text { etanol) } \\
\text { LNI1 (45mL:15L:7mL } \\
\text { etanol) } \\
\text { LNI1 (45mL:15L:7mL } \\
\text { etanol) } \\
\text { LNI1 (45mL: } 15 \mathrm{~L}: 7 \mathrm{~mL} \\
\text { etanol) } \\
\text { LNI1 (45mL: } 15 \mathrm{~L}: 7 \mathrm{~mL} \\
\text { etanol) }\end{array}$ & $\begin{array}{l}172 \\
180\end{array}$ & $\begin{array}{l}1646 \\
2985 \\
512 \\
771 \\
910 \\
1052 \\
\end{array}$ & $\begin{array}{c}793 \\
2363 \\
532 \\
890 \\
1001 \\
99 \\
\end{array}$ & $\begin{array}{l}492 \\
1241 \\
498 \\
1071 \\
417 \\
906 \\
\end{array}$ & $\begin{array}{l}1358 \\
2596 \\
353 \\
443 \\
550 \\
473 \\
\end{array}$ & $\begin{array}{c}633 \\
1988 \\
384 \\
494 \\
584 \\
49 \\
\end{array}$ & $\begin{array}{l}338 \\
829 \\
326 \\
713 \\
221 \\
332 \\
\end{array}$ & $\begin{array}{l}288 \\
389 \\
159 \\
328 \\
360 \\
579 \\
\end{array}$ & $\begin{array}{l}160 \\
375 \\
147 \\
396 \\
417 \\
51 \\
\end{array}$ & $\begin{array}{l}154 \\
412 \\
172 \\
358 \\
196 \\
574 \\
\end{array}$ \\
\hline 8 & $\begin{array}{c}\text { LNI1 (45mL:15L:7mL } \\
\text { etanol) } \\
\text { LNI1 (45mL:15L:7mL } \\
\text { etanol) } \\
\text { LNI1 (45mL:15L:7mL } \\
\text { etanol) } \\
\text { LNI1 (45mL:15L:7mL } \\
\text { etanol) } \\
\text { LNI1 (45mL: } 15 \mathrm{~L}: 7 \mathrm{~mL} \\
\text { etanol) } \\
\end{array}$ & $\begin{array}{l}235 \\
239 \\
245 \\
\end{array}$ & $\begin{array}{l}1057 \\
1057 \\
847 \\
1151 \\
1143 \\
\end{array}$ & $\begin{array}{l}896 \\
863 \\
732 \\
884 \\
942 \\
\end{array}$ & $\begin{array}{l}788 \\
855 \\
807 \\
751 \\
921 \\
\end{array}$ & $\begin{array}{l}712 \\
687 \\
413 \\
843 \\
709 \\
\end{array}$ & $\begin{array}{l}541 \\
560 \\
280 \\
574 \\
471 \\
\end{array}$ & $\begin{array}{l}420 \\
487 \\
439 \\
454 \\
426 \\
\end{array}$ & $\begin{array}{l}345 \\
370 \\
433 \\
308 \\
434 \\
\end{array}$ & $\begin{array}{l}355 \\
303 \\
452 \\
310 \\
471 \\
\end{array}$ & $\begin{array}{l}368 \\
368 \\
368 \\
297 \\
496 \\
\end{array}$ \\
\hline 1 & $\begin{array}{c}\text { LNI1 (45mL: } 15 \mathrm{~L}: 7 \mathrm{~mL} \\
\text { etanol) } \\
\text { LNII (45mL:15L:7mL } \\
\text { etanol) } \\
\text { LNII (45mL:15L:7mL } \\
\text { danol) } \\
\end{array}$ & $\begin{array}{l}250 \\
252 \\
257 \\
\end{array}$ & $\begin{array}{l}1126 \\
1220 \\
2136 \\
\end{array}$ & $\begin{array}{c}886 \\
1019 \\
2077 \\
\end{array}$ & $\begin{array}{c}983 \\
882 \\
1209 \\
\end{array}$ & $\begin{array}{r}772 \\
793 \\
1621 \\
\end{array}$ & $\begin{array}{c}515 \\
550 \\
1580 \\
\end{array}$ & $\begin{array}{l}649 \\
455 \\
679 \\
\end{array}$ & $\begin{array}{l}354 \\
428 \\
515 \\
\end{array}$ & $\begin{array}{r}371 \\
469 \\
497 \\
\end{array}$ & $\begin{array}{r}334 \\
427 \\
530 \\
\end{array}$ \\
\hline
\end{tabular}


TABELA A23. Sólidos totais, sólidos totais voláteis e sólidos totais fixos na água residuária sintética e efluente dos reatores anaeróbio e aeróbio: fase termofilica $\left(2^{\mathrm{a}}\right.$ a $5^{\mathrm{a}}$ etapa).

\begin{tabular}{|c|c|c|c|c|c|c|c|c|c|c|c|}
\hline \multirow{2}{*}{ " } & \multirow[t]{2}{*}{ Tipo de licore volume } & \multirow{2}{*}{$\begin{array}{c}\text { Tempo } \\
\text { (dia) }\end{array}$} & \multicolumn{3}{|c|}{$\overline{\text { ST }}$} & \multicolumn{3}{|c|}{$\overline{\text { STV }}$} & \multicolumn{3}{|c|}{ STF } \\
\hline & & & ARS & UASB & e-LA & ARS & UASB & e-LA & ARS & $\begin{array}{l}\text { e- } \\
\text { UASB }\end{array}$ & e-LA \\
\hline \multirow[t]{3}{*}{2} & $\begin{array}{l}\text { LNI1 (45mL:15L:7mL } \\
\text { etanol) }\end{array}$ & 259 & 1660 & 965 & 1091 & 1363 & 542 & 550 & 297 & 423 & 541 \\
\hline & etanol) & 264 & 1269 & 901 & 2373 & 798 & 522 & 2044 & 471 & 379 & 330 \\
\hline & $\begin{array}{c}\mathrm{LNII}(45 \mathrm{~mL}: 15 \mathrm{~L}: 7 \mathrm{~mL} \\
\text { etanol) }\end{array}$ & 266 & 1381 & 1259 & 811 & 821 & 674 & 405 & 560 & 585 & 406 \\
\hline \multirow[t]{2}{*}{3} & $\begin{array}{l}\text { LNI1 (45mL:15L:7mL } \\
\text { etanol) }\end{array}$ & 291 & 1218 & 1128 & 907 & 826 & 688 & 470 & 392 & 440 & 436 \\
\hline & etanol) & 293 & 1665 & 1875 & 1306 & 671 & 841 & 367 & 994 & 1034 & 939 \\
\hline \multirow[t]{11}{*}{4} & $\begin{array}{l}\text { LNI2 (30mL:15L:7mL } \\
\text { etanol) }\end{array}$ & 298 & 1308 & 746 & 1489 & 588 & 477 & 854 & 720 & 269 & 635 \\
\hline & $\begin{array}{c}\mathrm{LNI2} \text { (30mL:15L: } 7 \mathrm{~mL} \\
\text { etanol) }\end{array}$ & 300 & 872 & 1589 & 1229 & 566 & 1140 & 745 & 306 & 449 & 484 \\
\hline & $\begin{array}{l}\text { LN12 (30mL:15L:7mL } \\
\text { etanol) }\end{array}$ & 305 & 1214 & 1090 & 1055 & 802 & 734 & 593 & 412 & 356 & 462 \\
\hline & $\begin{array}{c}\text { LNI2 (30mL:15L:7mL } \\
\text { etanol) }\end{array}$ & 308 & 749 & 1272 & 783 & 430 & 863 & 344 & 319 & 409 & 439 \\
\hline & $\begin{array}{c}\text { LNI2 (30mL:15L:7mL } \\
\text { etanol) }\end{array}$ & 312 & 444 & 924 & 945 & 373 & 564 & 460 & 71 & 360 & 485 \\
\hline & LNI2 (30mL:15L:7mL & & & & & & & & & & \\
\hline & etanol) & 315 & 1600 & 1630 & 1116 & 1048 & 988 & 556 & 552 & 642 & 560 \\
\hline & $\begin{array}{c}\mathrm{LN} 12 \text { (30mLL:15L:7mL } \\
\text { etanol) }\end{array}$ & 326 & 825 & 865 & 785 & 419 & 349 & 288 & 406 & 516 & 497 \\
\hline & $\begin{array}{c}\text { LNI2 (30mL:15L:7mL } \\
\text { etanol) }\end{array}$ & 328 & 955 & 1049 & 959 & 488 & 646 & 578 & 467 & 403 & 381 \\
\hline & $\begin{array}{c}\text { LNI2 (30mL:15L:7mL } \\
\text { etanol) }\end{array}$ & 334 & 791 & 845 & 760 & 532 & 570 & 353 & 259 & 275 & 407 \\
\hline & $\begin{array}{c}\text { LNI2 (30mL:15L:7mL } \\
\text { etanol) }\end{array}$ & & 843 & & 944 & 395 & 466 & 361 & 448 & 741 & 583 \\
\hline \multirow{9}{*}{5} & LNI2 (30mL:15L:7mL & & & & & & & & & & \\
\hline & etanol) & 354 & 815 & 821 & 907 & 458 & 421 & 442 & 357 & 400 & 465 \\
\hline & $\begin{array}{c}\text { LNIL (30mLis: } \\
\text { etanol) }\end{array}$ & 357 & 979 & 851 & 855 & 576 & 449 & 461 & 403 & 402 & 394 \\
\hline & LNI2 (30mL:15L:7mL & & 1072 & & & & & & 1034 & & \\
\hline & etanol) & 362 & 6 & 857 & 951 & 380 & 441 & 473 & 6 & 416 & 478 \\
\hline & $\begin{array}{c}\text { LNI2 (30mL:15L:7mL } \\
\text { etanol) }\end{array}$ & 365 & 705 & 1262 & 1132 & 338 & 742 & 437 & 367 & 520 & 695 \\
\hline & $\begin{array}{c}\text { LNI2 (30mL:15L:7mL } \\
\text { etanol) }\end{array}$ & 367 & 981 & 479 & 1032 & 564 & 191 & 440 & 417 & 288 & 592 \\
\hline & $\begin{array}{c}\text { LNI2 (30mL:15L:7mL } \\
\text { etanol) }\end{array}$ & 374 & 839 & 1021 & 957 & 485 & 631 & 499 & 354 & 390 & 458 \\
\hline & $\begin{array}{c}\text { LNI2 (30mL:15L:7mL } \\
\text { etanol) }\end{array}$ & 381 & 843 & 1079 & 971 & 26 & 29 & 6 & 817 & 1050 & 965 \\
\hline
\end{tabular}


TABELA A24. Diferença entre o afluente e efluente dos reatores anaeróbio e aeróbio em relação a sólidos totais, sólidos totais voláteis e sólidos totais fixos: fase mesofilica ( $4^{\mathrm{a}}$ etapa a $8^{\mathrm{a}}$ etapa $)$ e fase termofilica ( $1^{\mathrm{a}}$ etapa).

\begin{tabular}{|c|c|c|c|c|c|c|c|c|c|}
\hline \multirow[b]{2}{*}{ in } & \multirow[t]{2}{*}{ Tipo de licore volume } & \multirow{2}{*}{$\begin{array}{c}\mathrm{T} \\
\left({ }^{0} \mathrm{C}\right)\end{array}$} & \multirow{2}{*}{$\begin{array}{c}\text { Tempo } \\
\text { (dia) }\end{array}$} & \multicolumn{2}{|c|}{ ST } & \multicolumn{2}{|c|}{ STV } & \multicolumn{2}{|c|}{ STF } \\
\hline & & & & e-UASB & e-LA & e-UASB & e-LA & e-UASB & e-LA \\
\hline \multirow[t]{4}{*}{4} & LNI1 (60mL:12L) & 25 & 118 & 589 & -101 & 559 & -56 & 30 & -45 \\
\hline & LNII (60mL:12L) & 25 & 130 & 465 & -95 & 533 & -101 & -68 & 6 \\
\hline & LNI1 (60mL:15L) & 25 & 137 & 96 & 149 & 144 & 113 & -48 & 36 \\
\hline & LNI1 (60mL:15L) & 25 & 146 & 258 & -358 & 8 & -299 & 250 & -59 \\
\hline 5 & $\begin{array}{c}\text { LNI1 (50mL:15L:5mL } \\
\text { etanol) }\end{array}$ & 30 & 158 & 226 & -4 & 220 & 18 & 6 & -22 \\
\hline \multirow[t]{3}{*}{6} & $\begin{array}{c}\text { LNI1 (50mL: } 15 \mathrm{~L}: 5 \mathrm{~mL} \\
\text { etanol) }\end{array}$ & 32,5 & 160 & 1 & -280 & 15 & -277 & -14 & -3 \\
\hline & $\begin{array}{c}\text { LNI1 (55mL:15L:7mL } \\
\text { etanol) }\end{array}$ & 32,5 & 166 & 874 & -746 & 534 & -429 & 341 & -317 \\
\hline & $\begin{array}{c}\text { LNI1 (55mL:15L:7mL } \\
\text { etanol) }\end{array}$ & 32,5 & 168 & 400 & 509 & 29 & 460 & 32 & 49 \\
\hline \multirow[t]{6}{*}{7} & $\begin{array}{c}\text { LNII (55mL:15L:7mL } \\
\text { etanol) }\end{array}$ & 35 & 172 & 853 & 301 & 725 & 295 & 128 & 5 \\
\hline & $\begin{array}{c}\text { LNII (45mL:15L:7mL } \\
\text { etanol) }\end{array}$ & 35 & 180 & 622 & 1122 & 608 & 1159 & 14 & -37 \\
\hline & $\begin{array}{c}\text { LNII (45mL:15L:7mL } \\
\text { ctanol) }\end{array}$ & 35 & 186 & -20 & 34 & -32 & 58 & 12 & -24 \\
\hline & $\begin{array}{c}\text { LNII (45mL:15L:7mL } \\
\text { etanol) }\end{array}$ & 37,5 & 201 & -119 & -181 & -51 & -219 & -68 & 38 \\
\hline & $\begin{array}{c}\text { LNII (45mL:15L:7mL } \\
\text { etanol) }\end{array}$ & 37,5 & 203 & -91 & 584 & -34 & 363 & -57 & 221 \\
\hline & $\begin{array}{c}\text { LNI1 (45mL: } 15 \mathrm{~L}: 7 \mathrm{~mL} \\
\text { etanol) }\end{array}$ & 37,5 & 207 & 953 & -807 & 424 & -283 & 528 & -523 \\
\hline \multirow[t]{5}{*}{8} & $\begin{array}{c}\text { LNII (45mL:15L:7mL } \\
\text { etanol) }\end{array}$ & 42,5 & 215 & 161 & 108 & 171 & 121 & -10 & -13 \\
\hline & $\begin{array}{c}\text { LNI1 (45mL:15L:7mL } \\
\text { etanol) }\end{array}$ & 42,5 & 232 & 194 & 8 & 127 & 73 & 67 & -65 \\
\hline & $\begin{array}{c}\text { LNI1 (45mL:15L:7mL } \\
\text { etanol) }\end{array}$ & 42,5 & 235 & 114 & -75 & 133 & -159 & -19 & 84 \\
\hline & $\begin{array}{c}\text { LNI1 (45mL:15L:7mL } \\
\text { etanol) }\end{array}$ & 42,5 & 239 & 267 & 133 & 269 & 120 & -2 & 13 \\
\hline & $\begin{array}{c}\text { LNI1 (45mL:15L:7mL } \\
\text { etanol) }\end{array}$ & 42,5 & 245 & 201 & 21 & 238 & 46 & -37 & -25 \\
\hline \multirow[t]{3}{*}{1} & $\begin{array}{c}\text { LNII (45mL:15L:7mL } \\
\text { etanol) }\end{array}$ & 45 & 250 & 240 & -97 & 257 & -134 & -17 & 37 \\
\hline & 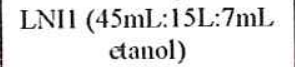 & 45 & 252 & 201 & 136 & 243 & 95 & -41 & 41 \\
\hline & $\begin{array}{c}\mathrm{LNI1}(45 \mathrm{~mL}: 15 \mathrm{~L}: 7 \mathrm{~mL} \\
\text { etanol })\end{array}$ & 45 & 257 & 59 & 869 & 41 & 901 & 18 & -33 \\
\hline
\end{tabular}


TABELA A25. Diferença entre o afluente e efluente dos reatores anaeróbio e aeróbio em relação a sólidos totais, sólidos totais voláteis e sólidos totais fixos: fase termofílica ( $2^{\mathrm{a}}$ a $5^{\mathrm{a}}$ etapa).

\begin{tabular}{|c|c|c|c|c|c|c|c|c|c|}
\hline \multirow{2}{*}{ os } & \multirow[t]{2}{*}{ Tipo de licore volume } & \multirow{2}{*}{$\begin{array}{c}\mathrm{T} \\
\left({ }^{0} \mathrm{C}\right)\end{array}$} & \multirow{2}{*}{$\begin{array}{c}\text { Tempo } \\
\text { (dia) }\end{array}$} & \multicolumn{2}{|c|}{ ST } & \multicolumn{2}{|c|}{ STV } & \multicolumn{2}{|c|}{ STF } \\
\hline & & & & e-UASB & e-LA & e-UASB & e-LA & e-UASB & e-LA \\
\hline \multirow[t]{3}{*}{2} & $\begin{array}{c}\text { LNI1 (45mL:15L:7mL } \\
\text { etanol) }\end{array}$ & 47,5 & 264 & 367 & -1472 & 276 & -1522 & 92 & 50 \\
\hline & $\begin{array}{c}\text { LNII (45mL: } 15 \mathrm{~L}: 7 \mathrm{~mL} \\
\text { etanol) }\end{array}$ & 47,5 & 266 & 122 & 448 & 147 & 269 & -25 & 179 \\
\hline & $\begin{array}{l}\text { LN11 (45mL: } 15 \mathrm{~L}: 7 \mathrm{~mL} \\
\text { etanol) }\end{array}$ & 47,5 & 291 & 89 & 222 & 138 & 218 & -48 & 4 \\
\hline \multirow[t]{2}{*}{3} & $\begin{array}{c}\text { LN11 (45mL:15L:7mL } \\
\text { etanol) }\end{array}$ & 52 & 293 & -210 & 569 & -170 & 474 & -40 & 95 \\
\hline & $\begin{array}{c}\text { LNI1 (45mL: } 15 \mathrm{~L}: 7 \mathrm{~mL} \\
\text { etanol) }\end{array}$ & 52 & 298 & 562 & -743 & 111 & -377 & 451 & -366 \\
\hline \multirow[t]{10}{*}{4} & $\begin{array}{c}\text { LN12 (30mL:15L:7mL } \\
\text { etanol) }\end{array}$ & 52 & 300 & -717 & 360 & -574 & 395 & -143 & -35 \\
\hline & $\begin{array}{l}\text { LNI2 (30mL:15L:7mL } \\
\text { eanol) }\end{array}$ & 52 & 305 & 124 & 35 & 68 & 141 & 56 & -106 \\
\hline & $\begin{array}{l}\text { LNI2 (30mL: } 15 \mathrm{~L}: 7 \mathrm{~mL} \\
\text { etanol) }\end{array}$ & 52 & 308 & -523 & 489 & -433 & 519 & -90 & -30 \\
\hline & $\begin{array}{c}\text { LN12 (30mL:15L:7mL } \\
\text { etanol) }\end{array}$ & 52 & 312 & -480 & -21 & -191 & 104 & -289 & -125 \\
\hline & $\begin{array}{l}\text { LNI2 (30mL: } 15 \mathrm{~L}: 7 \mathrm{~mL} \\
\text { danol) }\end{array}$ & 52 & 315 & -30 & 514 & 60 & 432 & -90 & 82 \\
\hline & $\begin{array}{c}\text { LN12 (30mL:15L:7mL } \\
\text { etanol) }\end{array}$ & 52 & 326 & -40 & 80 & 70 & 61 & -110 & 19 \\
\hline & $\begin{array}{c}\text { LN12 (30mL:15L:7mL } \\
\text { eanol) }\end{array}$ & 52 & 328 & -94 & 90 & -158 & 68 & 64 & 22 \\
\hline & $\begin{array}{l}\text { LNI2 (30mL: } 15 \mathrm{~L}: 7 \mathrm{~mL} \\
\text { etanol) }\end{array}$ & 52 & 334 & -54 & 85 & -38 & 217 & -16 & -132 \\
\hline & $\begin{array}{c}\text { LN12 (30mL:15L:7mL } \\
\text { etanol) }\end{array}$ & 52 & 336 & -364 & 263 & -71 & 105 & -293 & 158 \\
\hline & $\begin{array}{c}\text { LNI2 (30mL:15L:7mL } \\
\text { etanol) }\end{array}$ & 52 & 354 & -6 & -86 & 37 & -21 & -43 & -65 \\
\hline \multirow[t]{7}{*}{5} & $\begin{array}{c}\text { LN12 (30mL:15L:7mL } \\
\text { etanol) }\end{array}$ & 57 & 357 & 128 & -4 & 127 & -12 & 1 & 8 \\
\hline & $\begin{array}{c}\mathrm{LN} 12 \text { (30mL:15L:7mL } \\
\text { etanol) }\end{array}$ & 57 & 362 & 9869 & -94 & -61 & -32 & 9930 & -62 \\
\hline & $\begin{array}{c}\text { LN12 (30mL: } 15 \mathrm{~L}: 7 \mathrm{~mL} \\
\text { eanol) }\end{array}$ & 57 & 365 & -557 & 130 & -404 & 305 & -153 & -175 \\
\hline & $\begin{array}{c}\text { LNI2 (30mL:15L:7mL } \\
\text { etanol) }\end{array}$ & 57 & 367 & 502 & -553 & 373 & -249 & 129 & -304 \\
\hline & $\begin{array}{c}\text { LNI2 (30mL:15L:7mL } \\
\text { etanol) }\end{array}$ & 57 & 374 & -182 & 64 & -146 & 132 & -36 & -68 \\
\hline & $\begin{array}{l}\text { LNI2 (30mL: } 15 \mathrm{~L}: 7 \mathrm{~mL} \\
\text { etanol) }\end{array}$ & 57 & 381 & -236 & 108 & -3 & 23 & -233 & 85 \\
\hline & $\begin{array}{c}\text { LN12 (30mL: } 15 \mathrm{~L}: 7 \mathrm{~mL} \\
\text { tanol) }\end{array}$ & 57 & 389 & -293 & 45 & -235 & 220 & -58 & -175 \\
\hline
\end{tabular}


TABELA A26. Sólidos suspensos totais e voláteis na água residuária sintética e efluente dos reatores anaeróbio e aeróbio: fase mesofilica ( $4^{\mathrm{a}}$ etapa a $8^{\mathrm{a}}$ etapa) e fase termofílica ( $1^{\mathrm{a}}$ etapa).

\begin{tabular}{|c|c|c|c|c|c|c|c|c|}
\hline \multirow{2}{*}{ " } & \multirow[t]{2}{*}{ Tipo de licore volume } & \multirow{2}{*}{$\begin{array}{c}\text { Tempo } \\
\text { (dia) }\end{array}$} & \multicolumn{3}{|c|}{ SST } & \multicolumn{3}{|c|}{ SSTV } \\
\hline & & & ARS. & e-UASB & e-LA & ARS. & e-UASB & e-LA \\
\hline \multirow[t]{4}{*}{4} & LNII (60mL:12L) & 120 & 62 & 73 & 109 & 40 & 65 & 87 \\
\hline & LNI1 (60mL:12L) & 130 & 115 & 97 & 73 & 71 & 93 & 60 \\
\hline & LNII (60mL:15L) & 132 & 49 & 88 & 33 & 45 & 70 & 26 \\
\hline & LNII (60mL:15L) & 137 & 129 & 76 & 103 & 110 & 55 & 95 \\
\hline 5 & $\begin{array}{c}\text { LNII (50mL:15L:5mL } \\
\text { etanol) }\end{array}$ & 158 & 52 & 70 & 81 & 14 & 65 & 30 \\
\hline \multirow[t]{3}{*}{6} & $\begin{array}{l}\text { LNI1 (50mL: } 15 \mathrm{~L}: 5 \mathrm{~mL} \\
\text { etanol) }\end{array}$ & 161 & 51 & 83 & 22 & 39 & 80 & 16 \\
\hline & $\begin{array}{l}\text { LNII (55mL:15L:7mL } \\
\text { etanol) }\end{array}$ & 166 & 12 & 106 & 71 & 10 & 88 & 21 \\
\hline & $\begin{array}{l}\text { LNI1 (55mL:15L:7mL } \\
\text { etanol) }\end{array}$ & 168 & 26 & 106 & 40 & 19 & 74 & 12 \\
\hline \multirow[t]{6}{*}{7} & $\begin{array}{l}\text { LNI1 (55mL:15L:7mL } \\
\text { etanol) }\end{array}$ & 172 & 52 & 119 & 105 & 13 & 108 & 95 \\
\hline & $\begin{array}{l}\text { LNI1 (45mL:15L:7mL } \\
\text { etanol) }\end{array}$ & 174 & 41 & 115 & 89 & 19 & 102 & 69 \\
\hline & $\begin{array}{l}\text { LNI1 ( } 45 \mathrm{~mL}: 15 \mathrm{~L}: 7 \mathrm{~mL} \\
\text { etanol) }\end{array}$ & 180 & 388 & 103 & 490 & 374 & 56 & 452 \\
\hline & $\begin{array}{l}\text { LNI1 ( } \begin{array}{c}45 \mathrm{~mL}: 15 \mathrm{~L}: 7 \mathrm{~mL} \\
\text { etanol) }\end{array}\end{array}$ & 186 & 68 & 162 & 172 & 29 & 99 & 113 \\
\hline & $\begin{array}{c}\text { LNII }(45 \mathrm{~mL}: 15 \mathrm{~L}: 7 \mathrm{~mL} \\
\text { etanol) }\end{array}$ & 197 & 71 & 75 & 122 & 17 & 42 & 62 \\
\hline & $\begin{array}{c}\text { LNI1 (45mL: } 15 \mathrm{~L}: 7 \mathrm{~mL} \\
\text { etanol) }\end{array}$ & 201 & 69 & 61 & 83 & 60 & 53 & 71 \\
\hline \multirow[t]{5}{*}{8} & $\begin{array}{c}\text { LNII (45mL:15L:7mL } \\
\text { tanol) }\end{array}$ & 208 & 85 & 116 & 79 & 47 & 28 & 48 \\
\hline & $\begin{array}{l}\text { LNI1 (45mL: } 15 \mathrm{~L}: 7 \mathrm{~mL} \\
\text { etanol) }\end{array}$ & 215 & 43 & 96 & 36 & 25 & 79 & 21 \\
\hline & $\begin{array}{l}\text { LNI1 (45mL:15L:7mL } \\
\text { etanol) }\end{array}$ & 217 & 110 & 94 & 64 & 109 & 86 & 61 \\
\hline & $\begin{array}{c}\text { LNI1 (45mL:15L:7mL } \\
\text { etanol) }\end{array}$ & 232 & 87 & 118 & 99 & 48 & 77 & 50 \\
\hline & $\begin{array}{l}\text { LN11 (45mL:15L:7mL } \\
\text { etanol) }\end{array}$ & & 140 & 126 & 97 & 96 & 87 & 50 \\
\hline \multirow[t]{3}{*}{1} & $\begin{array}{c}\text { LNII (45mL:15L:7mL } \\
\text { etanol) }\end{array}$ & 245 & 48 & 66 & 35 & 35 & 50 & 27 \\
\hline & $\begin{array}{c}\text { LNII }(45 \mathrm{~mL}: 15 \mathrm{~L}: 7 \mathrm{~mL} \\
\text { etanol) }\end{array}$ & 250 & 72 & 89 & 83 & 38 & 68 & 18 \\
\hline & $\begin{array}{c}\text { LNII (45mL:15L:7mL } \\
\text { etanol) }\end{array}$ & 252 & 69 & 73 & 24 & 51 & 57 & 9 \\
\hline
\end{tabular}


TABELA A27. Sólidos suspensos totais e voláteis na água residuária sintética e efluente dos reatores anaeróbio e aeróbio: fase termofilica ( $2^{\mathrm{a}}$ a $5^{\mathrm{a}}$ etapa).

\begin{tabular}{|c|c|c|c|c|c|c|c|c|}
\hline \multirow[b]{2}{*}{ " } & \multirow{2}{*}{$\begin{array}{c}\text { Tipo de licore } \\
\text { volume }\end{array}$} & \multirow{2}{*}{$\begin{array}{c}\text { Tempo } \\
\text { (dia) }\end{array}$} & \multicolumn{3}{|c|}{ SST } & \multicolumn{3}{|c|}{ SSV } \\
\hline & & & ARS. & e-UASB & e-LA & ARS. & e-UASB & e-LA \\
\hline \multirow[t]{3}{*}{2} & $\begin{array}{c}\text { LN11 (45mL:15L:7mL } \\
\text { etanol) }\end{array}$ & 257 & 110 & 171 & 32 & 93 & 147. & 12 \\
\hline & $\begin{array}{c}\text { LN11 (45mL:15L:7mL } \\
\text { etanol) }\end{array}$ & 259 & 1005 & 108 & 110 & 899 & 83 & 70 \\
\hline & $\begin{array}{c}\text { LNII (45mL:15L:7mL } \\
\text { etanol) }\end{array}$ & 264 & 102 & 80 & 83 & 87 & 61 & 52 \\
\hline \multirow[t]{2}{*}{3} & $\begin{array}{l}\text { LNII (45mL: } 15 \mathrm{~L}: 7 \mathrm{~mL} \\
\text { etanol) }\end{array}$ & 266 & 316 & 265 & 74 & 242 & 207 & 48 \\
\hline & $\begin{array}{l}\text { LNI1 (45mL:15L:7mL } \\
\text { etanol) }\end{array}$ & 291 & 135 & 133 & 44 & 119 & 123 & 40 \\
\hline \multirow[t]{10}{*}{4} & $\begin{array}{c}\text { LNI2 (30mL:15L:7mL } \\
\text { etanol) }\end{array}$ & 293 & 105 & 101 & 102 & 55 & 4 & 29 \\
\hline & $\begin{array}{c}\text { LNI2 (30mL:15L:7mL } \\
\text { etanol) }\end{array}$ & 298 & 198 & 265 & 204 & 82 & 152 & 94 \\
\hline & $\begin{array}{l}\text { LNI2 (30mL:15L:7mL } \\
\text { etanol) }\end{array}$ & 300 & 81 & 179 & 100 & 63 & 161 & 94 \\
\hline & $\begin{array}{l}\text { LNI2 (30mL:15L:7mL } \\
\text { etanol) }\end{array}$ & 305 & 140 & 142 & 81 & 121 & 117 & 55 \\
\hline & $\begin{array}{c}\text { LNI2 (30mL:15L:7mL } \\
\text { danol) }\end{array}$ & 308 & 161 & 181 & 76 & 114 & 142 & 69 \\
\hline & $\begin{array}{c}\text { LNI2 (30mL:15L:7mL } \\
\text { etanol) }\end{array}$ & 312 & 83 & 174 & 126 & 40 & 140 & 95 \\
\hline & $\begin{array}{c}\text { LNI2 (30mL: } 15 \mathrm{~L}: 7 \mathrm{~mL} \\
\text { etanol) }\end{array}$ & 315 & 25 & 148 & 99 & 21 & 135 & 82 \\
\hline & $\begin{array}{c}\text { LNI2 (30mL: } 15 \mathrm{~L}: 7 \mathrm{~mL} \\
\text { etanol) }\end{array}$ & 326 & 38 & 384 & 100 & 29 & 353 & 82 \\
\hline & $\begin{array}{c}\text { LNI2 (30mL:15L:7mL } \\
\text { etanol) }\end{array}$ & 328 & 36 & 92 & 139 & 22 & 69 & 128 \\
\hline & $\begin{array}{c}\text { LNI2 (30mL:15L:7mL } \\
\text { etanol) }\end{array}$ & 334 & 117 & 168 & 149 & 94 & 135 & 101 \\
\hline \multirow[t]{9}{*}{5} & $\begin{array}{c}\text { LN12 (30mL:15L:7mL } \\
\text { etanol) }\end{array}$ & 336 & 50 & 116 & 50 & 32 & 85 & 24 \\
\hline & $\begin{array}{c}\text { LNI2 (30mL: } 15 \mathrm{~L}: 7 \mathrm{~mL} \\
\text { etanol) }\end{array}$ & 354 & 148 & 147 & 86 & 123 & 120 & 78 \\
\hline & $\begin{array}{l}\text { LNI2 (30mL: } 15 \mathrm{~L}: 7 \mathrm{~mL} \\
\text { etanol) }\end{array}$ & 356 & 189 & 140 & 167 & 170 & 116 & 143 \\
\hline & $\begin{array}{c}\text { LNI2 (30mL:15L:7mL } \\
\text { etanol) }\end{array}$ & 361 & 113 & 148 & 153 & 28 & 138 & 144 \\
\hline & $\begin{array}{c}\text { LNI2 (30mL:15L:7mL } \\
\text { etanol) }\end{array}$ & 364 & 38 & 150 & 67 & 34 & 132 & 40 \\
\hline & $\begin{array}{l}\text { LNI2 (30mL: } 15 \mathrm{LL}: 7 \mathrm{~mL} \\
\text { etanol) }\end{array}$ & 368 & 66 & 220 & 80 & 58 & 172 & 70 \\
\hline & $\begin{array}{c}\text { LNI2 (30mL:15L:7mL } \\
\text { etanol) }\end{array}$ & 375 & 59 & 170 & 96 & 51 & 168 & 87 \\
\hline & $\begin{array}{l}\text { LNI2 (30mL:15L:7mL } \\
\text { etanol) }\end{array}$ & 382 & 54 & 217 & 138 & 6 & 4 & 3 \\
\hline & $\begin{array}{l}\text { LNI2 (30mL:15L:7mL } \\
\text { etanol) }\end{array}$ & 390 & 160 & 149 & 136 & 136 & 129 & 129 \\
\hline
\end{tabular}


TABELA A28. Sólidos suspensos totais e voláteis na água residuária sintética e efluente dos reatores anaeróbio e aeróbio: fase mesofilica ( $4^{\mathrm{a}}$ etapa a $8^{\mathrm{a}}$ etapa) e fase termofilica ( $1^{\mathrm{a}}$ etapa).

\begin{tabular}{|c|c|c|c|c|c|c|c|}
\hline \multirow{2}{*}{ * } & \multirow{2}{*}{$\begin{array}{l}\text { Tipo de licore } \\
\text { volume }\end{array}$} & \multirow{2}{*}{$\begin{array}{c}\mathrm{T} \\
\left({ }^{0} \mathrm{C}\right)\end{array}$} & \multirow{2}{*}{$\begin{array}{l}\text { Tempo } \\
\text { (dia) }\end{array}$} & \multicolumn{2}{|c|}{ SSLM } & \multicolumn{2}{|c|}{ SSdecantador } \\
\hline & & & & SST & SSV & SST & SSV \\
\hline \multirow[t]{3}{*}{4} & LNI1 (60mL:12L) & 25 & 130 & 351 & 338 & & \\
\hline & LNI1 (60mL:12L) & 25 & 132 & 155 & 150 & & \\
\hline & LNI1 (60mL:15L) & 25 & 137 & 368 & 325 & & \\
\hline 5 & $\begin{array}{c}\text { LNII (50mL:15L:5mL } \\
\text { etanol) }\end{array}$ & 30 & 158 & 935 & 800 & 106 & 97 \\
\hline \multirow[t]{3}{*}{6} & $\begin{array}{l}\text { LNII (50mL: } 15 \mathrm{~L}: 5 \mathrm{~mL} \\
\text { etanol) }\end{array}$ & 32,5 & 161 & 496 & 431 & 122 & 102 \\
\hline & $\begin{array}{c}\text { LNII (55mL:15L:7mL } \\
\text { etanol) }\end{array}$ & 32,5 & 166 & 460 & 430 & 771 & 102 \\
\hline & $\begin{array}{l}\text { LNII (55mL:15L:7mL } \\
\text { etanol) }\end{array}$ & 32,5 & 168 & 521 & 475 & 65 & 48 \\
\hline \multirow[t]{7}{*}{7} & $\begin{array}{c}\text { LNI1 (55mL:15L:7mL } \\
\text { etanol) }\end{array}$ & 35 & 172 & 866 & 761 & 1749 & 1707 \\
\hline & $\begin{array}{c}\text { LNII (55mL:15L:7mL } \\
\text { etanol) }\end{array}$ & 35 & 174 & 90 & 72 & 108 & 103 \\
\hline & $\begin{array}{c}\text { LNII (45mL:15L:7mL } \\
\text { etanol) }\end{array}$ & 35 & 180 & 687 & 577 & 98 & 13 \\
\hline & $\begin{array}{l}\text { LNII (45mL: } 15 \mathrm{LL}: 7 \mathrm{~mL} \\
\text { etanol) }\end{array}$ & 35 & 186 & 2779 & 2696 & 4176 & 3931 \\
\hline & $\begin{array}{c}\text { LNII (45mL:15L:7mL } \\
\text { etanol) }\end{array}$ & 35 & 197 & 185 & 145 & 133 & 131 \\
\hline & $\begin{array}{c}\text { LNII (45mL: } 15 \mathrm{~L}: 7 \mathrm{~mL} \\
\text { ctanol) }\end{array}$ & 37,5 & 201 & & & 26 & 22 \\
\hline & $\begin{array}{c}\text { LNII (45mL:15L:7mL } \\
\text { (tanol) }\end{array}$ & 37,5 & 208 & 106 & 68 & 110 & 67 \\
\hline \multirow[t]{5}{*}{8} & $\begin{array}{c}\text { LNII (45mL:15L:7mL } \\
\text { etanol) }\end{array}$ & 42,5 & 215 & 438 & 422 & 104 & 96 \\
\hline & $\begin{array}{c}\text { LNII (45mL:15L:7mL } \\
\text { etanol) }\end{array}$ & 42,5 & 217 & 318 & 303 & 284 & 268 \\
\hline & $\begin{array}{c}\text { LNII (45mL: } 15 \mathrm{~L}: 7 \mathrm{~mL} \\
\text { tanol) }\end{array}$ & 42,5 & 232 & 94 & 47 & 87 & 69 \\
\hline & $\begin{array}{c}\text { LNII }(45 \mathrm{~mL}: 15 \mathrm{~L}: 7 \mathrm{~mL} \\
\text { etanol) }\end{array}$ & 42,5 & 239 & 113 & 17 & 136 & 84 \\
\hline & $\begin{array}{c}\text { LNII (45mL:15L:7mL } \\
\text { etanol) }\end{array}$ & 42,5 & 245 & 3449 & 2515 & 3493 & 2624 \\
\hline \multirow[t]{4}{*}{1} & $\begin{array}{c}\text { LNII (45mL: } 15 \mathrm{~L}: 7 \mathrm{~mL} \\
\text { etanol) }\end{array}$ & 45 & 250 & 37 & 22 & 19720 & 15937 \\
\hline & $\begin{array}{l}\text { LNII (45mL:15L:7mL } \\
\text { etanol) }\end{array}$ & 45 & 252 & 30 & 15 & 3395 & 4195 \\
\hline & $\begin{array}{l}\text { LNII (45mL:15L:7mL } \\
\text { etanol) }\end{array}$ & 45 & 257 & 63 & 16 & 3074 & 2374 \\
\hline & $\begin{array}{c}\text { LNII (45mL:15L:7mL } \\
\text { etanol) }\end{array}$ & 45 & 259 & 117 & 89 & 273 & 267 \\
\hline
\end{tabular}


TABELA A29. Diferença entre o afluente e efluente dos reatores anaeróbio e aeróbio em relação a sólidos totais, sólidos totais voláteis e sólidos totais fixos: fase termofílica ( $2^{\mathrm{a}}$ a $5^{\mathrm{a}}$ etapa).

\begin{tabular}{|c|c|c|c|c|c|c|c|}
\hline \multirow{2}{*}{$\sqrt{\infty}$} & \multirow{2}{*}{$\begin{array}{c}\text { Tipo de licore } \\
\text { volume }\end{array}$} & \multirow{2}{*}{$\begin{array}{c}\mathrm{T} \\
\left({ }^{0} \mathrm{C}\right)\end{array}$} & \multirow{2}{*}{$\begin{array}{c}\text { Tempo } \\
\text { (dia) }\end{array}$} & \multicolumn{2}{|c|}{ SSLM } & \multicolumn{2}{|c|}{ SSdecantador } \\
\hline & & & & SST & SSV & SST & SSV \\
\hline \multirow[t]{3}{*}{2} & \multirow{3}{*}{\begin{tabular}{|c|} 
LNII (45mL:15L:7mL \\
etanol) \\
LNI1 (45mL:15L:7mL \\
etanol) \\
LNI1 (45mL:15L:7mL \\
etanol)
\end{tabular}} & 47,5 & 264 & 396 & 355 & 12724 & 9550 \\
\hline & & 47,5 & 266 & 194 & 124 & 1109 & 859 \\
\hline & & 47,5 & 291 & 76 & 74 & 469 & 405 \\
\hline 3 & $\begin{array}{c}\begin{array}{c}\text { LNI1 (45mL:15L:7mL } \\
\text { tanol) }\end{array} \\
\end{array}$ & 52 & 293 & 132 & 32 & 337 & 223 \\
\hline \multirow{10}{*}{4} & \multirow{3}{*}{$\begin{array}{c}\text { LNI1 (45m: } 15 \mathrm{~L}: 7 \mathrm{~mL} \\
\text { etanol) } \\
\text { LNI2 (30mL: } 15 \mathrm{~L}: 7 \mathrm{~mL} \\
\text { etanol) } \\
\begin{array}{c}\text { LNI2 }(30 \mathrm{~mL}: 15 \mathrm{~L}: 7 \mathrm{~mL} \\
\text { etanol) }\end{array}\end{array}$} & 52 & 298 & 679 & 470 & 1670 & 1252 \\
\hline & & 52 & 300 & 362 & 326 & 853 & 742 \\
\hline & & 52 & 305 & 494 & 468 & 532 & 503 \\
\hline & \multirow{7}{*}{ 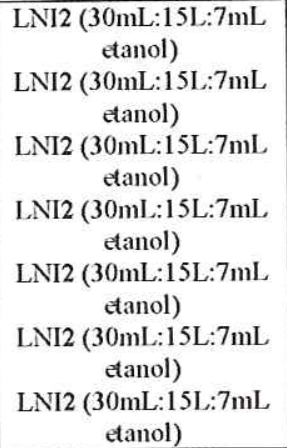 } & 52 & 308 & 269 & 246 & 177 & 173 \\
\hline & & 52 & 312 & 187 & 162 & 1400 & 1048 \\
\hline & & 52 & 315 & 138 & 122 & 102 & 87 \\
\hline & & 52 & 326 & 636 & 627 & 1359 & 1088 \\
\hline & & 52 & 328 & 350 & 298 & 300 & 252 \\
\hline & & 52 & 334 & 2222 & 2189 & 4040 & 3700 \\
\hline & & 52 & 336 & 2490 & 2220 & 4600 & 3950 \\
\hline \multirow{5}{*}{5} & \multirow{5}{*}{\begin{tabular}{|} 
LNI2 (30mL: $15 \mathrm{~L}: 7 \mathrm{~mL}$ \\
etanol) \\
LNI2 (30mL:15L:7mL \\
etanol) \\
LNI2 (30mL:15L:7mL \\
etanol) \\
LNI2 (30mL:15L:7mL \\
efanol) \\
$\begin{array}{c}\text { LNI2 (30mL:15L:7mL } \\
\text { etanol) }\end{array}$ \\
\end{tabular}} & 52 & 354 & 506 & 406 & 10740 & 10120 \\
\hline & & 57 & 356 & 1730 & 1570 & 2700 & 2383 \\
\hline & & 57 & 361 & 2740 & 2680 & 4120 & 3720 \\
\hline & & 57 & 364 & 3040 & 2840 & 4063 & 3850 \\
\hline & & 57 & 368 & 2183 & 1950 & 2529 & 2514 \\
\hline & \multirow{4}{*}{\begin{tabular}{|c} 
LNI2 (30mL:15L:7mL \\
etanol) \\
LNI2 (30mL: $15 \mathrm{~L}: 7 \mathrm{~mL}$ \\
etanol) \\
LNI2 (30mL:15L:7mL \\
etanol) \\
LNI1 (45mL:15L:7mL \\
etanol)
\end{tabular}} & 57 & 375 & 3040 & 2940 & 3320 & 3180 \\
\hline & & 57 & 382 & 3840 & 1880 & 3700 & 640 \\
\hline & & 57 & 390 & 2140 & 1940 & 3600 & 3260 \\
\hline 2 & & 47,5 & 264 & 396 & 355 & 12724 & 9550 \\
\hline
\end{tabular}


TABELA A30. Diferença entre o afluente e efluente dos reatores anaeróbio e aeróbio em relação a sólidos totais, sólidos totais voláteis e sólidos totais fixos: fase termofílica ( $2^{\mathrm{a}}$ a $5^{\mathrm{a}}$ etapa).

\begin{tabular}{|c|c|c|c|c|c|}
\hline \multirow[b]{2}{*}{ 苞 } & \multirow[t]{2}{*}{ Tipo de licor e volume } & \multirow[t]{2}{*}{$\mathrm{T}\left({ }^{0} \mathrm{C}\right)$} & \multirow[t]{2}{*}{ Tempo (dia) } & \multicolumn{2}{|c|}{ ST } \\
\hline & & & & e-UASB & e-LA \\
\hline 4 & $\begin{array}{l}\text { LNI1 (60mL:12L) } \\
\text { LNI1 (60mL:12L) } \\
\text { LNIl (60mL:15L) }\end{array}$ & $\begin{array}{l}25 \\
25 \\
25\end{array}$ & $\begin{array}{l}130 \\
132 \\
137 \\
\end{array}$ & $\begin{array}{l}-22 \\
-25 \\
55 \\
\end{array}$ & $\begin{array}{r}33 \\
44 \\
-40 \\
\end{array}$ \\
\hline 5 & LNII (50mL:15L:5mL etanol) & 30 & 158 & -51 & 35 \\
\hline 6 & $\begin{array}{l}\text { LNI1 (50mL:15L:5mL etanol) } \\
\text { LNI1 (55mL:15L:7mL etanol) } \\
\text { LNI1 (55mL:15L:7mL etanol) }\end{array}$ & $\begin{array}{l}32,5 \\
32,5 \\
32,5\end{array}$ & $\begin{array}{l}161 \\
166 \\
168 \\
\end{array}$ & $\begin{array}{l}-41 \\
-78 \\
-56 \\
\end{array}$ & $\begin{array}{l}64 \\
67 \\
62 \\
\end{array}$ \\
\hline 7 & $\begin{array}{l}\text { LNI1 (55mL:15L:7mL etanol) } \\
\text { LNI1 (55mL:15L:7mL etanol) } \\
\text { LNI1 (45mL:15L:7mL etanol) } \\
\text { LNI1 (45mL:15L:7mL etanol) } \\
\text { LNI1 (45mL:15L:7mL etanol) } \\
\text { LNI1 (45mL:15L:7mL etanol) } \\
\text { LNI1 (45mL:15L:7mL etanol) }\end{array}$ & $\begin{array}{c}35 \\
35 \\
35 \\
35 \\
35 \\
37,5 \\
37,5 \\
\end{array}$ & $\begin{array}{l}172 \\
174 \\
180 \\
186 \\
197 \\
201 \\
208\end{array}$ & $\begin{array}{c}-95 \\
-83 \\
318 \\
-70 \\
-25 \\
7 \\
19 \\
\end{array}$ & $\begin{array}{l}14 \\
33 \\
-395 \\
-14 \\
-20 \\
-18 \\
-20 \\
\end{array}$ \\
\hline 8 & $\begin{array}{l}\text { LNI1 (45mL:15L:7mL etanol) } \\
\text { LNI1 (45mL:15L:7mL etanol) } \\
\text { LNI1 (45mL:15L:7mL etanol) } \\
\text { LNI1 (45mL:15L:7mL etanol) } \\
\text { LNI1 (45mL:15L:7mL etanol) }\end{array}$ & $\begin{array}{l}42,5 \\
42,5 \\
42,5 \\
42,5 \\
42,5\end{array}$ & $\begin{array}{l}215 \\
217 \\
232 \\
239 \\
245\end{array}$ & $\begin{array}{c}-54 \\
22 \\
-29 \\
9 \\
-14\end{array}$ & $\begin{array}{l}58 \\
25 \\
27 \\
38 \\
23\end{array}$ \\
\hline 1 & $\begin{array}{l}\text { LNI1 (45mL:15L:7mL etanol) } \\
\text { LNI1 (45mL:15L:7mL etanol) } \\
\text { LNI1 (45mL:15L:7mL etanol) } \\
\text { LNI1 (45mL:15L:7mL etanol) } \\
\text { LNI1 (45mL:15L:7mL etanol) } \\
\text { LNI1 (45mL:15L:7mL etanol) } \\
\text { LNI1 (45mL:15L:7mL etanol) }\end{array}$ & $\begin{array}{c}45 \\
45 \\
45 \\
45 \\
47,5 \\
47,5 \\
52 \\
\end{array}$ & $\begin{array}{l}250 \\
252 \\
257 \\
259 \\
266 \\
291 \\
298\end{array}$ & $\begin{array}{l}-29 \\
-6 \\
-54 \\
817 \\
35 \\
-4 \\
-70\end{array}$ & $\begin{array}{c}50 \\
49 \\
135 \\
13 \\
159 \\
83 \\
58 \\
\end{array}$ \\
\hline 4 & $\begin{array}{l}\text { LNI2 (30mL:15L:7mL etanol) } \\
\text { LNI2 (30mL:15L:7mL etanol) } \\
\text { LNI2 (30mL:15L:7mL etanol) } \\
\text { LNI2 (30mL:15L:7mL etanol) } \\
\text { LNI2 (30mL:15L:7mL etanol) } \\
\text { LNI2 (30mL:15L:7mL etanol) } \\
\text { LNI2 (30mL:15L:7mL etanol) } \\
\text { LNI2 (30mL:15L:7mL etanol) } \\
\text { LNI2 (30mL:15L:7mL etanol) } \\
\text { LNI2 (30mL:15L:7mL etanol) }\end{array}$ & $\begin{array}{l}52 \\
52 \\
52 \\
52 \\
52 \\
52 \\
52 \\
52 \\
52 \\
52 \\
\end{array}$ & $\begin{array}{l}300 \\
305 \\
308 \\
312 \\
315 \\
326 \\
328 \\
334 \\
336 \\
354 \\
\end{array}$ & $\begin{array}{l}-98 \\
4 \\
-28 \\
-100 \\
-114 \\
-324 \\
-47 \\
-40 \\
-53 \\
3 \\
\end{array}$ & $\begin{array}{c}67 \\
62 \\
73 \\
46 \\
52 \\
271 \\
-59 \\
33 \\
61 \\
42 \\
\end{array}$ \\
\hline 5 & $\begin{array}{l}\text { LNI2 (30mL:15L:7mL etanol) } \\
\text { LNI2 (30mL:15L:7mL etanol) } \\
\text { LNI2 (30mL:15L:7mL etanol) } \\
\text { LNI2 (30mL:15L:7mL etanol) } \\
\text { LNI2 (30mL:15L:7mL etanol) } \\
\text { LNI2 (30mL:15L:7mL etanol) } \\
\text { LNI2 (30mL:15L:7mL etanol) }\end{array}$ & $\begin{array}{l}57 \\
57 \\
57 \\
57 \\
57 \\
57 \\
57\end{array}$ & $\begin{array}{l}356 \\
361 \\
364 \\
368 \\
375 \\
382 \\
390\end{array}$ & $\begin{array}{c}54 \\
-110 \\
-98 \\
-114 \\
-117 \\
2 \\
7\end{array}$ & $\begin{array}{c}-27 \\
-6 \\
92 \\
102 \\
81 \\
1 \\
0\end{array}$ \\
\hline
\end{tabular}


